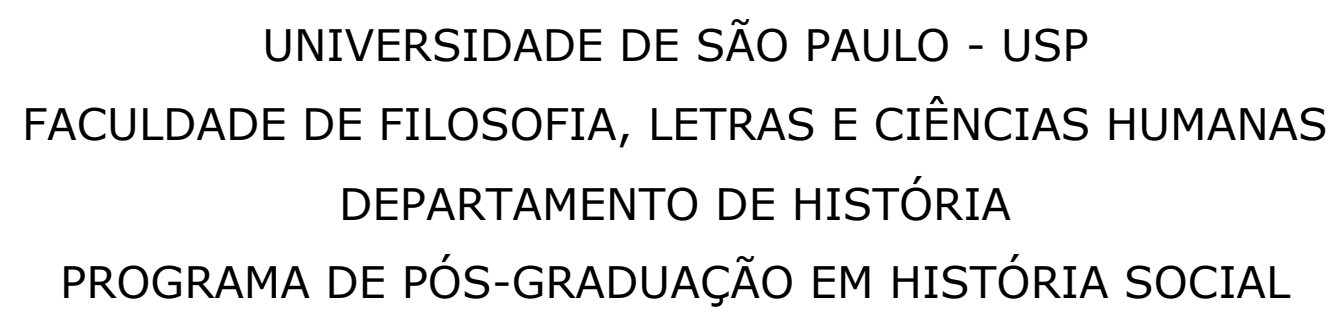

Fronts Islamistas no Brasil: prenúncios de uma radicalização incompleta face ao fundamentalismo existencial

Victor Begeres Bisneto

Versão Corrigida

São Paulo

2019 


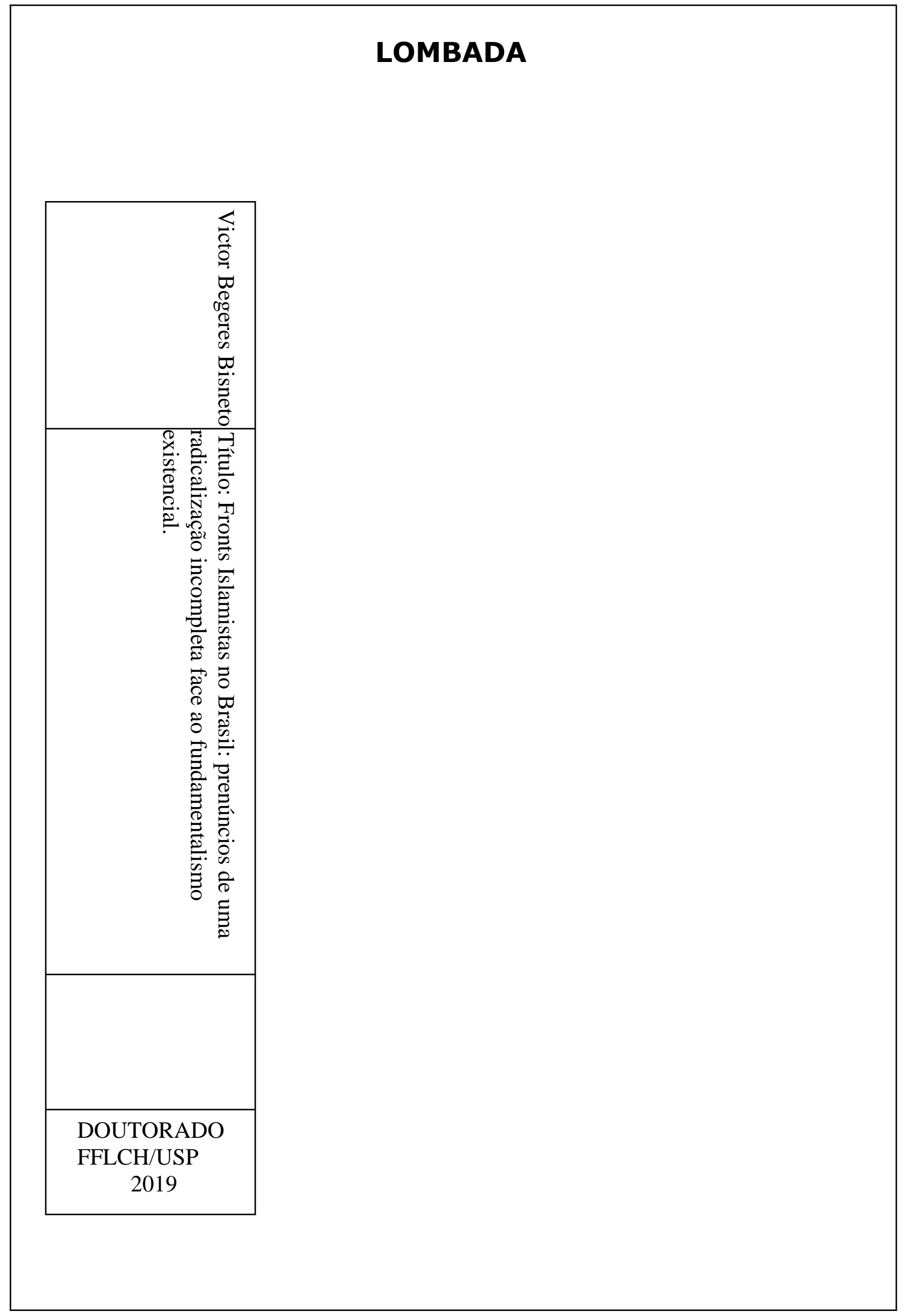




\author{
UNIVERSIDADE DE SÃO PAULO - USP \\ FACULDADE DE FILOSOFIA, LETRAS E CIÊNCIAS HUMANAS \\ DEPARTAMENTO DE HISTÓRIA \\ PROGRAMA DE PÓS-GRADUAÇÃO EM HISTÓRIA SOCIAL
}

\title{
Fronts Islamistas no Brasil: prenúncios de uma radicalização incompleta face ao fundamentalismo existencial
}

Tese de doutorado apresentada ao Departamento de História da Faculdade de Filosofia, Letras e Ciências Humanas da Universidade de São Paulo para a obtenção do título de doutor na área de História Social.

\section{Victor Begeres Bisneto}

Orientador: Prof. Dr. Peter Robert Demant

\section{Versão Corrigida}

São Paulo 
Autorizo a reprodução e divulgação total ou parcial deste trabalho, por qualquer meio convencional ou eletrônico, para fins de estudo e pesquisa, desde que citada a fonte.

Catalogação na Publicação

Serviço de Biblioteca e Documentação

Faculdade de Filosofia, Letras e Ciências Humanas da Universidade de São Paulo

B416f

Begeres Bisneto, Victor

Fronts Islamistas no Brasil: prenúncios de uma radicalização incompleta face ao fundamentalismo existencial / Victor Begeres Bisneto ; orientador Peter Robert Demant. - São Paulo, 2019.

$378 \mathrm{f}$.

Tese (Doutorado) - Faculdade de Filosofia, Letras e Ciências Humanas da Universidade de São Paulo. Departamento de História. Área de concentração: História Social.

1. Islam no Brasil. 2. Fundamentalismo islâmico. 3. Muçulmanos. 4. Existencialismo. 5. Modernidade. I. Demant, Peter Robert, orient. II. Título. 


\section{ENTREGA DO EXEMPLAR CORRIGIDO DA DISSERTACÃO/TESE}

Termo de Ciência e Concordância do (a) orientador (a)

Nome do (a) aluno (a): Victor Begeres Bisneto

Data da defesa: 01/11/2019

Nome do Prof. (a) orientador (a): Peter Robert Demant

Nos termos da legislação vigente, declaro ESTAR CIENTE do conteúdo deste EXEMPLAR CORRIGIDO elaborado em atenção às sugestões dos membros da comissão Julgadora na sessão de defesa do trabalho, manifestando-me plenamente favorável ao seu encaminhamento e publicação no Portal Digital de Teses da USP.

2019

Amsterdã, $2 / 12 / 2019$

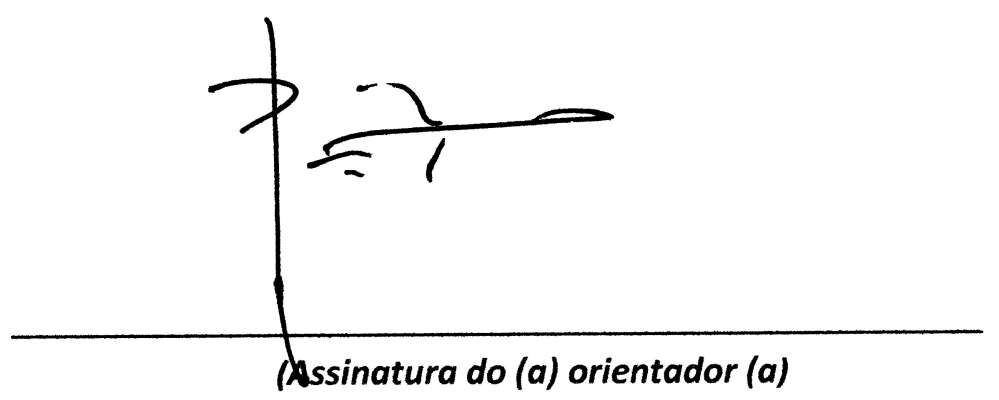


Nome: BEGERES BISNETO, Victor.

Título: Fronts islamistas no Brasil: prenúncios de uma radicalização incompleta face ao fundamentalismo existencial.

Aprovado em: 01/11/2019

Tese de doutorado apresentada ao Departamento de História da Faculdade de Filosofia, Letras e Ciências Humanas da Universidade de São Paulo para a obtenção do título de doutor na área de História Social.

\section{BANCA EXAMINADORA}

Instituição:

Julgamento Ass:

Instituição:

Julgamento Ass:

Instituição:

Julgamento Ass: 
À minha amada filha, Victoria, que deu novo sentido e cor à minha vida. 


\section{Agradecimentos}

Esta tese é a materialização de um sonho meu, mas compartilhado entre muitas pessoas as quais de alguma forma, direta ou indireta, contribuíram para sua realização. Presenciaram minhas alegrias, angústias e apostaram em mim neste percurso, o que muito me encorajou. Daí a prazerosa obrigação em oferecer esses merecidos agradecimentos.

Em primeiro lugar, agradeço a Deus por ter me dado saúde, oportunidades e colocado pessoas em meu caminho que possibilitaram a realização de meus projetos.

Agradeço à toda minha família, meus grandes incentivadores e que muito se sacrificaram para que eu pudesse chegar até aqui: meu pai Claudio, grande entusiasta da educação, meu "paidrasto" Tuca, meu irmão "guerreiro" Claudinho e minha amada irmã Letícia. Minha mãe, Lúcia, a quem tudo devo e que esteve ao meu lado em todos os momentos da minha vida (pilar maior da minha existência). Aos meus avós (in memorian) pessoas simples, forjados nas dificuldades da vida, e que certamente estariam orgulhosos de mim. Suas lembranças acalentam meu espírito. Este momento é uma pequena retribuição por tudo que fizeram e fazem por mim.

Aos meus queridos tios, Jorge e Lucimar, jamais poderia deixar de lembrar de vocês e da importância que têm em minha vida. Meus primos, Jorginho e Mari. Bah! Minha prima do sul, Iara, que descobri há pouco e que já é tão querida e próxima.

À minha linda e dedicada esposa Marianne. Pessoa a quem devo duas coisas essenciais: desculpas, pelo meu jeito irascível em boa parte do tempo, e gratidão, por nunca desistir de me mostrar o lado bom das coisas e em como tudo pode ser mais simples e leve. Amo você.

Não poderia faltar minha filha, Victoria, hoje com 1 ano e 10 meses. A inocência e espontaneidade em seus pequenos gestos alentam meu coração e renovam minhas forças. Meu esforço e sacrifícios, são para você. Que você siga sempre pela senda do conhecimento, do respeito às diferenças e em defesa da liberdade. Você é meu futuro compresente.

Aos meus queridos amigos, M.E, I.E, M.Y e Hossam Ammar, que me abriram a portas para o complexo e fascinante mundo islâmico. Cada momento em que estamos reunidos é sempre especial, repleto de alegria e cheio de aprendizados. Muito obrigado por sua sua amizade e carinho.

Aos meus grandes amigos/irmãos: Alexandre, Alcides, Rafael, Fábio e Graciela, companheiros para toda a vida. Notem: não tenho muitos amigos. Mas os poucos que a vida me deu, são os melhores.

Ao meu amigo e médico, Dr. Claudio Cidade Gomes, que há tanto tempo cuida da minha saúde quando ela esmorece e pela confiança que transmite, pelas ricas histórias sobre viagens 
que trocamos, pelas discussões políticas e pelo bom humor com que sempre me recebe. É um médico na essência e plenitude do termo.

Sou grato ao Colégio Liceu Salesiano, a quem devo minha formação básica e que desde 2006 me acolheu como professor. Aos amigos e colegas professores, e aos orientadores, coordenadores e diretores de ontem e de hoje, minha eterna reverência por sua dedicação nesta área tão essencial para a vida.

A todas as comunidades islâmicas por onde passei e a todos os meus interlocutores, meus sinceros e respeitosos agradecimentos. De norte a sul, sempre fui muito bem recebido e acolhido. Sem a contribuição de cada um de vocês, esse trabalho não teria sido possível. Que a paz esteja com todos vocês. Assalamu aleikum.

À Universidade de São Paulo (USP) e ao Departamento de História (FFLCH) por ter oferecido todo o suporte para o bom caminhar desta pesquisa. É um privilégio fazer parte de um ambiente acadêmico de excelência. Quero agradecer ao Grupo de Trabalho Oriente Médio e Mundo Muçulmano (GTOMMM) e enaltecer sua valiosa contribuição para o debate acadêmico dentro desta área tão desafiadora. Lá conheci pessoas dedicadas, comprometidas e solidárias na troca de conhecimento, especialmente nas figuras da Natalia Nahas, Rogel, Magno, Sandro, José Antônio, Ariel, Augusto e Cila.

Finalmente, gostaria de oferecer um agradecimento muito especial ao meu orientador, o prof. Dr. Peter Demant, que antes mesmo de me tornar seu orientando, de forma generosa, me acolheu nas diversas disciplinas que ministrou. Sua extrema competência e didática em ensinar temas tão complexos, a forma bem organizada de seus cursos, o entusiasmo por reflexões rigorosas e sempre ponderadas, suas preciosas orientações, críticas e recomendações de leituras, além da afabilidade que tem para com os outros, fazem dele uma grande fonte de inspiração e de amadurecimento acadêmico. Sempre terá minha gratidão e reverência. 
Mostrem-me um homem que não seja escravo das paixões, e terá conquistado, como tu, o meu coração.

William Shakespeare. "Hamlet". 


\section{Resumo}

BEGERES BISNETO, Victor. Fronts islamistas no Brasil: prenúncios de uma radicalização incompleta face ao fundamentalismo existencial. 2019. Tese de doutorado - Faculdade de Filosofia, Letras e Ciências Humanas, Departamento de História, Universidade de São Paulo, São Paulo, 2019.

Esta tese se dedica ao estudo do fundamentalismo islâmico no Brasil, em especial se há indícios da vertente jihadista, tema ainda opaco nas pesquisas acadêmicas do país e pouco sensível à sociedade brasileira, mais habituada com repercussões globais acerca do assunto. A partir dos recursos metodológicos oferecidos pela história oral e pela cartografia temática, pudemos traçar um perfil de algumas das mais importantes comunidades muçulmanas que aqui se constituíram, que a despeito de seu tamanho reduzido no conjunto da população, têm se expandido para novas regiões fora do eixo sul-sudeste, onde estão consolidadas há mais tempo. O contato com elas foi crucial para conhecermos a forma como elas percebem e reagem a temas sensíveis como o extremismo religioso e aos supostos estigmas aos quais muitas vezes são submetidas. Ainda que seja improvável a tendência de doutrinação jihadista dentro das mesquitas por suas lideranças, dado ao caráter pacífico que manifestam, fora delas há suspeitas sobre a ligação de muçulmanos brasileiros com o Hezbollah (Libanês), com o Estado Islâmico e que se articulam via redes sociais e dispositivos de comunicação. Amparados pela recente lei "antiterrorismo" (n.13.260/2016), a Polícia Federal e o Ministério Público Federal detectaram indícios e investigaram alguns desses muçulmanos que supostamente integravam células jihadistas. Diante desse quadro, propomos uma reflexão teóricoconceitual para esclarecer as origens, desmistificar os significados e analisar os contextos em que se insere o chamado fundamentalismo islâmico contemporâneo, e investigamos se o Brasil oferece um ambiente fértil para a radicalização islâmica. Ao que parece, a tese de que o autodidatismo religioso, os ambientes virtuais e o oportunismo de alguns dos que seguem islam, associados à modernidade que enseja comportamentos cada vez mais niilistas do ponto de vista filosóficoexistencial, parecem se firmar como o retrato de uma radicalização incompleta, improvável, mas não impossível.

Palavras-Chave: Islam no Brasil; fundamentalismo islâmico; muçulmanos; existencialismo; modernidade. 


\begin{abstract}
BEGERES BISNETO, Victor. Brazil: Peaceful Mosques, Jihadist Echoes: Realities and Possibilities. 2019. Doctorate thesis - Faculdade de Filosofia, Letras e Ciências Humanas, Departamento de História, Universtity of São Paulo, São Paulo, 2019.

This thesis dedicats itself to the study of Islamic fundamentalism in Brazil. Specifically it inquires if there are signs of a jihadist tendency, a theme still little studied in Brazilian academia and not much discussed in Brazilian society, more accustomed to see the global repercussions of this subject. From using methodological resources offered by oral history and thematic cartography, we sketch a profile of some of Brazil's most important Muslim communities. Despite their small size in the population as a whole, these have expanded from the southsoutheast axis, where they have long been consolidated, into other regions. Meeting with representatives of these communities has been crucial to understand how they perceive and respond to sensitive issues, such as religious extremism and the alleged stigmas they are often subjected to. Although jihadist indoctrination by their leaderships is unlikely, given the peaceful character that they manifest, outside the mosques suspicions arise regarding the connection of Brazilian Muslims with the (Lebanese) Hezbollah and/or the Islamic State, through social networks and communication devices. Empowered by the recent "antiterrorism" law (n.13.260/2016), the Federal Police and the Federal Public Prosecutor's Office have detected some cues and have investigated some Muslims allegedly members of jihadist cells. Given this framework, we develop a theoretical-conceptual analysis clarifying the origins, demystifying the meanings, and discussing the contexts in which the so-called contemporary Islamic fundamentalism is inserted. It seems that religious self-learning, a "virtual" environment and the opportunism of some of those who follow Islam, link up with a modernity from a philosophical-existential point of view, leads to increasingly nihilistic behaviors. Our investigation if Brazil offers a fertile environment for Islamic radicalization thus leads to the conclusion: an incomplete radicalization, though unlikely, is not impossible.
\end{abstract}

Keywords: Islam in Brazil; Islamic fundamentalism; Muslims; existentialism; modernity. 


\section{Résumé}

BEGERES BISNETO, Victor. Les Mosquées Pacifiques et les Échos Jihadistes au Brésil: réalités et possibilités. 2019. Thèse de doctorat - Faculté de Philosophie, Lettres et Sciences Humaines, Département d’Histoire, Université de São Paulo, São Paulo, 2019.

Cette thèse est consacrée à l'étude du fondamentalisme islamique au Brésil, et tout particulièrement à l'éventualité de la présence de son versant jihadiste, thème encore peu étudié dans les recherches académiques du pays et sujet peu sensible à la société brésilienne, plus habituée aux répercussions internationales de cette question. À partir de moyens méthodologiques offerts par l'histoire orale et par la cartographie thématique, nous avons pu tracer un profil de certaines des plus importantes communautés musulmanes qui se sont constituées ici, et en dépit de leurs dimensions réduites par rapport à l'ensemble de la population, se sont répandues vers d'autres régions en dehors de l'axe sud/sud-est, où elles s'étaient consolidées depuis plus longtemps. Le contact avec ces communautés a été fondamental pour connaître la manière dont elles perçoivent et réagissent aux thèmes sensibles comme celui de l'extrémisme religieux et aux supposés stigmates qui leur sont souvent imposés. Bien qu'une tendance à l'endoctrinement jihadiste soit improbable au sein des mosquées de la part de leurs chefs religieux, étant donné le caractère pacifique qu'ils manifestent, en dehors de celles-ci il y a des suspicions de liens entre certains musulmans brésiliens, le Hezbollah (Libanais) et/ou 1'État Islamique, s'articulant via les réseaux sociaux et des dispositifs de communication. S'appuyant sur la récente loi "anti-terrorisme" (n.13.260/2016), la Police Fédérale et le Ministère Publique Fédéral ont detecté des índices et ont mené des investigations sur certains de ces musulmans supposés être membres de cellules jihadistes. Compte tenu de ce tableau, nous proposons une réflexion théorico-conceptuelle pour éclaircir les origines, démystifier les sens et analyser les contextes dans lequel šinsère le dit fondamentalisme islamique contemporain, et nous cherchons si le Brésil offre un environnement fertile pour un mouvement radical islamique. La thèse selon laquelle l'auto-didactisme religieux, les milieux virtuels et l'opportunisme de certains affiliés à l'islam, associés à la modernité qui pousse vers des comportements toujours plus nihilistes du point de vue philosophico-existentialiste, discussion qui traverse aussi une grande partie de ce travail, semble confirmer la conclusion: une radicalisation incomplète, improbable, mais pas impossible.

Mots-Clés: Islam au Brésil; fondamentalisme islamique; musulmans; existentialisme; modernité. 
ملخص رسالة الاكتوراة

الباحث : فيكتور بيجيرس بيزنيتو

مسالمة المساجد والأصداء:الجهادية في البرازيل: الواقع والإمكانيات, سنة 2019.

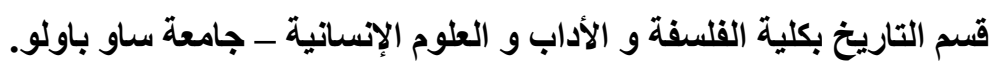

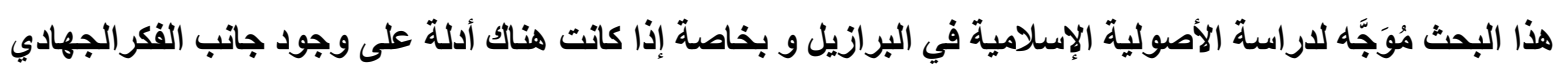

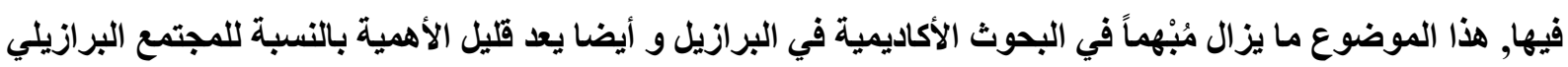

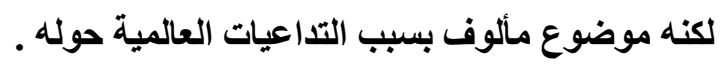
من خلال الوسائل المنهجية التي يوفرها التاريخ الثفوي و بواسطة رسم الخرائط المواضيعية تمكنتا من تتبع لمحة عن

بعض هذه المجتمعات الإسلامية الأكثر أهمية و التي تم تثكيلها هنا, و على الرغم من صِغَرِ حجمها بالنسبة للكثافة

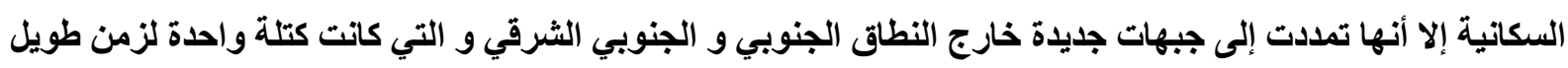

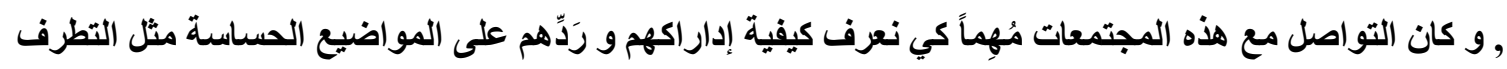
الايني و المنظور السلبي المفترض تجاههم و الأي يتعرضون إليه في كثثر من الأحيان. وعلى الرغم من عدم وجود دليل على أنه هناك إتجاه لتأصيل الفكر الجهادي عن طريق القيادات الدينية في المساجد نظراً إلى الطابع السلمي الأي يظهرونه, إلا أنه في خارج نطاق هذه القيادات توجد شكوك في وجود صلئ صلة لمسلمين برازيلين, بحزب الله اللبناني و بتظيم الدولة الإسلامية و اللذان يُعبران عن فكر هم من خلال شبكات التواصل الإنل الإجتماعي و وسائل

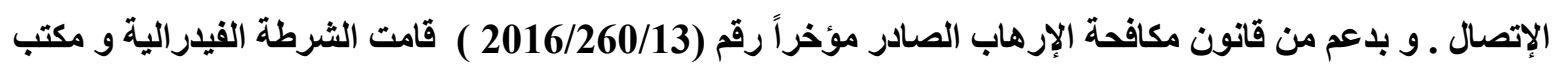
المدعي العام برصد بعض الإشارات و التحقيق مع بعض من هؤلاء المسلمين الذين زُعِمَ أنهم قـ إندمجوا في خلايا

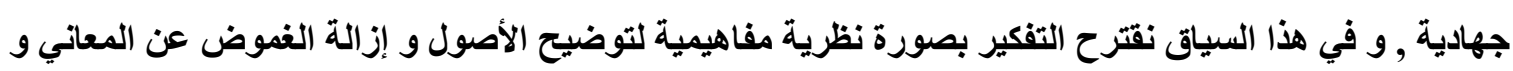
تحليل السياقات المتعلقة بالأصولية الإسلامية المعاصرة , و أيضا نقترح التحقيق فيما إذا كاتت البرازيل توفربيئة خصبة للتيارات الإسلامية المتطرفة.

و يبدو من خلال هذه الاراسة أن التعلم الاتاتي للاين و البيئات الإفتراضية و إنتهازية بعض ممن ينتسبون للإسلام قد الإسداء إرتبطوا بالحداثة التي تؤدي إلى سلوك العدمية بثكل متزايد من وجهة النظر القلسفية الوجودية و هذه مسألة تأخذ جانبا

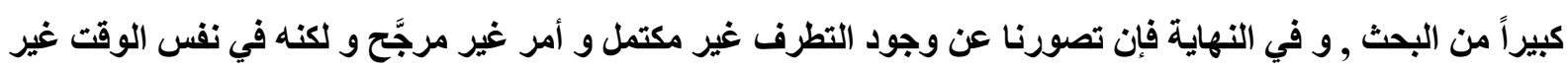

مستحيل.

كلمات هامة : الإسلام في البرازيل ـ الأصولية الإسلامية ـ المسلمون ـ الوجودية ـ الحداثة 


\section{LISTA DE SIGLAS}

ABIN

AMAL

CCBT

CCIB

CDIAL

$\mathrm{CIDH}$

EI

FAMBRAS

FBI

GAFI

GTD

GTI

GTOMMM

IM

JMB

MEC

MPF

MST

MTST

OCDE

OEA

ONU

PCC

PF

PLS

PSDB

PSL

SBMRN

SOBEM

UFF

UNI

UNICAMP

SIC
Agência Brasileira de Inteligência

Afwaj al-Muqawmat al-Lubnaniyya (Batalhão da Resistência Libanesa)

Centro Cultural Brasil-Turquia

Centro Cultural Islâmico da Bahia

Centro de Divulgação do Islam para América Latina

Convenção Interamericana de Direitos Humanos

Estado Islâmico

Federação das Associações Muçulmanas do Brasil

Federal Bureau of Investigation

Grupo de Ação Financeira Internacional

Global Terrorism Database

Global Terrorism Index

Grupo de Trabalho Oriente Médio e Mundo Muçulmano

Irmandade Muçulmana

Jihad Midia Battalion

Ministério da Eduação e Cultura

Ministério Público Federal

Movimento dos Sem-Terra

Movimento dos Trabalhadores Sem-Teto

Organização para Cooperação e Desenvolvimento Econômico

Organização dos Estados Americanos

Organização das Nações Unidas

Primeiro Comando da Capital

Polícia Federal

Projeto de Lei do Senado

Partido Social Democrata Brasileiro

Partido Social Liberal

Sociedade Beneficente Muçulmana do Rio Grande do Norte

Sociedade Beneficente Muçulmana de Santo Amaro

Universidade Federal Fluminense

União Nacional Islâmica

Universidade Estadual de Campinas

Sociedade Islâmica de Campinas 
SBMRJ

Sociedade Beneficente Muçulmana do Rio de Janeiro 


\section{SUMÁRIO DE DIAGRAMAS, FOTOGRAFIAS, INFOGRÁFICOS, QUADROS, MAPAS E TABELAS}

\section{DIAGRAMAS}

Diagrama 1 - As esferas do método de pesquisa.............................................................p.02

Diagrama 2 - Totalidade Dinâmica e o território usado.................................................p.20

Diagrama 3 - Dois pesos e duas medidas: globalização e fragmentação............................p.68

Diagrama 4 - Síntese a partir das ideias de Karen Armstrong...........................................p.129

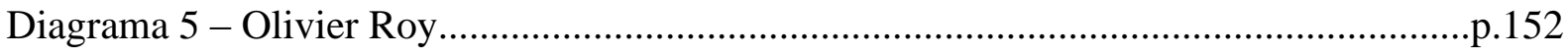

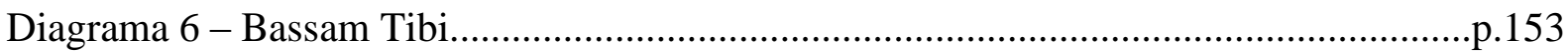

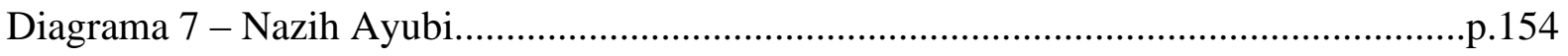

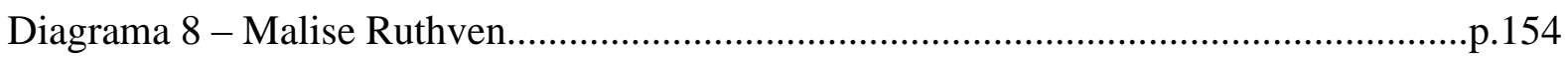

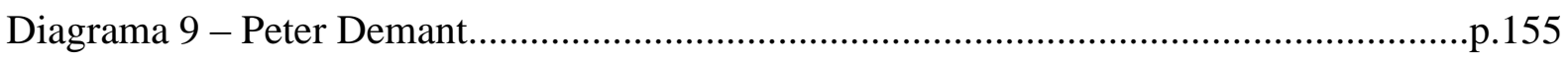

Diagrama 10 - Buruma e Margalit...............................................................................p. 156

Diagrama 11 - Síntese terminológica das correntes fundamentalistas..............................p.157

Diagrama 12 - As instâncias sociais e sua combinação no espectro islâmico....................p.158

\section{FOTOGRAFIAS}

Foto 1 - Escola para ensino do Alcorão e língua árabe - Foz do Iguaçu/PR......................p.17

Foto 2 - WAMY - São Bernardo do Campo/SP.................................................................... 17

Foto 3 - Mesquita de Campinas/SP (SIC) ...............................................................p. 17

Foto 4 - Colégio Árabe-Brasileiro - Foz do Iguaçu/PR.................................................p. 17

Foto 5 - Mesquita Brasil - São Paulo/SP........................................................................ 17

Foto 6 - Mesquita Abu Bakr Assadik - São Bernardo do Campo/SP..................................17

Foto 7 - Mesquita Omar Al-Khattab - Foz do Iguaçu/PR..............................................p.18

Foto 8 - Sociedade Muçulmana Beneficente de Natal/RN................................................p.18

Foto 9 - Centro Cultural Islâmico da Bahia (Salvador/BA)............................................p.18

Foto 10 - Husseinya Iman Al-Khomeini (Foz doIguaçu/PR).........................................p.18

Foto 11 - Sheikh Muhammed Khalil, 08.07.2015.........................................................p.36

Foto 12 - Sheikh Abdo Nasser, 07.07.2015................................................................p.37

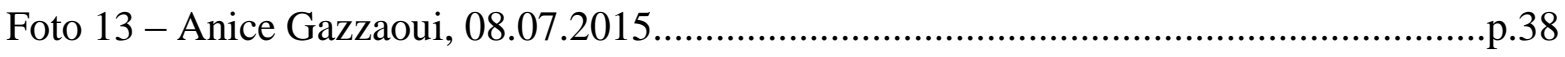

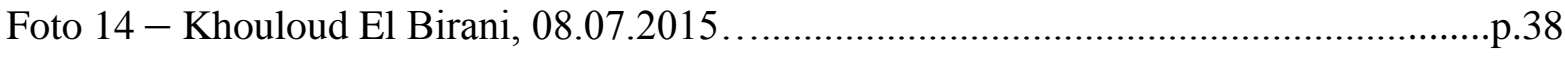

Foto 15 - Sheikh Jihad Hammadeh, 29.07.2015.................................p.39

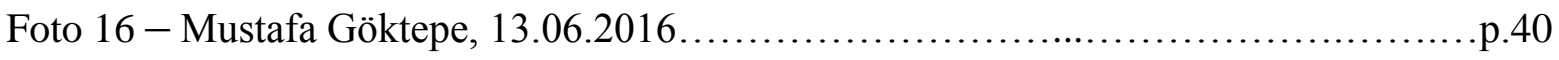


Foto 17 - Sheikh Abdelhamid Metwally, 07.01.2016..............................p.41

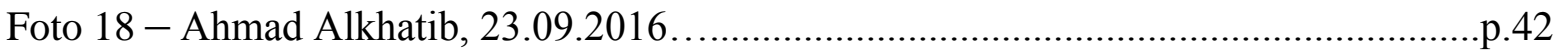

Foto 19 - Mohamed Tawfiq e Abdoul Hadi Savadogo, 24.02.2017..................................p.44

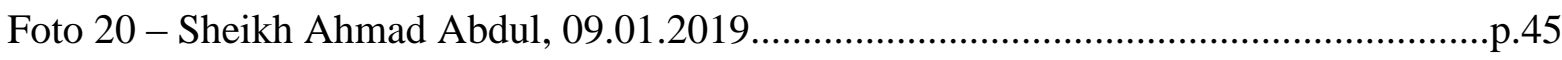

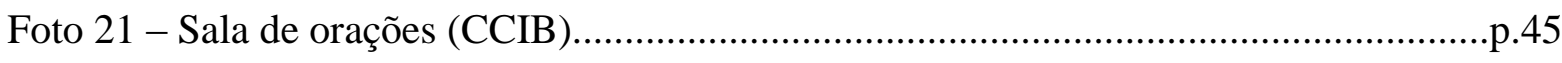

Foto 22 - Palestra do Prof. Mohammed Habibi na SIC, 29.11.2015.................................p.81

Foto 23 - Publicada no perfil do Facebook da Prof. Dr. Francirosy Campos Barbosa,

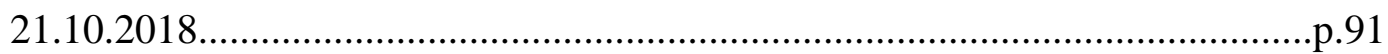

Foto 24 - Palestra na Mesquita Anoor, 15.12.2018 …...................................................p.94

Foto 25 - Folder de divulgação de palestra da Mesquita Anoor........................................p.94

Foto 26 - Palestra em um colégio privado de Campinas/SP, 22.10.2018..........................p.95

Foto 27 - Ação voluntária no centro da cidade, ago/set.2018..........................................p.96

\section{INFOGRÁFICO}

Infográfico 1 - A rede da Operação Átila. .p.221

\section{QUADROS}

Quadro 1 - Relação dos Entrevistados......................................................................p.46

Quadro 2 - Niilismo e fundamentalismo.................................................................p.180

Quadro 3 - Modelos de Muçulmanos............................................................................p.183

\section{TABELA}

Tabela 1 - Censo do IBGE 2010: Religião e População .p. 21

\section{MAPAS}

Mapa 1 - Brasil - População Islâmica 2010........................................................................p.22

Mapa 2 - Brasil - Mussalas.2012 .......................................................................p. 24

Mapa 3 - Brasil - Centros e Sociedades Beneficentes Islâmicas. 2010............................p.24

Mapa 4 - Brasil - Mesquitas. 1983...........................................................................p.26

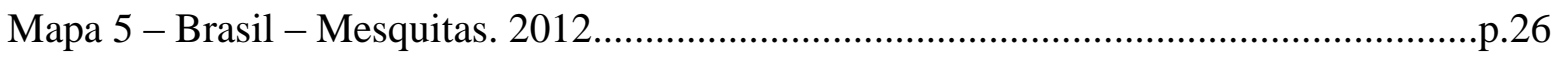

Mapa 6 - Brasil - Cemitérios Islâmicos. 2012 ..................................................................p.28

Mapa 7 - Brasil - Expansão Islamista. 2017 ................................................................p.29

Mapa 8 - Brasil - Trabalhos de Campo Realizados entre 2015 e 2017............................p.32

Mapa 9 - Global Terrorism Index..........................................................................p. 190 
Mapa 10 - Incidentes por terrorismo: Mundo e Brasil....................................................p.191 


\section{SUMÁRIO}

Apresentação. .p.xvi

1. Introdução. p. 01

PARTE 1 - Entre dilemas modernos e incertezas pós-modernas, as vozes e a expansão islâmicas no Brasil. ..p.06

2. As contribuições de pesquisas brasileiras sobre o islam ..p.07

3. A expansão islamista no Brasil: o "logos" territorial e o "mythos" da fé. .p.14

4. A importância da história oral no relato de vozes dissonantes e não hegemônicas. ..p.31

4.1. Modernidade e Islam: raízes modernas de um fenômeno pós-moderno .p.48

4.2. A Globalização: da fábula à realidade. .p.60

4.3. A violência da informação, o terrorismo midiático e o reino das conspirações .p.73

PARTE 2 - Da gramática do fundamentalismo islâmico à filosofia existencialista....p.100

5. Redefinindo o fundamentalismo islâmico face ao processo de globalização: rastreando as origens p.101

5.1. Sayyid Qutb: o progenitor do jihadismo moderno ..p.115

5.2. O fundamentalismo e seus significados. .p.127

5.3. Ensaios de uma genealogia do islam político. p.151

5.4. Uma Perspectiva Existêncialista do Fundamentalismo Islâmico. .p. 160

5.5. O que os modelos de muçulmanos têm a dizer?.... .p.181

PARTE 3 - Entre o pacifismo das mesquitas e a hostilidade virtual. .p.189

6. Radicalismo Islâmico no Brasil: possibilidades e realidade. .p. 190

6.1. América Latina e Brasil: indícios de novos horizontes do radicalismo islâmico? p.193

6.2. A Lei Antiterrorismo e o engodo normativo. ..p.199

6.3. O Brasil como improvável (mas não impossível) abrigo da radicalização. .p.212

7. Considerações finais. .p. 240

8. Bibliografia..... .p. 244 


\section{APRESENTAÇÃO: EXPLORANDO PEDRAS, DESCOBRINDO CAMINHOS}

Minha relação com o islam ${ }^{1}$, com o Oriente Médio, com os árabes, com os muçulmanos e os assuntos que os cercam, teve início de forma tardia. Me graduei em geografia e fiz mestrado, defendido em 2009, no campo da geografia urbana. Apenas em 2014, após longas jornadas de estudo, processos seletivos e de construção de contatos com uma área inteiramente nova para mim, ingressei em história social com a presente pesquisa.

Este caminho nada lógico não foi planejado, afinal, não sou um agente do caos! Mas para muitas pessoas da área acadêmica, principalmente, isso não é visto com bons olhos. A construção acadêmica de seu "lattes" se torna fragmentada, sem um fio condutor que possa dar continuidade e profundidade aos temas estudados de forma subsequente.

Mesmo sabendo disso, e vendo exemplos de muitos colegas que já acumulam anos dentro de uma linha de pesquisa e área do conhecimento, jamais sacrifiquei minha satisfação pessoal em estudar e me prender àquilo que realmente me deixa feliz, ainda que començando um novo projeto.

Creio que este projeto, ainda que de forma inconsciente, foi semeado em 2008/2009 de forma um tanto quanto heterodoxa, quando passei a estudar a língua árabe em uma pesquena escola (talvez a única que ensina esse idioma) da minha cidade, Campinas. Eu, juntamente com outro corajoso amigo, resolvi estudar esse difícil e fascinante idioma para tentar fazer dele uma ponte de conhecimento com a cultura árabe pela qual já tínhamos grande curiosidade. Curiosidade esta que vinha já sendo aguçada desde o fatídico 11 de setembro de 2001, passando pelo bombardeio midiático da "Guerra ao Terror" da doutrina Bush, as disputas intermináveis entre judeus israelenses e palestinos árabes e tudo que de ruim vinha do Oriente Médio e mundo muçulmano. Pensei então em usar o aprendizado do idioma árabe como pretexto para me aproximar desses terríveis inimigos do Ocidente!

Ao longo de três anos de curso, tive um professor egípcio e outro marroquino, ambos muçulmanos. Fui vencido pela dificuldade da língua e escassez de tempo para me dedicar ao seu estudo, mas ganhei algo de maior valor, dois bons amigos.

A proximidade me trouxe convites diversos, sem que jamais me sugerissem a conversão à religião. Entre uma visita à mesquita que frequentavam, a participação em pregações religiosas, festas, quebra do jejum ("iftar") em tempos de ramadan, e a simples troca de conhecimentos, despertou em mim um enorme interesse em poder estudar a fundo essas comunidades e aquilo que envolve o islam. Além do incentivo que sempre me deram, eles

\footnotetext{
${ }^{1}$ A grafia adotada neste trabalho, usa a palavra Islam (com "m”) ao invés de Islã. Isso se deve por rigor à grafia original em árabe que termina com a letra ("meem”) - الإسلام (")
} 
contribuíram muito para com a pesquisa me colocando em contato com outras pessoas e comunidades.

Neste ínterim viajei para países que nunca sonhei em conhecer, afinal eram mal falados por serem islâmicos. Marrocos, Turquia e Egito, lugares dos quais guardo as mais belas recordações e que me inspiraram a seguir por este caminho e a valorizar ainda mais a diversidade que faz desse mundo, apesar de todas as suas mazelas e tragédias, um lugar de extraordinária riqueza.

Inicialmente procurei na geografia, minha área de conhecimento, alguma linha de pesquisa que pudesse atender aos meus anseios de contribuir para ampliar o conhecimento neste campo cada vez mais importante e atual. Não tive sucesso a despeito das muitas tentativas que fiz para abrir esse "front" tão incipiente nessa disciplina. Foi então que decidi olhar para o outro lado do corredor na FFLCH da USP. Conheci o professor Peter Demant, meu atual orientador e grande especialista em assuntos do Oriente Médio e Mundo Muçulmano, que de forma muito gentil me abriu as portas do Departamento de História para que enfim transformasse minha grande curiosidade em um projeto acadêmico e de vida.

Mas não foi algo como “abre-te sésamo!”. Por aproximadamente três anos participei de seus cursos, ora como ouvinte, ora com o status de "aluno especial", e fui apresentado ao Grupo de Trabalho do Oriente Médio e Mundo Muçulmano (GTOMMM). Acumulei conhecimento, assimilei outros métodos de pesquisa, fiz novos colegas, mas faltava vencer as provas do processo seletivo da pós-graduação em história para finalmente por em prática meu projeto, e enfim, fazer valer todo o esforço feito até ali. Acumulei alguns fracassos que arranharam meu espírito, mas não minha persistência, que foi recompensada com a aprovação no programa que tanto queria em 2014.

Não tem sido uma jornada fácil conciliar minha vida de pai de uma linda menina de 1 ano e meio de idade, professor de ensino fundamental e médio em um colégio privado, e as demandas que a vida acadêmica enseja, especialmente no Brasil, que passa por momentos políticos e econômicos tão atribulados e incertos. Busco consolo na conversa entre Marco Polo e Kublai Khan no livro de Ítalo Calvino chamado As Cidades Invisíveis (2002):

"Marco Polo descreve uma ponte, pedra por pedra.

- Mas qual é a pedra que sustenta a ponte? - Pergunta Kublai Khan.

- A ponte não é sustentada por esta ou aquela pedra - responde Marco -, mas pela curva do arco que estas formam.

Kublai Khan permanece em silêncio, refletindo. Depois acrescenta:

- Por que falar de pedras? Só o arco me interessa. 
Polo responde:

- Sem pedras o arco não existe".

Espero que as pedras que escolhi acumular em meu caminho possam construir não o mais belo arco ou a mais bela ponte, mas o arco e a ponte mais fortes para que outros possam por ela caminhar rumo aos desconhecidos a serem explorados sobre as comunidades islâmicas no Brasil. 


\section{Introdução}

As questões que envolvem o islam e o fundamentalismo, especificamente quando manifestado em sua forma mais violenta, se tornaram muito visíveis atualmente em decorrência dos inúmeros episódios envolvendo muçulmanos em atentados terroristas, seja na Europa e ou nos Estados Unidos como também no mundo muçulmano, Oriente Médio, Ásia e Oceania.

Autores que se dedicam ao estudo e às análises desses eventos e comunidades passaram a ter cada vez mais destaque especialmente no hemisfério norte ocidental. A mídia, por sua vez, com seu aparato tecnológico e cada vez mais instantâneo em sua divulgação, contribui com as mais diversas imagens e fatos que muitas vezes reforçam visões parciais acerca da realidade.

No caso brasileiro, apenas a mídia se destaca como a grande porta-voz não só dos acontecimentos, mas também como protagonista das análises com uma gramática jornalística específica para lidar com o contexto islâmico. No entanto, tem se observado um aumento do interesse por temas que envolvem a geopolítica do Oriente Médio, o fundamentalismo islâmico e a presença islâmica crescente em países ocidentais em particular latino-americanos. O número de pesquisadores e de trabalhos com tais temáticas encontram-se às dezenas, como veremos no ítem 2 do trabalho. Mas se apenas considerarmos estudos com base em comunidades islâmicas no Brasil, especialmente aqueles que buscam conhecer ou identificar atividades jihadistas nessas comunidades o número ainda é incipiente.

Esse terreno opaco que é o Brasil e a América Latina com relação à presença de muçulmanos, pode significar justamente a oportunidade para que grupos islâmicos extremistas façam dessas sombras seu escritório? Os recentes episódios envolvendo a investigação de grupos de muçulmanos, rastreados pela Polícia Federal em suas conversas via aplicativos de comunicação por supostos envolvimentos com grupos jihadistas e com discursos radicais seriam a prova de que já é tempo de se discutir o extremismo em solo nacional?

Com o intuito de elaborar uma interpretação da realidade a partir das obras e dados dos quais dispomos, e daqueles que serão incorporados posteriormente durante a pesquisa, optamos por adotar uma postura metodológica que está ilustrada por três esferas (diagrama 1), ou pilares do nosso edifício teórico-metodológico, cuja intersecção de uma com as outras tangencia nosso objeto de pesquisa. 


\section{Diagrama 1 - As esferas do método de pesquisa.}

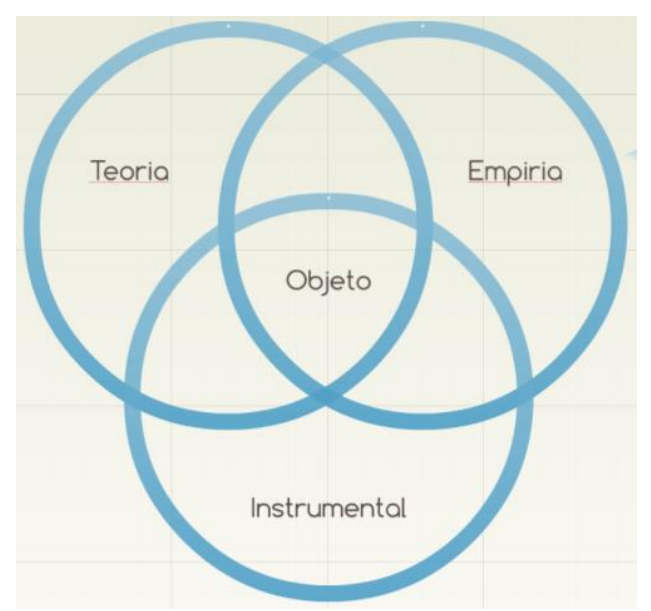

A primeira esfera a ser considerada é a esfera teórica, que contempla as discussões conceituais, os pressupostos teóricos e as variáveis-determinantes do período atual para que se obtenha uma interpretação coerente daquilo que se deseja estudar. Sendo assim, vamos abordar a influência do processo de globalização no fomento de grupos terroristas; a questão da modernidade e sua rejeição por certos grupos islâmicos; o fundamentalismo islâmico e suas possíveis periodizações; e discussões filosóficas sobre o porquê do radicalismo islâmico atual especialmente com o aporte existencialista/niilista. Desse modo esperamos clarificar e relacionar esses conceitos para que possamos embasar a tese e ao menos abrir uma nova linha de pesquisa que possa ser explorada por outros pesquisadores.

A segunda esfera é a empírica, que compreende o recorte espacial, em nosso caso o território brasileiro, e a busca por dados sobre a presença de grupos, dentre os muçulmanos, que se engajam no perfil mais radical do islam. Aqui interessa a forma como estão reagindo face aos acontecimentos globais e locais envolvendo o islam, e como se relacionam com os lugares que habitam, frequentam e convivem para que seja possível traçar um perfil geográfico e histórico desses grupos. O método oferecido pela história oral será de fundamental importância para que possamos conhecer algumas comunidades islâmicas brasileiras, como se organizam e o que pensam sobre determinados assuntos.

Finalmente, a esfera instrumental nos oferecerá um aparato mais técnico, com a obtenção de dados sobre as comunidades islâmicas, a criação de alguns cartogramas que nos auxiliará a espacializar a presença dessas comunidades e especialmente as pesquisas de campo (com entrevistas, fotos, gravações) e a possível e desejável imersão cultural dentro desses grupos quando possível.

É preciso deixar claro que essas esferas não são hierarquizadas, mas sim complementares e interdependentes entre si. Portanto, gostaríamos de propor que mais do que 
um conjunto de enunciados, proposições e procedimentos técnicos da pesquisa científica, o método refletirá também uma postura filosófica acerca da realidade com a qual nos deparamos no tocante à presença de muçulmanos no Brasil.

O primeiro desafio encontrado para traçar um panorama inicial sobre a presença de muçulmanos no Brasil, especialmente aqueles guiados por ideias fundamentalistas, é lidar com a escassez de obras sobre tais grupos como foi comentado anteriormente. Se por um lado isso ressalta o caráter inédito do trabalho, por outro nos revela a dimensão das dificuldades a serem mitigadas.

Esta tese foi dividida em três partes principais. A parte 1, chamada de "Entre dilemas modernos e incertezas pós-modernas, as vozes e expansão islâmicas no Brasil”, se debruça inicialmente sobre o "estado da arte" daquilo que se produziu em termos de pesquisas voltadas ao islam no Brasil em tempos recentes. Também é feita uma primeira aproximação mais empírica e quantitativa sobre as comunidades islâmicas no país, traduzida por alguns cartogramas que espacializam a presença delas no território nos permitindo observar seus pontos de concentração e tendências de expansão.

Além disso, esta parte revela os procedimentos metodológicos que foram seguidos para a obtenção de muitas das informações que ajudaram a construir essa pesquisa. Por meio dos recursos da história oral, foi possível não só mergulhar nas comunidades islâmicas de forma mais acurada como também reconhecer narrativas e visões de mundo muito peculiares.

Por fim, destacamos os dilemas engendrados pelo projeto da modernidade e a forma como o fundamentalismo islâmico, que oculta suas raízes nesse período, se projeta e se manifesta como um fenômeno da pós-modernidade. De que forma a globalização e suas idiossincrasias contribuem para a difusão do islam e do islamismo pelo mundo, seja por meio das migrações de muçulmanos, seja pelos meios virtuais, cujo fenômeno é visto por muitos de forma desconfiada e, às vezes, preconceituosa? A informação tem sido aliada, neutra ou inimiga quando se trata do islam do ponto de vista das comunidades islâmicas de modo geral? Veremos essas respostas, em grande medida, a partir dos registros orais obtidos através dos líderes de muitas das comunidades islâmicas brasileiras e como eventualmente podem se cruzar com as referências filosóficas que embasam essas discussões.

A parte 2, Da gramática do fundamentalismo islâmico à filosofia existencialista, a mais teórica desta pesquisa, vai discorrer sobre os inúmeros termos relacionados ao islam e ao fundamentalismo. Suas origens, os inúmeros usos, as variações terminológicas, os significados e a complexa rede de conceitos que de modo geral adjetivam o islam. À primeira vista, essa discussão pode parecer uma retórica tautológica que mais provoque confusão do que 
esclarecimento. No entanto, a ideia de revisitar esse "inventário" de conceitos se traduz essencialmente na missão de contribuir para com a produção do conhecimento acadêmico e em um segundo momento, informar o brasileiro e suas instituições, que de modo geral, pouco conhecem do islam e são pouco familiares aos termos que são vinculados a ele, uma vez que a maior parte da bibliografia sobre o assunto é estrangeira e menos acessível. Não temos a presunção de equacionar todas diferenças conceituais tão complexas sobre o tema, mas ao menos organizá-las, sistematizá-las e que instigue uma reflexão e não uma opinião tergiversada.

Esperamos que este trabalho possa contribuir no sentido de aprimorar o uso dos termos que muitas vezes são usados de forma muito aleatória, imprecisa, e por vezes, correndo o risco de se criarem estereótipos, especialmente pela mídia. Veremos que cada um dos autores que elencamos para discutir certas terminologias vinculadas ao islam, nem sempre convergem entre si, algo que também pode ser observado nas entrevistas que foram feitas com representantes das comunidades islâmicas no país. Eles se vêem como jihadistas? Fundamentalistas? Há problema em serem chamados de radicais? O que pensam sobre o terrorismo, em geral vinculado à religião que seguem?

Finalmente, esta parte do trabalho oferece uma contribuição às discussões preexistentes e que vem ganhando cada vez mais espaço entre intelectuais sobre o fundamentalismo islâmico que é seu caráter niilista. Por mais contraditório que possa ser associar o niilismo à religião, é possível enxergar elementos comuns que possam explicar o porquê de muitos muçulmanos se radicalizarem e a forma como isso se revela em suas falas e atos. Diante disso, algumas das características dessa miríade de termos se aplicam aos muçulmanos no Brasil? Há indícios de que o país possa gerar ou abrigar possíveis terroristas?

A resposta poderá ser encontrada na Parte 3, Entre o pacifismo das mesquitas e a hostilidade virtual, que faz uma varredura sobre as reais possibilidades de o Brasil ser abrigo de grupos com propósitos terroristas. O foco desta parte conclusiva do trabalho é listar situações em que o Brasil surge como ambiente para a consecução de práticas jihadistas e, ao mesmo tempo, esclarecer se tiveram alguma sustentação nos fatos concretos ou no perfil das comunidades islâmicas que se abrigam no país.

A discussão sobre a recente lei n.13.260/2016², banalmente chamada de "lei antiterrorismo", nos auxiliará nesta empreitada. O contexo de sua criação e seu conteúdo

\footnotetext{
${ }^{2}$ Cf. BRASIL. Lei 13.260 de 16 de março de 2016. Regulamenta o disposto no inciso XLIII do art. $5^{\circ}$ da Constituição Federal, disciplinando o terrorismo, tratando de disposições investigatórias e processuais e reformulando o conceito de organização terrorista; e altera as Leis n ${ }^{\circ} 7.960$, de 21 de dezembro de 1989, e 12.850, de 2 de agosto de 2013. Diário Oficial da União. Brasília, DF. 17 de março de 2016. Seção 1, p.1.
} 
polêmico, são abordados no intuito de observar se de fato sua publicação veio ao encontro da real possibilidade da existência de uma radicalização islâmica em curso no Brasil, ou com outros propósitos mais abrangentes. Seja de uma forma ou de outra, é certo que até aqui ela foi aplicada duas vezes, pela Operação Hashtag e pela Operação Átila (ambas deflagradas pela Polícia Federal). Em todas elas, muçulmanos estavam envolvidos. Entretanto, quem são essas pessoas? Foram doutrinadas nas mesquitas? São "autodidatas" formados em teologia pelas redes sociais?

Nos últimos dois anos a mídia tem dado grande destaque para essas operações, acompanhado de perto seus desdobramentos. No entanto, o acesso às fontes primárias desses processos é extremamente restrito, a julgar pelas negativas de todas as instituições públicas e autoridades com as quais entramos em contato no intuito de poder ter maior acesso a conteúdos exclusivos das investigações e operações policiais envolvendo essa lei e a prisão de muçulmanos. Apesar disso, houve êxito em estabelecer um precioso contato com um dos muçulmanos investigados pela Polícia Federal e Ministério Público Federal, que gentilmente concordou em falar comigo sobre o caso. Suas informações ajudaram a criar uma narrativa mais ponderada sobre a lei antiterrorismo e a obter um outro ponto de vista da situação, revelando que há muitas "pontas soltas" nesse imbricado novelo que é o estudo do islam e as possibilidades da radicalização em solo brasileiro. 


\section{ENTRE DILEMAS MODERNOS E INCERTEZAS PÓS-MODERNAS, AS VOZES E A EXPANSÃO ISLÂMICAS NO BRASIL}

PARTE 1

\footnotetext{
"Nosso desafio final será esclarecer o papel da história oral na formação da identidade numa era global. Eu acho que a influência da globalização, e as tendências em direção a uma cultura mundial homogeneizada, que é dada pela nossa crescente integração na economia global, fazem com que tendamos a fortalecer nossas raizes locais".
}

Paul Thompson. "História oral e contemporaneidade". 


\section{As contribuições de pesquisas brasileiras sobre o islam}

A presença de muçulmanos no Brasil que dentre todos os países latino-americanos é onde estão mais presentes, ainda é um tema pouco explorado tal como afirma Demant (2008, p.187), em que "o islam na América Latina constitui sem dúvida a parte menor - e menos estudada - do mundo muçulmano”. Muitas das obras encontradas são antigas, anteriores a 1990, e a maioria delas trata do assunto em termos historiográficos, literários e especialmente antropológicos. Por exemplo, Moreira (2004) descreve a chegada dos imigrantes muçulmanos ao Brasil enfatizando sua presença em São Paulo e Osman (1998 e 2016) que trata da história oral de famílias imigrantes - em especial libaneses - em São Paulo em que é feito uso da história oral para conhecer o processo migratório de algumas famílias que contam como se consolidaram na cidade, ascenderam socialmente bem como as transformações do modo de vida rural de onde vieram para o urbano em que passaram a viver.

Delval (1992), faz um minucioso apanhado da história das migrações de muçulmanos para diversos países da América Latina e a forma como se organizaram e se desenvolveram nestes países. Reis (1996), por outro lado, se dedica em narrar a história dos negros escravos em nosso país e que por vezes faz referência à influência do islam nestas comunidades coloniais e seus movimentos, como por exemplo, a revolta dos Malês em 1835.

Ainda se remetendo a essa época, Khaled Taky El Din ${ }^{3}$ elaborou um estudo chamado "Muçulmanos no Brasil: estudo sobre o manuscrito 'a diversão do estrangeiro em tudo que é incrível' que continha as memórias do sheikh Abdul Rahman al-Baghdadi, à época, imame da Marinha Otomana, em sua passagem pelo Brasil, especialmente no Rio de Janeiro, Bahia e Pernambuco. Ele teria sido o primeiro sábio do islam em terras brasileiras e veio em um navio Otomano que se desviou de seu caminho e atracou na então capital do país, o Rio de Janeiro em 1866. El Din destaca a situação dos escravos de religião islâmica no país especialmente eventos marcantes como a Revolta dos Malês, já mencionada e estudada por outros autores.

Segundo El Din, os manuscritos revelaram aspectos de sua viagem, dos lugares visitados, as condutas dos muçulmanos, a indignação e as más impressões do sheikh Abdul Rahman al-Baghdadi sobre as condições em que se encontravam os muçulmanos africanos, seu declínio em número e afastamento dos rituais islâmicos: muitos não conheciam os ensinamentos básicos do islam; o processo de batismo compulsório empreendido pela igreja; o

\footnotetext{
${ }^{3}$ Diretor de assuntos islâmicos da Federação das Associações Muçulmanas do Brasil, cofundador da Sociedade Ali Ibn Abi Talib, criador do Conselho Superior dos Teólogos e dos Assuntos Islâmicos no Brasil, fundador do primeiro canal árabe de televisão na Tríplice Fronteira em 1992, e criador dos primeiros sites islâmicos em língua portuguesa, entre eles www.islam.com.br e www.brasileiromuculmano.net/brasileiro .
} 
combate do governo aos aspectos ligados ao islam; e até mesmo distorções da religião causadas pelo intérprete que acompanhava muitos desses muçulmanos que deliberadamente contribuía para o afastamento e o descumprimento de regras importantes da religião, por exemplo o consumo de álcool. O intérprete, segundo o manuscrito, que autorizava essas práticas equivocadas, era um "judeu maligno" que assim como outros, se infiltrava entre os muçulmanos desvirtuando-os da religião.

Outro influente autor no estudo das comunidades muçulmanas no Brasil é Paulo Pinto (2005), que a partir de um olhar antropológico sobre a presença de muçulmanos no Rio de Janeiro, São Paulo e Paraná, dispõe de robustas informações sobre as ações de sociedades beneficentes islâmicas assim como suas formações. Em outra obra, Paulo Pinto (2010) além de analisar os novos espaços do islam no mundo, no caso Europa e Brasil, também discorre sobre aspectos importantes da religião islâmica como seus pilares, as divisões sectárias e os embates que engendram, além de traçar um panorama histórico do islam com base em pensadores islâmicos importantes desde reformistas aos fundamentalistas dos séculos XX e XXI.

Em sua dissertação de mestrado, Junior (2011) estuda uma comunidade sunita no Rio de Janeiro desde as origens de sua imigração à cidade, à conformação da Sociedade Beneficente Muçulmana do Rio de Janeiro até a criação da mesquita da Luz no bairro da Barra da Tijuca. Também discorre sobre os rituais, festas e códigos dessa comunidade bem como as formas que são transmitidas e comunicadas as doutrinas da fé islâmica, e por fim tentando identificar relações entre a ciência e o islam.

No trabalho de Oliveira (2006), são destacados assuntos como a incerteza com relação ao número de muçulmanos que vivem no Brasil e a questão da formação de novos sheikhs, que com o domínio do português se torna mais fácil o acesso às suas pregações, assim como sua função de promotores do islam. Além disso, busca compreender a formação e o funcionamento de sociedades beneficentes islâmicas no país e analisa o crescimento do número de convertidos ao islam e as tensões que passam a existir entre brasileiros muçulmanos e os árabes, algo recorrente em outros estudos. Finalmente, aborda a forte influência da escola wahhabita nessas comunidades, que com investimento saudita, constroem mesquitas e desenvolvem seus projetos, ainda que tais comunidades e mesquitas sejam núcleos isolados, sem conexão entre si o que suscita a falta de uma autoridade - algo comum no mundo muçulmano - que represente o islam no Brasil e que seja reconhecido por todos que aqui vivem.

Sob um ponto de vista mais religioso, destaco o trabalho de Sena (2007) que estuda a comunidade islâmica de Belo Horizonte/MG e suas transformações com o passar do tempo, sendo inicialmente composta por imigrantes e atualmente com maior presença de convertidos. 
A partir de entrevistas realizadas o autor estabeleceu um perfil para aquela comunidade e a forma como vive sua religiosidade.

Em outra perspectiva, Montenegro (2002), que é considerada uma das pioneiras na pesquisa sobre as comunidades islâmicas no Brasil, e Castro (2007), analisam de que maneira o islam é percebido pela mídia e as possíveis implicações de falsos estereótipos que ela pode ajudar a formar na população que de forma geral desconhece o islam e seus seguidores.

Outra importante referência é Ferreira (2009a), que entre suas muitas contribuições, também sob o olhar da antropologia, analisa diversas comunidades islâmicas no Brasil, especialmente São Paulo, em que estabelece paralelos e diferenças entre os nascidos muçulmanos e os convertidos, ou nas palavras da autora, "revertidos"4. A autora também é responsável por um site que divulga eventos, textos, documentários e informações sobre o islam ${ }^{5}$, em grande parte como produto de sua tese de doutorado defendida em 2007. Em sua pesquisa a autora abordou de forma robusta diversos aspectos etnográficos, religiosos - festas, rituais, o papel dos sheikhs - e sociais, como as relações entre brasileiros muçulmanos (convertidos) e os árabes muçulmanos, lançando mão de entrevistas e de uma intensa imersão cultural ao participar de pregações, eventos e acampamentos da WAMY (World Assembly of Muslim Youth $)^{6}$, tendo por base as comunidades de São Paulo e São Bernardo do Campo.

Em outro trabalho, Ferreira (2009b) inicialmente discute sobre a questão dos "revertidos" e as tensões geradas entre eles e os muçulmanos árabes, algo que é recorrente em diversos trabalhos sobre o islam no Brasil. Em seguida ela relata minuciosamente os aspectos ligados à oração islâmica, um importante pilar dessa religião. A importância das suratas do Alcorão, a questão do idioma árabe e as traduções do livro sagrado que são evitadas com o intuito de evitar distorções, a recitação, as súplicas, o chamamento para a oração através dos mиezins, as regras de purificação a partir das abluções e os gestos executados durante a salat (oração), inclusive exibidas em seu trabalho através de desenhos, são temas pelos quais a autora perpassa.

Analisando a comunidade do Rio de Janeiro, Chagas (2006) abordou de que maneira o islam, religião de caráter transnacional, se articula com as formas de vivência da religião localmente usando como metodologia a observação desse grupo. O trabalho também se ocupa em caracterizar a comunidade carioca no aspecto étnico. Nesse sentido, contrariamente às

\footnotetext{
${ }^{4}$ Termo principalmente usado entre muçulmanos em lugar de convertidos. Para eles, todos nascem muçulmanos e embora alguns professem outra religião e tenham se "desviado" do caminho, um dia retornarão ao islam.

${ }^{5}$ http://bit.ly/2KITM7c (acesso em 20.10.2016).

${ }^{6}$ Assembleia Mundial da Juventude Islâmica.
} 
comunidades de São Paulo e Foz do Iguaçu, formadas por árabes e seus descendentes, revelando um caráter islâmico mais etnicizado, no Rio de Janeiro a sociedade islâmica é composta principalmente por convertidos, se distanciando do marcador árabe.

Marques (2007 e 2008) é mais uma autora que lida com a questão do islam no Brasil em seus trabalhos de mestrado e doutorado. No primeiro caso ela se dedica a observar os motivos que levam os brasileiros a se reverterem ao islam e os desafios que essa mudança engendra não apenas do ponto de vista religioso, mas também social, identificando diversas tensões nas comunidades islâmicas entre convertidos e "nascidos-muçulmanos" em geral árabes. Essa constatação, aliás, se faz presente na fala de um dos meus informantes, Ahmed Al-Khatib ${ }^{7}$ que diz:

Então eles [muçulmanos árabes] não enxergam eles [revertidos brasileiros] com bons olhos. Então eles são assim....meio...os brasileiros são meio discriminados no meio da comunidade muçulmana árabe...e poucos sheikhs que falam o português, então eles são amigos daqueles que falam o português, que estão com eles né. O sheikh Abdu Nasser que nasceu aqui, o sheikh Jihad que nasceu aqui, eles são brasileiros, mas eles não têm esse tempo, a realidade deles não permite de eles estarem com os jovens né?

Indo ao encontro do trabalho de Chagas (2006), um desses desafios são as relações, por vezes tensas como foi detectado em Belo Horizonte/MG e Juiz de Fora/MG, entre os muçulmanos árabes e os convertidos, destacando o despertar de um sentimento antiarabista, não apenas em razão do menor conhecimento da religião, mas especialmente com relação à dificuldade com o idioma árabe. Também contempla em seus estudos o papel da mídia, a divulgação do islam no país, os conflitos e adaptações de práticas religiosas. Já no doutorado, a autora nessa mesma linha de pesquisa, promete oferecer um estudo comparativo das comunidades islâmicas brasileiras com aquelas que se estabeleceram em Portugal.

Barros (2013), tomando como recorte a Mesquita da Luz no Rio de Janeiro e com base em entrevistas, se debruça sobre os motivos das conversões de mulheres ao islam, que vão desde a perda de padrão de vida e problemas conjugais até problemas de saúde, destacando que experiências de injustiça, dor e sofrimento são em geral explicações para a inserção no islam. Além disso, a autora investiga como a reconfiguração do "self religioso", como aponta, se manifesta em sua forma de se relacionar com o mundo, com a feminilidade da mulher e com os novos códigos de comportamento que devem ser seguidos a partir de então.

\footnotetext{
${ }^{7}$ Entrevistado em 23.09.2016 via skype. Ele já foi sheikh da Mesquita de Campinas/SP e agora dirige uma ONG chamada Associação Livro Aberto (disponível em http://bit.ly/2MJil0V acesso em 20.10.2016).
} 
$\mathrm{Na}$ área jornalística, ressalto o trabalho de mestrado de Castro (2007) em que toma como objeto de pesquisa o estudo dos recortes textuais de dois dos jornais brasileiros de maior circulação (O Estado de S. Paulo e Folha de S. Paulo) e de que forma eles trataram o Oriente Médio seis meses antes e seis meses depois dos atentados de 11 de setembro de 2001. No período anterior ao trágico episódio é dada maior ênfase no conflito Israel-Palestina, ao Afeganistão e à presença do Taleban, e o conflito na Macedônia ligado aos albaneses muçulmanos. Posteriormente nota-se um aumento no número de notícias, textos e artigos opinativos sobre o Oriente Médio e com o terrorismo em evidência. Entre as conclusões apontadas pela autora, observa-se que a violência de árabes e muçulmanos foi destacada no primeiro período, enquanto isso, pós 11/09 a violência contra eles foi de certa forma suavizada. Além disso, os jornais contribuíram para a difusão de estereótipos com relação aos árabes, muçulmanos e o próprio Oriente Médio de que são pessoas e local de violência e opressão. Essa assertiva, segundo a autora, corrobora com a hipótese de que a mídia nacional carrega e difunde o orientalismo no sentido saidiano do termo.

Interessante notar que dentre as diversas pesquisas finalizadas ou em curso que têm por objeto de estudo as comunidades islâmicas no Brasil, grande parte delas é desenvolvida por mulheres, algo que é percebido tanto por Ferreira (2007) como por Marques (2008, p.04-05), que afirma e instiga:

as "pesquisadoras" têm se destacado, em número, em relação aos "pesquisadores", assim como as mulheres também têm sido o principal foco das pesquisas. Em relação a esse fato, considero como hipótese a maior facilidade de contato entre "pesquisadoras" e "muçulmanas". Embora não seja esse um dado relevante para meus estudos, destaco-o como forma de provocar e incentivar outros pesquisadores a percorrer esse tema tão polêmico e controverso na atualidade nacional e internacional.

$\mathrm{O}$ fato de a maioria das pessoas que pesquisam o islam no Brasil serem mulheres, por um lado facilita o trânsito, a inserção e a criação de laços de confiança entre as pesquisadoras e as mulheres muçulmanas. Não que isso represente uma falta de acesso aos homens, especialmente aos sheikhs, que sabem do caráter científico ao qual se presta a pesquisa e sua neutralidade no momento do trabalho de campo. Mesmo assim, o pesquisador pode ser submetido aos códigos religiosos e até mesmo culturais, seja com o uso do hijab (no caso de uma pesquisadora), na forma de agir (dependendo do interlocutor), ou no local de observação de um sermão em que homens não se misturam com mulheres, por exemplo.

Ferreira (2008, p.29) sintetiza esse argumento dizendo que 
no campo, o ser mulher, ganha destaque, porque tenho um lugar específico entre eles - o lugar que o grupo reserva ao sexo feminino -, embora tenha me esforçado para me aproximar tanto de homens quanto de mulheres, e ambos são meus interlocutores [...] É evidente que minha performance é situacional, e isso não apenas me ajuda a perguntar as mesmas coisas, com ênfases e modos diferentes, mas também a circular com a "mesma" desenvoltura pelos espaços masculinos e femininos. Andar por entre as veredas islâmica é como aprender a circular em universos únicos, onde a espacialidade também é constituída de muitos ruídos e textos que contribuem para a constituição da performance assumida. É um universo de meandros, gentilezas, de comportamento recatado, olhar baixo, ouvidos atentos, gestos comedidos, e até mesmo extravagantes, a depender da situação.

Ainda assim, para ser mais plenamente "aceita" no grupo de mulheres muçulmanas a estratégia descrita pela autora foi falar de seus filhos e da maternidade, fatores que geram empatia.

No meu caso, sendo homem casado, a proximidade com mulheres muçulmanas é restrita e meus contatos com elas quando em festas, eventos, jantares entre outras atividades, é efêmera. Percebo em muitos momentos que se formam "rodinhas" de conversa e tão logo me dou conta, homens e mulheres estão apartados.

Finalmente, o campo de menor contribuição para o estudo das religiões, e ainda menos sobre o islam no Brasil, é o da geografia das religiões, uma proposição temática que de modo geral estuda o papel do sagrado e do profano na organização espacial. Nessa linha é possível citar os trabalhos de Santos (2011) e Rosendahl (2002).

No primeiro caso, discute-se o que o autor chama de "geopolítica da religião" com ênfase nas principais religiões no Brasil, sua pluralidade e distribuição no território. Também investiga o porquê do crescimento da população "sem religião" e a suposta anarquia religiosa, conceito impreciso devido à sua polissemia, definido por ele como a soberania das pessoas em relação à fé, prescindindo de lideranças e instituições religiosas que possam controlá-las. Algo que soa como um autodidatismo religioso, termo que suponho ser mais adequado. No entanto ao tratar das religiões étnicas tal como enuncia, entre elas o islam, dedica menos de dez páginas de seu trabalho para isso, fazendo uma análise meramente descritiva.

No segundo caso, a autora debate de uma forma mais teórica a questão da territorialidade, o conceito de sagrado e profano, as migrações (peregrinações) religiosas e as difusões de algumas religiões pelo mundo, reservando pouco espaço para tratar do islam. 
Outro ponto a ser sublinhado é com relação aos anos de publicação dos trabalhos aqui aventados. A partir dos anos 2000, a quantidade de pesquisas, teses, dissertações e artigos se torna muito mais abundante. Igualmente, nota-se a ampliação de objetos técnicos como mesquitas, sociedades beneficentes, mussalas, escolas e frigoríficos halal $^{8}$ que são mais facilmente notados na paisagem de muitas cidades, especialmente no sul e sudeste do país.

Em primeiro lugar, dentre as possíveis causas desse incremento estão os eventos de grande repercussão mundial como os atentados de 11 de setembro de 2001, e todos os posteriores ataques terroristas que ocorreram em diversas partes do mundo, especialmente no Ocidente. Em segundo, a expansão do número de muçulmanos ${ }^{9}$ seja via imigração ${ }^{10}$, interesse ou curiosidade despertados pela novela "O Clone” veiculada entre 2001 e 2002 que também contribuiu para a conversão de muitos brasileiros.

Cabe lembrar do interessante trabalho de Porto (2012), que analisa o alcance e importância da mídia televisiva no Brasil como formadora de opinião e socializadora de informações, e a forma com que esta teledramaturgia retratou alguns valores islâmicos e da cultura árabe mediados por um enredo cativante e por seus personagens icônicos.

O autor demonstra como a novela exibiu elementos de construções literárias orientalistas, típicos de "As mil e uma noites", evocando certos esterótipos, e propalou alguns discursos que se remetiam às relações entre o Ocidente e o Oriente, à modernização e aos costumes religiosos. Diante disso, revisitou conceitos como o neofundamentalismo de Olivier Roy, o escrituralismo de Clifford Geertz e o ocidentalismo de Ian Buruma e Avishai Margalit que de alguma forma se manifestaram na trama de acordo com as falas e o perfil de alguns de seus personagens.

Nota-se que o estudo das comunidades islâmicas no Brasil ao longo dos anos vem adquirindo certa robustez em sua quantidade. Mas em termos temáticos observa-se que os estudos mais consistentes são produzidos pela antropologia e etnografia sobre algumas comunidades especialmente no eixo Rio-São Paulo.

No entanto, a contribuição que está sendo proposta é trazer à tona não um perfil de uma determinada comunidade do ponto de vista das conversões, dos rituais, das tensões entre muçulmanos árabes e brasileiros convertidos ou da influência da mídia sobre essas comunidades, mas de observar a possibilidade da presença de grupos ou discursos fundamentalistas salafistas e jihadistas no país e como as principais comunidades de

\footnotetext{
${ }^{8} \mathrm{Idem}$. Termo em árabe refere-se àquilo que é lícito, permitido.

${ }^{9} \mathrm{Cf}$. http://bit.ly/2KFU2Uw (acesso em 02.10.2016).

${ }^{10} \mathrm{Cf}$. http://bit.ly/2NnipVq (acesso em 20.10.2016).
} 
muçulmanos interpretam e pensam o fundamentalismo, o extremismo religioso, a radicalização e o terrorismo, e se as condições em que vivem no Brasil assim como os eventos mundiais envolvendo muçulmanos oferecem algum suporte para supor que há indícios no país de que seja possível fala em um ativismo islâmico no Brasil.

O período da globalização como produtora e difusora de modernizações diversas (Santos, 2002), poderia estar na origem de fundamentalismos (Esposito, 2002; Armstrong, 2000; Fukuyama, 2005; Demant, 2008)? Caso isso se confirme, qual a forma tomada por esses possíveis grupos fundamentalistas?

Seria restrita aos meios eletrônicos e virtuais, tomaria ares de manifestações públicas ou permaneceria fechada em seu próprio círculo de convivência? Como consequência, isso indicaria uma possível fraqueza de alguns Estados que não são capazes de controlar grupos mais radicais que possam fazer uso de elementos modernos contra o Ocidente em ataques terroristas (Fukuyama, 2004)?

\section{A expansão islamista no Brasil: o "logos" territorial e o "mythos" da fé}

Parafraseando Armstrong (2009), o título desse capítulo almeja lançar luz sobre a questão territorial do islam no Brasil. Ainda que a autora explore os conceitos de outra forma, como veremos no decorrer desta tese, eles também podem servir para mostrar que território e religião, o material e o imaterial, fazem parte de um todo.

Autores como Atwan (2008) e Roy (2002 e 2008), falam de desterritorialização, especialmente levando-se em consideração o avanço das redes virtuais para a disseminação do fundamentalismo e para a criação da "ummah" virtual que aos poucos substitui a real. Roy (2008, p.303) afirma que

il ne s'agit pas de dire que l'internet a remplacé le territoire. La tendence est certaine, mais la notion de lieu fait toujours sens: c'est plutôt le territoire qui s'efface, ou plutôt ce sont les nouveaux territoires qui sont devenus virtuelles.

La déterritorialization va de pair avec la recherche de territoires imaginaires (Oummah, Terre Saint, Gange, Lhassa.... ${ }^{11}$.

\footnotetext{
11 "Não quer dizer que a internet tenha substituído o território. A tendência é certa, mas a noção de lugar faz sempre sentido: é antes o território que se desvanece, ou melhor, são os novos territórios que se tornaram virtuais. A desterritorialização anda de mãos dadas com a busca de territórios imaginários (Ummah, Terra Santa, Ganges, Lhasa...)" (tradução minha).
} 
A internet como ferramenta para a prática da cyberjihad, atualizou a agenda de muitos grupos islamistas que fizeram de sua ideologia algo muito mais invasivo e fluido ao mesmo tempo em que as restrições físicas e geográficas se tornam cada vez mais irrelevantes.

Entretanto, não se pode aceitar passivamente que o espaço ou o território tenham perdido força no presente período.

Pelo viés econômico, Harvey (2007, p.265) sustenta que

a queda das barreiras espaciais não implica o decréscimo da significação do espaço. Vemos hoje, e não é pela primeira vez na história do capitalismo, evidências que apontam para a tese oposta. $\mathrm{O}$ aumento da competição em condições de crise coagiu os capitalistas a darem muito mais atenção às vantagens locacionais relativas, precisamente porque a diminuição das barreiras espaciais dá aos capitalistas o poder de explorar, com bom proveito, minúsculas diferenciações espaciais.

Ao encontro desse pensamento, Santos (2002, p.84) assevera que

o território não é apenas um conjunto de formas naturais, mas um conjunto de sistemas naturais e artificiais junto com as pessoas, as instituições e as empresas que abriga não importa seu poder. O território deve ser considerado em suas divisões jurídico-políticas, suas heranças históricas e seu atual conteúdo econômico, financeiro, fiscal e normativo. É desse modo que ele constitui, pelos lugares, aquele quadro de vida social onde tudo é interdependente, levando à fusão entre o local, global invasor e nacional sem defesa.

Levar em consideração o aspecto territorial é bastante relevante para a compreensão da dinâmica da realidade e das relações que engendra. Nesse caso basta observar a densidade populacional islâmica em Foz do Iguaçu/PR ${ }^{12}$, a porosidade da Tríplice Fronteira ${ }^{13}$ e de acordo com alguns meios de comunicação ${ }^{14}$, local que estava na agenda norte-americana de luta contra

\footnotetext{
${ }^{12}$ Cidade turística, localizada na Tríplice Fronteira (Brasil, Paraguai e Argentina), um dos focos dos estudos e relatórios aqui apresentados e que tem uma grande concentração de muçulmanos. Acredita-se que cerca de $10 \%$ da população da cidade é muçulmana. Segundo o IBGE, em 2016 estimava-se que a população total do município era de aproximadamente 263 mil habitantes

${ }^{13}$ PAULO PINTO; MONTENEGRO, S. 2008.

${ }^{14}$ Em 06.04.2011 a revista Veja, mídia de grande circulação nacional, em sua capa trazia o título: "A rede do terror no Brasil". Segundo a revista, a CIA, FBI, Interpol, Polícia Federal e Tesouro Americano teriam provas de que extremistas islâmicos usam o país como base de operações para possíveis atentados. Na reportagem a revista aponta cinco possíveis suspeitos de ligação com o terrorismo no Brasil especialmente em Foz do Iguaçu/PR e São Bernardo do Campo/SP.

Em 22 e 23.07.2016 o jornal O Estado de S. Paulo também publicou matérias sobre a prisão de 14 suspeitos de planejar atentados terroristas no Brasil em meios aos jogos olímpicos.

https://bit.ly/1MypXCD (acesso em 26.12.2016).
}

https://bit.ly/2PFKJqM (acesso em 26.12.2016). 
o terrorismo justamente pela grande concentração islâmica. São Paulo e São Bernardo do Campo/SP também possuem grande quantidade de muçulmanos em número absolutos e com grande presença de instituições islâmicas (mesquitas, mussalas, sociedade beneficentes etc.). Esta última cidade, inclusive, é apontada como a capital islâmica do Brasil (Ferreira, 2007 e 2009, Oliveira, 2006, e Marques 2008).

Esta presença condiciona o território, criando objetos, materialidade, rugosidades e estabelecendo uma rede de relações e até mesmo de normas que se manifestam no espaço. Em Foz do Iguaçu/PR há diversas ruas com nomes que remetem ao mundo muçulmano e ao Oriente Médio: Rua Palestina, Av. República do Líbano, Rua Meca (rua em que está situada a Mesquita Omar Ibn Al-Khattab). Restaurantes, escolas, lojas, sociedade beneficentes, frigoríficos hallal entre outros equipamentos também revelam na paisagem das cidades. É comum ir aos supermercados em Foz do Iguaçu/PR, por exemplo, e encontrar funcionárias usando o hijab. Isso ajuda a reforçar a identidade do lugar em comunhão com a sociedade que ali estabelece seu quadro de vida.

Montenegro (2013) analisa os discursos identitários dos imigrantes da Tríplice Fronteira, estabelecendo três categorias de narrativas: a) aqueles que são identificados apenas pelo trabalho, como uma "comunidade econômica" tal como são chineses e coreanos. Estes seriam comerciantes "sem muito tempo para a religião"; b) os que se identificam como membros da comunidade muçulmana, e que compartilham valores religiosos no sentido de torna-los menos "exóticos" ao olhos de brasileiros e paraguaios; c) daqueles que, ainda vinculados com o segundo grupo, projetam a diluição, transformação ou a fusão de sua identidade com os estilos de vida e práticas nativas ligadas aos contextos em que os imigrantes habitam.

Do ponto de vista religioso, o próprio Roy (2002, p.126) argumenta que

les musulmans en Occident tendent d'abord à se regrouper sur une base locale (mosque de quartier, association d'étudiants, centre culturel) - ce qui permet d'ailleurs de vivre sans drame l'hétérogénéité naturelle de la population musulmane, à la fois de par ses origines et dans as demande religieuse ${ }^{15}$.

Mesmo no caso de ações jihadistas, que também se apropriam das benesses da globalização para desenvolver e difundir sua ideologia - criando uma cyberjihad como outrora citado - elas não prescindem do território. Roy (ibid., p.177) confirma esse ponto de vista ao

\footnotetext{
15 “Os muçulmanos no Ocidente tendem a se agrupar em uma base local (mesquita de bairro, associação estudantil, centro cultural) - o que permite viver sem drama a heterogeneidade natural da população muçulmana, de uma vez, de uma vez, por suas origens e em uma demanda religiosa" (tradução minha).
} 
afirmar que "pour les djihadistes [...] eux se réclament d'une estratégie et il faut bien qu'ils inscrivent leur action militaire sur un territoir" ${ }^{\prime 6}$.

As fotos ${ }^{17}$ abaixo mostram a presença de alguns desses equipamentos nas cidades pelas quais passei para a consecução das entrevistas.

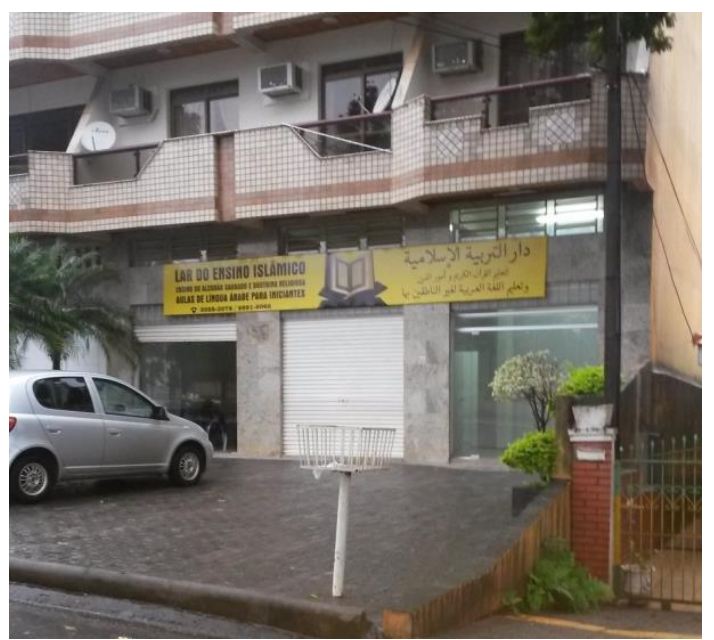

Foto 1 - Escola para Ensino do Alcorão e língua Árabe Foz do Iguaçu/PR

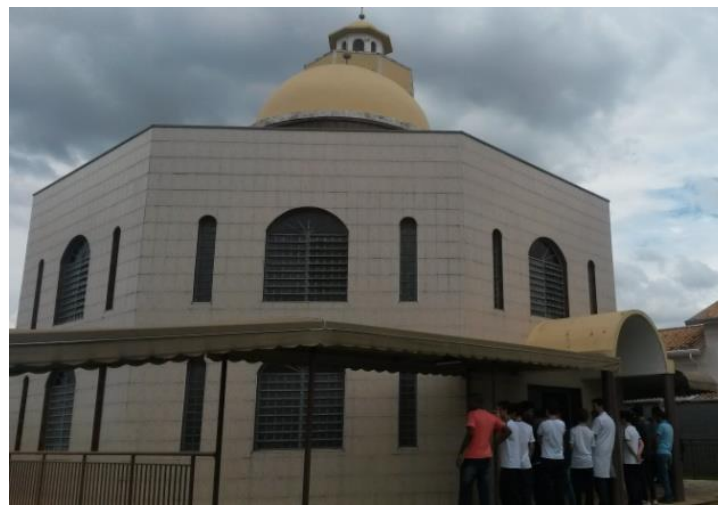

Foto 3 - Mesquita de Campinas/SP (SIC)

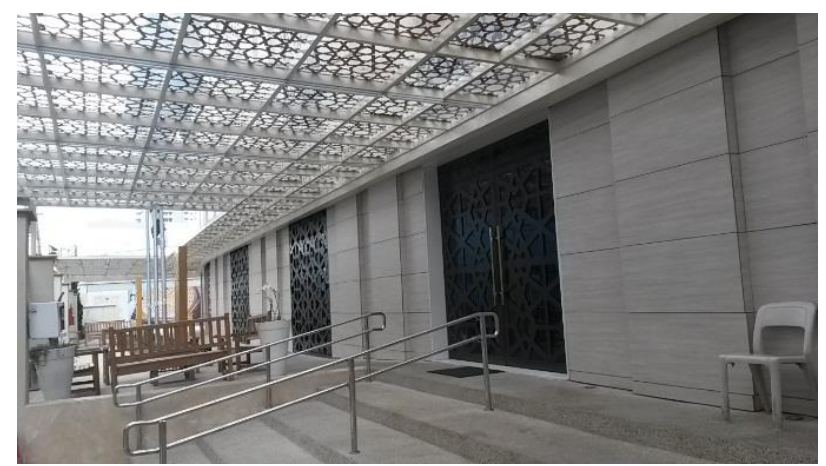

Foto 5 - Mesquita Brasil - São Paulo/SP

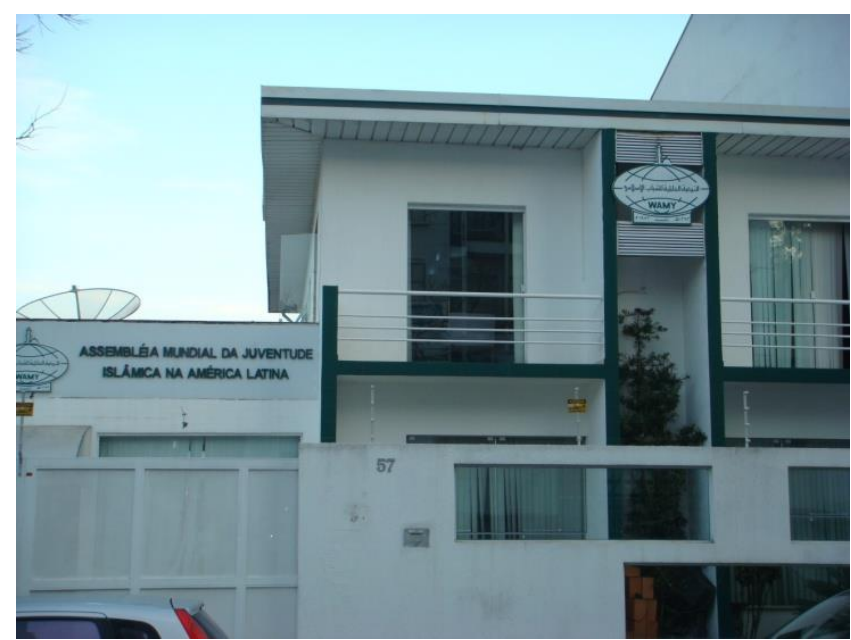

Foto 2- WAMY - São Bernardo do Campo/SP

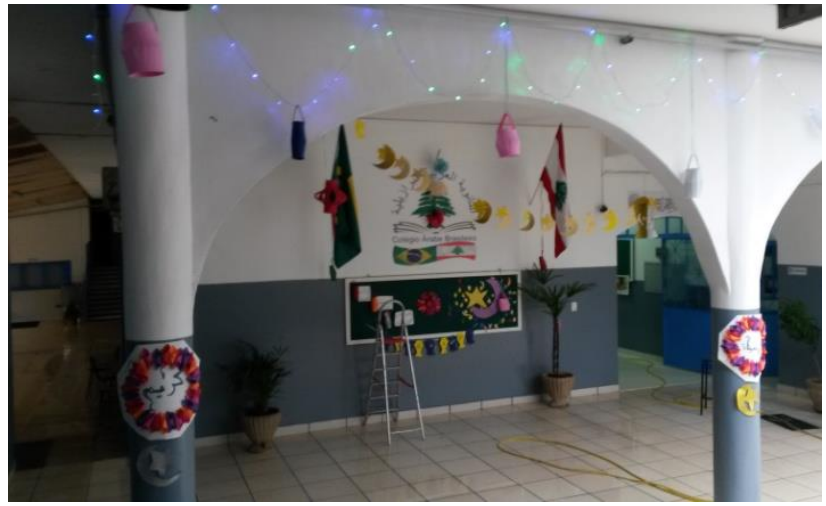

Foto 4 - Colégio Árabe-Brasileiro - Foz do Iguaçu/PR

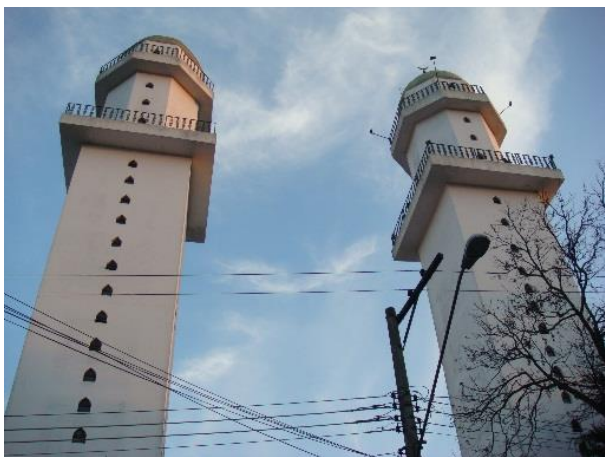

Foto 6 - Mesquita Abu Bakr Assadik - São Bernardo do Campo/SP

\footnotetext{
16 "para os jihadistas [...] eles reivindicam uma estratégia e é necessário que registrem sua ação militar em um território" (tradução minha).

${ }^{17}$ Todas elas tiradas por mim.
} 


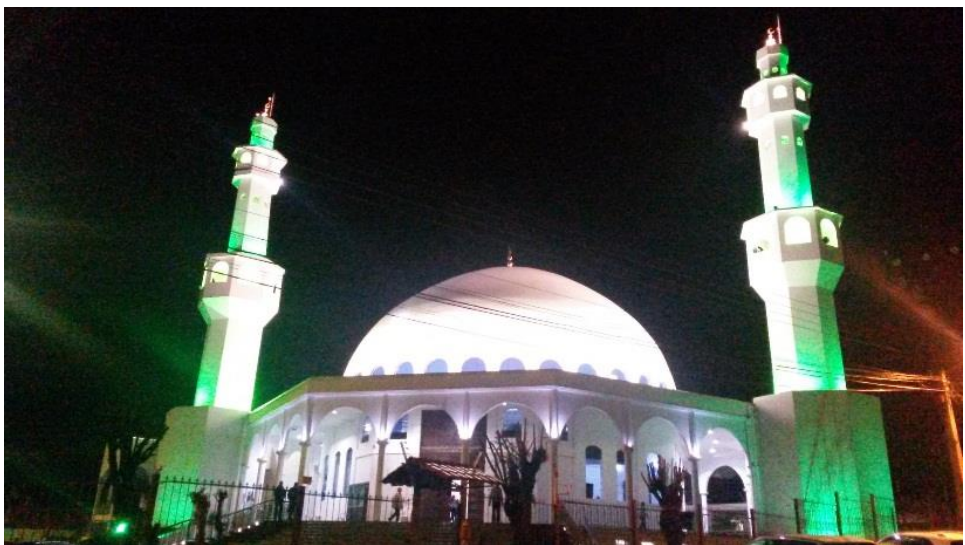

Foto 7 - Mesquita Omar Al-Khattab - Foz do Iguaçu/PR

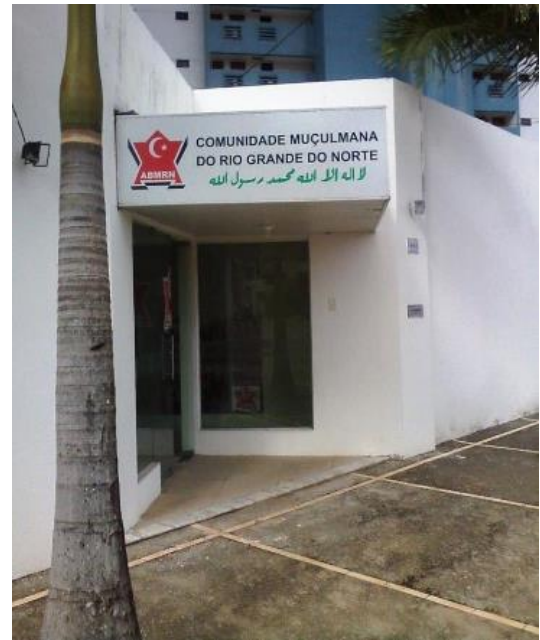

Foto 8 - Sociedade Muçulmana Beneficente de Natal/RN

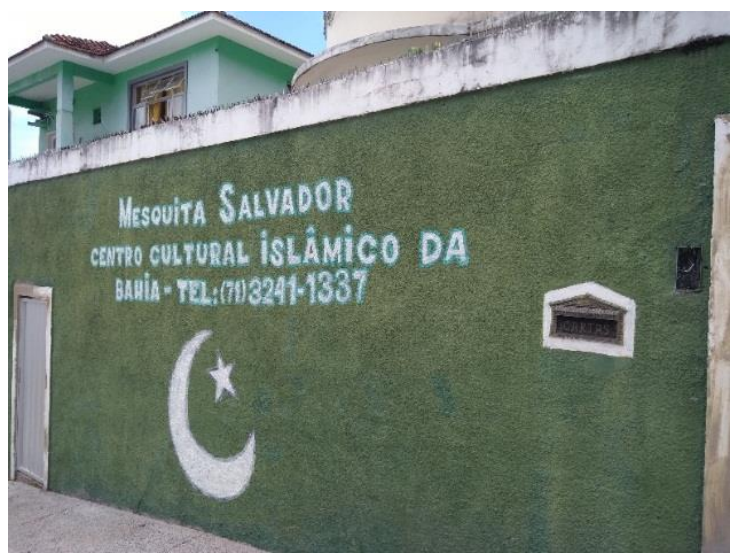

Foto 09 - Centro Cultural Islâmico da Bahia (Salvador/BA)

O dado virtual oferecido pela globalização, que pretende diminuir o peso dos lugares através da ideia de desterritorialização, na verdade o reforça. Os objetos se ancoram no território passando a compor a paisagem e a estruturar as relações sociais, no caso, religiosas.

A geometria espacial das redes geográfias e as racionalidades presentes no território ("logos"), substrato técnico, científico e informacional para o quadro de vida humano é indissociável dos usos que a dinâmica social faz dele. Para Armstrong (2009), a modernidade ocidental é produto do "logos" que se renova e se moderniza sempre.

A dinâmica social, por sua vez, como parte dessa totalidade, interage com essa modernidade das formas mais variadas: assimilando-a, reproduzindo-a, aperfeiçoando-a e, por vezes, sendo excluída por ela (tem termos das desigualdades socioespaciais) ou resistindo a ela. Aqui é onde entra o "mythos" religioso: constante, praticamente imutável, irreversível, livre de empiria, e que se apóia em raízes pré-modernas que subsistem nos cultos, rituais, cerimônias, festas e até mesmo na estética. Esse embate é revelado pelo território que expõe os lugares em 
que se concentram as pessoas que usam as formas modernas (redes virtuais ou físicas) para suas práticas religiosas.

A presença das comunidades islâmicas, assim como de outros credos e demais seguimentos sociais, condiciona o território, criando objetos, materialidade, e estabelecendo uma rede de relações e até mesmo de normas que se manifestam no território.

Com relação às normas, pode-se identificar aquela que permite que mulheres muçulmanas possam tirar documentos e cujas fotos possam ser feitas com o uso do véu, algo que não era possível anteriormente. Uma das responsáveis pela alteração dessa lei foi a vereadora Anice Ghazaoui, entrevistada em 08 de julho de 2015 em Foz do Iguaçu/PR. Nas palavras dela:

existe uma normativa no CONTRAN...O Detran/PR tinha uma interpretação de que poderia usar o véu para tirar carteira de motorista assim como nos documentos do Estado, como o RG. Depois houve uma nova interpretação por parte do Detran do Paraná, proibindo o uso do véu nas carteiras de motorista e outros documentos. E passou a ter constrangimento, pois a partir do momento que se decide usar o véu, obrigar a tirá-lo passou a ser visto como uma forma de agressão [...] policiais constrangiam as mulheres, colocando o rosto dentro do carro, perto do rosto delas...busquei ajuda e informações em São Paulo, como era a interpretação da lei em São Paulo, pedi orientações dos sheikhs de São Paulo, consultei mulheres que usam o véu em São Paulo, fizemos audiências públicas...criou-se uma comissão para debater esse tema, fui à Curitiba e me reuni com o diretor geral do DETRAN do Paraná, dei um parecer como advogada e levei o parecer do procurador do Estado do Paraná a favor da resolução. Enfim, após vários debates consegui com que mudasse a interpretação da lei.

O diagrama abaixo tenta ilustrar, grosso modo, as ideias expostas até aqui. 


\section{Diagrama 2 - Totalidade Dinâmica e o território usado.}

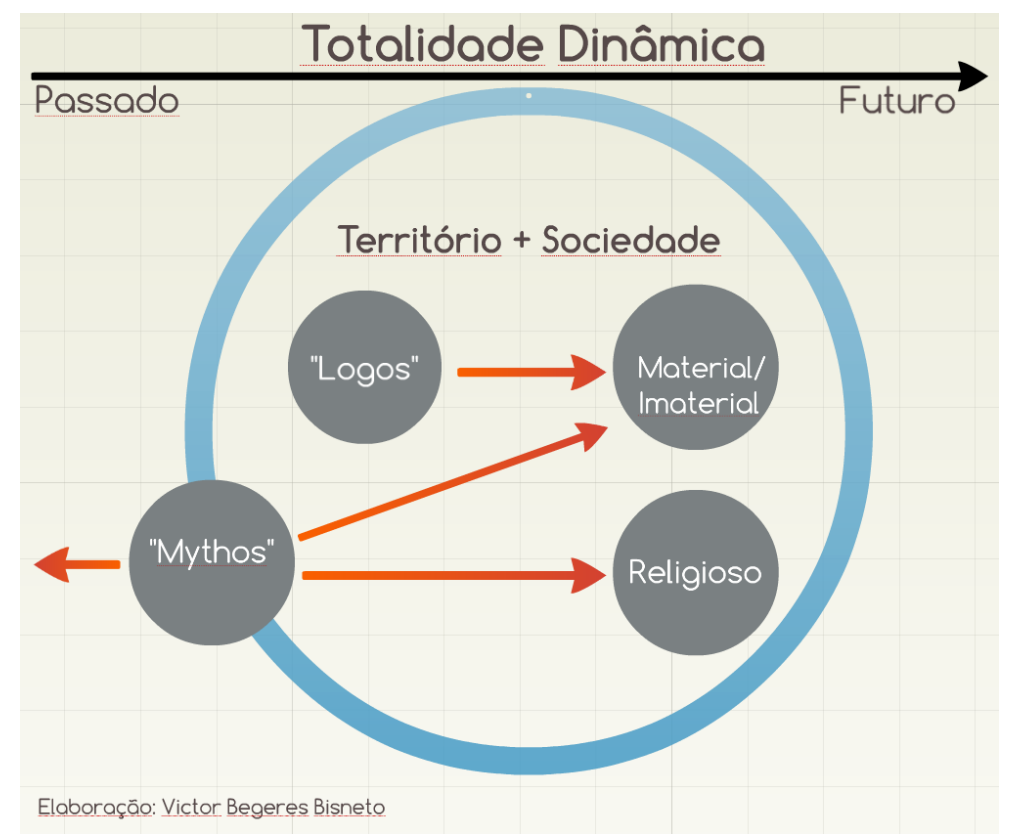

A totalidade dinâmica expressa o conjunto dessas categorias submetidas à passagem do tempo histórico, em que território e sociedade se fundem criando formações socioespaciais particulares (características únicas) em cada lugar do mundo. O “logos”, aqui, está relacionado ao material, às racionalidades, à ciência, às ténicas e ao imaterial, nesse caso, composto pelas informações e pelo conjunto de normas que regem o território e a sociedade. Esta categoria é fiél à passagem do tempo, ainda que a sua distribuição e uso não sejam iguais em todos os lugares do planeta.

Por outro lado, o "mythos" está associado às práticas religiosas, que por sua vez necessitam das bases materiais e imateriais para que possam se propagar de forma mais fluída (com uso da internet, por exemplo), e, ao mesmo tempo, criando vínculos com o território, dotanto aquele espaço de uma certa identidade mobilizada pela comunidade que ali está.

No entanto, como mostra o diagrama 2, o "mythos" está parcialmente dentro dessa totalidade dinâmica. Ele não responde de forma coerente ao transcorrer do tempo. Isto porque ele está mais preso ao passado e à constância das tradições que ele encerra. É no atrito gerado entre o "mythos" e essa totalidade dinâmica que podem ser encontrados grupos que, resistentes à modernização, se voltam contra ela nas mais variadas formas de fundamentalismo como veremos adiante.

Sobre a presença dessas comunidades islâmicas na América Latina e especialmente no Brasil, objeto de nosso estudo, seu número se revela como um dado complicado. 
Há que se ressaltar que não há dados estatísticos fidedignos a respeito desta população em específico. Dados de $1983^{18}$ estimavam cerca de 200 mil, em grande parte ligado à imigração árabe. Entidades muçulmanas ${ }^{19}$, entretanto, afirmam que o número é por volta de um a três milhões de seguidores. A FAMBRAS (Federação das Associações Muçulmanas do Brasil) aponta para cerca de 800 mil $^{20}$ muçulmanos no país. Dados que soam exagerados, talvez como resultado de uma retórica que tais comunidades usem para colocar o islam no mapa religioso brasileiro e que possa contrapor discursos estigmatizantes, conforme aponta Paulo Pinto (2013).

Em outra referência, um estudo realizado pelo Pew Research Center apontava em 2000, cerca de 172 mil muçulmanos no Brasil. Em 2010, o número chegou a 204 mil $^{21}$, um aumento de cerca de $15 \%$. Hoje, uma estimativa razoável seria por volta de 400 mil muçulmanos.

O IBGE, por sua vez, calcula que o número de pessoas que seguem o islam não passa de 40 mil indivíduos face aos mais de 200 milhões de brasileiros, conforme indica a tabela abaixo.

Tabela 1 - Censo do IBGE 2010: População e Religião

\begin{tabular}{|l|r|}
\hline \multicolumn{1}{|c|}{ Religião } & \multicolumn{1}{c|}{ Quantidade da População } \\
\hline Católica Apostólica Romana & 123.280 .172 \\
\hline Evangélica & 42.275 .440 \\
\hline Judaísmo & 107.329 \\
\hline Islamismo & 35.167 \\
\hline
\end{tabular}

Fonte: IBGE, censo de 2010.

O mapa 1 abaixo ilustra como, segundo o IBGE, essa população está distribuída.

\footnotetext{
${ }^{18}$ Delval, 1992.

${ }^{19} \mathrm{http}: / / \mathrm{bit} .1 \mathrm{y} / 2 \mathrm{KKu} 8 \mathrm{vm}$ (acesso 07.06.2012).

${ }^{20} \mathrm{http}: / / \mathrm{bit} .1 \mathrm{y} / 2 \mathrm{tPRHg} 5$ (acesso 01.05.2012) e http://bit.ly/2tOySJU (acesso em 31.01.2018).

${ }^{21}$ https://pewrsr.ch/2Nm1vGL e https://pewrsr.ch/1K0AGB0 (acesso em 02.07.2018).
} 
Mapa 1

BRASIL - POPULAÇÃO ISLÂMICA. 2010.

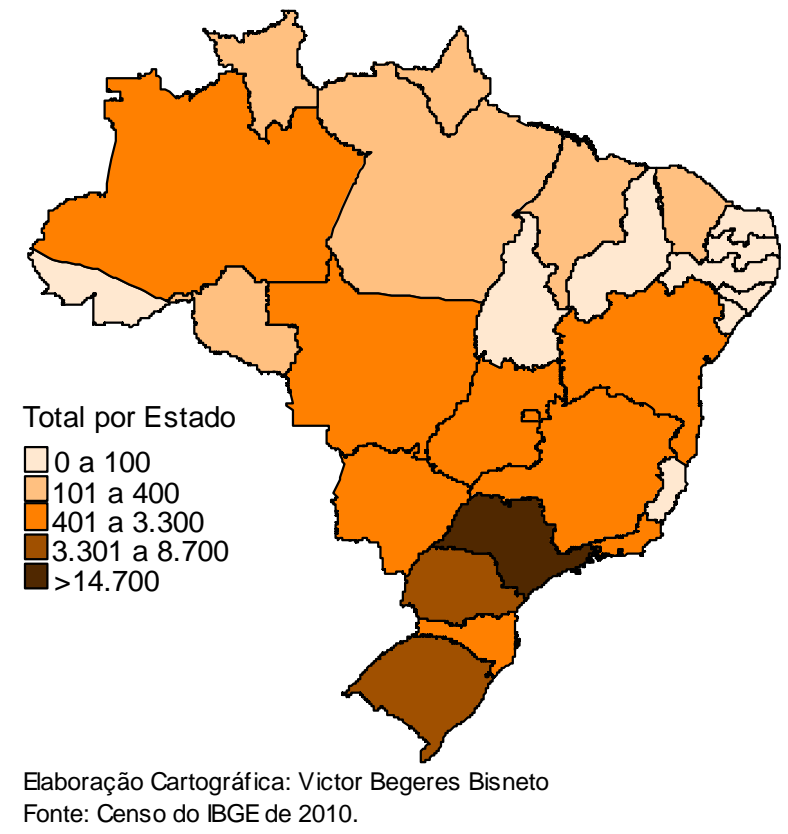

Nota-se que a maior concentração de muçulmanos se encontra no centro-sul do país, especialmente em São Paulo e Paraná. Mas outros estados como Rio de Janeiro, Brasília, Mato Grosso do Sul e Rio Grande do Sul também despontam com relevância.

Nesses estados é onde se encontra a maior quantidade de pessoas e ao mesmo tempo se configuram como os mais desenvolvidos do país por concentrar extensa rede de infraestrutura, centros de pesquisa e universidades, e todo tipo de atividades econômicas que vão desde a agricultura moderna, passando pela indústria de alta tecnologia à rede de serviços. Devido a tudo isso, essa área que inclui o Sul, Sudeste e parte do Centro-Oeste passou a ser chamada de "região concentrada" (Santos e Silveira, 2001). Quanto à irrisória concentração de muçulmanos nas regiões Norte e Nordeste do Brasil, esta última particularmente com maior densidade de negros (muçulmanos), isso pode ser explicado pelo passado colonial do país e da região conforme aponta Reis (1996). Fica claro aqui a maior concentração no centro sul do país enquanto as regiões Norte e Nordeste são aquelas em que se observa a menor quantidade de muçulmanos em dados absolutos.

Apesar de ainda serem números modestos em termos absolutos, o censo do IBGE de 2010, em relação ao de 2000, indica um crescimento de $29 \%$ nessa população. O aparente subregistro se comparado com outras fontes se deve, segundo Paulo Pinto (2013) a dois fatores: a dispersão da população islâmica não apenas no país, mas também no espaço urbano o que diminui a probabilidade de serem contemplados pela amostragem; e o subregistro de demais 
religiões frente ao grande número de opções referentes às denominações cristã e afrobrasileiras. "O entrevistado tenderia a perceber a opção por uma delas como mais legítima que a inclusão por ele próprio de uma categoria diferente" (ibid., p.269). O Mapa 1 reforça essa tese, já que o eixo sul-sudeste é aquele em que há uma maior concentração dessas comunidades, algo que a pesquisa por amostragem poderia ter maior sucesso de contemplá-las do que em regiões como o Norte.

O censo de 2010 também conclui que 99,2\% dos muçulmanos vivem em áreas urbanas, que a maioria é do gênero masculino $(59,6 \%)$ e se declaram majoritariamente como brancos, embora outras categorias de cor/raça tenham crescido muito em função das conversões que também tiveram um aumento nos últimos anos (ibid.).

Mais do que o número de muçulmanos no país, um dado que deve ser levado em conta é o aumento no número de instituições islâmicas ${ }^{22}$. Em 1983 havia cerca de 24 centros islâmicos/sociedades beneficentes muçulmanas e 9 mesquitas, enquanto em 2012 eram computadas 94 instituições islâmicas (sendo 34 mesquitas) espalhadas por 19 estados.

O mapa 2 nos revela a presença de mussalas ${ }^{23}$, algo que sem dúvida está subestimada, pois a sua constituição é mais microscópica e difícil de se identificar na paisagem. Assim, é bem provável que sejam em maior quantidade em relação àquilo que se mapeou e devam estar mais difusas no território.

22 "O número de centros islâmicos sobre 20\% em 2015 em São Paulo" https://bbc.in/2tMtQhh (acesso em 25.01.2017).

${ }^{23}$ A diferença entre Mequitas e Mussalas não diz respeito apenas à arquitetura (presença ou não de salão, minaretes, sala de ablução etc.) mas sim no fato de que as mussalas, pequenas salas de oração, que podem se localizar em residências ou em qualquer edifício, não possuem um sheikh e nem "salat jumuah" (oração da sexta-feira, dia religioso mais importante da semana). 
Mapa 2

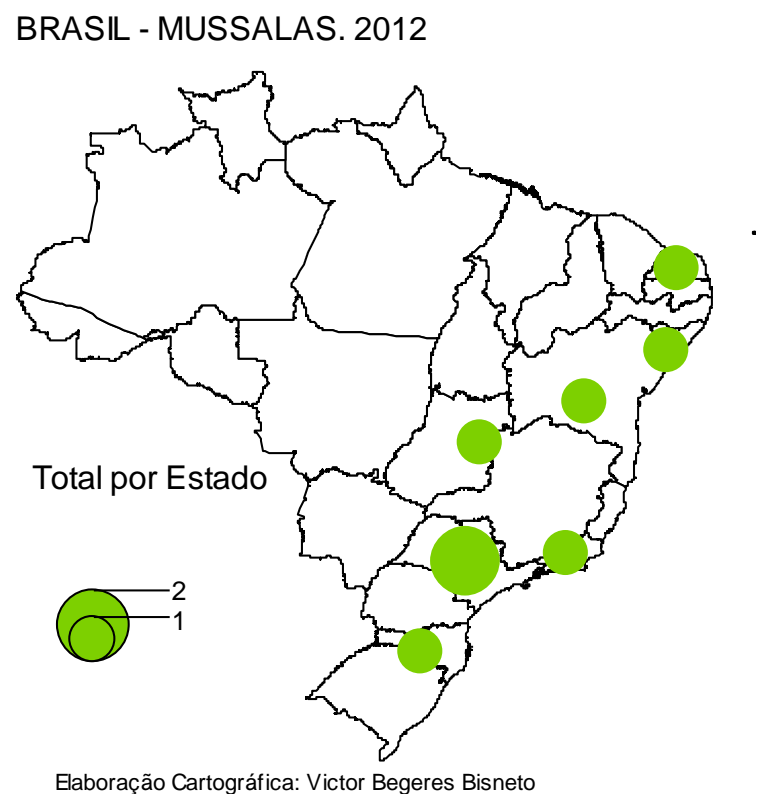

Eaboração Cartográfica: Victor Begeres Bisneto

Fonte: Paulo Pinto (2013) e contato com Centros Islâmicos e Associações Beneficentes.

O mapa 3 complementa o anterior com a existência de centros islâmicos, locais onde se reúnem muçulmanos para celebrar datas festivas, ensino do livro sagrado, o alcorão, e mesmo da língua árabe. Conforme veremos em breve, são importantes instituições que indicam o quanto determinada comunidade é numerosa e ainda busca preservar seus valores culturais e religiosos.

Mapa 3

BRASIL - CENTROS E SOCIEDADES BENEFICENTES ISLÂMICAS. 2012

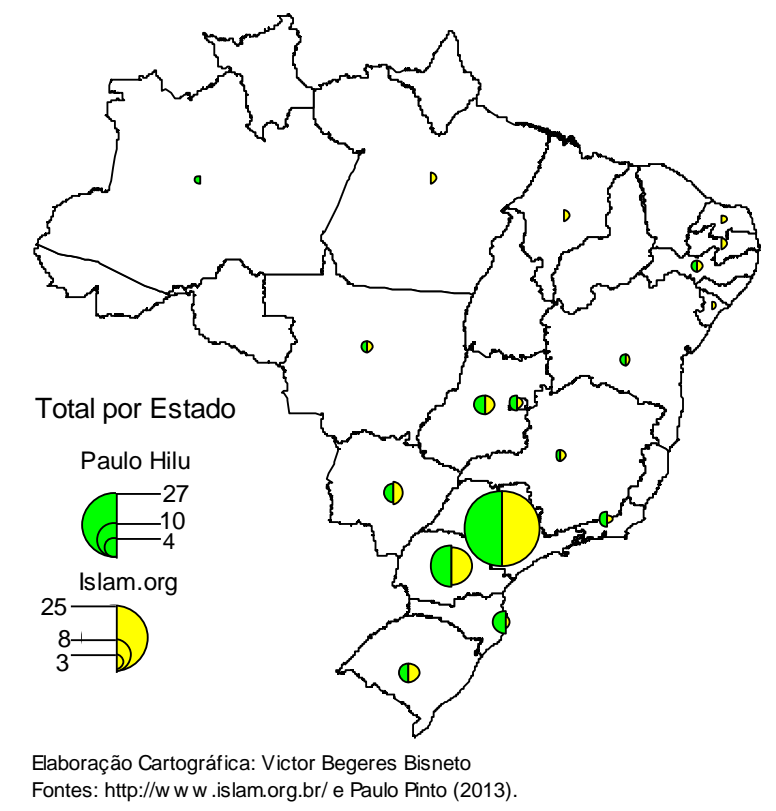

Ambos os mapas destacam São Paulo como o principal centro de concentração de muçulmanos, além de Paraná e Rio de Janeiro. 
Este mapa compara dados oferecidos pelo site de uma entidade islâmica e do pesquisador Paulo Pinto (2013). O número é muito compatível se observamos os Estados de São Paulo e Paraná, locais de grande concentração muçulmana. A partir do centro-norte do país, há discrepância entre os dados.

Um exemplo é o caso do Rio Grande do Norte. Enquanto Paulo Pinto (ibid.) não computava nenhum centro islâmico nessa localidade em 2012, a outra fonte indicava a presença de pelo menos um. Algo que foi confirmado por mim em minha pesquisa de campo em que entrevistei Mohamed Tawfiq, presidente da Associação Muçulmana Beneficente de Natal/RN. Ele disse que foi fundada em 2008 por quatro pessoas: três brasileiros e um africano. Ele ainda ressaltou a ausência de árabes na fundação. Segundo Tawfiq, a comunidade de Natal/RN é a terceira maior do Nordeste $^{24}$, atrás de Pernambuco e Bahia, maior da região, com cerca de 700 membros segundo o sheikh Ahmad Abdul. Mesmo assim, o único centro islâmico deste estado fica na capital, Salvador.

Por conta disso, com frequência ele e outros irmãos, como se referiu, fazem palestras no interior do estado. Quando há festas, entretanto, ele os convida para o centro islâmico de Salvador/BA.

Os mapas 4 e 5 a seguir, indicam a presença de mesquitas no Brasil. Há sites de comunidades muçulmanas ${ }^{25}$ e de outros canais virtuais ${ }^{26}$ que apontam a existência de mais de cem mesquitas. Provavelmente esse número deve incluir não apenas a quantidade de mesquitas como também de centros islâmicos e mussalas. Contudo, órgãos como o Centro Islâmico do Brasil e FAMBRAS, que já possui uma atuação mais antiga e reconhecida no país, revelam não mais do que 20 mesquitas. A presença de mesquitas é um dado significativo do mais alto grau de organização e presença de muçulmanos em um determinado território.

O destaque fica por conta da Mesquita Brasil em São Paulo (criada em 1957), que, aliás, abriga a maior quantidade de muçulmanos (sunitas) do país. Ela constituiu uma Sociedade Beneficente Islâmica já em 1929 e já ultrapassa 1.680 membros (Paulo Pinto, 2013), cujos líderes são oriundos de instituições de prestígio em estudos religiosos como a Al-Azhar no Egito. As funções da mesquita, ainda segundo o autor, vão além de atividades religiosas, já que em 2004 serviu como o espaço para a formatura de alunos pré-vestibulandos da Escola Islâmica de São Paulo. Segundo o Sheikh Abdulhamid, que hoje é líder dessa mesquita, ela é a maior da América Latina.

\footnotetext{
${ }^{24}$ Seriam 76 muçulmanos sendo 55 brasileiros (convertidos), 13 africanos e 08 árabes.

${ }^{25} \mathrm{http} / / / \mathrm{bit} .1 \mathrm{y} / 2 \mathrm{KKu} 8 \mathrm{vm}$ (acesso 07.06.2012).

${ }^{26}$ http://bit.ly/2tPRHg5 (acesso 22.01.2017).
} 
Mapa 4

BRASIL - MESQUITAS. 1983

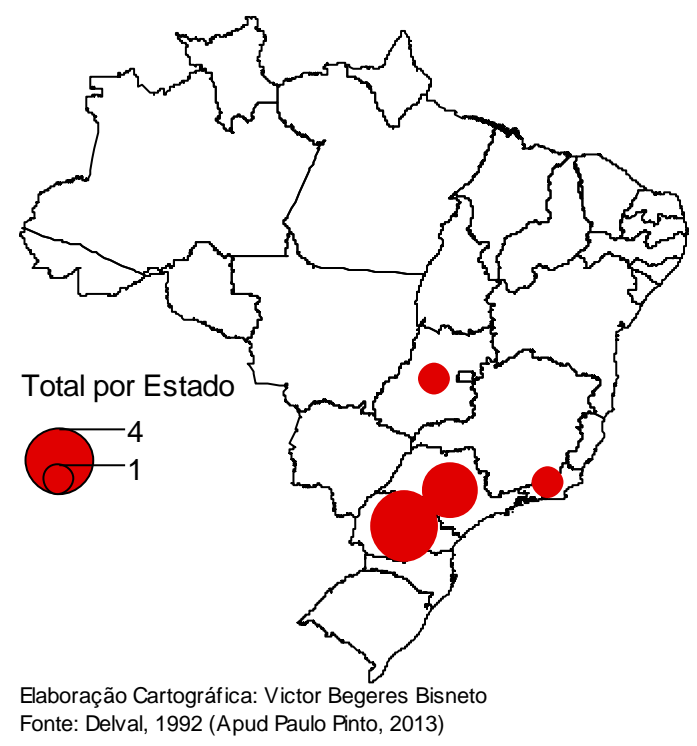

O mapa acima foi elaborado segundo informações obtidas por Delval (1992). Para o ano de 1983 encontravam-se em território nacional quatro mesquitas no Paraná, três em São Paulo e apenas uma em Goiás e Rio de Janeiro. Não apenas o número era exíguo, mas a sua distribuição também estava restrita ao Centro-Sul do país.

Mapa 5

BRASIL - MESQUITAS. 2012

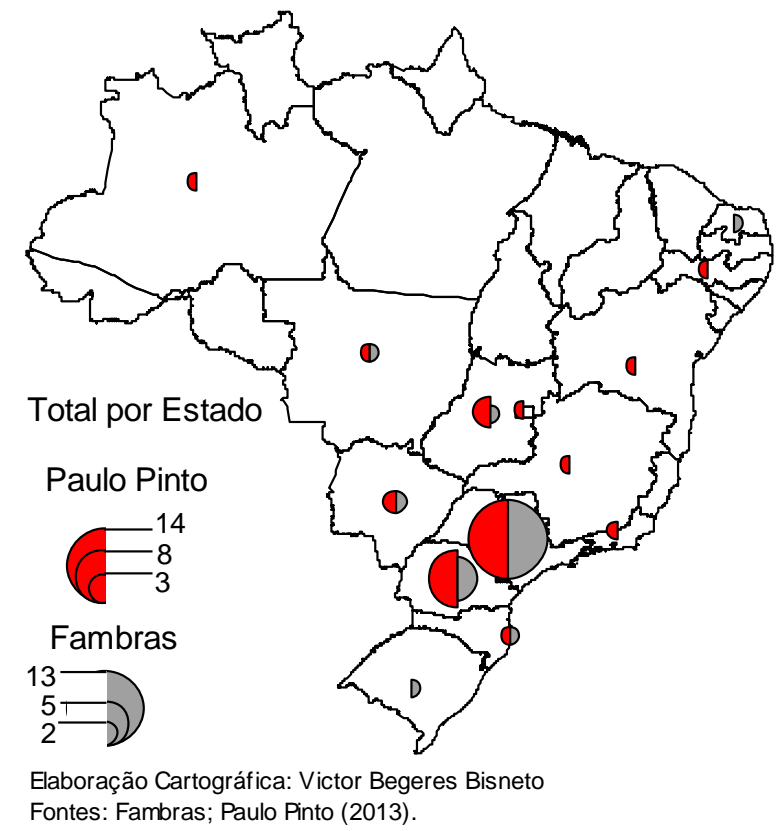

Com um intervalo de tempo de quase três décadas, o mapa 5 novamente compara dados de Paulo Pinto (2013) com os da FAMBRAS. Assim como no caso dos centros e sociedades islâmicas, observa-se que há pouca discrepância entre os dados da presença de mesquitas em 
São Paulo e Paraná principalmente, e em Santa Catarina e Mato Grosso. Contudo, outros estados como Rio Grande do Sul, Minas Gerais e Amazonas, há incompatibilidade entre os valores oferecidos pelas fontes. No caso do Rio Grande do Norte, a FAMBRAS aponta em seu site a existência de uma mesquita ${ }^{27}$. Na verdade, é uma mussala como eu mesmo pude constatar quando da minha visita em 2016 e que está apontada pelo mapa 3. O mesmo pode-se dizer do caso da Bahia.

Um dado importante é que este mapa não contempla a distinção entre mesquitas sunitas e xiitas, como por exemplo, a Mesquita xiita do Brás construída com grande influência persa (ibid.). No caso do Paraná, que possui uma importante e antiga comunidade muçulmana, datando de 1957, apresenta outra característica diferente das demais localidades, pois segundo Paulo Pinto (ibid.) há uma clara divisão sectária entre muçulmanos xiitas e sunitas provenientes do Egito, Líbano, Síria e Palestina. A presença xiita se fez sentir de forma mais clara a partir da década de 1970 com a ocupação do sul do Líbano por Israel que motivou a saída desse segmento. Já por volta da década de 1980 houve outra onda migratória para o Paraná, especificamente para Foz do Iguaçu, de libaneses que fugiram da guerra civil em seu país (Demant, 2008).

O descompasso que se identifica entre as fontes estatísticas da presença muçulmana no Brasil, nos passa a impressão de que o número de comunidades islâmicas só poderá ser realmente conhecido a partir de um árduo e longo trabalho de campo que possa listá-las, uma vez que nem elas possuem um banco de dados uno, oficial e confiável, e nem os órgãos técnicos e científicos oficiais dispõem igualmente desse controle. Além disso, a criação e a adoção de uma metodologia que permita equacionar esses números seriam muito desejáveis e úteis em trabalhos posteriores.

Apesar das divergências observadas, é importante considerar que nesse intervalo de tempo o número de mesquitas não só cresceu substancialmente, reforçando o peso de São Paulo e Paraná, como se distribuiu para outros lugares mais distantes do território. O Centro-Oeste, Norte e Nordeste deixam de ser zonas "opacas" para as comunidades islâmicas. Nesse sentido, a visualização dos dados cartografados corrobora as informações disponibilizadas pelo IBGE: se em valores absolutos elas ainda são microscópicas, em dados relativos de crescimento, o mesmo não pode ser dito. Se adotarmos o valor absoluto oferecido pelo Pew Research Center, que é aquele que mais se aproxima da realidade, os mapas comprovam igualmente que não

\footnotetext{
${ }^{27}$ http://bit.ly/2KufTib (acesso em 24.01.2018).
} 
apenas estão crescendo quantitativamente, mas estão se consolidando no território em formas cada vez mais organizadas.

O aprofundamento dessa organização pode ser visto pelo mapa 6 por meio da existência de cemitérios islâmicos.

Mapa 6

BRASIL - CEMITÉRIOS ISLÂMICOS. 2012

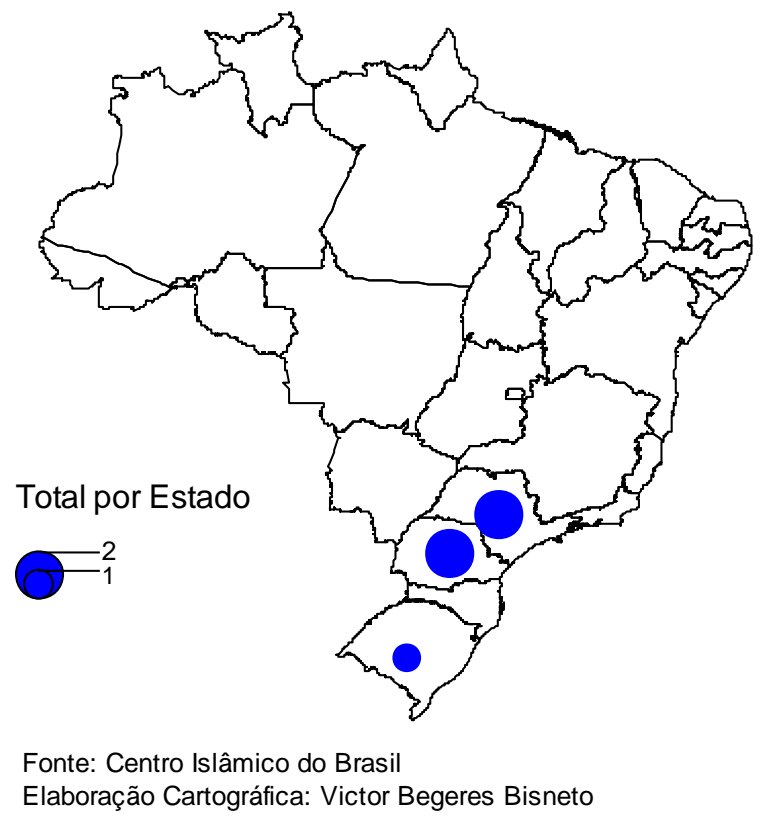

Nesse caso, não apenas a fonte exibida pelo mapa, mas outras que foram consultadas sobre esse aspecto concordam com a existência de cinco cemitérios no total. Dois no Paraná, dois em São Paulo e outro no Rio Grande do Sul, na cidade de Santana do Livramento, fronteira com o Uruguai. Exceto nesse lugar, os outros se encontram justamente naqueles locais em que as comunidades estão mais bem organizadas e consolidadas. Em dezembro de 2018, o mais recente cemitério islâmico foi inaugurado na cidade de Itapecerica de Serra/ $\mathrm{SP}^{28}$, e, segundo a FAMBRAS, o projeto foi inciado há 20 anos e conduzido pela Sociedade Beneficente Muçulmana de Santo Amaro (SOBEM). Ao lado dele, também foi construída a Mesquita Dar Al-Salam - Morada da Paz.

Até aqui, os mapas expostos oferecem uma noção espacial e quantitativa da presença islâmica no território nacional. Uma vez quantificadas e localizadas tais comunidades, ainda que com dados que carecem de maior precisão, o próximo passo foi criar um mapa cronológico da construção de mesquitas no território nacional, equipamento significativo da consolidação do quadro de vida religioso dessas comunidades.

${ }^{28}$ https://bit.ly/2GlQfuE (acesso em 17.12.2018). 
Se considerarmos a história, o Nordeste deveria surgir como a primeira base islâmica do Brasil em função da vinda de escravos e muitos deles islâmicos, algo que fica evidente no evento conhecido como a Revolta dos Malês de 1835. Entretanto, o mapa considera a infraestrutura mais proeminente criada por esses grupos como um fator de ancoragem no território. $\mathrm{O}$ critério para a cartografia foi a data da mesquita mais antiga na capital ou cidade em que foi construída. Assim, foi usada apenas uma por Estado na confecção do mapa 7 que é revelador dessa expansão islamista.

Mapa 7

BRASIL - EXPANSÃO ISLAMISTA. 2017.

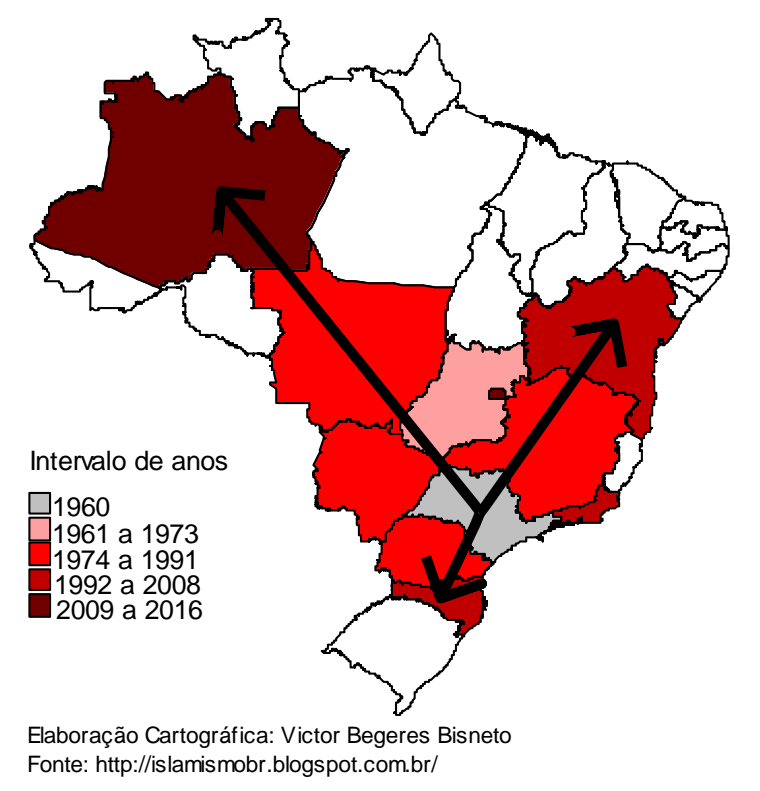

Houve certa dificuldade na obtenção das datas por meio dos sites ou notícias sobre a inauguração de mesquitas, pois em muitas situações isso não é mencionado. Algumas associações beneficentes responderam via e-mail ou por contato telefônico. No caso de outras, como a do Estado do Rio Grande do Sul, não obtivemos nenhum retorno.

Daí porque a elaboração de um mapa com a conformação das comunidades islâmicas considerando a criação de um centro, sociedade, associação beneficente ou mussala, que são mais numerosos do que o total de mesquitas, torna a tarefa ainda mais complicada e com margem de erros.

De qualquer forma, o mapa 7 nos ajuda a ter uma ideia de como o as comunidades islâmicas têm se expandido e se dinamizado para áreas interioranas do país, conforme indicam as setas. É a partir de São Paulo, lócus de uma das primeiras comunidades no Brasil, que o islam tem se irradiado para quase todas as direções e de forma contígua. Dentro do próprio Estado, São Bernardo do Campo é outra cidade representativa em termos islâmicos e que ainda abriga as sedes da e da CDIAL (Centro de Divulgação do Islam para América Latina). Ferreira (2009) 
lembra que "em matéria da revista Makka Al Mukarama, o sheikh Sadeq Al Otmani afirma que a cidade de São Bernardo do Campo é considerada a capital dos muçulmanos no Brasil”, justamente pela existência dessas instituições, além da editora islâmica Makkah, e pelas inúmeras atividades que lá são feitas como acampamentos e encontros islâmicos.

As cidades de Jundiaí e Campinas, também são importantes lugares em termos de presença islâmica. A primeira possui mesquita desde 1990 e a segunda, com mesquita desde 1979, a terceira mais antiga do Estado.

A despeito dessa nítida concentração islâmica no centro-sul brasileiro, observa-se uma tendência de que regiões como as do Norte e Nordeste representem essas novas tendências de expansão islamista. Entre os fatores que podem explicar esse processo, podemos elencar a existência de mais informação sobre a religião islâmica o que faz com que mais pessoas se convertam; as migrações internas no país que se tornaram mais dinâmicas a partir dos anos 60 e 70 (construção de Brasília, projetos desenvolvimentistas no Norte, agronegócio no CentroOeste, em particular, com cada vez mais frigoríficos aderindo ao abate hallal $^{29}$ etc.) e que eventualmente atraíram muçulmanos para as atividades comerciais mais dinâmicas na região $0^{30}$; financiamento para a construção de mesquitas e centros islâmicos provenientes de países do Oriente Médio como Arábia Saudita e Egito e também maior articulação de associações comerciais islâmicas, como é o caso da FAMBRAS, que também promove repasses financeiros para que as comunidades possam de alguma forma subsistir, ainda que com pouco.

O exemplo disso é percebido na fala de Mohamed Tawfiq, presidente da Associação Muçulmana Beneficente de Natal/RN:

“para ser sincero, para entender...entre eu e você só ${ }^{31}$, são 800 reais mensais só da FAMBRAS...800 reais mensais. Agradecidos. Dá para pagar o lanche, o almoço do mês. Qualquer centavo que entra não vamos dizer pouco ou muito, nós vamos dizer que estamos agradecidos, hamidulillah, como a gente fala, graças a Deus [...] Aí, 800 reais e mais nosso esforço aqui. Isso que você está vendo aqui [a sede da comunidade] um de nós doou e dois reformaram. Não chegou nenhum centavo de fora. Se ninguém aparecer para doar, paciência.

\footnotetext{
${ }^{29} \mathrm{https} / / / \mathrm{glo} . \mathrm{bo} / 2 \mathrm{R} \mathrm{Rlsgg}$ (acesso em 29.01.2018).

${ }^{30}$ Em contato com a FAMBRAS em 05.02.2018, a entidade acredita que a presença mais constante de muçulmanos nessa região possa seguir a maior dinamização da economia especialmente o comércio, setor que mais reúne muçulmanos.

${ }^{31}$ A gravação da conversa foi autorizada bem como seu uso. Nesse caso, a expressão "entre eu e você só" não se trata de uma informação sigilosa, apenas uma força de expressão.
} 
O caso da comunidade de Salvador, não parece ser diferente. O sheikh Ahmad Abdul revela que

aqui a FAMBRAS ajuda, principalmente com os livros. Saifi ${ }^{32}$ também ajuda. Ele que carregou tudo, até que chegou um ponto que eu disse para ele que não é vergonha para nós ter que pagar a luz, e ele disse que não tinha problema e continuou pagando. Algumas outras pessoas ajudam [...] Se eu preciso ir para fora, eu ligo para a FAMBRAS. Eles já me ligaram: "sheikh, você tá precisando de livro?” Não, agora não. É a mesma coisa com Saifi. Teve agora um congresso e mandaram passagem para mim, entendeu? Precisando de alguma coisa, a gente liga para eles. Todas as comunidades sabem o que Wamy, Saifi e FAMBRAS podem oferecer.

Diante disso é possível crer que muitas outras comunidades islâmicas espalhadas no país, especialmente nessas regiões de expansão mais recente não se façam mais visíveis em termos materais de organização pela dificuldade financeira, que depende de doação de fiéis e ajuda da FAMBRAS entre outras entidades. Esses parcos recursos com que subsistem, tomando ainda os casos de Natal/RN e Salvador/BA, não só inviabilizam a criação de espaços para seus rituais como também tornam difícil a vinda de sheikhs renomados no país para que possam ministrar algum tipo de palestra ou mesmo para o desenvolvimento de outras atividades.

\section{A importância da história oral no relato de vozes dissonantes e não hegemônicas}

Entre as metodologias adotadas na construção desta tese, talvez a mais importante tenha sido a realização de entrevistas que foram feitas em um período de um ano e meio, de julho de 2015 a janeiro de 2019.

Instrumento da história oral, definida por Thompson (2002, p.09) como a "interpretação da história e das mutáveis sociedades e culturas através da escuta das pessoas e do registro de suas lembranças e experiências", as entrevistas foram realizadas com líderes e demais membros de comunidades islâmicas em Foz do Iguaçu/PR, São Bernardo do Campo/SP, Guarulhos/SP, Campinas/SP, São Paulo/SP, Natal/RN e Salvador/BA, e que serviram de base empírica para o trabalho, conforme mostra o mapa 8 (abaixo).

\footnotetext{
${ }^{32}$ Ahmad Ali Saifi, atua no ramo comercial de carnes halal. Foi fundador da CDIAL em 1987 e do Movimento de Jovens Muçulmanos, dirigiu a Sociedade Beneficente Islâmica Mesquita Brasil de São Paulo/SP e a Sociedade Beneficente Abu Bakr Al Sedeek de São Bernardo do Campo/SP. Figura proeminente da comunidade islâmica brasileira. (Cf. http://www.cdialhalal.com.br/a-cdial-halal/ acesso em 14.01.19).
} 
Mapa 8

\section{BRASIL - TRABALHOS DE CAMPO REALIZADOS ENTRE 2015 E 2019}

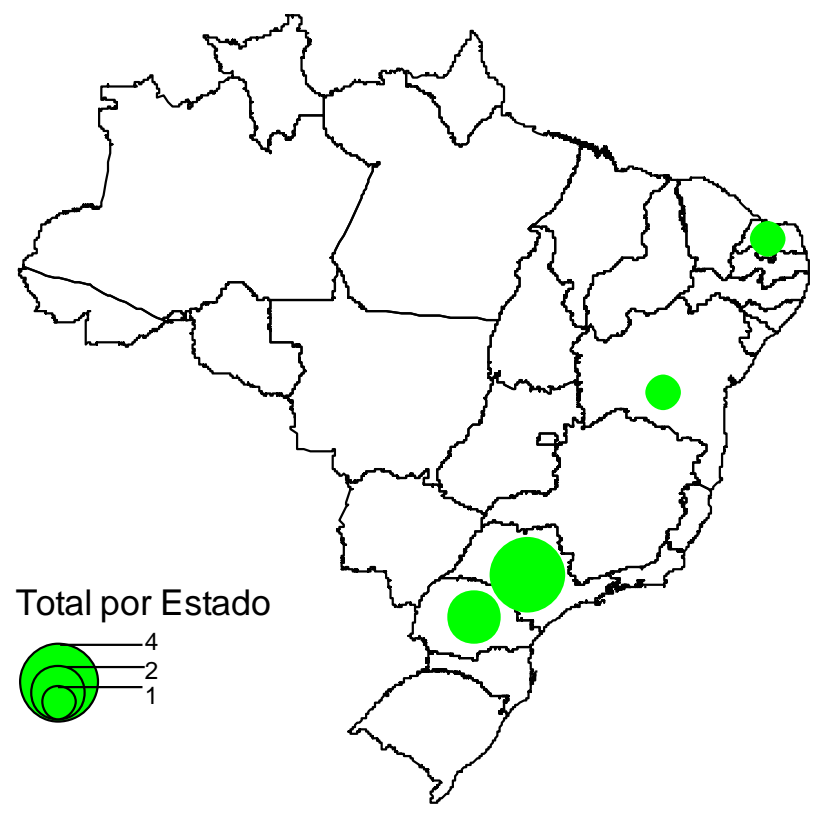

Elaboração Cartográfica: Victor Begeres Bisneto

O intuito de usar esse ferramental se baseou na premissa de que se estamos lidando com algo que é microscópico em termos numéricos e materiais no país em que se encontram as comunidades islâmicas. Com a preocupação de identificar traços fundamentalistas e/ou jihadistas, a história oral se apresenta como a área que tem a potencialidade de trazer à tona vozes e esferas ocultas que segundo Thompson (2002), permite acessar experiências daqueles cujas vidas e organizações estão à margem do interesse público e, portanto, menos propícias a serem documentadas. Assim pretendemos como diz Thompson (1998), democratizar a história especialmente sobre o islam que se manifesta no Brasil.

Os riscos e os desafios são muitos ao se adotar essa metodologia, mas os benefícios podem ser maiores se considerarmos o ineditismo e o impacto que algumas informações podem nos revelar. Entre os riscos, aquele que exige mais atenção é quanto a credibilidade da informação. Podemos acreditar deliberadamente nela? É provável que isso seja o ponto de maior debate entre os historiadores orais. O modo mais eficaz para ao menos reduzir esse risco é conquistar a confiança do entrevistado, tentar estabelecer laços que permitam acessar aquilo que não foi dito em determinado momento ou que está encoberto em entrelinhas tão sutis que por vezes passam despercebidas. Mas isso pode demandar algum tempo de relação entre o pesquisador e o informante. Daí a necessidade de estar em permanente contato, sejam durante as pregações, rituais, festas e mesmo via redes sociais, e, alternativamente, verificar informações com outros entrevistados. 
A realização das entrevistas e seu efetivo uso na tese fizeram parte de um longo processo de preparação e realização que incluiu as seguintes etapas:

1) A elaboração de questões possíveis de serem abordadas (ver em anexo o modelo utilizado).

A criação dessas perguntas levou certo tempo de preparação para que eu conseguisse elaborar um conjunto de questões que me orientaria no momento da entrevista. Esse processo contemplou uma pesquisa prévia por informações das comunidades em que eu me inseriria, por temas que repercutiam no Brasil e no mundo sobre o islam e os muçulmanos de forma geral e que pudessem ser eventualmente retomados durante as entrevistas, e, por fim, leituras diversas sobre história oral e de estudos sobre as comunidades islâmicas no Brasil que também fizeram uso dessa metodologia de pesquisa.

Ainda que eu estivesse de posse desse questionário pré-estruturado, todas as conversas que tive com meus informantes não o seguiram de forma estrita e inflexível. Pelo contrário, percorri o caminho explicado Portelli (1998, p.71), em que "rigidly structured interviews may exclude elements whose existence or relevance were previously unknown to the interviewer and not contemplated in the question schedule. Such interviews tend to confirm the historian's previous frame of reference"33. Samuel (1998, p.391) corrobora essa afirmação ao dizer que "the historian ought not to impose his own order on the speech of his informants" ${ }^{34}$. Assim, eu pretendia que o meu informante se sentisse livre para emitir sua opinião sobre os temas. Porém, em meio às suas falas eu tentava selecionar elementos que pudessem ser relevantes à pesquisa e que se relacionassem com o roteiro de questões.

Aprender a ouvir talvez tenha sido a grande lição. Morrissey (1998, p.108) diz que "a good interviewer is a good listener ${ }^{35}$ ". Também de acordo com Portelli (op.cit.,p.71), "the first requirement, therefore, is that the researcher 'accept' the informant, and give priority to what she or he wishes to tell, rather than what the researcher wants to hear, saving any unanswered questions for later or for another interview"36.

O historiador no papel de entrevistador e mediador do conhecimento deve se ater em respeitar o ritmo do seu colaborador, evitando ao máximo de retardá-lo ou apressá-lo se considerar lenta a transmissão de informações. Para Morrissey (op.cit., p.110) “we should let

\footnotetext{
33 "entrevistas com estruturas rígidas podem excluir elementos cuja existência ou relevância eram previamente desconhecidas do entrevistador. Tais entrevistas tendem a confirmar o quadro de referência prévio do historiador" (tradução minha).

34 "O historiador não deve impor sua ordem na fala de seus informantes" (tradução minha).

35 "um bom entrevistador é um bom ouvinte" (tradução minha).

36 “é preciso que o pesquisador 'aceite' o informante, dar prioridade ao que ele ou ela desejam falar, do que aquilo que o pesquisador quer ouvir, deixando as questões não respondidas para depois ou outra entrevista" (tradução minha).
} 
the interviewee set his own pace; if it is slow, from our viewpoint, nonetheless it is his pace. We should let him go at his own rate" 37 . Afinal, seja como for, o contato não termina naquele instante. Informações adicionais ou possíveis lacunas poderão ser requisitadas a posteriori. Igualmente, concluir frases e inserir palavras em momentos de hesitação por parte do interlocutor, o que poderia de certa forma induzi-lo a dizer algo que talvez não diria, também deve ser evitado (Morrissey, ibid.). É importante que se observe a neutralidade do pesquisador sobre os temas discutidos para impedir que os relatos possam ser enviesados e relatados de maneira que artificial, como sendo "aquilo que se quer ouvir". Estive sempre atento a esse "manual do entrevistador", ainda que em alguns momentos fosse difícil de preservar sua integridade, pois vez ou outra, de forma natural, também era solicitada minha opinião sobre alguns assuntos o que por muitas vezes fomentou novas discussões abrindo novos caminhos para a reflexão.

É importante registrar que ao longo dessas entrevistas, e apesar dos cuidados com sua realização e sucesso na obtenção de informações úteis ao trabalho, alguns desafios foram encontrados. Talvez o mais importante e recorrente fosse com relação à opinião de alguns colaboradores sobre certos temas que envolviam o islam, o Ocidente e grupos extremistas, como o Estado Islâmico.

Nesses casos os conteúdos das falas eram uníssonos, que repetido por várias pessoas de lugares diferentes poderia ser interpretado como algo incontestável. Era comum observar a manifestação de teorias e ideias conspiratórias sobre a mídia e de que grupos como o Estado Islâmico eram criações da tríade Estados Unidos/Europa/Sionismo, por exemplo. Tal situação vai ao encontro do que afirma Portelli (1998, p.68). Para ele, “oral sources are credible but with a different credibility. The importance of oral testimony may lie not in its adherence to fact, but rather in its departure from it, as imagination, symbolism, and desire emerge. Therefore, there are no 'false' oral sources ${ }^{38}$ ".

Doravante, mesmo entendendo que muitas das declarações poderiam ser oriundas de pontos de vista e visões de mundo tendenciosas, superficiais e às vezes preconceituosas, seu simbolismo pode encobrir angústias que podem ter origem em outro lugar ou no próprio passado do informante, mas ressentida aqui e agora.

\footnotetext{
37 "nós devíamos permitir que o entrevistado estabelecesse seu próprio ritmo. Se é devagar, do nosso ponto de vista, no entanto, é o ritmo dele. Nós devíamos deixá-lo seguir no seu próprio ritmo" (tradução minha).

38 “fontes orais são críveis, mas com uma credibilidade diferente. A importância do testemunho oral pode não residir na sua aderência ao fato, mas sim a partir dele, como a imaginação, simbolismo, e desejo de emergir. Portanto, não há 'falsas' fontes orais" (tradução minha).
} 
Até que ponto o conjunto de normas, experiências, valores e princípios de cada informante, imbuídos dessas reflexões, poderiam ser retroprojetados na realidade em que vivem? Isso poderia ser um indicativo, mesmo que primitivo, de um processo de radicalização ainda que em um ambiente pouco propício? Esse seria um dos interesses da pesquisa.

2) Os agendamentos com os informantes: critérios para a escolha do local, desconfiança, compatibilidade de agendas e distância como os elementos complicadores.

O processo de escolha de onde seriam realizadas as entrevistas e as pessoas com quem tive contato seguiram alguns critérios: a questão quantitativa, influência e facilidade de deslocamento para o trabalho de campo

Foz do Iguaçu/PR é a cidade que abriga a maior concentração de muçulmanos em termos proporcionais no Brasil. Cerca de $10 \%$ da população da cidade é muçulmana, com rica presença de árabes sírios e libaneses de origem e seus respectivos descendentes.

Campinas/SP, por sua vez, ainda que não seja tão expressiva em número de muçulmanos, é a cidade em que habito e onde aconteceram meus primeiros contatos com muçulmanos, muitos dos quais se tornaram amigos pessoais e que me ajudaram a estabelecer pontes e travar conhecimento com as demais comunidades que investiguei. Também é a cidade que tem recebido um número razoável de refugiados sírios que são amparados pela SIC (Sociedade Islâmica de Campinas), Mesquita Anoor, entre outras entidades e famílias muçulmanas. Foi através da SIC que pude tomar contato com as histórias de vida de alguns imigrantes que adotaram o Brasil como seu lar provisório.

São Paulo e São Bernardo do Campo/SP são muito importantes não só pela grande concentração em números absolutos, como também pela maior presença de mesquistas e de instuições como a WAMY.

Por fim, a escolha da comunidade islâmica de Salvador/BA e Natal/RN foi devido às minhas melhores opções para deslocamento, por estar uma região do Brasil mais carente em aspectos socioeconômicos e com menor presença islâmica em relação ao Centro-Sul. Por outro lado, levando-se apenas a região Nordeste, essas comunidades são a primeira e a terceira maior, respecticamente.

Enquanto que na comunidade baiana há por volta de 700 muçulmanos, a potiguar conta com 76 membros, dentre os quais, 55 brasileiros (muitos deles negros), 13 africanos e 08 árabes. Elas serviram como um contraponto interessante tendo em vista a organização, número de frequentadores, bem suas origens distintas. Se por um lado o sul e sudeste do Brasil têm como 
marca um islam de etnia árabe, no Nordeste é notória a forma como o islam negro marca presença.

O perfil dos entrevistados teve como parâmetro sempre que possível o seu grau de influência em determinada comunidade. Nesse caso, as informações foram em sua maioria oferecidas pelas lideranças dessas comunidades: sheikhs, presidentes das associações, secretários e frequentadores mais assíduos.

No caso de Foz do Iguaçu/PR, local onde fiz meus primeiros contatos para a pesquisa, consegui organizar minha visita de forma rápida. Estive na cidade entre os dias 06 e 10 de julho de 2015, período do Ramadan. Inicialmente contatei um amigo muçulmano de Campinas/SP, M.E, que me ajudou não apenas em estabelecer o contato, mas também em passar minha referência ao sheikh Abdo Nasser da Mesquita Mesquita Omar Ibn Al-Khattab. Em seguida, após alguns telefonemas, a secretária da mesquita de forma muito atenciosa e gentil, efetuou o agendamento para esse encontro. Ao mesmo tempo, seguindo orientações do professor Paulo Pinto da Universidade Federal Fluminense (UFF), contatei via telefonemas, a Husseinya Imam Al Khomeini (xiita) e consegui marcar um encontro com o sheikh Mohammed Khalil (Foto 11) para o período em que estaria na cidade. Após a realização das entrevistas, os contatos passam a ser mais pessoais. A confiança passou a ser adquirida aos poucos e os contatos passaram a ser feitos de forma mais fluida. No mesmo dia em que entrevistei o sheikh Abdo Nasser, ele mesmo me convidou para assistir ao sermão que aconteceria a noite.

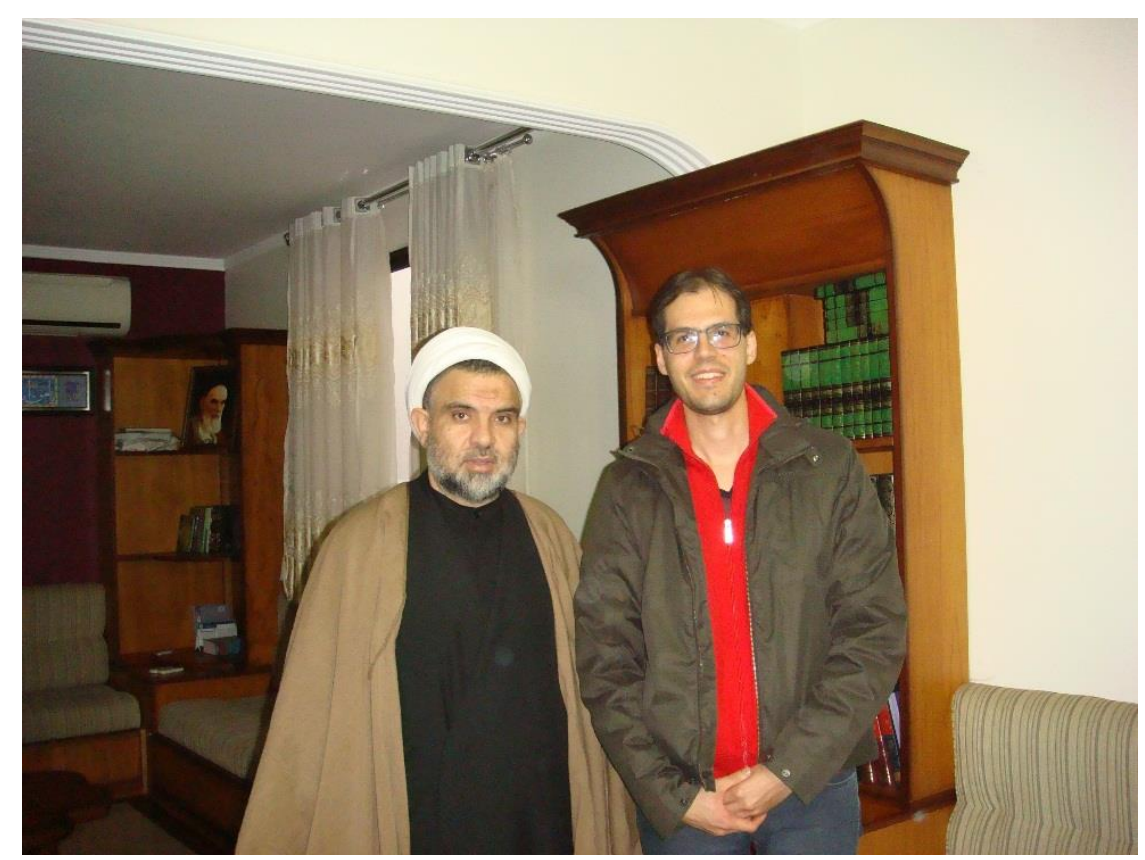

Foto 11 - Sheikh Mohammed Khalil, 08.07.2015.

Importante observar, que ao chegar no horário marcado, inicialmente minha entrada foi barrada pelo vigilante da mesquita, dizendo que só os muçulmanos e frequentadores poderiam 
participar. Expliquei que eu estava ali a convite do sheikh Abdo Nasser e que minha visita fazia parte de uma pesquisa. Ele retrucou dizendo que não havia recebido nenhuma orientação sobre minha entrada. Ficou evidente que ali havia um problema de comunicação entre a administração da mesquita e a guarita. Pedi então que o simpático vigia conversasse com alguém para que pudesse autorizar minha entrada antes do início da oração. Enquanto aguardava uma definição, passei a observei o frenético entrar de carros - a maior parte deles de modelos caros, sendo um indicativo de que grande parte daquele público possuía um elevado poder aquisitivo - no estacionamento onde as pessoas passaram a se aglomerar e que devido à insistente chuva que precipitava naquela noite, rapidamente se endereçavam ao pórtico principal da mesquita. Foi então que fui apresentado ao presidente da Mesquita, o Sr. Mohammad Khattib que desfez o mal-entendido sobre minha entrada. Ao final da oração, que durou cerca de uma hora, o sheikh Abdo me apresentou a outros membros da comunidade (Foto 12).

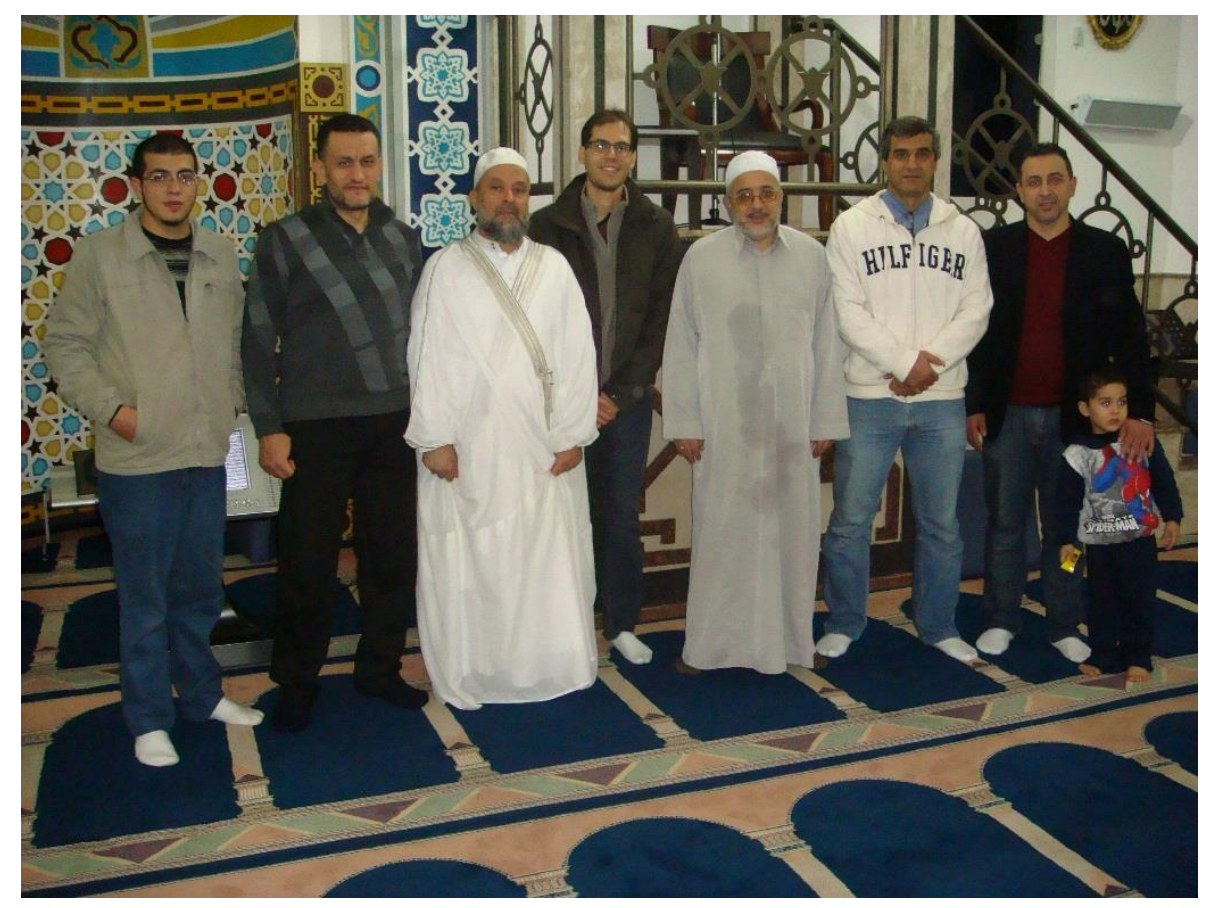

Foto 12 - Sheikh Abdo Nasser é o terceiro da esquerda para a direita, (07.07.2015).

Antes de ir embora, conversei novamente com o sr. Mohammed Khattib que sugeriu e viabilizou uma conversa com sua esposa, Anice Nagib Gazzaoui (Foto 13), que à época era vereadora da cidade. Nosso encontro se deu no dia seguinte na Escola Árabe-Brasileira, o que de forma muito auspiciosa contribuiu para me encontrar com a secretária-geral da escola, Khouloud El-Birani (Foto 14) que prontamente respondeu minhas perguntas e ainda me apresentou a instituição onde trabalha. 


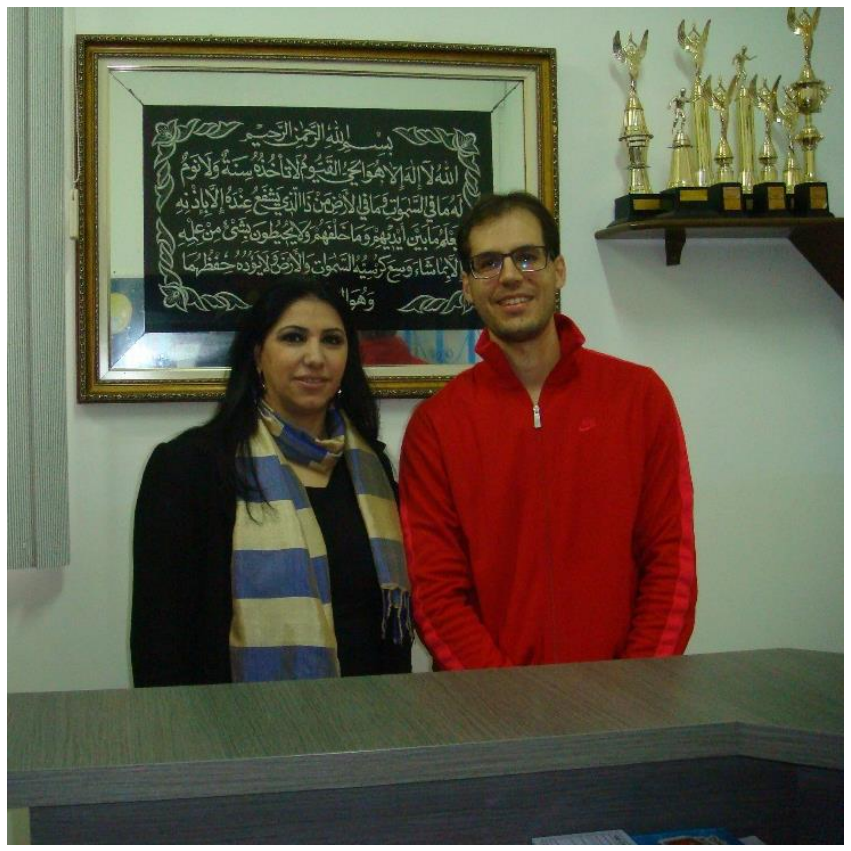

Foto 13 - Anice Gazzaoui, 08.07.2015

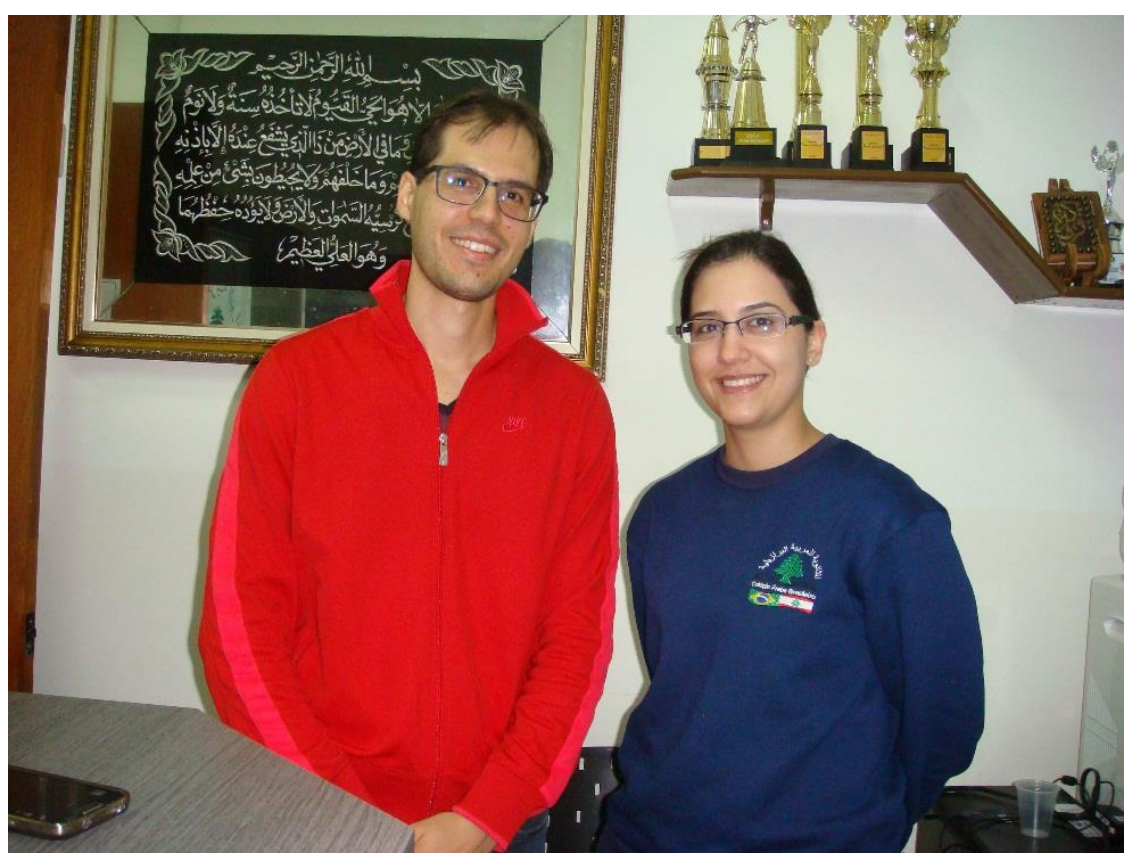

Foto 14 - Khouloud El Birani, 08.07.2015.

Nesse mesmo dia, na parte da tarde fui recebido na Husseinya Imam Al-Khomeini pelo sheikh Mohammed Khalil. Ele simpaticamente me acolheu em uma sala com sofás e estantes com livros, bem reservada. Interessante observar que em certa altura da entrevista fomos interrompidos pelo filho do sheikh que avisava da chegada de dois convidados. O sheikh educamente me pediu licença para atender os visitantes. Perguntei se ele desejava que eu me retirasse, mas ele disse que eu poderia ficar e observar a conversa que segundo ele levaria apenas alguns instantes. Diante disso acenei positivamente. Logo entraram um homem de meia idade e seu filho adolescente. A conversa entre eles durou cerca de 15 minutos, 
aproximadamente, toda em árabe e apenas entre o sheikh e o homem. $\mathrm{O}$ garoto apenas observava com uma feição enfastiada. Nesse momento, o pouco do árabe que aprendi me fez captar algumas palavras e o contexto geral: o pai buscava conselhos com o sheikh a respeito de algumas atitudes do filho e das escolhas que teria pela frente. Em alguns momentos o sheikh se dirigia ao garoto que apenas balbuciava modestas palavras.

O contato com o sheikh Jihad Hammadeh (Foto 15), que foi lembrado pelo sheikh Abdo Nasser, foi feito através de telefonemas para a WAMY. A secretária, de forma muito eficiente e gentil, conseguiu marcar o encontro com o sheikh na sede da WAMY em São Bernardo do Campo em 29 de julho de 2016. Interessante observar que o fato de já ter ido à Foz do Iguaçu e de já ter falado com membros dessa comunidade, pavimentara, de certa forma, o caminho para futuras entrevistas. Mesmo antes de realizá-las, sempre me apresentei dizendo o que estava fazendo, meus objetivos e com quem já havia me reunido. Isso de certa maneira já me garantia ao menos um mínimo de confiança por parte do meu informante.

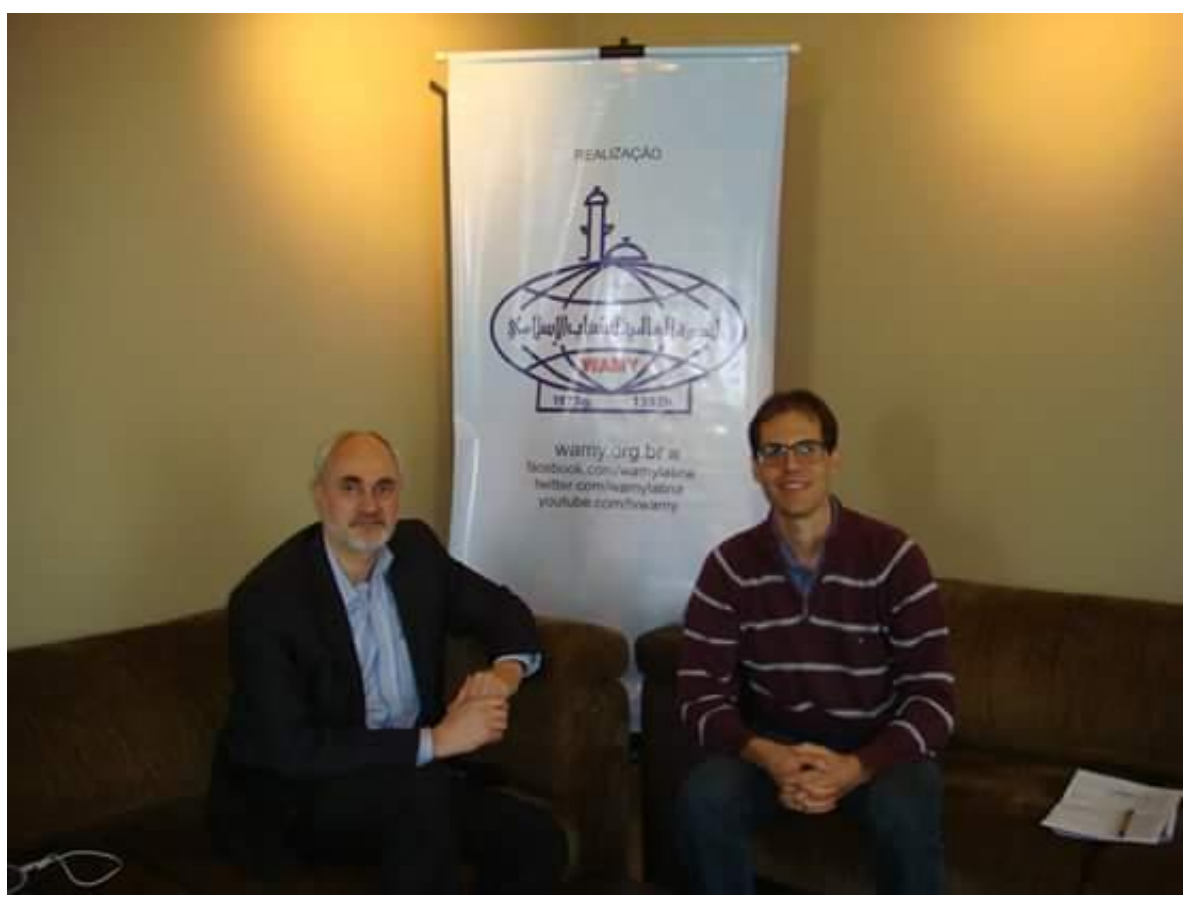

Foto 15 - Sheikh Jihad Hammadeh, 29.07.2015.

Em São Paulo/SP, pude conversar com membros do Centro Cultural Brasil-Turquia (CCBT) no dia 13 de junho de 2016. O contato com esse grupo talvez tenha sido o mais fácil de conseguir, uma vez que o Prof. Dr. Peter Demant já tem um grande trânsito nessa comunidade, e o fato de ser seu orientando permitiu que eu fosse atendido de forma rápida e muito agradável, inclusive sendo convidado para, após a entrevista, participar do jantar de iftar (romper o jejum do Ramadan). Neste dia estive com o presidente da instituição, prof. Mustafa 
Göktepe (Foto 16) ${ }^{39}$, com o Diretor do Centro Islâmico e de Diálogo Inter-religioso e Intercultural, Fatih Ozorpak, e com o jornalista da agência de notícias turca CIHAN, Kamil Ergin. Além de discutirmos aspectos que interessavam à pesquisa, falamos muito sobre a Turquia especificamente, que ainda que não seja o objeto de estudo, contribuiu para obter novas informações sobre a situação recente do país.

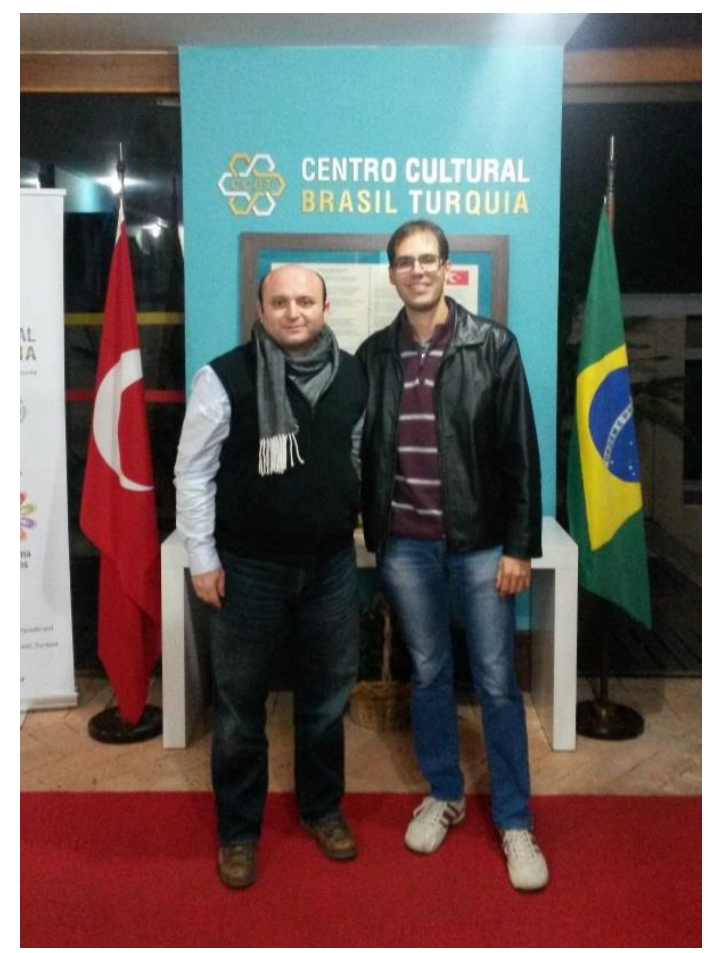

Foto 16 - Mustafa Göktepe, 13.06.2016.

Ainda nessa cidade, no dia 08 de janeiro de 2017 entrevistei o sheikh Abdelhamid Metwally $^{40}$ (Foto 17), imam da Mesquita Brasil, a mais antiga do Brasil e da América Latina, e vice-presidente do Conselho Superior dos Teólogos e Assuntos Islâmicos no Brasil. Realizei o agendamento via e-mail. $\mathrm{O}$ encontro aconteceu na própria mesquita. Há que se relatar algumas peculiaridades desse encontro. Ao chegar, acontecia uma aula de religião para mulheres islâmicas e alguns recém-convertidos. Aproximadamente 20 pessoas estavam presentes. Pretendia esperar o fim dessa aula para que então pudesse ser atendido pelo sheikh. Mas a convite dele, me juntei aos presentes e assim como os demais, ouvi a aula ministrada pelo sheikh que falava sempre em árabe, mas contava com a tradução de Yusuf.

\footnotetext{
39 Assumidamente identificado com o Movimento Hizmet cujo líder maior é Fethullah Gulen. Movimento que recentemente vem se opondo fortemente ao governo turco de Recep Erdogan, e, por isso, membros desse grupo têm sofrido perseguições políticas.

${ }^{40}$ Já não está mais à frente da comunidade da Mesquita Brasil. Desde 2018, em seu lugar, é o Sheikh Mohamad Bukhai quem conduz esta comunidade.
} 


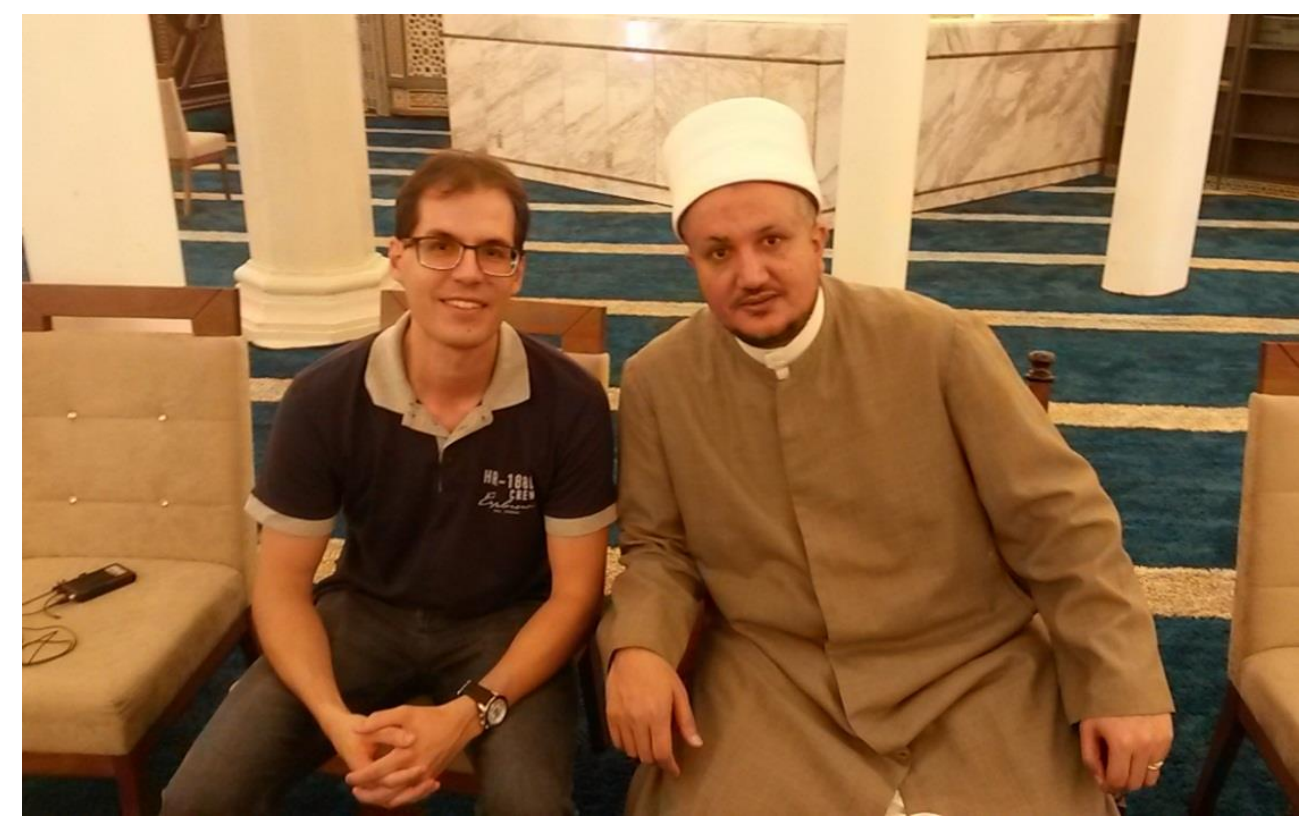

Foto 17 - Sheikh Abdelhamid Metwally, 07.01.2016.

Pensei que tivesse havido um mal-entendido, pois quando fiz o agendamento dessa visita junto à secretaria, deixei claro que gostaria de entrevistar o sheikh. Informaram-me que eu deveria chegar “às $12 \mathrm{~h}$, pois haveria aula de religião para mulheres”. Entendi que meu encontro se daria após esse compromisso. Não foi bem o que ocorreu. Quando entrei na sala principal da mesquita acreditava que a aula estava próxima do fim. No entanto, como ela durou até as $13 \mathrm{~h} 10$ aproximadamente, devo ter chegado logo no seu início.

Ao final da aula, houve uma rodada de perguntas feitas pelos presentes. Após algumas delas, o sheikh me convidou para fazer perguntas, mas respondi que o assunto que gostaria de tratar não tinha relação com o tema da aula e preferi fazê-las em particular, caso não houvesse objeção da parte dele. Foi nesse instante que suspeitei que a informação passada ao sheikh fosse a de que eu faria apenas uma visita. A entrevista não durou o tempo que eu previa, não sendo possível efetuar todos os questionamentos previstos. Mesmo assim, considerei proveitoso esse encontro. Comecei a me dar conta de uma maior movimentação na mesquita e que o sheikh teria outro compromisso. Ao final, o tom mais apressado marcou sua fala, quando nesse momento teve início a chamada à oração na mesquita feita por um jovem ao microfone. Foi a deixa para concluir a visita.

Em outra ocasião, entrevistei Ahmad Al-Khatib (Foto 18), outrora sheikh da Mesquita de Campinas por aproximadamente dois anos e hoje conduz uma $\mathrm{ONG}^{41}$ na cidade de Guarulhos/SP, me concedeu uma entrevista via skype em 23 de setembro de 2016. Foi a primeira entrevista por esse mecanismo e funcionou muito bem. Chegar até ele não foi tarefa

\footnotetext{
${ }^{41}$ Associação Livro Aberto. Site disponível pelo link http://bit.ly/2MJil0V (acesso em 23.09.2016).
} 
fácil. Em julho de 2016, a polícia federal deflagrou a Operação Hashtag ${ }^{42}$ que deteve 14 muçulmanos brasileiros suspeitos de planejar atentados terroristas durante os Jogos Olímpicos do Rio de Janeiro. Em razão desse episódio tentei localizar aqueles que já tinham sido liberados pela polícia. Primeiramente, a localização era muito difícil, especialmente daqueles que estariam dispostos a falar. Pedi ajuda ao sheikh Jihad, que diz conhecer alguns dos homens investigados, mas me adiantou que dificilmente ele cederia uma entrevista, pois tinha medo de uma exposição ainda maior, não apenas dele, mas de sua família, o que soou compreensível.

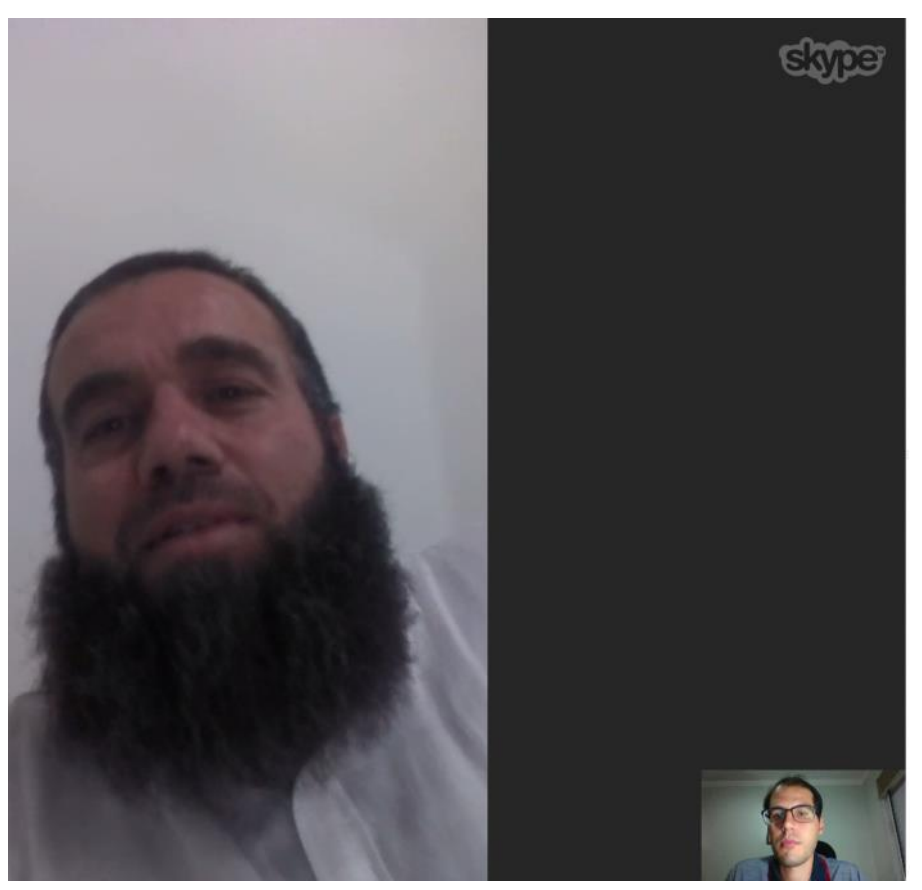

Foto 18 - Ahmad Alkhatib, 23.09.2016 (via Sype).

Nao me rendendo à dificuldade, durante um jantar com um amigo muçulmano Hossam, expus a minha dificuldade e ele decidiu me ajudar indicando Ahmed Al-Khatib, que está sob investigação da polícia pois foi citado por alguns dos homens presos como seu "orientador" para assuntos religiosos, entre eles, Antonio de Andrade que trabalhava com ele na ONG. Por meio das redes sociais eu o localizei e expliquei quem havia passado seu contato assim como meu interesse em ouvi-lo. Ele então gentilmente me atendeu pelo skype no dia combinado.

A comunidade de Campinas/SP é, sem dúvida, aquela com quem mais tenho maior proximidade e trânsito. Para começar minha imersão, iniciei aulas de árabe em uma escola de idiomas, onde lá estudei por aproximadamente três anos. Durante esse tempo, meus professores M.E (que é marroquino), que também é diretor dessa escola e mais recentemente assumiu a administração da Mesquita Anoor, e M.Y (egípcio) se tornaram amigos próximos, assim como

${ }^{42}$ http://bit.ly/2KuCyuT (acesso em 30.07.2016). 
suas famílias. Ao mesmo tempo, também me aproximei bastante da SIC que através das figuras de Nader, secretário da instituição e Mohammed Habib, professor da Unicamp e presidente da SIC, me acolheram na comunidade. Em ambas compareci a pregações, estive presente em celebrações importantes como as do mês do Ramadan participando do iftar e assisti a palestras diversas oferecidas por essas comunidades ${ }^{43}$.

Tais participações serviram para estreitar laços pessoais e acadêmicos e ampliar o círculo de relações. Muitas das pessoas com quem tenho me relacionado nesse período foram importantes para que eu pudesse estabelecer novos contatos para a pesquisa, entre os quais, um grupo de refugiados que entrevistei, em especial um de seus membros, Alaa, como gosta de ser chamado. O encontro foi mediado por Nader e ocorreu em 04 de novembro de 2015 na própria sede da SIC.

Outro refugiado com quem pude estreitar relações e obter informações é Issa, que conheci por intermédio de um amigo, Hossam. Pode-se dizer que essa entrevista se deu em dois momentos: o primeiro encontro aconteceu no dia 25 de julho de 2015 em um restaurante no centro de Campinas/SP que é administrado por uma família de refugiados sírios. Pude interagir com o dono do restaurante, o senhor Abu Kamel e os familiares de Issa que estavam presentes (Fadi, Jouny e Elias). No entanto, a conversa se polarizou em Issa e contou com a tradução de meu amigo Hossam que deu maior fluidez à conversa.

Em um segundo momento encontrei Issa em um shopping da cidade, pois era lá que estava trabalhando. Ao final de seu expediente pude conversar com ele e obter novas informações. Hoje continuamos nos falando, assim como acontece com quase todas as pessoas com quem tive contato, pelo aplicativo Whatsapp e por redes sociais, onde é possível também observar as publicações que efetuam bem como seu teor, algo que também contribui para analisar o perfil dessas pessoas e os grupos aos quais pertencem.

O penúltimo trabalho de campo foi realizado em Natal/RN entre os dias 23 e 24 de fevereiro de 2017. Por meio de contato via redes sociais e Whatsapp, consegui um encontro na Associação Beneficente Muçulmana do Rio Grande do Norte. A pequena comunidade é presidida por Muhamad Tawfiq (Foto 19), que gentilmente me recebeu no espaço onde funciona a mesquita e que estava sendo inaugurada justamente no dia de minha visita coincidentemente

\footnotetext{
${ }^{43}$ Como exemplo dessas palestras, em 08.11.2015, na SIC, participei de um encontro sobre a Saúde da Mulher e a questão dos refugiados em Campinas a convite do Centro Islâmico de Campinas onde foi realizado o evento. Em 19 e 20.05.2015, a convite da Mesquita Anoor, assisti às palestras proferidas pelo sheikh paquistanês Imran Hosein sobre o "Islam e o sistema monetário mundial" e "Jerusalém no Alcorão", que foram realizadas também com o apoio da Mesquita de Jundiaí. Além disso, quizenalmente a Mesquita Anoor oferece palestras com o sheikh Mohammed Mazloum que em geral discorre sobre as histórias de vida dos profetas do islam.
} 
ao "salat jumah" (oração da sexta-feira, dia mais importante para oração) algo que foi bastante auspicioso uma vez que pelo menos metade dos frequentadores estiveram presentes.

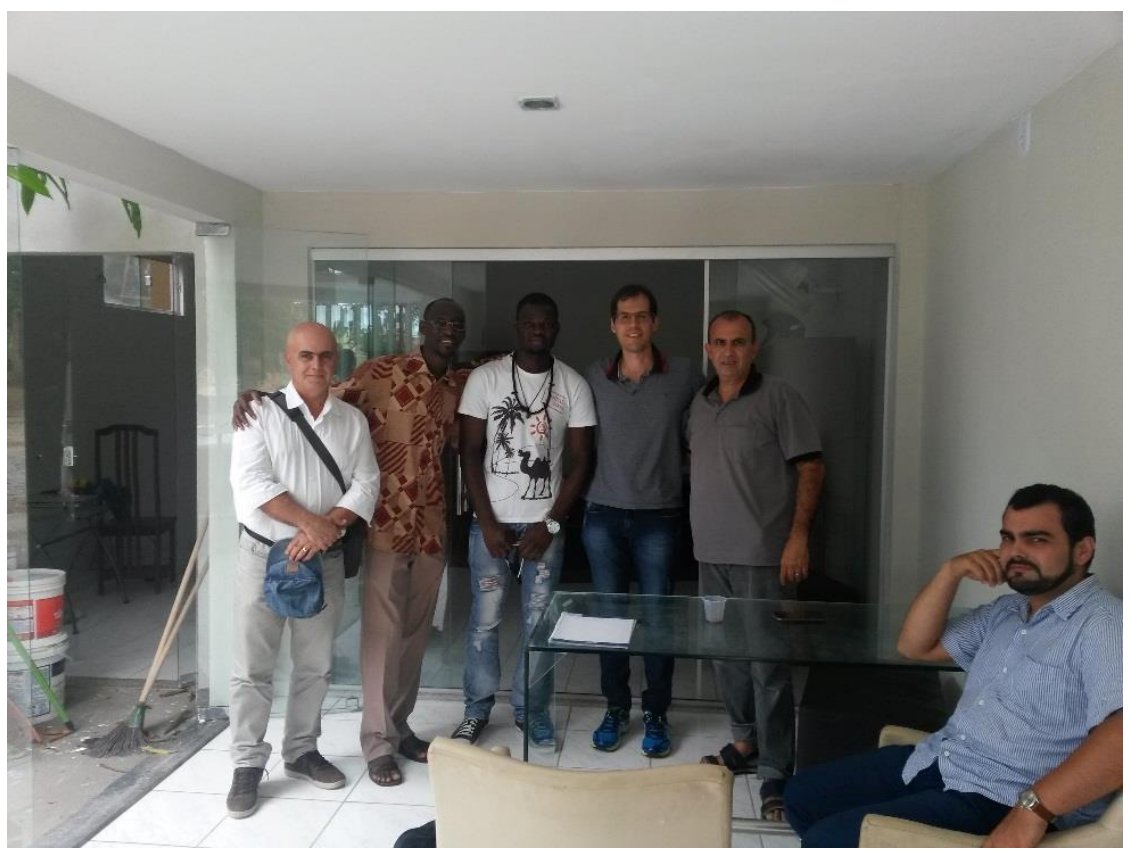

Foto 19 - Mohamed Tawfiq, o primeiro à direita em pé. Abdoul Hadi Savadogo, o segundo à esquerda. 24.02.2017.

Contrariamente ao que me ocorreu quando visitei a mesquita Omar Ibn Al-Khattab em que minha entrada foi barrada no momento da oração pela aparente falta de comunicação de minha visita, fui recebido pela comunidade em Nata/RN de forma muito aberta. Pensando em me prevenir do ocorrido em Foz do Iguaçu/PR, perguntei à Muhamad Tawfiq a quem eu deveria me identificar quando chegasse à sede da associação, e se a pessoa que me receberia, caso não fosse ele próprio, tinha conhecimento de minha visita. A resposta foi tão clara quanto austera: “na casa de Deus não precisa se identificar". Em seguida de forma mais gentil ele completou: "Se chegar antes de mim, pode entrar à vontade".

De fato, ao chegar, Muhamad Tawfiq não se encontrava. No entanto me apresentei aos que lá estavam lá me acolherem e me levaram para dentro do espaço, me mostrando a reforma e querendo saber de onde eu vinha, o que fazia e quanto tempo ficaria na cidade. Quando o presidente chegou, ele logo se dirigiu a mim de forma muito amistosa e me apresentou aos demais. Assisti à oração e ao sermão feitos por ele mesmo (não há sheikh nessa comunidade). Ao fim desse momento ele me disse que antes faríamos um lanche e então estaria disponível para a entrevista. Afirmei que não precisava se incomodar comigo e que aguardaria o tempo necessário, afinal não havia contribuído com nada para o almoço comunitário. Mas a hospitalidade e a insistência de muitos dos presentes, logo me fez me juntar aos demais para a refeição. 
Por fim, o derradeiro trabalho de campo realizado foi no Centro Cultural Islâmico da Bahia, situado na cidade de Salvador. A visita ao local e a entrevista com o sheikh Ahmad Abdul, que veio da Nigéria no início dos anos 90 e conduz a comunidade desde 1994, foi feita em uma oportunidade em que estive de passagem na cidade. Logo, o agendamento desse encontro foi feito às pressas, assumindo o risco de não ser concretizada em razão de prováveis compromissos já pré-agendados por parte do sheikh. No entanto, ele prontamente me atendeu assim que explicitei os motivos e a importância desse encontro.

Então, no dia 09 de janeiro de 2019 pude me reunir com o sheikh na Mesquita de Salvador (conforme indicava os escritos no muro da casa como indica a Foto 09).

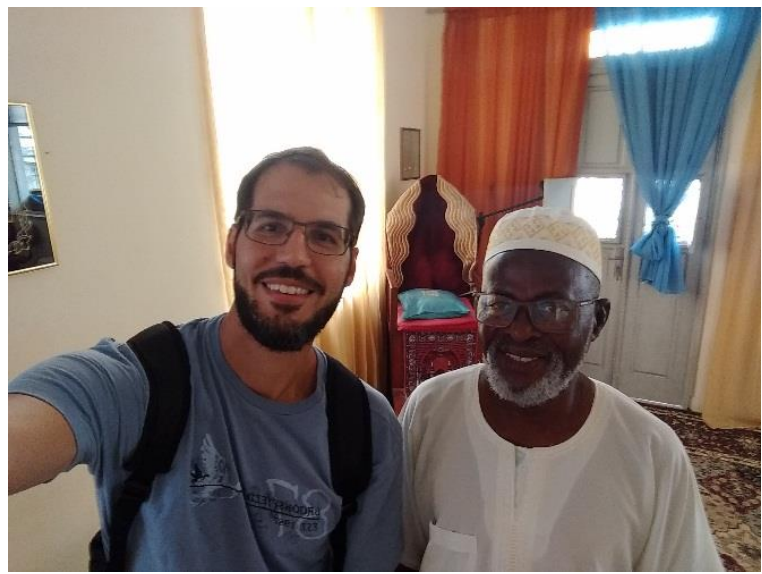

Foto 20 - Sheikh Ahmad Abdul, 09.01.2019

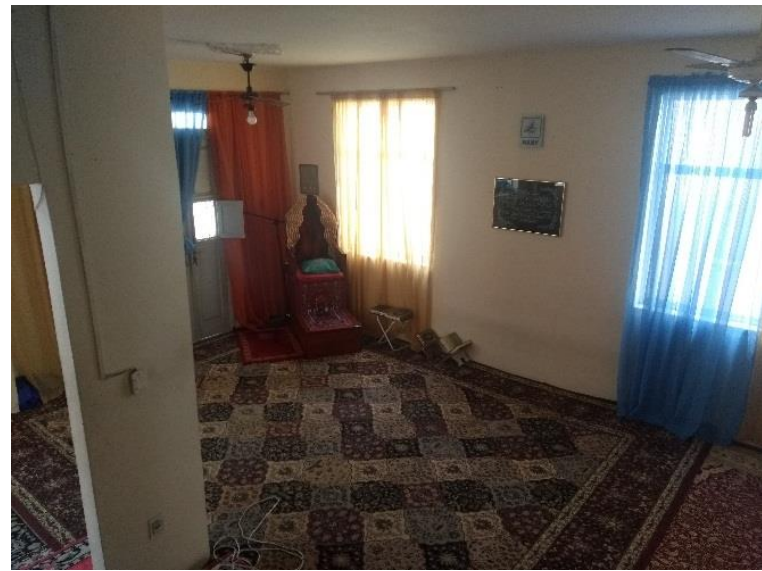

Foto 21 - Sala de orações (CCIB) 09.01.2019.

Como se observa através da foto 21 , a sala de orações está em um espaço muito exíguo, mas segundo o sheikh, adequado para o número médio de frequentadores que é de 130 aproximadamente, apenas na capital

A comunidade islâmica da Bahia, ainda que tenha pouco mais de 20 anos, é de extrema importância histórica, pois os primeiros muçulmanos que chegaram ao Brasil datam do período colonial e desembarcaram no estado através do tráfico de escravos, em particular, os Malês. Perguntado se ainda havia frequentadores da mesquita que eram descendentes desse povo, o sheikh acenou negativamente. Segundo ele, a última pessoa que teria laços com esse povo era uma senhora, dona Ivone, que faleceu nos anos 90.

Outro dado que confere relevância à comunidade baiana é o número de muçulmanos, que está em torno de 700 pessoas, o que a coloca como a maior da região nordeste.

Como forma de organizar relação dos entrevistados e os respectivos lugares e datas em que se deram os encontros, montamos o seguinte quadro. 
Quadro 1 - Relação dos entrevistados

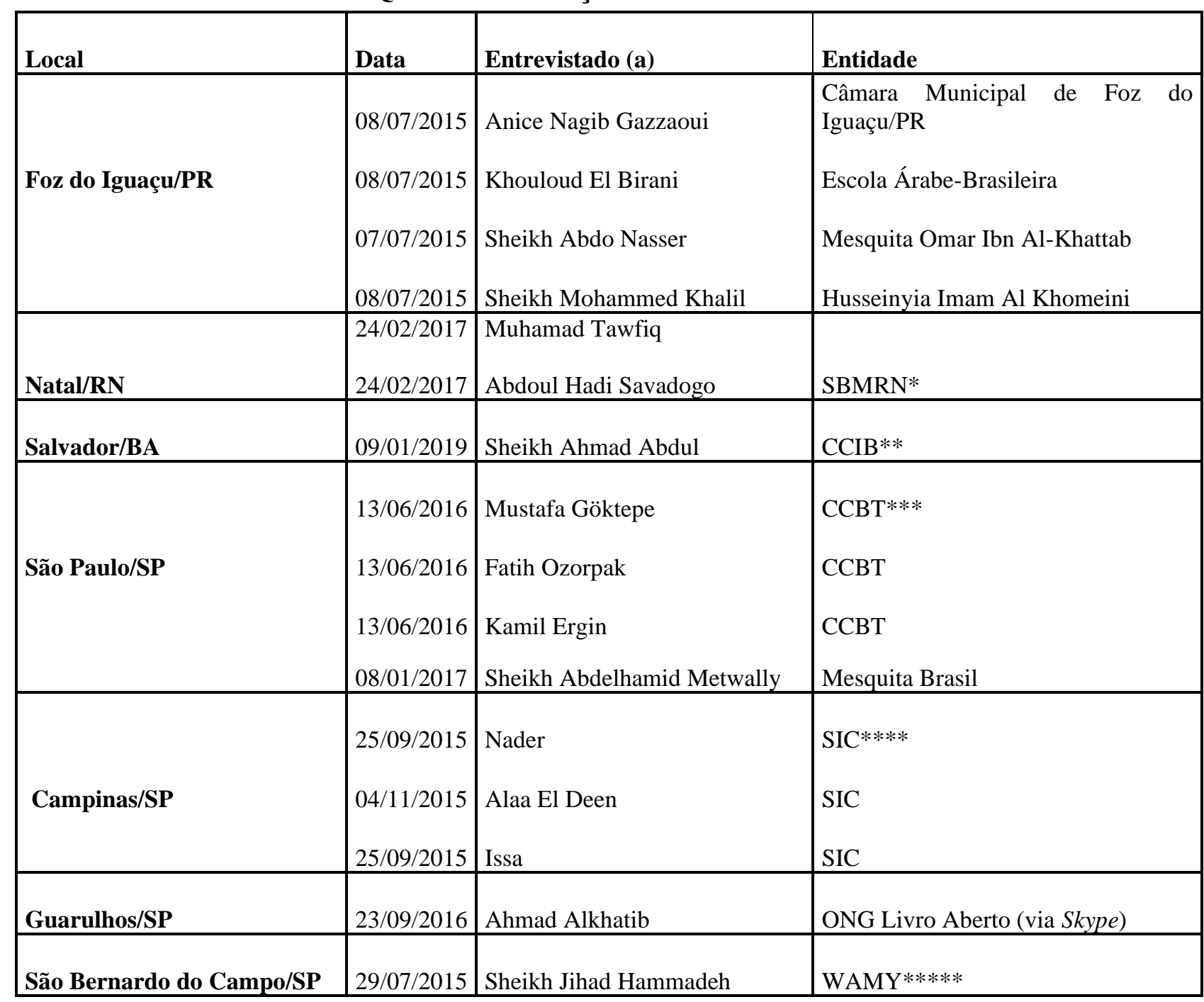

* SBMRN - Sociedade Beneficente Muçulmana de Natal

** CCIB - Centro Cultural Islâmico da Bahia

*** CCBT - Centro Cultural Brasil Turquia

**** SIC - Sociedade Islâmica de Campinas

***** WAMY - Assembleia Mundial da Juventude Islâmica (World Assembly of Muslins Youth)

\section{3) Transcrição das entrevistas.}

Essa parte do trabalho de campo talvez tenha sido a mais penosa. Foram registradas aproximadamente 16 horas de gravações somando todos os encontros que tive. Em muitas situações o som ambiente não favorecia uma boa compreensão da fala através do dispositivo de gravação, o que tornava demorada e difícil a missão de decifrar e transcrever corretamente algumas informações. Além disso, boa parte dos entrevistados por conta de sua origem árabe tinha um sotaque bastante marcante, o que em certos momentos dificultava o imediato entendimento. Mas nada que tornasse ininteligível a compreensão.

Todavia, de um modo geral, o maior esforço foi o de tentar passar para o papel não apenas o conteúdo das informações, mas também a maneira como elas eram transmitidas. Nesse 
processo a sintaxe não foi privilegiada. O tom de voz, os possíveis erros de concordância verbal ou nominal, as inúmeras interjeições, os gestos, eventuais "tics" na fala, hesitações, neologismos e mesmo o silêncio mais prolongado em certos momentos, tentaram ser representados nas transcrições sempre que possível. Como afirma Samuel (1998, p.391), "in other words, the artistry in his transcription is to convey in words the quality of the original speech" ${ }^{44}$.

Os sotaques carregados na maioria dos casos e o esforço em se fazer entender reforçam a originalidade dos registros que estão disponíveis em anexo em sua íntegra. Contudo, no corpo principal da tese optamos por efetuar as devidas correções e adequações para que o texto acadêmico possa ser mais fluido e para que aqueles informantes que estão representados por meio de suas falas não se sintam constrangidos ou "excluídos" pela língua, algo que de forma alguma tenha sido a intenção, muito pelo contrário conforme justificado a pouco.

Não apenas o que ouvi e vi, mas a forma como isso se deu ajuda a priorizar certos assuntos em detrimento de outros. Entretanto, há que se tomar cuidado em não apenas focar em como eles dizem o que dizem, mas principalmente sobre que tipo de reflexão que temos que ter com base naquilo que os entrevistados descrevem ${ }^{45}$.

Outro ponto a ser lembrado é que embora diversos assuntos tenham sido tratados nas entrevistas, eles não seguiram uma ordem rígida. Por inúmeras vezes os temas se intercalavam entre si à medida que a conversa se desdobrava. Do mesmo modo, tive o cuidado de manter a sequência das informações na transcrição evitando agrupar temas comuns com o intuito de preservar a fluidez da fala e a naturalidade com que a entrevista se realizou.

Justamente pela narração do informante se dar de forma aleatória, a transcrição é o momento em que se tornam mais nítidas as possíveis incoerências, contradições e dúvidas que surgem nas falas e que muitas delas não são imediatamente apreendidas no momento da conversa. Ao revisar as informações, nota-se a importância em se manter o contato com os entrevistados para que possam, em outros momentos, esclarecer alguns pontos de sua entrevista ou mesmo acrescentar novos elementos, uma vez que o testemunho oral nunca é o mesmo (Portelli,1998).

\footnotetext{
44 "Em outras palavras, a arte na sua transcrição é transmitir em palavras a qualidade da fala original" (tradução minha).

45 Thompson, P. 2002.
} 


\subsection{Modernidade e Islam: raízes modernas de um fenômeno pós- moderno}

Esta parte do trabalho se debruça sobre o contexto histórico atual em que o fundamentalismo islâmico se insere a partir do território brasileiro em que se ancoram suas diversas comunidades islâmicas. Tal como Eisenstadt (1999, p.03) argumenta, "fundamentalist movements have to be analyzed in the context of both the historical experience of their civilizations and their various religious traditions, as well as the cultural and political program of modernity" 46 .

Nesse sentido, como a modernidade e sua tributária, a globalização, podem influenciar na organização dessas comunidades e especialmente nas suas reações aos diversos eventos que envolvem o mundo muçulmano? Por que o período atual tem sido tão fértil para a gênese de grupos e ações jihadistas bem como sua profusão midiática mundo afora? As comunidades brasileiras podem conter germes do extremismo?

Para compreender o período atual e estabelecer relações com o tema dessa tese não podemos nos esquivar de discutir e problematizar os aspectos concernentes à modernidade que “é inerentemente globalizante" e que marca o período em que vivemos (Giddens, 1999, p.75).

A modernidade para Latour (1994, p.15) "possui tantos sentidos quantos forem os pensadores ou jornalistas". Bauman (2000, p.08) também concorda que é difícil explica-la e defini-la ao afirmar que ela "means many things, and its arrival and progress can be traced using many and different markers" ${ }^{\prime 4}$. Tendo isso em vista e longe de realizar um extenso debate sobre a modernidade e a globalização segundo diversas concepções políticas, ideológicas, sociais e econômicas, buscaremos refletir sobre algumas de suas variáveis que ajudam a entender os contextos em que estão inseridas as comunidades islâmicas no Brasil e os aspectos ligados ao fundamentalismo.

Um caminho para entender a modernidade e alguns dos fatores que ela engendra é nos aproximarmos de como é definida por alguns autores.

Huntington (1998, p.81) descreve a modernização como "produto da tremenda expansão do conhecimento científico e de engenharia que começou no século XVIII e que habilitou os seres humanos a controlar e moldar seu meio ambiente de modos inteiramente sem precedentes".

\footnotetext{
46 “movimentos fundamentalistas devem ser analisados em ambos os contextos, da experiência histórica de sua civilização e suas várias tradições religiosas, tanto quanto o programa cultural e político da modernidade" (tradução minha).

47 "significa muitas coisas, e sua chegada e progresso podem ser traçados usando muitos e diferentes marcadores" (tradução minha).
} 
O autor examina três grandes reações ao Ocidente e à modernização: uma rejeicionista, outra kemalista (que aceita tanto a modernização quanto a ocidentalização) e por fim a reformista. Em todas elas é possível incluir o islam. Na primeira, seria o caso de grupos fundamentalistas extremistas que desejam manter sua sociedade isenta de influências externas porque perniciosas; na segunda, caso da Turquia de Mustafa Kemal Ataturk que mesmo conduzindo uma sociedade islâmica, a moderniza e assimila a cultura ocidental; na terceira possibilidade, também podemos incluir o islam por meio de reformistas como Rashid Rida e Mohammad Abduh que sugeriam a adoção da modernização mas preservando os valores culturais, religiosos, as instituições e práticas da cultura autóctone, ou seja, evitando a ocidentalização.

Outro pensador que contribui para a discussão sobre modernidade é Harvey (2007), que lança mão da compressão espaço-tempo que promove uma aceleração do atual período dotandoo de um aspecto fugidio e efêmero, assim como as rupturas que provoca com quaisquer condições históricas precedentes e até mesmo internamente. Além disso, essa fase da história do mundo é marcadamente geradora de fragmentações sócio-espaciais, que por sua vez se manifestam no território na forma de desigualdades. O espaço passa a ser aniquilado pelo tempo segundo suas proposições, o que faz com que os objetos modernos sejam produzidos em uma escala e velocidades nunca vistas. Desse modo, nem todas as pessoas e lugares são capazes de assimilar tais tecnologias que são renovadas em intervalos de tempo cada vez mais reduzidos.

Com algumas semelhanças, Berman (2007) também discorre sobre a modernidade sob o espectro das artes, da filosofia, literatura e urbanismo. Ele exalta as grandes conquistas e avanços desse período no campo da ciência, na industrialização, na tecnologia, no poder de transformação do espaço e das relações sociais, e no acelerar do tempo. Contudo, não nos deixa esquecer que cada um desses avanços carrega consigo o seu "contrário". Berman (ibid., p.24) resume que

ser moderno é encontrar-se em um ambiente que promete aventura, poder, alegria, crescimento, autotransformação e transformação das coisas em redor - as ao mesmo tempo ameaça destruir tudo o que temos, tudo o que sabemos e tudo o que somos [...] ela nos despeja a todos um turbilhão de permanente desintegração e mudança, de luta e contradição, de ambiguidade e angústia.

Assim, as grandes cidades conhecem o problema da explosão demográfica acompanhada de uma espoliação urbana em que o trabalho e os direitos básicos se tornam precários para uma parcela cada vez maior da população. O meio ambiente e sua degradação se tornam centrais na agenda política. As lutas de classes se tornam mais constantes, e a fábrica moderna tira o 
protagonismo do homem, que para o autor não resta muito que fazer "além de apertar um botão".

Também usada como forma de marcar o tempo, e dividi-lo entre o antigo e o moderno, Hicks (2004) afirma que a modernidade é produto do Iluminismo, em que se pregava a razão como base elementar do progresso, a objetividade, o individualismo, o domínio científico da natureza para se libertar de suas imposições, e o capitalismo liberal no plano econômico.

Giddens (1999) corrobora essa linha de raciocínio ao se referir à modernidade como um estilo de vida e forma de organização social originada na Europa do século XVII e que se manifesta especialmente na mudança de relações entre o espaço e o tempo, na confiança nos sistemas técnicos, na insegurança frente à militarização do mundo, na rotinização da vida social e ruptura com a tradição promovendo uma série de "desencaixes" 48 e "reencaixes" das relações sociais.

Além disso, para Giddens (ibid., p.189),

quando falamos em modernidade, contudo, nos referimos a transformações institucionais que têm suas origens no Ocidente [...] é a modernidade um projeto ocidental em termos dos modos de vida forjados por essas duas grandes agências transformadoras [estado-nação e a produção capitalista]? A esta pergunta, a resposta imediata deve ser "sim".

Ainda que a modernização tenha grande influência ocidental, Huntington (1998, p.94) alerta que ela "não quer necessariamente dizer ocidentalização. As sociedades não-ocidentais podem se modernizar e têm se modernizado, sem abandonar suas próprias culturas e sem adotar de forma generalizada os valores, as instituições e as práticas ocidentais".

Mas muitos grupos fundamentalistas rejetiam quaisquer que sejam as influências ocidentais e suas modernizações. Segundo Khatab (2006), o período de 1939 a 1948 foi a fase em que Sayyid Qutb passou a focar suas ideias sobre o futuro do Egito e temia que o país abraçasse cegamente o projeto secular ocidental perdendo suas raízes islâmicas. Khatab (ibid., p.83) explica que

his objective, as he asserted, was to remind Egyptians of their Islamic identity and Islamic heritage, and 'to recover for the modern readers the original powerful charm of the Qur'an that the Arabs felt on first receiving it and falling under its spell' [...] Qutb had arrived at a point where he clearly saw

\footnotetext{
48 “Por desencaixe me refiro ao 'deslocamento' das relações sociais de contextos locais de interação e sua
} reestruturação através de extensões indefinidas de tempo-espaço” (Giddens, 1999, p.31). 
any adoption of European laws as a secular threat to the Islamic identity and culture of Egypt ${ }^{49}$.

Desse modo, a modernidade que tem entre seus atributos um caráter universalizante que é traduzido pela globalização, cria novas formas de interdependência e ainda coordena uma agenda global que ao invés de unir, unifica, seja por sedução ou pela imposição da força econômica ou militar. Como exemplo perverso dessa modernidade imposta, Hicks (2004, p.04), usando Lyotard como referência, diz:

Saddam Hussein is a product of Western departments of state and big companies, just as Hitler, Mussolini and Franco were born of the 'peace' imposed on their countries by the victors of the Great War. Saddam is such a product in an even more flagrant and cynical way ${ }^{50}$.

Isso de alguma forma também é notada na fala de sheikh Mohammed Khalil, quando em sua entrevista ele dá a entender que esse projeto ocidental moderno atua de forma indócil com relação ao Oriente Médio e os povos que lá habitam, inclusive cristãos. Ele afirma que

todas as guerras que acontecem no Oriente Médio, do fundo do coração, sem vaidade, estou lamentando pelos cristãos que vivem no Oriente Médio. Os cristãos criaram uma milícia, e quem os está treinando? São os xiitas, em Bagdá. Por que eles vieram aos xiitas e não foram ao Ocidente? Porque o Ocidente é infiel. Eles desconfiaram totalmente.

Outros sustentam que o recente califado criado pelo Estado Islâmico e todas as repercussões negativas que decorrem dele - seja a guerra civil na Síria, ou a maior crise de refugiados desde a Segunda Guerra Mundial, as movimentações no xadrez geopolítico e o terrorismo - seriam uma continuidade desse projeto Ocidental conduzido pelos Estados Unidos, OTAN e União Europeia. Dentre os inúmeros depoimentos sobre o assunto, apresento um deles, no qual o sheikh Jihad Hammadeh discute sobre a criação do Estado Islâmico. Em um tom bastante severo ele revela:

Quem é o maior beneficiado? É aquele que o criou. Então, se eles são um grupo muçulmano, os muçulmanos deveriam ser os primeiros beneficiados! $\mathrm{E}$ são? [risos] Eles são os que mais estão morrendo! [exclama]. Nós estamos sendo difamados por conta deles, por causa dessa minoria. Então,

\footnotetext{
49 "seu objetivo, como asseverado, era lembrar os egípcios da sua identidade islâmica e herança islâmica, e recuperar para os leitores modernos, o charme poderoso e original do corão que os árabes sentiram quando pela primeira vez o receberam e caíram sob seu encanto [...] Qutb chegou ao ponto onde ele claramente viu como ameaça a adoção de qualquer lei europeia para a identidade e cultura do Egito" (tradução minha).

50 "Saddam Hussein é produto de departamentos ocidentais de estado e grandes empresas, como Hitler, Mussolini e Franco nasceram da 'paz' imposta sobre seus países pelos vitoriosos da Grande Guerra. Saddam é tal produto de modo ainda mais flagrante e cínico" (tradução minha).
} 
imediatamente, fica claro para mim. Eu concluo que não foram os muçulmanos que criaram eles.

Entretanto, essa linha de raciocínio pode conduzir a um caminho demasiado arriscado ao usar modernidade e seus atributos como desculpa para os muitos crimes cometidos por esses ditadores, invertendo o papel de "réus" da história.

Esses argumentos fazem parte de um repertório muito usual entre teorias conspiratórias ao redor do mundo. Ainda que boa parte dos muçulmanos seja estigmatizada em função de atos de uma minoria, a questão é que "os muçulmanos", tal como se coloca de forma generalizante, não formam um grupo monolítico. Assim, o argumento cui prodest deve ser relativizado.

Por sua vez, Bauman (2000) consagra grande parte de seus escritos para discorrer sobre a modernidade. Para ele, ela é fruto da aceleração do tempo e se associa às mudanças nas relações humanas e à emancipação do espaço em relação ao tempo, implicando que se conhece por desterritorialização. Ele divide essa época em duas fases: a primeira definida como a "modernidade sólida" e a segunda como "modernidade líquida".

No primeiro caso, também apelidada de modernidade pesada (“heavy modernity"), é a fase em que o território possui grande importância, onde se depositam poder e riqueza. Coincide com o modo fordista de produção, de indústria pesada, início das ferrovias e quando o trabalho e o capital eram indissociáveis no tempo e no espaço, sem anseios ou capacidade de se locomoverem. Por sua vez, a modernidade líquida ou leve (“light modernity") é marcada pela fluidez, pelo desengajamento entre trabalho e capital, pela possibilidade de atingir qualquer parte do espaço em qualquer momento e pela extraterritorialidade e volatilidade de identidades, do capital e das relações humanas.

Em outra importante e intrigante contribuição, Latour (1994) questiona se de fato algum dia fomos modernos. O caminho que percorre para chegar a essa conclusão parte de uma reflexão aprofundada de que a modernidade implica na separação de duas práticas: a da tradução - ou mediação -, que produz híbridos, e a da purificação, que cria duas zonas ontológicas distintas, a dos humanos e a dos não humanos em instâncias estanques não permitindo que nada residisse no meio. Para o autor, há uma "constituição moderna" que crê ser possível separar o domínio da natureza, que se refere ao mundo natural, do domínio da política, que designa o mundo social.

Essa pretensa compartimentação que se reflete na produção do conhecimento científico é exemplificada em sua obra através dos experimentos de Hobbes e Boyle que representam os dois lados da ciência e do conhecimento: política, sociedade e religião de um lado, e a ciência, a natureza e a experimentação de outro. Tudo que estivesse entre esses dois polos, no caso os 
híbridos, não eram objeto de estudo a menos que fossem classificados de acordo com a polarização sociedade-natureza.

O problema que aflige o projeto moderno é que o mundo, de acordo com Latour (ibid., p.40), "vive da mistura" e, portanto, não funciona de acordo com as regras e garantias ${ }^{51}$ dessa "constituição moderna" que ignora os híbridos, transformando-os em entes naturais ou sociais para só então compreendê-los. A todo instante, mesmo que inadvertidamente, pensamos e agimos de forma cada vez mais híbrida ainda que tentemos nos manter presos ao domínio do nosso conhecimento. Logo, a modernidade não cumpre o que promete, "por isso jamais fomos modernos". Para Latour (ibid., p.16) "enquanto considerarmos separadamente essas práticas, seremos realmente modernos [...] A partir do momento em que desviamos nossa atenção simultaneamente para o trabalho de purificação e hibridização, deixamos instantaneamente de sermos modernos".

Sayyid Qutb ainda que sem recorrer explicitamente à ideia de híbridos, declara, de acordo com Khatab (2006, p.88) que

true knowledge is knowledge that emphasizes that the unity between spiritual and material forces is a fact of life. In humans, spirit and matter cannot be separated; a human is not human only on account of his physical (material) being, nor only by virtue of the spirit. Unity between matter and spirit is fundamental to life ${ }^{52}$.

Desse ponto de vista, a unidade entre o material e o espiritual, além de insinuar uma questão existencialista tal como iremos propor adiante, reflete uma postura "pré-moderna", quando não se permitia a separação entre natureza e sociedade uma vez que ela era cimentada pela presença do Criador, que na modernidade foi suprimido.

Se assim for, no decorrer da pesquisa seremos pegos muitas vezes nesse dédalo repleto de híbridos, portanto, não podemos nos considerar modernos, pois não somos capazes de reduzir a diversidade de fenômenos em dois pólos distintos passíveis de análises. Estudaremos conceitos e definições que perpassam campos do conhecimento que vão desde a antropologia, etnografia, geografia, sociologia e a história, e que inevitavelmente deverão ser

\footnotetext{
51 “ $1^{a}$ garantia: a natureza é transcendente, porém mobilizável (imanente); $2^{\mathrm{a}}$ garantia: a sociedade é imanente mas nos ultrapassa infinitamente (transcendente); $3^{a}$ garantia: a natureza e a sociedade são totalmente distintas e o trabalho de purificação não está relacionado com o trabalho de mediação; $4^{\mathrm{a}}$ garantia: o Deus suprimido está totalmente ausente, mas assegura a arbitragem entre os dois ramos do governo" (Latour, 1994, p.139).

52 "O verdadeiro conhecimento é aquele que enfatiza que a unidade entre as forças materiais e espirituais é um fato da vida. Em humanos, espírito e matéria não podem ser separados; um humano não é humano apenas levando-se em conta o ser físico, nem apenas pela virtude do espírito. A unidade entre matéria e espírito é fundamental à vida" (tradução minha).
} 
contextualizados e analisados à luz de um período histórico complexo e de uma metodologia edificada sob os alicerces da história oral.

Que o fio de Ariadne seja forte o suficiente para que se possa cruzar com êxito esse labirinto que atenta contra "constituição moderna" ao forçar nosso olhar para a totalidade, para as contradições ensejadas pela globalização e seus subprodutos: o religioso e o secular, o mythos e o logos, a homogeneização e a fragmentação, a velocidade e a lentidão, o global e o local, o tempo e o espaço, o islam e o Ocidente, a moderação e o jihad. Conceitos e noções carregadas de hibridez cuja existência é explicada por Latour (ibid., p.40) pelo fato de que "a constituição moderna permite, pelo contrário, a proliferação de híbridos cuja existência - e mesmo a possibilidade - ela nega".

A modernidade se compreende como perspectiva que varia segundo as mais diversas proposições encontradas na literatura. Se por um lado acreditarmos que jamais fomos modernos, então não deveríamos nos preocupar com o fato de que islam político, mais ativo e com consequências mais extremas, seja um produto da modernidade. Assim sendo, buscaríamos outras causas para sua emergência no mundo.

Mas se olharmos através de outro ponto de vista, daquele que parte de um muçulmano salafi, de uma corrente tradicionalista que reivindica justamente o trabalho de "purificação" do islam, a perfeição de sua crença, livre de próteses e remendos, que tenta se isolar e repelir elementos e influências externas, talvez ele estivesse mais próximo de ser moderno de acordo com a tese de Latour (ibid.)? Em suma, o dualismo encontrado nessa forma de interpretação islâmica do "nós e eles", "crentes e infiéis, dar ul-islam e dar ul-harb os tornaria modernos? A resposta é negativa, pois uma das garantias para que se cumpra a "constituição moderna" é a do Deus suprimido que permite que esse mecanismo dual se torne estável e sem a presença de um poder transcendental que desequilibre a balança. Latour (ibid, p.38) afirma que "ninguém é realmente moderno se não afastar Deus tanto do jogo das leis da natureza quanto das leis da República". Mas isso é exatamente algo que fundamentalistas não abrem mão.

O conceito de modernidade se assume como um caleidoscópio de significados e principalmente de perspectivas. Justamente por isso, Demant (2004), que também se preocupa em relacionar o fundamentalismo islâmico com a modernidade, indaga sobre qual modernidade o islamismo se opõe: com base em uma sociedade que se divide entre a esfera pública e a privada bem como seus direitos e liberdades; se no plano econômico industrial da atual fase do modo de produção capitalista; se do ponto de vista político; ou no quesito ideológico. Para Demant (ibid., p.319) “o fundamentalismo só pode emergir onde as condições sociais estão pelo menos em parte modernizadas. Movimentos para purificar a fé e recriar um passado 
idealizado são quase tão antigos quanto o próprio islã’. Eisenstadt (1997, p.01) corrobora essa posição ao dizer que

“o fundamentalismo é muitas vezes apresentado como um fenômeno antimoderno, como uma irrupção de forças tradicionais ou tradicionalistas reprimidas, por assim dizer, pelos regimes modernos e pelo programa cultural da modernidade".

Amir, Shuriye e Ismail (2012, p.64) afirmam que a

"modernity denotes the renunciation of the past, favoring a new beginning, and a reinterpretation of historical origin. Central to modernity is the emancipation from religion, especially the hegemony of Christianity, and subsequent call for secularization" ${ }^{53}$.

Se assim for, os muçulmanos tradicionalistas, salafistas e mesmo jihadistas são justamente opostos a essa definição. A renúncia ao passado seria como negar a própria origem enquanto a reinterpretação estaria fora de cogitação especialmente se ela ousar uma abertura a novas leituras e aos novos contextos. Finalmente, a emancipação religiosa e a secularização são difíceis de serem concebidas pelo islam e por parte de seus seguidores. Isso classifica o fundamentalismo islâmico, em particular a versão jihadista, como um fenônemo antimoderno.

Zizek (2002, p.162-163) também opina sobre esse assunto ao afirmar que

a atitude politicamente correta característica é enfatizar, com sintomática insistência, que os ataques terroristas nada têm a ver com o verdadeiro Islã, uma grande e sublime religião - não seria mais apropriado reconhecer a resistência do Islã à modernização? E, em vez de lamentar o fato de o Islã, de todas as grandes religiões, ser a mais resistente à modernização, deveríamos, pelo contrário, ver essa resistência como uma oportunidade aberta, ainda "por ser decidida": essa resistência não tem necessariamente de levar ao "islamofascismo"[...] Exatamente porque abriga os "piores" potenciais da resposta fascista às nossas dificuldades atuais, o Islã pode também abrigar os "melhores".

Todavia, "qual islam" é resistente à modernização? Nele há uma miríade de correntes, desde as reformistas até as mais tradicionalistas que também oferecem respostas à modernidade. Por exemplo, Demant (2004) elenca esses caminhos: há o tradicionalismo, o modernismo (que

\footnotetext{
53 “A modernidade denota a renúncia do passado, favorecendo um novo começo e uma reinterpretação da origem histórica. A emancipação da religião é central para a modernidade, especialmente a hegemonia do cristianismo, e subsequente apelo à secularização" (tradução minha).
} 
reforma o islam visando torná-lo compatível com a modernidade), o nacionalismo secular e por fim o fundamentalismo islâmico.

Zizek (2002) também ensaia pelo menos três escolhas: a) um fundamentalismo islamofascista, violento e reacionário; b) o desenvolvimento de um protestantismo islâmico que poderia compatibilizar o islam com a modernização do mundo; c) socialismo islâmico, que já foi tentado e fracassou.

Se jamais fomos modernos como defende Latour (1994), teríamos entrado diretamente na pós-modernidade? A situação se torna ainda mais complexa se levarmos em conta a possibilidade de que os fenômenos relacionados ao fundamentalismo islâmico possam estar ancorados não na modernidade, mas na pós-modernidade. Seria a modernidade o período de germinação do fundamentalismo, enquanto a pós-modernidade, aquele da sua difusão?

A realidade moderna dá lugar à "hiperrealidade" pós-moderna. Nesse caso, Giddens (1999) vê a pós-modernidade como algo ainda utópico que engendraria a desmilitarização criada no período predecessor, a participação mais democrática de múltiplas camadas da sociedade, prevê a humanização da tecnologia e que compreende um sistema pós-escassez que permitiria a redistribuição global da riqueza, que aos poucos substituiria o capitalismo como modo de produção dominante.

O pós-modernismo seria a correção da modernidade. Em vez de restringir os híbridos à natureza ou à sociedade, a pós-modernidade compreende-os em redes de relações com outros híbridos. A virtude pós-moderna consiste em não inventar distâncias entre os híbridos de si mesmos.

De outra maneira, Latour (idem, p.130) argumenta que a pós-modernidade é aquela em que

nada mais tem valor, tudo é reflexo, simulacro, são todos símbolos flutuantes - e esta fraqueza, segundo eles, irá quem sabe salvar-nos da invasão das técnicas, das ciências, das razões. Será preciso destruir tudo para que seja possível introduzir mudanças estruturais? O mundo vazio no qual evoluem os pós-modernos é um mundo esvaziado por eles, e por eles apenas, porque levaram os modernos ao pé da letra. O pós-modernismo é um sintoma da contradição do modernismo.

Novamente esse posicionamento sobre a pós-modernidade nos remete ao islam mais extremista, não necessariamente violento, mas que por outro lado tende para um maior isolamento. Sendo a modernidade um projeto com grandes influências ocidentais conforme sustentado anteriormente, seria natural de se esperar que esse islam mais conservador se 
enquadre na recusa de tudo aquilo que o período enseja e que possa macular a maneira como vivenciam sua fé e pensam sobre o mundo.

Harvey (2007) discorre sobre o pós-modernismo, mas se dedica em abordar aspectos relacionados à estética, à arte, à arquitetura e ao planejamento urbano. No entanto, abre espaço para refletir suas implicações epistemológicas e filosóficas convidando para o debate autores como Foucault, Derrida e Lyotard. Harvey (ibid., p.46) advoga que a pós-modernidade possui "aversão a todo projeto que buscasse a emancipação humana universal pela mobilização das forças da tecnologia, da ciência e da razão". O período pós-moderno e seus defensores questionam os postulados modernos, que segundo Latour (op.cit., p.15), "ficam suspensos entre a dúvida e a crença". O ceticismo, o relativismo e o subjetivismo são as marcas desse período que negam o Iluminismo e a primazia da razão (Hicks, 2004). As incertezas sobre a "razão", a "justiça" e a "liberdade" são marcas desse período.

Hicks (ibid., p.06) alega que ao contrário do individualismo que marca a modernidade, a pós-modernidade leva em conta o coletivismo da natureza humana, "holding that individual's identities are constructed largely by the social-linguistic groups that they are a part of, those groups varying radically across the dimensions of sex, race, ethnicity, and wealthy"54.

Levando em conta a primeira parte dessa citação, na qual as identidades são construídas por grupos sociais e linguísticos, um exemplo que se enquadraria nessa premissa é o da Sociedade Beneficente Muçulmana do Rio de Janeiro (SBMRJ). Nessa comunidade, frequentada principalmente por brasileiros convertidos, a questão da "arabização" é um dilema, pois não querem que a religião seja associada à religião "dos árabes" (Montenegro, 2000 e 2002). A religião, neste caso, transcende a comunidade árabe, não dependendo da origem de cada um.

Por outro lado, a comunidade de Foz do Iguaçu/PR tem muita influência de imigrantes árabes-muçulmanos de origem síria e libanesa. Lá, a língua árabe é muito mais falada mesmo em conversas informais. Esses perfis culturais, étnicos e linguísticos podem ser observados em cada comunidade que exala um contorno próprio. A "desetnização" da religião passa a ser uma tendência em alguns lugares que passam a definir sua identidade de uma forma mais homogênea.

Retomando uma entrevista com o turco Mustafa Goktepe, identifica-se algo que vai ao encontro dessa situação. Para ele, “essas diferenças culturais, regionais, podemos dizer

\footnotetext{
54 "Sustentando que as identidades individuais são construídas em grande parte pelos grupos sócio-linguísticos dos quais fazem parte, esses grupos variam radicalmente nas dimensões de sexo, raça, etnia e riqueza" (tradução minha).
} 
linguísticas talvez, mas muito mais políticas, fazem com que esse encontro não aconteça. Tenha várias vozes". Interrompo a fala dele e acrescento me referindo aos convertidos, se, por não possuírem esse marcador político e regional, eles poderiam tecer mais laços. Mustafá diz:

pior ainda! [se exalta]. Porque eles são convertidos através de orientadores, eles procuram alguém para saber tal, e geralmente eles têm uma formação de quem orientou ele, acaba sendo mais um. Até pior. Eles [revertidos] são muito mais isolados [...] E eles têm esse isolamento muito mais forte do que própria comunidade muçulmana. Eu sou muçulmano desde nascido e até eu estou um pouco isolado nas mesquitas porque tem árabe. A questão é um pouco mais cultural do que religiosa. Imagina eles [revertidos] ainda.

Fatih Ozorpak, também corrobora o que foi dito acima ao afirmar:

existe convertidos brasileiros que eu conheci que são pessoas maravilhosas, que interagem bem. Mas existe cultura, claro, que não vão ter a mesma tonalidade de pensamento e interpretação, mas islam é uma coisa que abrange a todos, e quando se fala de comunidade islâmica no Brasil, ele é uma grande variedade que tem libaneses, sírios, palestinos, africanos. Então cada um tem a sua própria cultura.

Observa-se que entre as comunidades islâmicas conhecidas no Brasil exista a formação de uma coletividade que se aglutina por meio de afinidades étnicas, linguísticas, culturais e até mesmo políticas. Esse tema ainda é polêmico, pois em diversas entrevistas essa questão foi abordada e apesar dos discursos uníssonos de união, na prática não é bem isso que se observa. A concha de retalhos que compõe o Oriente Médio e principalmente o mundo muçulmano também se revela no território nacional.

Mas o ponto mais importante que deve ser ponderado e sobre o qual buscaremos estabelecer uma interlocução com o tema do trabalho, diz respeito à apreensão da realidade por meio da razão, tese central da modernidade. Ainda que amplamente encontrada na filosofia grega e na escolástica, a racionalidade e a apreensão objetiva da realidade, tão centrais na modernidade, ganha novo impulso nos tempos Iluministas. Hicks (2004) também contempla em seus escritos, filósofos da corrente irracionalista que se divide entre os teístas e os ateístas, como por exemplo, de Kierkegaard à Schleiermacher passando por Nietzsche e Schopenhauer.

Como conhecer a realidade, especialmente nos dias de hoje levando-se em conta todo seu dinamismo? Através da razão? Hicks (2004., p.28) afirma que segundo Kant "reality - real noumenal reality - is forever cloused off to reason" 55 . De outra forma, a realidade é um produto

55 “realidade - real númeno - está sempre fechada para a razão" (tradução minha). 
da mente enquanto a razão possui apenas uma função criativa, algo que Hegel também assumiria segundo Hicks (ibid.).

Soren Kierkegaard sob o pseudônimo de Silentio (1994) fala sobre a crença ao limite usando o exemplo de Abraão quando sob ordem de Deus leva seu filho Isaac para o sacrifício. Abraão "desliga" sua mente e simplesmente mergulha no desconhecido movido apenas pela crença nas promessas divinas. Se a razão exercesse alguma influência poder-se-ia concluir que Deus seria um sádico imoral ao decretar a morte de uma pessoa inocente. Essa reflexão poderia estar incutida nos grupos fundamentalistas e jihadistas de hoje? Seriam eles movidos por essa ideia, a de um mergulho no absurdo que é íntimo de cada um? A razão, entretanto, impediria determinadas pessoas de enxergar além da névoa da realidade que se apresenta.

A resposta para isso pode ser encontrada na primeira fase dos escritos de Sayyid Qutb (1925 a 1939) segundo Khatab (2006, p.77), para quem "people can only be in harmony with the universe through belief in the unknown $\left(\right.$ al-ghayb) ${ }^{" 56}$. O intelecto humano, para ele, não é a fonte absoluta de conhecimento e só a soberania de Allah e a submissão a Ele é que seriam capazes de desalienar o homem reconectando criatura e criador.

Khatab (ibid., p.74) complementa que

Qutb stresses that spiritual power, not human intellect, is the only qualified Power able to connect humans with the great unity. The presence of both 'body and intellect' is the cause behind humanity's feeling of 'space and time' zones. By contrast, the spirit (al-ruh) is not limited in time or space; the spirit feels the 'absolute existence (wujud mutlaq)' ${ }^{57}$.

O intelecto humano para Qutb não é fonte do verdadeiro conhecimento. Apenas Allah seria aquele capaz de cimentar esses atributos materiais e imateriais em uma única unidade, somente assim teríamos um conhecimento pleno.

Nesse sentido, Nietzsche, segundo Hicks (2004, p.58), considera que "the reason is a tool of weaklings who are afraid to be naked in the face of a cruel and conflictual reality"

Hicks (ibid) também considera o ponto de vista de Heidegger sobre a realidade. Nesse caso, a emoção, em especial aquelas que nos "ensimesmam" como o tédio, a culpa e o medo

\footnotetext{
56 “pessoas só podem estar em harmonia com o universo através da crença no desconhecido (al-ghayb)" (tradução minha).

57 “Qubt ressalta que o poder espiritual, não o intelecto humano, é o único poder capaz de conectar os humanos em uma grande unidade. A presença de ambos 'corpo e intelecto' é a causa por detrás do sentimento humano das zonas de 'espaço e tempo'. Em revanche, o espírito (al-ruh) não limitado no tempo nem no espaço; o espírito sente a 'absoluta existência' (wujud mutlaq)" (tradução minha).

58 "A razão é uma ferramenta dos fracos que temem ficar nus diante de uma realidade cruel e conflituosa" (Tradução minha).
} 
nos fazem nos desconectar daquilo que trivial ${ }^{59}$, ordinário, daquilo que ocupa grande parte do tempo de nossas vidas. Esses sentimentos nos deixam em suspensão, o que permite compreender melhor a realidade e seus conflitos e contradições de forma total.

A partir daqui nos endereçamos para uma discussão que pretende abrir mais um caminho para se entender a questão do fundamentalismo a partir da filosofia, em especial levando-se em conta aspectos do existencialismo e do niilismo de Nietzsche, Heidegger e Kierkegaard. Isso será melhor desenvolvido no próximo capítulo. Por enquanto, é necessária uma reflexão acerca do período de globalização, que dentre outras coisas, deu maior visibilidade ao fundamentalismo islâmico.

\subsection{A Globalização: da fábula à realidade}

A globalização como processo e consequência da modernidade tem se colocado diante das comunidades islâmicas como uma encruzilhada. Dependendo das escolhas que fazem - seja se isolando, assimilando ou rejeitando influências externas - elas poderiam influenciar a forma como vivenciam a sua fé e que por sua vez desvelaria as ações que tais grupos serão capazes de executar?

Ao analizar algumas definições e as origens do termo "globalização", Brzezinski (2004, p.141) afirma que

globalization is not only an observable fact, but an explicit norm. It provides an interpretative mechanism as well as normative prescription. It is not merely a diagnostic tool but also an action program. Together, in a systematized form, these aspects of globalization amount to a doctrine, based on a morally confident assertion of its historical inevitability ${ }^{60}$.

Desta forma, ela se tornou uma espécie de idologia informal da elite política e econômica dos Estados Unidos, e abraçada pelas empresas multinacionais que atuaram como vetores globais dessa “doutrina”, como aponta Brzezinski (idem).

Friedman (2005) se remete à globalização dividindo-a em três períodos: a globalização 1.0, mais preocupada com a conexão entre os países e como os eles se inseririam na concorrência global, algo que situaria esse período entre os séculos XVI e XVII; a globalização 2.0 que diz respeito ao papel desempenhado pelas multinacionais, a criação de redes e

\footnotetext{
${ }^{59}$ Cf. Nietzsche, F (2013).

${ }^{60}$ A globalização não é apenas um fato observável, mas uma norma explítica. Ela fornece um mecanismo interpretativo, bem como uma prescrição normativa. Não é apenas uma ferramenta de diagnóstico, mas também um programa de ação. Juntos, de forma sistematizada, esses aspectos da globalização constituem uma doutrina, baseada em uma afirmação moralmente segura de sua inevitabilidade histórica (tradução minha).
} 
solidariedades organizacionais e a busca por mercados e mão-de-obra, período que compreenderia o século XIX e XX; por fim, a globalização 3.0 que se diferencia das anteriores por ampliar o protagonismo das nações e empresas que participam do processo e que não é mais monopólio dos ocidentais.

Além disso, como característica marcante, essa nova etapa global é movida por indivíduos que passam a se conectar entre si como nunca, por meio dos modernos meios de comunicação e sistemas de informação. Isso, segundo o autor, estaria provocando o "encolhimento" das distâncias, que de certa forma corrobora o pensamento de Harvey (2007), e ao seu "achatamento", que é a tese central trazida por Friedman (2005) através da noção de que "o mundo é plano".

Esta ideia está relacionada à capacidade que empresas, nações e indivíduos teriam de interagir globalmente partindo dos lugares. Assim, cada lugar seria à sua maneira, o mundo. A homogeneização das culturas, dos costumes, dos idiomas, dos modos de produção, dos meios de comunicação, entre outros fatores, estaria contribuindo para o aplainamento do mundo e a consecução de uma aldeia global metaforicamente apelidada de "McWorld", que nas palavras de Tibi (2001, p.192 e 195) é

the development of structural and institutional networking in economy, politics, transportation and communication has led to a hitherto unprecedented degree of interaction among all parts of humanity, regardless of religion, culture and ethnicity $[\ldots]$ a host of sovereign nation-states mutually acknowledging each other's sovereignty and thus creating systemic interaction and networking among one another on global grounds ${ }^{61}$.

À essa "fábula" da integração, da aldeia global, da supressão de fronteiras e da onipresença da tecnologia, se opõe a realidade concreta pautada na desigualdade, na fragmentação e nas resistências de toda ordem. A "planura” não está isenta de rugosidades, de atritos e "depressões" que trazem à tona desigualdades de toda ordem. Seriam elas os germes dos fundamentalismos extremistas? Giddens (1991, p.172) responde a essa pergunta dizendo que

as transformações do tempo presente ocorrem num mundo cindido por disparidades entre Estados ricos e pobres, onde a extensão das instituições

\footnotetext{
61 “o desenvolvimento da rede estrutural e institucional na economia, política, transporte e comunicação levou até agora a um grau sem precedentes de interação entre todas as partes da humanidade, independentemente da religião, cultura e etnicidade [...] uma série de estados-nação soberanos reconhecendo mutuamente a soberania de cada um e, assim, criando interação sistêmica e networking entre si em bases globais" (tradução minha).
} 
modernas traz à tona todo tipo de contracorrentes e influências, como o fundamentalismo religioso ou formas de tradicionalismo reacionário.

Tibi (2001, p.189) acredita que é um erro pensar que a globalização possa padronizar e "aplainar" culturas e civilizações. Portanto, é uma falácia considerar que termos como "McWorld" ou "McCulture" possam representar essa ideia. O autor também alerta que da mesma forma que a globalização não implica em um suposto igualitarismo, o pretenso universalismo islâmico que se choca com muitos valores ocidentais, também não ajuda a resolver os conflitos.

As questões que envolvem o fundamentalismo, o jihadismo e os extremismos de toda ordem, que são produtos "antimodernos da modernidade" (Demant, 2004, p.317), são complexas, históricas, e de difícil compreensão face à velocidade com que temos acesso às informações e à dificuldade em apreender, analisar e refletir sobre a realidade.

Entre as formas de nos aproximarmos dela está a compreensão das coexistências e a divisão do tempo em períodos. A coexistência implica em algo semelhante que é a compresença $a^{62}$, ou, a presença do patente e do latente ao mesmo tempo. Ortega y Gasset (1973, p.102-103) explica de forma clara esse conceito ao dizer que

enquanto este salão [por exemplo] é para nós sensu-stricto presente, é-nos compresente o resto do mundo, fora do salão e, como no caso da maçã, essa compresença daquilo que nos é patente, mas que uma experiência acumulada nos faz saber que mesmo não estando à vista, existe, está aí e se pode e se tem de contar com a sua possível presença, é um saber que em nós se converteu em habitual, que levamos em nós habitualizado.

Seguindo esta linha de raciocínio, o atual seria o presente e o habitual, o "compresente", isto é, devemos levar em conta não só aquilo que está diante de nossos olhos, mas o pano de fundo, os contextos em que certos eventos estão inseridos. Por isso, ao estudarmos as comunidades islâmicas no Brasil, objetivando compreender o fundamentalismo e suas variantes, também estamos atentos ao que acontece no mundo e que pode ou não repercutir na

\footnotetext{
62 "Certamente posso dar voltas em torno da maçã ou fazê-la girar na minha mão. Nesse movimento vão-se-me fazendo presentes aspectos, isto é, faces distintas da maçã, cada uma em continuidade à precedente. Quando estou vendo, o que se chama ver, a segunda face, lembro-me da que a vi antes e somo-a àquela. Bem entendido, porém: esta soma, do recordado ao efetivamente visto, não faz com que eu possa ver juntos todos os lados da maçã. Esta, pois, enquanto unidade total, portanto, no que entendo quando digo "maçã", jamais me está presente; assim, não é para mim com radical evidência, mas somente, em suma, com uma evidência de segunda ordem, - aqui corresponde à mera lembrança, - em que se conservam nossas experiências anteriores acerca de uma coisa. Daí, à efetiva presença daquilo que só é parte e uma coisa, se vai automaticamente acrescentando o resto dela, do qual diremos, pois, que não está apresentado, mas sim compresentado ou compresente". (ORTEGA y GASSET, 1973, pp.101-102).
} 
escala local. Tais contextos são a representação da totalidade em movimento que considera todo o contingente histórico, social e político que a engendra.

Quanto à cisão do tempo em períodos e fases que nos permitem congelar a dinâmica da realidade por breves instantes para que seja possível analisá-la, Kosik (2002, p.35) revela que "a realidade é interpretada não mediante a redução a algo diverso de si mesma, mas explicandoa com base na própria realidade, mediante o desenvolvimento e a ilustração das suas fases, dos momentos do seu movimento". Pensando nisso, em um próximo capítulo, algumas periodizações sobre a gênese e desenvolvimento do fundamentalismo serão propostas para que possamos melhor compreender a evolução dos aspectos ligados a esse conceito.

O grande problema é que para compreender a realidade devemos ultrapassar a densa névoa da pseudo-concreticidade ${ }^{63}$ composta de incontáveis ações, fenômenos, objetos e informações que espalham preconceitos, juízos de valor, paixões, suscitam opiniões, formam visões de mundo, estereótipos, e carregam ideologias que muitas vezes nos impedem de ver a realidade em sua "concreticidade", como realmente é. Trazer à tona os elementos ligados ao fundamentalismo nas comunidades islâmicas brasileiras, como eles são percebidos, como se manifestam e compreendê-los dentro do contexto histórico atual marcado pela globalização e pela modernidade, seria o mesmo que atingir sua essência. Por esse motivo, dentre as etapas desse trabalho, uma das mais importantes foi a realização de entrevistas com pessoas de diversas comunidades no Brasil, de Foz do Iguaçu/PR, passando por São Paulo, até Natal/RN.

Giddens (1999, p.29) atesta que o grande atributo do presente período é o distanciamento entre tempo e espaço, produto do que ele chama de "desencaixe", que desloca as relações sociais de seu contexto local. Para o autor "o advento da modernidade arranca crescentemente o espaço do tempo fomentando relações entre outros 'ausentes', localmente distantes de qualquer situação dada ou interação face a face". Essa situação culmina com a existência, segundo ele, de lugares "fantasmagóricos", pois que sua organização não se dá mais localmente, mas são moldados por influências distantes, globais. Bauman (2000, p.08) corrobora essa ideia da separação entre tempo e espaço como atributo da modernidade ao afirmar que a

modernity starts when space and time are separated from living practice and from each other and so become ready to be theorized as distinct and mutually independent categories of strategy and action, when they cease to be, as they used to be in long premodern centuries, the intertwined and so barely

${ }^{63}$ Cf. Kosik (2002). 
distinguishable aspects of living experience, locked in a stable and apparently invulnerable one-to-one correspondence ${ }^{64}$.

Essa característica dos novos tempos pode ser útil para compreender o jihadismo atual e as organizações que fazem uso do terror e do discurso religioso para empreender suas ações, que em sua grande parte estão fragmentadas espacialmente entre o planejar e o executar. As redes podem ser globais, mas as ações são sempre locais. Para Bauman (ibid., p.13) "we are witnessing the revenge of nomadism over the principle of territoriality and settlement. In the fluid stage of modernity, the settled majority is ruled by the nomadic and exterritorial elite" ${ }^{\prime 65}$. Aqui se encontra outro indício da forma como o islam político faz uso de meios modernos para resistir à modernidade.

A velocidade com que o mundo se transforma em que a cada instante novos eventos são produzidos e reproduzidos global e localmente nos revela a aceleração contemporânea ${ }^{66}$ a que somos submetidos justamente ao comprimir o espaço-tempo ${ }^{67}$. Isso torna a realidade e o mundo cada vez mais fugazes em sua apreensão e as relações sociais e econômicas cada vez mais complexas, imbricadas e sensíveis ao apelo global. Por isso, consideramos que o tempo e o espaço não se divorciaram. O local não perde importância, pelo contrário. Ele se torna palco e coxia das ações que se dão de forma cada mais simultânea dada às tecnologias da informação.

O que há em comum nas visões apresentadas acerca do tempo e do espaço é que em ambas o espaço e suas barreiras físicas parecem ser "aniquilados" pelo tempo. No primeiro caso há uma espécie de fusão temporo-espacial e nos demais casos, o espaço é apartado do tempo. Ahmed (2007, p.86) sustenta que a globalização "presupposes the dissolution of boundaries"68, assim, ela é dotada de uma capacidade de estabelecer relações entre indivíduos e instituições virtualmente, em uma velocidade impressionante. A simultaneidade das ações, dos eventos e

\footnotetext{
64 “a modernidade começa quando o espaço e o tempo são separados da prática viva e assim se tornam prontos a serem teorizados como categorias distintas e mutuamente independentes de estratégia e ação, quando deixam de ser, como costumavam ser em séculos pré-modernos. aspectos interligados e tão dificilmente distinguíveis da experiência de vida, trancados em uma correspondência estável e aparentemente invulnerável de um-para-um" (tradução minha).

65 “estamos testemunhando a revanche do nomadismo sobre o princípio de territorialidade e assentamento. No estágio fluido da modernidade, a maioria assentada é governada por uma elite extraterritorial e nômade" (tradução minha).

66 "a aceleração contemporânea impôs novos ritmos ao deslocamento dos corpos e ao transporte das ideias, mas também, acrescentou novos itens à história (...) a aceleração contemporânea é, por isso mesmo, um resultado também da banalização da invenção, do perecimento prematuro dos engenhos e de sua sucessão alucinante. São na verdade acelerações superpostas, concomitantes, as que hoje assistimos" (Santos, M. 1994, p30).

${ }^{67}$ Cf. Harvey (2007). Em síntese, as distâncias físicas são reduzidas através da evolução dos meios de comunição e transporte. O tempo que se leva para percorrer determinada distância é cada vez menor, dando a ideia de que o tempo aniquila o espaço derrubando as suas barreiras espaciais.

68 "pressupõe a dissolução das fronteiras" (tradução minha).
} 
informações é percebida em um “clique”, em uma videoconferência via Skype ou em mensagens via Whatsapp e Facebook.

Para Roy (2008, p.275), na globalização "les produits sont standartisés, les langues de marketing sont les langues vernaculaires ou bien les grandes langues de la mondialisation (anglais en tête) [...] les produits circulent grace à des vecteurs techniques universalistes: radios, internet, chaînes de télévision"69. Giddens (1991, p.76) completa que "a globalização pode ser assim definida como a intensificação das relações sociais em escala mundial, que ligam localidades distantes de tal maneira que acontecimentos locais são modelados por eventos ocorrendo a muitas milhas de distância e vice-versa".

Essa facilidade em se romper barreiras físicas, a produção de bens materiais que tornam a vida mais "confortável” e todas as fábulas produzidas pelo presente período, entretanto, não é privilégio de todos. A realidade, nesse caso, é lembrada por uma numerosa parcela da população mundial para quem algumas fronteiras físicas se tornam praticamente intransponíveis quando lançamos nossa atenção à crise de refugiados que aflige o Oriente Médio e a Europa, que cada vez mais ergue muros para conter a "invasão" estrangeira e principalmente islâmica. Fronteiras podem ser fluidas para mercadorias, empresas e negócios. Para pessoas, nem sempre. Cerca de um bilhão de pessoas não tem acesso à rede de esgoto ${ }^{70} \mathrm{e}$ outras centenas de milhões carecem de serviços básicos para sua sobrevivência. Isso sem falar na crescente concentração de renda que aflige muitos dos países subdesenvolvidos.

O ponto em que muitos autores concordam é com o par dialético globalizaçãofragmentação, atributo desses tempos. Conforme aponta Giddens (op.cit., p.190) "a globalização - que é um processo de desenvolvimento desigual que tanto fragmenta quanto coordena - introduz novas formas de interdependência mundial, nas quais mais uma vez, não há 'outros"”. Em outra referência, Giddens (ibid., p.33) afirma que a globalização "creates a world of winners and losers, a few on the fast track to prosperity, the majority condemned to a life of misery and despair"71.

Silveira (1999, p.363), indo ao encontro desses pensamentos, expõe que a globalização "no período contemporâneo, a força de um tempo único do mercado, busca homogeneizar os lugares através da produção, da regulação, do consumo e da cultura. $\mathrm{O}$ resultado desse ato de

\footnotetext{
69 “'Os produtos são padronizados, as linguagens de marketing são vernáculas ou então as principais linguagens da globalização (inglês principalmente) [...] os produtos circulam graças aos vetores técnicos universalistas: rádios, internet, canais de televisão" (tradução minha).

${ }^{70}$ Revista National Geographic, setembro de 2017.

71 "cria um mundo de vencedores e vencidos, alguns no caminho rápido para a prosperidade, a maioria condenada a uma vida de miséria e desespero" (tradução minha).
} 
império é a fragmentação do território, graças às suas resistências e oportunidades”. Igualmente, Tibi (2001, p.189) atesta que a

globalization intensifies the gap between both by simultaneously producing more cultural fragmentation. Here lies the assumed duality of globalization, which I address in terms of a simultaneity of two processes developing in adverse directions - globalization and fragmentation go hand in hand ${ }^{72}$.

Também com um olhar crítico e apontando os efeitos colaterais do período da globalização, Ahmed (2007, p.197) afirma que o

effect of globalization is that the gaps between the rich and poor within and among countries are growing, without any sign of slowing down. Already billions are living in poverty and close to starvation while three of the world's richest individuals are collectively richer than half the earth's inhabitants combined. Globalization and the free market policies of the World Bank and International Monetary Fund, meant to alleviate poverty worldwide, often do not help the disenfranchised in traditional societies ${ }^{73}$.

Parte das entrevistas que foram feitas coincidiram com o período de maior histeria midiática e comoção mundial acerca dos refugiados, com imagens das mais cruéis sendo bombardeadas por todos os meios de comunicação. Exemplificando como o global interage com o local, nesse caso específico, eis a fala de Nader, secretário da Sociedade Islâmica de Campinas/SP:

a gente vê daqui do Ocidente esses vagabundos lá matando pessoas de forma bárbara, de forma horrosa. Aquilo é assassinato! Dizem Allahu Akbar, e corta a cabeça do cara! Ateia fogo em outro! O que é isso? [se exalta]. No islam tem um versículo no Corão que se você mata um inocente equivale a ter matado a humanidade toda. Você não pode tirar a vida de ninguém. Então o que esses vagabundos estão fazendo não é o islam, isso é política, isso são grupos, guerrilhas armadas que não têm vínculo nenhum com a religião. E eles ficam lá com turbante, ficam gritando palavras de ordem. São um bando de vagabundos. Eles não são muçulmanos.

\footnotetext{
72 "a globalização intensifica a lacuna entre ambos, produzindo simultaneamente mais fragmentação cultural. Aqui reside a dualidade assumida da globalização, a qual abordo em termos de uma simultaneidade de dois processos que se desenvolvem em direções adversas - a globalização e a fragmentação andam de mãos dadas" (tradução minha).

73 "O efeito da globalização é que as diferenças entre ricos e pobres dentro e entre países estão crescendo, sem qualquer sinal de desaceleração. Já há bilhões vivendo na pobreza e perto da fome, enquanto três dos indivíduos mais ricos do mundo são coletivamente mais ricos do que metade dos habitantes da Terra combinados. A globalização e as políticas de livre mercado do Banco Mundial e do Fundo Monetário Internacional, destinadas a aliviar a pobreza em todo o mundo, muitas vezes não ajudam os desprivilegiados na sociedade tradicional" (tradução minha).
} 
A reação posterior a essa fala vem do próprio Nader e que também foi observada pela maioria dos entrevistados ${ }^{74}$, é que a responsabilidade é do Ocidente especialmente Estados Unidos e Europa:

Os Estados Unidos foram lá e arrebentaram. Eles compraram Saddam Hussein, depois o transformaram num vilão, arrebentaram com ele. Depois o Gadafi, arrebentaram com ele. E olha como esses caras morreram! [exclamou]. Então, os americanos vão ocupando aquela região dessa maneira [...] os americanos patrocinam, deram treinamento para eles na Inglaterra, providenciaram armas e os britânicos treinaram.

Com relação a esse assunto, a sensibilidade de todas as pessoas com as quais tive contato era patente. Muitos dos informantes pareciam ansiar em ter sua imagem como muçulmano desvinculada de qualquer grupo radical, sempre destacando a pacifismo do islam. Implicitamente sinalizavam que suas vidas sofriam algum impacto quando uma facção islâmica extremista agia, e a minha interlocução parecia servir de canal para externar essa insatisfação.

A globalização ou mundialização, como preferem os francófonos, são termos cujas definições podem variar segundo as mais diferentes áreas e autores, um conceito abrangente e multifacetado que comporta inúmeras variáveis determinantes desse período: religião, consumo, pobreza e desigualdade, divisão internacional do trabalho, industrialização, novas tecnologias, inovação, entre outros.

Ela vende fábulas tais como a noção de aldeia global, as maravilhas da tecnologia, das comunicações, dos transportes, dos avanços na medicina e nas mais diversas áreas, e na possibilidade da interação entre povos e culturas. Contudo, sabemos que a realidade que muitas vezes se apresenta é perversa e pode produzir reações de onde, de quando e de quem menos se espera.

A ilustração abaixo oferece uma breve síntese dos elementos que compõem o atual período da globalização e seu par dialético, a fragmentação socioespacial.

\footnotetext{
${ }^{74}$ Eis algumas falas: sheikh Abdo: "quem mais matou na bósnia? Quem praticou o imperialismo na África? E a I e II Guerras Mundiais, quem travou não foram os muçulmanos. Hoje, há nações muçulmanas invadidas por ocidentais [...] O próprio G. W. Bush quando invadiu o Iraque, iniciou uma nova cruzada".

Sheikh Mohammed Khalil: "No Ocidente há duas linhas vermelhas: o petróleo e Israel. Essas duas coisas para o Ocidente são mais valiosas. O que eles fizeram no Iraque? Colin Powell, fez uma renovação de mentiras. Armas nucleares, foguetes [...] Então, vamos dizer, o Estado Islâmico é um estado ligado 100\% às inteligências dos países que têm benefícios no Oriente Médio, sejam econômicos, políticos e de segurança também".

Khouloud: "Quem formou esses grupos são países que têm interesses políticos. Esses grupos não são islâmicos, pois quem financiou são os Estados Unidos e Israel. Porque a religião não ensina isso!”
} 


\section{Diagrama 3 - Dois pesos e duas medidas: globalização e fragmentação}

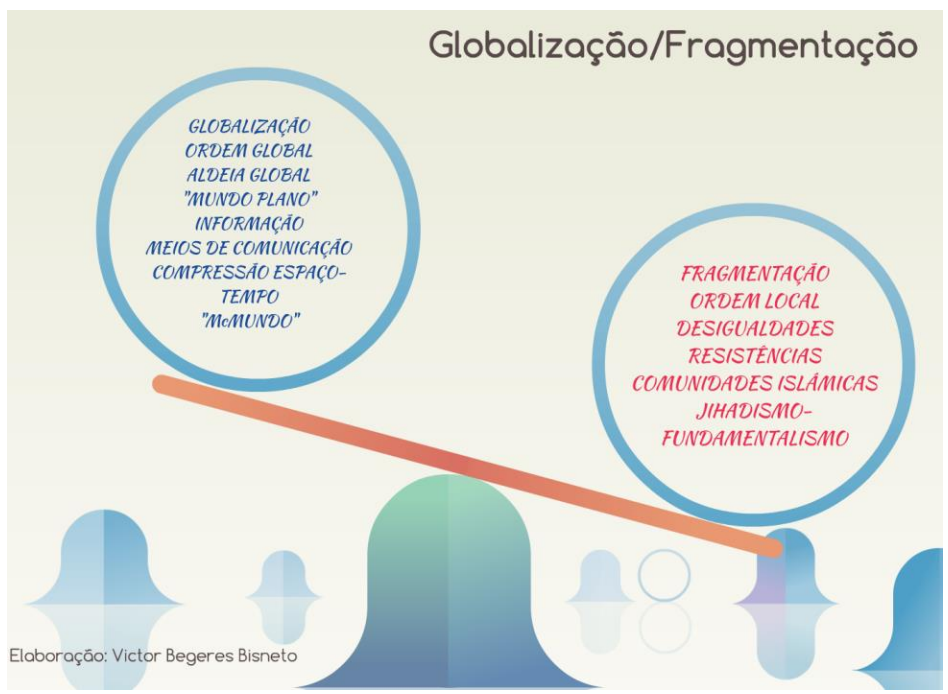

Nesta "balança" global-local nota-se o maior "peso" exercido pelos dos lugares, onde aspectos da globalização anseiam se cristalizar produzindo as rugosidades ${ }^{75}$ no espaço. É nos lugares que se ancoram as normas, ações e objetos que sofrem ou não resistências à sua imposição. Isso contraria a noção de desterritorialização e de que o espaço perdeu sua importância nos tempos atuais, que ele não impõe mais limites à ação e seus efeitos, tese defendida por alguns autores como Bauman (2000).

Por outro lado, notamos a "leveza" do global com suas incontáveis técnicas que são invasivas, velozes, que se impõem a todos os lugares, sejam como possibilidade ou realidade, e que pressupõem um "achatamento" do mundo ignorando as especificidades sociais, religiosas, étnicas e territoriais. $\mathrm{O}$ alastramento desse dado da realidade presente, entretanto, não se dá sem atrito. A difusão das técnicas modernas e tudo o que decorre da modernização do mundo é feita de forma seletiva, encontrando resistências nos lugares em que visam se instalar. A ordem global muitas vezes é confrontada como uma ordem local e suas normas, e visões de mundo.

Devemos considerar que embora na conjuntura atual o raciocínio seja coerente, a longo prazo pode ser que o peso dos fatores de "fragmentação" diminua com o tempo, à medida em que as reações e resistências se arrefeçam. Por outro lado, novos contextos "globalizantes" continuariam se proliferando e instigando novas reações.

É neste momento que vemos emergir a possibilidade de reações diversas que sob o ponto de vista religioso aponta para um islam político que se desdobra muitas vezes em um ativismo violento.

75 "Chamemos rugosidade ao que fica do passado como forma, espaço construído, paisagem, o que resta do processo de supressão, acumulação, superposição, com que as coisas se substituem e acumulam em todos os lugares. As rugosidades se apresentam como formas isoladas ou como arranjos" (Santos 2002, p.140). 
Muitos grupos se apropriam de algumas das técnicas, informações e elementos da modernidade para justamente usá-las contra aquilo que condenam: a globalização, o Ocidente, e a própria modernidade com seus valores. A possibilidade das migrações tão em voga atualmente, a relativa ideia de liberdade, a condição socioeconômica desfavorável de muitos, a deturpação de muitos valores, o sentimento de "nada a perder", e as ideologias tão fluidas como a informação transmitida por cabos de fibra ótica, são atributos dessa aparente "leveza".

Partindo de uma visão mais otimista sobre os novos tempos de globalização, Gülen (2004) alerta para a urgência do diálogo entre civilizações e culturas. Nesse sentido, o atual período possui os elementos essenciais para que se criem pontes entre os diferentes povos para que a paz e a tolerância prevaleçam. Ainda assim, para Gülen (2004, p.v) a globalização ainda se revela de forma perversa como se observa na passagem a seguir:

In fact, globalism has popularized wealth, technology, democratic pluralism, production, and consumption. And then again, it has helped to spread all types of pollution; human, environmental, or political. Poverty, ecologic pollution, weapons of mass destruction, terrorism, and violence have all been globalized as well ${ }^{76}$.

Em razão disso, Santos (2000, p.34) argumenta que o período atual da globalização é ao mesmo tempo um período (parte de um processo histórico), e uma crise constante. Para o autor, como período, as suas variáveis características instalam-se em toda parte e a tudo influenciam, direta ou indiretamente. Daí a denominação de globalização. Como crise, as mesmas variáveis construtoras do sistema estão continuamente chocando-se e exigindo novas definições e novos arranjos.

As crises que fazem parte desse processo globalizante podem ser vistas não apenas na economia, mas também na sociedade: violência, desigualdade, terrorismo, conflitos étnicoreligiosos e migrações em massa são provas de que a história não teve um fim como sugeriu Francis Fukuyama no início dos anos 90.

Diante desse raciocínio, como as comunidades islâmicas no Brasil reagem a essa crise do ponto de vista religioso, desse pretenso "choque de civilizações" cada vez mais cultuado pela mídia? De que forma o que acontece no mundo é absorvido por esses grupos que aqui se instalaram? Como as múltiplas crises que se observam mundo afora também se manifestam na escala local?

\footnotetext{
76 "De fato, o globalismo popularizou a riqueza, a tecnologia, o pluralismo democrático, a produção e o consumo. E mais uma vez, ajudou a espalhar todos os tipos de poluição; humanos, ambientais ou políticos. Pobreza, poluição ecológica, armas de destruição em massa, terrorismo e violência também foram globalizadas" (tradução minha).
} 
Uma possível resposta pode ser encontrada em postagens em redes sociais ou em outros meios fazendo críticas ao que acontece no mundo. $\mathrm{O}$ inconformismo pelas injustiças promovidas pela globalização, ou em supostas apologias a grupos que lutam contra os interesses ocidentais culminaram com uma série de prisões no Brasil em julho de 2016, acusados de planejar atentados em meio aos Jogos Olímpicos. Sobre isso pude conversar com o Ahmad Alkhatib, uma das pessoas investigadas e que aceitou revelar:

Eu tenho uma ONG, e nela tinham duas pessoas que trabalhavam comigo e que foram presos. E nessas conversas entre eles, criaram um grupo, grupo cujo objetivo era lutar contra a injustiça do mundo, contra os incrédulos. Nesses grupos eles sempre tentam escolher um sheikh, eles tentam escolher um líder que direciona a vida deles conforme a jurisprudência islâmica. Na conversa entre eles, que foi pega pela Polícia Federal, eu fui mencionado como o sheikh deles [...] O que os fazem se radicalizarem é a situação dos muçulmanos no mundo, não é? A situação que está na Síria, nesses lugares, a forma como os muçulmanos são tratados.

O grande questionamento é se essas críticas a respeito de injustiças cometidas contra muçulmanos, seja no Brasil ou no mundo, também se repetem ou são incitadas dentro das mesquitas. Ao que pude observar, é que esse tipo de sermão não é feito. Assim, nos resta pensar apenas na questão individual, de como cada um assimila o período atual e as informações divulgadas. A leitura corânica autodidata de muçulmanos, convertidos ou nativos, se revela como um problema nesse caso?

A liberdade que o mundo sugere, a convite de suas técnicas de comunicação e transporte, não necessariamente se traduz em uma bênção. Ela pode, se partimos de uma concepção existencialista e niilista ${ }^{77}$, em muitos casos gerar problemas. Para Bauman (ibid., p. 28-29) "being modern means being perpetually ahead of oneself, in a state of constant transgression (in Nietzsche's terms) ${ }^{978}$. Bauman (ibid., p.17) complementa esse raciocínio se referindo a Schopenhauer e ao fato de a realidade ser produto da vontade de cada um: "it is the stubborn indifference of the world to my intention, the world's reluctance to submit to my will, that rebounds in the perception of the world as 'real' - constraining, limiting and disobedient"79. Seria esse o pensamento de muitos jihadistas que fazem uso de sua liberdade e de sua

\footnotetext{
${ }^{77}$ Será aprofundado na Parte 2 do trabalho.

78 "ser moderno significa estar perpetuamente a frente de si, em um estado de constante transgressão (nos termos de Nietzsche)" (tradução minha).

79 “é a teimosa indiferença do mundo à minha intenção, a relutância do mundo em submeter-se à minha vontade, que repercute na percepção do mundo como 'real' - constrangedor, limitador e desobediente" (tradução minha).
} 
indignação para reagir de forma violenta ao mundo que não está moldado aos seus interesses ou aos supostos interesses de Deus?

O mundo que se apresenta carrega o atributo da individualidade. Giddens (1991) alerta que esse período transformou a intimidade em impessoalidade, processo oriundo dos mecanismos de "desencaixe", em que as relações sociais são cada vez mais efêmeras, mais virtuais e menos físicas. A confiança e a segurança que antes, em sociedade pré-modernas, eram dadas pela tradição que cimentava o passado, presente e futuro em práticas sociais rotinizadas, deram lugar a um ambiente em que a industrialização da guerra, o surgimento de conflitos diversos e o "reencaixe" das relações sociais em novos e diversos contextos, surgem como sintomas do atual período.

Partindo do ponto de vista das comunidades islâmicas brasileiras, é possível identificar esse universalismo ao qual o islam se advoga e que entra em choque com a globalização dos valores, normas e eventos? Para a Ahmad Alkhatib há indícios de que o projeto global que se apresenta não é compactuado pelas comunidades islâmicas, que resistem à sua imposição. De acordo com ele,

dividiram a sociedade e o governo em um grupo e a religião se tornou um hobby no Ocidente. Não é um hobby que se tornou? Ela não comanda nem rege nossas vidas no Ocidente, não é verdade? Então, no mundo oriental, no oriente islâmico, no mundo islâmico, o que rege a vida deles é a religião.

Para o turco Fatih Ozorpak "hoje estamos em um momento mais moderno e todo mundo tem que ser respeitado onde ele está".

Pelo fato de a globalização, entre outras coisas, difundir em uma velocidade impressionante uma grande quantidade de informações pelo mundo, as comunidades islâmicas brasileiras poderiam ser influenciadas por eventos externos ao lugar que habitam?

O sheikh Jihad oferece algumas pistas sobre isso ao dizer que

a realidade é um reflexo ainda pequeno do que acontece lá fora. É de se esperar, porque quando você se torna a pauta do jornalismo no mundo todo, você espera diversas reações, tanto uma reação contrária como a favor, porque desperta curiosidade. Ao mesmo tempo que desperta em alguns um ódio e discriminação, vai despertar em outros curiosidade.

Essa situação também é observada pelo sheikh como um dos motivos que fazem com que muitos brasileiros se convertam ao islam. A curiosidade de muitos, no caso, conduz em muitas vezes à conversão ao islam. 
Diante desse cenário, é impossível pensar que as comunidades islâmicas no Brasil estejam inertes nesse mundo assim como todas as demais comunidades religiosas, isso sem falar de outros aspectos sociais e econômicos. Nem mesmo de modo conscrito ao Brasil essas comunidades mantêm relações entre si e sequer possuem um discurso coeso e uníssono como veremos em outras partes da tese. Claro que os meios de comunicação e a facilidade em ter acesso à informação dotaram essas comunidades de um poder de integração com outros lugares e pessoas muito mais amplo. Obviamente, há que se ter em mente a seletividade desses recursos e informações. A tecnologia e os dados se mostram neutros até que sejam apropriados e usados. O que se faz com eles oferecerá respostas para algumas situações que observamos na realidade, seja de isolamento ou de confronto em casos mais extremos.

Se os eventos que chegam do universal ao particular provocam desarranjos, mal-estar, desconfiança e mesmo agressões, como seria o caminho inverso? O que é produzido localmente poderia repercutir em esferas superiores? No caso de essas comunidades reagirem às agressões externas, seja por meios violentos ou apenas se isolando, isso poderia contribuir para a criação de um ciclo vicioso? Ciclo este que só seria quebrado quando as comunidades que se sentem atingidas ou não representadas por ações violentas que ocorrem no mundo tivessem uma voz mais ativa e um posicionamento mais rigoroso contra tais atos que elas mesmas condenam.

Desta forma, é possível que as reações das comunidades islâmicas no Brasil sejam cada vez mais integradas com o que se passa em outros lugares com outras comunidades? Novas solidariedades e redes diversas podem ser tecidas a partir desse dado da globalização? Em síntese, a aldeia global é uma manifestação real e que de fato engloba a todos da mesma maneira, ou é possível que os lugares resistam aos apelos globais produzindo "contraracionalidades", resistências e vozes dissonantes?

Segundo o sheikh Jihad, "seus filhos gostam de você por causa do seu dinheiro (pausa). Está havendo uma desestruturação social. Qual é solução? Vai ter que correr para o islam. A religião tem a resposta disso. Eu falo islam porque sou muçulmano".

Essa fala resume de certa forma o pensamento de que apesar do poder ubíquo da globalização que tende homogeneizar, apagar fronteiras materiais e imateriais e promulgar um padrão de consumo no mundo, ela não consegue universalizar valores, normas e culturas com a mesma competência com que faz com suas estruturas.

Neste caso, a mídia e a informação têm um papel fundamental e umbilical a serviço da globalização. Ela tenta impor padrões, viabilizar normas e sanções, legitimar ações e formar discursos e narrativas coerentes com os interesses de grandes grupos políticos e financeiros. 
Entretanto, essas forças nem sempre encontram respaldo nos lugares que conformam certos grupos sociais que muitas vezes, por não fazerem parte das "grandes vozes" do planeta ou por não serem protagonistas no cenário global e mesmo local, não se sentem representados nas narrativas contemporâneas.

Diante deste quadro, a seguir será proposta uma reflexão acerca de como as "vozes ocultas" das comunidades islâmicas brasileiras enxergam e reagem à influência da mídia. Isto poderá indicar algum elemento que viabilize ou reforce comportamentos extremados da população muçulmana?

\subsection{A violência da informação, o terrorismo midiático e o reino das conspirações}

A informação no atual período de globalização é caracterizada por meio de quatro atributos principais: ela é veloz ${ }^{80}$, já que é impulsionada pelos mais modernos meios de comunicação; é invasiva, porque atinge uma infinidade de lugares pelo mundo de forma quase instantânea e diversa; e é inevitável, porque se tornou uma marca indelével da paisagem contemporânea e das relações sociais.

Estes predicados têm engendrado uma panaceia midiática fortalecida pela difusão cada vez mais capilar e quase que instantânea das chamadas "fake news" (notícias falsas). Muitas dessas informações, face ao seu elevado número e frequência de compartilhamentos, não são comprovadas ou corrigidas pelo dado correto.

Este contexto cria, em certas situações, ambientes férteis para se propagar o ódio e o preconceito, e para se tecer polarizações das mais diversas. Tal cenário imediatista e raso, é perfeito para aqueles que "não têm tempo" ou interesse para se aprofundar sobre o que é discutido. A busca pelo conhecimento através do embate de múltiplas visões de mundo munidas de materiais e métodos fidedignos é cada vez mais raro de acontecer. Sem isso, não é possível lançar mão de algum tipo de juízo de forma ponderada e consciente.

Como veremos mais adiante, o uso indiscriminado das redes sociais e aplicativos de comunicação que deflagram todo tipo de intencionalidade, passou a ser o grande alvo das autoridades brasileiras. Amparadas pela recente "lei antiterrorismo", elas têm monitorado atividades suspeitas promovidas por alguns indivíduos que estariam envolvidos com o jihadismo internacional e que poderiam executar alguma ação violenta em território nacional.

${ }^{80}$ Giddens, A. 1991. 
Os ambientes virtuais têm contribuído de modo eficaz para a propagação do radicalismo islâmico ainda que não contíguo territorialmente. Neste caso, as comunidades locais se tornam coadjuvantes no processo de uma eventual doutrinação religiosa, posto que, como veremos, alguns dos investigados ou têm pouco ou nenhum vínculo com centros islâmicos, ou sofrem de desequilíbrios psiquiátricos. No entanto, entre eles havia uma pretensa forma de cooperação via redes sociais e aplicativos de comunicação, meios pelos quais foram investigados e em alguns casos, detidos pela Polícia Federal.

O germe da ignorância, que tantas vezes foi suscitada por muitos dos meus informantes a respeito do islam e dos muçulmanos, está incubada no seio de uma sociedade que paulatinamente tem dado mais crédito ao que se veicula por redes sociais e whatsapp, do que em pesquisas acadêmicas, publicações de canais probos e profissionais que dedicam grande parte de suas vidas em explicar fenômenos sociológicos, históricos, geográficos e religiosos.

Há muitos exemplos que ilustram essa situação. Um deles é a existência de um vídeo postado no Youtube e que circulou pelas redes sociais em 2017, em que a embaixada Palestina em Brasília/DF é mostrada ao fundo da gravação, e, diante dela, em primeiro plano, uma mulher vocifera dezenas de frases depreciativas em relação aos palestinos e ao governo brasileiro, que estaria "patrocinando o terrorismo no Brasil". A mulher diz:

eu quero dizer para vocês: São Paulo, Belo Horizonte, Rio, sul do Brasil, todos os lugares. Já tem terroristas espalhados querendo nos impedir de termos liberdade em nosso país. Porque é assim que eles chegam: eles chegam como imigrantes, querem implantar sua cultura, querem ensinar o árabe [...].

A embaixada, quando da sua inauguração em 2016, causou um certo furor entre os meios mais conservadores e retrógrados do país, que alardearam de forma inconsequente, ser "área soberana do Hamas no coração de Brasília" ${ }^{\text {. }}$.

O compartilhamento desses tipos de mensagens, na visão das comunidades islâmicas, serve apenas para reforçar a ignorância por parte da população local e os preconceitos muitas vezes pré-existentes. As relações "árabe-terrorista” ou "muçulmano-terrorista, se tornam sintagmas naturalizados e de uso banal, que rapidamente "colam" nos que seguem o islam. Por sua vez, as comunidades islâmicas, que igualmente dipõem de modernos meios de comunicação e cada vez mais os utilizam como plataformas de divulgação da cultura árabe e do islam ${ }^{82}$, como o faz com frequência o Sheikh Jihad em sua página no Instagram, em que responde a diversas dúvidas sobre a religião, acabam por não ter a mesma visibilidade ou número de "likes", como

\footnotetext{
${ }^{81}$ https://abr.ai/2CWuor0 (acesso em 18.10.2018).

${ }^{82}$ Cf. Montenegro (2002, pp.63-91) que relata os olhares da mídia sobre o islam no Brasil e os contra-discursos.
} 
se diz no linguajar digital. Em certos casos, quando oferecem contra-argumentos também são interpretações demasiado enviesadas, compreensíveis como um mecanismo de defesa.

Para Bauman (2000, p.188),

The game of domination in the era of liquid modernity is not played between the "bigger" and the "smaller", but between the quicker and the slower. Those who are able to accelerate beyond the catching power of their opponents' rule. When velocity means domination, the "appropriation, utilization and population of territory" becomes a handicap - a liability, not an asset ${ }^{83}$.

Um exemplo dessa velocidade e da forma como a informação pode implicar dialeticamente o local e o global, pode ser visto a partir do ataque terrorista ao periódico francês Charlie Hebdo em 2015 que repercutiu intensamente na mídia mundial.

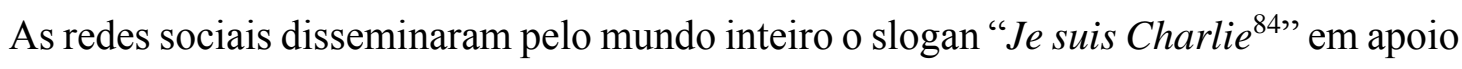
às vítimas, ainda que muitos sequer soubessem do conteúdo veiculado pelo jornal satírico e muito menos da existência do mesmo. Ao mesmo tempo, atentados na Turquia, Paquistão, ou Líbia, não têm a mesma repercussão. A histeria e a comoção seletivas, marcas deste período, são condenadas pelo sheikh Jihad Hammadeh, que mostrou a seguinte intepretação do episódio francês carregada de doses conspiratórias:

a questão aqui é que se forem [muçulmanos], eles não estão seguindo, saíram à regra. Pois, se fosse uma regra geral comum [praticar atos violentos], todos os muçulmanos que estão na França deveriam ser obrigados a ter feito isso já em 2006 quando foi a primeira vez que eles [Charlie Hebdo] fizeram isso. Principalmente em um mês que o jornal ia fechar. Mais do que isso. Aqui cabem outras análises [pausa]...às 9 horas da manhã não passava um carro lá na rua. [pausa longa] E quem filmou, como é que filmou? [Pausa curta] Não passou carro nem nas ruas adjacentes? Numa quarta-feira? A outra questão básica: os que morreram. Nós vimos a ação? Tem vídeos mostrando matando? Teve tiroteio? Ou apareceram mortos? Uma outra pergunta: por que o carro que aparece na filmagem, o retrovisor era de uma cor e o carro que eles disseram que foi abandonado, que foi utilizado no atentado, o retrovisor externo tinha uma outra cor? Um era cromado e o outro não. Como? [Pausa] Outra questão: um dos terroristas esqueceu a carteira de motorista dentro do porta-luvas! Imagine ele saindo e levou a carteira de motorista porque se a

\footnotetext{
83 “'O jogo de dominação na era da modernidade líquida não é jogado entre o ‘maior’ e o 'menor', mas entre o mais rápido e o mais lento. Aqueles que são capazes de acelerar além do poder de captura de seus oponentes dominam. Quando velocidade significa dominação, a 'apropriação, utilização e população do território' torna-se uma desvantagem - um passivo, não um ativo" (tradução minha).

84 "Eu sou Charlie" (tradução minha).
} 
polícia parar, ele consegue provar, cheio de armas, mascarado, ele consegue comprovar que é ele! Esqueceu dentro do carro [trecho carregado de ironia]. Outra questão: o policial que falaram que era muçulmano, o Ahmed, que é executado por um dos supostos terroristas - ele caiu no chão, tava fazendo a segurança, né - ele cai no chão. Ele é atingido por um tiro, ele cai. Preste atenção, ele é atingido por um tiro de fuzil, ele cai, aí o terrorista vem e à queima roupa o executa com um fuzil, com uma bala mais ou menos assim [e mostra com as mãos seu tamanho], e não existe um pingo de sangue! [pausa]. Na realidade, a entrada de uma bala de fuzil, ela explode, ela na entrada ela explode, não é na saída [do corpo] [...] é impossível! Estranho é alguma coisa que não é nítida. E aquilo é nítido! É impossível! E outra, ele dá um tiro e não dá tranco, um fuzil, daquele jeito? No mínimo estouraria a cabeça e ricochetearia, porque ele está atirando pra baixo, muito forte. Não se viu nada disso, nem um pingo de sangue. O que eu espero de um tiro de fuzil é explodir a cabeça dele.

Intepretações como essa são comuns de serem observadas entre os muçulmanos no mundo inteiro. Há um grande senso crítico a respeito de todos os eventos violentos que envolvem seu grupo religioso, explorando minúcias dos fatos, deslegitimando aqueles que cometem os ataques acusando-os de não serem muçulmanos, e confabulando teses que desembocam quase sempre em uma responsabilidade externa, especialmente sionistaestadunidense.

Para o sheikh Jihad, de forma geral, eventos como esse contribuem de forma negativa para a imagem das comunidades islâmicas do mundo inteiro, inclusive no Brasil. Ele afirma, com conhecimento de causa, que "é nítido que você vai criar dentro da sociedade uma aversão, uma discriminação, um preconceito".

De todo modo, sempre que atentados de grande vulto são divulgados pelos diversos meios de comunicação, são registradas ondas de agressões verbais e físicas ${ }^{85}$ contra os muçulmanos no Brasil. Efeitos colaterais da forma espetacularizada como esses eventos são exibidos. $\mathrm{O}$ sheikh Jihad lembra que uma de suas alunas foi alvo de pedradas na rua.

Ele ainda estabelece uma comparação entre o preconceito que existe contra muçulmanos na Europa e no Brasil:

Na Europa, o motivo dele é histórico, então ele é consciente. Por que a Turquia hoje não consegue, não permitem que ela entre na União Europeia, por que

\footnotetext{
${ }^{85} \mathrm{https} / / /$ glo.bo/2LweiVB (acesso em 26.12.2016). Esse evento ocorreu posteriormente ao ataque executado em Paris na casa shows Bataclan em 2016.
} 
criam dificuldade? A Bósnia, por que não entra na comunidade europeia, não a aceitam? Então existe algo premeditado e consciente, diferente da América Latina e do Brasil. Existe aqui uma discriminação e um preconceito, mas embasado em ignorância e falta de conhecimento.

Outro sheikh com quem conversei, Abdo Nasser, da Mesquita Omar Ibn Al-Khattab de Foz do Iguaçu/PR, converge com essa ideia ao dizer que "a mídia não é aliada dos muçulmanos seja no Brasil como no Mundo. Nos trata de forma preconceituosa e apenas destaca notícias ruins sobre a religião". Ele complementa que os judeus são os que controlam os veículos de comunicação, e como forma de exercer seu domínio no mundo, distorcem tudo o que provém do islam. Como dito anteriormente, essa frase retrata um pouco da retórica conspiratória.

Assim como narrado pelo filme "My Name is Khan" (2010), logo após os atentados do 11 de setembro de 2001, os muçulmanos passam a ser vistos com desconfiança, preconceito e de forma genérica, como se todos fossem terroristas ou que praticassem uma religião que incita a violência. No filme, o protagonista busca desvincular a impressão negativa que se tem dos muçulmanos mostrando que não são terroristas e que querem colaborar com a comunidade local, enquanto outros planejam se vingar das agressões.

Os ataques ao "Charlie Hebdo" e em todos os outros em que os muçulmanos e o islam estiverem no "olho do furacão", para o sheikh Abdo, repercutirão de forma prejudicial à comunidade de Foz do Iguaçu/PR, como por exemplo, pela queda do turismo na cidade prejudicando a economia e a vida locais.

O sheikh Mohammed Khalil da Husseinya de Foz do Iguaçu/PR, vai ao encontro do que diz seu colega sunita. Se referindo à matéria publicada pela Revista Veja em 06 de abril de 2011 sobre a possível presença de células terroristas na Tríplice Fronteira, ele assevera:

a [Revista] Veja é a campeã do sensacionalismo [...] dizia que Bin Laden passou em nossa mesquita aqui, isto é, teria passado pela Tríplice Fronteira e frequentado a mesquita [...] sabe qual a percentagem de turistas que diminuiu? Bastante. Porque a cidade sofreu bastante, sofreram todos os hotéis. Infelizmente, o Brasil, eu tinha falado isso muitas vezes para jornalistas de alta qualidade aqui, dizendo que infelizmente, o jornalismo brasileiro é um jornalismo lactante, que ainda toma leite dos outros.

O sheikh Ahmad Abdul do CCIB conta dois exemplos que se passaram com ele e que denotam como a mídia, em certas ocasiões, pode criar e reforçar preconceitos. Assim ele conta: Algumas pessoas da mídia por interesse ou ignorância, entendeu? Tem gente que não sabe nada do islam. É verdade. Qualquer coisa que do Estado Islâmico, é coisa de muçulmano. Muçulmano é assim. Qualquer coisa em 
países árabes é o islam que ensina isso. Eu não estou generalizando, mas parece que o objetivo principal da mídia é o quê? Chamar atenção. Pelo aspecto negativo.

Aqui nessa casa, teve uma entrevista comigo. Duas horas. Da TV Bahia. Uma coisa que ia passar domingo a noite. E começou a divulgar a chamada. Aí um irmão me ligou e me disse:

- Sheikh, você não está vendo tv?

- Mas o que está acontecendo?

- Disse que você falou alguma coisa que...

Falaram: olha, domingo vai passar a religião que diz isso e aquilo, que a mulher isso e aquilo...

O que eu fiz? Vamo processar TV Bahia. Primeiro vou ligar.

- Posso falar com Paulo?

- Paulo não tá aqui, por quê?

- Ele me entrevistou. Pode passar o celular dele?

- Não posso.

- Se ele não está, quero falar com o chefe dele.

- Não, a gente não pode fazer isso. Sobre o quê?

- Senhora, eu não falei tudo isso na tv não.

A moça disse:

- Tá bom. Por favor, não fala com diretor. Porque isso vai prejudicar Paulo.

Eu falei:

- Mas Paulo pode prejudicar a gente? Eu vou falar com o diretor.

- Deixa, eu vou verificar primeiro. Aí eu ligo para você.

Dez minutos depois ela me ligou e disse:

- Sheikh, por favor, desculpa. Não tem nada a ver o que chamada está dizendo.

Depois, Paulo mesmo vem para cá pedir desculpas. Uma moça esatava com ele e disse:

- Sabe o que é isso? A chamada é para público.

- Então não pode fazer chamada da maneira que fizeram.

- Mas tem que ter uma coisa que tem novidade, impacto.

Mas essa moça não sabia que isso pode prejudicar a gente. Por ignorância.

Não sabia que quando vai pra tv, pode prejudicar as pessoas. O interesse é só para chamar a atenção de muitos.

Tem revista aqui...como que chama?...revista Veja ou...como chama? Teve aqui um ano, de São Paulo e me entrevistou. A gente chega aqui e não vê revista porque não saiu aqui. Mas a moça disse para não me preocupar. $\mathrm{A}$ 
Wamy ligou pra mim. Todos ligaram.'Sheikh, o que está acontecendo aí? você falou tudo isso?'

Distorceram tudo. Eles sabem que tudo que está falando nenhum sheikh vai falar isso. Então peguei a revista, liguei para lá. $\mathrm{O}$ diretor de setor disse:

- Por favor, não fale mais. A gente quer pedir perdão. Porque o centro islâmico aqui está dizendo que vai processar a gente. A gente vai fazer outra coisa.

- Me conta o que aconteceu?

- A moça saiu da Bahia, entrevistou você, entrevistou alguém de outra religião e a parte do islam ela perdeu, sumiu. Então para não deixar o espaço livre, o que ela sabia do islam, o que estava na cabeça dela, ela colocou.

- Ela colocou uma coisa que está prejudicando o islam não só aqui, mas no mundo inteiro.

Essa pessoa ligou e se desculpou. Então, centro islâmico me ligou e disse que não precisa mais processar.

Imagine, o que está acontecendo não é só comigo. Eu falei para você. Algumas mídias estão fazendo a cabeça desses jovens, que por ignorância não sabem o que é islam.

Khouloud El-Birani, outra entrevistada em Foz do Iguaçu/PR, além de farmacêutica, ela é secretária-geral da Escola Árabe-Brasileira ${ }^{86}$ da cidade, e como tal, presencia o cotidiano das crianças e jovens. Ela afirma que todas as vezes em que acontece algum episódio violento envolvendo muçulmanos, muitos alunos comentam sobre piadas de mau gosto que são feitas sobre eles, mas que "levam na esportiva" e que a "escola tenta 'filtrar' muito do que vem de fora".

Fazendo eco ao que diz o próprio sheikh da mesquita local, Abdo Nasser, ela assevera que "a mídia não está a favor [de nós] [...] já presenciei muçulmanas sendo chamadas de terroristas na rua [...] quem são os proprietários da [Rede] Globo? São judeus! Por isso há interesses políticos e econômicos".

Essa ideia é complementada pelo sheikh Abdel Hamid, da Mesquita Brasil de São Paulo, que reclama da desinformação do brasileiro em relação a diversos aspectos, em particular, sobre o islam. Ele afirma que

\footnotetext{
${ }^{86}$ Em 20.11.2019, a Escola publicou uma carta aberta à comunidade informando o encerramento de suas atividades a partir de 20.12.2019, em razão do "desinteresse e a falta de apoio da própria comunidade árabe a qual o Colégio atende". Aponta também que "o fechamento do Colégio Árabe-Brasileiro representa o insucesso da comunidade árabe de Foz do Iguaçu em preservar uma instituição de ensino, uma instituição "educacional, que talvez represente um dos mais nobres instrumentos de formação de cidadãos críticos, éticos, responsáveis e transformadores" (disponível em https://bit.ly/35pVNvL acesso em 20.11.19).
} 
infelizmente as pessoas não querem ler, não querem estudar. Querem ouvir só o que a mídia fala. A Globonews não sei o que disse, e acabou! Mas nós estamos vendo que a própria mídia está a frente de tudo para conseguir manipular a favor deles [se exalta]. Têm muitos que vem aqui pesquisar e tentar conhecer a face verdadeira do islam.

Para ele, as pessoas não deveriam se ater ao que a imprensa diz, mas ir até as comunidades, conhecê-las mais de perto para aprender sobre a religião. Ele diz que muitos dos que fizeram isso "acabaram abraçando o islam", inclusive.

Fatih Özorpak compartilha dessa ideia quando diz que "nesse período precisamos conhecer mais a religião". Ele complementa dizendo que

a mídia tem uma responsabilidade muito grande, mas não tem como comparar, uma pessoa que matou outra, a mídia já está mostrando, já está julgado, já está feito, já está condenado [...] A mídia quer mostrar quem está batendo no outro, quem está tirando cabeça do outro. É isso o que ela quer mostrar, e não quer mostrar uma coisa boa.

Mohammad Tawfiq, também quando questionado sobre a influência da mídia, alega que a mídia brasileira, infelizmente, fizeram várias reportagens conosco aqui. Só que quando eles lançaram na TV, no programa, na grade deles, assistimos. Meu Deus! [diz com voz de desânimo]. Não fala nada do islam, fala dos costumes. Porque o repórter, coitado, não conhece o islam. O repórter, coitado, está sendo pressionado para fazer a reportagem. Ele tem que fazer uma coisa bonita para agradar o patrão dele. Então ele não vai escolher as palavras, sei lá, o ângulo, talvez o fundo, talvez o sorriso, talvez a mão assim ou assim, e não sai nada do islam, só os costumes. Então o que sai na mídia, não sai do islam verdadeiro. Sai uma mulher usando o hijab, alguém orando. A gente vê dia e noite na TV e depois dizem terroristas [exclama]. Aqui não falou de terroristas, mas a gente já ouviu que somos terroristas de outra pessoa. Porque a mídia não tem obrigação de explicar o que é o islam. Tem um canal aqui da Assembleia Legislativa. Fizeram reportagem conosco. Como esse canal tem grade pequena, fica repetindo, passou mais de dezenas de vezes. Tem algumas coisas boas, não tem nada ruim, mas ele não fala muito sobre o islam. Só que o bom para nós é que está dizendo 'tem muçulmanos aqui na cidade. Ei, acorda! Tem muçulmanos aqui na cidade'. Temos página no Facebook e tem gente que entra lá querendo conhecer. 
Aqui, a preocupação com a forma é maior do que com o conteúdo, o que na visão de Mohammad Tawfiq, não serve para explicar e informar a comunidade brasileira sobre o essencial do islam e das comunidades muçulmanas.

Em novembro de 2015 participei de uma palestra (Foto 22) ministrada pelo professor da UNICAMP, Mohammed Habib, cujo tema era "O colonialismo europeu e o islamismo político", realizado na Sociedade Islâmica de Campinas (SIC). Seu objetivo era esclarecer os episódios envolvendo os atentados que aconteceram em Paris naquele ano e desmistificar o que a mídia transmitia, que segundo ele, era uma série de inverdades que descontextualizam e mascaram os reais motivos daqueles e de outros ataques provenientes de grupos jihadistas. Ele mesmo assume, que na preparação de sua fala, que se baseou apenas em documentos que o próprio Ocidente produz já que é dele o monopólio do conhecimento e da informação.

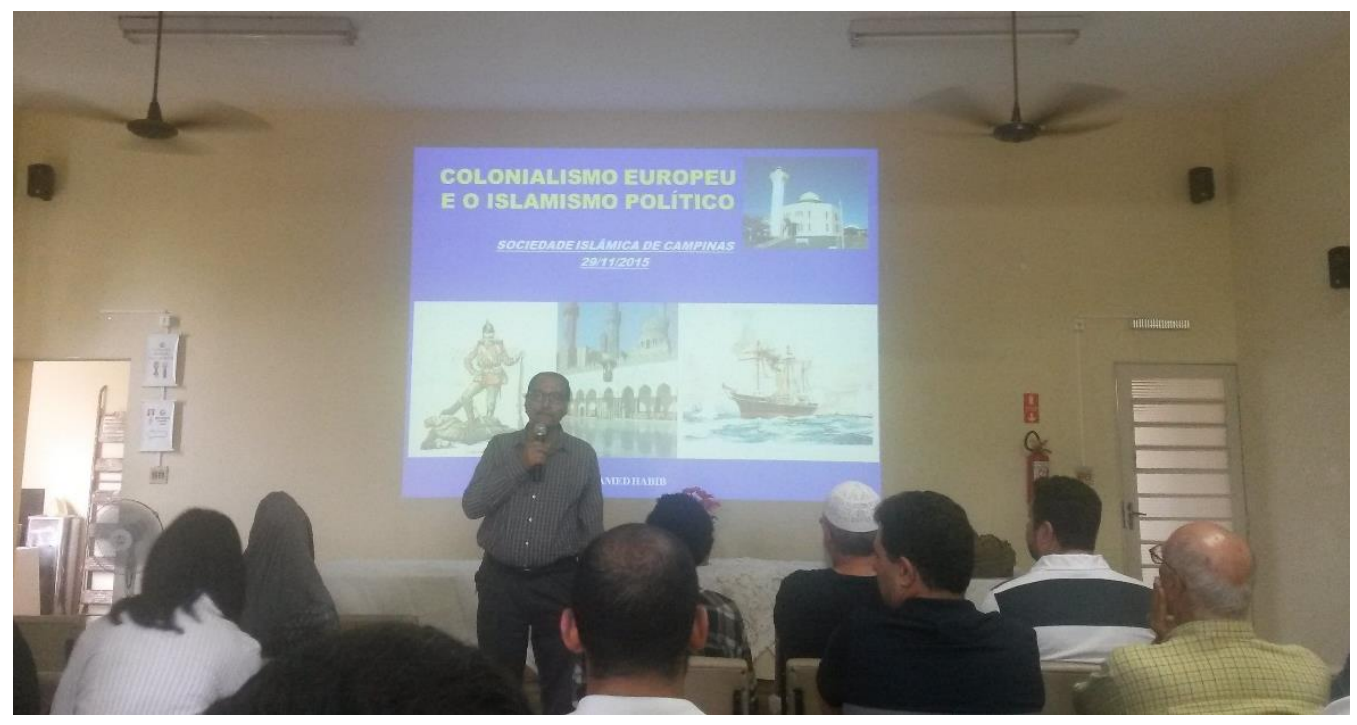

Foto 22- Palestra do Prof. Mohammed Habib na SIC, 29.11.2015.

Para o professor Habib, a mídia tem projetado uma imagem de um islam violento, "briguento", quando na realidade a religião é pacifista. Ao longo de sua apresentação, ele mostra a parcialidade da mídia e a indignação seletivas, já que morrem muito mais muçulmanos em zonas de conflito do que na Europa, mas pouco disso é noticiado. Também é feito um histório que perpassa a época das cruzadas, a questão do Destino Manisfesto americano e o uso da força contra nativos, até o colonialismo europeu que, para ele, "abriu as portas para tudo isso que está acontecendo", não se esquecendo de mencionar os percalços gerados pelos Acordos de Sykes-Picot (1916) e pela Declaração de Balfour (1917).

O professor também faz uma análise dos movimentos nacionalistas seculares que se sucederam no Oriente Médio, enfatizando o Egito (sua terra natal), que lutavam pela independência e combate à colonização. Após o fracasso de muitos deles, ganham força os movimentos islamistas encabeçados pela Irmandade Muçulmana (I.M), principalmente sob a 
figura de Sayyid Qutb, a quem o professor Habibi se refere como um "grande intelectual", e do sheikh Kishk, terceiro líder da I.M ${ }^{87}$.

Por fim, são expostos dois projetos que tinham por objetivo semear mais problemas e divisões no Oriente Médio. O primeiro a ser discutido foi o "Yinon Plan" publicado em 1982, em que estrategistas judeus, sustentados pelos escritos do "pai do sionismo", Theodor Herzl, pregavam o "Grande Israel”, representado num mapa em que o Estado judeu era compreendido desde o rio Tigre no Iraque ao rio Nilo no Egito.

O segundo, "The New Middle East Map"88, foi apresentado em 2006 pela então secretária de estado dos Estados Unidos, Condolleezza Rice, que através do chamado "caos construtivo" geraria um ambiente propício a guerras que tornaria possível aos Estados Unidos, aos britânicos e ao Estado de Israel redesenhar os mapas da região de acordo com suas necessidades estratégicas.

Está claro que o professor oferece uma narrativa basicamente externalista sobre muitas das situações que envolvem o Oriente Médio e os muçulmanos de modo geral, ignorando certos impasses inerentes ao mundo árabe e islâmico. Para ele, a região é mostrada como objeto da cobiça ocidental que seria a grande causadora dos problemas que a afligem, mas que a mídia insiste em não revelar tais interesses.

O Oriente Médio e os muçulmanos, desta forma, são vítimas de uma série histórica de planos ocidentais conspiratórios que além de favorecer a exploração de países da região, acabam por denegrir a imagem do islam e de seus fiéis.

Está implícito nestas narrativas, que a violência praticada por grupos terroristas ganha muito mais repercussão do que quando um muçulmano faz algo de positivo. Aliás, algo que não é específico do islam. Retomando o exemplo dos ataques ao Charlie Hebdo, pouco se falou da atitude altruísta de um muçulmano, funcionário de um supermercado kosher, durante os tiroteios em Paris ao proteger os clientes dentro da câmara frigorífica do estabelecimento, como noticiado pelo The Guardian ${ }^{89}$. Esta situação resume bem a fala do professor Habib, para quem, da forma como se apresenta, a repetição de imagens e fatos negativos, aos poucos cimentam a ideia de que os muçulmanos seguem uma religião que promove o mal.

O sheikh Jihad sintetiza esses aspectos ao asseverar que

\footnotetext{
${ }^{87}$ Interessante notar que nesta palestra o professor Habibi estabelece a seguinte divisão do islam político: A I.M é "islamista moderado"; o Hamas é "jihadista armado"; o Hezbollah é "jihadista institucional”; e a Al-Qaeda e EI são "jihadistas armados caóticos”.

${ }^{88} \mathrm{https}$ ://bit.ly/2AY7luO (acesso em 20.11.2018).

${ }^{89}$ https://bit.ly/2NDwLjF (acesso em 23.07.2018).
} 
num ciclo de dez anos, começando em 2001 a 2011, a mídia ocidental desconstruiu e vem desconstruindo o indivíduo islâmico. Terrorista muçulmano, muçulmano terrorista, extremista muçulmano, nunca tem um nome, sempre o indivíduo muçulmano. O muçulmano virou um adjetivo, sempre ligado ao negativo. Depois do memorável discurso de Obama na Universidade de Al-Azhar no Egito, fecha-se um ciclo e abre-se outro, que é a desconstrução da entidade islâmica, e surge o Estado Islâmico. Não mais o indivíduo islâmico, mas um grupo islâmico. Então, desconstruía-se o indivíduo, agora desconstrói-se o coletivo, em nome de um Estado Islâmico. Mostrando que o coletivo islâmico é prejudicial à saúde [risos]. É incompatível com a sociedade e os valores ocidentais. Um grupo pequeno fazendo um alarde danado através dos holofotes, do palanque ocidental, pela mídia ocidental e a mídia brasileira sendo coadjuvante nisso, né?

De fato, muitos exemplos deste raciocínio podem ser observados mundo afora. Em novembro de 2015, após os violentos ataques à casa de shows Bataclan em Paris, era comum observar referências de que os perpetradores eram franceses de "origem argelina" ou belgas de "origem marroquina" ou simplesmente franceses-muçulmanos ou belgas-muçulmanos. Os termos "extremistas islâmicos", "radicais" e "fundamentalistas" eram usados corriqueiramente. O denominador comum passou a ser a religião islâmica ou a nacionalidade de origem, que por sua vez está ligada ao islam. A adjetivação do islam se tornou banal, carente de reflexão e, portanto, terreno fértil para a criação de estereótipos que mais confundem do que esclarecem.

Este panorama não se restringe ao contexto atual, pois podemos ver que esse problema já havia sido detectado há quase vinte anos. Castro (2007, p.72), ao analisar o conteúdo e o volume de notícias dos seis meses anteriores e dos seis meses posteriores os atentados de 11 de setembro de 2001 ao World Trade Center em Nova Iorque, reforça essa ideia ao concluir que

o sintagma, quando usado com um modificador, como nos casos de 'grupo extremista islâmico', 'grupo islâmico', e 'milícia islâmica', reforça a ideia de que o Taleban é um representante do islã em geral e não uma parte muito ínfima dentro do universo de mais de 1,5 bilhão de fiéis. Percebe-se também que ao abreviar a expressão 'grupo extremista islâmico' para 'grupo extremista', e variar o uso de 'grupo islâmico' e 'grupo extremista', a palavra extremista acaba fazendo as vezes de um sinônimo de 'islâmico'. A partir daí é possível associar extremista com islâmico e vice-versa, o que colabora para a cristalização do velho estereótipo de que muçulmanos são violentos. 
Isso se enquadra naquilo que Said (2005) definiu como o terceiro sentido do orientalismo, o discurso. $\mathrm{O}$ uso de expressões que vinculam árabes e muçulmanos à violência, reproduzindo estereótipos, são formas de se levantar barreiras entre "nós" e os "outros".

Em anos mais recentes, parte da mídia - exceto aquelas de caráter mais conservador ou com pouco profissionalismo, comum em muitos canais da internet - tem tido o cuidado de adotar um tom mais brando para com os muçulmanos receando insultar ou reforçar estereótipos negativos.

Em outra referência, Said (2007) faz um levantamento de muitos dos veículos midiáticos dos Estados Unidos e a forma com que retratavam o islam e os muçulmanos. A cobertura feita pela imprensa, para ele, tinha um viés negativo e muito generalista. Said (ibid., p.42) afirma que o

Islam has entered the consciousness of most Americans - even of academic and general intellectuals who know a great deal about Europe and Latin America - principally if not exclusively because it has been connected to newsworthy issues like oil, Iran and Afghanistan, or terrorism ${ }^{90}$.

Eventos como a crise do petróleo de 1973, a Revolução Iraniana de 1979 seguida da invasão da embaixada norte-americana em Teerã, a Guerra dos Seis Dias e os graves desdobramentos do conflito Israel-Palestina, catapultaram a imagem (negativa) do Oriente Médio no Ocidente. As caracterizações dos muçulmanos e do "Oriente" de modo geral eram de hostilidade, beligerância e com estereótipos descomedidos.

Said (ibid., p.07) pondera dizendo que

I am not saying that Muslims have not attacked and injured Israelis and Westerners in the name of Islam. But I am saying that much of what one reads and sees in the media about Islam represents the aggression as coming from Islam because that is what "Islam" is ${ }^{91}$.

No Brasil, a mídia não parece seguir outro caminho. O sheikh Mohammed Khalil afirma que a mídia brasileira é "lactante", ou seja, se alimenta daquilo que é produzido por outros lugares e veículos de imprensa. Nas palavras dele,

infelizmente, o Brasil, eu tinha falado isso muitas vezes para jornalistas de alta qualidade aqui, dizendo que infelizmente, o jornalismo brasileiro é um

\footnotetext{
90 “O Islam entrou na consciência da maioria dos americanos - até mesmo dos intelectuais acadêmicos que sabem muito sobre a Europa e a América Latina - principalmente se não exclusivamente, porque está ligado a questões como petróleo, Irã e Afeganistão ou terrorismo" (tradução minha).

91 "Não estou dizendo que os muçulmanos não atacaram e feriram israelenses e ocidentais em nome do Islã. Mas eu estou dizendo que muito do que se lê e vê na mídia sobre o Islã representa a agressão como vinda do Islã, porque é isso que o 'Islã' é" (tradução minha).
} 
jornalismo lactante, que ainda toma leite dos outros. Os jornalistas brasileiros devem ter uma independência de pesquisa, de notícia, de não traduzir...eles traduzem de outras mídias. Não é bom para um jornalista traduzir um texto inteiro e jogar no seu jornal. É um crime! Como assim? Eu traduzo uma coisa que eu não estou observando, vivendo? A notícia tem que ser imparcial, para ganhar credibilidade junto à população.

Da mesma forma, pensamentos e opiniões enviesadas são atribuídas aos grandes meios de comunicação, como aponta Castro (2007), especialmente após os atentados de setembro de 2001.

A visão em relação aos árabes e muçulmanos só não foi ainda mais arranhada, pois em seguida aos ataques, a maior emissora de televisão do país, a Rede Globo, passou a exibir a novela "O Clone" 92 , que se tornou sucesso nacional e internacional, sendo exibida em diversos países. O sheikh Jihad, que foi o consultor da produção do programa, revelou:

no mesmo canal que no noticiário das 8 [horas] falava-se "muçulmanos terroristas, muçulmanos tal, terrorismo islâmico", uma desconstrução do indivíduo muçulmano, logo depois vinha uma novela que falava sobre o profeta, sobre os muçulmanos, sobre os valores, sobre o 'tio Ali' dando exemplo tal, então um desconstruía e o outro construía. Nítida uma [pausa na fala] falta de comunicação interna do meio de comunicação, mas também ao mesmo tempo, falta de uma ideia definida sobre o muçulmano. O que é o muçulmano? De repente eu estou descendo o sarrafo e depois eu estou elogiando! Mostrando-o bonzinho!

A novela era um oportuno contraponto às frequentes manchetes negativas, fragmentadas e espetaculosas após os atentados e ao início da "Guerra ao Terror" encabeçada por George W. Bush, então presidente dos Estados Unidos. Mesmo assim, segundo o sheikh Jihad, foi um período quando muitas pessoas passaram a conhecer o islam e a cultura árabe, e muitas delas se converteram.

Quando a novela chegou ao seu termo final, observou-se que a mídia tendeu cada vez mais para uma abordagem hostil em temas envolvendo o Oriente Médio e os muçulmanos, incutindo na sociedade um receio cada vez maior com relação ao islam e seus seguidores. Neste processo, algumas pessoas com certa influência na formação da opinião passaram a se manifestar de forma mais aberta e por vezes com um discurso agressivo sobre o islam.

\footnotetext{
92 Exibida entre outubro de 2001 e junho de 2002.
} 
Olavo de Carvalho, ainda que não tenha nenhuma formação acadêmica - se autodenomina um autodidata - é citado como filósofo, ensaísta, escritor, jornalista e islamólogo ${ }^{93}$. Dos livros que publicou, raros são os que objetivam discutir o islam. Em geral, ele expõe suas ideias por meio de seu website ${ }^{94}$, redes sociais - como o Facebook -, e através de seu canal no Youtube $e^{95}$.

Apelidado de "guru da direita" no Brasil, ele é conhecido por suas ideias conservadoras e polêmicas, pelo uso de linguagem de baixo calão em suas exposições, e por ser feroz com relação aos seus críticos. Entre suas ideias a respeito do islam, ele acredita que vivemos hoje uma invasão islâmica do Ocidente, algo que compromete a nossa segurança. Recentemente ele entrou em rota de colisão, em razão de algumas de suas afirmações, com a página História Islâmica $^{96}$ (no Facebook). Esta interessante página, possui cerca de 57 mil seguidores e constantemente publica imagens, mapas antigos e informações historiográficas relacionadas ao islam com um bom nível de embasamento e de forma muito democrática na forma como aceita e debate comentários e questionamentos adversos.

Esta página, na tentativa de corrigir, explicar e contextualizar alguns dos comentários publicados $^{97}$ por Olavo de Carvalho, engendrou um debate virtual acalorado com ele, que replicou de forma ácida, como lhe é peculiar. Entre seus seguidores, também é comum observar aqueles que emitem opiniões pouco simpáticas aos muçulmanos e ao islam de modo geral.

Outra pessoa que também é conhecida por tecer críticas ao islam, especialmente quando há eventos violentos a ele relacionados, embora esse não seja o tema principal de seus comentários, é o colunista da Revista Veja, Reinaldo Azevedo. Na esteira dos atentados na França em 2015, uma série de comentários foram publicados por ele em textos e vídeos. Em uma dessas publicações ${ }^{98}$, no blog da Revista Veja, ele afirma que a

islamofobia, é uma mentira inventada pela máquina de propaganda dos centros culturais de difusão do Islã no Ocidente [...] o islamismo nasce para a guerra. Surge e se impõe como organização militar. Faz, em certa medida, trajetória contrária à do catolicismo.

\footnotetext{
${ }^{93}$ Ele afirma, inclusive, já ter feito parte de uma "tariqa" (uma confraria ligada à corrente esotérica islâmica sufi), que segundo ele, é uma forma de globalismo islâmico, um ecumenismo islâmico.

94 https://bit.ly/2LOk6Kc (acesso em 25.07.2018).

95 https://bit.ly/2wn4LwI (acesso em 25.07.2018). O canal possui certa de 183 mil inscritos. No Facebook, sua página tem mais de meio milhão de seguidores.

96 https://abr.ai/2CWuor0 (acesso em 22.10.2018).

97 https://bit.ly/2yQugIe (acesso em 23.07.2018). Olavo de Carvalho sugere em um de seus "posts" que o islam não é uma via de salvação.

${ }^{98}$ https://abr.ai/2v5GTu9 (acesso em 23.07.2018). Publicado em 09.01.2015.
} 
O colunista defende a discussão de uma "cristofobia" já que para ele está claro que o islam não é uma religião pacífica ${ }^{99}$, anunciando isso de forma irresponsável, generalizante e sem as devidas ponderações e reflexões.

Em outro texto, ele questiona o fato de Jerusalém ser uma cidade sagrada para os muçulmanos, pois segundo ele, a cidade não é sequer citada no Alcorão ${ }^{100}$. Reinaldo Azevedo parece ignorar a surata 17 , versículo 1, Al-Isrá (a sura da viagem noturna) ${ }^{101}$ revelada em Meca. Lá se diz: "Glorificado seja quem ao Seu servo Muhammad viajar à noite - da Mesquita Sagrada para a Mesquita Al-Aqsa [grifo nosso]”. Aqui a mesquita Al-Aqsa é citada diretamente. No entanto, existem outros versículos em que a citação é indireta. Nos ditos (ahadith) do profeta Mohammed $^{102}$ (Maomé) há várias passagens que sacralizam a cidade de Jerusalém. Além disso, quando os seguidores de Maomé começaram a cumprir as orações (salat), a orientação era para Jerusalém, tal como se orientavam todos os profetas antes dele, até que uma ordem divina trazida pelo Arcanjo Gabriel fez mudar essa orientação (alkibla) para Meca.

Reinaldo Azevedo ainda tece severas críticas sobre a incompatibilidade entre o islam e a democracia - que compreende uma vasta bibliografia ${ }^{103}$ - comparando frequentemente com o cristianismo e sua "evolução", especialmente no aspecto da separação entre Estado e religião. Embora exista algum fundamento, ainda que de forma grosseira, ele não esclarece como comunidades muçulmanas ao redor do mundo em países não islâmicos, incluindo o Brasil, vivem de forma pacífica e bem integrada. Parece que certas generalizações se tornam a regra para ele.

Felipe Moura Brasil, ex-colunista da Revista Veja e organizador de um dos livros de Olavo de Carvalho, também tem uma série de publicações na internet a respeito do radicalismo islâmico. A mais conhecida delas é intitulada de "O mito da minoria radical islâmica"104, baseada exclusivamente em um vídeo ${ }^{105}$, de mesmo título, de Ben Shapiro ${ }^{106}$.

\footnotetext{
${ }^{99} \mathrm{https} / / / \mathrm{bit} .1 \mathrm{l} / 2 \mathrm{v} 3 \mathrm{QPUJ}$ (acesso em 25.07.2018). Vídeo no Youtube de 16.11.2015.

$100 \mathrm{https} / / / \mathrm{abr} . \mathrm{ai} / 2 \mathrm{~K} 056 \mathrm{XY}$ (acesso em 25.07.2018). Publicado em 06.12.2017.

101 Alcorão Sagrado, 2014.

102 Assim como optamos pela grafia da palavra "islam" com "m", como já explicado anteriormente, faremos uso da palavra "Mohammed" e não Maomé (como em geral é traduzido) por se tratar de uma categoria nativa e assim verbalizada por todos os interlocutores com quem tive contato. Materemos Maomé apenas quando o termo estiver assim transcrito em citações de livros, periódicos e afins.

103 Cf. Bukay, David. Can There Be an Islamic Democracy? [incl. John Esposito, John Voll, Bernard Lewis, Noah Feldman, et al.]. The Middle East Quarterly, 2007. Disponível em https://bit.ly/2MvVHxU acesso em 07.06.2019. Cf. Ruthven, Malise. Mosque and State. The Future of Political Islam. Foreign Affairs. Sep/Oct 2016. Disponível em https://fam.ag/2cv5mhp acesso em 07.06.2019.

${ }^{104}$ https://abr.ai/2vcLv1F (acesso em 25.07.2018).

105 https://bit.ly/2v8qogC (acesso em 25.07.2018). Vídeo no Youtube publicado em 28.07.2017.

106 Benjamin Aaron Shapiro, um jovem articulista conservador dos Estados Unidos.
} 
A partir da exposição de uma série de dados populacionais dos principais países de maioria muçulmana, ele estabelece um percentual de quanto dessa população é radical.

Ele conclui que cerca de 800 milhões de muçulmanos são radicais. Não necessariamente aqueles que praticam os atos terroristas de fato, mas também aqueles que dão apoio moral, financeiro e religioso a esses grupos. Para tanto, os critérios usados são questionamentos feitos a cada população, como a simpatia por terroristas como Osama Bin Laden, se são contrários ao Estado de Israel e aos Estados Unidos, se consideram justas as agressões a mulheres por questões de honra, e sobre o seu apoio à imposição da sharia por exemplo.

$\mathrm{O}$ número apontado soa superdimensionado se comparado ao que afirma Esposito e Mogahed (2008), para quem seria cerca de $10 \%$ da população muçulmana. Ainda assim, seriam 150 milhões, quantidade considerável. O mesmo percentual também é encontrado por Ahmed (2007) através de seus questionários distribuídos em oito países do Oriente Médio e Sudeste Asiático. Questionando qual seria o "modelo de muçulmano" para uma amostra de uma centena de pessoas, de 10\% a 15\% delas, tem Ahmed Yassin (ex-líder do Hamas), Sayyid Qutb e Sayyed Abu Ala Maududi, como suas referências.

Ferreira (2018) discute alguns aspectos da sharia em um texto publicado na internet ${ }^{107}$ em 25 de julho de 2018. Lá ela afirma, em contraposição a Ben Shapiro, que

vale dizer aos desentendidos de Xaria, isto é, a maioria dos leitores, que a Xaria é praticada em $80 \%$ mais ou menos em todos os países que há muçulmanos, inclusive no Brasil, porque faz parte da Xaria: rezar, fazer jejum, pagar o zakat, fazer o Hajj, adorar a Deus, enfim muitas práticas são advindas da Xaria (Alcorão e Sunnah).

O que Ben Shapiro leva em consideração são apenas os aspectos punitivos presentes da lei islâmica, que para a Ferreira (ibid),

as penalizações (código Penal) se referem a $4 \%$ da lei islâmica e isso só é decidido por conselhos de juristas e sábios, hoje muito do que se aplicava antigamente é revisto pela Ijtihad (Interpretação) ferramenta jurídica que contribui para avaliação de vários casos.

As formas polarizadas de pensamentos, seja com tendências islamófobas ou islamófilas, produzem mais desinformação do que esclarecimento. Ao mesmo tempo, os conteúdos transmitidos por alguns veículos midiáticos, que ajudam a entender o porquê da "mídia lactante", como apelidou o sheikh Mohammed Khalil, ajudam a frutificar a ignorância e

${ }^{107}$ https://bit.ly/2mKNW7C (acesso em 26.07.2018). 
desinformação na população, pavimentando o caminho da estigmatização das comunidades islâmicas.

Em 2017, essa ignorância foi observada em uma manifestação feita por grupos de evangélicos na cidade do Rio de Janeiro/RJ contra os muçulmanos ${ }^{108}$, especialmente em razão do influxo sírios refugiados que chegam ao país. Em seus cartazes era possível ler: "Alcorão é guia de estupros e assassinatos" e "assassinos pedófilos"109. O refugiado sírio, Mohammed Ali, que vendia esfihas no bairro de Copacabana, foi insultado por manifestantes e teve parte de sua mercadoria perdida ao vandalizarem seu carrinho. Dias depois, em solidariedade à sua situação, muitas pessoas ajudaram o rapaz. Fizeram fila para comprar suas esfihas e criaram uma "vaquinha" para comprar um novo food truck para ele $\mathrm{e}^{110}$.

Ano passado, a Mesquita Omar Ibn Al-Khattab de Foz do Iguaçu/PR, publicou uma carta aberta ${ }^{111}$ em sua página no Facebook para esclarecer a comunidade sobre um suposto encontro entre a instituição e o então candidato à presidência da república, Jair Messias Bolsonaro (PSL) ${ }^{112}$, que aconteceria dia 28 de julho de 2018 na cidade. O candidato, apoiado por alas evangélicas, é conhecido por suas ideias ultraconservadoras, por ser entusiasta da ditadura militar no Brasil (1964-1985) e por declarações polêmicas a respeito de homossexuais, de negros e por sua postura xenofóbica ${ }^{113}$. Em setembro de 2015, em entrevista ao Jornal Opção de Goiás ${ }^{114}$, o deputado disse:

Não sei qual é a adesão dos comandantes, mas, caso venham reduzir o efetivo [das Forças Armadas] é menos gente nas ruas para fazer frente aos marginais do MST, dos haitianos, senegaleses, bolivianos e tudo que é escória do mundo que, agora, está chegando os sírios também. A escória do mundo está chegando ao Brasil como se nós não tivéssemos problema demais para resolver.

A Mesquita Omar Ibn Al-Khattab afirmou em sua carta seu compromisso com a democracia e com o diálogo salutar, alegando que sequer foi avisada sobre o encontro com Jair Bolsonaro e que dificilmente ele aconteceria devido a divergências de ideias, muitas das quais

\footnotetext{
108 https://bit.ly/2mJFp51 (acesso em 25.07.2018). O evento aconteceu em 12.08.2017.

109 https://glo.bo/2JRR2EX (acesso em 25.07.2018).

$110 \mathrm{https://glo.bo/2LLD8kx}$ (acesso em 25.07.2018).

111 https://bit.ly/2uSpTYL (acesso em 26.07.2018).

112 Foi eleito presidente da república com cerca de 55\% dos votos válidos em 27.10.2018. Tomou posse em 01.01.2019 para um mandato de quatro anos. Atualmente está sem partido (se desfiliou do PSL em nov.2019).

${ }^{113}$ Em um discurso, chamou os refugiados de "escória do mundo" (disponível em https://abr.ai/2tatfpk, publicado em 22.09.2015 e acessado em 26.07.2018). Em discursos no plenário da Câmara Federal, ele também defendeu a fim da imigração islâmica e de outros povos ao Brasil.

${ }^{114}$ https://bit.ly/2Mu5vby (acesso em 16.10.2018).
} 
expressadas pelo candidato em outras situações que contrariam os pressupostos defendidos pela entidade, servindo de um ato oportunista para sua promoção política.

O que chama a atenção é que em um dos itens constituintes da nota publicada vai ao encontro daquilo que expusemos até aqui. Ela diz em seu segundo tópico:

O Brasil tem sido palco de propagação de ódio aos árabes e seus descendentes, especialmente por meio da promoção ativa da xenofobia e da islamofobia em parte dos grandes veículos comerciais de comunicação de massa, tanto em sua formas noticiosas quanto em seus programas de entretenimento, razão pela qual, infelizmente e para assombro de toda a comunidade árabe-brasileira, professantes do islamismo e algumas de suas instituições sociais e religiosas passaram a sofrer ataques, todos formalmente comunicados às autoridades competentes. Parte considerável desta escalada na promoção do ódio aos árabe-brasileiros só tem sido possível graças ao ativismo de lideranças e setores extremistas da sociedade que, ainda que minoritários, têm exacerbado a questão com divulgações de dados e atos/fatos absolutamente falsos, sempre depreciativos dos muçulmanos em geral e dos árabes em particular. Como parte de nossas lideranças, alguns políticos fazem ecoar publicamente tal ideologia de ódio ao próximo e reforçar um caminho de extremismo que está na contramão do que defendemos, contramão dos princípios da nação brasileira.

Em outubro de 2018, cerca de dez grupos de comunidades judaicas e muçulmanas, representando cerca de 10 mil pessoas, divulgaram um manifesto contrário a Jair Bolsonaro. $\mathrm{O}$ teor desse documento pode ser lido neste trecho divulgado pela revista Exame ${ }^{115}$ :

nós, muçulmanos e judeus, que conhecemos os horrores da islamofobia e do antissemitismo, temos a sensibilidade aguçada para perceber que, entre todas as barbaridades proferidas por este candidato, a mais emblemática, por atingir vários segmentos, foi a de que as minorias devem se curvar à maioria.

No dia 21 de outubro de 2018, em uma manifestação a favor de Jair Bolsonaro na cidade de São Paulo, foram vistas fotos como a que está logo abaixo, em que algumas pessoas ostentavam a bandeira de Israel enquanto repudiavam a presença islâmica.

${ }^{115}$ https://abr.ai/2CldnFH (acesso em 16.10.2018). 


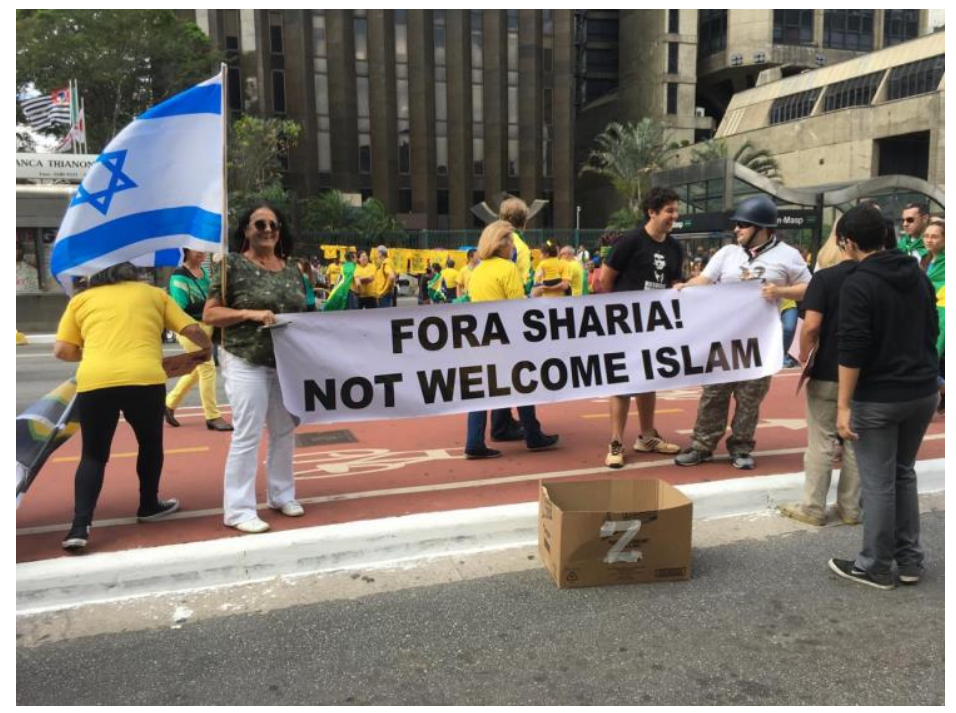

Foto 23 - Publicada no perfil do Facebook da Profa. Dra. Francirosy Campos Barbosa. 21.10.2018.

Evidentemente, isso não condiz com a posição assumida por parte das comunidades judaicas que emitiram parecer contrário à política de Bolsonaro ${ }^{116}$. Consultados, alguns dos meus informantes contemporizaram essa situação alegando que se trata de um caso isolado.

Dias após ter vencido o pleito presidencial, Jair Bolsonaro declarou que pretendia transferir a embaixada brasileira em Israel de Tel-Aviv (onde está atualmente) para Jerusalém ${ }^{117}$, a exemplo do que já fizeram os Estados Unidos e outros sete países ${ }^{118}$, inaugurando uma nova agenda das relações exteriores do Brasil.

Em entrevista ao jornal Israel Hayom ${ }^{119}$, Jair Bolsonaro afirmou que Donald Trump tem feito um bom trabalho nos Estados Unidos e que pretende usar muitos de seus exemplos, um deles é com relação à transferência da embaixada brasileira. Sobre isso, ele disse ao jornal:

Israel is a sovereign state. If you decide on your capital city, we will act in accordance. When I was asked during the campaign if I'd do it [move the embassy] when I was president, I said yes, and that you're the ones who decide on the capital of Israel, not other people ${ }^{120}$.

\footnotetext{
${ }^{116}$ Importante lembrar que muitos judeus contribuíram com seu voto à eleição para Presidente de Jair Bolsonaro em parte por seu discurso de apoio a Israel, que por sua vez faz parte da agenda de muitas comunidades evangélicas que também apoiam Jair Bolsonaro. Cabe ainda registrar que em 2017, na sede da Hebraica do Rio de Janeiro, Jair Bolsonaro fez discursos considerados preconceituosos contra negros e quilombolas e foi aplaudido (Ver https://bit.ly/37dQPDT. Acesso em 18.11.19).

${ }^{117}$ Em visita a Israel no começo de abril deste ano, o presidente Bolsonaro declarou que irá abrir um "escritório de negócios" na cidade de Jerusalém, como um primeiro passo antes de transferir a embaixada, conforme prometido em campanha.

118 Guatemala, Honduras, Ilhas Marshall, Palau, Nauru, Micronésia e Togo.

$119 \mathrm{https}$ ://bit.ly/2SGPnmg (acesso em 03.11.2018).

120 "Israel é um Estado soberano. Se os senhores decidirem qual é a sua capital, nós os seguiremos. Quando me perguntaram durante a campanha se transferiria a embaixada se fosse eleito presidente, respondi que sim. Vocês decidem sobre a capital de Israel, não outros povos” (Tradução minha).
} 
$\mathrm{O}$ assunto repercutiu na mídia brasileira, que o indagou sobre o caso da embaixada palestina em Brasília/DF. O presidente se posicionou da seguinte forma:

Quanto à embaixada da Palestina, ela foi construída muito perto do palácio presidencial. Nenhuma embaixada pode estar tão perto do palácio presidencial, então pretendemos mudar. Não há outro caminho, na minha opinião. Fora isso, Palestina primeiro precisa ser um estado para ter o direito de uma embaixada ${ }^{121}$.

Em 2012, a Organização das Nações Unidas (ONU) já havia alterado o status da Palestina para "Estado observador" 122 não membro, cuja capital seria Jerusalém Oriental. Antes disso, segundo o Itamaraty ${ }^{123}$, desde 2010 o Brasil reconhece o Estado da Palestina nas fronteiras de 1967.

O Brasil, que até então vinha mantendo uma postura mais ou menos equilibrada diante do conflito entre árabes e judeus, com o anúncio dessa medida, recebeu uma série de reações negativas, tanto por parte do Hamas, que administra a Faixa de Gaza, quanto da Câmara de Comércio Árabe-Brasileira que prevê maiores dificuldades em acordos com países árabes, que representam o quinto maior parceiro comercial do Brasil. As embaixadas árabes e demais comunidades islâmicas, no entanto, disseram que não irão comentar nada até que isso se torne oficial.

Esse conjunto de situações, ainda que muitas vezes contemporizadas pelas comunidades islâmicas do país, gera um desconforto em relação à forma como árabes e muçulmanos são vistos e tratados por certos segmentos da população brasileira, pela mídia e por determinados grupos políticos.

Há, entretanto, muitas vozes e ações que buscam ampliar o conhecimento sobre os costumes e ritos islâmicos que ao mesmo tempo contribuem para desmistificar certos preconceitos.

Neste quesito, é notório o crescimento de “youtubers" e blogueiras muçulmanas ${ }^{124}$ que criaram canais para, entre outras coisas, esclarecer o público a respeito de assuntos ligados ao islam, como por exemplo, o uso do hijab, o casamento, o significado da morte e de alguns rituais

\footnotetext{
${ }^{121} \mathrm{https}: / / \mathrm{glo.bo} / 2 \mathrm{CYa6wi}$ (acesso em 03.11.2018).

122 https://bit.ly/2P5VBOl (acesso em 03.11.2018).

${ }^{123} \mathrm{https}: / / \mathrm{bit} .1 \mathrm{y} / 29 \mathrm{efEUB}$ (acesso em 03.11.2018).

${ }^{124}$ https://glo.bo/2OWdBef (acesso em 29.10.18). Reportagem publicada em 27.10.2018.
} 
islâmicos. Os canais "Fala, Fatuma"125, de uma jovem de 19 anos, filha de libaneses, e o "Mag Halat"126, de 25 anos, abordam assuntos de moda e beleza além dos assuntos islâmicos ${ }^{127}$.

Nos vídeos, as influenciadoras digitais, como comumente se diz, também discorrem sobre algumas situações constrangedoras pelas quais já passaram por serem muçulmanas e por usarem o hijab. Relatam que seus canais se tornaram alvo de comentários depreciativos e preconceituosos. Apesar de afirmarem que no início isso lhes causava grande tristeza e desconforto, atualmente, de forma leve e descontraída, usam esses casos para conscientizar seus seguidores com informações diversas sobre o islam, algo que acreditam faltar a muitos brasileiros, o que ajuda a explicar esse mau comportamento de alguns nativos.

A geração dos "millenials", aqueles que não conheceram o mundo sem internet e estão na faixa etária dos 20 anos de idade, em geral têm se distanciado dos hábitos religiosos tradicionais. Contrariamente, os jovens muçulmanos, chamados de "geração M", segundo reportagem da revista Correio Braziliense, de 25 de novembro de 2018, são muito conectados à sua fé e orgulhosos em professá-la através de sua vestimenta e costumes.

Segundo Ali Zoghbi (vice-presidente da FAMBRAS) “os jovens muçulmanos são experts em conciliar as práticas e condutas religiosas com o mundo moderno”. Ali afirma que os jovens para os quais dá aulas estão perfeitamente inseridos no contexto social brasileiro sem que isso comprometa a vivência do islamismo. "São jovens que frequentam jogos de futebol pela tarde e à noite estão na mesquita", explica a reportagem ${ }^{128}$.

Há ainda muitas ações nas mais diferentes comunidades que buscam alternativas para ampliar o conhecimento do islam. Na cidade de Campinas/SP, por exemplo, a Mesquita Anoor frequentemente oferece palestras abertas ao público ${ }^{129}$. Contudo, ainda contam com pouca adesão entre os não muçulmanos.

\footnotetext{
${ }^{125}$ https://bit.ly/2zapqCz - Canal no Youtube. Há cerca de 29 mil inscritos neste canal e mais de um milhão de visualizações.

${ }^{126}$ https://bit.ly/2COWnba - Canal no Youtube. Há cerca 89 mil inscritos neste canal e mais de três milhões de visualizações.

127 Há ainda os canais chamados "Eu Muslimah TV”127 e "MakTube” 127, ambos com aproximadamente 7 mil inscritos, e que seguem temáticas parecidas aos seus correlatos mais famosos. (Cf. canais nos links https://bit.ly/2Q2T9EL e https://bit.ly/2ENLSYc do Youtube).

${ }^{128} \mathrm{https}$ ://bit.ly/2Q4trnk (acesso em 29.11.2018).

${ }^{129}$ Em 15.12.2018 ocorreu a palestra cujo título era "Venha conhecer o Islam antes de julgá-lo".
} 


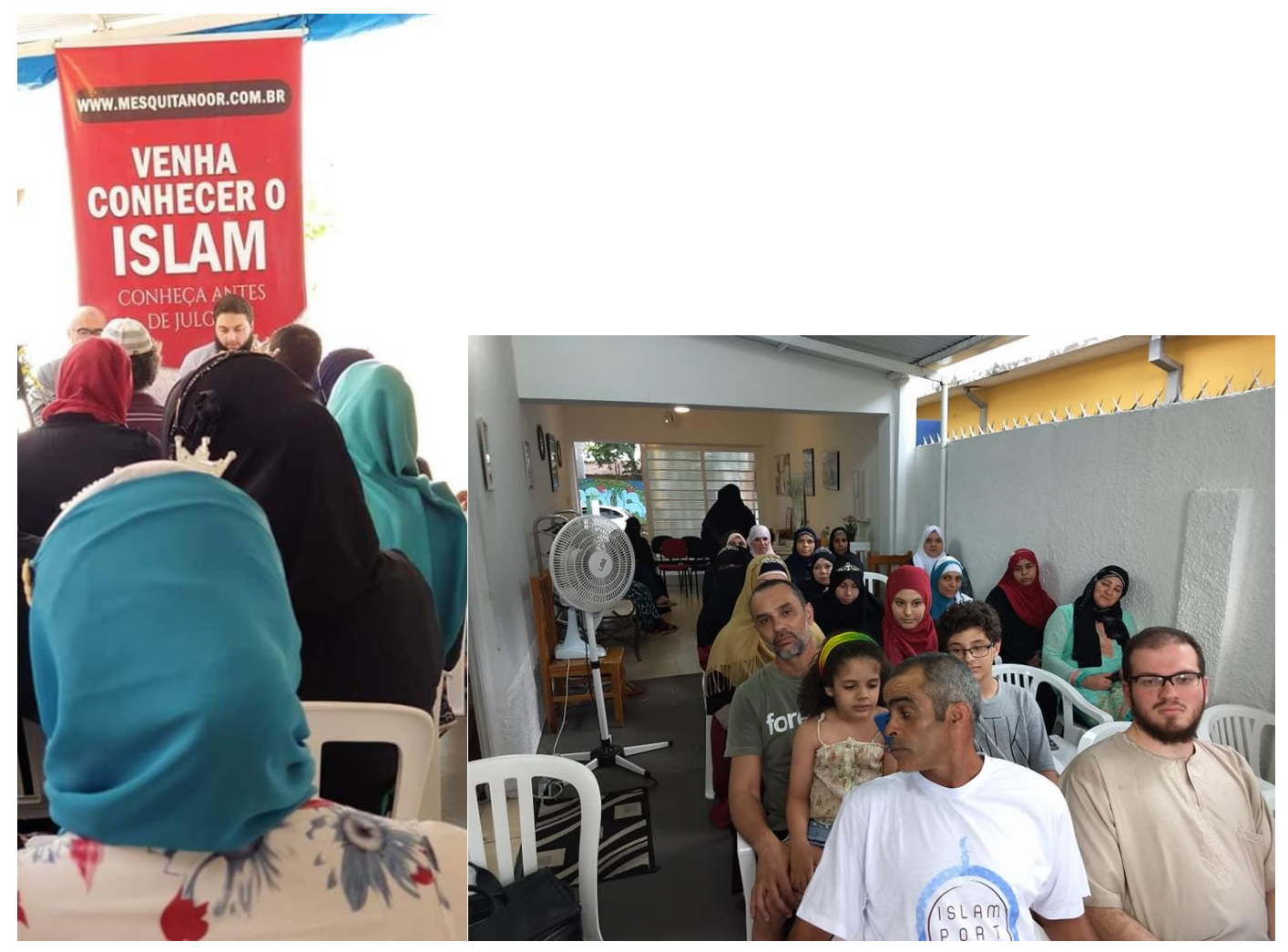

Foto 24 - Palestra na Mesquita Anoor, 15.12.2018.

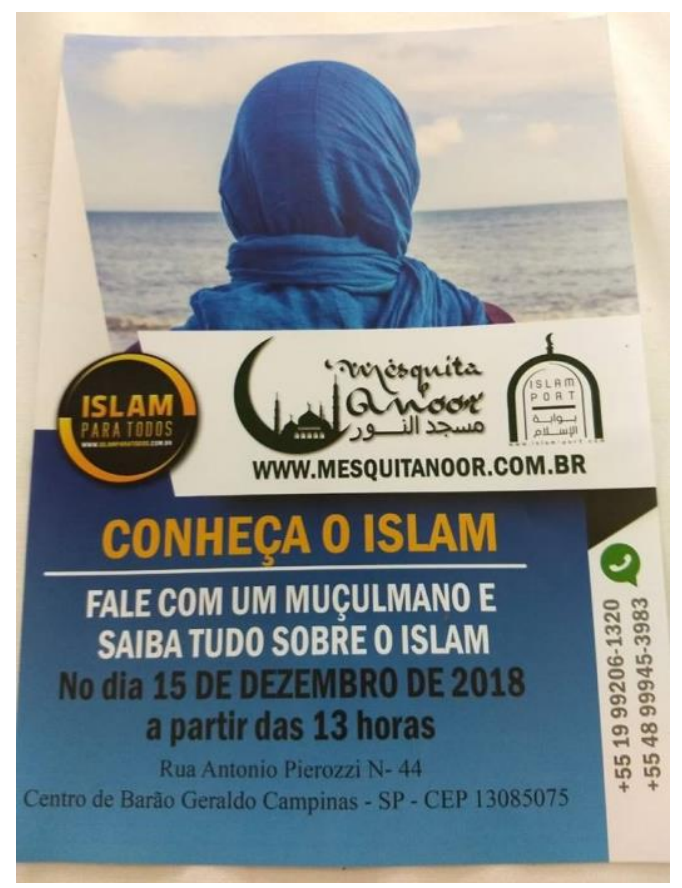

Foto 25 - Folder de divulgação de palestra da Mesquita Anoor.

Palestras em escolas da cidade também são feitas como forma de mostrar aos mais jovens a importância de conhecer para então aprender a respeitar as diferenças. Nessas palestras princípios e valores do islam, educação e igualdade são abordados. O mote principal é mostrar que há muito mais daquilo que nos une do que daquilo que nos separa. 


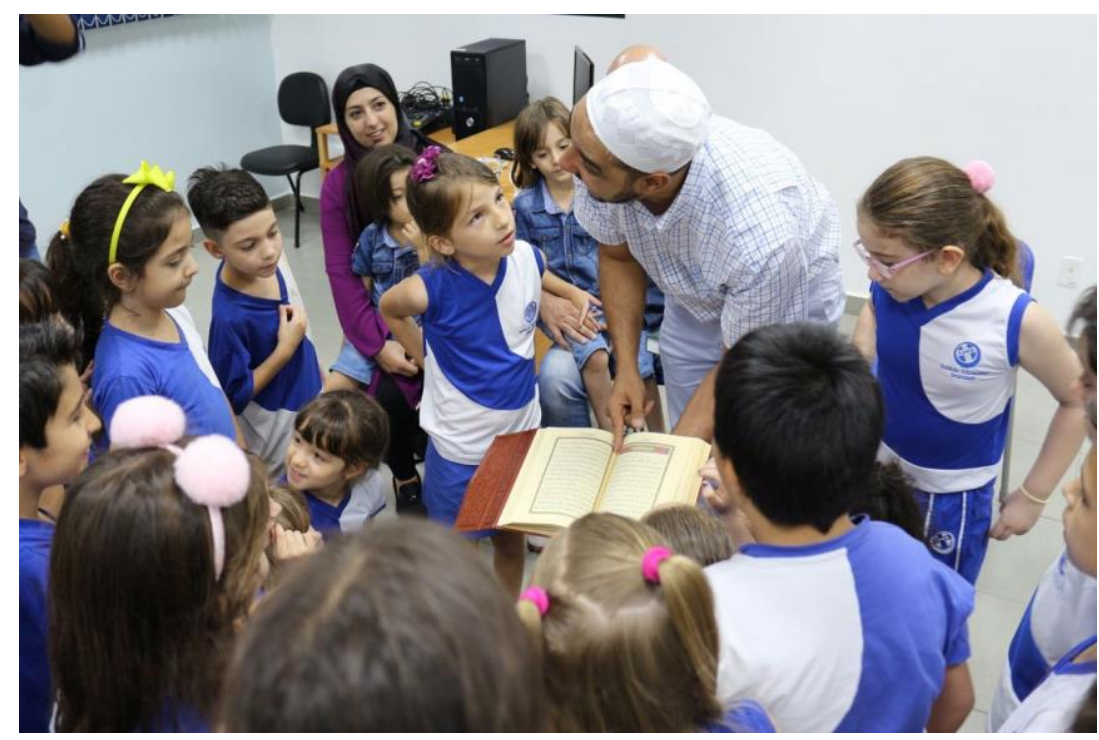

Foto 26 - Palestra em um colégio privado de Campinas/SP, 22.10.2018.

O detalhe importante é que a foto acima retrata uma palestra feita em um colégio privado de grande renome na cidade e que possui orientação católica, administrado por freiras. Em abril de 2019, a mesma instituição promoveu um novo evento aos moldes do anterior. Ao final da palestra, a pedido de professores que acompanhavam os alunos, foi feita uma oração em árabe, cujas frases eram repetidas pelos alunos. Tudo foi filmado como forma de promover e divulgar a atividade na comunidade escolar.

Quase que instantaneamente, o vídeo foi compartilhado por uma página no Instagram intitulada de "resistência_católica", que condenava veementemente o evento, exigindo uma explicação da escola, instigando os pais e cobrando a própria igreja por estar perdendo espaço para uma religião "do mal”. Os comentários que se seguiam ao longo da página variavam entre o sentimento de incredulidade pelo ocorrido na escola, e réplica de preconceitos como "religião que prega a morte" e até mesmo apologia à morte de muçulmanos, num claro e infeliz exemplo de ignorância de parte da população diante de outra religião e seus seguidores ${ }^{130}$.

Em outra situação concreta, esta mesma mesquita, assim como tantas outras comunidades, proporcionou atos de filantropia e trabalho voluntário ajudando moradores de rua no centro da cidade, distribuindo comida, doando roupas e cobertores, especialmente nos dias mais frios do inverno. As fotografias abaixo ilustram alguns desses momentos.

${ }^{130}$ O caso (que ainda corre em sigilo) já está sendo investigado pelo Ministério Público, que arrolou administradores da página e aqueles que nela postaram seus comentários. 

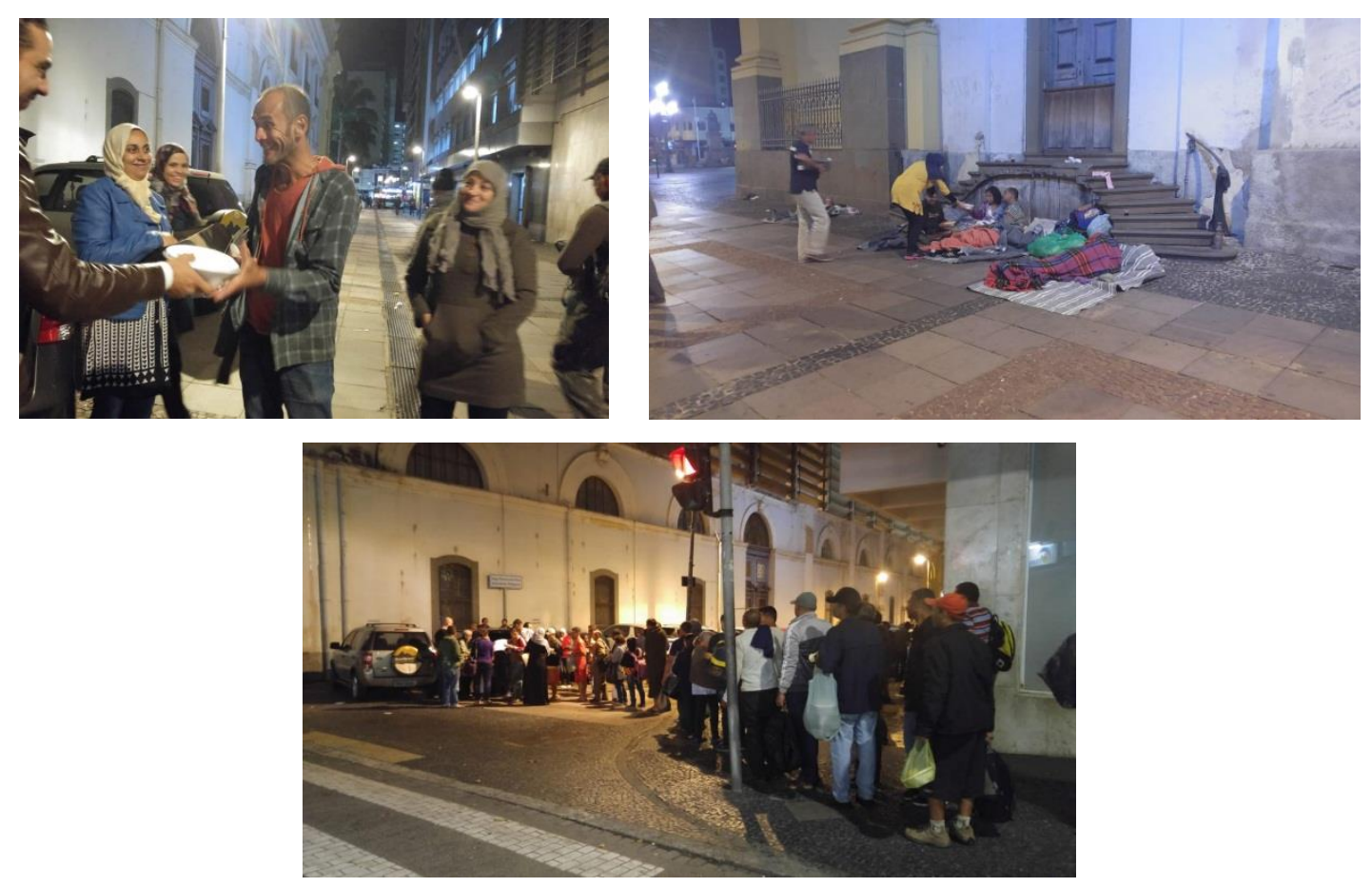

Foto 27 - Ação voluntária no centro da cidade, ago/set.2018

Tais práticas são muito importantes e ajudam muito na construção de uma outra imagem do islam e dos muçulmanos além daquilo que geralmente é mostrado pela mídia, contudo, têm pouca visibilidade.

A despeito dessas ações que visam mostrar o "outro lado" do islam a partir de ações instrutivas e humanitárias que, aliás, é comum a todas as religiões, é importante mostrar que nem todos os indivíduos ou pequenos grupos adotam um tom de apaziguamento, reagindo de modo mais contestador e emocionalmente inflamado, como podemos ver pelos depoimentos abaixo que foram extraídos de uma rede social.

O contexto dessas mensagens ${ }^{131}$ englobam os atentados ocorridos em dezembro de 2016 em Berlim em que um caminhão atropelou e matou doze pessoas no Mercado de Natal da cidade. $\mathrm{O}$ ato foi reivindicado pelo Estado Islâmico à época.

\footnotetext{
${ }^{131} \mathrm{O}$ nome do autor das postagens foi omitido para preservar sua identidade e por ser conhecido de um informante da pesquisa. Mensagens postadas em 20 e 21.12.2016.
} 
Alguém ouviu na mídia sobre o ataque a uma mesquita em Zürich ontem a noite? Uma pessoa armada, entrou na mesquita e abriu fogo contra os muçulmanos que rezavam o "ishá" (última oração à noite); sim, exatamente na hora da oração, enquanto as pessoas rezavam..

Até agora 18 feridos e dois mortos..

Ouviram algo?

E sobre o acidente com o caminhão em Berlim? Souberam de alguma coisa?

E não querem dizer que são imparciais... e nem precisa... suas ações falam mais que livros!

E hoje, "dois dias depois", os policiais alemães acharam a identidade de um tunisiano na boléa co caminhão que bateu no mercado de natal em Berlim....

O paquistanês que tinham sido preso dois minutos depois do acidente, já foi solto...

e DOIS DIAS depois, eles acharam um bilhete de identidade que $\circ$ "terrorista deixou cair" dentro do caminhão... e clarol Ele é muçulmano e tunisiano...

É surreal essa guerra contra o Islam e os muçulmanos..

우우웅

Os sentimentos de indignação com tons de ironia recaem especialmente sobre a suposta parcialidade da cobertura midiática e pela "guerra travada contra o islam e os muçulmanos". A tese saidiana do "nós" versus "eles" que se materializa nesses tipos de mensagens, não são difíceis de serem encontradas.

Sobre o conflito na Síria, há leituras igualmente extremas como se observa em outra postagem na mesma rede social abaixo, seguido de um comentário de outro muçulmano.

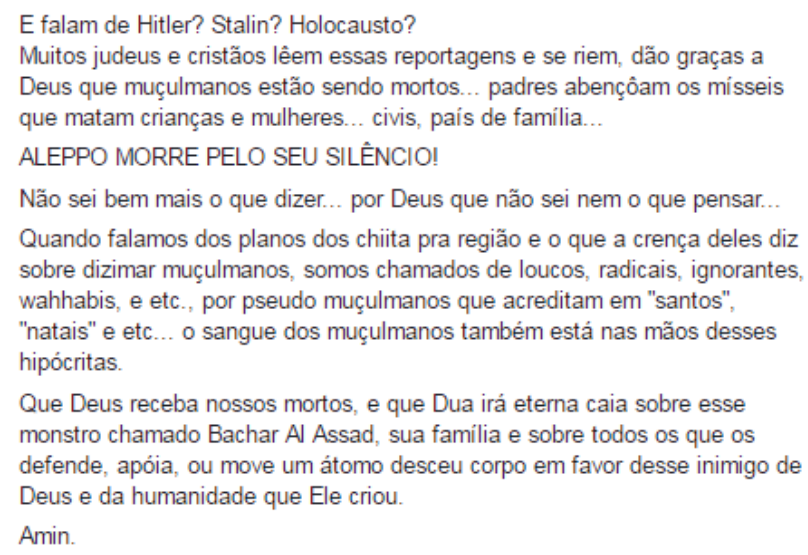

Finalmente, em outro extremo do que foi exposto até aqui, ventila-se sobre o suposto jihadismo no Brasil, podendo implicar em violência física e consequências mais extremadas. 
Aqui, incluem-se as pessoas que foram presas e investigadas em duas operações da Polícia Federal (PF), em 2016 e 2018, respectivamente, a Operação Hashtag e a Operação Átila.

Por meio do rastreamento de conversas por aplicativos de comunicação e norteada pela recém-criada e polêmica "lei antiterrorismo" (lei n.13.260/2016), a PF identificou planos de ataques terroristas no país e hipotéticos vínculos com organizações terroristas internacionais, assunto que será abordado com maior profundidade na última parte do trabalho.

Alguns veículos de mídia, grupos políticos e setores da sociedade, não têm sido tão afáveis para com os muçulmanos, expondo uma faceta carregada de estereótipos e fazendo uso de abordagens semânticas pouco simpáticas, disseminadas em determinados momentos por pessoas que demonstram pouca intimidade com o assunto. Isso tem ajudado a semear reações que vão desde as mais contemporizadoras até aquelas mais combativas.

Por outro lado, as comunidades islâmicas expressam, por meio de suas lideranças, que grande parte da culpa por detrás da má reputação que lhes é imputada, vem da parceria sionistaestadunidense, que como uma distopia zamiatiana, vigia, controla e corrompe tudo e a todos.

Assim, elementos conspiratórios aliados ao processo de vitimização que podem ser encontrados nestas entrelinhas, ampliam o hiato entre essas comunidades e a parte da população local ao invés de aproximá-las. É imperativo uma maior integração entre as comunidades islâmicas livre de cismas religiosos, sectários e culturais, associado à criação e popularização de meios em que possam se tornar mais visíveis suas angústias, críticas e posicionamentos diante de fatos que eventualmente repercutam negativamente em sua conduta religiosa e ética.

É fundamental forjar onde não exista e fortalecer onde já está consolidada, uma solidariedade orgânica entre as comunidades islâmicas e o lugar em que estão presentes, produzindo uma relação de confiança que seja capaz de resistir a qualquer ataque que possam sofrer no plano físico ou das ideias. Antes mesmo que certos preconceitos possam ser difundidos no meio em que se encontram, eles deverão passar pelo filtro protetor do senso crítico.

Ao mesmo tempo, resta esperar que as altas lideranças políticas no país, eleitas recentemente, tenham uma agenda de união, integração e respeito às minorias religiosas que fazem parte de nossa formação sócioespacial.

Por outro lado, é de suma importância que haja um debate sério, democrático, isento de paixões e discursos pré-moldados, entre representantes das comunidades islâmicas e demais religiões, acadêmicos e setores da sociedade dispostos a contribuir para que o conhecimento produza uma convivência cada vez mais harmoniosa, conhecedora das necessidades e dos 
desafios inerentes ao período histórico atual criando um ambiente cada vez mais estéril para qualquer forma de extremismo.

Caso contrário, até que ponto, diante das situações apresentadas e dos novos contextos que se desenham para o futuro em termos políticos, o Brasil poderia ser usado como base para eventuais ações extremistas de grupos islâmicos? As perversidades materializadas pela globalização nos lugares ajudariam a reforçar respostas mais temerosas? Daí a importância em se discutir sobre as relações entre o local e o global, como ela é assimilada por grupos islâmicos no Brasil e se de fato grupos ou indivíduos poderão vestir a roupa do radicalismo islâmico. 


\title{
DA GRAMÁTICA DO FUNDAMENTALISMO À FILOSOFIA EXISTENCIALISTA
}

\section{PARTE 2}

\begin{abstract}
"Acredito que a sindrome de nossa época é a luta universal entre fanáticos, todos os tipos de fanáticos, e o resto de nós. Entre os que crêem que seus fins justificam os meios, todos os meios, e o resto de nós que julga que a vida humana é um fim em si mesma [...] O sinal indicador do fanatismo não é o volume da sua voz, mas a atitude com as vozes dos outros". Amós Oz. "Como curar um fanático."

"Ainda não aconteceu que todos ou muitos povos tivessem um deus comum, mas cada um sempre teve um deus particular. Quando os deuses começam a ser comuns, é sinal da destruição dos povos. Quando os deuses se tornam comuns, morrem os deuses e a fé neles junto com os próprios povos. Quanto mais forte é um povo, mais particular é o seu deus. Ainda não existiu, nunca, um povo sem religião, ou seja, sem um conceito de bem e de mal. Cada povo tem seu próprio conceito de bem e de mal e seu próprio bem e mal".
\end{abstract} Fiodor Dostoievski. "Os Demônios". 


\section{Redefinindo o fundamentalismo islâmico face ao processo de globalização: rastreando Origens}

Neste capítulo, serão destacadas as origens e os significados do fundamentalismo, especialmente o islâmico. Esse termo, em razão dos elementos, fatos, contextos e sujeitos que o cercam, ativos ou passivos, adquiriu uma carga de significados que parecem estar atrelados às circunstâncias e a juízos de valor tão diversos e muitas vezes subjetivos, que se tornou difícil validá-lo como uma categoria historicizada, isto é, conectada com o tempo e os contextos, um conceito que possa nos auxiliar a entender algumas situações e processos atuais (Granger, 2004) de forma mais objetiva, sem as interferências externas contaminadas por discursos políticos, religiosos e midiáticos.

Com a globalização e a veloz difusão das novas tecnologias que deram ainda maior propulsão à difusão de notícias, a atualização de categorias e conceitos bem como o surgimento de uma nova e poliglota gramática do terror e das agendas geopolíticas, se faz necessária uma releitura de algumas terminiologias e sua aplicação no tempo e no espaço.

Esses e outros ataques como aqueles perpetrados ao periódico Charlie Hebdo em janeiro de 2015, ou em Istambul que mataram dezenas de pessoas em uma grande área turística da cidade, ou mesmo do massacre em uma universidade na cidade de Charsadda, norte do Paquistão, matando dezenas de estudantes, ambos em janeiro de 2016, apenas para relembrar casos recentes, são descritos e amplamente divulgados pela mídia como atos de terrorismo promovidos por jihadistas, fundamentalistas islâmicos, extremistas, radicais islâmicos, milícias islâmicas, grupos islâmicos entre outras denominações.

Os nomes são inúmeros e por vezes se sobrepõem. É evidente, contudo, que quando esse tipo de violência acontece na Europa, as repercussões têm mais eco do que aqueles que se passam na Turquia ou no Sahel africano. Mas será que o uso indiscriminado desses termos, tratados quase sempre como sinônimos, não ajuda a reforçar alguns preconceitos e perigosas generalizações? Lewis (2004a, p.129) assegura que

a maior parte dos muçulmanos não é composta de fundamentalistas e a maior parte desses não é terrorista, mas a maior parte dos terroristas atuais é muçulmana e tem orgulho de se identificar como tal. Compreensivelmente, os muçulmanos reclamam que a mídia fala de movimentos e ações terroristas como 'islâmicos', e perguntam por que a mídia também não identifica os terroristas e o terrorismo irlandês e basco como 'cristãos'. A resposta é simples e óbvia - eles não descrevem a si mesmos como cristãos.

Ibn Warraq (1995, p.185) é mais incisivo em sua leitura ao afirmar que 
Muslims - all Muslims — still take the Koran literally. Hence, in my view, there is no difference between Islam and Islamic fundamentalism. Islam is deeply embedded in every Muslim society, and "fundamentalism" is simply the excess of this culture ${ }^{132}$.

A forma categórica em aceitar que a religião islâmica e o fundamentalismo são um só, sem uma distinção entre a religião e a forma como seus seguidores a praticam, como se fossem um corpo monolítico e homogêneo, não pode ser levada em conta sem a devida reflexão. Demant (2015, p.34) ressalta que "the central dilemma seems to lie in the difficulty to differentiate critique of religion from criticism of Muslims as a group. We need to distinguish dogmas, beliefs and worldviews on the one hand, from individuals and groups on the other"133. Igualmente, Ruthven (2005, p.05) acrescenta que "if all believing Muslims are 'fundamentalists' in this sense of the word, then the term is meaningless, because it fails to distinguish between the hard-edged militant who seeks to 'Islamize' his society and the quietist who avoids politics completely"134.

Ainda que a mídia nesses últimos episódios tenha tomado certo cuidado, em maior ou menor grau, em ressaltar que tais eventos violentos foram praticados por uma minoria dentro dos mais de 1,5 bilhão de muçulmanos no planeta, esses grupos que sequestram a religião em nome de uma ideologia e de interesses políticos acabam lançando sobre o islam e a grande maioria de seus seguidores, um estigma perverso de intolerância, ressentimento e violência.

$\mathrm{O}$ fundamentalismo tem sido tratado como a face perversa da modernidade $\mathrm{e}$ comumente associada ao radicalismo, à intolerância e à violência, que tem tomado grande espaço nos noticiários. Na verdade, o termo em si evoca essas primeiras reações. Porém, quando se adjetiva essa palavra com o termo "islâmico", reforça-se um estereótipo que há tempos vem sendo atrelado peremptoriamente aos muçulmanos de um modo geral e que poderia contribuir para aumentar a sensação de preconceito e receio quanto a essas populações, que por sua vez podem reagir se fechando ainda mais em seus grupos ou mesmo partindo para o enfrentamento alimentando um ciclo vicioso.

\footnotetext{
132 "Muçulmanos - todos os muçulmanos - ainda tomam o Alcorão literalmente. Portanto, a meu ver, não há diferença entre o islamismo e o fundamentalismo islâmico. O Islam está profundamente enraizado em toda sociedade muçulmana, e o 'fundamentalismo' é simplesmente o excesso dessa cultura” (tradução minha).

133 “o dilema central parece residir na dificuldade em diferenciar a crítica da religião da crítica dos muçulmanos como um grupo. Nós precisamos distinguir dogmas, crenças e visões de mundo de um lado, de indivíduos e grupos de outro" (tradução minha).

134 “se todo fiél muçulmano é 'fundamentalista' nesse sentido da palavra, então o termo não tem significado, porque ele falha em distinguir entre os militantes obstinados que procuram islamizar sua sociedade e o quietista que evita a política completamente" (tradução minha).
} 
Portanto, primeiramente buscaremos pontuar quais as raízes do fundamentalismo de forma geral e em quais contextos ele foi forjado, bem como a evolução (ou não) de seu significado no transcorrer do tempo e suas variantes semânticas. Para isso, será proposta uma breve periodização de suas prováveis origens, principalmente islâmicas, e finalmente, com base em entrevistas coletadas entre os muçulmanos que vivem no Brasil, propor um novo entendimento desse termo que possa abrir novas perspectivas de compreensão sobre aquilo que o encerra.

Diversos autores concordam que o primeiro indício do fundamentalismo ocorreu no sul dos Estados Unidos e na Califórnia no final do século XIX e início do século XX, aproximadamente na década de 1910 entre os protestantes (Eisenstadt, 1997). Eles foram os primeiros a usar o termo fundamentalismo, pois um grupo mais conservador queria se distinguir de outros mais liberais, já que estes distorciam a fé cristã (Armstrong, 2009). O livro "The fundamentals - a testimony of truth" (op.cit., 1997), editado por teólogos conservadores, considerava como "fundamental" a inerrância da Bíblia, contrastando com qualquer ideia contrária da criação, como exemplo as teorias darwinianas, que "estava levando os jovens a perderem a fé em Deus, na Bíblia e em doutrinas fundamentais do cristianismo" (Armstrong, ibid., p.243). A autora recorda ainda a história de Charles Hodges, catedrático em teologia que em 1873 lançou o livro "Systematic Theology" e para quem a Bíblia é fiel aos fatos porque "Deus inspirou cada uma das palavras da Bíblia, portanto era preciso levá-las a sério e não distorcê-las com exegeses alegóricas ou simbólicas" (ibid., p.198).

O conceito de "fundamental" teve o acréscimo do sufixo "ista" através de Curtis Lee Laws, um editor batista conservador que definia fundamentalista(s) como "those who were ready to do battle royal for The Fundamentals" (Ruthven, 2005, p.12) ${ }^{135}$ ou "alguém que está disposto a recuperar territórios perdidos para o Anticristo e a lutar pelos fundamentos da fé" (Armstrong, 2009, p.241).

Parece claro que o fundamentalismo protestante, em termos de significado, estaria mais preocupado com o progresso científico e com a possibilidade de a ciência suplantar as explicações religiosas. Se assim for, o que dizer da igreja católica durante a inquisição e os processos condenatórios de Galileu e a teoria heliocêntrica no século XVII? Nesse caso, ainda que não se usasse o termo fundamentalista, seu enredo de obediência, infalibilidade das escrituras e rigor quanto a determinados princípios, já se faziam presentes. Assim como o personagem Robert Langdon de "Anjos e Demônios" de Dan Brown se encontra em meio à

135 “aqueles que estão prontos para a batalha real pelo The Fundamentals" (tradução minha). 
disputa entre ciência e religião, cujo jogo de forças promete estremecer os alicerces da fé cristã, o fundamentalismo religioso se torna o cisma desse embate.

Se por um lado a origem do fundamentalismo cristão pode ser mais bem rastreada, assim como os motivos que os teria forjado, o mesmo não pode ser dito com relação ao islâmico. Não há um consenso quanto à época e quanto aos contextos em que teria efetivamente se constituído, não podendo atrelá-los a priori única e exclusivamente ao embate entre ciência e religião, moderno e tradicional, razão e fé. Além disso, uma profusão de nomenclaturas para o mesmo fenômeno ou derivados dele são amplamente discutidos por diversos autores, muçulmanos ou não.

Entre o final dos anos 80 e meados dos 90, o governo estadunidense financiou estudos sobre o tema fundamentalismo. Daí surgiu o Fundamentalism Project, que conduzido por Martin E. Marty and R. Scott Appleby, deu origem à coleção de livros em seis volumes. Investigaram não apenas a tradição islâmica, mas a cristã, judaica, hindu, sikh e budista e a forma como os movimentos religiosos impactam na economia, ciência, relações familiares, educação, mídia entre outros fatores. Embora não tenham deixado muito claro uma definição precisa do termo, a obra aponta os diferentes aspectos dos diversos movimentos religiosos e que os mais extremistas são avessos à modernidade.

Alguns autores podem oferecer pistas de quando e por que o fundamentalismo islâmico teria se deflagrado. Esse é o caso de Armstrong (2009), em que podemos apreender que esse período poderia ter coincidido com o agressivo colonialismo europeu em meados do século XIX e se consolidado nos anos 50-60 com o egípcio Sayyid Qutb quando as discussões acerca da modernidade, da "ocidentalização" do mundo e com a emergência dos nacionalismos em diversas partes do Oriente Médio, especialmente no Egito, eram centrais na agenda islâmica.

Durante o período colonialista, Sayyid Jamal al-Din al-Afghani (1838-1897) e seu discípulo Mohammed Abduh (1849-1905), considerados reformadores islâmicos modernistas que para Lewis (2002) teriam sido influenciados pela Revolução Francesa, acreditavam que o islam poderia ser tão eficaz quando as ideologias ocidentais da sua época e que ele poderia ser moderno à sua maneira, sem apêndices externos. Eles ainda tentavam conciliar a ciência com a fé, o Ocidente com o Oriente e aceitavam a modernização sem se esquecer da religião. Nesse sentido pode-se crer que a adoção da ciência moderna pelos fundamentalistas poderia ser interpretada como um ato de repossuir algo que já era deles e foi apropriado pelo Ocidente (Tibi, 2001).

Contudo, essas ideias foram rechaçadas pelo orientalista francês Ernest Renan que estudava o papel do islam com relação à modernidade. Esse autor passou a destilar uma forte 
aversão ao islam e tudo aquilo que lhe dizia respeito. Armstrong (2009, p.221) afirma que "para Renan, o hebraico e o árabe eram idiomas corruptos [...] O islam era particularmente incompatível com a modernidade, conforme atestava a evidente inferioridade dos países muçulmanos, com seus governos decadentes e sua nulidade intelectual”. Said (2005, p.158) diz que

Renan, lui-même le démontrait par son préjugé raciste notoire à l'égard de ces mêmes Sémites orientaux dont l'étude avait fait sa renommée professionnelle — un homme qui séparait durement les hommes en races supérieures et inférieures, un critique libéral dont l'oeuvre hébergeait les notions les plus ésotériques de temporalité, d'origine, de développement, de rapports et de valeur humaine ${ }^{136}$.

Além de Renan, outras personalidades da época como os Lords Balfour e Cromer também ventilavam a superioridade Europeia em detrimento da fragilidade do Oriente Médio, justificando suas conquistas pela incapacidade de governos e das populações nativas que seriam, como relembra Said (2005, p.54), “des menteurs invétérés, ils sont 'léthargiques et soupçonneux' et s'opposent en tout à la clarté, à la droiture et à la noblesse de la race anglosaxonne" "137. Mas é importante ressaltar que Said (2005) parece levar em conta apenas os fatores externos ao suposto atraso e inferioridade dos muçulmanos e do Oriente Médio de forma geral, desprezando possíveis fraquezas internas.

Tendo em vista esse panorama, Armstrong (2009, p.222) resume que "o pensamento islâmico assumira uma postura defensiva, em face de uma ameaça bem real. A visão estereotipada e imprecisa que pensadores modernos como Renan tinham do islam, justificaria a invasão colonial dos países muçulmanos". Nesse sentido, o fundamentalismo ainda lactante, poderia ser considerado como uma reação a essas pretensões ainda que o ativismo político não fosse exacerbado como nos dias de hoje.

Ruthven (2005), por outro lado, sugere que o fundamentalismo islâmico teria sido cunhado por H.A.R Gibb, um orientalista escocês, em seu livro "Mohammedanism - an historical survey" e depois reintitulado de "Islam - an historical survey", publicado em 1949. Esse mesmo autor fez em 1945 uma conferência intitulada de "Modern trends in Islam" que mencionado por Said (2005, p.125), falava da "l'aversion des musulmans pour le processus

\footnotetext{
136 “Renan, ele mesmo o demonstrava por seu preconceito racista e notório ao olhar dos mesmos semitas orientais cujo estudo tinha criada seu renome profissional - um homem que separava duramente os homens em raças superiores e inferiores, uma crítica liberal na qual a obra abrigava noções das mais esotéricas de temporalidade, de origem, de desenvolvimento, de relações e de valor humano" (tradução minha).

137 "Mentirosos inveterados, eles são letárgicos e suspeitos e se opõem com toda clareza, à destreza e nobreza da raça anglo-saxã” (tradução minha).
} 
intellectuel du rationalisme". Indicava então uma característica em comum com o fundamentalismo cristão, a negação do racionalismo.

Para Tibi (2001), o contexto aludido é mais recente, especialmente na década de 1970, com o aumento das incertezas e conflitos no Oriente Médio, que acabara de assistir à Guerra dos Seis Dias em Israel, a Revolução Islâmica iraniana de 1979 e ao petróleo saudita que poderia alavancar o wahhabismo aumentando a polaridade entre xiitas e sunitas. Tibi (ibid., p.14) alega que para o Ocidente "people believe that the turning point for the rise of Islamic fundamentalism aimed at restoring Islamic order was the Islamic revolution in Iran in 1979"138. Entretanto, foi categórico em negar essa ideia ao dizer: "This is wrong. In fact, the crushing Arab defeat in the Six-Day-War in 1967 was that turning point"139.

A Guerra dos Seis Dias, que surpreendeu o mundo com uma vitória avassaladora de Israel, colocando os árabes em uma condição humilhante, contribuiu para fortalecer grupos mais radicais que reforçaram seu engajamento contra a fracassada a fórmula de governos nacionalistas e apóstatas que sucumbiam a cada conflito que se sucedia ou que eram coniventes aos interesses ocidentais, sendo permissivos demais a eles. Concordando com Bassam Tibi nesse aspecto, Demant (2008, p.200) afirma que "desde essas derrotas consecutivas - morais tanto quanto políticas e militares - o mundo árabe se encontra numa crise que se aprofunda ano a ano. É na fenda dessa crise que surgiu o islamismo, ou seja, o fundamentalismo islâmico".

Apesar disso, Tibi (2001) ainda faz questão de considerar que o ano de 1928 possa também ter sido um marco na ascensão do fundamentalismo com o surgimento da Irmandade Muçulmana no Egito pelas mãos de Hassan Al-Banna, que como uma hidra, espalharia seus pólipos em outras partes do mundo como o Hamas palestino.

Kepel (2003) considera que movimentos islamistas foram germinados pelas mãos de Sayyid Qutb, Mawdudi e Khomeini e teria se destacado nos anos 70, especialmente com o conflito de Yom Kippur em 1973, quando a Arábia Saudita e outros exportadores de petróleo no Oriente Médio teriam pesado a favor dos árabes nesse momento. Já a Revolução Islâmica no Irã teria fornecido o élan necessário para o desenvolvimento de outros movimentos nas décadas seguintes.

Concordando com essa possibilidade, Esposito (2002, p.83) complementa dizendo que Iran's Islamic Revolution of 1978-1979 abruptly detoured the march toward Western modernization. Leading modernizing governments in Iran, Egypt,

\footnotetext{
138 "as pessoas acreditam que a guinada para o crescimento do fundamentalismo islâmico que objetivava restaurar a ordem foi a Revolução Islâmica no Irã em 1979" (tradução minha).

139 “isto está errado. De fato, a derrota árabe na Guerra dos Seis Dias foi a guinada” (tradução minha).
} 
and Lebanon seemed to be experiencing the revenge of God. They were not alone. Islamic revivalism produced a wave of fundamentalist movements from Egypt, Sudan and Iran to Pakistan, Afghanistan, and Malaysia. The causes of resurgence vary by country and region, but there are common threads: widespread feelings of failure and loss of identity in many Muslim societies, as well as failed political systems and economy ${ }^{140}$.

Enquanto Tibi (2001) é mais assertivo em colocar a guerra de julho de 1967 como o marco na emergência do fundamentalismo islâmico, e não a Revolução Islâmica de 1979, Esposito (2002) expõe uma variedade de causas e mesmo motivos para a erupção de movimentos islamistas, inclusive considerando a Revolução Iraniana. Talvez não tenhamos que nos preocupar em identificar a data e os eventos precisos do surgimento do fundamentalismo, mas observá-lo como parte de um processo, partes de “ondas" fundamentalistas conforme propõe Demant (2008). Para esse autor seria possível periodizar, grosso modo, em três momentos:

$1^{\circ}$ 1950-60 com a cristalização da ideologia fundamentalista sunita com Sayyid Qutb e Abu alAla Mawdudi, época que também coincide com a Guerra dos Seis Dias, comentada anteriormente e que serviria também de pretexto à tal corrente;

$2^{\mathbf{0}}$ 1970-80, período de maturação do fundamentalismo com as experiências no mundo xiita com a Revolução Iraniana e o Hezbollah libanês e também com novos e malfadados conflitos como Yom Kippur e os acordos de paz de Camp David que escandalizou muitos egípcios pela acomodação de seu país frente à Israel;

$3^{\text {o }}$ Pós 1980, quando o islamismo se confronta crises econômicas e políticas e se difunde apoiado pela mesma globalização que rejeitam, mas que possibilita novos contatos, novas articulações agora em rede global e permite lançar sua ideologia não apenas em alguns enclaves territoriais como o Hamas na Faixa de Gaza, mas em escala global haja visto o processo de migração cada vez mais frequente. $\mathrm{O}$ islam passa definitivamente ao Ocidente, como sugere Roy (2008), através dos processos migratórios engendrados por conflitos no Oriente Médio e melhores condições de vida e trabalho na Europa, especialmente pós II Guerra Mundial.

\footnotetext{
140 “a Revolução Islâmica do Irã de 1978-1979 abruptamente desviou a marcha em direção à modernização do Ocidente. Os governos que lideravam a modernização no Irã, Egito e Líbano pareciam ter experimentado a vingança de Deus. Eles não estavam sozinhos. O revivalismo islâmico produziu uma onda de movimentos fundamentalistas do Egito, Sudão e Irã ao Paquistão, Afeganistão e Malásia. As causas do ressurgimento variam de país e região, mas eles têm temas comuns: sentimentos generalizados de fracasso e perda da identidade em muitas sociedades islâmicas, como também sistemas políticos e econômicos fracassados" (tradução minha).
} 
Esse autor talvez incluiria um novo período aos momentos listados acima, que seria datado pelo início dos anos 90. Em seu livro "L’échec de l'Islam Politique" de 1992, ele alertava para possível fracasso do islam político/islamismo oferecendo como exemplo, países como o Irã, Afeganistão e Argélia, onde a islamização da sociedade de "cima para baixo" começava a demonstrar sinais de esgotamento e ao mesmo tempo ocasionando o surgimento do chamado neofundamentalismo, que contrariamente, islamizaria a sociedade de "baixo para cima", de porta em porta. A busca por um Estado Islâmico para então conduzir esse processo já não era mais premente, marcando o afastamento da política pelos neofundamentalistas conservadores.

Além disso, crises econômicas e a própria marginalização de grupos islâmicos por outros, foram determinantes fatores dessa crise. Roy (1994, p.ix) resume esse fracasso ao afirmar que o "islamism has been transformed into a type of neofundamentalism concerned solely with reestablishing Muslim law, the sharia, without inventing new political forms ${ }^{141}$ ". Mas é questionável abraçar essa formulação sem o devido cuidado visto que há grupos extremistas que tem uma agenda política ativa e em processo de elaboração, tal como o do Estado Islâmico (Daesh ${ }^{142}$ ).

Esse pensamento corrobora com a tese de Kepel (2003) sobre o declínio dos movimentos islamistas nesse período em razão das fissuras internas nesses movimentos, aos conflitos entre países no Oriente Médio, à perda de fôlego em islamistas conquistarem Estados e mesmo nos reveses que alguns grupos tiveram quando enfim chegaram ao poder, como na Argélia e Afeganistão por exemplo.

Entretanto, é provável que seja um exagero falarmos do fracasso do islam político. Talvez seja mais prudente pensarmos em uma mudança no perfil desses movimentos islamistas que não necessariamente signifique sua derrocada. Se um dos argumentos para esse declínio pudesse ser a falta de eventos espetacularmente trágicos, pela pouca efetividade com que as ideologias islamistas eram propagadas e executadas, o fim dos anos 90, início dos anos 2000 e mesmo atualmente, testemunharam o contrário. Basta pensar nas ações da Al-Qaeda que promoveram a queda das torres gêmeas nos Estados Unidos ou dos atentados em trens de Madri em 2004, deslanchando uma guerra contra “o terror" que teve o Afeganistão e o Iraque como grandes alvos, e com a erupção do Estado Islâmico na Síria e no Iraque, a partir de 2010.

\footnotetext{
141 “o islamismo tem se transformado em um tipo de neofundamentalismo preocupado somente em reestabelecer a lei islâmica, a sharia, sem inventar novas formas políticas" (tradução minha).

142 Daesh é acrônimo para Al-Dawlah al-Islamiyah fi'l - 'Iraq wal-sham, também chamdo de Estado Islâmico do Iraque e do Levante - EIIL (tradução para o português) ou ISIS (em inglês).
} 
Observando tempos mais remotos e com base nas diversas fontes consultadas, que indicavam, segundo seus pontos de vista, marcos importantes no surgimento e evolução do chamado fundamentalismo islâmico, é possível sugerir outra periodização que de forma geral reuniu pontos em comum entre os diversos autores que se debruçaram sobre esse tema. Para Ahmed (2007, p.12) "one obvious way to better understand Muslim society, it seemed, was to find out who has inspired its members and shaped their values from the past to the present"143. Dessa forma, podemos nos remeter a três grandes períodos:

$1^{\circ}$ Período: séculos XIII e XIV, com Ibn Taymiyya (1268-1328).

O contexto em questão é da Europa medieval, feudal, de instabilidades políticas, de orientação cristã que inaugurava a inquisição como sistema jurídico católico de combate ao sectarismo, heresia, e posteriormente, de ataque aos avanços da ciência. Esse período assistiu ao desequilíbrio populacional gerado pela Peste Negra que assolou a Europa e também os avanços do Império Mongol que havia posto fim ao califado árabe abássida. Ao mesmo tempo, o Império Turco-Otomano tomava contornos cada vez mais importantes.

A imagem que se fazia dos muçulmanos nesse período pode ser retratada por Alighieri (2002 [1321], p.116) em sua viagem ao inferno juntamente com o poeta Virgílio, em que narram seu encontro com Maomé que residia na nona vala do oitavo círculo infernal, reservado aos que "desencadeavam cismas religiosos, e os que semearam o ódio e a discórdia". A punição era a perpétua mutilação, que se regenerava para em seguida ocorrer nova dilaceração. Ainda segundo Alighieri (ibid., p.117) lê-se a seguinte passagem:

repara como tenho lacerado o peito! Vê quão estropiado ficou Maomé. Precede-me na marcha e nos lamentos Ali, que traz desfeito o rosto, do mento à testa. $\mathrm{E}$ todos os mais que por aqui percebes foram em vida semeadores de cismas e de escândalos. Somos perseguidos por um demônio cruel, que nos mutila sem descanso. Ao fim de giro completo desta dolorosa estrada, as feridas se fecham antes que se volte a defrontá-lo.

Em outra obra, a loucura personificada por Roterdã (2005, p.96) ${ }^{144}$ assume que "os turcos e uma multidão de demais povos bárbaros como eles, gabam-se de possuírem a única e verdadeira religião, criticando com piedade as crenças dos supersticiosos cristãos".

\footnotetext{
143 "um caminho óbvio para entender melhor a sociedade islâmica, ao que parece, foi procurar quem inspirou seus membros e moldaram seus valores do passado até o presente" (tradução minha).

${ }^{144}$ Em versão e-book da editora Atena, Roterdã (2002) afirma: "turcos e todos os outros povos semelhantes, que não passam de um ajuntamento de bárbaros, se jactam de serem os únicos que vivem no seio da verdadeira religião, ridicularizando as superstições e a idolatria dos cristãos".
} 
Em ambos os casos, se estes trechos fossem ilustrados na capa do Charlie Hebdo seria de se esperar reações temerárias por parte grupos jihadistas. Mas na época vivida por Ibn Taymyyia, esses versos poderiam ter tido algum tipo de repercussão? Enquanto a igreja perseguia aqueles que se afastavam dela, no meio islâmico esse importante precursor dos fundamentalistas modernos, atacava atitudes conformistas, a corrente esotérica dos sufis, xiitas e tudo aquilo que desviasse da sunnah. Igualmente pregava a indissociabilidade entre religião e Estado, pois só uma autoridade poderia conduzir o "bem” e afastar o "mal" (Jackson, 2006). Além disso, estabelecia distinções entre domínios de paz e domínios de guerra (Dar Al-Salam e Dar Al-Harb).

Esse pensador era, segundo Roy (2004, p.153), "qui sert donc autant de référence aux islamistes qu'aux néo-fondamentalistes"145. Assim, Wahhab, Sayyid Qutb, Hassan Al-Banna entre outros tiveram grande influência de Ibn Taymiyya. Para Esposito (2002, p.45-46)

Ibn Taymiyya called on a rigorous, literalist interpretation of the sacred sources (the Quran and Sunnah, and the example of the early Muslim community) for the cruciality needed Islamic renewal and reform of his society $[\ldots]$ he regarded the community of Medina as the model for an Islamic state. His goal was the purification of Islam. A return to the pristine purity of the period of Muhammad and the First Four Righteous Caliphs, he believed, was necessary to restore the Islamic community's past power and greatness ${ }^{146}$.

Jackson (2006, p.129) corrobora com essa ideia ao afirmar que

Ibn Taymiyya was also reflecting the faith of the ordinary Muslims of the early period of Islam who were for the most part encouraged to accept a literal interpretation of faith without delving into the possible hidden meanings. In part this was a defense mechanism against the possibility of Islam becoming watered down or submerged by the various other faiths the Muslims encountered as they expanded ${ }^{147}$.

\footnotetext{
145 “que serve de referência tanto aos islamistas quanto aos neofundamentalistas" (tradução minha).

146 “Ibn Taymiyya apelou a uma interpretação literal e rigorosa das fontes sagradas (o Alcorão e a Sunnah, e o exemplo da comunidade muçulmana inicial) para a crucialidade necessária para a renovação islâmica e a reforma de sua sociedade [...] ele considerava a comunidade de Medina como a modelo para um estado islâmico. Seu objetivo era a purificação do Islã. Um retorno à pureza imaculada do período de Maomé e dos Quatro Primeiros Califas Justos, acreditava ele, era necessário para restaurar o poder e a grandeza do passado da comunidade islâmica" (tradução minha).

147 “Ibn Taymiyya também estava refletindo a fé dos muçulmanos comuns do período inicial do Islã que, na maior parte dos casos, foram encorajados a aceitar uma interpretação literal da fé sem se aprofundar nos possíveis significados ocultos. Em parte, isso era um mecanismo de defesa contra a possibilidade de o islam ser diluído ou submerso pelas várias outras religiões que os muçulmanos encontraram, à medida que se expandiam" (tradução minha).
} 
Com uma opinião um tanto distinta e que pode soar contraditória em relação aos últimos autores citados, Ahmed (2007, p.135) ressalta que Ibn Taymiyya

stressed the need to keep Islamic law as flexible as possible within the concept of ijtihad (independent reasoning based on the Quran or scholarly texts). Islamic law, he argued, was open to reinterpretation and needed to take into account the context in which society functioned. Ijtihad must remain active, he said, for otherwise Islamic law itself would become ossified and irrelevant $^{148}$.

Nesse contexto, Ibn Taymiyya não queria deixar o islam "engessado" no tempo, aceitando uma abertura à ijtihad. Talvez em um primeiro momento o literalismo fosse necessário para solidificar os alicerces islâmicos que estavam sob ameaça das invasões mongóis juntamente com a lei yasa ${ }^{149}$ de Genghis Khan. Uma vez vencida a batalha com os mongóis, a ijtihad seria aberta, adquirindo leituras mais pessoais do Alcorão e das ahadith, mas sem abrir mão do exemplo da comunidade de Meca nos tempos de Maomé.

É importante ressaltar que uma de suas grandes inovações foi usar como critério para definir um bom muçulmano, não apenas o fato de que o indivíduo cumpra os cinco pilares do islam, mas que possa obedecer e seguir a sharia (Sivan, 1985). Nesse caso, os mongóis que abraçaram o islam e que apesar de cumprir com os preceitos de sua nova religião, continuassem sob a égide da Yasa, isso os desviaria da sunnah e os tornaria infiéis. O mesmo critério pode ser aplicado aos governantes muçulmanos que como explica Sivan (ibid., p.99), "for him, a Sunni ruler becomes illegitimate if he does not apply a substancial part of the Shari'a. The illegitimacy is defined in ulama terms: the ruler who neglects or transgresses Islamic law is ipso facto an infidel, or rather an apostate, hence object of jihad" ${ }^{150}$. Nesse sentido, nos dias de hoje ainda é possível ver essa orientação reverberar entre grupos de fundamentalistas com relação a governos, como no caso do Egito ou da Líbia pré-primavera árabe por exemplo.

$2^{\circ}$ Período: século XVIII com Muhammad ibn Abd al-Wahhab (1703-1792).

Influenciado por Ibn Taymiyya, especialmente no tocante à sharia, Jackson (2006, p.162) explica que

\footnotetext{
148 “enfatizaram a necessidade de manter a lei islâmica o mais flexível possível dentro do conceito de ijtihad (raciocínio independente baseado no Alcorão ou em textos acadêmicos). A lei islâmica, argumentava ele, estava aberta à reinterpretação e precisava levar em conta o contexto em que a sociedade funcionava. Ijtihad deve permanecer ativo, disse ele, pois de outra forma a própria lei islâmica se tornaria ossificada e irrelevante" (tradução minha).

${ }^{149}$ Lei que continha contribuições cristãs, judaicas e islâmicas, além de outras tradições, e por isso era vista como panteísta e incompatível com a sharia e, portanto, deveria ser combatida (Sivan, 1985).

150 "para ele, um legislador sunita se torna ilegítimo se ele não aplica uma parte substancial da sharia. A ilegitimidade é definida nos termos do ulemá: o legislador que negligencia ou transgressa a lei islâmica é ipso facto um infiel, ou ainda um apóstata, ainda objeto de jihad" (tradução minha).
} 
al-Wahhab emphasised the importance of obedience to shari'a, it was also important that shari'a should be in accordance with the Qur'an, that is the word of God, and this required a degree of interpretation. Al-Wahhab did not want Muslims to follow shari'a merely because it is the law, but rather because it was in tune with the word of $\operatorname{God}^{151}$.

Essas ideias foram abraçadas por governantes sauditas desde o início da consolidação do reino saudita com Abdul-Aziz Ibn Saud nos anos 30 a 50 do século 20 e seus contextos locais, mas também como resposta à influência Ocidental. As ideias wahhabitas descrevem um ramo mais puritano, ultraconservador, literalista, rígido e exclusivista segundo Esposito (2002), e que pretendia, como afirma Lewis (2004a, p.116), "lançar uma campanha de purificação e renovação. Seu objetivo declarado era retornar ao puro e autêntico islam do fundador, removendo e, onde necessário, destruindo todos os posteriores acréscimos e distorções”. Com uma visão literalista das escrituras, Jackson (2006, p.162) afirma que o "Wahhabism allowed that anything that is not explicitly forbidden in the Qur'an or in the sunna was therefore permitted"152. Era proibido celebrar o aniversário do profeta Maomé, cortar a barba, visitar túmulos e decorar mesquitas. A música, a dança e a poesia eram banidas nos tempos de Wahhab. Todos os ensinamentos deviam ser transmitidos à sociedade, como o são até os dias atuais, de "baixo para cima", através da educação e de programas culturais e educacionais patrocinados pela monarquia saudita ao redor do mundo.

Apesar das características desse movimento, o termo fundamentalista não era usado na época em que foi criado. Ruthven (2005), entretanto, afirma que as origens do fundamentalismo, poderiam ser encontradas mais adiante nos anos de 1930 através desse mesmo wahabismo imposto pelo rei Abdul-Aziz Ibn Saud, quando o ministro britânico Reader Bullard se refere a ele pela primeira vez como um forte "fundamentalista".

$3^{\circ}$ Período: século XX com Hasan Al-Banna (1906-1949), Sayyid Qutb (1906-1966) e Abdu Ala Mawdudi (1903-1979). Pela corrente xiita, Aiatolá Khomeini (1902 - 1989).

Os períodos em questão e os contextos vivenciados por esses personagens são bastante complexos e sofreram grandes transformações.

\footnotetext{
151 “al-Wahhab enfatizou a importância da obediência à sharia, e era importante que a sharia pudesse estar de acordo com o Alcorão, que é a palavra de Deus, e isso requer um grau de interpretação. Al-Wahhab não queria que os muçulmanos seguissem a sharia simplesmente porque é uma lei, mas sim porque estava em sintonia com a palavra de Deus" (tradução minha).

152 "O wahhabismo permitiu que qualquer coisa que não fosse explicitamente proibida no Alcorão ou na suna fosse, portanto, permitida" (tradução minha).
} 
A Índia de Mawdudi, importante referência entre os fundamentalistas, passava pelo jugo do domínio britânico e todos os embates entre a população hindu e a muçulmana, que a partir de 1947 têm o Paquistão como lar dos muçulmanos, mesmo ano de independência da Índia dos britânicos após um grande período de ebulição social, étnica e religiosa no país. Um aspecto importante no pensamento de Mawdudi é sua visão peculiar sobre a ijtihad, a interpretação das escrituras sagradas. Para ele, isso deve ser feito apenas por aqueles que possuem tal capacidade para interpretar. Mas entre essas pessoas, apenas uma minoria dos muçulmanos teria essa autoridade (Jackson, 2006).

A "governança divina" ou a "teo-democracia", não deveriam ser contestadas. Aqui há um indício muito forte de que qualquer tentativa de se instaurar a democracia ou qualquer outro modelo importado deveria ser evitado. Sobre isso, Jackson (ibid., p.192) explica que "Mawdudi greatly feared Western-style democracy, which he believed to be nothing more than majority rule, whether its views are right or wrong: majority rule was not a moral imperative, merely the tyranny of the majority" ${ }^{\prime 153}$.

Outro ponto a ser lembrado é que para muitos estudiosos, o conceito de jahiliyya, que é bastante desenvolvido por Sayyid Qutb, teria sido cunhado por Mawdudi, porém com significado diferente. Para ele, remetia-se ao paganismo hinduísta. Mas não há consenso quanto a isso segundo Calvert (2013), já que há indícios de que Qutb tenha já falado do assunto já nos anos 30, portanto, anterior a Mawdudi. De qualquer forma, essa ideia se mostra como central no pensamento de ambos assim como a admiração e respeito.

No Irã de Khomeini, que exilado assiste à queda do xá nos anos 70, retorna ao país e comanda a revolução islâmica que rompe laços econômicos e políticos com o Ocidente e coloca o país sob a égide de uma rigorosa lei islâmica. O país está cada vez mais atuante na agenda geopolítica regional no caso da guerra da Síria, em sua parceria com a Rússia, no auxílio aos houthis do Iêmen e especialmente no tocante ao desenvolvimento de seu programa nuclear que em meio a muitas controvérsias e críticas por parte de Israel, teve um acordo com o Ocidente. No entanto, em 2018, os Estados Unidos de Donald Trump romperam sua participação e reforçaram suas críticas à teocracia do aiatolá Khamenei ao se referir, entre outros temas, ao patrocínio do terrorismo no mundo e por ferir direitos humanos, algo que elevou a tensão entre os dois países.

\footnotetext{
153 "Mawdudi temia pelo estilo ocidental de democracia que ele acreditava ser nada mais do que a lei da maioria, se suas visões estão certas ou erradas: a lei da maioria não era a moral imperativa, mas meramente a tirania da maioria" (Tradução minha).
} 
O Egito de Banna e Qutb foi aquele da independência do país ainda que com a influência inglesa no governo do rei Farouk I, em que se lutava contra a submissão de parte da população aos interesses britânicos. Também é o momento em que o país se torna uma república especialmente sob o comando do nacionalismo de esquerda de Gamal Abdel Nasser, avesso aos islamistas em seu país.

Esse período parece ser crucial no desenvolvimento do fundamentalismo islâmico no sentido de inicialmente se contrapor ao colonialismo europeu em vigor e posteriormente em se salvaguardar de todo o avanço ocidental em termos bélicos, políticos, econômicos e científicos.

O temor de que o Egito pudesse emular o Ocidente já era expresso nos textos de Qutb dos anos 30 assim como o apelo à jihad para libertar o país dessa possibilidade. A identidade islâmica deveria estar acima de tudo.

Os pensadores islâmicos desse período foram influenciados por aqueles representantes do primeiro, pois como afirma Ahmed (2007, p.36)

Taymiyya is the inspiration for a wide range of Muslim scholars such as Sayed Qutb and Maulana Maududi, schools of thought such as Deoband, and activists like bin Laden and the leaders of the Muslim Brotherhood. Today, Taymiyya's message has been reduced to two precepts: the need to actively defend Islam and, simultaneously, to strive to re-create the purity of early Muslim society ${ }^{154}$.

Se Qutb havia se impressionado com a permissividade e depravação do Ocidente a partir de sua visita aos Estados Unidos, Banna, fundador da Irmandade Muçulmana em 1928, notou parte dessa realidade no próprio país, o Egito, ainda sob influência britânica. A desigualdade e aparente inferioridade e fragilidade dos muçulmanos face aos estrangeiros era gritante. Banna então percebia que a política era um fator de desunião entre seus conterrâneos muçulmanos e era fonte de desequilíbrios. Desde então, a irmandade muçulmana passa a atuar como um "estado dentro de outro estado" (Jackson, 2006) construindo uma rede de infraestrutura e equipamentos para a população, despertando olhares dos líderes do país que aos poucos passaram a marginalizar o grupo e seus membros, culminando com a passagem à ilegalidade pelas mãos de Gamal Abdel Nasser nos anos 50. A questão colocada de que Banna desaprovava a política, segundo Jackson (ibid.) afasta os termos "islam político" ou "islamismo" do

154 “Taymiyya é a inspiração para uma larga gama de estudiosos muçulmanos como Sayed Qutb e Maulana Mawdudi, escolas de pensamento como a Deobandi, e ativistas como Bin Laden e os líderes da Irmandade Muçulmana. Hoje, a mensagem de Taymiyya tem sido reduzida a dois preceitos: a necessidade ativa de defender o islam e, simultaneamente, de lutar para recriar a pureza das primeiras sociedades islâmicas" (tradução minha). 
fundamentalismo, como defendem alguns autores que veremos em breve, mas por outro lado, aproxima o perfil de Banna ao salafismo, tal como assumira ser (Jackson, idem).

Portanto, o resgate do orgulho e de suas riquezas deveria ser um objetivo a ser perseguido, ainda que com o aproveitamento de tecnologias oferecidas pela modernidade desde que no contexto islâmico, para não incorrer nas temidas ocidentalização e secularização da sociedade.

A periodização proposta por mim acima é uma entre tantas possíveis segundo os mais diversos autores, mas ajuda a melhor visualizar como o chamado fundamentalismo tomou forma e sob quais contextos e lideranças. Tendo encontrado alguns elementos forjadores desse movimento, cabe agora esmiuçar seus significados e variantes. À medida que o tempo passa, o islam passa a ser conhecido cada vez mais por movimentos, grupos, organizações e seus seguidores que passaram a moldar a religião segundo visões de mundo bastante peculiares e carregando novas conotações.

\subsection{Sayyid Qutb: o progenitor do jihadismo moderno.}

Existe um certo consenso de que Sayyid Qutb (1906-1966) seja um dos mais importantes ideólogos do atual islam político e do pan-islamismo, algo que membros da própria Al-Qaeda já teriam enunciado. Pela periodização sugerida anteriormente, ele se enquadra no período de maturação do fundamentalismo islâmico. Qutb teria tido fortes influências salafistas, assim como Banna, e consideravam que os tempos do profeta Maomé eram de total justiça social, e, portanto, deviam servir como protótipo civilizacional (Jackson, 2006). Até os dias de hoje, a influência de Qutb sobre radicais muçulmanos faz dessa figura, segundo Khatab (2006), Calvert (2013) e Armstrong (2009), o criador e ideólogo do fundamentalismo sunita e do islam político ao redor do mundo.

As exegeses do Alcorão produzidas por ele, especialmente de forma mais profícua nos anos 50, serviram para fomentar ruminações a respeito do sentido e das implicações do Corão para a vida na época e que se mantém vivas até hoje. O islam é mostrado como um completo quadro de vida, o que remete ao slogan da Irmandade Muçulmana "o islam é a solução".

Autores que estudaram a vida e obra de Sayyid Qutb mostram como seu pensamento evoluiu em direção ao radicalismo e ao combate de todas as formas de jahiliyya conclamando os verdadeiros muçulmanos para um jihad com esse objetivo. Interessante notar que suas ideias fluíram pari passu aos eventos que envolveram sua vida pessoal, acadêmica e religiosa criando uma totalidade interdependente. 
No entanto, passados mais de 50 anos de sua morte, ainda é possível notar sua influência atualmente? Ou, tal qual a brincadeira infantil do "telefone sem fio", a mensagem que ele pregava foi esmaecendo, sendo distorcida, adaptada ou mesmo substituída?

Para achar essas respostas, é interessante resumir algumas das suas principais ideias que foram se tornando cada vez mais consistentes no decorrer de sua vida.

O contexto histórico em que viveu e desenvolveu suas ideias coincidiu inicialmente quando o Egito era um protetorado britânico (1882 a 1922 ), posteriormente quando o país se torna uma monarquia independente, mas sob influência britânica (1922 a 1952), e, por fim, vivenciou a "era dos nacionalismos", em particular sob o domínio de Nasser (pró-socialista, antiocidental, pan-árabe e anti-islamista).

Segundo Khatab (2006), baseando-se nas mais diversas obras produzidas por Qutb é possível identificar três importantes fases em seu pensamento e que mais ou menos coincidem com aspectos ligados à sua vida pessoal e acadêmica.

A primeira, que vai de 1921 a 1939 foi o momento de um crescimento de grupos nacionalistas (watanistas) contrários a presença de britânicos no país que teriam agravado os problemas relacionados à pobreza e desigualdade na população. É nessa época que Qutb escreve diversas novelas, poemas e artigos que versavam sobre assuntos morais, sociopolíticos, além de criticar a desigualdade. Sua educação se deu em escolas de ensino secular uma vez que eram probidas aquelas que ofereciam estudos corânicos. Nesta fase, Qutb criticava a forma como se dava o ensino em seu país, pois seguiam um modelo ocidental e que ajudavam a espalhar os valores e hábitos estrangeiros. Da mesma forma, via com muitas reservas a presença de residentes estrangeiros em seu país, que segundo ele patrocinavam a invasão cultural (Calvert, 2013).

Qutb ainda não advogava que o país deveria ser governado segundo princípios corânicos. Ele apenas reivindicava um maior fortalecimento e auto-determinação da cultura islâmica-egípcia em detrimento das próteses que viam se fora, como por exemplo os idiomas inglês e francês.

A segunda fase que compreende os anos entre 1939 e 1948 é aquela em que Qutb passa a se interessar cada vez mais pelo futuro do Egito, por assuntos islâmicos e é quando a aversão pelo Ocidente passa a crescer. É quando seus estudos sobre a jahiliyya se tornam quase que uma obsessão, ele escreve um dos seus mais famosos livros, "Justiça Social no Islam”. Livro considerado como o mais radical, carregado de ideologia e que coloca o islam como o mais completo quadro de vida humana, isto é, entende que não há separação entre a vida humana e a religião que se encontram, segundo ele, divorciadas, justificando a jahiliyya. 
Qutb sustentava uma "limpeza religiosa" em que só verdadeiros muçulmanos iriam para o paraíso, pois o tempo era de uma nova jahiliyya pior que à época do profeta, uma vez que agora seria a negação da religião e dos valores de modo consciente, e era preciso combatê-la. A soberania de Allah (hakimiyya) era a antítese de jahiliyya, que incluía todos aqueles que não se submetiam a ela (Khatab, 2006). Essa jahiliyya, não era específica de uma época, local ou povo, mas uma condição de oposição a Deus. Qutb ainda distinguia a jahiliyya pré-islâmica e pós-islâmica. No primeiro caso, o conceito era mais dirigido àqueles que eram descrentes ( $a l$ $k u f r$, enquanto no segundo seria o desvio, uma desobediência a Allah. Contudo, esse conceito desenvolvido por Qutb, segundo uma leitura mais atual não teria uma distinção, pois englobaria todos aqueles que não acreditam em Allah e os que se desviaram deles, sejam pessoas ou governos islâmicos. Inerente à essa ideia, a "ignorância" moderna era a não submissão à ordem divina. O culto à nação como símbolo de adoração deveria ser evitado (Kepel, 2003). Para Khatab (op.cit., p. 09),

Qutb rejected nationalism, capitalism, socialism, communism and modernity, as well as those Muslim societies which did not practise the Islamic law. He left the door open to the use of fiqh to guide interpretation of the Qur'an and the sunnah to make them relevant to everyday life ${ }^{155}$.

Neste período, Qutb revela sua desconfiança em relação ao intelecto humano como fonte absoluta de conhecimento. Para ele o poder espiritual é mais importante. Todos precisam de um guia para orientar as decisões, portanto o Alcorão é "the only source of balanced knowledge for a balanced life"156 (ibid., p.89). Os vários dualismos que identifica tais quais o espiritual e material, a religião e o estado, o terreno e o celestial são combatidos por Qutb para quem apenas a unidade existe e é divinamente inspirada.

A terceira e mais curta fase enunciada por Khatab (idem) é aquela compreendida entre 1948 e 1950, período em que esteve em viagem aos Estados Unidos, inclusive incentivada pelo governo egípcio que também desejava seu afastamento do país em razão do seu crescente engajamento político. Do contrário, sua prisão seria o caminho mais provável.

As cartas que enviou para sua família e amigos foram as principais fontes documentais de sua estada no país. Nelas, Qutb chegou a revelar um certo fascínio por aquela civilização, tendo gostado de Washington e da pequena cidade de Greeley (situada no Colorado) por seu perfil mais conservador, que inclusive proibia o álcool, algo igualmente evitado pelos

\footnotetext{
155 “Qutb rejeita o nacionalismo, capitalismo, socialismo, comunismo e a modernidade, tanto quanto as sociedades muçulmanas que não praticassem a lei islâmica. Ele deixou aberta a porta para o uso da fiqh (jurisprudência) para guiar a interpretação do Corão e da sunna para torná-las relevantes na vida cotidiana" (tradução minha).

156 "a única fonte equilibrada de conhecimento para uma vida equilibrada" (tradução minha).
} 
muçulmanos. Calvert (2013) escreve que Qutb também teceu duras críticas àquela civilização no tocante ao materialismo adorado pelas pessoas, à exposição exacerbada das mulheres, ao flagrante racismo norte-americano e principalmente à falta de equilíbrio entre a espiritualidade e materialidade. Calvert (ibid., p.150) afirma que "nobody [he writes], "can compete with the Americans in building churches...Yet, despite all this, no one is as distant as the Americans from appreciating the spirituality and sanctity of religion" 157 .

Neste interim, houve a criação do Estado de Israel e a Nakba palestina, que contribuíram para aguçar ainda mais o ativismo de Qutb que se revoltou com o não reconhecimento de um Estado palestino pelas nações ocidentais. Envolto por esse contexto, Qutb escreveu:

All [the Western nations] take their bearings from one source, and that is the materialistic civilization that has no heart and no moral conscience. It is a civilization that does not hear anything except the sound of machines, and does not speak of anything but commerce... How I hate and disdain those Westerners! [grifo meu]. All of them, without exception ${ }^{158}$ (Calvert, 2013, p.121).

Complementando essa ideia, Khatab (2003) mostra que

[...] in 1946, Qutb developed his earlier idea of 'anger', which appeared in his poetry (1935) and in an article 'Anger is a Sign of Freedom' (1941), to 'Schools of Anger' (Madaris al-Sukht'). He proposed a special educational programme to teach the Egyptians how to develop their political maturity, how to observe their freedom and how to be angry in the face of corruption ${ }^{159}$.

O ódio ao Ocidente e aos judeus passa a ser destilado de forma cada vez mais explícita e em tons cada vez mais contundentes.

Ao retornar ao Egito em 1950, ele está seguro de que seu país teria sido dominado por uma cultura inferior e que, portanto, qualquer vínculo com o Ocidente deveria ser desfeito ou evitado visando preservar a identidade islâmica do país. Preconizava-se uma ruptura radical com a ordem vigente, conclamando uma reforma social urgente em seu país. Essa reforma

\footnotetext{
157 "Ninguém" [ele escreve], "pode competir com os Americanos na construção de igrejas...ainda, a despeito disso, ninguém é tão distante quanto os Americanos em apreciar a espiritualidade e a santidade da religião" (tradução minha).

158 “Todas [as nações ocidentais] se orientam a partir de uma fonte, que é a civilização materialista que não tem coração nem consciência moral. É essa civilização que não escuta nada exceto os sons das máquinas, e não fala nada que não seja comércio...como eu odeio e desdenho esses ocidentais! Todos eles, sem exceção" (tradução minha).

159 [...] “em 1946, Qutb desenvolveu sua ideia inicial de 'ódio', que apareceu em sua poesia (1935) e em um artigo 'Ódio é sinal de liberdade' (1941), para 'Escolas do ódio' (Madaris al-Sukht'). Ele propôs um programa de educação especial para ensinar os egípcios como desenvolver sua maturidade política, como observar sua liberdade e como ter raiva em face da corrupção" (tradução minha).
} 
deveria ter o islam como norteador não só da política, mas de todo quadro de vida humano. Khatab (2003, p.76) ressalta o ultimato dado por Qutb no livro "Islam: The Religion of the Future": "either a people strictly follow this system and thus becomes Muslims, or they adopt some other man-made way of life and embrace the jahiliyyah of atheism"160

Finalmente, a quarta e última fase, segundo Khatab (ibid.) vai de 1950 a 1966, ano de sua morte. Importantes livros são publicados como "A batalha entre o islam e o capitalismo" de 1951, e o mais famoso deles, "Milestones" de 1964. Para Khatab (ibid.) e Calvert (2013), esta fase que também compreende o perído em que esteve preso por estar associado às atividades da então banida Irmandade Muçulmana, é aquela em que seu radicalismo se tornou mais insuflado.

Qutb pregava um sistema educacional em que prevalecesse os princípios islâmicos e ideias derivadas da sharia, convocava os muçulmanos a se voltarem contra os tiranos para restabelecer a soberania de Allah, governantes que se diziam muçulmanos, mas que não seguiam as ideias islâmicas, constituindo o pior tipo de jahiliyya. A influência de Taymiyya é bem clara nesse aspecto, ao condenar líderes muçulmanos que não seguem os preceitos islâmicos. Os nacionalismos, de outra maneira, poderiam ser muito perigosos uma vez que dividiriam os povos ao invés de uni-los sob a bandeira do islam, a verdadeira "nação". Tanto Qutb como Banna, viam o fracasso do nacionalismo liberal no Egito refletido tanto na criação de Israel e o consequente deslocamento de palestinos, quanto a ocupação britânica, desemprego, pobreza e corrupção. A ideologia comum era a de um islam total, com a aplicação da sharia e com o sentimento de que o Ocidente teria enfraquecido o islam.

O período em que esteve encarcerado e pelas torturas a que foi submetido reforçou ainda mais a crença de que sua morte seria um bem para a humanidade. Como aponta Calvert (2013, p.263), ao narrar a cena de seu enforcamento quando o carrasco oferece clemência à Qutb, observa a seguinte resposta: "Sayyid looked up with his clear eyes. A smile, which one cannot describe, appeared on his face. He told the officer in a surprisingly calm tone: 'Never! I would not exchange this temporary life [for] a life which will never disappear!""161

Entretanto, de acordo com Buruma e Margalit (2006, p.116) Qutb "não pregava um ataque violento aos Estados Ocidentais. Seus alvos imediatos eram os governantes ocidentalizados do Egito e de outras nações islâmicas”. Calvert (2013, p.243) complementa:

\footnotetext{
160 “Ou as pessoas seguem rigorosamente esse sistema [islâmico] e assim se tornam muçulmanos, ou eles adotam algum outro estilo de vida feito pelo homem e abraçam a jahiliyya do ateísmo" (tradução minha).

161 "Sayyid olhou com seus olhos claros. Um sorriso, que não pode ser descrito, apareceu em sua face. Ele disse ao oficial com um tom calmo surpreendente: 'Nunca! Eu nunca trocaria essa vida temporária [por] uma vida que nunca vai desaparecer"” (Tradução minha).
} 
However, on second thoughts, Qutb and his colleagues decided to shelve plans for the destruction of infrastructure. They might go ahead with assassinations, but the destruction of bridges and the barrage, they came to understand, would impose hardships on the innocent people of the city and its environs. Moreover, such attacks would weaken Egypt's economy and play to the advantage of Israel, the implacable enemy of the Muslims [...] the organization only targeted select leaders, and in ways that upheld Qur'anic dictates. 'Islam forbids Muslims from torturing and humiliating its enemies. It also forbids rendering women and children homeless, unable to provide for themselves ${ }^{\prime 162}$.

Armstrong (2009, p.328-329) ao encontro dessa ideia, afirma que

os muçulmanos do presente precisavam igualmente rejeitar a jahiliyya contemporânea e contruir um enclave islâmico puro. Podiam, e de fato deviam, ser gentis com os descrentes e os apóstatas de sua sociedade, mas tinham de restringir os contatos a um mínimo e adotar uma política de não cooperação em assuntos vitais como a eduação.

Para Qutb, o islam não está fechado para outras culturas, desde que elas não tentassem interferir ou ameaçar a cultura islâmica. Igualmente, Calvert (op.cit.) alerta que a ciência moderna e a tecnologia também não eram repudiadas por Qutb, desde que contemplassem em suas explicações a referência divina, que não estivessem divorciadas da religião. Nesse caso, seriam também consideradas uma forma de jahiliyya.

Diante desse modesto perfil de uma das maiores referências do radicalismo islâmico, é inegável que hoje ainda se encontram vestígios de sua influência em grupos jihadistas pelo mundo. A queda das Torres Gêmeas em 2001, símbolo material da cultura ocidental e capitalista no país que mais teria se envolvido em assuntos internos de países do mundo muçulmano, seria um exemplo dramático do antiocidentalismo. Contudo, a respeito de certos temas, algumas de suas ideias podem ter sido alteradas haja visto o número exorbitante de civis que perderam suas vidas em ataques terroristas nos últimos anos, algo que alguns autores concordam que Qutb não teria sancionado tais ações.

\footnotetext{
162 Contudo, em pensamentos secundários, Qutb e seus colegas decidiram guardar os planos de destruição da infraestrutura. Eles poderiam ir em frente com assassinatos, mas a destruição de pontes e a barragem, eles entenderam, poderia impor dificuldades para as pessoas inocentes da cidade e alhures. Além disso, tais ataques poderiam enfraquecer a economia do Egito dando vantagens à Israel, o implacável inimigo dos muçulmanos [...] a organização mirava lideranças selecionadas e no sentido de garantir os ditados corânicos. 'O islam proíbe os muçulmanos de torturar e humilhar seus inimigos. Também proíbe deixar mulheres e crianças sem lar, incapazes de sustentarem a si mesmos. (Tradução minha).
} 
Outro exemplo é a escala à qual Qutb se referia. Para ele, seria necessária a criação de um enclave islâmico, preservado em suas raízes culturais e islâmicas, livre de governantes apóstatas e das influências ocidentais onde prevaleceria a soberania divina, a única capaz de promover o equilíbrio necessário para uma vida ideal e em paz. O jihad atual assumiu proporções globais mesmo onde os muçulmanos são minoria. Houve uma pulverização da presença e de interesses: a grosso modo, o Hamas almeja o fim do Estado de Israel; o Estado Islâmico, a aniquilação de todos que se colocam contra a criação de um Estado teocrático pautado na sharia; Al Qaeda objetiva o fim da presença americana nas terras sagradas de Meca e Medina; e a infinidade de grupelhos espalhados em todas as partes do mundo, especialmente na América e Europa que reclamam da marginalização de suas comunidades, no tratamento indecoroso de certos veículos da mídia com relação ao seu profeta e das guerras travadas pelo Ocidente em terras islâmicas.

Em suma, a ideia inicial de Qutb seria um movimento no sentido de expelir "corpos estranhos" da sociedade islâmica (de dentro para fora). Atualmente o que se observa é um movimento contrário, de fora para dentro, que visa fagocitar o mundo transformando-o em islâmico por inteiro. O que podemos deduzir é que não existe uma incompatibilidade de objetivos, mas provavelmente divergência de prioridades estratégicas.

Kepel (2003) resume essa ideia a partir dos conceitos de Dar el Islam (domínio da paz), Darl el Harb (domínio da guerra), onde os fiéis devem travar o jihad, e a Dar el Ahd (domínio da paz contratual). Essa é última seria uma porção do domínio infiel (Dar el Harb), mas onde os fiéis podem viver em paz, mas sem reclamar a aplicação da sharia, pois o governante é um infiel (Kafir). Devido à grande presença de muçulmanos na Europa, para Kepel (ibid., p.309), o continente teria assumido a posição de domínio da paz. Neste caso as organizações islâmicas se organizam aplicando a sharia e intervindo na ordem política.

Roy (2017) aponta um alto percentual de indivíduos (convertidos e intitulados de "lobos solitários") que praticaram atos terroristas na Europa na última década e que nunca entraram em uma mesquita ou eram frequentadores assíduos.

Os meios virtuais têm sido as preferidas ferramentas para promover o aliciamento e o autodidatismo, que podem levar ao radicalismo a partir do conhecimento das ideias daqueles que vislumbram o mundo e o islam tal como os mentores dos anos 50. Fazendo uma busca rápida no Google pelo nome de Sayyid Qutb, aparecem quase 800 mil resultados relacionados, indicando sua importância e possibilidades de acesso ao seu pensamento. No Facebook há uma página (em árabe) dedicada a ele com cerca de 240 mil seguidores. 


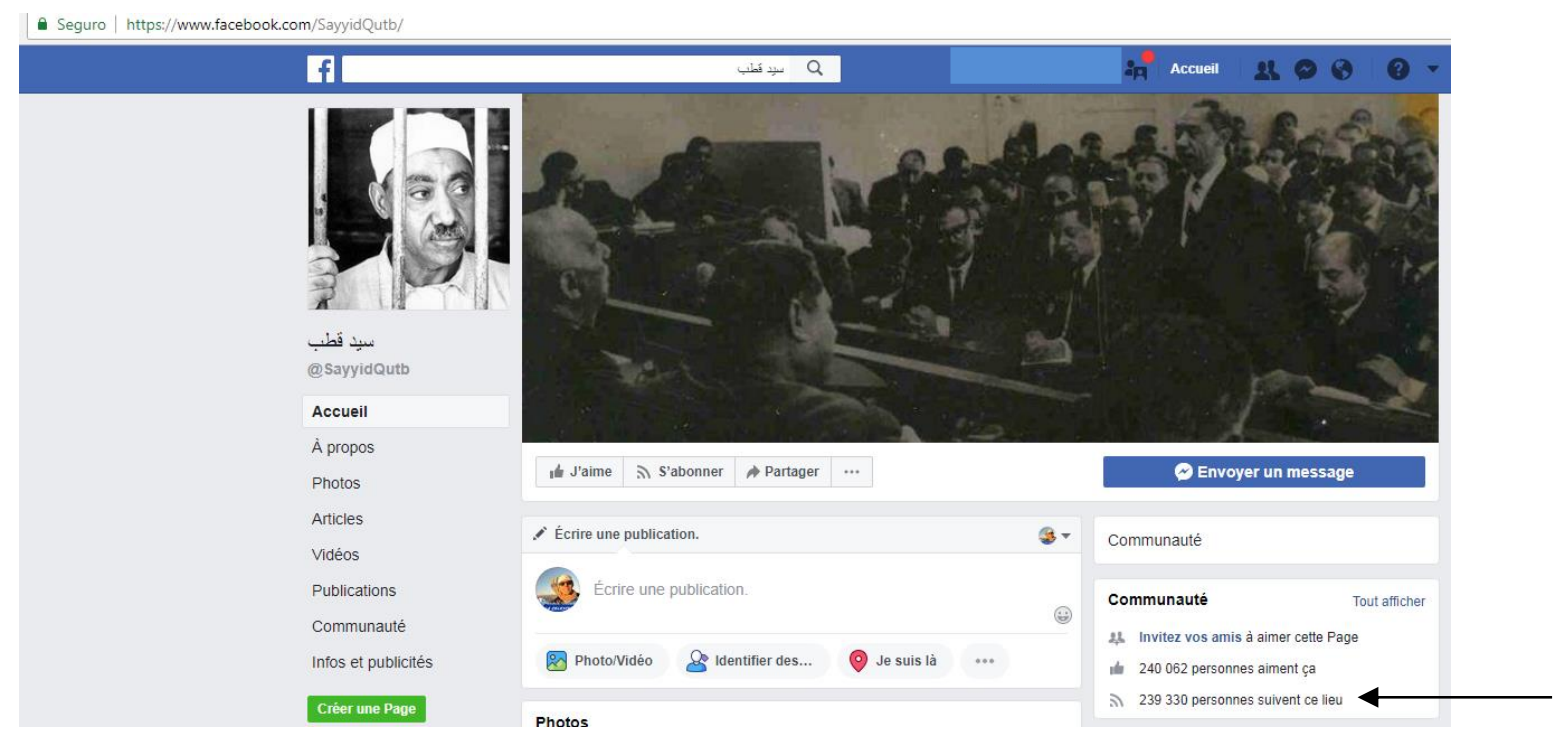

Fonte: www.facebook.com/sayyidQutb/ acesso em 10.07.2018.

A leitura de sua obra assim como a incorporação de suas ideias, assim como de outros como Abu Al Ala Mawdudi no Paquistão, sem a devida ponderação, contextualização e visão crítica, certamente pode levar algumas pessoas a percorrer um caminho obscuro de isolamento, ódio e em casos extremados, de violência.

E no caso do Brasil? Há comunidades islâmicas que defendem os princípios sustentados por Qutb? Qual a imagem de Sayyid Qutb entre alguns de seus líderes e membros?

Quando entrevistei o sheikh Jihad Hammadeh, levantei a questão do fundamentalismo, e ele, ainda que sem mencionar Qutb, acaba abordando uma de suas ideias a respeito da inseparabilidade da vida e da religião e da busca por um equilíbrio entre o material e o espiritual, e entre o científico e o religioso. Ele diz:

“[...] na visão da separação entre ser religioso e não ser é uma ideia errada da religião. Pelo contrário. Se eu sou fundamentalista, eu tenho que ter essa visão equilibrada entre razão e fé, entre o secular e o religioso, porque eu não vivo só no religioso e eu não vivo só no secular. Eu vivo nos dois.

Em outro momento da entrevista, novamente o sheikh diz algo que Qutb concordaria: "hoje o maior prejuízo do capitalismo é o materialismo. Transformou as pessoas em mercadorias, em produtos. Se é materialista, não tem mais humano, se não tem mais humano não tem sentimentos", ideia que certamente Fethullah Gülen, líder do movimento Hizmet, concordaria.

Em outra conversa que tive com o sheikh Jihad sobre sua posição perante os ensinamentos de Sayyid Qutb e a influência que ele exerce nos extremistas de hoje, ele coloca duas situações.

A primeira é que o discurso de Qutb é específico de uma determinada época e lugar que tinham seus próprios desafios, especialmente a partir do momento de sua prisão e torturas às 
quais foi submetido, que teriam afetado o seu discurso e seu modo de pensar. Mas o grande problema, segundo o sheikh, não está naquilo que ele pregava, e sim na percepção daqueles se dispunham a ouvir suas ideias, aqueles que estavam mais propensos a uma queda pelo extremismo. O sheikh Jihad cita o exemplo do próprio Alcorão, que para muitos ocidentais trata-se de um livro que fomenta a violência. Por isso depende muito do olhar daquele que se debruça sobre as escrituras ou ideias. No entanto, a partir dos escritos de Qutb, é possível que ele tenha tirado lições violentas do Alcorão em algumas ocasiões, especialmente no embate com o Ocidente e àquilo que considerava como desvios do islam.

A segunda posição está mais ligada ao poder da influência das ideias de Qutb sobre grupos radicais modernos. Ele cita a Al-Qaeda e até mesmo os Talibãs, em que é comum ouvir falar que Osama Bin Laden, por exemplo teria sido afetado pelo pensamento de Qutb. Entretanto, a verdade, segundo o sheikh Jihad, é que eles tinham aversão a Sayyid Qutb. Isso contraria Calvert (2013, p.06-07) quando afirma que

the ideologues of Al Qaeda also explicitly recognize him as an important progenitor of the global jihadi cause [...] In the search for Al Qaeda's origins, even well-intentioned observers tend to focus on points of similarity between Qutb's thought and that of Al Qaeda ${ }^{163}$.

A justificativa é que "os salafis (salafitas) não batem com os integrantes e com o movimento da Irmanda Muçulmana [...] isso é o básico, eles não se bicam porque a Irmandade Muçulmana ela tem uma visão mais amena, apesar de ser estratégica, enquanto que os salafitas acreditam no uso da força...só com o uso da força e da violência é que se chega ao governo, ao poder. Os integrantes da Irmandade Muçulmana já acreditam que devem se envolver com a política", explica o sheikh Jihad.

Embora circulem no mesmo campo ideológico (antiliberais, antiocidentais e antidemocráticos), devemos ponderar que salafis e jihadis divergem quanto ao uso da violência, sendo os primeiros, em geral, não violentos como analisaremos melhor algumas páginas adiante.

O sheikh Mohammed Khalil de Foz do Iguaçu/PR, quando questionado a respeito de Sayyid Qutb, oferece a seguinte reflexão:

na realidade, durante a história islâmica, desde que surgiu o islam, foram criados e fundados, vamos dizer assim, grupos extremistas. Chamados de $\mathrm{Al}$ -

\footnotetext{
163 “os ideólogos da Al Qaeda também o reconhecem explicitamente como um importante progenitor da causa jihadista global [...] Na busca pelas origens da Al Qaeda, mesmo observadores bem intencionados tendem a se concentrar em pontos de semelhança entre o pensamento de Qutb e o da Al Qaeda" (tradução minha).
} 
Khawarij, rebeldes, contra os califas, especialmente contra o quarto califa. $\mathrm{Na}$ época do quarto califa, o imã Ali, quando ele conseguiu governar a nação islâmica naquela época, aproximadamente 35 anos após a migração profética, foram criados grupos rebeldes extremistas que utilizavam o ódio e a raiva e massacravam os muçulmanos mesmos. E mataram também os netos do profeta Mohammed. Fizeram o massacre em Karbala contra Hussein. Esses grupos, na classificação islâmica são chamados de rebeldes. Na realidade eles saíram contra a seguridade da nação islâmica, contra os muçulmanos modestos e honestos daquela época. Claro que em cada época, em cada ciclo, foram renovadas as mesmas ideias. As mesmas ideologias extremistas deles foram renovadas pelas pessoas. Inclusive por essas pessoas como Sayyid Qutb e, também Abu Ala Mawdudi...e agora como outros em nossa época atual: AlQaeda de Bin Laden, Al-Zawahiri, como mulá Omar no Iraque [Afeganistão], com Daesh [Estado Islâmico], etc. São pessoas que carregam a bandeira de matança, de desumanidade que eles querem realizar contra qualquer outro que não segue o pensamento deles. Claro que este não representa nada do islamismo. Allah, Deus altíssimo, quando mencionou a missão do profeta Mohammed, falou da misericórdia para toda a humanidade. Eles, essas pessoas, e esses seguidores desse pensamento rigoroso e desumano, eles alteraram a misericórdia do profeta Mohammed para dizer que o profeta Mohammed era um matador - Deus me livre! -. Então esses grupos são recusados, na realidade eles que criaram o ódio entre todas as pessoas especialmente na nossa região do Oriente Médio: no Iraque, Palestina, Síria, Líbano. Em todas essas regiões quando existiam outras pessoas que vivem de outras religiões e outras escolas de pensamento, eles não aceitaram nenhuma pessoa e não podem conviver com qualquer outra pessoa, infelizmente. Esses são Sayyid Qutb e Mawdudi...são fundadores do exstremismo e de ódio, fundadores de ideologias e de pensamento cheio de ódio e de veneno contra a humanidade. Por isso são recusados por nós nesse pensamento, nesta ideologia e neste paradigma da vida deles.

Nota-se claramente nesse pensamento o passado ainda se faz presente. Considerando que o sheikh Mohammed Khalil é da corrente xiita, ele não deixa de relembrar o massacre de Hussein, a quem os xiitas consideram ser o herdeiro da linhagem profética. Portanto, a origem do radicalismo islâmico estaria vinculada à criação do grande cisma entre os muçulmanos. Cisma que se renovou ao longo dos anos e hoje é muito flagrante nas atuais relações entre Irã 
e Arábia Saudita e na geopolítica regional envolvendo a participação desses países nos conflitos da Síria e Iêmen, por exemplo.

Ao mesmo tempo, Sayyid Qutb e Mawdudi, sendo sunitas, também teriam contribuído para elevar o tom hostil entre os muçulmanos, especialmente aqueles que viviam na jahiliyya, na qual os xiitas também estariam inclusos. Por consequência, seus seguidores recentes também estariam levando adiante essa mensagem.

O sheikh Mohammed Khalil ainda afirma que "o problema é o fanatismo, quando o ser humano perde seu equilíbrio [...] o Corão serve para quando uma pessoa está calma, equilibrada”. Outra vez a questão do equilíbrio vem à tona. Nesse aspecto há uma divergência, uma vez que foi sob o mesmo discurso de equilíbrio, que Qutb desencadeou o fanatismo.

Não devemos nos enganar, entretanto. A leitura qutbista é que justamente por causa da existência da jahilyyia que contaminava o mundo, seriam necessárias atitudes drásticas para restaurar o equilíbrio. Os fanatismos recentes espalhados pelo mundo em suas mais diversas formas acreditam que a restauração deste equilíbrio será resultado de suas ações, que paradoxalmente, vem ampliando cada vez mais o rastro de destruição material e humana.

Muhamad Tawfiq, presidente da Associação Muçulmana Beneficente de Natal/RN, ao ser questionado sobre a influência e importância de Qutb, disse que

suas ideias promovem a violência e ódio. Ele é um mau exemplo para ser seguido. Ele não é referência no islam, é apenas mais um. Nós não falamos dele e nem de suas ideias para os novatos. O verdadeiro muçulmano é aquele que segue a palavra de Deus e seus mensageiros.

Contrariamente, o sheikh Ahmad Abdul do Centro Cultural Islâmico da Bahia (CCIB) afirma, de modo apaziguador, que Qutb e outros pensadores como Mawdudi e Banna, que "na minha opinião esses sheikhs não são extremistas. As pessoas é que traduzem as palavras deles errado. Até tem algumas palavras que parece como radical. Mas as intenções deles não são essas absolutamente. Mas eles são seres humanos".

Eventuais semelhanças no discurso, no uso de algumas expressões ou conceitos não significam que automaticamente possamos apontar este ou aquele como um extremista religioso que propaga ideologias jihadistas e referenciadas por pessoas como Sayyid Qutb. Como retomaremos no item 6.1, muito se fala sobre o financiamento de mesquitas e eventos com recursos sauditas como se isso representasse o patrocínio de atividades wahhabitas e por consequência o extremismo religioso.

Este é um exemplo do que acontece em todas as comunidades islâmicas brasileiras com as quais tive contato. A mera menção sobre as ideias de Qutb é minimizada ou até mesmo 
ignorada no sentido de não torná-las visíveis àqueles que porventura tenham algum tipo de inclinação mais extremada e muito menos servirem para fomentar discursos de ódio. Assim, a formação de pessoas com base na "escola" qutbista simplesmente não é incentivada e muito menos desenvolvida.

Veremos na Parte 3 da tese (item 6.1) que há estudos que têm demonstrado a existência de elos entre grupos radicais islâmicos com brasileiros muçulmanos, indícios de que o extremismo religiso tem se expandido em nosso território.

Nos anos de 2016 e de 2018 a Polícia Federal investigou dois grupos com catorze e onze indivíduos, respectivamente, por supostas atividades terroristas e vínculos com o Estado Islâmico. investigações se basearam nas conversas e contatos estabelecidos via internet, redes sociais e aplicativos de comunicação como o Telegram e o Whatsapp. Em nenhuma situação, a partir das informações apuradas, é possível identificar uma linha de pensamento que possa minimamente remeter-se à algum pensador islâmico ou corrente ideológica. Os fatos se resumem principalmente em jargões odiosos como "morte aos infiéis", "guerra ao Estado de Israel e ao sionismo", "jihad contra os cruzados"; "criação de um califado islâmico no Brasil".

Palavras soltas de ideologias que se traduzem mais em invólucros vazios do que propriamente em algo com base teológica ou alicerçadas no mainstream intelectual do radicalismo islâmico, simbolizado por Ibn Taymiyya, Mawdudi ou Qutb.

Tanto o sheikh Jihad quanto o sheikh Mohammed e muitas outras pessoas da comunidade islâmica brasileira, partilham das mesmas críticas com relação à forma como o islam vem sendo sistematicamente desconstruído pelo Ocidente e pelos meios midiáticos, que ora estereotipam, ora desejam justificar certas interferências no mundo muçulmano especialmente no Oriente Médio. Grande parte disso também motivada por indivíduos e grupos que se espelham em pensamentos e ruminações tais quais as de Sayyid Qutb. No entanto, não se pode reificar o Ocidente e usá-lo de forma generalizante, ignorando eventuais fraturas internas e inerentes ao mundo muçulmano. 


\subsection{O fundamentalismo e seus significados}

Ao se fazer uma consulta no Dicionário Aurélio ${ }^{164}$ sobre o termo fundamentalismo, a definição encontrada se remete à "doutrina que defende a fidelidade absoluta à interpretação literal dos textos religiosos. Atitude de intransigência ou rigidez na obediência a determinados princípios ou regras". Com base nesse enunciado, me veio à mente o décimo romance de Charles Dickens, "Hard Times" (Tempos Difíceis) de 1854. Escrito em tons cinzentos e esmufaçados pelas fábricas e suas chaminés em meio ao processo de industrialização que vigorava na Inglaterra vitoriana, o autor produz uma forte crítica àquela sociedade clivada entre a rica burguesia industrial e a pobreza extrema de grande parte da população. O domínio de um pelo outro se dava através da educação de crianças, da disciplina, da massificação do corpo e do espírito moldados à obediência. Aspectos sintetizados no personagem principal Thomas Gradgrind, "a man of realities. A man of fact and calculations. A man who proceeds upon the principle that two and two are four, and nothing over [...]"165 (Dickens, 2012, p.05). A imaginação, a criatividade e o pluralismo não são aceitáveis e eram prontamente censurados e corrigidos como tantas vezes o foram Sissy Jupe e Louisa, que sucumbe aos poucos à mecânica da disciplina.

Além desse, outro paralelo pode ser feito com o filme austríaco chamado "Das weisse Band" (A Fita Branca) de 2009. Dirigido por Michael Haneke e ambientado em uma vila Alemã pouco antes da Primeira Guerra Mundial, ele mostra a forma como os jovens dessa vila eram educados: com estrito rigor, emoções reprimidas e com castigos tais quais aqueles impostos pelo pastor local aos seus filhos, obrigando-os a usar uma fita branca no braço como sinal de vergonha pelos pecados cometidos, mostrando os germes do totalitarismo religioso e político. Isso marcaria uma geração que anos depois faria parte da sociedade que vivenciou o regime nazista. A disciplina, a obediência e mesmo a ausência de traços de remorso ou de culpa são flagrantes.

Desse ponto de vista os fundamentalistas, à primeira vista, também vestiriam a carapuça da obra inglesa e do cinema austríaco. Se os fatos, sejam eles quais forem, religiosos ou até mesmo científicos, são colocados acima de tudo, com interpretações tão rigorosas que não caberiam devaneios que pudessem contemplar outros aspectos da realidade presente, aqueles que creem na infalibilidade da Bíblia, do Alcorão, das leis da termodinâmica e da natureza, e

\footnotetext{
${ }^{164} \mathrm{http}: / / \mathrm{bit} .1 \mathrm{y} / 2 \mathrm{tO} 1 \mathrm{DXw}$ (acesso em 01.07.2016).

165 "um homem de realidades. Um homem de fatos e cálculos. Um homem que procede segundo o princípio de dois e dois são quatro e nada mais" (tradução minha).
} 
que vivessem na elite da fictícia Coketown de Dickens ou no norte da Alemanha pré-Grande Guerra, seriam então todos fundamentalistas.

Se na Bíblia é possível ler em Levíticos 24:16, que "aquele que blasfemar o nome do Senhor, certamente morrerá; toda a congregação certamente o apedrejará; assim o estrangeiro como natural, blasfemando o nome do Senhor, será morto" e no Alcorão Sagrado 9:29 igualmente pode-se ler "combatei aqueles que não creem em Allah e no Dia do Juízo Final, nem abstêm do que Allah e Seu Mensageiro proibiram, e nem professam a verdadeira religião daqueles que receberam o Livro, até que paguem de bom grado a jizya [taxa ou tributo pago pelos não-muçulmanos dentro do Estado Islâmico] e se sintam submissos", adquirimos uma noção sombria do fundamentalismo qualquer que seja o credo.

Igualmente, se citássemos versículos e suratas com mensagens aprazíveis de boa convivência e tolerância, divulgar-se-ia um fundamentalismo positivo como na poesia dos Salmos 133:1, “oh! Quão bom e quão suave é que os irmãos vivam em união!" e no Alcorão $5: 32$, em "[...] que quem matar uma pessoa, sem que esta tenha cometido homicídio ou semeado a corrupção na terra, será considerado como se tivesse assassinado toda a humanidade; quem a salvar, será reputado como se tivesse salvo toda a humanidade [...]”.

O que não muda, entretanto, é que em ambos os casos se mantêm no caminho da obediência, rigidez e disciplina aos preceitos das escrituras. O caminho é o mesmo, mas a paisagem é diferente.

Quando Armstrong (2009, p.191) afirma, também apoiada em Dickens que "descreveu a cidade industrializada como um inferno e mostrou que o moderno racionalismo pragmático poderia destruir a moralidade e a individualidade", é possível imaginar como alguns grupos criaram alternativas para, 150 anos depois, com o advento de novas tecnologias e dos modernos meios de comunicação e transporte, cada vez mais invasivos e capilares, evitar que modernização (ocidental), a ciência e a uniformização das sociedades, suplantassem os valores religiosos sagrados. O "racionalismo científico era uma nova religião secular", escreve Armstrong (ibid., p.139). Era preciso combatê-lo. A autora justifica o fundamentalismo a partir da divisão do mundo regido pelo logos, que contempla o moderno, o racional, o secular e mesmo o ocidental, e o mythos, mais ligado ao plano espiritual das emoções, tradições, constância e observância do passado. O mythos, falso e supersticioso, seria algo que Thomas Gradgrind evitaria.

O diagrama abaixo tenta resumir a relação entre esses dois conceitos apontados por Armstrong (ibid.). 


\section{Diagrama 4 - Síntese a partir das ideias de Karen Armstrong.}

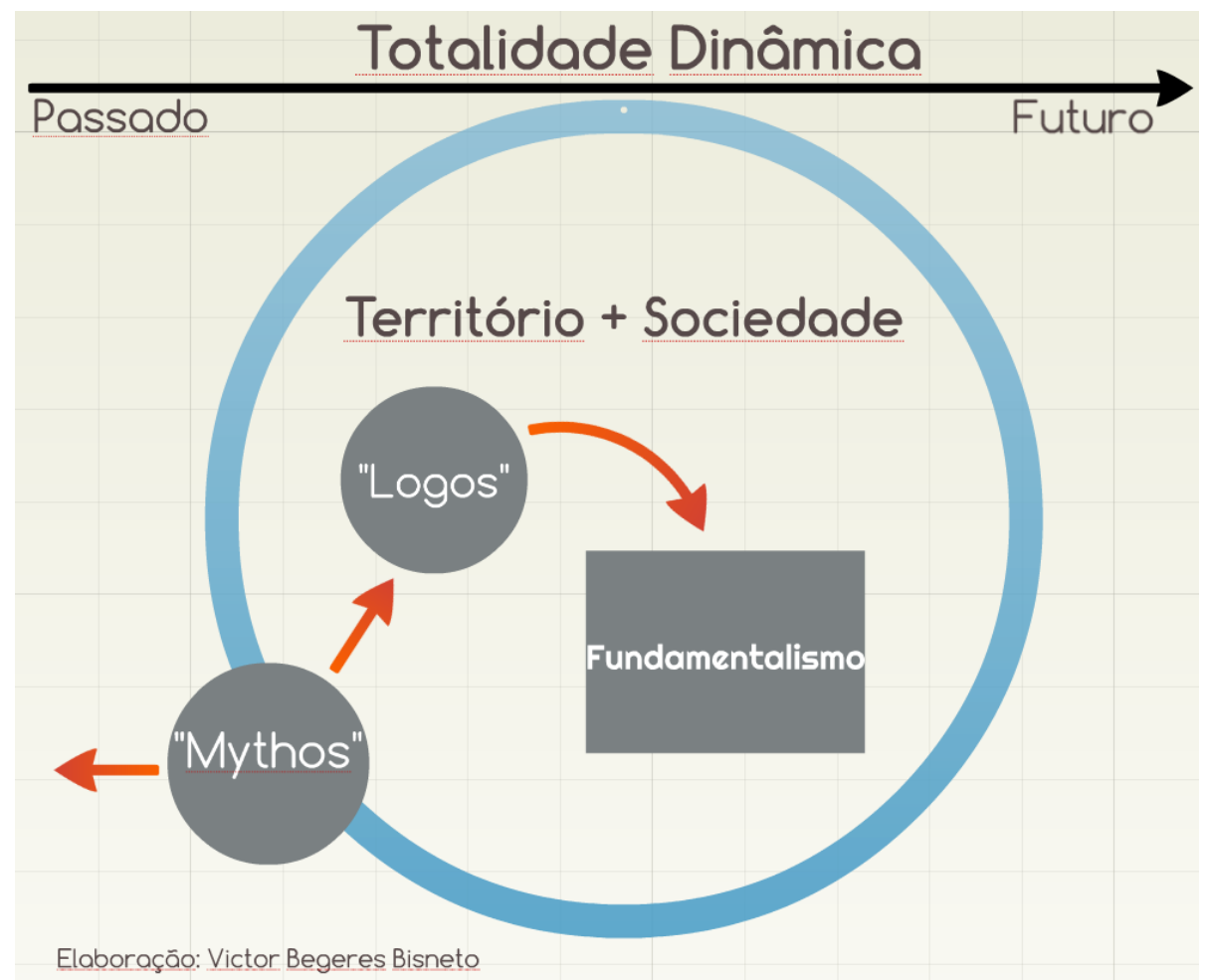

Aproveitando o modelo discutido pelo diagrama 2 (p.20) no início da pesquisa, o fundamentalismo seria a tentativa de alguns grupos em transformar em "logos", o "mythos" de sua fé, isto é, buscar explicações e soluções racionais a partir da sua religião. Seria um retorno ao "fundamental" face às influências perniciosas do mundo secular e moderno que negligencia o "mythos". Tais grupos se revelam como produtos da modernidade, mas que reivindicam a volta ao passado, às origens da religião islâmica, como modelo civilizatório a ser vivido no presente. Contudo, essa anacronia não é completa justamente porque muitos desses grupos fazem uso de atributos modernos para alcançar seus objetivos ou combater aqueles que consideram ter se desviado do caminho.

Esse contexto de globalização e modernização, que contribuíram não só para mudar o perfil de atuação dos grupos islamistas, mas também para publicizar suas causas, Roy (2008, p.26) explica que o fundamentalismo islâmico "est la forme du religieux la mieux adaptée à la mondialisation, parce qu'il assume sa propre déculturation et en fait l'instrument de sa prétention à l'université"166.

Nesse caso, o autor estabelece como premissa o processo de separação entre a cultura e a religião chamado por ele de "desculturação". Assim, o embrião do neofundamentalismo estaria nos processos migratórios, na penetração de outros povos em culturas distintas, no caso

166 "é a forma do religioso melhor adaptada à mundaliazação, porque ela assume sua própria desculturação e de fato o instrumento de sua pretensão à universalidade" (tradução minha). 
os árabes, os turcos, os paquistaneses entre outros, que vão em direção à Europa vivendo sua religiosidade em um ambiente dominado por uma cultura diferente da sua, elemento primordial para o aprofundamento de seu contato com a religião e com a busca pelo "fundamental".

Lewis (2004a, p.126) também ancora os elementos que caracterizam o fundamentalismo na modernização ao afirmar que

em termos amplos, fundamentalistas muçulmanos são aqueles que sentem que os atuais problemas do mundo muçulmano resultam não da modernização insuficiente, mas de excessiva modernização, que veem como uma traição aos autênticos valores islâmicos.

Eisenstadt (1997) faz uma interessante reflexão sobre o fundamentalismo como uma espécie de revolução, e que sendo assim, partilha de algumas características presentes nas grandes revoluções, como a Americana e a Francesa como seu elemento jacobino que pressupunham que as mudanças políticas e sociais seriam obtidas a partir da violência, na ideologização da política, numa visão total de mundo e na habilidade do homem em reconstruir a sociedade de acordo com algumas visões transcedentais. Contudo, o que distingue as grandes revoluções do fundamentalismo é que este último possui um componente religioso mais exacerbado do que a própria política, embora saibamos que outros autores associam o fundamentalismo islâmico como uma forma de politização da religião (Ayubi,1991 e Demant, 2006).

O islam político ou islamismo são tratados como sinônimos por Roy (1994 e 2004) Demant (2008), Ayubi (1991) e Tibi (2001). Seriam eles fenômenos diferentes do fundamentalismo ou apenas faces de uma mesma moeda? Em geral, para os autores citados, esses termos seriam uma ideologia que faz uso do discurso cultural para fins políticos. O islam quando politizado, sequestra a sociedade e a própria religião para a consecução de seus projetos que por sua vez amplia as lacunas entre o islam e o Ocidente. Para Tibi (idem, p.01) "it is not Islam, but its politicisation that results in creating 'faultlines' between the people of Islam and those of other civilisations" 167 .

Ayubi (1991) associa o termo islam político ao fundamentalismo. Para o autor, este seria um sintoma de uma crise social perpetrada pelo Ocidente, mas que não tem um plano para solucioná-la. Sua ideologia pode até consolar a alma, mas não os conflitos sociais, econômicos e culturais. O slogan da Irmandade Muçulmana, "o islam é a solução" não passaria de uma retórica vazia de conteúdo prático. A ressalva quanto ao raciocínio de Ayubi (idem) é que os

\footnotetext{
167 “não é o islam, mas sua politização que resulta na criação de 'lacunas' entre as pessoas do islam e aqueles de outras civilizações" (tradução minha).
} 
termos e os movimentos islamistas mudaram bastante desde quando se discutiu essa questão. É possível que naquela época o maior exemplo de movimento islamista fosse o Irã. Atualmente, os analistas devem incluir em suas análises a profusão de grupos e suas ideologias nem sempre similares, como o Boko Haram, Al Shabbab, Irmandade Muçulmana e o Estado Islâmico (Daesh).

Lewis (2004b, p.329) ao afirmar que "ultimately, the struggle of the fundamentalists is against two enemies, secularism and modernism”, acaba na mesma conclusão de Demant (2008, p.201) para quem

o islamismo é uma ideologia antimoderna, anti-secularista, anti-ocidental, cujo projeto é converter o indivíduo para que se torne um muçulmano religioso observante, é transformar a sociedade formalmente muçulmana em uma comunidade religiosa voltada ao serviço a Deus e estabelecer o reino de Deus em toda a Terra. A tendência fundamentalista é provavelmente a vertente predominante no islã atual.

Ali (2015), uma das mais contundentes críticas do islam, para quem essa religião por meios de seus textos sagrados justificam e conclamam a violência, subdivide os muçulmanos (e não o islam) em três categorias: a dos muçulmanos dissidentes que buscam uma reforma do islam; a dos muçulmanos de Meca (maior grupo), considerados fieis às escrituras e praticam com fervor sua fé mas sem inclinação para a violência; e por fim, os fundamentalistas ou o chamado grupo dos muçulmanos de Medina ${ }^{168}$ para os quais um regime só pode ser baseado na sharia e que sua fé seja imposta a todos os demais. Além disso, defendem um islam idêntico ao inaugurado por Maomé e não toleram outros credos.

Enquanto os modernistas islâmicos buscavam um caminho de conciliação entre a religião e a ciência, que naquele momento poderiam chegar a admirar e a emular a civilização ocidental em alguns aspectos, e os salafis, contrariamente, se fechavam em torno da imutabilidade da religião face ao tempo e seus contextos, o fundamentalismo islâmico (ou islamismo), de acordo com Demant (2008) seria uma corrente que teria como fórmula a combinação das outras duas e que possuiria um vínculo maior com a política. Essa corrente, produto dos novos tempos, faz uso da modernidade contra aquele que a teria criado e expandido, o Ocidente, justificando suas ações com base na religião. Tal situação vai ao encontro do que pensa Armstrong (2009), ao propor a apropriação dos logos da razão pelo mythos da fé. Nesse

\footnotetext{
${ }^{168}$ Em oposição à Meca, Medina seria o local onde as principais suratas que depõem a favor da violência teriam sido reveladas.
} 
sentido, o multiculturalismo, o assimilacionismo e mesmo o integracionismo seriam formas de convivência que não seriam aceitas.

Buruma e Margalit (2006), ainda que não se dediquem em explicitar as origens do fundamentalismo islâmico, estabelecem outra divisão dentro do islamismo. De um lado haveria o ramo dos islamistas políticos e, de outro, dos puritanos islâmicos. Enquanto os primeiros estão interessados no poder, na criação de Estados Islâmicos, na política e na construção desses estados sobre as "ruínas" do estado da jahiliyya (ignorância) como Maomé fez em sua época, os outros são mais engajados em reforçar a moral coletiva. Estes seriam fundamentalistas na visão dos autores. Roy (1994, p.80) complementa, que esse puritanismo

is characterized by the rejection of all distraction, of music, theater, and all diversion in the Pascalian sense of the word, and the desire to eradicate places of pleasure and leisure (cafes, video and dance clubs, cinemas, certain sports clubs). Preaching focuses on a return to the essentials: religious practice and fear of $\operatorname{God}^{169}$.

Ambos, islamistas políticos e puritanos, enxergam o mundo ocidental como o grande responsável por impor dificuldades à realização de seus projetos, ora agindo contrariamente à criação de Estados Islâmicos, ora submetendo os valores islâmicos aos costumes e práticas ocidentais, criando assim, uma espécie de ocidentalismo, isto é, uma visão negativa do Ocidente. Para estes fundamentalistas, o Ocidente seria arrogante e pecaminoso, uma universidade com apenas uma faculdade, a razão, que visa se impor ao mundo.

Mas essa visão que distingue islamistas políticos de puritanos fundamentalistas não é partilhada por alguns autores como Bassam Tibi, Nazih Ayubi, Peter Demant e Olivier Roy, que consideram o fundamentalismo islâmico como sinônimo de islamismo que por sua vez também pode ser chamado de islam político. As duas vertentes apresentadas por Buruma e Margalit (2006), atualmente são quase indissociáveis. Possivelmente, a diferença que está implícita nessa pretensa separação é na forma como esses grupos agem. Os critérios como a forma como esses movimentos lidam com a modernidade e com o ativismo político podem distinguir um do outro.

Dito de outra forma, o termo fundamentalismo acaba sendo um invólucro que compreende muitas interpretações. Ele passa a ser usado sob tantas formas que, por fim, mais se presta em confundir do que esclarecer. Por isso, consideramos que as nomenclaturas mais

\footnotetext{
169 “é caracterizada pela rejeição de todas distração, da música, teatro, e toda diversão no sentido Pascal da palavra, e o desejo de erradicar lugares de prazer e lazer (cafés, vídeos e discotecas, cinemas, certos clubes esportivos). Rezar foca no retorno do essencial: a prática da religião e o medo de Deus" (tradução minha).
} 
consistentes para caracterizar esses grupos hostis ao Ocidente, à modernidade, ao secularismo, e que se engajam em um projeto político-religioso, são o jihadismo e o islam político.

Jihad é um termo que carrega algumas interpretações. A primeira e menos difundida ou esclarecida, é que em árabe ela se traduz por esforço, resistência, perseverança e uma luta interior de disciplina moral e dedicação à Allah. Essa seria o grande jihad. Porém é verdade também que o islam sanciona levantes e rebeliões contra aqueles que consideram injustos (muçulmanos ou não) ou que os agridem, caso das recentes incursões estrangeiras no Oriente Médio por potências ocidentais, mobilizando assim, uma luta política, social e mesmo militar, apelidada de "guerra santa".

A capa da revista Aventuras na História de abril de 2016, mostra a figura do clérigo sudanês Muhammad Ahmed bin Abd Allah (1844-1895), conhecido como Mahdi, como o "primeiro jihadista da história". Marton (2016) diz que ele empregou seu carisma e suas ideias de um islam puro, com a observância de uma interpretação literal do Alcorão, dos valores islâmicos e aplicação da sharia, na condução de um jihad anti-imperialista contra os britânicos e seu protetorado egípcio assim como os otomanos a quem considerava corruptos e incapazes de liderar uma verdadeira comunidade islâmica. Para Voll (apud Eisenstadt, 1997),

the case of Muhammad Ahmad, the Sudanese leader who proclaimed his mission as Mahdi and drove the Ottoman-Egyptian forces out of his country in the 1880s [...] the Sudanese Mahdi rejected the corrupt practices of the Turko-Egyptian rulers and fought the British, but he did not reject modern military technology ${ }^{170}$

Sobre a questão do jihad, os xiitas Assayed e Fadlullah (2005, p.47) escrevem:

o Islam confia ao homem a responsabilidade de conduzir o Jihad e de combater, com todos os seus bens e até com sua vida, àqueles que lutam contra os Caminhos de Deus e planejam ações contra os fiéis em Deus. Nada além destes caminhos devem animar as energias do homem, pois esse é o sentido da fé, sua verdade e sua realidade. Essa é a base moral que justifica o combate do homem e que pode conduzi-lo a reagir para se defender.

Isso configura o chamado pequeno jihad. Não obstante, tal assertiva não significa de um modo geral que essa interpretação legitime a matança indiscriminada, pois na tradição muçulmana se condena massacres contra inocentes independentemente do credo ou etnia. $\mathrm{O}$

\footnotetext{
170 “o caso de Muhammad Ahmad, o líder sudanês que proclamou sua missão como Mahdi e conduziu as forças otomanas-egípcias fora de seu país nos anos de 1880 [...] o Mahdi sudanês rejeitou as práticas de corrupção dos governantes turco-egípcios e lutou contra os britânicos, mas ele não rejeitou a moderna tecnologia militar" (tradução minha).
} 
próprio Alcorão, conforme passagem descrita anteriormente atesta esse princípio. Entretanto, temos visto que grupos como o Estado Islâmico (Daesh) são uma exceção, uma vez que se baseiam em interpretações enviesadas para justificar os assassinatos e massacres de minorias religiosas ou daqueles que não concordam com seus atos.

A "guerra santa" e o pequeno jihad, entretanto, são mais comumente veiculados pelos canais de comunicação e se tornaram parte do vocabulário usado em relação aos acontecimentos violentos de grupos islâmicos. Para Esposito (2002, p.65), "jihad is often simply translated and equated with aggressive holy war. For many in the West, it has come to symbolize Islam as a religion of violence and fanaticism" ${ }^{\prime 171}$.

O predomínio desse significado se justifica pelos apelos de radicais islâmicos conclamando os muçulmanos a combater o Ocidente, os cruzados, sionistas e infiéis. Não é difícil encontrar referências como essa nas falas de islamistas como Osama bin Laden, que em uma de suas gravações publicadas pelo jornal inglês The Independent, em janeiro de 2009, dizia: " 172 the jihad [grifo nosso] of your sons against the Crusader-Zionist coalition is one of the key reasons for these destructive effects among our enemies ${ }^{173}$ ". Kepel (2003, p.486) nos recorda que em 1996, o mesmo Bin Laden teria difundido uma "déclaration de jihad contre les Américains occupant la terre des deux 'Lieux Saints', plus connue par son sous-titre 'Expulsez les polythéistes de la péninsule Arabique" "174.

Estudando os movimentos islamistas especialmente na Ásia Central em países como Casaquistão e Uzbequistão, Rashid (2003, p.32-33) analisa o conceito de jihad e os grupos que fazem parte dessa ideologia, e afirma em tom de crítica que

os novos grupos de jihad não têm nenhum manifesto econômico, nenhum plano para um governo melhor ou para a formação de instituições políticas, nenhum projeto para gerar participação democrática no processo decisório e de seus futuros Estados Islâmicos. Dependem antes de um único líder carismático, um amir, do que de uma organização ou partido constituído mais democraticamente para governar. Acreditam que são mais as virtudes de caráter, devoção e pureza do líder do que suas habilidades políticas, educação, ou experiência que o habilitarão a conduzir a nova sociedade. Assim surgiu o fenômeno dos cultos ao mulá Muhammad Omar, do Talibã, a Osama Bin

\footnotetext{
171 “jihad é frequentemente simplesmente traduzida e equacionada com a agressiva guerra santa. Para muitos no Ocidente, isso simboliza o islam como a religião da violência e fanatismo" (Tradução minha).

172 "a jihad de seus filhos contra a coalização cruzada-sionista é uma das razões chave para esses efeitos destrutivos entre nossos inimigos" (tradução minha).

173 https://ind.pn/2KG7unY (acesso em 10.02.2016).

174 “declaração de jihad contra os americanos que ocupavam a terra entre os dois 'lugares santos', mais conhecidos pelo seu subtítulo 'expulsem os politeístas da península árabica”" (tradução minha).
} 
Laden, Al-Qaeda e a Juma Namangani, do Movimento Islâmico do Uzbequistão. Os novos grupos do jihad são igualmente obcecados pela implementação da chariá (lei islâmica). Entretanto, consideram a chariá, não como um caminho para criar uma sociedade justa, mas simplesmente como um meio para controlar o comportamento pessoal e os códigos de vestuário dos muçulmanos - um conceito que distorce séculos de tradição, cultura, história e a própria religião islâmica.

Recentemente o grupo que mais destila essa concepção e esse projeto de sociedade é o Estado Islâmico (Daesh) na Síria e no Iraque, liderado pelo autoproclamado califa Abu Bakr al-Baghdadi, mas que contrariando parte do exposto acima, possui um plano econômico, político e social para os territórios e habitantes sob os quais legislam.

O jihad visto desse ponto de vista, é uma variável importante do fundamentalismo que hoje seleciona entre os elementos modernos aquilo que pode ajudar em sua difusão contra a própria modernidade, se apropriando de tecnologias, especialmente dos meios bélicos e de comunicação, como as redes sociais e sites para poder se articular em rede aumentando a capilaridade de sua ideologia. Cockburn (2015, p.160) reforça essa ideia ao desvendar:

'metade do jihad é mída' é um slogan postado num website jihadista [...] as ideias, ações e objetivos dos jihadistas fundamentalistas sunitas estão difundidos diariamente por estações de TV via satélite, YouTube, Twitter e Facebook. Enquanto tais meios poderosos de propaganda existirem, grupos similares à Al-Qaeda nunca sofrerão por falta de dinheiro ou recrutas.

A Al-Qaeda teria sido a pioneira no uso desse recurso para internacionalizar sua causa como afirma Atwan (2008, p.144) em que

a internet tornou-se um elemento-chave no treinamento da Al-Qaeda, em seu planejamento e sua logística, e o ciberespaço acabou por se transformar em um campo de batalha. Alguns comentaristas foram ainda mais longe, ao declarar que a Al-Qaeda é a primeira rede de guerrilha direcionada à rede.

Esse "cyberjihad" é servido por uma profusão de páginas na internet, em múltiplos idiomas que transmitem desde fatwas de diversos líderes religiosos ${ }^{175}$, passando pela existência de um Alcorão digital em que há instruções de como lê-lo, até websites de perguntas e respostas sobre diversos aspectos da vida social, da religião e da relação entre muçulmanos e não muçulmanos ${ }^{176}$. Atwan (ibid.) argumenta que há mais de 4.500 sites jihadistas e muitos deles ensinam como preparar minas, fazer explosivos, manipular veneno entre outros artifícios. Isso

${ }^{175} \mathrm{http}: / /$ bit.ly/2z5nKNX (acesso em 11.02.2016)

${ }^{176}$ https://bit.ly/2KG6obQ (acesso em 11.02.2016) 
não significa apenas um ativismo virtual, mas principalmente expõe a desterritorialização do islam político do atual período.

Apesar dessa densidade de conteúdos ligados ao jihad, que passa a ser conhecida apenas por um viés, Ferreira (2016) oferece uma visão mais otimista e corajosa, porque enfrenta um estereótipo criado por uma leitura parcial do termo. Para ela, todos os muçulmanos são jihadistas uma vez que toma o grande jihad como referência, aquele que é pouco divulgado e esclarecido entre a população em geral e a mídia. Ferreira (ibid., p.04) afirma que

todos os muçulmanos são jihadistas, pois é obrigação de todos o esforço, a dedicação e o empenho em suas atividades. Se se perguntar a um professor muçulmano qual é a sua jihad, ele dirá que é ser um professor melhor a cada dia. Se se perguntar a um médico, advogado, pedreiro, agricultor, todos vão dizer que a sua jihad é se dedicar em fazer sua atividade cada dia melhor e se empenhar em serem seres bons muçulmanos. Esta é a jihad maior de todo muçulmano.

Há que se ponderar que a primeira frase da citação acima induz a um sofisma que impossibilita a análise do jihad sob o viés da violência que também pode engendrar em determinados casos.

Menos engajado politicamente, temos o salafismo, cujo radical salafi oriundo da palavra salafiyya, é muitas vezes tido como sinônimo de fundamentalismo islâmico (Ayubi, 1991) não apenas pelas suas qualificações, mas também porque em árabe é usada no lugar de "fundamentalista" (Ruthven, 2005). O termo de fato não é comum em árabe, mas um ramo dos estudos islâmicos chamado de usul al-din (fundamentos da religião) é o mais próximo que chegamos desse termo.

Buruma e Margalit (2006) como vimos, sugerem que puritanos islâmicos seriam fundamentalistas. Porém pela definição dada, se enquadrariam mais no termo salafi. Tibi (2001, p.62), por outro lado, discorda dessas interpretações ao afirmar que "in contemporary Islam, salafiyya is a traditionalism. In contrast, political Islam being a variety of fundamentalism differs greatly from traditionalism" 177 . O tradicionalismo, tomado como salafismo, nesse caso diz respeito a uma corrente rígida do islam, porém seriam os mais "quietos", que se isolariam do mundo e da ignorância (jahiliyya, pré-islâmica). Pregam que a religião deveria permanecer imutável porque perfeita. Assim são menos simpáticos à fiqh (jurisprudência), às livres interpretações das escrituras e a próteses geográficas e culturais que possam forçar uma adaptação da religião a elas.

177 “no islam contemporâneo, salafiyya é um tradicionalismo” (tradução minha). 
Entretanto, se analisarmos a concepção de Olivier Roy, percebemos que pode haver mais de uma interpretação para o salafismo. Em "L’échec de l'Islam Politique" de 1992, se assume que o islamismo, portanto o islam político,

the Islamists generally adopt Salafist theology: they preach a return to the Quran, the Sunna, and the sharia and reject the commentaries that have been part of the tradition ${ }^{178}$ (idem.,1994, p.35-36).

Em outro período mais recente, nota-se uma mudança em sua linha de pensamento, em que o termo significa a

valorisation des premiers temps au détriment de l'Histoire se retrouve en islam parmi ceux qui voient dans la primière communauté musulmane le paradigme indépassable de toute société musulmane, et qui considèrent que l'achèvement de la dévotion est l'imitation du Prophète (comme chez les tablighs et les salafistes), et non le savoir théologique ${ }^{179}$ (idem., 2008, p.240).

Nessa visão, o islamismo teria grande influência do salafismo ou até mesmo se confundiria com ele. Situação que vai ao encontro do pensamento de Lewis (2004a, p.126) ao alegar que para o fundamentalismo islâmico "a solução é um retorno ao verdadeiro islam, incluindo a abolição de todas as leis e de outros arranjos sociais tomados emprestados do Ocidente, com a restauração da lei sagrada islâmica, a shari'a, como a efetiva lei da terra”.

Tibi (2001) alertava que salafismo é o mesmo que tradicionalismo e, por sua vez, está na contramão do islamismo. O que intriga nesse jogo de palavras é que Roy (1994, p.03) parece concordar com Tibi, assumindo que o islamismo não é tradicionalismo, pois

they live with the values of the modern city-consumerism and upward social mobility; they left behind the old forms of conviviality, respect for elders and for consensus, when they left their villages. These followers are fascinated by the values of consumerism imparted by the shop windows of the large Metropolises; they live in a world of movie theaters, cafes, jeans, video, and sports, but they live precariously from menial jobs or remain unemployed in immigrant ghettos, with the frustration inherent in an unattainable consumerist world $^{180}$.

\footnotetext{
178 "Os islamistas geralmente adotam a teologia salafista: eles pregam o retorno ao Corão, à sunna, e à sharia e rejeitam comentários que têm sido parte da tradição" (tradução livre).

179 "valorização dos primeiros tempos em detrimento da história se encontra no islam entre aqueles que vêem em uma primeira comunidade muçulmana o paradigma intransponível de toda sociedade muçulmana, e que consideram que o sucesso da devoção é a imitação do profeta (como na época dos tablighs e os salafistas), e não o saber teológico" (tradução minha).

180 "eles vivem com os valores da moderna cidade-consumismo e mobilidade social ascendente; eles deixaram para trás as velhas formas de convivência, respeito pelos mais velhos e por consenso, quando deixaram suas aldeias. Esses seguidores são fascinados pelos valores do consumismo transmitidos pelas vitrines das grandes metrópoles;
} 
Comparando as afirmações acima, e com obras mais recentes do autor é possível obter ao menos duas conclusões: a) que na versão original de 1992 e na tradução inglesa de 1994, há uma clara contradição em se afirmar que islamismo não é tradicionalismo, mas posteriormente assumir que islamismo se confunde com salafismo, tido por muitos autores como a manifestação da corrente tradicionalista; b) se observarmos outras obras mais contemporâneas do autor, percebe-se que há uma mudança no pensamento ou na forma em que concebe esses termos. Em se considerando o fundamentalismo islâmico como sinônimo de islamismo, Roy (2004, p.33) afirma que são chamados de "islamistes, les mouvements qui voient dans l'islam une idéologie politique et qui considèrent que l'islamisation de la société passe par l'instauration d'un État Islamique, et pas seulement par la mise en œuvre de la charia"181.

Nesse caso, Abu Ala Mawdudi, Sayyid Qutb e Hasan Al-Banna fariam parte desses movimentos. Os islamistas aqui são aqueles que deixam o isolamento e procuram formas de islamizar a sociedade. Em termos teológicos há resquícios do salafismo, mas em termos práticos, faz uso de objetos modernos que sirvam aos propósitos do seu ativismo.

Roy (2004) também distingue entre os grupos islamistas em duas vertentes: o islamismo nacionalista, ainda preocupado com a política externa e o islamismo reacionário, que teria abandonado o internacionalismo da "causa" com o passar do tempo e assumido um caráter mais nacional, menos preocupado com o mundo externo e mais com as questões envolvendo suas lideranças, combinando forças contra a corrupção, contra os "falsos muçulmanos" e a favor do conservadorismo; Para Roy (2008, p.236)

des groupes radicaux musulmans, inspirés par la pensée de Said Qutb, rompent avec l'islam majoritaire en déclarant apostats les dirigeants musulmans qui ne suivent pas une ligne de rupture envers l'Occident et les regimes existants: cela se traduit d'abord par l'assassinat de plusieurs dignitaires religieux musulmans en Egypte ${ }^{182}$.

Interessante notar que para o autor esse é o momento em que há uma ruptura entre o fundamentalismo clássico, ancorado nas escrituras como de praxe, bastante ideologizado, etnicamente mais homogêneo, territorializado e imerso em contextos variados, e o chamado

\footnotetext{
Vivem em um mundo de cinemas, cafés, jeans, vídeos e esportes, mas vivem precariamente de empregos subalternos ou permanecem desempregados em guetos de imigrantes, com a frustração inerente a um mundo consumista inatingível" (tradução minha).

181 "islamistas, os movimentos que vêem no islam uma ideologia política e consideram que a islamização da sociedade passe pela instauração de um Estado Islâmico e não somente com a implementação da sharia" (tradução minha).

182 "os grupos radicais islâmicos, inspirados pelo pensamento de Said Qutb, rompem com o islam majoritário declarando apostatas os dirigentes muçulmanos que não seguem uma linha de ruptura em relação ao Ocidente e os regimes existentes: isso se traduz inicialmente pelo assassinato de muitos dignatários religiosos muçulmanos no Egito" (tradução minha).
} 
neofundamentalismo, que para Roy (2004, p.57) surge como uma "conséquence de la crise de l'État, islamique ou non, mais aussi de la déterritorialisation de l'Islam, sous l'effet, entre autres, de son passage à l'Ouest" ${ }^{\prime 183}$.

Roy (ibid., p.83) acrescenta que eles "vivent sur une vision défensive d'une communauté musulmane qui serait menacée de destruction, mais surtout d'assimilation ${ }^{184 \text { " }} \mathrm{e}$ que também estariam em busca do verdadeiro islam tal como os salafistas. Mas as semelhanças entre os termos estão restritas nesse ponto. Esse verdadeiro islam residiria na conciliação da tradição com a modernidade, mas selecionando aquilo que pode ser apropriado. Assim, Roy (2008, p.30) esclarece que o neofundamentalismo é definido como

structures familiales modernes (c'est-à-dire couples d'âge et d'éducation similaires) mais valeurs conservatrices, lobbying politique pour promouvoir le valeurs morales, mais indifferénce à l'idéologie politique et à la forme de l'État, femmes à la fois militantes et cantonnées à des roles traditionnels (les nouvelles femmes voilées s'exhibent comme telles), professions modernes (ingénieurs, fonctionnaires) mais discours de la 'tradition'185

$\mathrm{O}$ autor ainda cita como exemplo o movimento wahhabita, os movimentos como o Jama'at ut-tabligh (fundado em 1926), os talebãs afegãos e os movimentos qutbistas egípcios nascidos em meados dos anos 80 como o Takfir wal hijra como sendo neofundamentalistas (idem., 2004, p.151). Roy (2008, p.162) conclui dizendo que

il est clair que le neo-fondamentalisme lutte contre toute forme d'assimilation et d'occidentalisation sur les mêmes bases qu'il s'oppose aux islams tranditionels. Il est important de voir que son hostilité à l'occidentalisation est dans le prolongement de son projet de purification et de refondation de l'islam $^{186}$.

Rashid (2003) vai além e diz que o neofundamentalismo seria um desvirtuamento do jihad como forma de justificar o massacre de inocentes, algo que vai ao encontro do que pensa

\footnotetext{
183 “consequência da crise do estado, islâmico ou não, mas também da desterritorialização do islam sob efeito, entre outros, de sua passagem ao oeste" (tradução minha).

184 “eles vivem sobre uma visão defensiva de uma comunidade muçulmana que seria levada à destruição, mas sobretudo à assimilação" (tradução minha).

185 “estruturas familiares modernas (isto é, casais de idade e educação semelhantes), mas valores conservadores, lobby político para promover valores morais, mas indiferença à ideologia política e à forma de estado, mulheres ambos militantes e confinados a papéis tradicionais (as novas mulheres veladas estão se exibindo como tais), profissões modernas (engenheiros, funcionários públicos), mas discursos de 'tradição'” (tradução minha).

186 “é claro que o neo-fundamentalismo luta contra todas as formas de assimilação e ocidentalização nas mesmas bases em que se opõe aos islãs tradicionais. É importante ver que sua hostilidade à ocidentalização está na extensão de seu projeto de purificação e refundação do Islam" (tradução minha).
} 
Ayubi (1991, p.52), que também menciona o mesmo termo e o define como "groups from the larger fundamentalist gatherings, and are usually more radical or militant in orientation" 187 .

Seja como for, o neofundamentalismo de faceta jihadista seria a forma mais moderna de reação do islam político à modernização, ao Ocidente e também às crises econômicas e sociais vividas por parte da comunidade muçulmana. É também a manifestação da passagem do islam ao Ocidente, em particular para a Europa.

Roy (2004 e 2008) apregoa que há o processo de separação entre a cultura e a religião, naquilo que ele denomina como desculturação seguido de um processo de aculturação ou inculturação, isto é, quando busca adaptar-se à cultura dominante e a espaços em sua maioria laicos. O islam e os muçulmanos constituídos como minorias fora de seu país de origem e de seu conformismo social e cultural permitem-se voltar a um islam mais genuíno, em que o indivíduo se liga ainda mais à sua religiosidade proporcionando uma reconstrução da identidade, ou uma “neo-etnicidade”. Para Roy (2004, p.90) “certains auteurs vont jusqu'à valoriser ce passage, faisant paradoxalement de l'émigration un paralèle inversé de la hijra du Prophète: émigrer vers des terres non musulmanes permet de mieux revenir à un islam authentique ${ }^{188,}$.

Tal situação faz com que diversos grupos étnicos quando dispersos, se unam pela religião. A prefeitura de Foz do Iguaçu ${ }^{189}$, nesse sentido, se orgulha em divulgar que abriga mais de 80 nacionalidades, das quais grande parte é de árabes libaneses e muçulmanos de correntes distintas, e que de acordo com a vereadora Anice Ghazzawi ${ }^{190}$, eles se conformam harmonicamente na cidade. Quando a globalização e o atributo da modernidade rompem com o híbrido de religião e cultura, fazendo o marcador religioso se sobressair, o (neo) fundamentalismo toma forma.

É sabido que no islam não há um clérigo, não existe uma figura central que possa comandar os caminhos da religião uma vez que não há mais o califa para conduzir a ummah (comunidade islâmica) ainda que hoje possam existir pseudocalifados como o Estado Islâmico (Daesh) centrado na figura enigmática de Abu Bakr al-Baghdadi. Lewis (2002, p.116) corrobora com este pensamento ao afirmar que "o islam não reconhece nenhuma ordenação, nenhum sacramento, nenhuma mediação sacerdotal entre o crente e Deus. O chamado clérigo

\footnotetext{
187 "grupos das grandes correntes fundamentalistas, e geralmente são mais radicais ou militantes na orientação" (tradução minha).

188 “alguns autores chegam ao ponto de valorizar essa passagem, paradoxalmente tornando a emigração um paralelo invertido da hijra do Profeta: emigrar para terras não-muçulmanas pode retornar melhor a um islam autêntico" (tradução minha).

${ }^{189} \mathrm{https}$ ://bit.ly/2MGkRoT acesso em 02.07.2018.

${ }^{190}$ Entrevistada em 08.07.2015, ela vereadora pelo Partido dos Trabalhadores em Foz do Iguaçu.
} 
é percebido como um mestre, um guia, um estudioso da teologia e da lei, não como um sacerdote". Assim, são os sheikhs ou imames que orientam as comunidades islâmicas locais. A partir do momento em que os muçulmanos deixam seu local de origem para viver em outro país seja como refugiados, sejam como imigrantes ou já como cidadãos daquele novo lugar como resultado de segundas e terceiras gerações, perde-se o quadro de referência cultural e social. A crise de identidade que se produz, cria uma lacuna pela qual se manifesta o marcador religioso. Mas este já não tem mais o amparo da antiga comunidade e de seus "guias".

Todo esse contexto se torna um terreno fértil para uma crise de autoridade já bastante combalida pela ausência de um líder ou uma figura central a exemplo do Papa para o catolicismo, que mesmo assim enfrenta múltiplas dificuldades. A crise se amplia à medida que o islam passa a ser seguido por novos autodidatas da religião, que sem orientação adquirem uma perigosa liberdade de interpretar as escrituras sagradas podendo, em casos mais extremos, em se atribuir o direito de proclamar fatwas ainda que não seja reconhecido na comunidade islâmica. Roy (2002, p.19) confirma esse raciocínio ao dizer que "la crise de l'autorité et la fragmentation qui caractérisent l'islam d'aujoud'hui ne sont pas favorables à la diffusion d'une nouvelle théologie"191.

Roy (2004, p.99) também assevera que essa crise de autoridade, conduit à un phenomène d'autodidactisme et d'autoproclamation, et cette liberte prise avec la tradition comme avec les autorités savantes débouchent rarement sur un discours critique et une recherche de la compréhension, mais plus souvent sur l'affirmation dogmatique de principes intangibles. ${ }^{192}$

A questão do autodidatismo e a autoproclamação como "sábio" do islam repercutem na fala do sheikh Jihad Hammadeh ${ }^{193}$, que considera esse processo um perigo, pois o islam é um só justamente porque tem apenas uma interpretação e muitos

não têm conhecimento, interpretam à sua maneira, sem estudos corânicos. Quem poderia ajudar seriam apenas os sheikhs, os eruditos. Mas como é que o erudito se torna erudito? Com conhecimento. Só que aqui, o conhecimento

\footnotetext{
191 “ a crise de autoridade e a fragmentação que caracterizam o islam de hoje não são favoráveis à difusão de uma nova teologia" (tradução minha).

192 "leva a um fenômeno de autodidatismo e autoproclamação, e essa liberdade, tomada com tradição e com autoridades acadêmicas, raramente leva a um discurso crítico e a uma busca de compreensão, mas mais frequentemente à afirmação dogmática de princípios intangíveis" (tradução minha).

${ }^{193}$ Entrevistado em 29.07.2015 em São Bernardo do Campo na sede da WAMY (World Assembly of Muslim Youth). Ele é vice-presidente da WAMY e líder da comunidade islâmica de São Bernado do Campo. ViceRepresentante da Comunidade Islâmica no Brasil Presidente do Conselho de Ética da UNI (União Nacional Islâmica). A WAMY é uma organização internacional e não-governamental, criada em 1973, com sede na Arábia Saudita. Está a serviço dos muçulmanos em geral e da juventude islâmica em particular, atuando através de uma série de programas sociais, culturais e educacionais.
} 
não é restrito aos eruditos, está aberto para todos. Cada muçulmano tem que ter um sheikh como consultor.

Essa questão também é abordada pelo sheikh Ahmad Abdul que afirma:

O que eu quero dizer pra você, meu amigo, esses grupos radicais que estão no mundo islâmico hoje, por ignorância, não querem ficar com os sheikhs. Eles querem um sheikh deles. Não estudam nada! [se exalta]. Bota barba, pega um pouquinho do Alcorão e procura alguns lugares lá. Olha! Aqui diz que pode fazer jihad! [exclama].

Fica muito evidente nestas falas, assim como de outros sheikhs entrevistados, que não aceitam margem para considerar o islam como diverso, plural e, portanto, passível de diversas interpretações. A manutenção de um islam pétreo e uniforme não condiz com a realidade com a qual nos deparamos.

O Sheikh Jihad ainda acrescenta, especialmente entre aqueles que se tornam jihadistas e constantemente emitem fatwas para justificar seus programas e ataques ao redor do mundo, que elas

são sentenças que só os eruditos renomados e reconhecidos, com bagagem de conhecimento para dá-las. Fatwa de jihad só um grupo de eruditos podem fazer isso. Não é qualquer sheikh ou qualquer pessoa que pode fazer isso. Então tem um nível de fatwas que só um grupo de eruditos renomados é que podem emiti-las. Aí aparece um cara do Estado Islâmico que nunca escreveu, Bin Laden, que nunca li um texto dele sequer, não sei onde ele nasceu, onde ele se formou. Não tem reputação dentro dos eruditos islâmicos, não é reconhecido como sheikh. A fatwa dele nem pode ser lida, nem pode ser considerada.

Concordando com esse raciocínio, o sheikh Abdo Nasser ${ }^{194}$ da Mesquita Omar Ibn AlKhattab de Foz do Iguaçu, diz que "não aceita interpretações que pregam a guerra ou o terror, uma vez que o Alcorão não tem esse objetivo. E quem faz isso, faz uso de versículos isolados fora de contexto para que atendam interesses particulares". Mais uma vez estamos diante da iminência do autodidatismo que pode levar a caminhos perigosos.

Outro informante que mencionou esse assunto é o turco Fatih Ozorpak, ${ }^{195}$ que faz uma crítica aos que distorcem os ensinamentos do islam e aos que se alegam autoridades islâmicas que podem lançar mão de fatwas para promover conflitos. Ele diz:

\footnotetext{
${ }^{194}$ Entrevistado em 07.07.2015 em Foz do Iguaçu na Mesquita Omar Ibn Al-Khattab.

195 Entrevistado em 13.06.2016 em São Paulo no Centro Cultural Brasil-Turquia (CCBT). Ele é diretor do Centro Islâmico e de Diálogo Inter-religioso e Intercultural.
} 
hoje não existe um país que pode declarar guerra para outros muçulmanos entrarem. Então isso praticamente não existe. Uma pessoa que sai e declara guerra em nome da religião, ou seja, guerra sagrada [jihad], ele não tem uma justificativa religiosa. Todo mundo está sabendo disso. E a gente acredita que quando uma pessoa se envolve com esse tipo de atividade [terrorista], a religião manda que ele nunca sairá do inferno. Então existe uma contrapartida desse ponto. Quando uma pessoa vai matar alguém em nome da religião, na verdade ele está enganado ou então voltamos no mesmo assunto de ignorância, falta de ensino e manipulação, que levam as pessoas a praticarem atividades violentas. Eu acredito que muitos que estão envolvidos ou são criminosos, ou são mal orientados, ou drogados. Então ninguém vai se matar na frente de todos, ou seja, a religião proíbe o suicídio. Então, aceitar que uma pessoa vai matar alguém, não tem justificativa [...] E outro ponto muito importante também: a pessoa não fez estudo islâmico, não conhece a vida do profeta, não conhece como vieram as revelações, o que aconteceu e como que veio parar aqui a revelação. A pessoa deve conhecer toda aquela história. Além disso, a tradução do Alcorão não é Alcorão. O árabe é uma língua muito avançada, muito complicada, às vezes uma parte gramatical cria outro sentido. Então a pessoa que vai conhecer a religião dessa maneira, é impossível. Alguém vai falar que a religião islâmica é extremismo. Precisa de uma pessoa que entenda o Alcorão. Alguém que tenha uma habilitação. Da mesma forma: você vai para um médico não habilitado? Ele vai matar você! Nós temos um ditado em turco que diz: 'desabilitado um médico que tira sua vida, desabilitado um sheikh que tira sua outra vida'. Então, dessa maneira nós precisamos ter muito cuidado $[\ldots]$.

Eu complemento empregando a palavra autodidatismo, algo que é confimado pelo prof. Fatih, que continua:

você vê uma pessoa que não lê, não estuda, só de falar o que ele está ouvindo, ele é a pessoa mais perigosa de todos. Então a religião não tem problema, os muçulmanos têm culpas. Em outro artigo que foi dado pelo Sr. Gulen, diz que os muçulmanos precisam, necessitam, devem fazer autocrítica. Por que nós estamos chegando nesse ponto? Como isso aconteceu? Porque um muçulmano que as pessoas estão vendo, estão colocando no lugar de um terrorista. $\mathrm{Ou}$ seja, se você falar para qualquer pessoa, fecha seu olho, imagina um muçulmano e ele vai ver Osama Bin Laden ou Baghdadhi. 
Como exemplo disso, em seguida o sheikh Mohammed Khali1 ${ }^{196}$ cita a seguinte passagem do imam Ali.

certa vez teve um problema muito grande na história islâmica quanto a um grupo de rebeldes, Muawiya e seus simpatizantes. O Imam Ali chegou para a nação islâmica inteira e entregou para ele o poder. Mas milhares foram à casa de Ali e se manifestaram democraticamente a favor dele, pedindo para ele assumir o poder, por isso ele ser o $4^{\circ}$ califa. Mas $1 / 4$ do mundo islâmico estava em Damasco e quem estava lá era Muawiya, e pediu para ele desistir. E fez uma guerra contra Ali. Ali mandou seu primo e ministro para conversar antes das batalhas para pelo menos explicar algumas coisas. Ali recomendou ao seu primo Abdullah: 'ô meu primo, não utilizo o sagrado Alcorão nos teus argumentos, nas tuas provas contra eles, porque o sagrado Alcorão tem a possibilidade de ser interpretado de maneiras diferentes'.

Por fim, com relação à interpretação do Alcorão, Mustafa Goktepe ${ }^{197}$ também afirma que não deve haver múltiplas interpretações para o Alcorão. Elas são pétreas. A questão é saber adequar as escrituras ao contexto histórico que é mutável. O grande complicador para ele é que essas interpretações, ou melhor, não devem prescindir da existência de um sábio, de alguém com grande conhecimento do islam. Ele explica:

Tem a realidade de 1400 anos e tem a realidade de hoje. Como na nossa crença o islam é a última religião, não tem uma adaptação, uma interpretação para hoje, para amanhã, para sempre, vamos dizer. Você colocou bem o dedo. Muitos interpretam. Mas não são só imames, pessoas [leigas] também. Até imames interpretam. Não deveriam, não podem".

Então eu questiono se não há problema com o fundamentalismo, isto é, no sentido de ler o "fundamento" da religião. Mustafá responde:

isso é errado! Pode ler, mas não pode agir com o que leu lá. Até árabe, mesmo que a língua do Alcorão seja árabe. Porque não é só a língua o negócio. O negócio é o conhecimento total. Inclusive a fé. Tem também uma expressão interna. Você ser muçulmano não é só "nasceu dos pais, ler o corão, falar árabe”, não é isso. É essa série de fatores que falta em muitas pessoas que orientam muçulmanos, que fazem com que as pessoas interpretem dessa forma, inclusive os sheikhs. E todos eles acham justificativas pelo que fazem. Todas acham, justamente por falta de conhecimento, por falta dessa

\footnotetext{
${ }^{196}$ Entrevistado em 08.07.2015 na Mesquita Xiita Imam Al-Khomeini de Foz do Iguaçu.

${ }^{197}$ Entrevistado em 13.06.2016 no Centro Cultural Brasil-Turquia (CCBT). Mustafá Goktepe é presidente do CCBT.
} 
atualização, na própria vida, na própria consciência, formação, conhecimento, inspiração, podemos dizer tudo isso. O fundamentalismo é para se fundamentar no Alcorão. Justamente é o que eles fazem. Mas eles entendem ao pé da letra, literalmente! Mas não é isso, porque aquilo não são simplesmente palavras, como alguém qualquer escreveu. Você tem uma realidade de 1500 anos, tem a realidade de lá, porque se eu não precisasse de interpretação, não precisaríamos de profeta! [se exalta]. Deus simplesmente deixaria o Alcorão e todo mundo leria e interpretaria. Aí sairia uma religião por cabeça. O profeta viveu 23 anos durante a revelação para interpretar da forma que Deus mandou. A vida do profeta, as palavras dele, justamente são a interpretação completa do Alcorão sagrado. O que ele fez justamente é o que era a palavra naqueles tempos, para aquela realidade. No [Império] Otomano teve um bom tempo que tinha pessoas que poderiam interpretar. Tivemos quase três séculos completos com total tranquilidade na representação do islam muito bem feito e com admiração total do mundo muçulmano e inclusive um envolvimento muito grande com a Europa, com os ocidentais. Até meados de 1800, talvez século XVII, mas isso não existe hoje. Tem pessoas, logicamente, que possam interpretar, ler, atualizar, só que o efeito deles é limitado, porque uma ação dessas, um muçulmano mal interpretando, mata 50 pessoas num bar. O Fethullah Gulen tenta fazer já há 40 anos um islam moderado como a gente vive aqui e apresenta um islam, não vou dizer pacífico, pois o islam já é uma religião pacífica como qualquer outra religião na realidade. $\mathrm{O}$ islam moderado, o islam atualizado ou interpretado para esse tempo vivido por milhares de pessoas, talvez milhões de pessoas, como meus amigos aqui e em muitos lugares do mundo, mas o efeito disso é demorado.

O perfil dos sheikhs entrevistados indica o fechamento da ijtihad aos leigos, que pouco conhecem ou estudaram o Alcorão e demais fontes, concentrando nas autoridades religiosas o dever de orientar os fiéis e em algumas universidades teológicas a missão de formá-los. Se por um lado a difusão do autodidatismo é vista com perigo pelo risco de interpretações equivocadas e até mesmo convenientes para certos fins e grupos, por outro, a exclusividade da interpretação caber apenas aos sheikhs e imames culminaria em uma possível doutrinação.

Um pouco disso foi percebido nas falas de alguns fiéis que entrevistei, cujas respostas e reflexões convergiam sobre os mais diversos assuntos, especialmente quanto ao cenário internacional, as ingerências de países ocidentais no Oriente Médio e sobre a mídia brasileira e internacional no trato para com os muçulmanos. Como exemplo dessa convergência de opiniões, acerca do Estado Islâmico e de violência ligada a grupos extremistas, Issa, refugiado 
sírio em Campinas/SP, alega que a "América paga 1 milhão de dolars para terroristas...1 milhão! vai parar na mão de terroristas".

Além da fala dele, é possível destacar certas falas de alguns dos entrevistados:

a) Khouloud El-Birani ${ }^{198}$ :

eu canso de dizer: eles não nos representam! Como alguém que decapita um ser humano vai ser muçulmano? E os árabes muçulmanos que estão decapitando? Quem formou esses grupos são países que têm interesses políticos. Esses grupos não são islâmicos, quem financiou são os Estados Unidos, Israel. Porque a religião não ensina isso! O PCC representa o Brasil? Então o Estado Islâmico não representa os muçulmanos.

b) Sheikh Jihad Hammadeh:

quem deu essa representação para eles? Não podemos ser simplistas e ver com o olhar do senso comum. Nem tudo o que a mídia passa pra mim eu tenho que aceitar. Eu tenho que analisar primeiro. Primeiro: quem deu notoriedade pra essa minoria? Quem deu voz a ela e quem deu essa representatividade? Foram os muçulmanos? [Pausa]. Quem os colocou como representantes? Quem divulgou o nome de Estado Islâmico? Você ficou sabendo através de quem? Através de mim? Através dos muçulmanos? A mídia é uma mídia islâmica ou ocidental? Agora eu pergunto [pausa]: primeiro, quem escolheu o Estado Islâmico, esse nome? Porque ele é um nome estratégico. Segundo, porque tudo isso eu tenho que analisar como senso crítico, eu tenho que analisar de forma detalhada - essas armas vêm de onde? A roupa que eles usam, quem as costura? Quem faz as produções hollywoodianas deles? As facas são do mesmo fabricante [que eles degolam as pessoas], quem me garante que não é um grupo, como era conhecido antigamente, a Legião Estrangeira, de contratar essas pessoas que estão vindo da Europa, dos outros lugares. Onde eles estão embasados para matar tanta gente e matar principalmente muçulmanos [pausa]. De onde vem o dinheiro deles? Nós não podemos absorver o que a mídia diz e ficar por isso mesmo, como sendo uma verdade. Existem muitas verdades por trás disso. Por exemplo: a fonte de riqueza deles, de onde vem? Ok, da venda de petróleo...muito bom...e esse petróleo está indo para os países através de quem, de qual meio? Petroleiros, oleodutos, galões, virtualmente? Ok, conseguiram levar esse petróleo. Mas como estão recebendo pagamento? Através de qual banco? São questões que eu gostaria

${ }^{198}$ Famarcêutica e secretária geral da Escola Árabe-Brasileira de Foz do Iguaçu. Escola que ocupa o mesmo terreno da Mesquita Omar Ibn Al-Khattab. 
de saber. Coisas simples! Bem arcaicas! Vamos pegar essas contas e bloquear!!! [Se exalta]. Essas contas estão onde? Quando eles compram armas, eles compram de quem? Quem é o fabricante daquelas armas? Todos os soldados tem a mesma altura, não tem gordo, só tem magro. Aí você olha e se pergunta: esses são os árabes? [pausa] Que eu saiba os árabes tem de tudo, careca, baixinhos, gordinhos [risos].

c) Sheikh Mohammed Khalil:

Então, vamos dizer, o Estado Islâmico é um estado ligado $100 \%$ às inteligências dos países que têm benefícios no oriente médio, sejam econômicos, políticos e de segurança também. A Turquia tem um papel, Israel tem outro papel, Arábia Saudita e Qatar são os que detém poderes econômicos e esses dois últimos ideologicamente ligados ao wahhabismo. Esses grupos não representam a comunidade muçulmana.

d) Sheikh Abdul Nasser: "eles não apresentam o espírito da religião, não representam a nação islâmica, não representam os muçulmanos. São grupos estranhos, talvez criados por serviços de inteligência...pode ser americana ou outra qualquer”.

e) Nader 199: “os americanos patrocinam, deram treinamento para eles na Inglaterra, providenciaram armas e os britânicos treinaram".

Muitos podem achar que essa visão padronizada seja um sintoma do fundamentalismo porque é alienante. O sheikh Abdul Nasser entende que o termo fundamentalismo islâmico soa como pejorativo, pois está associado sempre à violência.

Alternativamente, o sheikh xiita Mohammed Khalil apesar de concordar com a afirmação acima, faz uma ressalva apontando que isso pode induzir a um erro, pois para ele “quando Deus deixou o texto, deixou também ao ser humano fazer uma conclusão do islam". Nesse caso, existe a possibilidade de uma abertura à ijtihad, mas condicionada ao estudo das escrituras orientada pelos sheikhs e imames.

Quando entrevistei o sheikh Jihad Hammadeh, também procurei saber sua opinião sobre o assunto e o instiguei ao mencionar se o discurso daqueles que acusam os muçulmanos de fundamentalistas é justamente devido à separação entre fé e Estado, religião e ciência, ou apenas sobre a questão envolvendo a forma de interpretar o Alcorão. Nesse caso, perguntei se haveriam outras possibilidades para definir o fundamentalismo, ou seja, ele é a leitura literal das escrituras ou a pessoa é fundamentalista porque ele deixou de ser secular e se voltou exclusivamente à sua religião.

\footnotetext{
${ }^{199}$ Secretário da Sociedade Islâmica de Campinas/SP.
} 
O sheikh então explica que na primeira visão, da leitura literal,

se você não for fundamentalista, automaticamente você é fanático. Significa o quê? Por que o fanático se torna fanático, extremista? Porque ele não segue os fundamentos da religião! [E a voz se altera]...que é a paz, o amor a Deus, seguir a Deus, então ele se torna, porque ele vai seguir a opinião dele, o entendimento dele e não mais o entendimento que Deus quer colocar. Então ele largou o fundamentalismo, o fundamental da religião e ele se tornou um pecador. Então se ele não segue os fundamentos da religião, ele não é religioso! Nem fundamentalismo e nem radical são palavras ruins. O que é ruim? Extremismo e fanatismo. Isso é que nós temos que usar. Agora, na outra visão da separação entre ser religioso e não ser é uma ideia errada da religião. Pelo contrário. Se eu sou fundamentalista, eu tenho que ter essa visão equilibrada entre razão e fé, entre o secular e o religioso, porque eu não vivo só no religioso e eu não vivo só no secular. Eu vivo nos dois. Quando eu estou na mesquita, eu tenho valores islâmicos. Quando eu saio da mesquita eu não tenho mais valores islâmicos? Quais são os valores islâmicos? Ser honesto, ser uma pessoa correta, solidário, ser respeitoso, incorruptível [pausa]. São valores religiosos. Quando eu sou presidente, quando eu sou ministro, deputado, político, comerciante, empresário, gari, eu deixei esses valores na mesquita? Por que eles só fazem parte da minha fé? Eu me isolei deles? Eu tirei a camisa da honestidade e agora eu sou secular? Ou o secular também fala para ser honesto? Esse indivíduo que é dentro da mesquita, se ele esetá se lapidando como pessoa, esse benefício será visto, será distribuído e terá frutos na sociedade secular

Esse trecho é bastante enriquecedor, pois traz elementos que também ajudam a definir o que é ser fundamentalista, aquele que segue rigorosamente os valores e princípios religiosos ao mesmo tempo em que tenta descolar a palavra daqueles que usam a religião para práticas violentas, terrorismo. Então ele sugere dois termos como o fanatismo e o extremismo. Fundamentalista e radical não seriam problemas, pois significam na visão dele, os fundamentos, a "raiz" da religião.

Argumentei com ele que muitos muçulmanos de grande influência entre os "extremistas", para usar a denominação por ele sugerida, veem que o secularismo, baseado na separação igreja e Estado, não é compatível com o islam. Sobre isso, Jackson (2006, p.192) lembra que

in Mawdudi's writings, the term employed to translate "secular" in fact literally means 'religionless': he believed that a secular society, such as was 
envisaged for an independent India, would really be an oppressor of minority groups (i.e. Muslims) and partisan towards the religious majority (i.e. Hindu $)^{200}$.

Mas a visão do sheikh é mais aberta à sociedade secular. Para ele, os valores religiosos são compatíveis com a vida secular e afirma:

de novo vamos voltar à análise simplista do Ocidente quando ele fala sobre isso. Então quando se diz sobre separar a religião do que é secular, do que é a ciência, aqui é a falta do entendimento da religião de novo. Porque está se julgando o islam a partir de uma ideia que se tem do cristianismo, da igreja. $\mathrm{O}$ que eu percebo é que o Ocidente ele ainda...ele saiu de um extremo e caiu em outro extremo...ele está precisando buscar o equilíbrio. Saiu da extremidade de uma fé, totalmente contrária à ciência, para ir para a ciência totalmente contrária à fé. E não estão conseguindo se entender e não vão se entender enquanto não juntar esses dois. O ser humano ele não é feito só de um nem só do outro. Nós somos feitos de fé e de ciência, de teoria e de prática, de oculto e de presente, de algo factível. Por exemplo, a alma e o corpo. Eu toco no corpo e não toco na alma! Você pode discutir 300 mil anos aqui e a gente não vai chegar numa solução sobre o que é a alma, mas sobre o corpo a gente chega em dois segundos. Corpo é isso [e aponta para uma parte do corpo]. E a alma? Onde está? A alma é fé. Inteligência? Eu quero tocá-la, eu só acredito vendo. Onde está a minha inteligência? Coloque na palma da minha mão! Conhecimento? Eu vou ter que acreditar, vou ter que ter fé que existe. Nem tudo que eu não vejo, não quer dizer que não exista, então imagine: que falase de uma religião - eu tiro de você, de qualquer pessoa que esteja ouvindo essa conversa amanhã - ah, os muçulmanos terroristas gostam de matar, degolar e tal, e não sei o que lá [exclama]. Tudo bem, mas por que falam tanto desses muçulmanos e ao mesmo tempo é a religião que mais cresce no mundo? O que acontece? "Sabe de uma coisa? Eu vou parar, vou dar uma lida. Já estou com ódio desses muçulmanos. Eu vou ler para buscar mais informações a respeito desse bando de fanáticos". Aí ele começa a ver essa conversa nossa, e fala: "calma aí! O que é isso? Como assim? Não é lógico? No mínimo vai provocar uma reflexão. Você tem o muçulmano como bicho-papão e de

200 "Nos escritos de Mawdudi, o termo empregado para traduzir secular, significa literalmente "sem religião: ele acreditava que uma sociedade secular, como a que seria prevista para uma Índia independente, seria realmente um opressor de grupos minoritários (isto é, muçulmanos) e partidários em relação à maioria religiosa (ou seja, hindu). (Tradução minha). 
repente você conhece um muçulmano, ele sorri pra você e você fala: "mas o bicho não é tão feio assim não".

A prova de que o termo fundamentalismo é muitas vezes confundido com radicalismo, mas em um sentido pejorativo, foi quando tive contato com um refugiado sírio chamado Alaa el-Deen e pude perguntar sobre sua visão acerca desse assunto. Intermediado por Nader, secretário da Sociedade Islâmica de Campinas que ajudou com a tradução, Alaa - como prefere ser chamado - afirma que "não pode generalizar. Nem todo muçulmano é radical. Não gosto e não aceito, eles são minoria".

A primeira impressão é que não passou em sua mente o sentindo da leitura estrita, como se costuma pensar, mas que o fundamentalismo se liga ao jihadismo e à violência, atribuindo um sentido negativo ao termo. Isso vai de encontro com a assertiva do sheikh Jihad, para quem fundamentalismo e radicalismo não são ruins. Eis como esses conceitos, até mesmo por suas eventuais traduções, são difíceis de serem classificados de forma objetiva.

O sheikh Mohammed Khalil ${ }^{201}$, faz um alerta com relação às traduções. Ele diz: não recomendo dar o sagrado Alcorão traduzido para qualquer pessoa. Porque o sagrado Alcorão é um código! Como um código da justiça, vamos dizer assim, um código de direito. Se você não é especialista não vai compreender. Ao contrário, vai compreender ao contrário. Vai compreender coisas erradas do islam.

O termo fundamentalismo implica em muitas formas de interpretação. Com elas, surgem novos termos, que como uma matrioska russa, se abre em outros novos sentidos até que corremos o risco de perder o fio inicial desse intricado novelo. Trata-se de um conceito que parece mudar suas características para se adaptar ao meio e aos seus contextos para sobreviver, mas que estando em mãos erradas, pode tomar uma forma mais agressiva.

À medida que o tempo passou até o advento do período da globalização e suas modernas formas técnicas, científicas e informacionais, a popularização do fundamentalismo como algo a ser combatido, pois incompatível com o modo de vida orquestrado pelo secularismo, pela ciência e democracia, contamina e estereotipa não só o termo, mas os grupos para quem o fundamentalismo é apenas uma forma de seguir a religião como um código de conduta, mas sem excluir outras possibilidades de convivência. $\mathrm{O}$ fato de o fundamentalismo possibilitar diferentes nuances de interpretação provoca uma confusão no entendimento dos próprios muçulmanos e dos autores que se esforçam em explicar esse fenômeno mutante.

${ }^{201}$ Sheikh xiita da Mesquita Imam Al-Khomeini. 
Da simples e mera leitura literal das escrituras, passando pelo quietismo salafista e seu extremismo jihadista, até o chamado neofundamentalismo que seria a resposta mais recente ao período em que vivemos, marcado pelas crises identitárias, o geógrafo francês Claude Raffestin (1993, p.124) oferece um ponto de vista em que

as grandes religiões são aquelas que conseguem controlar porções importantes do invólucro espaço-temporal das coletividades. Pode-se afirmar que sejam relações religiosas puras? Não, de fato essas relações estão subentendidas por relações políticas e é sem dúvida nisso que a relação sagrado e profano alcança todo seu valor. Valores profanos e valores sagrados, valores religiosos e valores políticos estão em estreita relação.

Desse modo, o fundamentalismo apesar de seu genótipo plural, possui um gene que sugere uma relação de poder entre a coisa divina e a coisa humana, reforçando a tese de Armstrong (2009) do mythos e logos que permeou parte das discussões desse capítulo. Os debates sobre o ijtihad, a livre interpretação dos textos islâmicos, e se ela deve estar aberta a todos ou restrita aos líderes das comunidades islâmicas, também podem subjazer às relações de poder. De um lado, caso esteja aberta à livre interpretação, pode formar um perigoso autodidatismo que justifique determinados objetivos escusos. Por outro, enquanto monopolizada pelos sheikhs e imames, pode incutir em seus fiéis visões de mundo coniventes com seus interesses, além da possibilidade de forjar e disseminar teorias conspiratórias que envolvem o islam, a geopolítica do Oriente Médio e o mundo muçulmano de forma geral. Por fim, devemos considerar que o ijtihad também pode oferecer leituras mais progressistas ainda que sejam pouco aceitas pelos líderes religiosos em muitos casos.

Em todos os casos, essa microfísica do poder está embutida sejam quais forem os caminhos. Assim como o islam não é único e monolítico, também o é o fundamentalismo. Se o fundamentalismo é difícil de ser definido em poucas linhas, talvez seja mais fácil encontrar outro denominador comum ao se referir aos muçulmanos de forma geral para que não sejam todos uniformizados segundo determinadas visões, especialmente aquelas produzidas pela mídia tanto nacional quanto internacional.

\subsection{Ensaios de uma genealogia do islam político}

Se antes era possível delinear três grandes caminhos ou respostas à modernização, secularização e ocidentalização do mundo, especialmente o muçulmano, sejam elas o tradicionalismo, que procurava o isolamento e a repulsa a tudo que era estranho ao islam; o modernismo, que ensaiava conciliar a ciência e a fé, aceitava apêndices externos à religião 
desde que não ferisse alguns de seus preceitos; e o fundamentalismo, a corrente que politiza a religião, se apropriando de instrumentos e meios modernos para fazer deles a condição de sua resistência aos valores ocidentais, agora, contudo, esse termo apresenta outras designações que para alguns autores são tratados como sinônimos e por outros como novas denominações com características e perfis diferentes.

Inspirando-se em Demant (2008) que elaborou uma genealogia do islamismo, apontando as principais correntes e grupos com seus respectivos líderes e países, serão feitos alguns apontamentos sobre determinados autores que em suas obras lidaram com a questão do fundamentalismo e seus correlatos e a forma como organizam esses conceitos. Serão apresentados diagramas que contemplarão os termos mais utilizados por seis importantes autores: Olivier Roy, Bassam Tibi, Nizah Ayubi, Malise Ruthven, Peter Demant e Ian Buruma e Avishai Margalit. O intuito é mostrar as correlações feitas entre certos termos usados. Em um momento posterior serão discutidas suas devidas qualificações e definições.

O primeiro caso é de Olivier Roy. Com base em três de suas publicações, " $L$ 'échec de L'Islam Politique" (1992), "L'Islam Mondialisé" (2004) e "La Sainte Ignorance" (2008) foi possível traçar o seguinte diagrama.

\section{Diagrama 5 - OLIVIER ROY}

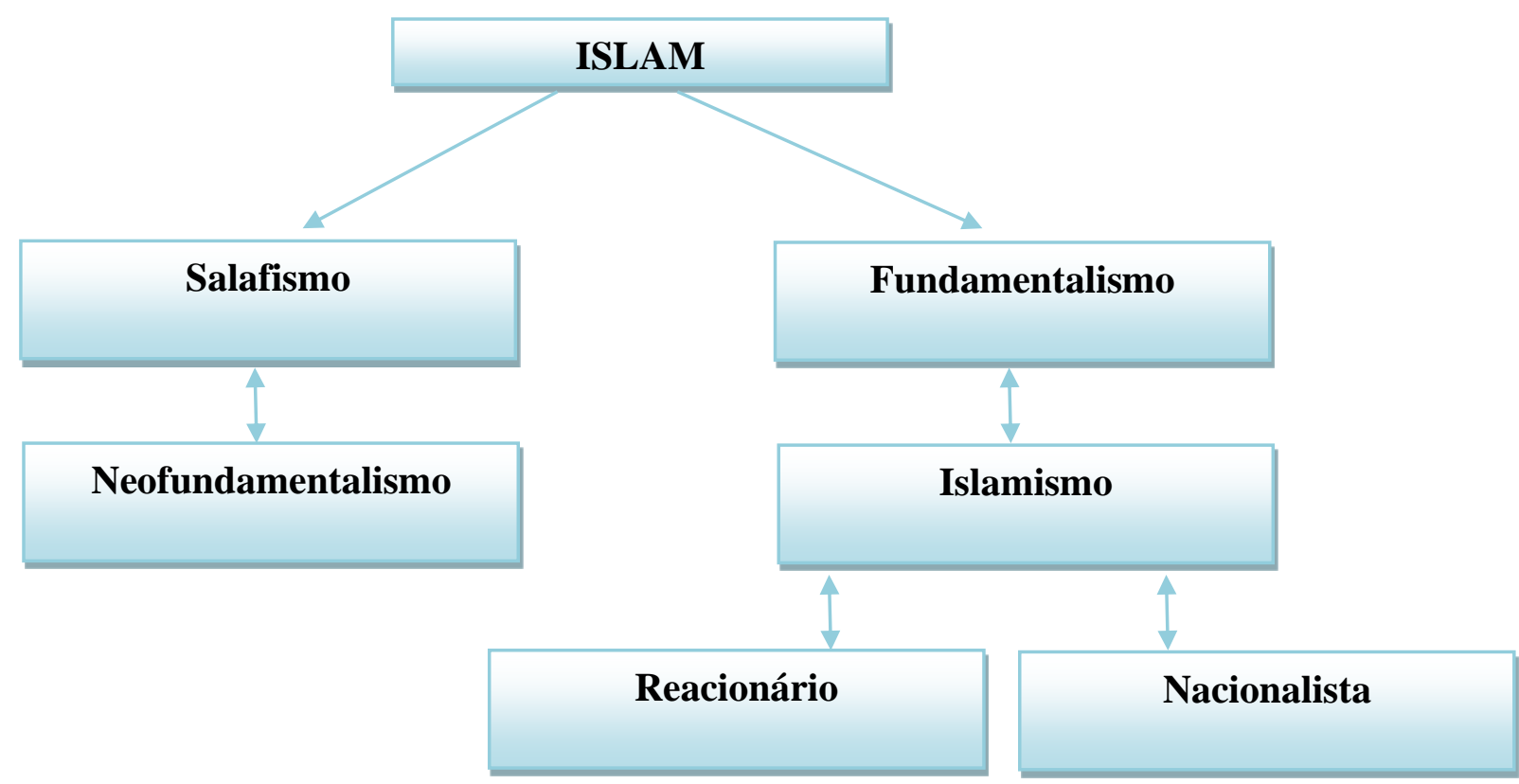

Nota-se que o autor faz uso de seis termos, dos quais "salafismo" e "neofundamentalismo" tem uma correlação mais estreita, enquanto "fundamentalismo" e “islamismo" são aparentemente sinônimos, mas situam-se em lados díspares, apontando para características diferentes daqueles na coluna esquerda. Observa-se que do termo "islamismo", há ainda duas vertentes que especificam ainda mais a corrente fundamentalista. Outra questão 
que se coloca é quanto ao nacionalismo. Ainda que certos islamistas combinem islam com nacionalismo, a exemplo do Hamas palestino, a princípio esta é uma ideologia secular.

A dúvida que resta e que tentaremos mitigar posteriormente é quanto às diferenças entre o fundamentalismo e o neofundamentalismo. Uma seria o desdobramento da outra? Quais as nuances desse caso? Que critérios foram usados para essa divisão?

A situação abaixo retrata a posição de Bassam Tibi em seu livro "Islam Between Culture and Politics" de 2001.

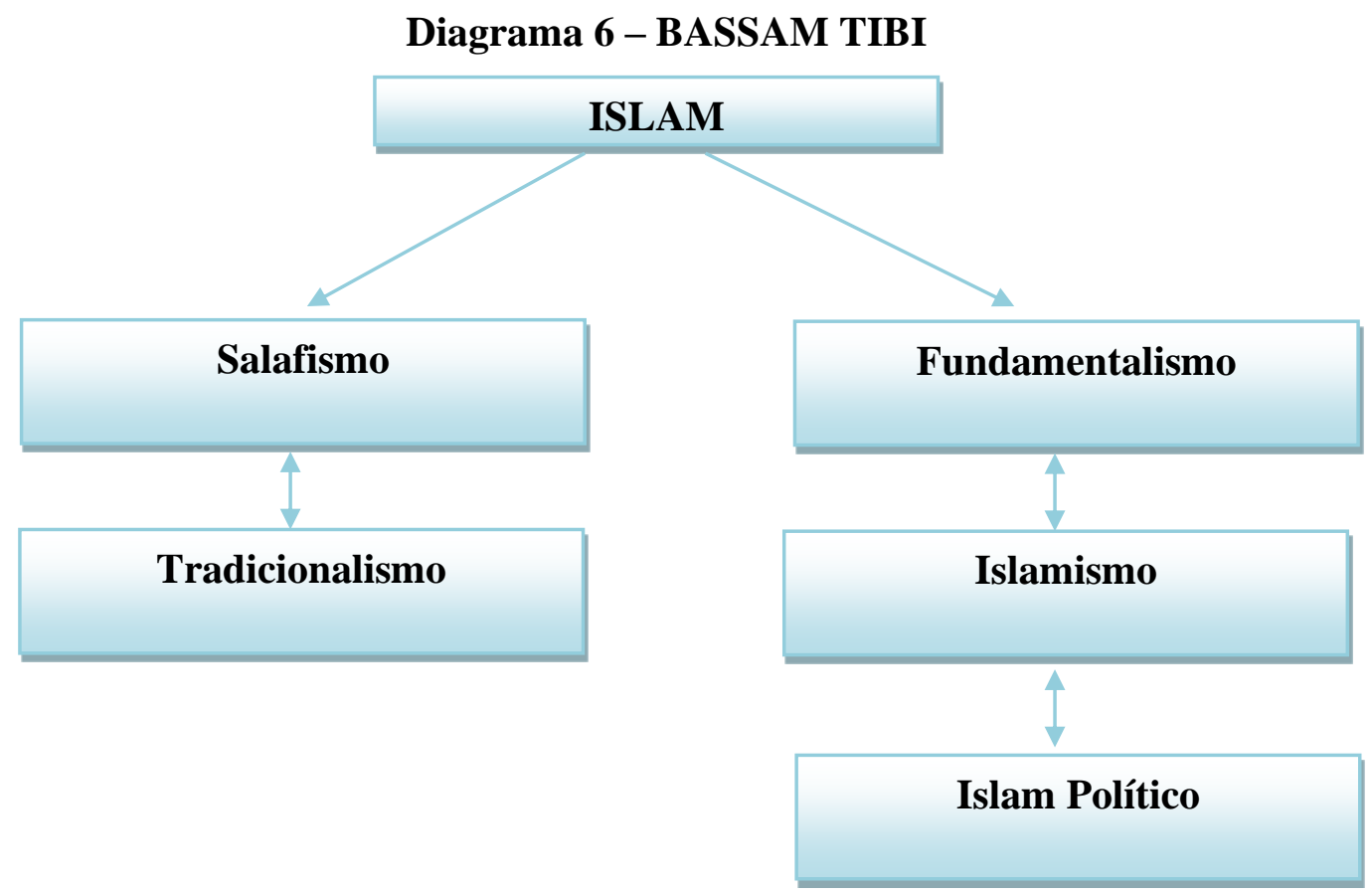

Aqui já é possível notar algumas diferenças para Olivier Roy. "Salafismo" é tratado como sinônimo de "Tradicionalismo", que por sua vez difere de "Fundamentalismo", "Islamismo" e "Islam Político", todos com a mesma característica. Fica claro que o componente político denota um engajamento e um ativismo mais amplo que a vertente à esquerda, que pressupõe um maior afastamento das esferas estatais e dos possíveis usos tecnológicos pela comunidade em questão. Aqui se encontram duas respostas claras de como a comunidade islâmica, no ponto de vista desse autor, se porta de modo geral.

Continuando com essa breve demonstração terminológica dos diversos autores, o próximo é Nazih Ayubi a partir do livro "Political Islam, Religion and Politics in the Arab World" de 1991. 


\section{Diagrama 7 - NAZIH AYUBI}

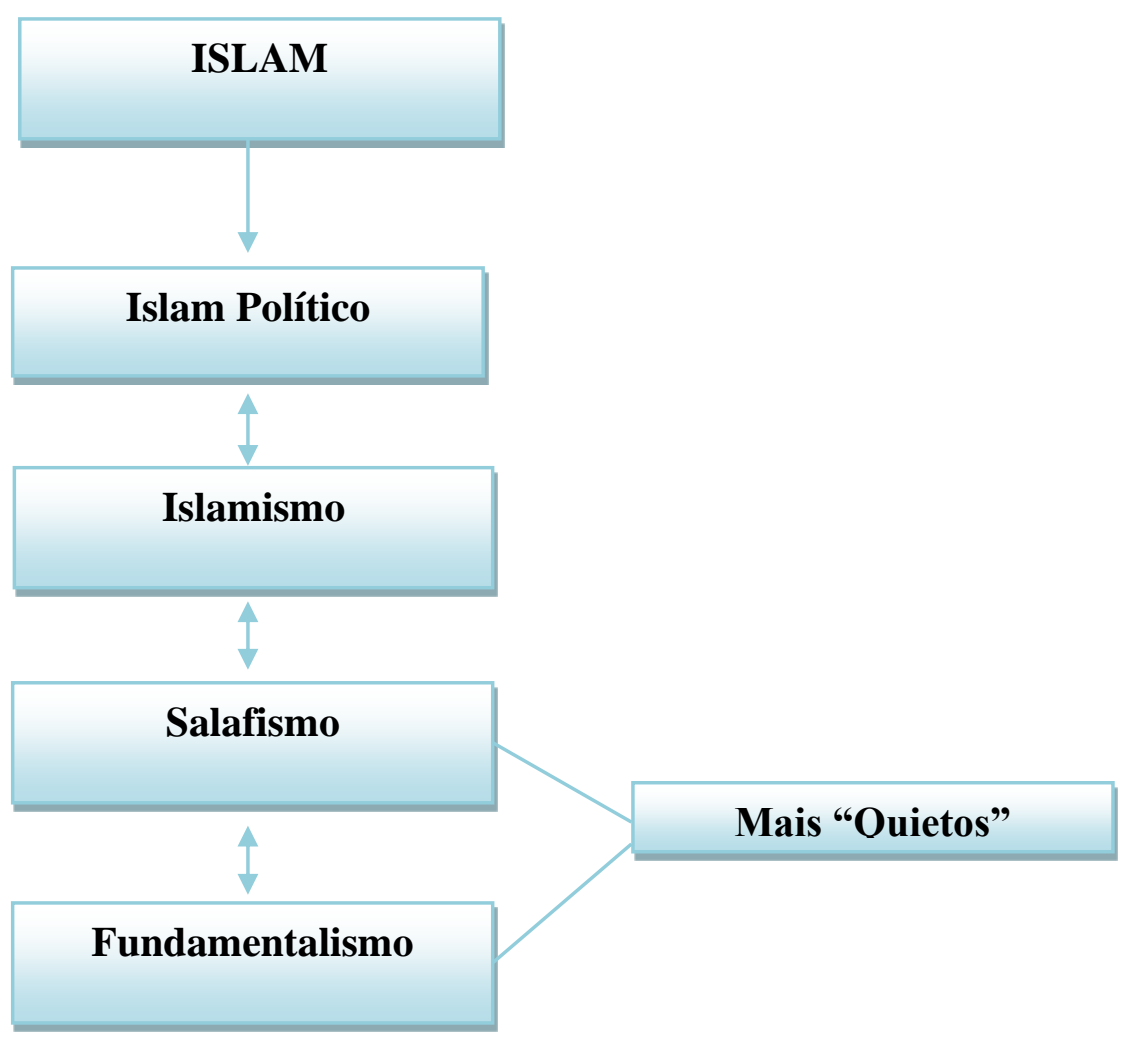

Como se percebe, esse diagrama mais linear indica que o autor aceita que os diversos termos sejam lidos como pertencentes à mesma categoria de conceitos. A diferença a ser ressaltada é que os salafistas e fundamentalistas seriam mais "quietos", menos engajados politicamente e mais avessos aos aspectos da modernidade e do Ocidente que seus "irmãos" islamistas políticos, para quem a transformação da sociedade islâmica deve passar pela política e muitas vezes pelo enfrentamento. Aqui, portanto, há um ponto que converge com o raciocínio de Bassam Tibi.

Malise Ruthven apresenta uma proposta mais enxuta em seu livro "Fundamentalism: the search for meaning" de 2005, conforme podemos ver no diagrama abaixo.

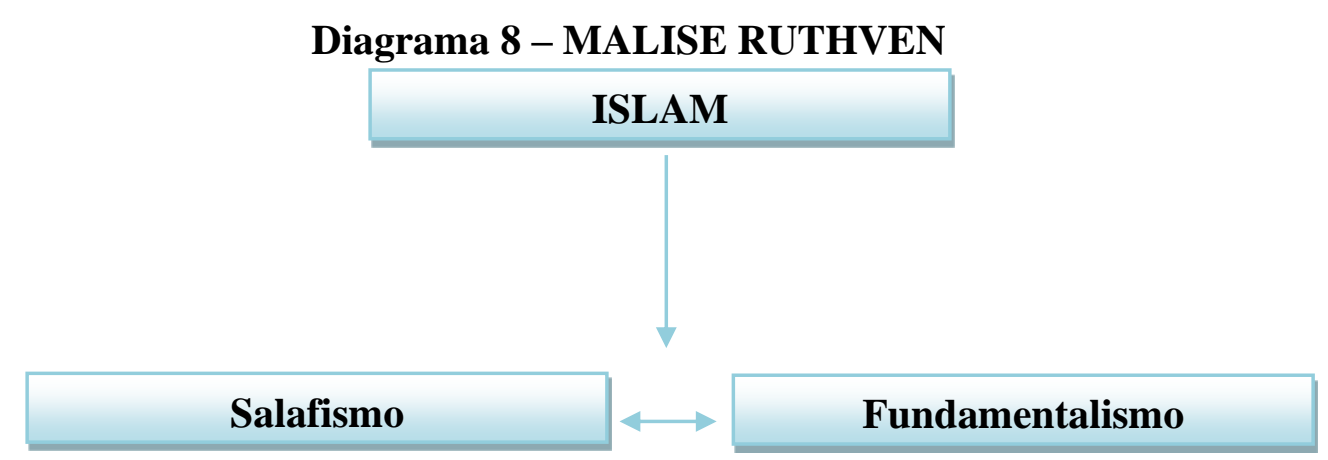

Para o autor, o fundamentalismo e o salafismo seriam faces de uma mesma moeda uma vez que em árabe a palavra salafi existe e possui um significado enquanto fundamentalismo não 
é usual nesse idioma. Mas, partindo do pressuposto que salafis são aqueles que buscam o retorno ao islam "original”, o fundamentalismo se não carrega o mesmo conteúdo, como para muitos autores, pelo menos tem suas origens e influência no salafismo. A princípio, essa relação fica mais nítida em Ayubi (1991) para quem os termos se equiparam, mas possuem um sentido menos ativista.

Baseando-se no livro "O mundo muçulmano" de autoria de Peter Demant, a primeira edição publicada em 2004, identifica-se a seguinte ideia.

\section{Diagrama 9 - PETER DEMANT}

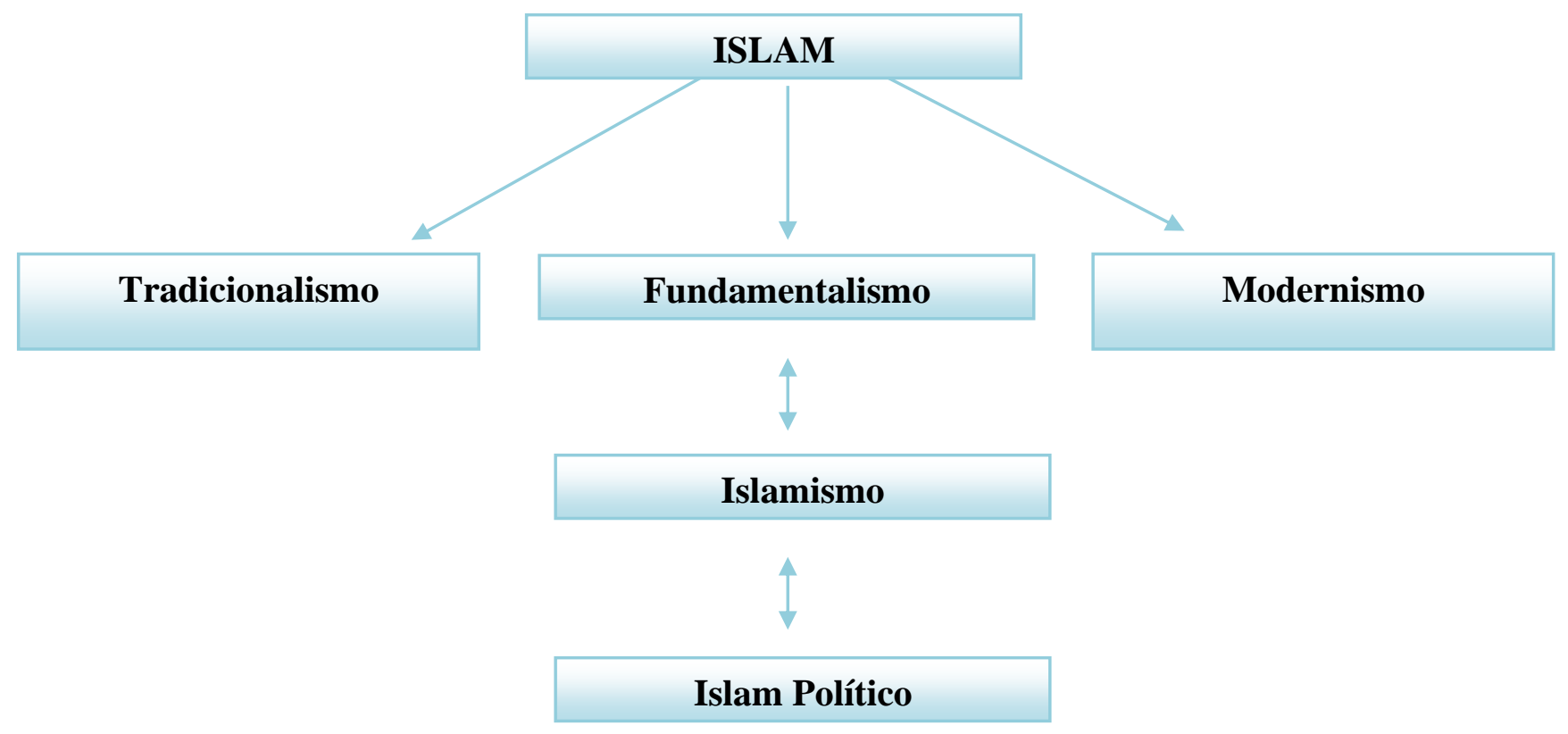

Indo ao encontro do raciocínio de Bassam Tibi, para o autor, o ponto central na correlação entre fundamentalismo, islamismo e islam político é o ativismo de certos grupos contra a modernidade, o Ocidente, o secularismo, a laicidade dos Estados e em muitos casos ao culto ao nacionalismo. Paralelamente, ainda há o tradicionalismo que poderia estar associado ao salafismo, como uma resposta igualmente antiocidental e antimoderna, mas sem o enfrentamento e engajamento dos fundamentalistas. Por fim, o modernismo seria uma vertente que busca estabelecer laços entre a religião e a ciência, aceitando elementos da modernidade sem abandonar os preceitos islâmicos, que agora "justificam" e "legitimam" as conquistas da ciência.

Por fim, Ian Buruma e Avishai Margalit em "Ocidentalismo: o Ocidente aos olhos de seus inimigos" de 2006, título que nos remete à lembrança do "orientalismo" de Edward Said, nos permite traçar o seguinte perfil. 


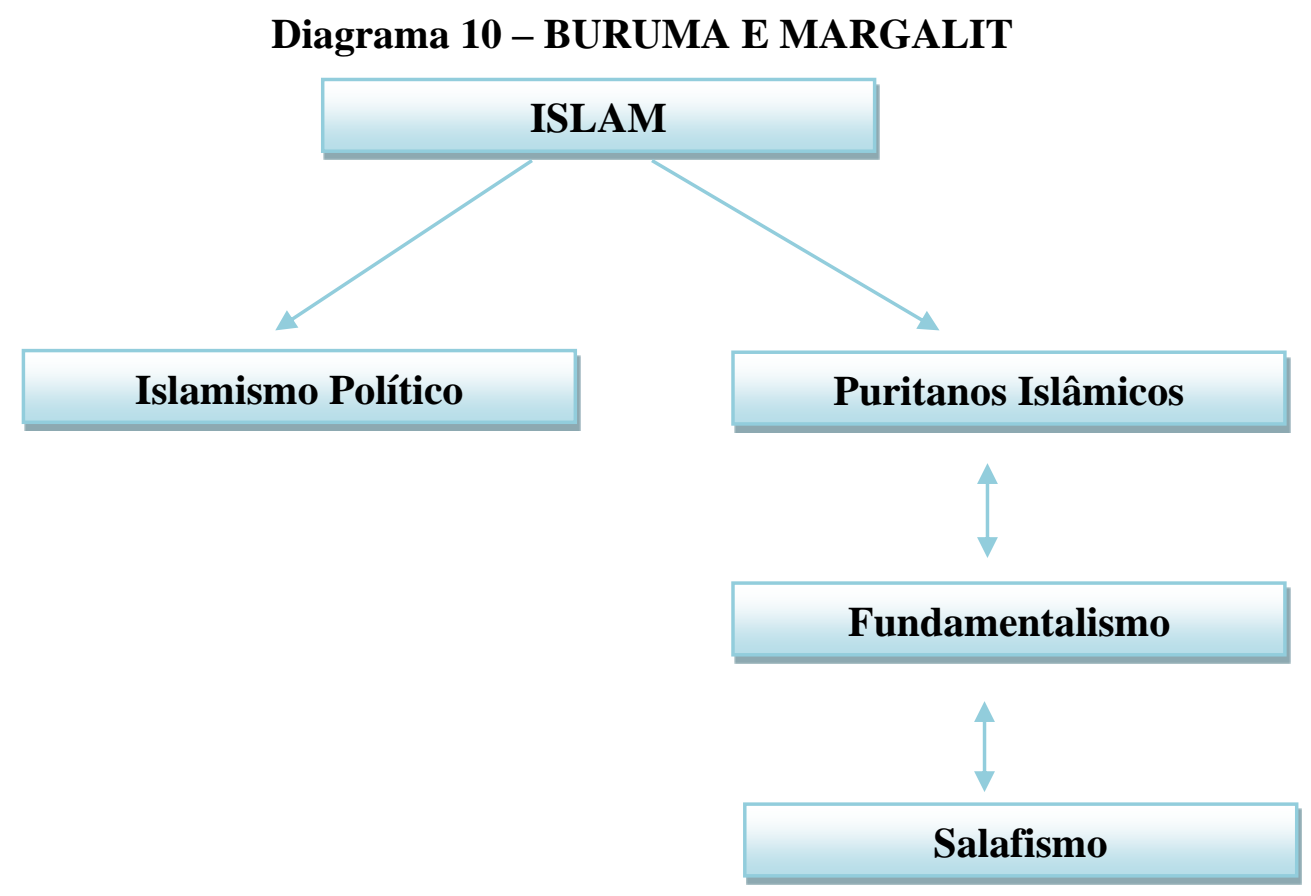

Diferentemente de Peter Demant, o "islamismo político", algo que soaria como redundante para esse autor visto que o islamismo é político, se distingue do fundamentalismo. Enquanto o primeiro termo reflete o ativismo político, o segundo se identifica com o "quietismo", que também se apresenta como uma característica do salafismo e do puritanismo islâmico, leitura, aliás, muito parecida com a de Nazih Ayubi. Enquanto os assim chamados puritanos islâmicos - fundamentalistas - salafistas se preocupam com a moral e a preservação dos costumes, os islamistas políticos têm como projeto a edificação de estados islâmicos para a imposição da sharia e na conversão, de "cima para baixo", dos "domínios de guerra" (Dar alHarb) em “domínios de paz” (Dar al-Salam).

Sintetizando as múltiplas possibilidades apresentadas e defendidas pelos autores citados, é proposto a seguir um esboço de como esses termos e seus afins poderiam minimamente se entrelaçar, tendo como denominador comum as semelhanças semânticas entre si e que serão discutidas no próximo item desse capítulo.

Assim, o islam apresentaria grosso modo dois grandes eixos (Diagrama 11) como respostas aos desafios engendrados pela modernização, grandemente produzida e difundida pelo Ocidente. 


\section{Diagrama 11 - Síntese Terminológica das Correntes Fundamentalistas.}

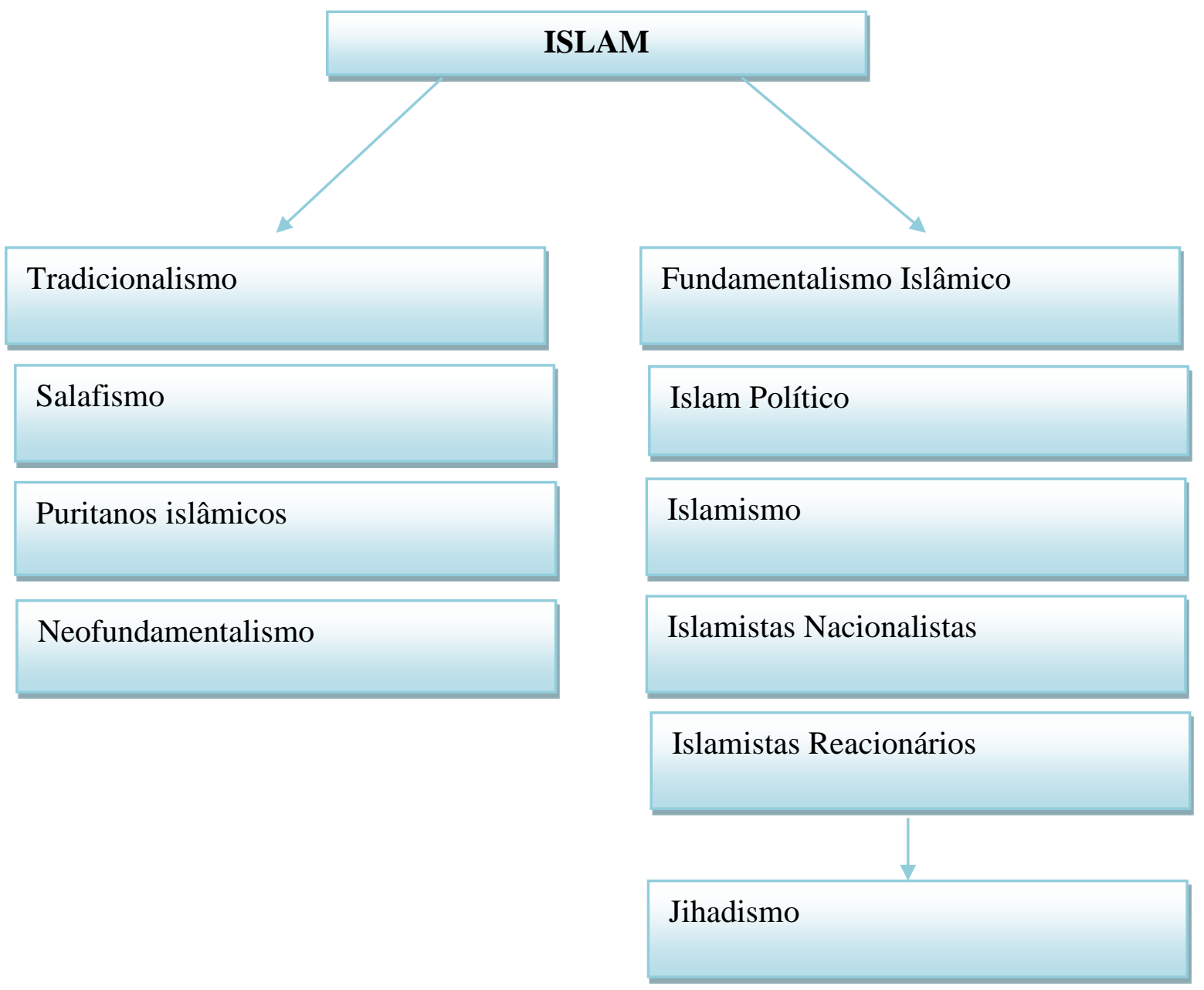

Como se percebe, a reação mais "conservadora" é aquela traduzida pelo tradicionalismo, salafismo, puritanismo islâmico e o neofundamentalismo, que não perde de vista a infalibilidade das escrituras, "desterritorializada" e representada por aqueles que muitas vezes vivem fora de seu conformismo social e religioso original que os faz viver a religiosidade de forma mais intensa e que visa islamizar a sociedade de "baixo para cima".

Diferentemente, a alternativa mais engajada politicamente e com maior diversidade de grupos que dela participam é aquela representada pelo fundamentalismo islâmico, islam político e seus derivados. Ela seleciona elementos da modernidade como instrumentos de seu ativismo, visando criar estados islâmicos com base na lei islâmica, a sharia, em oposição às leis seculares, à democracia que afronta a soberania de Deus, aos aparelhos de estado e suas superestruturas laicas, e às sociedades corroídas pela imoralidade. O jihadismo seria uma derivação violenta desse eixo, dividido entre aqueles que advogam a luta de longo prazo contra os inimigos da fé e os que pensam que já é possível estabelecer o califado agora.

Finalmente, integrando essas variáveis e suas designações, chegamos a um diagrama baseado em três grandes instâncias: religião, cultura e política como se vê abaixo. 


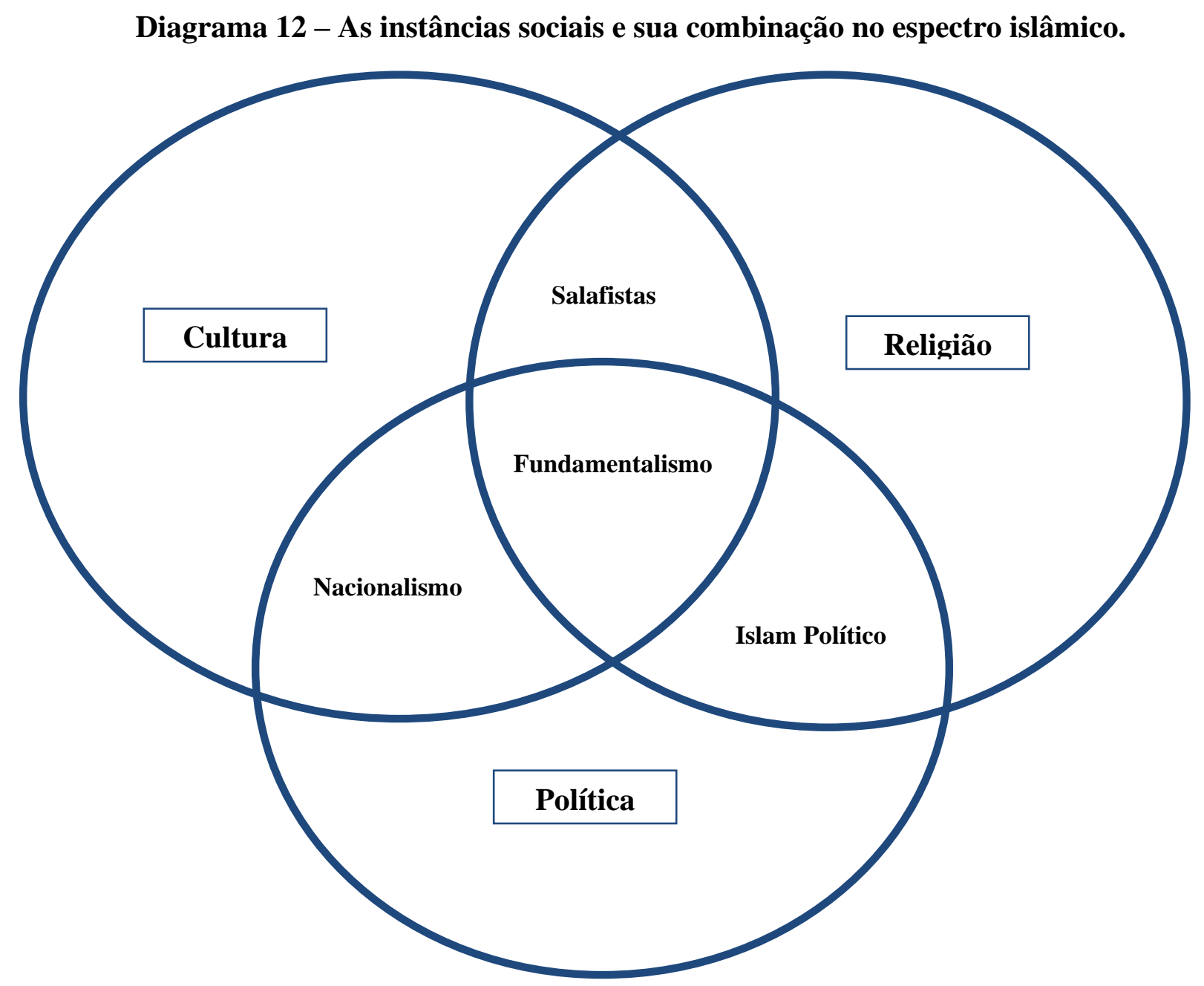

As três grandes instâncias mostradas são "denominadores comuns" sob os quais diversos autores examinam o islam de acordo com suas orientações filosóficas e metodológicas.

Nesse caso, algumas possibilidades podem ser extraídas desse diagrama e que coincidem com o pensamento dos autores que investigamos anteriormente. O islam político ou islamismo se baseiam na união da política com a religião, tendo como resultado um ativismo e um maior engajamento objetivando a consecução de um estado islâmico regido sob as leis da sharia.

Se acrescentarmos a instância cultural nesse melting pot, aflora-se o fundamentalismo: politizado, mas que entra em conflito com a cultura e todos os tipos de acréscimos e próteses locacionais, querendo voltar-se para a religião em estado puro. Por outro lado, se o fator religioso enfraquece ao passo que o cultural ganha destaque, ele pode adquirir contornos nacionalistas ou reacionários dependendo do lugar e seus contextos.

O choque com outras culturas e civilizações a exemplo do que sugere Samuel Huntington (1998) passa a ser percebido com maior frequência. Roy (2004 e 2008) vai além e aventa que a "desculturação" seguida de uma "inculturação", ou seja, o momento em que um 
muçulmano deixa seu local de origem, em seu conformismo social e passa a viver como minoria em terras não muçulmanas e em muitos casos tem de se adaptar à cultura dominante, há a transição do fundamentalismo para o neofundamentalismo. Os marcadores religiosos e culturais saem de uma zona de estabilidade e devem, portanto, se reajustar à nova realidade. Mas se o marcador religioso cede em benefício do cultural, nacionalismos podem aflorar e em outros casos, se assimilarem à cultura dominante.

Mas há uma outra interpretação que contraria essa leitura, a de que imigrantes muçulmanos que vão para países ocidentais não são em geral fundamentalistas e vivem uma religiosidade tradicional onde elementos culturais (por exemplo, a mutilação genital feminina, o uso de amuletos etc.) se misturam com o núcleo universal e imutável da religião, sem contar os muçulmanos menos religiosos. Nesse caso, as dificuldades relativas à exclusão social, alienação cultural e xenofobia por parte da sociedade ocidental que os acolhe, em um dado momento levam certos imigrantes a se voltarem para a religião de uma forma mais "ortodoxa" do que eles conheciam em sua terra natal. O processo de radicalização que pode conduzir à forma jihadista é mais recente e atinge em particular as segundas ou terceiras gerações já nascidas em solo estrangeiro e parcialmente assimilada. Além de novos convertidos em busca de algo que a sociedade ocidental não oferece.

Por fim, se apenas as instâncias cultural e religiosa se combinam, o salafismo seria um dos produtos dessa intersecção. Menos ativista e menos engajado politicamente, porém mais purista, tradicional e literalista, o salafismo do qual emergiram grandes nomes desde as correntes mais tradicionais como Ibn Hanbal, Hasan Al-Banna e mesmo Sayyid Qutb, até modernistas como Rashid Rida, seria o terreno fértil para o florescimento de outras versões que com o atributo da política, tentaram mudar o mundo de uma forma mais contundente e por vezes com violência.

É importante ressaltar que essas combinações não são herméticas. Ao observar essas três "lentes" que representam suas respectivas instâncias, seus "aros" não são rígidos, mas sim porosos e permeáveis. Nesse sentido, tanto o salafismo, como o fundamentalismo e o islam político, por exemplo, apresentam influências mútuas em diversos casos. O fundamentalismo, ao mesmo tempo em que busca uma leitura literal das escrituras sagradas, tal como os salafistas, acreditam que é importante em muitos casos haver um estado e uma liderança que possa zelar pela aplicação da sharia. Além disso, a cultura também pode se combinar nesse processo como um ingrediente complicador no caso dos imigrantes, e que na tentativa de reconstruir ou mesmo de manter sua identidade pode percorrer caminhos tão diversos quantos seriam as interpretações 
do Alcorão e das ahadith. A própria ijtihad, como vimos a partir de algumas lideranças muçulmanas, é passível de discussão sobre sua abertura ou fechamento.

Esses tons de influência entre si, não apenas entre as instâncias, mas entre seus subprodutos, é que tornam difícil a tarefa de qualificar de forma precisa e objetiva a miríade de significados que implicam o uso de cada terminologia.

\subsection{Uma perspectiva existencialista do fundamentalismo islâmico}

O mythos e o logos aclamados por Armstrong (2009) ao se discutir o fundamentalismo e tudo aquilo que o encerra, nos faz pensar no aspecto dialético dessa resposta religiosa ao progresso técnico, científico e informacional do mundo. O fundamentalismo que deita suas raízes nas escrituras sagradas, mas que se revela sob várias denominações e práticas, desde as mais pacíficas até as mais extremadas, pode engendrar uma discussão sob o viés existencial?

Ao decompor o fundamentalismo islâmico em suas variáveis determinantes como o Alcorão, as ahadith, os fiéis muçulmanos, a fé, a jahiliyya, o ijtihad, a sharia, o jihad, a modernização do mundo, entre outros elementos que gravitam o termo, veremos que elas podem ser classificadas em dois grandes compartimentos dialéticos cujos nomes podem variar segundo diversos autores e suas linhas de pensamento: Platão propôs a separação entre o mundo real, apreendido pelo nosso intelecto, e o mundo aparente, que se revela aos homens através dos sentidos; Santos (2002) de objetos e ações ${ }^{202}$ ou ainda de tecnosfera e psicosfera ${ }^{203}$; e Sartre (1943) de aparência e essência ${ }^{204}$.

Independentemente do nome utilizado, o fato é que o fundamentalismo pode ser visto sob esses pares dialéticos. As ações, normas e códigos - parte constituinte do reino da "psicosfera" - obtidos através dos fundamentos da religião, implicam na consecução de objetivos que se materializam e se manifestam nos lugares de forma cada vez mais global, como pela construção de uma mesquita, de uma madrassa, uma sociedade beneficente islâmica, a emissão de uma fatwa, um jornal islâmico, a perpetração de ataques terroristas, a propagação do ódio ao

\footnotetext{
202 "Sistemas de objetos e sistemas de ações interagem. De um lado, os sistemas de objetos condicionam a forma como se dão as ações e, de outro lado, o sistema de ações leva à criação de objetos novos ou se realiza sobre objetos preexistentes. É assim que o espaço encontra sua dinâmica e se transforma" (Santos, 2002, p.63).

${ }^{203}$ Tecnosfera, entendida como a materialidade, o reino dos objetos símbolos da modernidade, e da psicosfera, centro das paixões humanas, das ações, normas e visões de mundo. Para Santos (2002, p.255-256) "ao mesmo tempo que se instala uma tecnosfera dependente da ciência e tecnologia, cria-se paralelamente, e com as mesmas bases, uma psicosfera $[\ldots]$ reino das ideias, crenças e paixões".

204 “L'apparence ne cache pas l'essence, elle la révèle: elle est l'essence. L'essence d'un existant n'est plus une vertu enfoncée au creux de cet existant, c'est la loi manifeste qui préside à la succession de sés apparitions, c'est la raison de la série". (Sartre, 1943, p.12). (A aparência não esconde a essência, ele a revela: ele é a essência. A essência de um existente não é mais uma virtude enterrada no vazio desse existente, é a lei manifesta que preside a sucessão de suas aparições, é a razão da série. Tradução minha).
} 
Ocidente e aos seus símbolos, e a declaração de guerra para a conformação de um Estado, a exemplo do Estado Islâmico.

Todavia, tais ações passam a ser coodernadas à distância, com a ajuda de satélites e meios de comunicação e informação modernos, parte da tecnosfera, "presente-aparente". Essas ações, moderadas ou violentas, são cada vez mais precisas, porém cegas porque são obedientes a projetos alheios, estranhos ao lugar e muitas vezes ao contexto religioso e cultural em que se aplicam.

O logos, a racionalidade dessas ações propiciadas pelo uso cada vez mais sofisticado de objetos técnicos, busca no mythos religioso uma explicação racional para elas. Quando assistimos a um ataque como os de Paris em 2015 ou Bruxellas e Istambul no primeiro trimestre de 2016, estamos diante de um "presente-compresente". Vemos seu fim, sua aparência presente, mas não o processo de planejamento, de onde e de quem partiram as ordens para sua ação, que estão “compresentadas” naquele momento como a maçã de Ortega y Gasset. A aparência, como ensinou Sartre (1943), revela a essência. Saber observar esses sinais materiais pode permitir compreender as normas e códigos que regem determinadas ações.

Com base na racionalidade e nas paixões que estruturam o fundamentalismo, seria possível pensá-lo sob a égide existencialista, especialmente as variantes mais extremistas e fanáticas representadas por aqueles que oferecem sua própria vida pela "causa" que defendem? Qual o sentido da vida, ou melhor, da existência, para aqueles que aparentemente não a valorizam tal como imaginamos? Para Camus (2013), essa questão é o ponto fundamental da filosofia.

Se nos lembrarmos da tese de Lewis (2004a) para quem a maior parte dos muçulmanos não é fundamentalista e desses, a menor parte é terrorista, mas que por outro lado, grande parte dos terroristas é de muçulmanos, até que ponto a religião pode catapultar esses grupos em direção à violência e à aniquilação? O desespero kierkegaardiano dos que enxergam um mundo sem Deus ou dominado por outro "deus" que não o seu é manifestado por meio de um terror com base nas suratas? Qual a raison d'être dos jihadistas? Podemos pensar em um “fundamentalismo existencial"? Seriam o fundamentalismo e a religião ilusões que dotam os indivíduos de um sentido existencial, pois que não o encontram nessa realidade cada vez mais hostil, opressora e "ocidentalizante", segundo seu ponto de vista?

Para Sartre (op.cit.) o homem é um projeto e como tal está aberto ao conjunto infinito de possibilidades que dão sentido à sua existência. Somos uma página em branco e a partir das escolhas que fazemos, que, aliás, são infinitas, projetamos nosso ser e nossa essência. A liberdade é condição da existência. Abordando essa visão, Pratt (2016) explica que 
when we abandon illusions, life is revealed as nothing; and for the existentialists, nothingness is the source of not only absolute freedom but also existential horror and emotional anguish. Nothingness reveals each individual as an isolated being "thrown" into an alien and unresponsive universe, barred forever from knowing why yet required to invent meaning. It's a situation that's nothing short of absurd. ${ }^{205}$

Camus (2005, p.07), logo no primeiro parágrafo do livro “L'étranger" escreve: “aujourd'hui, maman est morte. Ou peut-être hier, je ne sais pas. J'ai reçu un télégramme de l'asile: 'mère décédée. Enterrement demain. Sentiments distingués'. Cela ne veut rien dire. C'était peut-être hier"'206. A indiferença marca a trajetória do personagem Meursault que sempre repetia a frase "cela m'était égal"207. $\mathrm{O}$ assassinato que comete por um motivo aparentemente banal e sua reação de fumar um cigarro após o ato evidenciando sua incapacidade de sentir remorso ou de se sensibilizar com aquilo que ronda sua vida, inclusive a morte da própria mãe, nos oferece quais ensinamentos quando pensamos na questão do fundamentalismo existencial, que aparentemente se aliena do "mundo aparente" atribuindo insignificância ao que é externo ao seu "mundo real" governado pela religião? De que maneira o fundamentalismo se encaixa nesse novelo existencial?

Uma pequena pista que pode nos ajudar a seguir por essa senda, pode estar em Sayyid Qutb, um dos arautos do fundamentalismo recente. Vimos que ele considerava toda forma materialista de progresso e mesmo a democracia ocidental como aspectos inegáveis da jahiliyya, que se manifesta de forma ainda pior que nos tempos do profeta Maomé, pois agora é consciente e planejada. Jackson (2006, p.204-205) chama a atenção quando escreve que "Qutb's writings are also Kierkegaardian in his individualism" e acrescenta que "it relies upon intuition in that the believer will simply 'know' what to do in the circumstance. Again, similarities can be observed with Nietzsche's Übermensch ('Superman')"208.

\footnotetext{
205 "quando abandonamos as ilusões, a vida é revelada como nada; e para os existencialistas, o nada é a fonte não apenas da liberdade absoluta, mas também do horror existencial e da angústia emocional. O nada revela cada indivíduo como um ser isolado "jogado" em um universo alienígena e indiferente, barrado para sempre por saber por que ainda é necessário inventar o significado. É uma situação que é nada menos que absurda" (tradução minha). 206 "hoje mãe está morta. Ou talvez ontem, eu não sei. Eu recebi um telegrama do asilo: 'mãe falecida. Enterro amanhă. Sentimentos distintos'. Isso não significa nada. Talvez tenha sido ontem”' (tradução minha).

207 "Tanto faz" (tradução minha).

208 "Os escritos de Qutb são também kierkegaardianos em seu individualismo "e acrescenta que" se baseia na intuição de que o crente simplesmente "saberá" o que fazer na circunstância. Mais uma vez, similaridades podem ser observadas com o Übermensch de Nietzsche ('Superhomem')" (tradução minha).
} 
Khatab (2006, p.06) indo ao encontro dessa afirmação assevera que "in several places he [Sayyid Qutb] describes Islam as practical, realistic, concerned with life, down to earth. The rhetoric which he employs in these passages seems heavily influenced by existentialism'.

A náusea sartreana como lembrança do peso do "existir" teria relações com o fundamentalismo? Ao mesmo tempo, é possível detectar similaridades entre Qutb e o "alémdo-homem" ou o "super-homem" (Übermensch) de Friedrich Nietzsche? O que dizer com relação à Soren Kierkegaard e a angústia pela compreensão da liberdade absoluta e a vertigem que se tem quando tomamos conhecimento dela?

Esses conceitos refletem, grosso modo, a possibilidade de encarar a existência sem as próteses ou "consolos" de que o homem precisou ao longo da história para suportar sua existência. A história de nossa cultura, para Nietzsche, é aquela da invenção desses “consolos", de perspectivas de sentido religioso, ético e moral. Essas invenções tentam remediar ou mesmo negligenciar a experiência da finitude e da morte, por isso inventam-se "outros" mundos, vida eterna, o paraíso etc. Sem isso não seria possível suportar a vida. Para Kierkegaard (2004, p.3536)

a orientação para Deus dota o eu de infinito, mas esta infinitização, nesse caso, quando o eu for devorado pelo imaginário, apenas conduz o homem a uma embriaguez no vácuo. Desse modo, poder-se-á achar insuportável a ideia de existir para Deus, não podendo o homem regressar ao seu eu, torna-se ele mesmo.

Nesse contexto os homens imersos em seus cultos, ritos, leituras rigorosas, louvores e tudo o que os cercam, inebriados por um imaginário e por um mundo possível, latente, um "além-mundo", se afastam de si mesmos. Vive-se uma vida alegórica, sem o "peso" da vida a que se referia Kundera (2008). Camus (2013, p.20) em sua reflexão sobre o absurdo e da busca por um sentido à vida, vai ao encontro disso ao afirmar que

dans un univers soudain privé d'illusions et de lumiéres, l'homme se sent un étranger. Cet exil est sans recours puisqu'il est privé des souvenirs d'une partie perdue ou de l'espoir d'une terre promise. Ce divorce entre l'homme de sa vie, l'acteur et son décor, c'est proprement le sentiment de l'absurdité. Tous les hommes sains ayant songé à leur propro suicide, on pourra reconnaître, sans plus d'explications, qu'il y a un lien direct entre ce sentiment et l'aspiration vers le néant ${ }^{209}$.

209 “em um universo repentinamente privado de ilusões e luz, o homem se sente um estranho. Este exílio é sem recurso, uma vez que ele é privado de memórias de uma parte perdida, ou da esperança de uma terra prometida. Esse divórcio entre o homem de sua vida, o ator e seu palco, é na verdade o sentimento do absurdo. Todos os 
Para ser esse Übermensch é primordial aceitar a possibilidade de viver radicalmente a finita existência e a morte sem alívios ou ilusões. De acordo com Nietzsche, o Übermensch é um modo de ser que fundamentalmente afirma a vida. É alguém que pode se tornar o portador do sentido não do mundo do "além", mas aqui ${ }^{210}$.

No livro "Os Demônios" de Dostoievski, baseado no verídico caso do assassinato de um estudante por um grupo niilista em 1869 na Rússia, se discute sobre o terrorismo, suicídio e anarquia. Na obra em questão há um personagem chamado Kirílov, considerado por alguns críticos o precursor do suposto Übermensch nietzschiano. Isso fica evidente na parte em que Dostoievski (2013, p.120), através do personagem, afirma que

a vida é dor, a vida é o medo, e o homem é um infeliz. Hoje tudo é dor e medo. Hoje o homem ama a vida porque ama a dor e o medo. E foi assim que fizeram. Agora a vida se apresenta como dor e medo, e nisso está todo o engano. Hoje o homem ainda não é aquele homem. Haverá um novo homem, feliz e altivo. Aquele para quem for indiferente viver ou não viver será o novo homem. Quem vencer a dor e o medo, esse mesmo será Deus. E o outro Deus não existirá.

Em outra obra, Dostoievski (2001) por meio de seu personagem anônimo, reclama da matematização do mundo que subjuga as vontades e desejos, parametrizando a vida. A "vida real" oprime o indivíduo encurralando-o ao seu subsolo de tédio, ódio, amargor e indiferença. O homem deve tentar provar que é homem e não engrenagem. Ele mesmo alega ser um homem mau e sombrio, encurralado em seu "subsolo" onde se sente mais a vontade do que em meio à sociedade opressora que experimenta ao longo das três histórias que narra.

A busca por um sentido de vida que passa por uma tomada de consciência profunda para apreender as suas nuances, é um dos objetivos do personagem. Para tanto ele sente necessidade de agir, de acabar com a indiferença que sofria, ao ponto de provocar uma briga para acabar com o tédio. Dostoievski (ibid., p.63) descreve:

eu me mantinha junto do bilhar, e, não conhecendo nada do jogo, incomodava os jogadores. Querendo passar, o oficial me tomou pelos ombros, e sem uma explicação, sem uma palavra, empurrou-me e passou como se eu não existisse. Eu teria perdoado levar pancada, mas o que não pude suportar foi que me empurrasse em silêncio. $\mathrm{O}$ diabo sabe o que eu teria dado então por uma boa disputa regular, por uma briga conveniente, literária, por assim dizer.

\footnotetext{
homens sãos tendo pensado seu suicídio, podemos reconhecer, sem mais explicações, que existe uma ligação direta entre esse sentimento e a aspiração ao nada" (tradução minha).

${ }^{210}$ Kim, Douglas. O Livro da Filosofia. São Paulo: Globo livros, 2011.
} 
De acordo com essa passagem, seria possível pensar que os mártires jihadistas, os homens-bomba que tanto chamam a atenção do mundo ao promover banhos de sangue e destruição usando seu próprio corpo, se encaixam nesse perfil do "novo homem", para quem é indiferente viver ou morrer. Seu questionamento seria aquele exemplificado por Dostoievski (ibid., p.155) segundo o qual "o que é preferível: uma felicidade vulgar, ou sofrimentos elevados? Dizei-me o que vale mais!”.

A diferença é que mesmo vencendo a dor e o medo como sugere Kirílov, ele não se considera Deus, pois entende ser sua criatura.

Esse fundamentalismo seria uma reação à sociedade despótica, superficial, matematizante, que molda corpos e espíritos? As práticas jihadistas seriam formas de acabar com o tédio e com a indiferença? Por outro lado, a religião tomada segundo interpretações particulares e extremistas não faria do homem sua engrenagem? Em busca da liberdade enquanto homem e não enquanto engrenagem, os jihadistas não estariam apenas sendo substituídos de uma engrenagem por outra?

Em outro momento bastante revelador de como o Übermensch reafirma a vida em sua essência, sem distrações, chicanas ou ilusões, está no diálogo a seguir criado por Dostoievski (2013, p.237) envolvendo Kirílov e Stavroguin:

- Você gosta de criança?

- Gosto - respondeu Kirílov, satisfeito, aliás indiferente.

- Então gosta da vida.

- Sim, gosto também da vida, e daí?

- Mas decidiu se matar...

- E daí? Por que as duas juntas? A vida é um particular, a morte também é um particular. A vida existe, mas a morte não existe absolutamente.

- Você passou a acreditar na futura vida eterna?

- Não, não na futura vida eterna, mas na vida eterna aqui. Há momentos, você chega a esse momento, em que de repente o tempo para e acontece a eternidade.

- Você espera chegar a esse momento?

- Sim.

Nietzsche (2005) assume que a religião (e usa o cristianismo como exemplo) afasta as pessoas do mundo real, projetando no "além" o real sentido da vida. A existência não deve ter justificativa religiosa, ética ou mesmo metafísica. Isso o fundamentalismo e os fundamentalistas não suportam. Não há ordem objetiva ou estrutura no mundo que não sejam aquelas que "nós" 
damos a ele. O peso da existência e da liberdade em determinar os sentidos e valores das coisas não parece ser o perfil dos fundamentalistas.

Sobre isso, Kundera (2008, p.11) avalia que

o mais pesado dos fardos é, portanto, ao mesmo tempo a imagem da realização vital mais intensa. Quanto mais pesado é o fardo, mais próxima da terra está nossa vida, e mais real e verdadeira ela é. Em compensação, a ausência total de fardo leva o ser humano a se tornar mais leve do que o ar, leva-o a voar, a se distanciar da terra, do ser terrestre, a se tornar semirreal, e leva seus movimentos a ser tão livres como insignificantes.

A vida pautada estritamente pela religião, sobretudo a islâmica, cujos inúmeros códigos regem não só os ritos religiosos, mas grande parte da vida social - e pela promessa de mitos e de eternidade no paraíso - é contrária a essa ideia. A religião ao invés de ancorar a existência no "real" dá asas a ela. Talvez as formas, ritos e normas religiosas sejam apenas uma falsa impressão de "peso" da vida, quando na verdade a essência desses atributos não está nesse mundo, nessa existência. Vive-se o rascunho de uma vida que será passada a limpo no "juízo final".

Enquanto isso, segundo a leitura rigorosa e obtusa dos livros sagrados que estão entre os qualificadores do fundamentalismo, busca-se satisfazer a vontade divina ora se isolando do mundo por completo, rejeitando aquilo que é estranho, ora se assimilando a uma cultura dominante, mas entendendo isso como parte de um exercício mais desafiador na afirmação de sua religiosidade (o neofundamentalismo), ora partindo para o enfrentamento (jihadismo).

Nesse primeiro momento parece não haver muito do Übermensch em Qutb como sugere Jackson (2006). Mas há outras pistas que possam ligar ambas as personalidades? É possível.

Talvez essa discussão permita abrir um novo horizonte de reflexão acerca do fundamentalismo, mas do ponto de vista existencial, em particular, no espectro niilista. Nesse quesito, há um lusco-fusco, um flerte fugaz entre o fundamentalismo e o niilismo. Quando pensamos ter encontrado similitudes que possam associá-los, logo encontramos algo que os separa. Se tomarmos algumas variáveis do fundamentalismo isoladamente, é provável que se encontrem traços niilistas. Mas no conjunto das características, a relação se perde.

A totalidade de fato não é a soma de suas partes. O fundamentalismo, assim como o mundo, está sempre em movimento, em um processo contínuo de "totalização" em que as partes atuam de forma combinada, mas que somente de forma independente são apreendidas. Esse é o risco em se criarem generalizações do tipo, "todo muçulmano é terrorista". Isola-se uma característica, uma parte que vale pelo todo e um perigoso silogismo se manifesta. 
Por volta dos anos de 1830, o termo niilismo ganhava notoriedade especialmente através da obra "Pais e filhos" do escritor russo Ivan Turguêniev. O protagonista, Bazárov, grande adepto do cientificismo, se coloca sempre de forma blasé em face de tudo aquilo que não cultue o positivismo, a ciência, a empiria e a razão, maximizando tudo o que é útil para si. A definição de niilismo pode ser identificada através da conversa entre Arkádi, discípulo de Bazárov, seu pai Nikolai Petrovitch e seu tio Pável Petrovitch, proposto por Turguêniev (2011, p.48-49):

- O que Bazárov é? - sorriu Arkádi. - Tio, o senhor quer que eu lhe diga o que ele é, precisamente?

- Faça-me esse favor, meu sobrinho.

- É um niilista.

- Como? - Perguntou Nicolai Petróvitch, equanto Pável Petróvitch se punha imóvel, a faca erguida no ar com um pouco de manteiga na ponta da lâmina. - Ele é um niilista - repetiu Arkádi.

- Niilista - disse Nikolai Petróvitch. - Vem do latim nihil, nada, até onde posso julgar; portanto, essa palavra designa uma pessoa que... não admite nada?

- Digamos: que não respeita nada - emendou Pável Petróvich e novamente se pôs a passar manteiga no pão.

- Aquele que considera tudo de um ponto de vista crítico - observou Arkádi.

- E não é a mesma coisa? Indagou Pável Petrovitch.

- Não, não é a mesma coisa. O niilista é uma pessoa que não se curva diante de nenhuma autoridade, que não admite nenhum princípio aceito sem provas, com base na fé, por mais que esse princípio esteja cercado de respeito.

Vattimo (1998, p.824) escreve que o niilismo é “também uma condição geral da cultura e da existência - em que se negam o ser e os valores, e se afirma, ao contrário, o nada como a única 'realidade"”. Cunningham (2002, p.170) ao traçar uma genealogia do niilismo perpassando diversos autores desde Avicenna até Sartre, Nietzsche e Deleuze, escreve que o "nihilism is not a choice but all choices"211.

Para Pratt (idem), o niilismo existencial é a noção de que a vida não tem um valor intrínseco ou significado. A liberdade é a única regra e tudo aquilo que possa restringi-la, como o Estado ou a religião, deve ser destruído. Para esse autor, “by rejecting man’s spiritual essence in favor of a solely materialistic one, nihilists denounced God and religious authority as antithetical to freedom" ${ }^{212}$. Todavia, essa pretensa liberdade total se torna relativa à medida que

\footnotetext{
211 "Niilismo não é uma escolha, mas todas as escolhas" (tradução minha).

212 "rejeitando a essência espiritual do homem em favor de uma essência apenas materialista, os niilistas denunciaram Deus e a autoridade religiosa como antitética à liberdade" (tradução minha)
} 
a religião, no caso a islâmica, é aquela que induz à convicção de determinados atos, mas que para Nietzsche (2005, p.104) tais convicções soam como "prisões".

Buruma e Margalit (2006, p.96) complementam o raciocínio apontando que

o niilismo é, de fato, mais um estado de espírito do que uma doutrina, mas o principal objetivo é minar tudo o que não possa ter como base a ciência e o pensamento racional, quer seja a autoridade em todas as suas formas - a Igreja, a família ou o Estado.

Analisando em partes, o fundamentalismo partilha de algumas características com o niilismo como o fato de possuir um ponto de vista crítico acerca do mundo e que não admite situações como as que não estão de acordo com os preceitos de sua religião, como aquilo que possa desviar os fiéis dela ou imposições de valores e princípios que sejam estranhos aos seus.

Contudo, o fato de o niilismo não se curvar diante de nenhuma autoridade, incluindo Deus, e que também é preciso se apoiar em provas concretas, positivas, naquilo que é produzido pela ciência, tecnologia e modernidade, faz com que essa ligação entre os termos seja rompida. É como um círculo que quando está prestes a se fechar, se parte.

Ao se discutir a metamorfose dos valores modernos a partir do pensamento marxista, em que tudo se torna valor de troca, inclusive a honra e dignidade pessoais, Berman (2007, p.136) afirma que

com isso, qualquer espécie de conduta humana se torna permissível no instante em que se mostre economicamente viável, tornando-se "valiosa"; tudo o que pagar bem terá livre curso. Eis aí a essência do niilismo moderno. Dostoievski, Nietzsche e seus sucessores do século XX atribuirão isso à ciência, ao racionalismo, à morte de Deus

Ao encontro dessa ideia, destacamos uma fala do sheikh Jihad Hammadeh, que dá exemplos de como a questão do materialismo é nociva e faz com que as pessoas se afastem da religião e deixem de ser "humanas". Segundo ele,

hoje o maior prejuízo do capitalismo é o materialismo. Transformou as pessoas em mercadorias, em produtos. Se é materialista, não tem mais humano, se não tem mais humano não tem sentimentos. Então, se não tem sentimentos, trair não tem problema. Se eu traio ou sou traído acabou a confiança. Faltou confiança, como é que você vai dar bom dia para seu vizinho? Seus filhos gostam de você por causa do seu dinheiro [pausa] está havendo uma desestruturação social. Qual é solução? Vai ter que correr para o islam. 
A opinião acima de uma certa forma é corroborada pelo meu informante Ahmad Al$\mathrm{Khatab}^{213}$, ao afirmar que

isso faz parte da família, o mundo material. As pessoas me procuram quando tem um problema entre marido e mulher. Eu conversei com um homem, faz seis anos - ele é parente meu - ele brigou com a mulher dele e fui falar com ele. Eu disse: "tio, por que você fez isso? -Ah, ela me dá muito prejuízo". Eu fiquei chocado! "Vocês estão fazendo negócio? Um dando prejuízo para o outro?" Você ouve isso muito entre os casais. "Eu vou casar com ele porque ele tem grana”. Não existe mais família [se exalta]. Existe dinheiro. Então se o núcleo da sociedade está nisso, então imagina o resto. A mídia fez o ser humano virar isso, dominou a mente do ser humano. Hoje, o materialismo se tornou mais importante que qualquer outra coisa. Meu filho está aqui, está me ouvindo. A Polícia Federal levou tudo, inclusive o iPad dele, o meu e o da minha mulher. Eu tenho a empresa e eles levaram tudo da empresa né. Aí meu filho a cada duas semanas ou a cada semana pergunta: "quando eles vão devolver meu iPad?" Ele não me pergunta o que vai acontecer comigo, o que aconteceu com o Antonio ${ }^{214}$, que também era educava ele, dava aula para ele. Estou falando do meu filho, que só se importa com o material.

Em Marcos 8:36, se lê: "pois que aproveitaria ao homem ganhar todo o mundo e perder sua alma?” (Bíblia, 1984, p.66). Não distante dessa concepção, o islam seria a tábua de salvação para a humanidade, um refúgio do "mundo aparente" e suas rugosidades que embrutecem, alienam e "fetichizam" as relações sociais no sentido marxista.

A inversão do niilismo clássico que o fundamentalismo sugere é clara ao se atribuir não à religião, mas aos objetos, à materialidade, à razão hegemônica ocidental os verdadeiros desvios e distrações para a firmação do ser, de um “Übermensch". Não é a religião, mas o mundo aparente com suas próteses cada vez mais invasivas na forma e irreversíveis no tempo que suprimem a liberdade.

Essa fetichização também pode encontrar outra explicação. A modernidade tem criado ídolos, imagens muitas delas criadas pelos homens à sua semelhança, como um "retroprojetor", mas que adquirem autonomia se desvencilhando de quem as criou, se tornando fetiches, sinônimos de falsidade. Latour (2002, p.11) oferece uma interessante reflexão sobre isso quando escreve:

\footnotetext{
${ }^{213}$ Ahmad Al-Khatab foi intimado a prestar depoimentos durante a Operação Hashtag da Polícia Federal que prendeu em 21.07 e 11.08.2016, 14 muçulmanos suspeitos de planejar atentados terroristas.

${ }^{214}$ Antonio Andrade dos Santos Junior trabalhava na ONG Livro Aberto com meu informante, e foi detido e posteriormente liberado pela Operação Hashtag.
} 
Diz-se que os povos de pele clara que habitam a faixa setentrional do Atlântico praticam uma forma particular de culto às divindades. Eles partem em expedição a outras nações, apropriam-se das estátuas de seus deuses, e as destroem em imensas fogueiras, conspurcando-as com as palavras fetiches! fetiches!, que em sua língua bárbara parece significar fabricação, falsidade, mentira. Ainda que afirmem não possuir nenhum fetiche e ter recebido apenas de si próprios a missão de livrar as outras nações dos mesmos, parece que suas divindades são muito poderosas.

Com base nesse raciocínio, logo vêm à mente as ações do Estado Islâmico na Síria e no Iraque, ou os Talibãs no Afeganistão, quando nos recordamos da destruição de sítios arqueológicos da antiguidade e junto com eles tudo aquilo que remetia às suas divindades, como se fossem hereges, inferiores e primitivas, ao mesmo tempo em que atacam minorias religiosas. No entanto, é possível usar a citação acima não apenas sob o viés religioso, mas também econômico.

Nesse caso, como não se lembrar dos atentados ao World Trade Center em 11 de setembro de 2001? As torres em chamas simbolizando a derrocada do "shaitan" (demônio) ocidental representado pelo capitalismo opressor e pelo dinheiro que financia todo tipo de aparato de dominação, da bélica à tecnológica e científica. Historicamente, o islam tem sido fonte de inovação científica, pelo menos até o fechamendo da ijtihad por volta de 1000 d.C. Mas para alguns grupos, há que se aniquilar o culto à divindade do dinheiro, da materialidade e da ciência que relegam a criação e o criador a papéis de mero coadjuvantes. Mentiras, fetiches e falsificações de uma vida que só faz sentido quando abraçada ao islam. Essa seria uma leitura fundamentalista.

O fundamentalismo jihadista também busca suprimir o diálogo, sinônimo de fraqueza. A ausência de comunicação ou a comunição unilateral com base em gritos e palavras de ordem impossibilitam a compreensão e o convívio. Cria-se um mundo de estrangeiros, tal como Meursault. Karnal (2016, p.C7) recorda que "o discurso fundamentalista ocupa um pouco do niilismo da modernidade, demarcando fronteiras absolutas onde a liquidez deixou muita gente perdida $[\ldots]$ os militantes fundamentalistas vivem como virtude aquilo que rejeitamos como defeito".

Nessa direção, Calvert (2013) aponta que

it is also true that Islamists, especially those in the ultraradical Al Qaeda mould, are nihilists or anarchists in the style made famous by Dostoevsky. For 
nihilists, ends typically justify means, with conventional morality giving way to merciless purpose $\mathrm{e}^{215}$.

Roy (2017, p.03) ao investigar as causas aparentes do novo jihadismo bem como o perfil de quem o pratica, especialmente em relação às ações violentas observadas na Europa nos últimos anos, corrobora esse raciocínio ao afirmar que "the systematic association with death is one of the keys to understanding today's radicalisation: the nihilist dimension is central. What seduces and fascinates is the idea of pure revolt. Violence is not a means. It is an end in itself" 216 .

Para o autor, a radicalização atual - em particular na Europa - é espontânea e não tem ligação com mesquitas ou com leituras equivocadas das escrituras, muito menos se observam ligações com o passado ou com a possível luta de seus pais. Nesse contexto, Roy (ibid.) questiona se de fato há uma radicalização do islam, ou, contrariamente, uma islamização do radicalismo que é a tese que está mais inclinado a acreditar.

Zizek (2011, p.61) lembra que

John Gray ${ }^{217}$ está certo então quando diz que "os fundamentalistas religiosos se veem como se tivessem o remédio para as doenças do mundo moderno. $\mathrm{Na}$ realidade, são os sintomas da doença que pretendem curar". Nos termos de Nietzsche, eles são os supremos niilistas, já que a própria forma de sua atividade (mobilização midiática espetacular etc.) destrói sua mensagem.

Nota-se que a relação entre o niilismo e o aspecto radical do islam não são impossíveis de serem relacionados.

A religião e a fé surgem como entraves ao niilismo, mas a despeito disso, recuperando as associações feitas por Armstrong (2009) entre o mythos e o logos que buscam uma explicação racional para os fundamentos religiosos, ainda é possível pensar em uma distorção do niilismo para tais propósitos? Tratar-se-ia então de um niilismo às avessas? A rejeição ou negligência de muitas correntes fundamentalistas pela ciência, tecnologia, democracia e, em casos mais severos, dos direitos humanos, outras religiões e sentimentos nacionalistas é o caminho para a libertação do espírito e para se aproximar de Deus. Libertar-se do Ocidente com suas próteses e rugosidades materiais, morais e religiosas seria a forma mais plena de existir (para Deus).

\footnotetext{
215 “Também é verdade que os islamistas, especialmente aqueles nos moldes ultra-radicais da Al Qaeda, são niilistas ou anarquistas no estilo que ficou famoso por Dostoiévski. Para os niilistas, os fins tipicamente justificam os meios, com a moralidade convencional dando lugar ao propósito impiedoso" (Tradução minha).

216 “a associação sistemática com a morte é uma das chaves para entender a radicalização de hoje: a dimensão niilista é central. O que seduz e fascina é a ideia de pura revolta. Violência não é um meio. É um fim em si mesmo" (tradução minha).

${ }^{217}$ GRAY, Jonh. Straw Dogs. Londres: Granta, 2003, p. 18. [Ed. bras.: Cachorros de palha. Rio de Janeiro: Record, 2005.]
} 
Nota-se à primeira vista que o fundamentalismo em seus variados tons possui algumas semelhanças com o exposto acima, exceto por ser balizado pela religião que é tratada como um empecilho à liberdade.

As motivações e "aparências" dos fundamentalistas sejam se isolando em sua forma salafista ou partindo para o enfrentamento em sua face jihadista, soam ambas como um modo de afastamento do mundo "presente", um mundo de aparência, vazio, um mundo que se deve transcender e não desfrutar, pois a corrupção está nele instalada. Mas ao se fazer isso, afasta-se da própria vida em favor de um mito, um mundo "real" imaginário situado em outro lugar. Em determinado aspecto a visão nietzschiana vai ao encontro desse raciocínio para o qual a única solução é o fim dessa dicotomia (real - aparente), pois só há um mundo possível.

É possível que na visão dos fundamentalistas, as ilusões que atrapalham o entendimento do mundo e que impedem que a vida se manifeste como um "nada" e, portanto, fonte inesgotável de liberdade, representem justamente esse mundo aparente sensível aos sentidos em que vivemos e pautado em visões de mundo dominadas pelo Ocidente. A religião, condenada pelo niilismo, seria o fio condutor para esse outro mundo "real" e ideal, pois governado por Deus. Não obstante, ainda caberiam breves reflexões sobre três casos ao se considerar a forma como alguns fundamentalistas mais extremados buscam para atingir esse "outro mundo":

a) há aqueles que desejam transpor ao "mundo aparente" a lei divina dos livros sagrados, governado pela corrupção, pelo materialismo, pelas guerras, pela democracia, transformandoo no mundo "real" a partir do isolamento, criando um mundo próprio dentro do mundo, ou a partir de uma revolução;

b) há os que sonham com o martírio, que os levaria ao Paraíso encarado como $o$ mundo verdadeiro e "real" libertando a si próprio desse mundo "aparente", sem conteúdo e pernicioso, algo que para a maioria dos muçulmanos não é aceitável, pois trata-se de suicídio.

c) outros buscam o martírio como forma de contribuição para que o mundo aparente em que vivemos seja transformado no mundo "real" tal como o pretende uma visão de mundo particular.

$\mathrm{Na}$ primeira situação se aboliria a dicotomia "mundo aparente" e "mundo real" sintetizando um único mundo, mas pautado exclusivamente pela religião.

Na segunda, nota-se a antítese à visão nietzschiana, pois as pessoas se desprendem da vida em troca de um mito e uma falsificação. Sobre isso, Nietzsche (2005, p.48) afirma que “em nome de Deus, se expressa o ódio à vida, à natureza, à vontade de viver! Deus, a fórmula para toda a difamação do 'aqui e agora', para toda a mentira do 'além'. Não há no islam um 
ideal de "escapar do mundo", mas de sacralizá-lo. Mas há aqueles que optam pela morte como instrumento para sacralizá-lo. O personagem Kirílov de Dostoievski (2013, p.598), corrobora esse raciocínio ao enunciar que

para mim não existe ideia superior à de que Deus não existe [...] o homem não tem feito outra coisa senão inventar um deus para viver, sem se matar; nisso tem consistido toda a história do mundo até hoje. Sou o único na história do mundo que pela primeira vez não quis inventar um deus.

Para Kirílov, a exemplo de Nietzsche, ao não aceitar a existência de Deus, as pessoas se tornam elas mesmas, deuses. A liberdade passa a ser a grande divindade.

Nietzsche (op.cit., p.84) ainda pondera que, "quando o centro de gravidade da vida não se põe na vida, mas no 'além', - no nada -, suprime-se à vida o centro de gravidade”.

Por fim, no terceiro exemplo, o apreço à vida também é indiferente, mas se dá pelo desespero como uma "enfermidade do eu" tal qual fala Kierkegaard (2004), por uma causa que levou ao extremo a individualidade e a liberdade total, a vida sem valor ou significado. Vivese a morte, "no desespero, o morrer continuamente se transforma em viver. Quem desespera não pode morrer” (ibid., p. 24). Tal afirmação também é sustentada por Dostoievski (2001, p.15) ao afirmar que, "entretanto - estou firmemente convencido -, a consciência, toda consciência é uma enfermidade". Muitos passam a vida se preparando para a morte como é o caso de muitos dos mártires muçulmanos, e quando isso acontece sua existência continua viva para os que ficam.

É sabido que para várias religiões, entre elas o islam, o suicídio é considerado um grave pecado. O Alcorão (4, 29-30) diz: "e não cometais suicídio, porque Allah é Misericordioso para convosco. Àquele que o fizer, perversa e iniquamente, introduzi-lo-emos no fogo infernal, porque isso é fácil a Allah". Na ocasião de um atentado terrorista cometido por jihadistas, independente do grupo do qual fazem parte, o suposto arbítrio em tirar a própria vida, prova da extrema liberdade que um indivíduo possa ter e o descumprimento dessa ordem divina, na leitura niilista seria um atributo da "divindade pessoal", da insubordinação a qualquer entidade ou autoridade, conforme exaltaria Kirílov.

Os fundamentalistas, entretanto, não encaram esse fato como uma insubordinação à autoridade divina, mas interpretam o suposto pecado como uma glória em nome de Allah. O arbítrio praticado e elogiado pelo niilismo é ao mesmo tempo usado pelos fundamentalistas e imediatamente distorcido por eles, porque fazem o que fazem como se cumprissem uma ordem divina para quem o martírio, e não o suicídio, seja um ato de sacrifício em prol de Deus. 
Camus (2013) talvez aceitasse o jihadista como um "homem-absurdo" uma vez que ele sintetiza a desproporção que existe entre sua intenção e a realidade que o espera. Para Camus (idib., 23) “l'esquive mortelle [...] c'est l'espoir d'une autre vie qu'il faut 'mériter', ou tricherie de ceux qui vivente non pour la vie elle-même, mais pour quelque grande idée qui la dépasse, la sublime, lui donne uns sens et la trahit ${ }^{218 "}$.

Em “Crime e Castigo", o personagem central da trama, Raskólnikov, formula uma tese que divide os homens em duas categorias, assim descrita por Dostoievski (2001, p.268):

todos os indivíduos se dividiriam em 'ordinários' e 'extraordinários'. Os ordinários devem viver na obediência e não têm o direito de infringir a lei porque eles, vejam só, são ordinários. Já os extraordinários têm o direito de cometer toda sorte de crimes e infringir a lei de todas as maneiras precisamente porque são extraordinários [...] o homem extraordinário tem o direito... ou seja, não o direito oficial, mas ele mesmo tem o direito de permitir à sua consciência passar...por cima de diferentes obstáculos, e unicamente no caso em que a execução da sua ideia (às vezes salvadora, talvez para toda a humanidade) o exija.

Destarte, os fundamentalistas, sejam salafistas ou jihadistas, seriam seres “extraordinários" já que suas condutas são afirmadas e legitimadas por uma visão de mundo particular oferecida pela religião que autoriza práticas que na maioria das vezes não são vistas como éticas e morais pelo Ocidente, tido como espaço hegemônico de ideias e valores. Esse poder "extraordinário" é o que os coloca acima de outros seres, entenda-se os infiéis (kafir), os impuros. Tais seres religiosos são imbuídos de um poder cuja essência lhes é divina o que os separa de todo o resto, os sujeitos “ordinários". Mas retomando Qutb e sua ideia de universalidade do islam, quando levada ao plano político, ela excluiria qualquer soberania do homem sobre os outros homens, culminando em uma igualdade radical. Mas isso, quando o mundo todo for islâmico.

A vontade de poder de alguns grupos, que só não é maior que o poder de Deus, soa $a$ priori compatível com o pensamento de Nietzsche (2005, p.33), para quem "onde falta vontade [de poder] há degenerência. Afirmo que esta vontade falta em todos os valores supremos da humanidade que, sob os mais sagrados nomes, dominam os valores da decadência, os valores niilistas".

\footnotetext{
218 “a evasão [...] mortal é a esperança de outra vida que deve ser 'merecida', ou trapaça daqueles que vivem não pela vida em si, mas por alguma grande idéia que a excede, a sublima, dá um significado e a trai” (tradução minha).
} 
Como viver em um mundo sem Deus ou "outro" Deus (caso do Ocidente na visão dos fundamentalistas)? Nietzsche insiste que a religião é um empecilho, um meandro que deve ser evitado.

Ao criticar o cristianismo e seus sacerdotes como "envenenadores profissionais", Nietzsche (2005, p.40) afirma que quando alguém assume deveres sagrados - por exemplo, tornar os homens melhores em salvá-los, redimi-los -, quando no peito traz a divindade, quando se é porta-voz de imperativos sobrenaturais com tal missão, é natural que se coloque acima dos julgamentos simplesmente racionais - ele próprio se sente santificado por tal tarefa, sente-se membro de uma hierarquia superior!...que interessa a ciência a um sacerdote? Encontra-se excessivamente acima dela!

Considerando as devidas diferenças entre os sacerdotes cristãos e os líderes religiosos islâmicos com relação às suas funções e atribuições, seria possível transpor elementos desse pensamento para alguns sheikhs e imames? Seriam eles também "envenenadores" que levam ao desespero inconsciente do radicalismo? Não estariam eles manipulando mentes frágeis e vulneráveis? Esses "envenenadores" não usariam seu "status" de porta-vozes da religião para se colocarem acima de outros julgamentos, e como tais, poderiam contribuir para a formação de uma massa de fundamentalistas que desembocam em "subtipos" mais extremistas? Para o sheikh Ahmad Abdul, esses recorrem ao que ele intitula de "sheikhs do Google".

No caso brasileiro, entre os líderes religiosos entrevistados, não foi possível concluir que possuem esse perfil. Em primeiro lugar, ainda que sejam necessárias avaliações mais aprofundadas quanto ao perfil dos líderes dessas comunidades, à primeira vista se mostram moderados. Além disso, as comunidades islâmicas brasileiras não se constituem em uma rede muito coesa e sim em organismos com elevado grau de independência, o que torna eventuais discursos mais extremistas estanques, com menos probabilidade de se difundirem. Sobre isso, o sheikh Jihad Hammadeh afirmou que apesar de haver um empenho em se criar uma rede, e que já existe um diálogo para estruturar uma hierarquia entre as instituições islâmicas,

parecemos [isolados entre si] porque eu to fazendo uma autocrítica aqui e uma autoanálise. O que aparece nos sites é diferente da realidade. Por que eu digo isso? A nossa comunicação externa ainda não está adequada. Pois, como estamos trabalhando internamente, ainda falhamos nessa questão de nos expormos, de nos externarmos para a sociedade. Nós estamos num processo de reorganização interna.

O sheikh Abdul Nasser complementa dizendo que "a comunicação entre outras mesquitas pelo país é mais frouxa". 
Em segundo lugar, os fiéis brasileiros não possuem um perfil socioeconômico de vulnerabilidade como se observa em outras partes do mundo como na Europa e mesmo no Oriente Médio em países como a Tunísia (Packer, 2016) ${ }^{219}$. Contudo, a partir das entrevistas concedidas por pessoas que frequentam as mesquitas, nota-se que seus discursos são parecidos e se coadunam em grande parte com aquilo que é ensinado pelos sheikhs. Um exemplo disso é quando recusam o Estado Islâmico como representante do islam e quanto aos possíveis criadores desse grupo, baseado em uma conspiração sionista-estadunidense como vimos anteriormente.

Se nas mesquitas não se encontra um discurso que incite a radicalização a partir da influência de líderes religiosos, é possível que o ensino nas escolas árabes conduza crianças e jovens por um caminho do isolamento ou até mesmo que justifique ações mais impositivas perante a sociedade?

Khouloud El Birani, quando entrevistada, disse que a Escola Árabe-Brasileira de Foz do Iguaçu possui cerca de 460 onde 5\% deles não são muçulmanos. Quanto aos professores, a proporção é diferente, já que apenas os de língua árabe, ensino religioso e inglês são muçulmanos. Os livros que os alunos utilizam são baseados nos currículos estipulados pelo Ministério da Educação (MEC), mas que acrescentam a disciplina de língua árabe e do ensino religioso desde as séries iniciais. O currículo da disciplina árabe se assemelha ao que se faz com a língua portuguesa: gramática, produção e leitura de textos. Quanto ao ensino religioso e ao uso do véu pelas meninas Khouloud diz:

As meninas não são obrigadas a usar o véu, mas podem fazê-lo se o desejarem. Mas o uniforme é regra. No caso da disciplina de ensino religioso, o material é produzido pelo próprio professor abordando temas específicos em cada nível. Mas é comum a todos eles a conscientização social, regras de boa convivência, solidariedade e sobre a vida dos profetas. Não é ensinado apenas com o viés do islam, mas sua influência é marcante uma vez que se trabalham e se estudam diversos versículos do Alcorão, sempre destacando seus aspectos positivos. Não é um ensino religioso voltado só para o islam apesar de estar muito presente no material, que destaca a importância em viver na diversidade, respeitando as diferenças.

Como se nota, no caso do ensino religioso há um esforço em não tomar partido apenas do islam ao abordar temas mais abrangentes como forma também de contemplar os alunos não muçulmanos. Contudo, é nítida a influência e a base de referência corânica dentro de um

${ }^{219}$ https://bit.ly/1ReqaHu (acesso em 09.05.2019) 
contexto de interpretações, segundo Khouloud, "positivas", no intuito da compreensão da diversidade e do respeito.

Sobre isso, a secretária-geral da Escola Árabe-Brasileira, defende

que a convivência em Foz é muito pacífica. Então o que vem de fora, trazido pela mídia em termos de conflitos ou estereótipos, os alunos não reagem a isso. Não se nota uma reação das crianças quanto aos preconceitos induzidos pela mídia. 'Levam na esportiva', não refletem o que vem de fora. A escola também tenta filtrar muito do que vem de fora.

Isso indica um caminho diferente àquele proposto por grupos jihadistas que muito se assemelham com a forma niilista moderna como define Pratt (2016). Para ele,

by the late $20^{\text {th }}$ century, "nihilism" had assumed two different castes. In one form, "nihilist" is used to characterize the postmodern person, a dehumanized conformist, alienated, indifferent, and baffled, directing psychological energy into hedonistic narcissism or into a deep ressentiment that often explodes in violence $^{220}$.

O neofundamentalismo proposto por Olivier Roy ou a face jihadista mais violenta teriam uma expressão existencial para quem o aniquilamento ("annihilate") do "outro deus", da modernização e do secularismo é condição sine qua non para a "liberdade". A contradição se torna a regra. A "minha" extrema liberdade me permite anular a dos outros. "Sou” tão livre que posso me extinguir quando bem entender, pois a verdadeira vida não é aqui, mas no Jardim do Éden, em Valhalla, no Paraíso! É estranho pensar que essa pretensa liberdade total possa estar contraditoramente presa à obediência divina, que autoriza tais práticas violentas segundo uma leitura autodidata das escrituras, apenas aceitável enquanto martírio por jihadistas.

Mais de um século depois, vemos que o terrorismo se tornou um fenômeno bastante capilar no mundo e encontra no suicídio ou no martírio (referência jihadista) uma forma de atingir seus objetivos e realizar suas convicções. Para Ali (2015), a morte passa a ser o auge da glória para aqueles que se matam por Allah. A autora relembra o caso de uma mãe palestina que encorajou três dos seus filhos a executar ataques contra Israel, pois segundo ela o melhor para eles não era a vida nesse mundo.

A alienação, indiferença e desumanização que deságua em violência nesse contemporâneo niilismo distorcido, encontra eco nos grupos mais violentos e extremistas como

\footnotetext{
220 “No final do século 20, o 'niilismo' havia assumido duas castas diferentes. De uma forma, 'niilista' é usado para caracterizar a pessoa pós-moderna, desumanizada conformista, alienada, indiferente e desconcertada, dirigindo a energia psicológica para o narcisismo hedonista ou para um profundo ressentimento que muitas vezes explode na violência" (tradução minha).
} 
Al-Qaeda, Al-Shabbab, Boko Haram e Estado Islâmico ao justificar religiosamente a escravização sexual de mulheres de minorias étnicas e religiosas raptadas durante o conflito no Iraque e na Síria, por exemplo.

Na visão desses grupos não há pecado, pois em sua visão, é algo justificado pela religão. Isso se coaduna em parte com o pensamento de Kierkegaard (2004, p.86) ao esclarecer que o homem que finge de justo não peca, portanto. Se não peca, é por não o ter compreendido. A verdadeira compreensão do justo depressa o levaria a fazêlo, e ele seria em breve o eco da sua compreensão: ergo - portanto - pecar é ignorar.

Retomando o personagem Kirílov, este justifica o suicídio como forma de ser tornar uma espécie de deus, ou ao menos de se aproximar dessa entidade. Todo o resto não teria essa coragem. Entretanto, para ele há dois motivos para que não se cometa suicídio, um pequeno e um grande. O pequeno é a dor, o medo de senti-la. Já o grande motivo é o "outro mundo", o suicídio como pecado e pelo castigo que Deus atribuiria àqueles que o cometesse. Apesar disso, Dostoievski (2013, p.120) em outro diálogo envolvendo Kirílov, esclarece:

- Se for indiferente viver e não viver, todos matarão uns aos outros, e eis, talvez, em que haverá a mudança.

- Isso é indiferente. Matarão o engano. Aquele que desejar a liberdade essencial, deve atrever-se a matar-se. Aquele que se atrever a matar-se terá descoberto o segredo do engano. Além disso, não há liberdade; nisso está tudo, além disso não há nada. Aquele que se atrever a matar-se será Deus.

Sartre (1943, p.77) vai ao encontro do exposto acima ao demonstrar que "cette liberté qui m'inquiéterait si elle était liberté em face du Moi, je tente de la reporter au sein de mon essence, c'est-à dire de mon Moi. II s'agit d'envisager le Moi comme un petit Dieu qui m'habiterait et qui posséderait ma liberté comme une vertu métaphysique" ${ }^{221}$. O suicídio para um pagão seria um crime contra Deus (Kierkegaard, 2004). Um muçulmano extremista interpretaria isso como uma forma de agradá-lo.

Ainda sobre a questão sobre essência e aparência, Sayyid Qutb, resvala nesse tema em alguns dos seus escritos. Segundo Khatab (2006). A dificuldade na distinção entre matéria e espírito, entre a soberania de Deus e do intelecto, por exemplo, seria uma das características da jahilyyiah, tema caro a Qutb.

\footnotetext{
221 “essa liberdade que me preocuparia se fosse a liberdade em face do Eu, tento transferí-la à minha essência, isto é, a mim mesmo. É uma questão de considerar o Eu como um pequeno Deus que me habita e que possui minha liberdade como uma virtude metafísica" (tradução minha).
} 
Kierkegaard (2004, p.69) ao falar da liberdade de escolhas e o desespero que se sente quando temos consciência delas, afirma que "quanto mais o desespero se espiritualiza, tanto mais a interioridade se isola como um mundo incluso no hermetismo, tanto mais indiferente se torna o aspecto exterior sob o qual o desespero se esconde".

Em um niilismo "ao contrário", no caso fundamentalista, nega-se a ciência e a modernidade em benefício da purificação do ser e do mundo com base na religião. Ali (2015) relembra a frase em um cartaz da polícia taleban que dizia: "jogue a razão aos cães - ela fede a corrupção". De outra forma, Sayyid Qutb, ícone entre os fundamentalistas islâmicos não se colocava contra as ciências, mas sim quando eram vistas de modo separado de Deus, sem que em suas explanações à presença divina fosse considerada.

Subvertendo o niilismo "original", do elogio ao positivismo, à ciência, à empiria, à razão, não se vê nenhum sentido na existência, no real, no mundo aparente, daí o desespero e a angústia que levam alguns ao suicídio em prol de uma causa "fictícia", religiosa, deificada. Aquele que se mata com consciência, caso dos terroristas, maior seria seu desespero. Mas qual desespero? A negação da existência que não seja aquela ao lado de Allah ou em um mundo governado por ele e suas leis.

Quando Jackson (2006) associara Qutb ao Übermensch e aos seus escritos de teor kierkegaardiano ao se elogiar o individualismo, em que o Alcorão é percebido por um tipo de prisma com base nas próprias experiências e percepções, era pouco provável crer na relação entre o fundamentalismo e o niilismo. Contudo, ao tentar esmiuçar essa improvável relação, foi possível observar que apesar de muitos pontos divergentes, a começar pela influência da religião que deve ser abolida para que se possa viver de modo pleno e sem desvios, o fundamentalismo moderno tangencia temas caros a essa opção filosófica. Entre eles destacamse o próprio entendimento da vida, a constituição do mundo aparente e do mundo real como o "além-mundo", a relação que o indivíduo estabelece com a morte especialmente no caso do martírio, as possibilidades que o fundamentalismo, ou melhor, o neofundamentalismo oferece através da liberdade do autodidatismo e da firmação do "ser" como um "pequeno deus", de alguém que se distingue pelo seu caráter "extraordinário".

Tudo isso seria plenamente compatível com os preceitos niilistas não fosse a religião. $\mathrm{O}$ niilismo às avessas, se realiza ao colocar em evidência a religião. Ela é o fio condutor da pretensa "liberdade" do ser, é aquela que atribui um peso e um sentido à vida, mas não nesse mundo ou pelo menos na forma em que se encontra. De acordo com Jackson (idem) Qutb acreditava que o islam guarda todas as respostas para todas as "doenças" da sociedade. Para 
isso, há que estar preparado para interpretar os sinais e cada um fará isso segundo suas próprias circunstâncias.

Nesse sentido Mawdudi é lembrado por Jackson (idem) quando se fala da ijtihad, que deveria ser independente à medida que os muçulmanos atingirem determinada capacidade para interpretar as escrituras. O "Übermensch muçulmano" seria de certa forma aquele que atingisse esse estágio de maturidade na compreensão do islam e de como usá-lo para transformar esse mundo em um mundo "real", livre das "aparências" que servem apenas para desvirtuar os indivíduos, ainda que frequentemente faça uso de meios modernos para consecução dos seus objetivos.

O Quadro 2 abaixo busca sintetizar as diferenças entre o niilismo "original" e o niilismo de caráter fundamentalista.

\section{Quadro 2 - Niilismo e Fundamentalismo}

\begin{tabular}{|l|l|}
\hline Niilismo & Niilismo fundamentalista \\
\hline Tecnologia, ciência e visão utilitarista. & $\begin{array}{l}\text { Tecnologia a serviço da causa de Allah, } \\
\text { transforma em logos o mythos da fé. } \\
\text { Modernidade como "fetiche”. }\end{array}$ \\
\hline $\begin{array}{l}\text { Realidade Única: ênfase na empiria, no mundo } \\
\text { aparente, não há outros mundos. }\end{array}$ & $\begin{array}{l}\text { Múltiplas realidades: mundo aparente é falso. O } \\
\text { real é o “outro mundo" no "além”, ou a } \\
\text { transformação deste pela religião. }\end{array}$ \\
\hline Ausência de religião. & Religião é o "fio condutor" da vida \\
\hline Liberdade extremada, arbítrio. & Liberdade relativa \\
\hline Atitude blasé, alienação do indivíduo. & Desumanização \\
\hline
\end{tabular}

Para o niilismo fundamentalista entendido como uma "subversão" do niilismo original, as categorias que nos ajudam a defini-lo são comuns. Enquanto um valoriza a ciência, o outro não a exclui por completo, mas ao contrário, faz uso daquilo que é importante para a difusão ou realização de seus objetivos. Além disso, se o niilismo pressupõe uma única realidade na qual a vida deve se desenrolar de forma plena, livre, com o devido peso existencial e, sobretudo consciente de sua complexidade e finitude, o fundamentalismo, guiado pela religião, prevê a multidimensionalidade do mundo. Nele, seja aqui ou no "além", Deus governará de forma soberana. Vive-se a contradição da esperança de uma vida em outro mundo possível, o "desespero do possível" ao qual se refere Kierkegaard (2004), e a realidade que cerca o indivíduo. 
Se para os niilistas a religião é um dos maiores consolos para se encarar o peso da vida e por isso deve ser evitada, para os fundamentalistas, o mundo aparente com todas suas rugosidades materiais e imateriais, promíscuas, globalizantes e homogeneizantes são as distrações que fazem a humanidade se afastar de Deus. Por isso, quanto mais se dá valor à religião, mais "livre" se torna o espírito.

Se por um lado a liberdade total é atingida com atitudes de indiferença perante as coisas do mundo que nos desviam da razão, pelo lado inverso do fundamentalismo, a liberdade está condicionada à destruição do pecado em um mundo habitado por muitos infiéis. Por isso a observância das leis de Deus é o melhor caminho para se livrar dos diversos tipos de cárceres, como o nacionalismo, o secularismo e a modernização que escravizam e desviam o foco de Deus. Nesse sentido, a forma para se libertar desse mundo aparente pode estar na desumanização, na maneira indiferente com que se lida com a vida. Nesse caso, as práticas terroristas com a supressão da própria vida e das de outrem, uma vez que não há inocentes, simbolizam esse aparente desprendimento e liberdade total, se aproximando inclusive da primeira forma de niilismo.

Jihadistas seriam "homens-absurdos"222, segundo Camus (2013). Eles já abraçaram as três consequências do absurdo: a revolta, a liberdade e paixão. A revolta, por se encontrarem

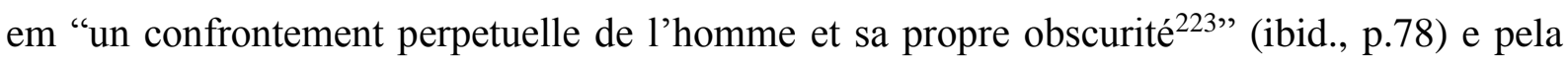
constatação inicial da falta de um sentido da vida, mas que é logo preenchida por Deus. A liberdade, haja vista a condição humana, pelas escolhas que são feitas e que são solitárias e soberanas. A paixão, consciência da vida, que, a partir dessas escolhas, não pode ser vivida de outro modo.

Como na mitologia que descreve a condição de Sísifo e sua árdua e eterna tarefa perante os deuses, os jihadistas contemplam seus tormentos, mas que com sua vontade exacerbada se tornam felizes no absurdo de suas vidas.

\subsection{O que os modelos de muçulmanos têm a dizer?}

Nas entrevistas que foram realizadas, a última das perguntas visava conhecer qual o modelo de muçulmano que serve de inspiração ao entrevistado, um exemplo que pudesse ser seguido e admirado. Essa questão era colocada ao final da conversa para que se pudesse

\footnotetext{
222 "L'homme absurde ne peut que tout épuiser, et s'épuiser". ("O homem absurdo pode esgotar tudo e se esgotar)" (tradução minha). (Camus 2013, p.80).

223 "Um confronto perpétuo entre o homem e sua própria obscuridade" (tradução minha).
} 
minimamente avaliar se as informações transmitidas na entrevista estavam coerentes com o perfil do "modelo" de muçulmano que cativava o informante.

Tal metodologia foi inspirada e adaptada a partir da pesquisa de Ahmed (2007), em que o autor faz a mesma pergunta aos seus 120 entrevistados de lugares diferentes, mas dentro da realidade indiana, recorte principal do trabalho. Para o autor, ao se conhecer qual seria o muçulmano inspirador do entrevistado seja ele um líder político, militar ou apenas religioso, vivo ou não, ajudaria a traçar um perfil da visão de mundo do próprio entrevistado. Ele então poderia ser classificado como um muçulmano reformista, moderado ou mesmo extremista. Ahmed (ibid., p.15) explica através de exemplos que

For instance, the first question of the list asks for five contemporary role models among Muslims (if the respondent had none, examples from outside Muslim society could be given). If the mystic poet Maulana Rumi was named here, we knew the respondent was more likely to be tolerant of others; if Pervez Musharraf was named, then the respondent might favor economic and political cooperation with the West. And if Osama bin Laden or Mahmoud Ahmadinejad were named, then the respondent probably preferred a role model that would "stand up to the West" 224.

Dependendo da idade e mesmo da cidade em que foram entrevistados, seus perfis se alteravam. Entre os resultados obtidos através desse questionamento, observou-se que muitos dos informantes de Ahmed (2007) apontaram duas personalidades importantes, mas em tempos remotos: o califa Omar e o grande personagem da época das cruzadas, Saladino. Segundo o autor, ambos os conquistadores de Jerusalém refletiam o perfil de serem magnânimos, pios e vitoriosos em batalhas.

Entre os jovens em particular, o resultado foi bastante revelador e intrigante ao mesmo tempo. Os exemplos de muçulmanos apontados, além de conhecidos de tempos recentes, apresentavam um caráter mais hostil e polêmico, especialmente com relação ao Ocidente. Segundo Ahmed (ibid., p.23)

They were sweet, funny kids who wanted to take pictures afterward and ask questions about the U.S.Why, then, did roughly 75 percent of them list as their role models people like Osama bin Laden, Saddam Hussein, Ayatollah

\footnotetext{
224 "Por exemplo, a primeira questão da lista entre os muçulmanos (se o entrevistado não tivesse nenhum, exemplos de fora da sociedade muçulmana poderiam ser dados). Se o poeta místico Maulana Rumi fosse nomeado aqui, seríamos mais tolerantes com os outros; se Pervez Musharraf fosse nomeado, o respondente poderia favorecer a cooperação econômica e política com o Ocidente. E se Osama bin Laden ou Mahmoud Ahmadinejad fossem nomeados, então o entrevistado provavelmente preferia um modelo que "resistiria ao Ocidente" (tradução minha).
} 
Khomeini, Yousef al-Qaradawi (of Al-Jazeera), Yasser Arafat, and Iranian President Mahmoud Ahmadinejad? We obviously have a problem. If these young students are choosing as heroes people who are hostile to the U.S. ${ }^{225}$

Nos oito países - incluindo Oriente Médio e Sudeste Asiático - os modelos de muçulmanos não tiveram um padrão de escolha entre os entrevistados. Em alguns lugares, a tendência era mais moderada e identificada com o "modelo Aligarth", enquanto em outros, mais conservadora e hostil, como o "modelo Deoband". No entanto, o percentual de personalidades ligadas a uma visão mais extresmista não passou de $15 \%$ dos entrevistados.

No caso da presente tese não temos um número considerável como o de Ahmed (ibid.), mas, mesmo assim vale o exercício. Entre nossos 16 entrevistados, primeiramente é possível classificá-los por idade. Quatorze deles têm mais de 40 anos e 2 deles, menos de 30 anos.

As respostas foram as seguintes conforme mostra o Quadro 3 abaixo:

Quadro 3 - Modelos de Muçulmanos

\begin{tabular}{|l|l|l|}
\hline Nome & Idade & Modelo de Muçulmano \\
\hline Alaa El Deen & 24 & Mohammed \\
\hline Khouloud El Birani & 25 & Mohammed e Malala \\
\hline Sheikh Ahmad Abdul & 68 & Mohammed \\
\hline Sheikh Jihad Hammadeh & 54 & Mohammed e Saladino \\
\hline Anice Ghazzawi & 44 & Indira Gandhi (?) \\
\hline Sheikh Mohammed Khalil & 49 & Mohammed e o Imam Said Musa Sadr \\
\hline Sheikh Abdul Nasser & 59 & Mohammed \\
\hline Ahmed Al-Khatib & Aprox. 40 & Mohammed \\
\hline Mustafa Goktepe & 40 & Fethullah Gülen \\
\hline Fatih Ozorpak & Aprox. 40 & Fethullah Gülen \\
\hline Kamil Ergin & 34 & Fethullah Gülen \\
\hline Sheikh Abdel Hamed Mohammed Ali Metwally & 44 & Mohammed \\
\hline Muhamad Tawfiq & Aprox. 45 & Não especificou \\
\hline Issa Alturk & 35 anos & Não especificou \\
\hline Nader & Aprox. 30 & Mohammed \\
\hline Abdoul Hadi Savadogo & Aprox. 40 & Mohammed \\
\hline
\end{tabular}

No geral, percebe-se nitidamente que Mohammed (Maomé) é figura central entre os entrevistados. Líder político, militar e religioso além de ser o grande personagem da

225 "Eles eram doces, engraçadas crianças que queriam tirar fotos depois e fazer a pergunta sobre os Estados Unidos. Por que, então, Cerca de 75 por cento deles listam como seus modelos pessoas como Osama bin Laden, Saddam Hussein, o aiatolá Khomeini, Yousef al-Qaradawi (da Al-Jazeera), Yasser Arafat e o presidente iraniano Mahmoud Ahmadinejad? Nós obviamente temos um problema. Se esses jovens estão escolhendo pessoas que são hostis aos EUA" (tradução minha). 
"revelação" da palavra de Deus e cujo comportamento e ações que praticou em sua vida são observados e seguidos por muitos muçulmanos através das ahadith. Tal predileção tem uma explicação segundo Ahmed Al-Kahtib. Para ele,

no Alcorão está dizendo Deus para os muçulmanos não terem exemplos entre os seres humanos, exceto em Mohammed. Para nós, os profetas, os mensageiros de Deus até Jesus, Salomão, até Davi, até Ló...eu mencionei eles de propósito esses 4. Para os muçulmanos e para os cristãos originais, esses homens são escolhidos de Deus e são protegidos, não praticam erros...erros graves eu falo. Todos são seres humanos, mas não praticam erros como fornicação, como roubar...entendeu? Então nós temos eles como exemplos, os mensageiros de Deus, não podemos ter outros como exemplos.

Contudo, é importante ressaltar que outros nomes surgiram e podem indicar uma provável orientação do entrevistado.

Khouloud, em uma primeira reação à pergunta citou de chofre Nelson Mandela e Mahatma Gandhi, nenhum deles muçulmano. Mas ao se dar conta do seu equívoco inicial, citou Maomé. Para desfazer o engano ela disse: "É que você perguntou sobre uma pessoa e não um profeta. Eu já entendo diferente: que o profeta é uma coisa, a pessoa é outra coisa”. Subentendese, pois, que Maomé sendo um profeta não seria uma pessoa comum. Nada se aproximaria da importância e influência de Maomé.

Além dele, Malala Yousafzay foi citada. A jovem paquistanesa que tem uma história trágica em seu país, mas ao sobreviver a um ataque extremista motivado pela contrariedade ao ensino para mulheres, passou a lutar pela causa da educação e igualdade. Seu ativismo cresceu concomitantemente à sua fama de jovem de coragem, produzindo livros e culminando com o recebimento do Nobel da Paz em 2014, sendo a mais nova a ganhá-lo. Sua história de vida e popularidade amplificada pela mídia de fato tem cativado especialmente os mais jovens.

Entre os mais velhos há alguns destaques importantes. Anice, ao responder Indira Gandhi, alegou que ela lhe "inspira paz além de ser uma mulher de fibra", mas não se atentou para o fato de ela ser hindu. Não quis interrompê-la acreditando que ainda pudesse rever sua resposta, fato que não se concretizou. Mas no transcorrer da conversa, por ter falado algumas vezes da importância de Maomé, é possível que como os outros ele teria sido apontado como exemplo.

O sheikh Abdul Nasser ao responder à pergunta, sem titubear também citou Maomé e disse que ele "foi o maior líder político, espiritual e militar que o mundo conheceu". Daí sua preferência. 
Diferentemente, o sheikh Jihad Hammadeh, a exemplo do que Ahmed (2007) já havia mostrado em suas pesquisas, citou Saladino, que em suas palavras, "era um líder, um estrategista, um comandante muçulmano, um devoto, uma pessoa justa e que tratou seu inimigo com justiça e compaixão. O Ocidente tem que tirar o chapéu para ele. O tratamento que ele deu, ficou na história”.

Tal influência se justifica quando aprendemos com Jackson (2006) que Saladino foi levado às batalhas por seu tio a contragosto já que preferia usar o tempo para aprofundar as leituras religiosas ou mesmo jogar xadrez. Mas quando se transforma em um grande líder ganhando o respeito de seus aliados e mesmo inimigos, como Ricardo Coração de Leão, seu prestígio, entre outras coisas, o auxilia a unificar grupos de muçulmanos. Além disso, sempre teve uma vida baseada no desprendimento material, sendo avesso ao luxo e à ostentação, dormindo em tendas militares simples durante suas campanhas. Portanto, Saladino seria o retrato da humildade, benevolência e da unidade entre os muçulmanos, mas também alguém que ganhou o respeito de seus adversários.

Mohamad Tawfiq não especificou um exemplo, mas foi incisivo ao dizer que meu modelo, é seguir o Alcorão e a sunna do profeta. Fomos criados somente para adorar a Allah, não atribuir parceiros a Ele, cumprir as orações, pagar o zakat, jejuar o Ramdan, realizar o hajj, ser benevolente com meus pais, fazer o bem, ser justo, e respeitar os vizinhos, mesmo não muçulmanos. Afastar de tudo que Allah proibiu para mim: associar a alguém a Ele, matar, roubar, mentir, trair.

Sheikh Mohammed Khalil, diferentemente dos outros, revelou, além de Maomé, ser o Imam Said Musa Sadr sua grande inspiração e exemplo de muçulmano. Lembrando que o sheikh Mohammed é xiita, não poderia deixar de apontar uma referência dessa corrente. Ele se entusiasma ao lembrar-se dessa referência e acrescenta:

ele foi sequestrado pelo Gaddafi há 37 anos na Líbia. Tinha origem libanesa, mas seu pai emigrou ao Irã e ele nasceu lá. Aos 38 anos de idade, se formou como líder religioso em Qom, ainda na época do xá. Em 1957, foi chamado por outro líder religioso supremo Abdul Hussein Sharif Al Din para substituílo. Depois, no ano de 1978, em 31 de agosto, foi sequestrado por Gaddhafi, na verdade desapareceu na Líbia. Teria ido à Líbia a convite do Gaddafi para uma celebração. Nós acusamos o regime da Líbia, claro! [Com um tom de nostalgia, continua] Musa Sadr, homem com mentalidade aberta, linda! Uma personalidade extraordinária! Esse um bom líder contemporâneo. Eu tinha 
entre 14 e 15 anos quando ele desapareceu. Mas a família sentiu muito a falta dele e, para pedir justiça para encontrá-lo, participou de manifestações.

É importante também observar que Musa Sadr teve papel muito importante nos anos 60 e 70 para a comunidade xiita do Líbano. Ele criou o Movimento dos Desprovidos (Harakat alMahrumin) em 1974, e em 1975, ano da eclosão da Guerra Civil Libanesa, ele criou o Harakat Amal (Movimento da Esperança), ou apenas AMAL (Afwaj al-Muqawama al-Lubnaniya Destacamento da Resistência Libanesa). Esse grupo se constituiu como uma milícia do Movimento dos Desprovidos que tinha por objetivo promover a segurança no sul do Líbano se colocando como opositor aos grupos armados palestinos e às forças de defesa de Israel, especialmente em 1978. Posteriormente, especialmente após seu misterioso e controverso desaparecimento, se encaminha aos poucos para se transformar em um partido político no Líbano $^{226}$.

Imam Sadr, tal como é lembrado pelo sheikh Mohammed Khalil, teria lutado por melhores condições de vida e representatividade dos xiitas, em especial aqueles do sul do Líbano, local conflituoso e negligenciado pelo governo Libanês nos anos em que ali viveu. Seria uma personalidade muito exaltada entre seus seguidores como ilustra o sheikh, algo evidenciado por Norton (1988, p.55) ao escrever que "his followers applaud his humanity, selflessness, and stauch commitment to Lebanon's 'disinherited' and Lebanon itself'. Contudo, nota-se que em determinado momento de sua vida, diante de grandes injustiças contra os xiitas, ele previa se fosse necessário lançaria mão do conflito armado. A revolução pelas armas parecia ser o caminho apontado segundo um discurso em Bidnayil em fevereiro de 1974 para milhares de pessoas e reproduzido em parte por Norton (1988, p.47):

even though this costs us our blood and our lives. Husain faced the enemy with 70 men; the enemy was very numerous. Today we are more than 70 , and our enemy is not the quarter of the whole world...we do not want sentiments, but action. We are tired of words, feelings, speeches...I have made more speeches than anyone else. And I am the one who most often called for calm...From today on I will not keep silent. If you keep quiet, I will not...227

A opção por Musa Sadr não deve indicar um possível traço mais extremista na visão do Sheikh Mohammed Khalil. Claro que a observância das leis religiosas e das escrituras era um

\footnotetext{
${ }^{226}$ Cf. Norton, 1988.

227 "mesmo que isso nos custe nosso sangue e nossas vidas. Husain enfrentou o inimigo com 70 homens; o inimigo era muito numeroso. Hoje somos mais de 70 e nosso inimigo não é o quarto do mundo inteiro...não queremos sentimentos, mas ação. Estamos cansados de palavras, sentimentos, discursos... Eu fiz mais discursos do que qualquer outra pessoa. E eu sou aquele que mais frequentemente pedia calma... A partir de hoje eu não vou ficar calado. Se você ficar quieto, eu não vou..." (tradução minha).
} 
fator importante na personalidade de Musa Sadr, mas ao que tudo indica, os objetivos de seu engajamento político eram essencialmente voltados à proteção e à igualdade de direitos e serviços à população xiita ainda que sob o viés armado em um Líbano fragmentado socialmente e efervescente devido à Guerra Civil, e posteriormente, em 1978, à invasão israelense com a operação Litani. Sua formação religiosa, engajamento político, oposição ao xá do Irã e aos comunistas, habilidade em fazer dos símbolos religiosos e suas celebrações como as da Ashura, modos de erguer e sedimentar a solidariedade e a consciência política entre seus seguidores, podem fazer dele antes um neofundamentalista do que propriamente um jihadista.

Por fim, Mustafá Goktepe apontou como sua inspiração o líder religioso turco Fethullah Gülen, influenciado pela corrente sufi do islam, prega um islam tolerante, a convivência na diversidade, que busca conciliar religião e modernização, defende um diálogo interconfessional e aponta a democracia como o melhor sistema de governo. Essas ideias inspiram o Movimento Hizmet $^{228}$ (a serviço da humanidade) que se declara não-político, não religioso e muito menos uma seita. Trata-se de um movimento de sociedade civil que se ampara em uma rede de escolas, creches e universidades, na mídia (jornais como o Zaman turco, TV e internet) e no apoio de empresários que alimentam as obras sociais com donativos.

Mustafá justifica sua escolha dizendo:

Eu leio, sigo e vejo e justamente toda minha posição. Ele é o único líder religioso muçulmano que se posiciona diante das coisas atuais, escrevendo para jornais internacionais de grande impacto e sem receio nenhum de se posicionar. Isso não é qualquer um que faz. Eu, igualmente, penso como ele. Logicamente ele forma minha opinião, minha fé. E valores humanos, que vale para todos.

Em resumo, as primeiras entrevistas indicam um perfil que tende mais para o lado moderado do que extremista. Valores como a compaixão, o respeito, a união, a justiça, humildade e abnegação são mais nítidos do que seus antônimos. Ainda que muitos dos modelos estejam associados a conflitos ou mesmo inseridos em contextos complexos e hostis do ponto de vista social e militar, as qualidades positivas se sobressaem às negativas.

Contudo, é bom lembrar que ao se referir ao perfil de "moderado", é importante ter o mesmo cuidado que Ahmed (2007, p.23). Ele diz: "I hesitate to use the word 'moderate' because of its negative connotations. From what I've gathered, moderates are viewed as people who are

\footnotetext{
${ }^{228}$ Recentemente o movimento vem sendo muito hostilizado pelo governo de Recep Tayyip Erdogan que dentre algumas de suas atitudes, passou a controlar grande parte da mídia na Turquia, censurando jornalistas e vem acusando Fethullah Gülen por ser o suposto mentor da mais recente tentativa de golpe militar na Turquia em julho de 2016
} 
unwilling to stand up for anything"229. Ahmed (ibid.) então define esses "moderados" como aqueles que "are practicing the compassionate and just Islam that is taught in the Quran without rejecting modernity and the West" ${ }^{\prime 230}$.

229 'Hesito em usar a palavra 'moderada' por causa de suas conotações negativas. Daquilo que eu reuní, os moderados são vistos como pessoas que não estão dispostas a defender qualquer coisa" (tradução minha).

230 "Estão praticando o islam justo e de compaixão que é ensinado no corão, sem rejeitar a modernidade e o Ocidente" (tradução minha). 


\section{ENTRE O PACIFISMO DAS MESQUISTAS E A HOSTILIDADE VIRTUAL \\ PARTE 3}

"Ela quer se converter ao islam. Eu perguntei para ela o que ela sabe do islam. Onde você estuda? Ela disse: 'na internet' [...] eu brinco com os irmãos aqui, sheikh de Google”

Sheikh Ahmad Abdul (CCIB).

“Como fosse grande arabista, achou no Corão que Maomé declara veneráveis os doidos, pela consideração de que Alá lhes tira o juízo para que não pequem. A ideia pareceu-lhe bonita e profunda, e ele a fez gravar no frontispício da casa; mas, como tinha medo ao vigário, e por tabela ao bispo, atribuiu o pensamento a Benedito VIII [...]"

Machado de Assis. "O Alienista”. 


\section{Radicalismo islâmico no Brasil: possibilidades e realidade}

Há uma lenda em que o rei Salomão, conhecido por falar com os animais, passava com sua caravana quando avistou um grupo de formigas trabalhando. Quando viram a passagem de Sua Majestade, todas pararam para reverenciá-lo, exceto uma, que continuava trabalhando. Carregando um grão de duna por vez, a formiga desejava construir uma ponte que a levasse à sua amada, do outro lado de um rio. O rei, perplexo, quis saber se ela teria a longevidade e a paciência para concluir tamanho trabalho. Mas a formiga lhe respondeu que preferiria morrer tentando, mas imbuída de esperança e amor ${ }^{231}$.

Infelizmente, ao contrário daquela formiga, muitos pensam em mudar o mundo com base na violência e na intolerância. Diante de tantos extremismos, o religioso, em especial o islâmico, tem protagonizado as manchetes dos diversos veículos midiáticos mundo afora nos últimos anos. Paris, Bruxelas, Orlando, Manchester, Mossul, Istambul, Parachinar, Colombo e Cabul, são exemplos recentes da grande extensão geográfica que os ataques terroristas têm assumido. Eles também mostram que o Ocidente, contrariamente àquilo que a grande mídia nos faz crer, não tem sido o único e principal alvo dos atentados.

Um exemplo disso é o ano de 2013, em que quase 18 mil pessoas morreram vítimas de ataques terroristas, porém $82 \%$ delas se concentrou em apenas 5 países: Iraque, Afeganistão, Nigéria, Paquistão e Síria ${ }^{232}$, países imersos em guerras civis e terreno dos principais grupos terroristas da atualidade como Al-Qaeda, Estado Islâmico e Boko Haram.

O ano de 2018 não traz dados muito diferentes como revela o mapa abaixo.

Mapa 9

\section{Global Terrorism Index}

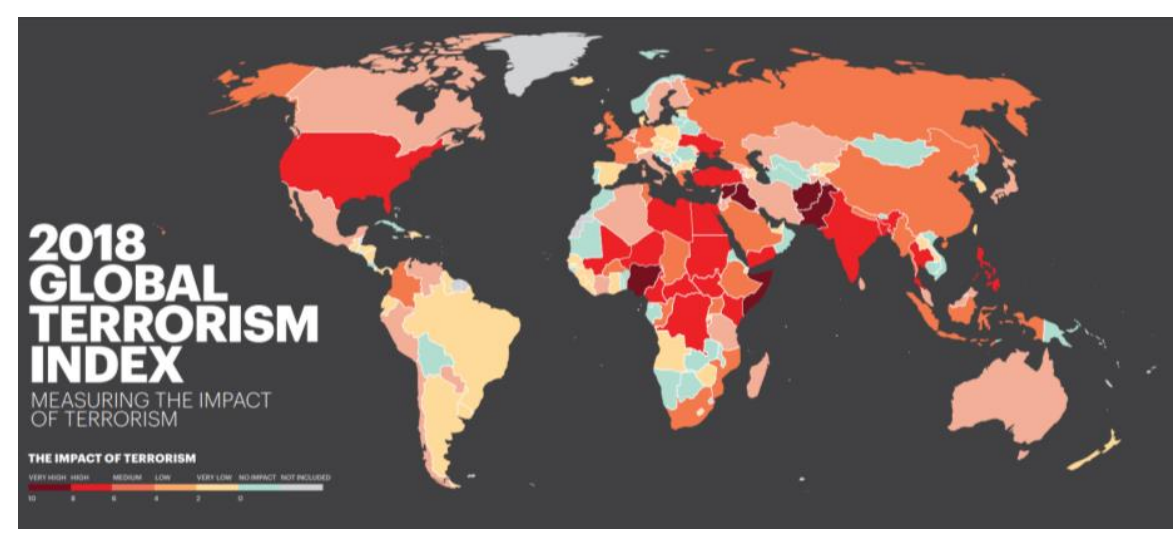

https://bit.ly/2KsdGob (acesso em 08.05.2019).

\footnotetext{
${ }^{231}$ Essa história pode ser conhecida por meio do site https://bit.ly/2MMcMPh (acesso em 08.05.2019).

${ }^{232}$ Gilsinan, Kathy. The Geography of Terrorism. The Atlantic. 18 nov.2014. Disponível em https://bit.ly/2nMf8li (acesso em 08.05.2019).
} 
O mapa expõe o Global Terrorism Index (GTI), publicado pelo Institute for Economics and Peace baseado nos dados do Global Terrorism Database (GTD), da Universidade de Maryland ${ }^{233}$. Foram compiladas informações de mais de 150 mil incidentes de atividades terroristas globais em 163 países e seus efeitos em termos de número de mortos, feridos e danos à propriedade. Novamente, o centro-norte do continente africano, Oriente Médio, Ásia Central e Sudeste Asiático são os locais com maior número de incidentes.

No caso específico da América Latina e em particular o Brasil, objeto de nossa reflexão, é praticamente irrisório o número de incidentes. Abaixo é possível constatar em que dentre os 163 países considerados, o Brasil, em 2016, ocupava a posição de número 87.

Mapa 10

Incidentes por Terrorismo: Mundo e Brasil

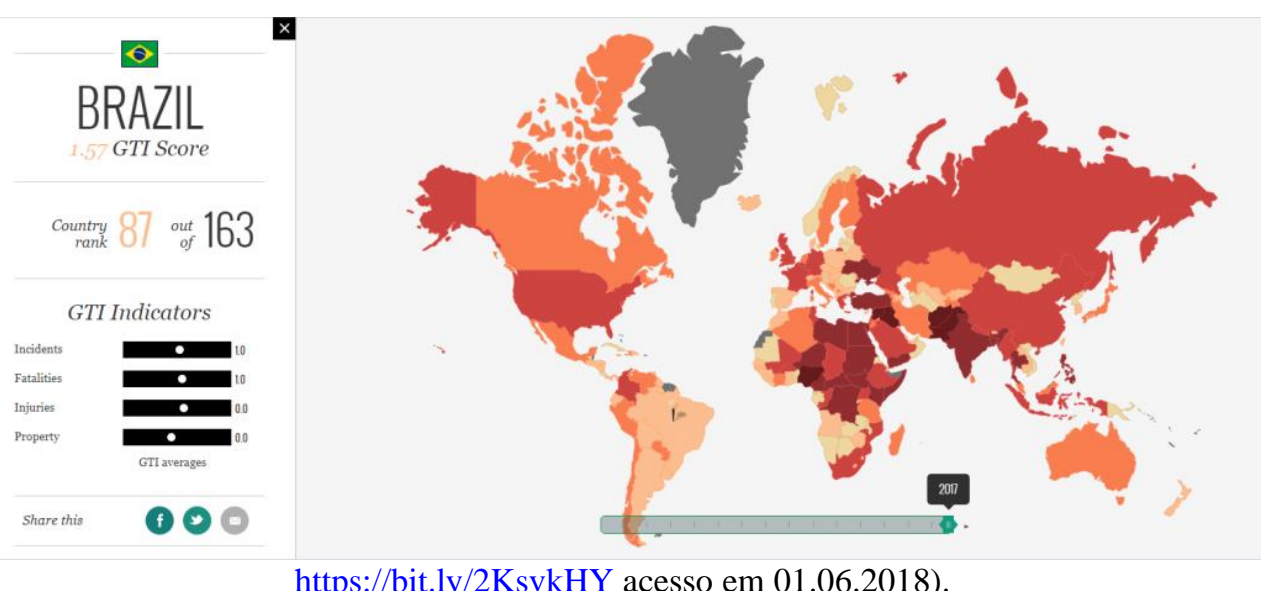

No entanto, é preciso esclarecer que os incidentes declarados pelo mapa para o caso brasileiro não estão relacionados a grupos terroristas e muito menos islâmicos. Uma das hipóteses que ele suscita é a relação desses dados com a instabilidade política e econômica pela qual o país tem passado nos últimos anos e que tem se traduzido, desde 2015, em ondas de protestos e manifestações políticas massivas em que muitas delas tiveram interações violentas com a polícia além de causarem danos ao patrimônio em situações isoladas. O Brasil também desponta como um dos piores países em termos de crimes contra a pessoa. Segundo dados

\footnotetext{
${ }^{233}$ A definição de terrorismo adotada pelo GTD é: "the threatened or actual use of illegal force and violence by a non-state actor to attain a political, economic, religious, or social goal through fear, coercion, or intimidation" (Disponível em https://bit.ly/2MCOlbY, acesso em 11.06.2019). "O uso, ou ameaça de uso, de força ilegal e da violência por um ator não-estatal para atingir um objetivo político, econômico, religioso ou social através do medo, coerção ou intimidação" (Tradução minha). A definição usada pela Universidade de Maryland exclui questões polêmicas como o chamado terrorismo de Estado e não diferencia ataques contra alvos militares definidos de ataques indiscriminados contra civis - duas questões presentes na maioria dos debates acerca do tema.
} 
recentes do Atlas da Violência divulgado pelo IPEA ${ }^{234}$, a violência no Brasil atingiu os maiores patamares de sua história com mais de 65 mil assassinatos em 2017, e uma taxa relativa de 31,6 homicídios por 100 mil habitantes.

O termo "terrorismo", segundo a metodologia usada para a confecção dos mapas acima é bastante discutível do ponto de vista conceitual. É mais fácil nomear e identificar esses incidentes no Oriente Médio, Ásia e Norte da África do que na América Latina em razão da reconhecida presença de grupos terroristas e que por sua vez assumem a autoria dos ataques, além de estarem engajados em lutas territoriais, étnicas e religiosas conforme aponta uma vasta bibliografia e dados empíricos ${ }^{235}$. É certo que não podemos escapar do debate que envolve a definição de terrorismo, algo que faremos no item 6.2 desta pesquisa.

Diante desse quadro, é possível que o Brasil, tão distante geograficamente dessas áreas em convulsão, possa abrigar grupos extremistas islâmicos? Ou ainda, ser alvo de futuro terrorismo e ações jihadistas? Existe um ambiente no país que propicie a radicalização de muçulmanos? Para a Revista Brasileira de Inteligência (2007, pp.09-10),

atentados, em tese, podem ocorrer no Brasil, em função das já mencionadas condições de presumível inadequação das medidas antiterroristas, da vulnerabilidade e permeabilidade das extensas fronteiras nacionais e da existência de alvos em número significativo. Assim, o Brasil pode ser, sempre em tese, palco de um atentado contra alvos tradicionais do terrorismo aqui estabelecidos (representações diplomáticas, estabelecimentos religiosos, culturais e educacionais de comunidades-alvo) ou em trânsito (autoridades estrangeiras em visita ou com presença temporária). Atentados podem acontecer por ocasião de grandes eventos, que proporcionem grande visibilidade, como os recentes Jogos Pan-Americanos de 2007, no Rio de Janeiro.

A lei antiterrorismo ${ }^{236}$ sancionada pela então presidente Dilma Rousseff às vésperas dos Jogos Olímpicos do Rio de Janeiro seria uma resposta à essa possibilidade hostil? Sob os auspícios da recente lei, a deflagração da Operação Hashtag pela Polícia Federal, que deteve entre julho e agosto de 2016, catorze suspeitos de envolvimento com organizações terroristas, e a denúncia de outros onze brasileiros em maio de 2018 implicados em uma organização

\footnotetext{
${ }^{234}$ https://bit.ly/2wF41k7 (acesso em 06.06.2019).

235 Cf. COCKBURN, Patrick. A origem do estado islâmico: o fracasso da guerra ao terror e a ascensão jihadista. São Paulo: Autonomia Literária, 2015.

Cf. Global Terrorism Index 2018. Disponível em https://bit.ly/2E2QXtG (acesso em 07.06.2019).

Cf. Jalal, Ayesha. Combatentes de Alá: a jihad no sul da Ásia. São Paulo: Larousse do Brasil, 2009.

${ }^{236}$ Lei n.13.260, de 16 de março de 2016. Disponível em: https://bit.ly/2xkhTDz (acesso em 08.05.2019).
} 
criminosa e de suporte ao Estado Islâmico (EI), seriam os maiores indícios de que o país pode estar na rota do terrorismo?

Existe uma maior tendência para recusarmos essas ilações, posto que no Brasil, de uma forma geral, as religiões e suas comunidades convivem de maneira harmoniosa. Além disso, no plano político das relações internacionais, o país não exerce um protagonismo agudo no tocante aos temas sensíveis que permeiam as disputas que ocorrem no Oriente Médio e alhures e que, portanto, não devem reverberar internamente ao ponto de tornar o país um alvo de grupos jihadistas. Apesar desse cenário igualmente se enquadrar ao da Nova-Zelândia, que viveu em maio de 2019 o pior ataque terrorista de sua história, quando um homem branco, cristão e seguidor de ideias neonazistas, entrou em uma mesquita e executou dezenas de pessoas enquanto rezavam. Tudo foi filmado e transmitido ao vivo via redes sociais, chocando a comunidade local e internacional.

Ainda assim, há vozes dissonantes que entendem que a América Latina e o Brasil devem estar alertas à presença de organizações terroristas face ao crescimento do número de muçulmanos na região e às possíveis influências de instituições, grupos e governos de países do Oriente Médio nas comunidades daqui.

\subsection{América Latina e Brasil: indícios de novos horizontes do radicalismo islâmico?}

As suposições de que a América Latina e o Brasil podem ser nós de redes terroristas globais, a princípio soam como algo estranho e difícil de se imaginar, tal como um formigueiro sem rainha. No entanto, alguns autores e meios de comunicação sugerem essa possibilidade com base em alguns indícios e situações envolvendo indivíduos que buscam tecer redes de cooperação com organizações de caráter terrorista.

Segundo Montenegro (2013, p.16) para alguns grupos de imigrantes na fronteira, essa estigmatização

como "terroristas" e "fundamentalistas", tão difundida na mídia, escondia conflitos e guerras comerciais, "ataques ao comércio árabe na fronteira", uma retaliação dos Estados Unidos porque os comerciantes árabes de Ciudad del Este tinham deixado de comprar produtos de Miami e agora os importavam da China.

Paulo Pinto (2010) afirma que os governos norte-americano e argentino promoveram uma campanha de investigação da comunidade islâmica na Tríplice Fronteira e foi amplificada 
pela mídia internacional e brasileira. As suspeitas remontam aos atentados à embaixada de Israel em Buenos Aires em 1992 e 1994.

Grantham (2017) ${ }^{237}$ alerta e aconselha o governo americano a investir em estratégias e suporte aos governos dos países da América Latina no desmantelamento de supostas redes extremistas, especialmente em países do chamado grande Caribe como Suriname e Trinidade e Tobago, de onde teriam partido dezenas de pessoas aliciadas pelo Estado Islâmico em direção às áreas de conflito.

O autor cita a saída dessas pessoas, mas não levanta quaisquer suspeitas quanto à vinda jihadistas para a América Latina infiltrados entre os refugiados sírios que chegam ao Brasil. Algo que ainda assim seria difícil de sustentar não só pela quantidade ser muito inferior àquela que vai em direção à Europa como também em relação às motivações, de virem para uma região cuja agenda política é pouco influente no Oriente Médio.

Por outro lado, Grantham (ibid.) aponta Venezuela, Chile, Argentina e Brasil, como locais em que se constituíram redes de suporte financeiro a grupos como Hezbollah, por exemplo, que segundo o autor, tem sua principal base na Tríplice Fronteira (Brasil, Paraguai e Argentina).

Há pelos menos duas linhas de sustentação no relatório de Grantham (ibid., p.03) que o leva à conclusão de que "the growth of extremist activity in Latin America is a major security threat" ${ }^{238}$ :

a) O financiamento milionário para a construção de mesquitas e centros culturais em países latino-americanos pela Arábia Saudita, estaria contribuindo para a difusão da corrente ultraconservadora Wahhabita, que fomentaria a ideologia jihadista;

b) A facilidade de locomoção devido à porosidade das fronteiras, a falta de rigor na fiscalização e a ineficiência de mecanismos que coíbam a obtenção e envio de recursos financeiros de modo ilícito para organizações terroristas.

Sobre o financiamento Saudita e sua influência nas instituições islâmicas brasileiras, Oliveira (2006) também alega essa possibilidade, algo que estimularia o "tipo" de islam mais rígido e purista a ser praticado nessas comunidades. A autora vincula esses investimentos sauditas em instituições como a WAMY e a CDIAL com o mercado de comida halal e sua certificação, conduzida pelos sheikhs das comunidades e estimulando negócios com países árabes.

Diferentemente, Ferreira (2009, p.18) diverge quanto ao vínculo de sheikhs com o wahabismo. Ela revela que em São Paulo, por exemplo, “não há preocupação com a conversão

\footnotetext{
${ }^{237}$ https://bit.ly/2KCHsFz (acesso em 08.05.2019).

238 "o crescimento da atividade extremista na América Latina é uma grande ameaça à segurança" (tradução minha).
} 
de brasileiros pelo fato de os sheiks estarem mais voltados para sua identidade étnica". Ao contrário, ela ressalta que há tensões entre brasileiros e árabes, mas que não significa que a comunidade não se preocupe com aqueles que querem saber mais da religião.

Ferreira (2007) não nega que instituições como a WAMY sejam financiadas por órgãos sauditas. Ainda acrescenta que a formação de sheikhs, como o caso de Jihad Hammadeh foi realizada no país wahhabita, onde ele estudou durante 11 anos. Contudo, em entrevista realizada com o sheikh, ele se assume como moderado, estimula o estudo e conhecimento de outras escolas islâmicas e alega que a associação entre wahhabismo e radicalismo é um estereótipo que foi criado no Ocidente. A melhor relação seria com o tradicionalismo.

Paulo Pinto (2010, p.208) afirma que "a proliferação de mesquitas, em geral, contou com financiamento da Arábia Saudita e Irã, cuja disputa pelo controle da imaginação religiosa islâmica passava pelo estabelecimento de canais de influência em comunidades muçulmanas no mundo inteiro". A mesquita mais antiga do país, a Mesquita Brasil em São Paulo, foi construída com doações da monarquia egípcia. Inclusive, a maioria dos sheikhs que passaram por essa mesquita, inclusive o atual sheikh Abdelhamid Metwally, veio do Egito e foi formada na prestigiada e conservadora universidade Al-Azhar.

Meu informante, o sheikh Ahmad Abdul, aborda esse tema em sua entrevista. Eu o questiono se o fato de haver financiamento de governos ou entidades de outros países, como a Arábia Saudita, poderia influenciar a maneira como o islam é pregado nessas comunidades adotando, em certos casos, visões mais conservadoras tal como a wahhabita. Como esperado, ele responde:

Não! Não tem nada a ver. Não tem nada a ver se a gente tem alguma coisa que não pertence ao islam. De estar divulgando uma coisa que não tem nada a ver com o islam. Aí não vai ter apoio dessas pessoas. Nem apoio da Arábia Saudita, nem apoio do Kuwait, nem apoio de Saif e nem apoio da Wamy, porque islam é regra, entendeu? Quando você desvia dessa regra principal, não tem apoio. Eu estudei na Arábia Saudita. São as pessoas que falam que é wahhabista. Nós sabemos quem são eles. Não existe isso não.

No entanto, não é prudente generalizar. Parte das comunidades islâmicas brasileiras, de mussalas a mesquitas, não contam com ajuda saudita ou de qualquer outro país, centro religioso ou instituição. Muitas são fundadas e mantidas com recursos dos próprios membros ou com ajuda de órgãos públicos nacionais. A imponente mesquita Omar Ibn Al-Khattab foi construída em um terreno cedido pela prefeitura de Foz do Iguaçu/PR. Seu sheikh, Abdul Nasser ${ }^{239}$ é

${ }^{239}$ Entrevista realizada em 07.07.2015 na Mesquita Omar Ibn Al-Khattab. 
brasileiro e toda sua formação foi obtida no Líbano. A Mesquita Anoor (fundada em 2013 em Campinas/SP) e a Sociedade Islâmica de Campinas/SP com sua mesquita (a terceira mais antiga do Estado) foram construídas e são mantidas por famílias de muçulmanos e alguns comerciantes.

Em outro exemplo, de acordo com Muhamad Tawfiq ${ }^{240}$, presidente da Associação Muçulmana Beneficente de Natal/RN (AMBRN) ${ }^{241}$, sua modesta comunidade usa o espaço cedido por um de seus membros e se mantém com a colaboração dos próprios fiéis e de singelos 800 reais mensais, conforme já enunciado anteriormente, enviados pela FAMBRAS ${ }^{242}$.

No tocante à porosidade da Tríplice Fronteira conforme discutida por Grantham (2017), a reportagem da Revista Veja (já mencionada na p.77), corrobora com ele ao afirmar que Osama Bin Laden e Khalid Shaikh Mohammed, que o ajudou a planejar os ataques ao World Trade Center em 2001, estiveram em Foz do Iguaçu/PR em 1995.

Esta informação foi ridicularizada pelos sheikhs Abdul Nasser e Mohammed Khalil ${ }^{243}$, da Mesquita Imam Al-Khomeini também em Foz do Iguaçu/PR. Ele acrescentou que ficou feliz quando um promotor federal condenou a notícia publicada pela Veja (2011), que dizia que "Bin Laden foi passado à nossa mesquita aqui, isto é, teria passado pela Tríplice Fronteira e frequentado a mesquita". O sheikh lembrou quando em 2002, o secretário de turismo da cidade acionou a promotoria do município para pedir explicações à CNN depois dos atentados do WTC por ter insinuado a presença de terroristas no Brasil e que a Veja teria vinculado isso em uma de suas reportagens" 244 . Também questionou com um ar de insatisfação: "sabe qual a percentagem de turistas que diminuiu? Bastante!”

As principais lideranças islâmicas das comunidades que conheci, convergem no seguinte ponto: as vozes que insinuam a presença de organizações terroristas na América Latina e Brasil possuem mais convicções do que provas, e usam a mídia como veículo propagador de fatos mais interesseiros do que interessados em esclarecer e apurar a verdade.

Outro autor que atua no sentido de alertar para a provável presença de grupos jihadistas no âmbito latino-americano é Ottolenghi (2016). Para ele, a combinação de fronteiras porosas e a deficiência em sua fiscalização, governos centrais fracos e a carência de legislações de combate ao terrorismo facilitam o estabelecimento de redes terroristas no território. Nesse caso,

\footnotetext{
${ }^{240}$ Entrevista realizada em 24.02.2017 na AMBN.

${ }^{241} \mathrm{https}: / /$ bit.ly/2NgYojn (acesso em 01.06.2018).

${ }^{242}$ https://bit.ly/2tQcboO (acesso em 09.05.2019). Instituição filantrópica fundada em 1979 que também está ligada às atividades de produção e certificação de alimentos halal, e que auxilia por meio de parcerias, muitas comunidades islâmicas no Brasil.

${ }^{243}$ Entrevista realizada em 08.07.2015 na Mesquita Imam Al-Khomeini.

${ }^{244}$ Essa informação pode ser confirmada através do site: https://bit.ly/2V9d4Uo (acesso em 09.05.2019).
} 
o foco de seu estudo está em avaliar as atividades que estariam contribuindo para ajudar o Hezbollah especificamente.

Dentre elas figuram o tráfico de drogas, evasão de divisas e lavagem de dinheiro por meio de empresas de importação e exportação e de pequenos comércios como aqueles situados na então Galeria Pagé, em São Paulo. Esses crimes seriam importantes mecanismos para o financiamento das atividades do grupo libanês, principalmente na região da Tríplice Fronteira.

Outro exemplo que demonstra a presença de atividades do Hezbollah no Brasil é a partir da associação desse grupo com o Primeiro Comando da Capital (PCC), facção criminosa presente em diversas penitenciárias brasileiras e que sustenta uma série de ações ligadas ao tráfico de drogas e violência em algumas partes do território. Essa relação simbiótica foi apontada por alguns veículos de comunicação em 2014. Eles revelaram indícios de que libaneses ligados ao Hezbollah e detidos porque operavam o tráfico de entorpecentes para obtenção de recursos ao grupo, seriam protegidos pelo PCC em troca de favores como a obtenção de armas por meios ilícitos ${ }^{245}$.

Em outros dois artigos, Ottolenghi e Hannah (2016 e 2017) apontam elos entre a Venezuela e o Irã. O país sul-americano estaria facilitando a obtenção de passaportes para pessoas do Oriente Médio, de certa forma permitindo a entrada de possíveis islamistas na região. Além disso, a Venezuela estaria auxiliando o Irã a propagar um virulento antiamericanismo pela América Latina, uma vez que desde a chegada ao poder de Hugo Chavez no final dos anos 90 e recentemente com Nicolas Maduro, a relações entre Estados Unidos e Venezuela se tornaram cada vez mais débeis. Para Ottolenghi e Hannah (2017, p.03) "indeed, Venezuela has increasingly become a center for Iran's revolutionary agitation in the Western Hemisphere" 246.

O Hezbollah, por sua vez, também segundo Ottolenghi e Hannah (ibid, p.03),

has used South America as a base for its terror-finance networks for decades, laundering money on behalf of criminal organizations and using the profits to finance its quest for power in Lebanon, military adventurism in Syria, and terrorism overseas. In turn, its criminal activities benefit the Venezuelan regime as well ${ }^{247}$

\footnotetext{
245 https://glo.bo/2KIVW6C e https://abr.ai/2u28rQr (acesso em 08.05.2019).

246 "De fato, a Venezuela tornou-se cada vez mais um centro para a agitação revolucionária do Irã no hemisfério ocidental" (tradução minha).

247 "Usou a América do Sul como base para suas redes de financiamento do terrorismo por décadas, lavando dinheiro em nome de organizações criminosas e usando os lucros para financiar sua busca pelo poder no Líbano, em aventura militar na Síria e terrorismo no exterior. Por sua vez, suas atividades criminosas beneficiam bem o regime venezuelano" (tradução minha).
} 
Assim como a Venezuela, o Paraguai está no radar dos países suspeitos em possuir vínculos com o Hezbollah. Não apenas pela porosidade das fronteiras desse país com Brasil e Argentina, mas pela fragilidade de suas leis bem como sua fiscalização, o que facilitaria negócios ilícitos que fomentam o poder econômico do grupo libanês. Um exemplo disso, apontado por Ottolenghi e Hannah (ibid.), é a participação e o engajamento do embaixador libanês no Paraguai, Hassan Khalil Dia, que tem trabalhado para aprofundar o interesse do Hezbollah no país e colaborando para a constituição de uma rede de influências.

Por conta disso, os relatórios e artigos produzidos por esses autores sugerem uma maior atenção do governo estadunidense quanto aos aspectos levantados, de modo que os Estados Unidos possam colaborar com as investigações dessas operações suspeitas e até com a imposição de algumas sanções. Além disso, recomendam que "the Trump administration could target entire foreign jurisdictions in Latin America as zones of concern, much the same way that Washington previously punished Iran's banking system for its role in financing terrorism and proliferation" (Ottolenghi e Hannah, ibid., p.05) no intuito de cooperar com o controle das imigrações ilegais.

Mesmo com esses indícios de colaboração financeira entre o Hezbollah e agentes locais espalhados em países da América Latina ainda é preciso ponderar algumas situações:

a) Países como Suriname, Trinidade e Tobago, Venezuela e Paraguai, esses dois últimos com maior destaque, são aqueles que se tem registro do maior número de indícios de atividades criminosas ligadas ao narcotráfico, à ordem econômica, ou de cunho militante no suposto apoio ao Hezbollah e a outros grupos extremistas. O Brasil, mesmo sendo o maior país da região, não parece ter o mesmo peso de seus vizinhos nessas situações. Desse modo, como mostrado, seriam poucas as chances de essas organizações atuarem em solo brasileiro. Os fenômenos retratados se mostram pontuais no tempo e no espaço.

b) Ainda que se comprovem as ilações feitas no que diz respeito à participação de indivíduos e grupos ligados a organizações jihadistas em território brasileiro, elas aparentemente se dão no âmbito econômico-financeiro, e não na militância armada, aliciamento e radicalização de pessoas que poderiam ameaçar outros grupos religiosos ou instituições governamentais no país.

Os supostos crimes imputados a essas quadrilhas são crimes financeiros como tantos outros praticados nos países da região. Em alguns casos estão relacionados com enriquecimento ilícito, outros com o narcotráfico e nesse caso específico, alimentariam a violência, a luta armada e o terrorismo em outras partes do mundo, mas sem indicativos de que poderiam ocorrer na região. É necessário que se combata esses crimes, mas não somente por terem um viés islâmico radical. 
c) Os relatórios publicados que investigam tais associações criminosas com grupos extremistas oferecem diversas recomendações aos órgãos governamentais competentes dos Estados Unidos, servindo de subsídio para, hipoteticamente, ampliar a influência dos Estados Unidos nas áreas política, de segurança e econômica na América Latina. Quanto aos países citados e objetos desses estudos, não são feitas proposições concretas para que as autoridades locais possam administrar medidas de combate ou que coíbam práticas criminosas dentro dessa esfera específica. A materialidade dos argumentos expostos pelos autores não sustenta e não condiz com a realidade histórica ordeira e pacífica das comunidades islâmicas brasileiras e da América do Sul.

Essas publicações, ao não se preocuparem em tratar do assunto de modo mais ponderado de forma a também considerar vozes locais e sua organização no território, acabam por aumentar a desconfiança sobre essas comunidades já estigmatizadas pelos meios de comunicação e por alguns segmentos da sociedade. Acabam tomando a formiga pelo formigueiro.

\subsection{A Lei Antiterrorismo e os dilemas normativos e conceituais}

Como a lei n.13.260 de 16 de março de 2016, conhecida como a lei antiterrorismo, com base na qual catorze suspeitos foram enquadrados em junho daquele ano e novamente em maio de 2018, pode ajudar a esclarecer algumas das preocupações dos autores citados que praticamente a ignoram em seus postulados? É possível afirmar que essa lei foi criada por uma exclusiva preocupação quanto à possibilidade de atentados ou à presença de grupos terroristas?

O Brasil era um dos poucos países no Ocidente a não ter uma lei antiterrorismo ${ }^{248}$ até a proposta surgir por meio do Projeto de Lei do Senado (PLS) ${ }^{249}$ de autoria do senador Aloysio Nunes Ferreira (PSDB) em 2011. Ela foi apreciada por diversos relatores na Comissão de Cidadania e Justiça (CCJ) durante seu processo de tramitação, até ser aprovada em plenário e sancionada pela então presidente da república Dilma Rousseff, em março de 2016, às vésperas dos Jogos Olímpicos do Rio de Janeiro. Objetivamente, ela visa definir crimes de terrorismo e cria procedimentos investigatórios e processuais.

Todavia, sua tramitação foi marcada por polêmicas e discussões no tocante ao seu conteúdo, objetivos, aplicação, alegações de que ela poderia limitar liberdades civis

\footnotetext{
248 https://bit.ly/2VywJNx (acesso em 18.05.19). No blog de Reinaldo Azevedo da Revista Veja, publicado em 10.11.2014, ele denuncia a falta de uma lei que trate do terrorismo no país e que a Polícia Federal dispunha, à época, de provas de que o PCC (Primeiro Comando da Capital) e o Hezbollah teriam uma parceria no Brasil. ${ }^{249}$ PLS n.762 de 2011. Disponível em https://bit.ly/2tShSTh (acesso em 10.05.2019).
} 
fundamentais, que arriscava criminalizar movimentos sociais, violando, assim, regras firmadas pela Convenção Intermericana de Direitos Humanos $(\mathrm{CIDH})^{250}$, além de conter problemas na tipificação dos crimes de terrorismo. Instituições como a Organização das Nações Unidas $(\mathrm{ONU})^{251}$, a Associação de Procuradores Federais da República ${ }^{252}$, além de movimentos sociais como o Movimento dos Sem-Terra (MST) e Movimento dos Trabalhadores Sem-Teto (MTST), se manifestaram com desconfiança à lei.

A preocupação com a tipificação do terrorismo vem desde o início desta década, segundo Buzanelli (2013), que destaca possíveis ambiguidades que ensejam o enquadramento de movimentos sociais. Outra preocupação no tocante a esse tema, segundo o autor (idem, p.12) é que

o crime de terrorismo não se exaure nos comportamentos criminosos já devidamente tipificados no CP [Código Penal]. No crime de terrorismo, transcendendo as condutas, há um plano maior, o de ameaçar a ordem e a paz social ou impor uma vontade ou ainda coagir entes institucionalmente estabelecidos. Assim, os tipos penais existentes revelam-se insuficientes para combater o terrorismo, pois aqueles praticados por um agente terrorista, mesmo atuando isoladamente, como no caso norueguês ou do "Unabomber", nos Estados Unidos, obedecem, quase sempre, a um plano cuidadosamente preparado, voltado para um objetivo que transcende a finalidade intrínseca de cada uma das condutas delitivas individualmente consideradas.

Além dos problemas de ordem técnica, há outros de caráter conceitual, como por exemplo, a definição do que é terrorismo.

Analisando algumas fontes, especialmente aquelas advindas do poder público, que é o principal responsável por criar, implantar e zelas pelas normas, descobrimos que a Revista Brasileira de Inteligência (2007) da ABIN, dedicou uma edição inteira para se debruçar sobre o terrorismo. Nela, há uma coletânea de artigos que abordam temas ligados a medidas de contraterrorismo, ao terrorismo cibernético, ao terrorismo de Estado entre outros assuntos. No tocante à definição de terrorismo no Brasil, Paniago (2007, p.15) afirma que

o Grupo de Trabalho (GT) constituído pela Comissão de Relações Exteriores

e Defesa Nacional (Creden), do Conselho de Governo (organismo do Poder

\footnotetext{
250 Também conhecida como Pacto de San José, de 1969, e que representa todos os membros da Organização dos Estados Americanos. Como exemplo de regras que poderiam ser violadas desse Pacto, ver artigos 15 e 16, que tratam, respectivamente, do "direito de reunião" e da "liberdade de associação". Disponível em https://bit.ly/2Kyb7hA (acesso em 18.11.19).

${ }^{251}$ Jornal O Estado de São Paulo, 05.11.2015, p.A12 e https://bit.ly/1Ryhdwc (acesso em 10.05.2019).

252 Jornal O Estado de São Paulo, 11.07.2015, p.A10.
} 
Executivo), composta por integrantes de vários ministérios civis e militares, que tem a atribuição de analisar, estudar e propor soluções de governo para temas de segurança -, elaborou três definições de terrorismo, que ainda estão em estudo. A definição genérica elaborada pelo GT da Creden classifica como terrorismo todo "ato com motivação política ou religiosa, que emprega força ou violência física ou psicológica, para infundir terror, intimidando ou coagindo as instituições nacionais, a população ou um segmento da sociedade". A Abin segue a definição específica elaborada pela Creden. Nela, define-se terrorismo como: ato de devastar, saquear, explodir bombas, seqüestrar, incendiar, depredar ou praticar atentado pessoal ou sabotagem, causando perigo efetivo ou dano a pessoas ou bens, por indivíduos ou grupos, com emprego da força ou violência, física ou psicológica, por motivo de facciosismo político, religioso, étnico/racial ou ideológico, para infundir terror com o propósito de intimidar ou coagir um governo, a população civil ou um segmento da sociedade, a fim de alcançar objetivos políticos ou sociais.

A definição acima proposta é claramente inspirada no projeto de lei n.6764 de 2002, art. $371^{253}$, que manifesta uma perigosa generalização. Neste caso, uma briga entre torcedores de equipes de futebol, uma manifestação política ou social, a depredação de prédios públicos ou privados, poderiam ser enquadrados como terrorismo.

No caso da recente lei 13.260 de 2016, o art. $1^{\text {o }}$ "regulamenta o disposto no inciso XLIII do art. $5^{\circ}$ da Constituição Federal, disciplinando o terrorismo, tratando de disposições investigatórias e processuais e reformulando o conceito de organização terrorista [grifo nosso]. No entanto, ainda que tenha refinado alguns de seus critérios, ela guarda margem para crítica tanto quanto à definição quanto para o artigo que lida com os chamados atos preparatórios ${ }^{254}$. O texto é vago ao definir o conceito como qualquer ato que cause "terror social ou generalizado, expondo a perigo pessoa, patrimônio, a paz pública ou a incolumidade pública" $\left(\operatorname{art} .2^{\circ}\right)^{255}$. A própria incitação e divulgação de ideias mais radicais já habilitam a aplicação da lei, especialmente se pensarmos na questão do compartilhamento via redes sociais e conteúdos que possam sugerir ações terroristas. Em outras palavras, isso significa que não é necessário que o ato se concretize de fato, pois só a intenção já é o suficiente.

\footnotetext{
253 “Acrescenta o Título XII, que trata dos crimes contra o Estado Democrático de Direito, à Parte Especial do Decreto-Lei n ${ }^{\circ} 2.848$, de 7 de dezembro de 1940 - Código Penal, e dá outras providências”.

${ }^{254}$ Cf. art. $5^{\circ}$ da lei 13260 de 2016.

${ }^{255}$ Cf. BRASIL. Lei 13.260 de 16 de março de 2016. Regulamenta o disposto no inciso XLIII do art. $5^{\circ}$ da Constituição Federal, disciplinando o terrorismo, tratando de disposições investigatórias e processuais e reformulando o conceito de organização terrorista; e altera as Leis n ${ }^{\circ} 7.960$, de 21 de dezembro de 1989, e 12.850, de 2 de agosto de 2013. Diário Oficial da União, Brasília, DF, 17 de março de 2016. Seção 1, p.1.
} 
Gonçalves e Machado (2015) apontam incertezas quanto à aplicação da lei em alguns casos, como por exemplo, como tipificar a apologia ao terrorismo se o próprio conceito é vago? Para os autores,

seria o compartilhamento de conteúdo com viés terrorista uma apologia ao terrorismo? E o que dizer do curtir ou outro recurso digital muito comum em redes sociais? Seria essa ação digital também uma conduta de apologia? Apesar de todas essas incertezas admitidas pelo próprio senador, ele mantém a tipificação do crime, alegando que bastaria a redução da pena - de três a oito anos de reclusão -, que, diga-se de passagem, só pode ser considerada branda se o critério de comparação for as penas excessivamente altas dos demais tipos desse mesmo projeto de lei. Em outras palavras, o senador [Aloysio Nunes] admite que um sujeito pode ficar preso até oito anos de sua vida por ter "curtido" um post de "viés terrorista" no Facebook, seja lá o que for entendido como "viés terrorista" (p.04).

Vejamos três casos que possam ilustar a dubiedade do conceito de terrorismo que se tem alegado.

No primeiro caso, em 06 de setembro de 2018, o então candidato à presidência da república, Jair Messias Bolsonaro do Partido Social Liberal (PSL), foi esfaqueado por um homem enquanto fazia ato de campanha nas ruas de Juiz de Fora/MG. O agressor, que estava no meio da multidão, se aproveitou da confusão em torno do candidato para desferir o ataque que o deixou gravemente ferido ${ }^{256}$.

Ele foi preso imediatamente e a Polícia Federal abriu uma investigação do caso. Chama a atenção, que em seu depoimento à polícia, Adélio Bispo de Oliveira confessa que cometeu o atentado por motivações políticas e religiosas. Ele disse que se sentia ameaçado pelo propalado discurso de ódio ${ }^{257}$ do candidato e que teria recebido uma “ordem de Deus" para tirar a vida de sua vítima ${ }^{258}$.

Sua defesa alega insanidade mental, demonstrando provas do uso de medicamentos para tratamento psiquiátrico ao qual Adélio vem sendo submetido ${ }^{259}$.

Na segunda situação, há diversos casos semelhantes como o que se passou em uma escola em Suzano/SP em 13 de março de 2019 quando dois jovens entraram atirando em colegas

\footnotetext{
256 Jair Bolsonaro foi socorrido, passou por algumas cirurgias, e está plenamente recuperado.

${ }^{257}$ Jairo Bolsonaro é conhecido por suas falas polêmicas que se traduzem muitas vezes em um discurso militarista, homofóbico, misógino e de apologia ao porte de armas, à tortura e à ditadura militar brasileira (1964-1985).

${ }^{258}$ https://abr.ai/2DGG3eO (acesso em 10.05.2019).

${ }^{259}$ Em junho de 2019, o juiz federal Bruno Savino, da $3^{\text {a }}$ vara da Justiça Federal em Juiz de Fora (MG), absolveu Adélio Bispo de Oliveira por se tratar de um réu inimputável dado seu transtorno mental. Ele deverá ser internado por tempo indeterminado em uma clínica psiquiátrica.
} 
e funcionários (sete mortes no total) e em seguida tirando suas próprias vidas ${ }^{260}$. Outro caso se passou em 28 de setembro de 2018, quando se noticiou a violência em uma escola na cidade de Medianeira/PR ${ }^{261}$. Um aluno de 15 anos, portando uma arma de fogo, atirou em seus colegas ferindo dois deles. Algo semelhante ao que aconteceu em 2011 quando um atirador de 23 anos entrou na escola onde estudou, no bairro do Realengo/RJ, matando 12 pessoas e se suicidando em seguida ${ }^{262}$. O episódio ficou conhecido popularmente como o "Massacre de Realengo". Entre as alegações para todos estes crimes foi vingança em decorrência de bullying sofrido na escola.

Em 14 dezembro de 2018, Euler Grandolpho entrou atirando na Catedral Metropolitana da cidade de Campinas/SP logo após a missa. Ele matou cinco pessoas e três ficaram feridas. Logo após a chegada da polícia, Euler pos um termo à sua vida com um tiro na cabeça. As investigações mostraram por meio de relatos de familiares e cartas deixadas por ele, que há tempos ele manifestava o desejo de fazer "algo grande", citando um possível massacre. Nos documentos encontrados em sua casa, havia recortes de jornal dos quais um deles trazia como título, "Uma sociedade suicida"263.

Em suma, a polícia e os próprios amigos e familiares do agressor asseveraram que Euler sofria de depressão e esquizofrenia.

Nestas três situações concretas e efetivas de violência, o termo terrorismo jamais foi empregado, ainda que os ataques tenham sido feitos de forma premeditada, contra civis desarmados e inadvertidos. Um deles, inclusive, com motivação religiosa confessa. A insanidade mental e depressão em função de humilhações são os argumentos recorrentes nos demais casos.

Mazzetti e Schmitt (2016) discutem essa questão. Eles se baseiam em duas situações: a primeira, em que um homem de meia idade atropelou mais de dez pedestres (sem registro de mortes) na cidade de Dijon na França, enquanto gritava slogans islâmicos da janela do carro. Em outro caso, meses depois, o episódio protagonizado por Mohamed Bouhlel, que massacrou dezenas de pessoas com um caminhão em uma festa nacional em Nice, também na França.

Se na primeira situação, a promotora de Dijon descreveu o autor do ataque como "mentalmente desequilibrado com motivações vagas e incoerentes", na segunda, as autoridades não hesitaram em definí-lo como um terrorista ligado ao islam radical, ainda que não houvesse

\footnotetext{
${ }^{260} \mathrm{https} / / / \mathrm{bit} .1 \mathrm{y} / 30 \mathrm{aN} 5 \mathrm{yN}$ (acesso em 02.07.2019),

${ }^{261} \mathrm{https} / / / \mathrm{bit} .1 \mathrm{y} / 2 \mathrm{Qn} 6 \mathrm{R} 5 \mathrm{p}$ (acesso em 10.05.2019).

$262 \mathrm{https}: / / \mathrm{glo} . \mathrm{bo} / 2 \mathrm{R} 5 \mathrm{WaOH}$ (acesso em 10.05.2019).

263 https://glo.bo/2BnicfN (acesso em 10.05.2019).
} 
nenhum vínculo claro com algum grupo terrorista, exceto por possuir alguns antecedentes criminais por pequenos delitos.

Estes casos ainda não explicam a definição de terrorismo, apenas indicam que em muitos deles parece haver uma "zona cinzenta" em que o perpetrador não deixa evidente seus motivos.

Justamente por isso, devemos abordar a complexidade e da falta de consenso na definição do termo. A dificuldade em se ter uma maior uniformidade na definição de terrorismo é uma preocupação de Laqueur (1997, p.226), ao destacar que

many forms of political violence, ranging from government repression to civil war and rural guerrilla war, are indiscriminately lumped together under the heading terrorism in various research programs and statistics as if terrorism was a synonym for political violence in general [...] all statistics on terrorism are suspect -partly because there are genuine difficulties of definition; it is not always easy to establish, whether, for instance, the hijacking of a plane or a kidnapping was politically motivated or not ${ }^{264}$.

Exemplos dessa multiplicidade de definições ${ }^{265}$ não são difíceis de se encontrar. Instituições, organismos internacionais, departamentos de estado e o meio acadêmico são prolíficos neste sentido.

Nos Estados Unidos, o Federal Bureau of Investigation (FBI ${ }^{266}$ diferencia o terrorismo internacional do terrorismo doméstico. No primeiro caso, ele é "perpetrated by individuals and/or groups inspired by or associated with designated foreign terrorist organizations or nations (state-sponsored)"267. Já no segundo, o terrorismo é "perpetrated by individuals and/or groups inspired by or associated with primarily U.S.-based movements that espouse extremist ideologies of a political, religious, social, racial, or environmental nature" ${ }^{268}$. Em ambas as situações, um aprofundamento em sua tipificação ainda se faz necessária.

\footnotetext{
264 "Muitas formas de violência política, no espectro de repressão governamental à guerra civil e guerra de guerrilhas rurais, são indiscriminadamente agrupadas juntas sob o título de 'terrorismo' em vários programas de pesquisa e estatísticas como se terrorismo fosse sinônimo para violência política em geral [...] Todas as estatísticas sobre o terrorismo são suspeitas - em parte porque há dificuldades genuínas na definição; não é sempre fácil estabelecer, se, por exemplo, o sequestro de um avião ou um sequestro foi politicamente motivado ou não" (Tradução minha). Cf. Walzer (2006, pp.176-196) que estabelece diferenças entre o terrorismo e guerrilha. Entre as principais delas, na guerrilha há uma grande cumplicidade da população (ou importante parte dela); há um claro interesse em atingir oficiais ou colaboradores notórios; o campo de batalha é mais amplo, abrangendo grandes partes do território e com uma duração mais prolongada; e, finalmente, o uso de uniformes para identificação. Cf. Laqueur (1997, p.05).

${ }^{265}$ O jornal O Estado de S. Paulo, na edição do dia 11 de setembro de 2016 (p.A17), nos quinze anos dos ataques às Torres Gêmeas, debateu justamente esse tema.

266 Disponível em https://bit.ly/2ctFfXW (acesso em 11.06.2019).

267 "Perpetrado por indivíduos e/ou grupos inspirados ou associados a organizações terroristas estrangeiras ou nações (patrocinado pelo estado). (Tradução minha).

268 "Perpetrado por indivíduos e/ou grupos inspirados ou associados principalmente a movimentos americanso que defendem ideologias extremistas de natureza política, religiosa, social, racial ou ambiental". (Tradução minha).
} 
A OCDE reconhece que há diferenças entre os termos "atos de terrorismo" e "terrorismo" e nas formas como são empregados pelos países que compõem esse grupo. Para tentar clarificá-los, o órgão disponibiliza uma tabela ${ }^{269}$ que contempla cinco critérios e como eles são preenchidos pelos países da organização. Os critérios avaliados são: 1) status da definição de terrorismo; 2) intenção do ato terrorista; 3) identificação dos que estão por trás dos atos; 4) meios utilizados; e 5) alvos/efeitos. A título de comparação, a Espanha leva em conta como meios utilizados, "atos de violência, atos de destruição e incêndios deliberados", cujos alvos são "pessoas e bens", o que soa muito vago. Enquanto isso, a Áustria, segundo os mesmos critérios, estabelece que os meios usados são "atos ou ameaça de violência" e cujos alvos são a "vida humana, propriedade tangível ou intangível e infraestrutura" ${ }^{270}$. Novamente, algo pouco objetivo e específico.

A ONU não possui uma definição de terrorismo ${ }^{271}$. No entanto, há algumas recomendações e resoluções como a res.49/60 de 1994, que trata de medidas para eliminar o terrorismo internacional e define alguns de seus elementos centrais ${ }^{272}$.

No meio acadêmico, Walzer (2006) é uma importante referência no assunto, propondo uma discussão instigante sobre o terrorismo. A questão de cidadãos combatentes e não combatentes é resgatada pelo autor, que estabelece alguns comparativos entre o "velho terrorismo", que se caracterizava por uma espécie de código moral que balizava as ações limitando-as a alvos pré-determinados, relacionados com agentes políticos do Estado identificados como opressores e poupando pessoas inocentes. Muito característico, aliás, de grupos anarquistas e revolucionários do final do século XIX e início do $\mathrm{XX}^{273}$, tema que foi muito bem representado na peça teatral de Camus (1950), em que se encontram preciosos diálogos sobre a manutenção da honra do movimento revolucionário.

No caso, um dos terroristas hesita em atirar uma bomba na diligência de um membro do governo, pois que era acompanhado de crianças. Trata-se de se matar uma ideia, e não pessoas,

\footnotetext{
${ }^{269}$ Disponível em https://bit.ly/2R5mWxU (acesso em 11.06.2019).

270 Idem.

${ }^{271}$ Disponível em https://bit.ly/2WDGoIk (acesso em 12.06.2019).

$272 \mathrm{O}$ terrorismo, segundo tal resolução, envolve "criminal acts intended or calculated to provoke a state of terror in the general public, a group of persons or particular persons for political purposes are in any circumstance unjustifiable, whatever the considerations of a political, philosophical, ideological, racial, ethnic, religious or any other nature that may be invoked to justify them". Atos criminosos intencionais ou calculados para provocar um estado de terror no público em geral, um grupo de pessoas ou pessoas específicas para fins políticos são em qualquer circunstância, injustificáveis, quaisquer que sejam as considerações políticas, filosóficas, ideológicas, racias, étnicas, religiosas ou de outra natureza, que possa ser invocada para justificá-los). [Tradução minha]. Disponível em https://bit.ly/2IbRviy (acesso em 12.06.2019).

${ }^{273}$ Cf. Laqueur (1997).
} 
como escreve Camus (ibid, p.42) através do personagem Kaliayev: “ce n’est pas lui que je tue. Je tue le despotisme"274.

Contudo, o "novo terrorismo" que começa a se desvelar após a II Guerra Mundial em forma de movimentos de libertação colonial ou antiditaduras, segundo Walzer (2006), gradativamente perde seu componente moral à medida em que pessoas são atingidas arbitratiamente, inclusive sendo elas mesmas, os próprios alvos. Os instrumentais se tornam mais sofisticados, a área de ação é ilimitada e os alvos "são todos e ninguém", ampliando a letalidade. Walzer (idem, p197) assim resume o conceito:

Its purpose is to destroy the morale of a nation or a class, to undercut its solidarity; its method is the random murder of innocent people. Randomness is the crucial feature of terrorist activity. If one wishes fear to spread and intensify over time, it is not desirable to kill specific people identified in some particular way with a regime, a party, or a policy ${ }^{275}$.

Laqueur (1997) alerta que nenhuma definição de terrorismo é capaz de cobrir todas a muitas formas de terrorismo ao longo da história. Para o autor, não se trata de uma ideologia, mas de uma estratégia insurrecional, um meio para consecução de certos fins.

Dentro dessa linha de raciocínio, Demant (2007) afirma que o terrorismo é a "arma do mais fraco", que aceita o uso dessa ferramenta violenta (o terrorismo visto como um meio para determinados fins) contra pessoas que, às vezes, são ainda mais fracas. Ele ainda aponta três critérios que permitem filtrar boa parte dos casos mais recentes e que poderia auxiliar a balizar melhor a lei brasileira: a) violência com fins políticos e/ou ideológicos (excluídos casos de psicopatas e mafiosos); b) praticados contra pessoas indefesas (não-militares); c) ato oposicional em relação a regime, grupo social ou forma de poder (social ou religioso) considerado inaceitável ${ }^{276}$.

Stepanova (2008, p.15) acrescenta aos critérios acima descritos, a questão da assimetria que o confronto assume, já que

it is the asymmetrical nature of terrorism that explains the terrorists' perceived need to attack civilians or non-combatants. They perceive it as serving as a

\footnotetext{
274 “não é ele que eu mato. Eu mato o despotismo" (Tradução minha).

275 "Sua finalidade é destruir o moral de uma nação ou de uma classe, minar sua solidariedade; seu método é o assassinato aleatório de pessoas inocentes. A arbitrariedade é a característica crucial da atividade terrorista. Se alguém desejar que o medo se espalhe e se intensifique com o tempo, não é desejável matar pessoas específicas identificadas de alguma forma particular com um regime, um partido ou uma política" (tradução minha).

${ }^{276}$ Cf. Demant (2016, p.32), Why be jihadist? Public intellectuals' blind spot for islamist terrorism.
} 
force multiplier that compensates for conventional military weakness and as a public relations tool to exert pressure on the state and society at large $\mathrm{e}^{277}$.

Diante desse apanhado de importantes referências e discussões acerca da múltiplas definições e formas que engendram o termo "terrorismo", percebe-se que ele deixa de ser apenas uma categoria de análise que nos auxilia a entender a realidade, para se tornar um conceito, que ganha novos significados com o passar do tempo e seus novos contextos históricos. Em outras palavras, a cada momento histórico, ele é preenchido com um conteúdo atual à sua época, daí seu caráter multifacetado.

Retomando o caso brasileiro, a partir da promulgação da lei antiterrorismo é mandatório que também esteja claro a concepção de terrorismo adotada e sobre quais fundamentos se ampara. Assim como foi levantado no início deste item, nota-se que há um problema em se tipificar o crime de terrorismo. Afinal, como criminalizar um ato que não está bem definido de antemão?

O primeiro juiz a aplicar a lei n.13.260/2016, Marcos Josegrei da Silva, da $14^{\mathrm{a}}$ vara Federal de Curitiba, a elogiou ${ }^{278}$ pelo seu caráter antecipatório de crimes envolvendo o terrorismo e por permitir aos magistrados a adoção de medidas cautelares. No entanto, ele também assumiu que a lei merecia ajustes especialmente quanto às motivações do terrorismo bem como salvaguardar movimentos sociais para que não sejam enquadrados nessa lei, algo que foi contemplado no $\S 2^{\circ}$ do art. $2^{\circ}$ da lei ${ }^{279}$.

A polêmica questão envolvendo os atos preparatórios implica que o princípio da presunção da inocência, base da doutrina jurídica e constitucional, possa ser pervertido. Algo que lembra o filme Minority Report (2002), do diretor Steven Spielberg, em que três pessoas com poderes visionários previam os crimes antes mesmo de acontecerem, possibilitando a prisão dos “pré-criminosos".

A defesa dos réus implicados na Operação Átila usa argumentos que vão ao encontro dessa crítica. Para eles as "provas" são exclusivamente as trocas de mensagens, não configurando nada concreto em termos de promoção e execução de atos terroristas. O uso do

\footnotetext{
277 "É a natureza assimétrica do terrorismo que explica a notória necessidade dos terroristas em atacar civis ou não-combatentes. Eles percebem isso como servindo como um multiplicador de força que compensa convencional fraqueza militar e como uma ferramenta de relações públicas para exercer pressão sobre o estado e a sociedade em geral" (tradução minha).

${ }^{278}$ Jornal O Estado de São Paulo de 17.05.2018. P. A16.

${ }^{279} \S 2^{\circ} \mathrm{O}$ disposto neste artigo não se aplica à conduta individual ou coletiva de pessoas em manifestações políticas, movimentos sociais, sindicais, religiosos, de classe ou de categoria profissional, direcionados por propósitos sociais ou reivindicatórios, visando a contestar, criticar, protestar ou apoiar, com o objetivo de defender direitos, garantias e liberdades constitucionais, sem prejuízo da tipificação penal contida em lei.
} 
termo "promover" o terrorismo é tido como genérico pelos advogados. Independente das interpretações jurídicas, é certa a existência de inconsistências na lei.

O que acaba de ser citado foi exatamente aquilo que levou a Polícia Federal a investigar catorze muçulmanos, sendo oito deles já condenados ${ }^{280}$. Meu informante, Ahmad Alkhatib ${ }^{281}$ foi um deles e relata:

até eu estou sendo investigado ainda, entendeu? Tudo pela lei nova [antiterrorismo]. Você não pode compartilhar um vídeo do Estado Islâmico. Uma vez eu compartilhei um vídeo, acho que em 2014, de um artista russo que se tornou famoso na Rússia. Fugiu lá para o Estado Islâmico. E tem uma doutora, reitora de uma universidade da Arábia Saudita - o pai dela era muito sábio, tinha vários livros - e ela fugiu para lá. A gente tenta entender por que essas pessoas largam essa vida tão confortável. Um advogado bem-sucedido na Califórnia...Então eles [Polícia Federal] me perguntaram: "por que você? Porque no Líbano..." - discutiu comigo - "que quem vai pra lá sempre as pessoas que são loucas né?" Mas eu mandei para ele um vídeo do cara que é um artista na Rússia, que é bem de vida, falei do advogado da Califórnia, a reitora da universidade da Arábia Saudita, e falei: me explica, o que é isso? Então eles entenderam. Mas "por que você compartilhou isso daí?" Compartilhei para mostrar. Foi em 2014, não tinha lei nenhuma. Foi pra mostrar. Eu não tenho participação. Eu nunca compartilhei e nunca incentivei e nunca elogiei, nunca falei nada! Foi um modo de mostrar para ele um vídeo no meu facebook.

Para Ahmad, essa operação e as detenções efetuadas serviram para justificar a lei. Ainda tentei argumentar sobre o fato de que dois deles, entre eles El Kadre, que foi condenado com a maior pena (15 anos em regime fechado), estiveram implicados na compra de armas no Paraguai oferecendo justificativa para uma possível atividade criminosa. Ao que Ahmad responde:

pelo que eu fiquei sabendo das conversas que a Polícia Federal teve, que eu tive acesso pelo meu advogado, um deles parece que tentou comprar arma. Um deles já tinha problemas com a justiça, que se tornou muçulmano. Ele estava preso e tudo mais. Então esse El Kadre que chamou eles pra criar esse

\footnotetext{
${ }^{280} \mathrm{Em}$ 04.05.2017, oito réus foram condenados com base nessa lei com penas que variaram de 5 a 15 anos de detenção. Disponível em https://glo.bo/2paNNcw (acesso em 10.05.2019).

${ }^{281}$ Ele foi uma das pessoas que foi investigada pela Polícia Federal durante a Operação Hashtag, e conhecia e trabalhava com duas das pessoas que foram presas nessa operação. A entrevista aconteceu no dia 23.07.2016, via Skype. Até o dia da entrevista seus equipamentos eletrônicos ainda estavam de posse da Polícia Federal para averiguação, sem data para devolução.
} 
grupo parece que tentou comprar arma. Mas o resto não. Nunca revelou essa ideia. Os dois [que trabalhavam com ele] eu conheço muito bem, nunca tiveram essa ideia.

Por fim, ainda tentei instigá-lo com uma notícia sobre um membro do Estado Islâmico que teria publicado em redes sociais, em francês, de que o Brasil, durante os Jogos Olímpicos poderia ser o próximo alvo ${ }^{282}$. Ahmad respondeu: “essa informação não é verdadeira [...] Com poucas palavras, eu digo que isso é falso [se exalta]".

Em entrevista concedida a Tulio Kruse do jornal O Estado de S. Paulo na edição do dia 25 de novembro de 2018, Wellington Moreira de Carvalho recém absolvido da acusação de terrorismo, afirmou que “essa lei antiterrorismo acaba sendo uma lei 'anti-islâmica'. Se uma pessoa é presa na rua por porte de arma e não for muçulmana, vai receber uma sentença apenas por porte de arma. Se for muçulmana, ela talvez tenha uma sentença por planejar, por estar indo cometer um atentado" (p.A14).

Perguntado sobre essa lei e suas implicações, o sheikh Ahmad Abdul pondera:

olha bem meu amigo. A gente tem pessoas responsáveis. Nosso irmão, nosso presidente sheikh Abdulhamid Metwally, e sheikh Abduni também, eles estão à frente. E o grupo da gente não está contra a lei. A lei serve para todos nós. O problema é quem está aplicando essa lei. Pega as pessoas erradas, entendeu? Com motivo ou sem motivo. Eu falo do Ahmad [Alkhatib], porque as vezes ele estava com algumas dessas pessoas. Eu liguei pra São Paulo. E me disseram que ele estava tentando resolver isso. Então quando acontece isso, ali mesmo não tem problema. $\mathrm{O}$ problema são as pessoas que aplicam a lei no lugar errado.

Tais declarações soam com um certo exagero e demasiadamente superficiais, sem a devida reflexão das motivações, interesses envolvidos e, principalmente, reconhecer que se há muçulmanos envolvidos, ponderar o que pode ter acontecido para chegar nesta situação.

Um ponto que chama a atenção para além dos aspectos ambíguos da lei, e, principalmente a real motivação para sua criação e aprovação é a sua notável relação com compromissos internacionais ${ }^{283}$ firmados pelo país com a Organização para Cooperação e Desenvolvimento Econômico (OCDE), em cujo âmbito funciona o Grupo de Ação Financeira

\footnotetext{
${ }^{282}$ https://bit.ly/1SbseAx (acesso em 10.05.2019).

${ }^{283}$ https://bit.ly/2KrC1tI (acesso em 10.05.2019).
} 
Internacional (Gafi) ${ }^{284}$ - órgão criado em 1989 para coibir a lavagem de dinheiro do crime organizado e as fontes de financiamento do terrorismo.

Muito mais que uma preocupação com a possibilidade da formação de grupos terroristas no território nacional e suas conexões escusas, a aprovação dessa lei foi fundamental para evitar que o país não sofra eventuais sanções econômicas ou prejudicar seu rating junto às agências de classificação de risco para investimento. A busca por certificação internacional que avalize um investimento seguro, especialmente perante o período de crise política e financeira que o país atravessaou nesses últimos anos, pode ter sido o principal motivo.

Diante desse cenário, a relação entre as críticas feitas à lei no tocante ao seu aspecto técnico e sua importância para a inserção competitiva do país no mercado global, pode ser resumida por Gonçalves e Machado (2015, p.03):

se o fim social último do Gafi é proteger a integridade do sistema financeiro, quando tal integridade está associada à promoção de um megaevento esportivo, seu foco de oposição - os movimentos políticos e sociais - tornamse fatores de insegurança para os negócios. Nesse contexto, não é difícil justificar o temor por parte dos movimentos sociais de serem considerados os "terroristas", alvo dessa lei. A análise dos aspectos técnicos e jurídico-penais do PL n. 2.016/2015 285 mostra que esse risco não é apenas uma elucubração conspiratória.

Sendo assim, a crítica levantada por algumas instituições, movimentos sociais e alguns veículos de comunicação sobre o possível uso da lei para criminalizar aqueles contrários à agenda política e econômica do país, passa a ter fundamento ainda que sob o disfarce da preocupação com o terrorismo islâmico. Desde a Operação Átila em 2018, entretanto, não foram observados episódios que pudessem ser objeto dessa norma. Cabe agora observarmos futuros desdobramentos que possam oferecer mais subsídios para uma análise mais aprofundada do tema.

Ao contrário do que é ventilado pela mídia e por alguns estudos que são em grande parte embasados em investigações policiais e jornalísticas, a metodologia ancorada na história oral feita por meio de trabalhos de campo, entrevistas, participação em eventos religiosos e sociais,

\footnotetext{
${ }^{284}$ O Gafi integra uma rede de proteção que busca atuar em relação a padrões institucionais que possam produzir efeitos negativos sobre a "integridade" do sistema financeiro. O objetivo do grupo, como lembram os ministros em sua justificativa, é reagir às ameaças advindas da lavagem de dinheiro e do financiamento ao terrorismo. Para tanto, o Gafi desenvolve uma série de recomendações baseadas em seu julgamento a respeito de vulnerabilidades no âmbito nacional e, em seguida, monitora a aplicação dessas medidas em seus países membros. (Gonçalves e Machado, 2015, p.02).

285 https://bit.ly/1M0mBWX (acesso em 10.05.2019).
} 
e o contato mais próximo com as diversas comunidades islâmicas no Brasil, permite sustentar a tese de que o Brasil não é terreno fértil para radicalização e muito menos para a constituição e atuação de redes terroristas.

O caráter moderado das comunidades que por sua vez não possuem articulação entre si e ainda assim compartilham discursos semelhantes sem viés político, não supõe uma contribuição institucionalizada para o radicalismo. Apesar dessa fragmentação tanto territorial quando institucional, há um consenso em rechaçar e em querer se distanciar de tudo aquilo que vincula o islam e os muçulmanos com atividades jihadistas, de intolerância e violência.

Ainda que exista a participação econômica para a manutenção de algumas comunidades islâmicas no Brasil, o que implicaria em supostas influências ideológicas e religiosas mais conservadoras, não é o suficiente para levantar suspeitas sobre radicalização e o patrocínio de atividades jihadistas em solo nacional. Cabe lembrar que grande parte dessas comunidades sobrevive com recursos próprios e escassos, sendo isentas de qualquer obrigação para com governos e organizações nacionais e estrangeiras. Suas atividades se baseiam em eventos religiosos e sociais (celebrações, festas, palestras, encontros de jovens, acampamentos, filantropia entre outros) e não ao incentivo e condução de movimentos politicamente engajados.

Também é importante lembrar que as comunidades islâmicas brasileiras estão cada vez mais povoadas de brasileiros convertidos, inclusive com a formação de sheikhs nativos. Desse modo, muitas dessas comunidades se afastam de um islam mais étnico associado à cultura árabe e se aproximam de um "islam nacional". Isso de certa forma ameniza eventuais tendências em se apropriar dos problemas e das lutas que fazem parte da agenda do Médio Oriente e de alguns países islâmicos.

No caso da lei antiterrorismo criada no Brasil em 2016, percebe-se que seu processo de criação e seu conteúdo refletem primordialmente o contexto político-econômico do país em detrimento de ameaças latentes de organizações terroristas. A falta de um consenso e de uma maior precisão na definição de terrorismo por parte dos legisladores, por si só reflete a pouca intimidade com o tema e vínculo com situações reais. A inserção competitiva do país no mundo globalizado e a busca por confiança junto aos agentes financeiros diante de sua maior crise econômica e política, despontam como motivos balizadores dessa norma.

Ainda que tenha sido aplicada pela primeira vez na investigação de ações terroristas de viés islâmico (já que todos os presos e investigados eram muçulmanos) e coincidentemente (ou seria convenientemente?) próximo do início dos Jogos Olímpicos, o fato é que os casos suscitados são pontuais no tempo e no espaço, não adicionando novas e graves preocupações 
além daquelas já tão conhecidas pela sociedade por meio da violência urbana (latrocínios, homicídios, sequestros entre outros).

Contudo, diante da dinâmica do mundo moderno, não podemos fechar os olhos e arriscar todas as fichas no axioma de que o Brasil e a América Latina estão imunes a qualquer possibilidade de desenvolvimento de redes jihadistas ou de envolvimento de certas pessoas e comunidades com organizações terroristas no futuro.

Nesse sentido, estudos mais acurados sobre os caminhos que "autodidatismo" apontam são importantes e desejáveis. Se os líderes religiosos atuais não dão sinais de qualquer comprometimento com ideais beligerantes e com um islam político exacerbado, indivíduos convertidos que se responsabilizam por leituras corânicas sem a devida orientação, teriam que tipo de posicionamento? As comunidades islâmicas mais modestas e que carecem da presença de um sheikh, poderiam fortuitamente fazer germinar tendências mais extremistas?

Além disso, se no espaço concreto não se identificam traços contundentes de radicalização, o espaço virtual, através das redes sociais e demais possibilidades que essa tecnologia oferece, se constituiria em uma brecha para futuras atividades jihadistas na região? A lei antiterrorismo é um instrumento que se atenta para isso, mas necessita ainda de um maior refinamento que só deve acontecer por meio de um debate mais amplo.

Enquanto aqueles que se preocupam apenas com algumas formigas que se perderam do rastro deixado por seus feromônios e batem cabeça tentando achar um caminho, que pode ser a segurança do formigueiro ou o perigo do abismo, deixam de compreender e conhecer melhor os formigueiros. Somente a compreensão dessa totalidade dinâmica nos permitirá verificar com maior clareza os rumos que o radicalismo islâmico pode ou não tomar no Brasil e no âmbito latino-americano.

\subsection{Brasil como improvável (mas não impossível) abrigo da radicalização}

Uma notícia divulgada no Portal G1 em 2010 alerta que o Brasil abriga "genuínos" radicais $^{286}$ islâmicos em São Paulo/SP e Foz do Iguçu/PR. O relatório feito pelo consulado dos Estados Unidos em São Paulo/SP é o autor da denúncia. O cônsul geral do Líbano na cidade, Joseph Sayah, e o vice-presidente da WAMY, sheikh Jihad Hammadeh ${ }^{287}$, são os principais apontados pelos relatórios como promotores de uma linha islâmica fortemente fundamentalista. Além disso, integrariam uma rede de contatos entre outros sheikhs que destilam críticas aos

${ }^{286}$ https://glo.bo/2KBGhpV (acesso em 10.05.2019). 
Estados Unidos. O sheikh Jihad, com quem tive e mantenho contato, desqualificou as descrições contidas nos relatórios divulgados.

De fato, o sheikh é um grande defensor dos rituais, costumes e comportamentos islâmicos. Todavia, ao acompanhar suas redes sociais, trabalhos junto à WAMY, aulas e palestras nota-se que está longe do fanatismo. Mostra-se muito aberto à troca de ideias e contemporizador de situações, mas sem abrir mão dos ensinamentos islâmicos.

Em trabalho de Ferreira (2007), o mesmo questionamento é feito sobre o suposto conservadorismo do sheikh Jihad e sua simpatia pela linha wahhabita ainda mais pela ligação da WAMY com a Arábia Saudita. Ele relativiza o conservadorismo entre as diversas pessoas e comunidades e afirma não ser conservador.

Afinal, a notícia acaba trazendo um assunto importante de forma superficial, além de misturar, sem a devida reflexão, conservadorismo com radicalismo. De forma desnecessária, isso ajuda a cimentar ainda mais os estigmas sobre a população islâmica no Brasil cuja população, em geral, sabidamente não detém o conhecimento e o discernimento necessários para compreender os temas que envolvem o islam e seus seguidores.

Em abril de 2011 a Revista Veja ${ }^{288}$, uma das maiores hebdomadárias do país, publicou uma edição cujo título indicava: "A rede: o terror finca raízes no Brasil". O jornalista que assina a reportagem, Leonardo Coutinho, aponta os eventuais estágios dessa "ancoragem do mal" em território nacional.

Primeiro, o Brasil serviria de rota de passagem de supostos terroristas pela Tríplice Fronteira após os atentados a bomba na embaixada de Israel em Buenos Aires. Em seguida, esses indivíduos iniciariam o processo de estabelecimento no Brasil por meio de casamento com brasileiras e da concepção de filhos. O terceiro estágio cuidaria do processo de aliciamento, enviando brasileiros para serem doutrinados em alguns países do Oriente Médio. Por fim, na quarta etapa, o Brasil passaria a servir como base de financiamento e centro de propagação de ataques terroristas.

Este roteiro hollywoodiano estaria amparado por investigações da Polícia Federal que, em 2009, prendeu Khaled Hussein Ali (apelidado de "Príncipe"), libanês que vivia no Brasil há 20 anos e que era considerado coordenador do Jihad Media Batallion (JMB). Além de cuidar da propaganda da Al-Qaeda em cerca de 17 países, era ele quem autorizava a divulgação de vídeos do grupo a partir de sua base em São Paulo. Ali foi indiciado à incitação de crimes 
diversos e formação de quadrilha, mas não por terrorismo, pois não havia legislação sobre isso à época.

Ali ficou detido por cerca de vinte dias e então foi solto. O ministério público não ofereceu denúncia e as investigações da Polícia Federal foram encerradas ${ }^{289}$. Não foi possível provar que ele de fato pertencia à alguma organização terrorista e não havia antecedentes ou motivações que exigissem sua prisão. Entre os eventos que foram relevantes à sua detenção é o fato de que Ali teria publicado comentários no site da JMB. Algo muito parecido com o que se passou durante a Operação Hashtag da Polícia Federal, mas já enquadradas na recente lei antiterrorismo.

De acordo com Paulo Pinto (2010, p.210-211) "essas acusações, que nunca foram comprovadas por qualquer investigação realizada, colocaram grande pressão na comunidade de Foz do Iguaçu, que se viu obrigada a se defender das acusações de terrorismo veiculadas pela mídia”. Mais uma vez leva-se à tona um tema delicado para toda a comunidade islâmica que cada vez mais fica sob o olhar desconfiado da população. Para a Revista Brasileira de Inteligência (2007, p.17) corrobora o autor acima ao afirmar que

não há evidências de células terroristas em atividade no Brasil. Todas as denúncias sobre existência de campos de treinamento e de células "adormecidas" têm sido investigadas e não foram encontrados sinais desse tipo de atividade em nosso País, principalmente na região da Tríplice Fronteira.

Evidentemente, esse é um grande problema no tocante às investigações antiterroristas em qualquer país. Cria-se um dilema: obviamente que é necessário um serviço de inteligência que tenha a competência e o timing de intervir "profilaticamente" antes da execução do ato terrorista. No entanto, o consubstanciamento em provas robustas e o cuidado em não "queimar" suas fontes de informação, é de suma importância para que todo o processo tenha margens de erros e efeitos colaterais os menores possíveis.

Em outra situação, após alertas feitos pelo FBI às autoridades brasileiras sobre a existência de uma célula terrorista internacional do Estado Islâmico, em 2016, a 15 dias da abertura dos Jogos Olímpicos do Rio de Janeiro, a Polícia Federal brasileira deflagrou a chamada Operação Hashtag.

Ela culminou com a investigação e prisão de catorze suspeitos (treze deles são convertidos) por envolvimento, especialmente via redes sociais, com o Estado Islâmico. Oito

289 https://glo.bo/2NkUqpG (acesso em 10.05.2019). 
deles foram condenados e se encontram presos em penas que variam de 5 a 15 anos de detenção de acordo com a lei antiterrorismo, então acionada pela primeira vez.

Trocas de mensagens via internet, aplicativos de comunicação e uso das redes sociais com supostas apologias às ações do Estado Islâmico, além da detenção de um indivíduo que havia comprado armas no Paraguai, serviram de base para a aplicação da lei antiterrorismo. Segundo o jornal O Estado de S. Paulo de 22 de julho de 2016, essas pessoas participavam de um grupo virtual chamado de Defensores da Sharia.

As notícias à época diziam que os Jogos Olímpicos do Rio de Janeiro e a Parada Gay de São Paulo poderiam ser oportunidades para que ataques pudessem ser feitos em razão de serem eventos com grandes aglomerações de pessoas e da sua grande visibilidade. $\mathrm{O}$ fato é que a interceptação desse grupo teria se dado em fase inicial e preparatória das supostas agressões. Contudo, apesar do tom grave dessas informações, houve um certo senso comum de que o grupo era extremamente amador, com pouca ou nenhuma organização ou qualquer experiência prévia para concretizar tais pretensões.

Meu informante, Ahmad Alkhatib, foi um dos muçulmanos investigados pela Operação Hashtag. Respondendo ao processo em liberdade, ele me concedeu uma entrevista que pode ajudar a revelar o peso do autodidatismo, sua visão sobre a lei antiterrorismo, a indignação com problemas que ocorrem no mundo e no Brasil, o protagonismo que as redes sociais assumem nesses tempos recentes e a possibilidade de radicalização no Brasil.

Questionado sobre se as pessoas detidas pela Polícia Federal com base na lei antiterrorismo de fato eram radicais ou se haviam indícios de que planejavam atentados terroristas, meu interlocutor afirma:

Acredito eu, existia moleques, rapazes que são brasileiros que são revertidos $^{290}$ ao islamismo, e eles não tinham intenção nenhuma de fazer terrorismo acredito eu. Eles poderiam ser pessoas assim, revolucionárias. São jovens, muito jovens. Então são pessoas revolucionárias, revoltadas com a situação que acontece nos países muçulmanos porque é como eles são novos muçulmanos e eles captam as mensagens e informações deles dos livros. Não têm essa experiência de um muçulmano que nasceu muçulmano. Então eles já se revoltam pela injustiça que acontece no mundo inclusive terrorismo. No terrorismo, os mais injustiçados são os muçulmanos. Quem analisa bem, vê que são os muçulmanos os mais injustiçados com isso né. Então, veja o que

\footnotetext{
${ }^{290}$ Termos usado especialmente por muçulmanos em lugar de convertidos. Ao usar esse termo, assume-se que mesmo tendo adotado outras religiões, as pessoas jamais deixaram der ser muçulmanas, pois só o islam é a verdadeira religião. Elas não se convertem ao islam, mas retornam a ele.
} 
está acontecendo no Iraque, na Síria, no Iêmen, na Palestina. Então, às vezes, eles [os rapazes presos] mencionam na internet algo errado.

Em seguida, quando perguntado o porquê de estar sendo investigado e por ter sido envolvido nesse caso, ele argumenta:

Eu trato muito bem os brasileiros então eles têm comigo uma aliança muito forte. Então é por isso que eles me escolheram como sheikh ${ }^{291}$. Existe já uma comunidade muito grande de muçulmanos brasileiros. Já está crescendo muito, né? O islamismo está crescendo muito até aqui no Brasil, né? Então eles procuram líderes que estejam com eles, né? Então através da minha ONG, a maioria dos brasileiros muçulmanos, eles vão lá, tem os projetos deles, os sonhos deles do islamismo, a gente tenta colocar em prática. Então por isso que foi mencionado numa das conversas entre eles e a Polícia Federal me chamou:

- é verdade que você é o orientador, não sei o quê, sobre os meninos?

- Falei não. Nem estou sabendo dessa conversa e ninguém incentiva eles a fazer isso.

Mas graças a Deus, os dois que trabalhavam lá comigo na ONG saíram, não estão mais presos. E os outros que tentaram comprar arma estão presos. [...] $\mathrm{Eu}$ estou sofrendo com isso. Estou sofrendo muito porque eles mencionaram meu nome, também pediram informações para mim e eu passei informações para eles da religião islâmica [...] Meu filho está aqui, está me ouvindo. A Polícia Federal levou tudo. O iPad dele, meu, da minha mulher. Eu tenho a empresa e eles levaram tudo da empresa, né?

Mesmo acreditando na inocência daqueles que conhecia e que foram detidos, eu pergunto a Ahmed Alkhatib se existe um ambiente propício à radicalização no Brasil e, caso exista, quais os motivos que poderiam pavimentar esse caminho, inclusive, entre eles, a discriminação que eventualmente sofram e as diferenças entre muçulmanos nativos e convertidos. Ele responde:

Não, isso não faz eles se radicalizarem, de jeito nenhum. O que faz eles se radicalizarem é a situação dos muçulmanos no mundo, né? A situação que está na Síria, nesses lugares, como os muçulmanos são tratados. E só isso não faz eles serem radicais, mas serem simpatizantes, entendeu? É eles tentarem

\footnotetext{
${ }^{291}$ Em conversa com o sheikh Abdelhamid Metwally, citei esse trecho da entrevista de Ahmad Alkhatib. Ele então respondeu: "então...primeiro, o sheikh Ahmad não tem qualificação, não tem nenhum certificado que prove que ele é um sheikh...alguma coisa, sabe? Mas provavelmente se ele estudou, não tem. Como também não tem nenhuma sociedade que ele representa como sheikh...uma mesquita ou algo parecido". Sobre isso, apontei que durante um período ele teria passado por Campinas/SP. Sou interrompido. Ele então finaliza: "ele ia só fazer sermão e voltava".
} 
gostar mais de um lado do que de outro. E tem outra coisa. Eu queria te contar, mas já que você antecipou: as mesquitas aqui não são motivos nenhum para eles ter nada [radicalismo]. Os muçulmanos brasileiros não gostam, na verdade não têm uma boa relação com os muçulmanos árabes, e poucos sheikhs que falam o português, então eles são amigos daqueles que falam o português, que estão com eles né. O sheikh Abdul Nasser que nasceu aqui, o sheikh Jihad que nasceu aqui, eles são brasileiros, mas eles não têm esse tempo, a realidade deles não permite de eles estarem com os jovens né. Eles não têm tempo para acolher essas pessoas, que têm desejos, sonhos, projetos, são pessoas superinteligentes para falar a verdade viu. Um deles, o que foi preso, o Antonio Andrade que trabalhava comigo na ONG é superinteligente, é universitário, formado na universidade, não é uma pessoa leiga. O outro fala três línguas, mas o Brasil não dá oportunidade para esses jovens - não estou falando dos muçulmanos só, mas de qualquer jovem - Não dá oportunidade de se expandir, de conseguir executar um projeto, seja qual for: econômico, social, qualquer coisa. Então eles ficam presos. Quando eles encontram uma porta, uma saída, eles vão para aquela saída. E às vezes uma saída errada. O Antônio Andrade é uma pessoa informada! Ele lê e pesquisa. Hoje você pode abrir o jornal, eu estava agora a pouco assistindo a RedeTV, e oitenta e uma crianças foram massacradas por um avião russo [se exalta], entendeu? Aí, quando explode um carro na França o mundo faz passeatas, faz tudo! Até o Facebook pinta com a bandeira da França. Agora, aquelas crianças não têm nome? [se exalta novamente]. Então ele fica revoltado ${ }^{292}$ [...] eu volto a falar assim: O Estado Islâmico não tem intenção nenhuma, nem com a Bolívia, Argentina, Brasil, nem com a América Latina toda, nada. Eles não participam da guerra lá. Não há terrorismo do Estado Islâmico no Brasil [...] pelo que eu estudei, pelo que eu sei, o Estado Islâmico não tem nenhuma intenção aqui. Primeira coisa. Agora, se alguns rapazes querem "causar", aí já é outro tipo. Acho que o Brasil tem que buscar o que que falta que nós devemos oferecer para nossos jovens para eles não participarem disso.

\footnotetext{
${ }^{292}$ Coloquei a mesma questão para Muhamad Tawfiq, da ABMRN, e sua resposta foi ao encontro desse relato de Ahmad: "não, absolutamente...no Brasil não tem. Mas Victor, essas pessoas que são indignados, revoltam contra injustiça, injustiça social. Mas o prablema é que aqui no Brasil não vai resolver o prablema no Oriente Médio com simples anúncio no Facebook. Você acaba com a comunidade islâmica pacífica aqui no Brasil. Porque você não tá sozinho!”
} 
Por fim, procuro saber se a interpretação do Corão feita de forma autodidata e eventualmente enviesada, principalmente entre convertidos, como foi o caso da maioria dos investigados pela Polícia Federal, também poderia servir de pretexto para ações mais extremadas desses indivíduos. Ele assevera:

Esses jovens...não é nada de interpretação [do Alcorão], viu? É revolta, é revolta. Revolta do mundo por ter dois pesos e duas medidas. Isso é informação correta que eu to lhe passando. Isso para gente ser fiel com as pessoas. Eu não falaria isso pra Polícia Federal! Eu passei coisas pra Polícia Federal, mas eu não aceito que você [Polícia Federal] escreva isso! Eu acho que vocês devem se informar, eu falei isso pra Polícia Federal, vocês devem se informar. Por que você quer o quê? Proteger seu povo? Não dá para proteger com injustiça. Tem que ser com justiça.

Ele conclui que existe uma falta de informação sobre o islam e sobre as comunidades islâmicas, tanto por parte da população como principalmente de órgãos governamentais, contribuindo para a produção de discursos e ações pouco simpáticas aos muçulmanos de modo geral. Para ele, as questões envolvendo a radicalização e as motivações que levaram alguns muçulmanos à prisão, não estão no cerne da teologia islâmica, mas nos contextos nacionais e internacionais e a forma como são assimilados pelas pessoas.

A Revista Brasileira de Inteligência (2017), em artigo assinado por dois oficiais da inteligência e um bacharel em direito ${ }^{293}$, revela que a ABIN vem estudando há algum tempo o terrorismo internacional e possíveis células no Brasil. Além disso, tenta estabelecer uma espécie de "taxonomia da radicalização" com base no perfil dos investigados na Operação Hashtag, e o artigo da lei antiterrorismo sob o qual eles foram enquadrados, o que indicaria seu nível de radicalização.

Segundo este artigo, o ambiente "psicossocial", as frustrações pessoais, as redes sociais, e a influência do Estado Islâmico (EI), oferecem as principais condições para o estímulo de pensamentos extremistas, que se manifestam particularmente em brasileiros convertidos e com pouca ou nenhuma participação nas principais comunidades islâmicas do país. Alguns dos quais tendo sido expurgados por essas comunidades por seu perfil combativo e agressivo. Mas o que mais chama a atenção no artigo é o trecho do relato em que transcreve parte da denúncia do MPF, em que se afirma:

\footnotetext{
293 Allan, S; Augusto, O; Thiago, A. O processo de radicalização e a ameaça terrorista no contexto brasileiro a partir da Operação Hashtag. Revista Brasileira de Inteligência. Brasília: Abin, n. 12, dezembro 2017.
} 
Em determinado momento, membros do grupo sugerem nomes, entre os indivíduos reconhecidos por possuírem mais conhecimento do Islã de linha radical, para desempenharem o papel de possíveis líderes religiosos da célula. Alguns, inclusive, chegaram a ser convidados para serem "imã" do grupo. Nesse sentido, pode-se especular que muitos desses indivíduos, pela ausência de uma liderança religiosa que chancelasse suas ações, permaneceram no estágio de transição entre os ciclos de radicalização e da ação até a operação policial que interrompeu as atividades do grupo. Essa parece ser uma situação peculiar ao caso brasileiro, em função do baixo conhecimento religioso e grau de radicalização dos membros da rede, que não conseguiram alcançar um estágio de organização física e logística, dentro do ciclo da ação, necessário para um processo estruturado da ação [...] (p.17).

Esse trecho se remete fortemente ao que foi dito no relato do meu informante Ahmad Alkhatib (p.215) o que de certo modo sustenta a veracidade da informação que me foi passada.

Aproximadamente dois anos após a entrevista com esse informante, outra operação da Polícia Federal e Ministério Público Federal foi colocada em prática. O país volta a ser surpreendido com essa possível ameaça, uma "novidade" entre as mais diferentes formas de violência que tanto assolam o país cotidianamente.

Mais uma vez apontaram-se os holofotes sobre a possível existência de radicais islâmicos no Brasil. Em 17 de maio de 2018, o jornal O Estado de S. Paulo publicou uma nova sequência de reportagens sobre a Operação Átila ${ }^{294}$ executada Polícia Federal, em que onze pessoas foram denunciadas pelo Ministério Público Federal (MPF) pelos crimes de organização criminosa e promoção do Estado Islâmico, algo muito semelhante ao caso anterior. Esta operação monitorou três grupos de trocas de mensagens intitulados de "Uma bala na cabeça de todo apóstata"; "Estado do Califado Islâmico" e "Na via de Alá, vamos".

As investigações tiveram início em 2016 a partir de alertas feitos pela Guarda Civil da Espanha que revelou que foram encontrados números telefônicos de brasileiros em grupos de Whatsapp.

Em uma das mensagens trocadas no dia 31 de agosto de 2017, de acordo com o jornal digital Nexo, o texto do procurador do processo continha a informação de que "o Estado Islâmico ameaça executar um refém por dia, caso os presos da Operação Hashtag não fossem soltos, devolvendo as cabeças dos infiéis num saco". ${ }^{295}$

\footnotetext{
${ }^{294}$ Em referência ao rei do Hunos, conhecido por sua crueldade e violência, que aterrorizou a Europa e Ásia no século V.

${ }^{295}$ https://bit.ly/2z8ikC5 (acesso em 10.05.2019).
} 
O grupo teria sido interceptado pela Polícia Federal com base em conversas via aplicativos de mensagens e redes sociais, em que estariam recrutando pessoas para se juntar a terroristas na Síria e objetivando a promoção de atentados durante o Carnaval de 2018. Além disso, o jornal apontava que as conversas mantidas entre eles e com outras células na Espanha e na Síria, indicavam planos para formar uma célula terrorista no Brasil, para obter informações sobre táticas de guerrilha, para adquirir instruções sobre fabricação de explosivos, e promover e propagandear as ações do Estado Islâmico em solo nacional.

Até julho de 2018 o processo estava em fase de citação e tramitando na $5^{\text {a }}$ Vara de Justiça Criminal de Goiânia. Estavam sendo expedidos ofícios às comarcas das cidades em que vivem os indiciados para que eles tomassem conhecimento do processo e organizassem sua defesa. $\mathrm{O}$ único em prisão preventiva era Wellington Moreira de Carvalho, como mostra o Infográfico 1 (p.221).

Com o objetivo de buscar mais informações, ver e analisar concretamente o teor das conversas, a forma com que esses indivíduos se posicionavam entre si, a maneira que o islam foi usado, o grau de seu protagonismo nas supostas intenções manifestadas por eles, e para acompanhar mais de perto o andamento dos processos em suas fontes primárias, tentei localizar o processo judicial via e-proc ${ }^{296}$ em 03 de julho de 2018. Não obtive sucesso, pois não possuía acesso ao número do processo e a consulta pelo nome das partes investigadas também não se fizeram úteis.

Neste mesmo dia, contatei a Polícia Federal e o Ministério Público Federal de Goiás (MPF-GO), que iniciou as investigações e acolheu a denúncia, respectivamente. No entanto, em ambos os casos as respostas foram muito parecidas. O MPF-GO alegou que os procuradores que atuaram e/ou atuam no caso não estão falando sobre as operações e me orientaram a contatar a Polícia Federal, que por sua vez respondeu que ela não se manifesta a respeito de investigações em andamento, nem sobre investigados.

Em um segundo contato feito em 12 de julho de 2018 com o MPF-GO, fui informado de que o processo está em sigilo por conta da presença de inúmeras diligências de interceptações telefônicas e pela existência de menores de idade envolvidos. Também me disseram que eu poderia tentar acesso aos autos, ainda que de forma parcial, na 11 ${ }^{\mathrm{a}}$ Vara Federal da Seção Judiciária de Goiás onde esses documentos estariam.

\footnotetext{
${ }^{296}$ Sistema de consulta e transmissão eletrônica de atos processuais da Justiça Federal. https://bit.ly/2Lb75dn (acesso em 03.07.2018).
} 
Sendo assim, imediatamente segui essas orientações e tive a resposta de que "a operação em referência não tramita nesta Vara", divergindo da informação inicial de que o processo estaria na $5^{\mathrm{a}}$ Vara, como mencionado anteriormente.

Estabeleci uma terceira tentativa ainda no dia 12 de julho objetivando dirimir essa inconsistência, e se eu poderia falar diretamente com o procurador da república, Dr. Célio Vieira da Silva ( $5^{\circ}$ Ofício da PR-GO), que atualmente é o responsável pela presente fase do processo. Infelizmente, também não houve sucesso.

Posteriormente ainda foram feitas outras tentativas de comunicação com a $5^{\mathrm{a}}$ Vara de Justiça Criminal de Goiânia, local onde se encontram os autos, mas igualmente sem resposta. Cheguei a cogitar uma visita ao local onde correm os processos, mas fui desencorajado pelas negativas que tive nesses e-mails e das incertezas sobre meu acesso aos autos.

Assim sendo, a solução foi seguir de perto publicações sobre o caso reveladas pela mídia. Encontrei o infográfico abaixo que ilustra a rede de contatos entre os investigados na Operação Átila e outras informações úteis graças a contatos que consegui estabelecer com um jornalista do jornal O Estado de S. Paulo que está acompanhando o caso.

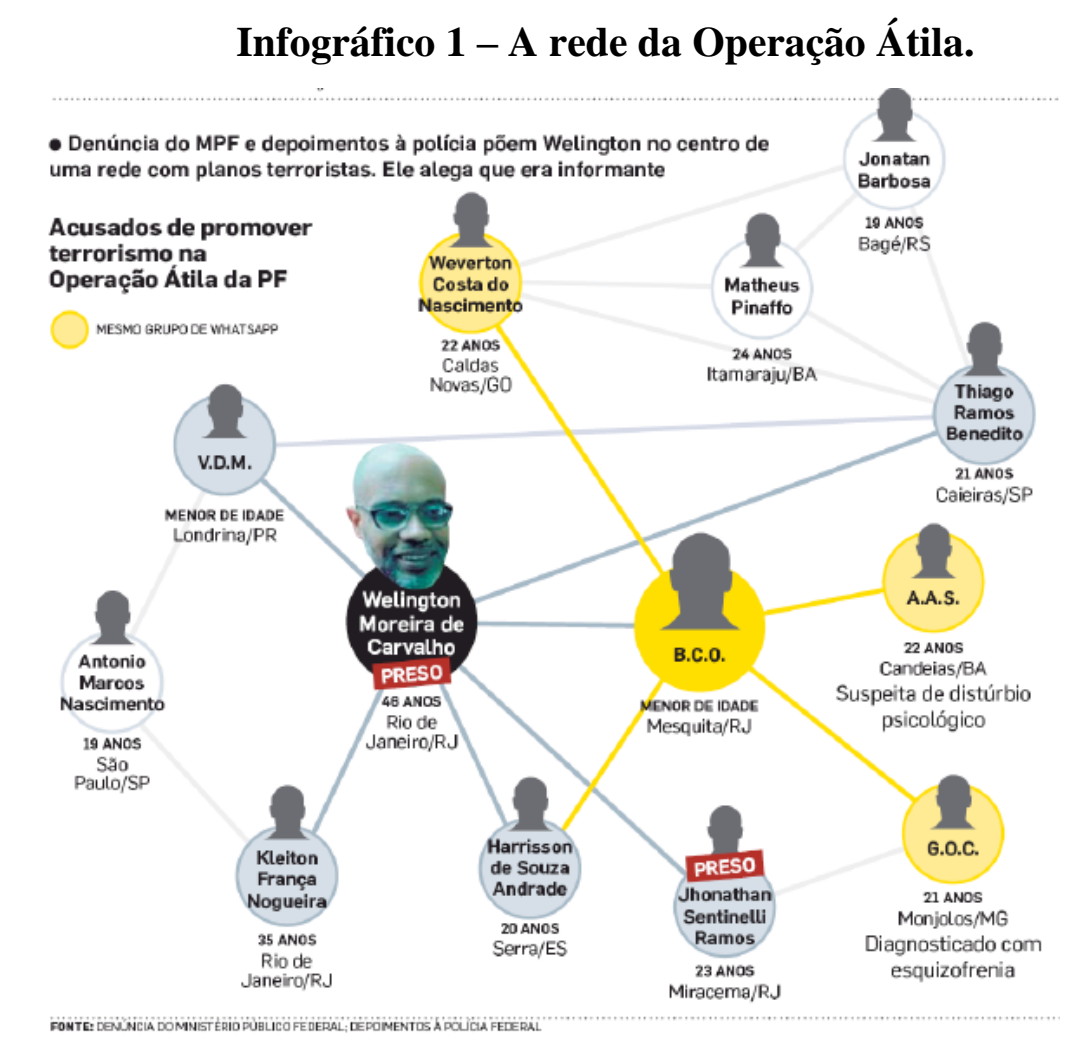

Fonte: Jornal O Estado de S. Paulo, 14 de outubro de 2018. 
Nem todos os investigados indicados no infográfico tinham ligações entre si nem estavam nos mesmos grupos de Whatsapp, objeto de investigação da Polícia Federal. B.C.O ${ }^{297}$, menor de idade à época da publicação, teria sido aliciado por outras pessoas do grupo e seria o elo de ligação mais importante na acusação por ser aquele que tinha contatos com pessoas de grupos diferentes. Segundo informações, boa parte da investigação teria se baseado nos depoimentos dele.

Ainda através dessas conversas, teria sido possível identificar as formas que os pretensos ataques se dariam: por meio de atropelamento de multidões, tal qual em Londres em 2017 e Nice em 2016, esfaqueamentos e até mesmo sequestro de turistas.

Em um recente desdobramento das investigações da Operação Átila, Wellington Moreira de Carvalho, único réu mantido em prisão preventiva até então, afirmou em cartas direcionadas a juízes e em depoimentos à polícia, que na verdade estaria infiltrado em salas de oração islâmicas no Rio de Janeiro/RJ a serviço da Agência Brasileira de Inteligência (ABIN). Sua missão seria identificar possíveis extremistas, especialmente estrangeiros, nas comunidades islâmicas e via redes sociais. De acordo com as informações publicadas pelo jornal Estado de S. Paulo de 14 de outubro de 2018, ele tinha anotações com nomes e endereços dos frequentadores bem como rixas entre os diversos segmentos islâmicos.

Wellington afirmou ter abandonado a religião islâmica desde 2014, mas que estaria fingindo ser muçulmano para ter maior acesso a essas comunidades. Em entrevista, ele afirmou de modo lacônico e confuso que "hoje, eu acredito que o meu Deus é o Deus dos filósofos. Eu acredito que Deus é uma coisa muito incognoscível, está além...É um mistério [...] Eu não tenho religião. Tenho fé, mas não tenho doutrina”.

Nos computadores apreendidos, existiam pastas com planilhas de possíveis gastos que ele teria ao monitorar movimentos suspeitos durante os Jogos Olímpicos do Rio de Janeiro. Além disso, ele diz ter um contato na ABIN chamado apenas de "Claudio", que faria pagamentos extras por mais informações. No entanto, não há registros de que essas informações e demandas foram enviadas para a ABIN, que afirmou não poder interferir na questão, pois o processo corre em segredo de justiça.

Segundo a reportagem do jornal O Estado de S. Paulo de 14 de outubro de 2018, em seu depoimento ao juiz (por videoconferência), quando questionado sobre as acusações, Wellington afirmou: "Vossa excelência, isso não passa de 'bravata', até porque não existem condições financeiras nem 'know how' para tal empreendimento” (p.A12).

\footnotetext{
${ }^{297}$ Bruno Calazans de Oliveira (nome divulgado pelo jornal O Globo, disponível em https://glo.bo/2rOGhb8, acesso em 10.05.2019).
} 
Na edição de 10 de novembro de 2018, o jornal O Estado de São Paulo trouxe a informação de que Wellington foi absolvido pelo juiz Alderico Rocha Santos, da $5^{\text {a }}$ Vara Federal de Goiânia, da acusação de promover o terrorismo. Foi a primeira sentença da Operação Átila. Sua prisão preventiva, que durou 11 meses em presídio federal, foi revogada. No entanto, foi condenado por outras acusações: a de apologia ao crime e corrupção de menores, cuja pena imputada foi de dois anos e quatro meses, das quais a mais pesada é a segunda (dois anos).

Na sentença que o absolveu da promoção de terrorismo, o juiz alegou que o Ministério Público não conseguiu comprovar que o réu se preparava para um ataque ou que treinava grupos paramilitares para tal. Admite que houve a exaltação de atos terroristas, porém nenhum plano foi posto em prática. O próprio Wellington confima em sua entrevista a Tulio Kruse do jornal O Estado de S.Paulo, que

foram cogitadas muitas coisas. De tráfico a prostituição [para arrecadar dinheiro, segundo a denúncia], mas você vê que é incoerente, isso. Tráfico, prostituição, sequestro, assalto a banco, enfim. Tudo foi cogitado, mas nada foi planejado. O próprio juiz viu que não tinha substância.

Além disso, no tocante às afirmações de que Wellington estava cooperando com a ABIN, o juiz entendeu que não houve esse vínculo e que sua versão não é convincente.

Destarte, de alguma forma isso revela que a lei antiterrorismo possui brechas no tocante à presunção de inocência. Em sua decisão, o juiz deixou nas entrelinhas de que não se poderia responsabilizá-lo por algo que ainda não tinha acontecido, tanto a materialidade dos planos como suas execuções. Abre-se uma jurisprudência que pode flexibilizar o entendimento da lei e não punir com rigor extremo aqueles que "curtem" ou "compartilham" mensagens, vídeos e afins ligados a grupos extremistas ou atentados terroristas.

Em publicação do jornal O Estado de S. Paulo do dia 25 de novembro de 2018, Tulio Kruse entrevistou Wellington Moreira de Carvalho em sua cidade natal logo após ter sua soltura decretada. Em contatos que tive com o jornalista, ele gentilmente colaborou com esta pesquisa ao me repassar na íntegra, a conversa que ele teve com Wellington, que é reveladora em muitos aspectos.

Primeiro, o jornalista pede que ele explique como tudo teria começado, sua relação com outros réus do processo, e sobre a formação de grupos de Whatsapp e as conversas que mantinha, objeto principal da acusação e da aplicação da lei antiterrorismo. Ele assim responde:

Na internet. Eu só conheci mesmo, pessoalmente, o Mohamed Abdul Hassam. Os outros eu não conheci pessoalmente, só conheci na Superintendência da Polícia Federal em Brasília. E na internet, a maioria é 'fake'. Como, por 
exemplo, o menor que foi preso. Ele, eu conheci pelo perfil de Facebook. Para ter perfil no Facebook, tem de ser 'de maior'. Eu não teria como saber a idade dele. A maior parte das pessoas que eu conheci, foi na internet. Pessoalmente, o Bruno eu conheci na mussala. Mas bem próximo já de ele ser preso. Fiquei sabendo que ele era menor só no finalzinho. Durante o processo que eu conheci ele, eu não fiquei sabendo que ele era 'de menor'. Eu lembro que ele tinha um perfil 'fake'. E ele era muito divulgador do EI. Então ele me atraiu... (para) estar monitorando ele. As pessoas te adicionam em vários grupos, né? E aí você nem...Te dão o telefone e vão te adicionando. De vários grupos, eu já participei. Tantos que eu nem me lembro, nem o nome. As pessoas vão te adicionando e, quando você vê, está participando de vários grupos sem ter a mínima noção. Vão me colocando, e aí eu vou saindo de alguns.

Wellington destaca a importância das redes sociais e aplicativos de comunicação nesse processo de conformação de intencionalidades e de uma rede solidária de projetos comuns voltados para uma "proto-cyberjihad". Sua relação com outro investigado, Harrisson de Souza Andrade $^{298}$ (ver infográfico 1), e sua periculosidade, são exploradas em outro trecho da entrevista.

No inquérito, Harrisson, cuja esposa tinha sido presa na Operação Hashtag, é mostrado em fotos posando com o que parecem ser armas. Wellington diz:

Acho que não, porque conversando com ele quando estávamos preso, ele... A mulher dele ficou grávida, né? Quando a mulher dele ficou grávida, ele tinha, pelo que me contava, planos de ir para a Al Qaeda, lá fora. Não aqui no Brasil. Depois que a mulher dele ficou grávida, ele...Porque dentro dos ahadith [registro de tradições islâmicas ligadas a ações e frases de Maomé], pelo conhecimento que tenho, quem tem filho não pode abandoná-lo para ir ao combate. Você tem de estar apto à família. Acredito que ele desistiu a partir desse momento em que começou a formar uma família. Mas aí ele já estava no inquérito, aquela coisa toda. E ele foi preso com armas de fabricação caseira. Eu creio até que era para fazer comércio. Ele foi até justo porque não me envolveu nisso. Poderia ter me envolvido se quisesse me prejudicar mais. Foi até justo, falou o que era uma verdade mesmo: que as armas eram dele, que as armas nunca seriam para mim. Ele foi até justo nesse ponto. Eu creio que ele mudou. Então eu vi que ele não tinha mais uma periculosidade...Não

298 Também conhecido como Mohamed Abdul Hassam. 
representava uma ameaça. Eu não identifiquei ninguém que representasse uma ameaça [...] Ele praticava islã, praticava umbanda, misturava religiões.

Wellington, segundo informações do processo, escreveu diversas cartas no período em que esteve em cárcere. Em algumas delas, ele aponta alguns dos motivos que teriam influenciado a interpretação de que ele e demais réus poderiam ser uma ameaça à segurança nacional. Ele afirma que "juntou em um caldeirão" seu trabalho na ABIN, o islam e uma "revolta" que brasileiros patriotas sentem em relação à política. Ele diz que

minha revolta? Acho que influenciou porque o Brasil é um país muito rico em recursos naturais. Não deveria estar nessa posição de país periférico em que está hoje. Eu posso ter me influenciado de uma forma mais... revolucionária. Nas palavras, não que eu fosse fazer alguma coisa. Eu posso ter sido influenciado em uma questão revolucionária, nesse sentido.

A manifestação de indignação com o momento político do país, associada à religião islâmica, seria um indício para a configuração do "islam político" no Brasil? É pouco provável, uma vez que não se detectou qualquer menção à busca por um estado nacional de orientação estritamente islâmica. Por outro lado, se excluirmos o caráter islâmico proveniente de quem estaria indignado com a situação do país, haveria motivos para a execução da lei antiterrorismo? Residiria aqui uma das críticas direcionadas à lei, de que ela poderia criminalizar movimentos sociais?

Segundo, na entrevista ele insiste em reforçar sua atuação como colaborador da ABIN afirmando que em todas as cidades-sede da Copa do Mundo de 2014 em que havia mesquitas, havia monitoramento por parte da inteligência. Ele alega que a Polícia Federal sabia que havia infiltrados nas mesquitas e mussalas a serviço da $\mathrm{ABIN}$, porém não sabia quem eram as pessoas. Ao ser questionado sobre como ele monitorava pessoas envolvidas na operação Átila, ele afirma:

Muita coisa na internet. Eu me passava como um comum, igual a eles, para monitorar. Por exemplo, quando um agente está infiltrado, por exemplo, no narcotráfico - não é o meu caso, é bom deixar bem claro. Eu até fiquei preso com uma galera do tráfico. É bom que esteja claro que eu nunca estive no presídio monitorando ninguém, porque lá, às vezes, alguém pode achar que eu estive no presídio também fazendo trabalho de monitoração. Não é verdade. Eu estava preso igual a eles. Eu tive muito apoio dos presos lá. Meu trabalho era basicamente estar...eu sempre conheci muita gente aqui no Brasil. Eu sou conhecido até lá fora com o meu nome, que eu usava antes, Salahuddin - e também tem milhares, centenas de pessoas chamadas Salahuddin. Então eu 
era conhecido. A mussala era conhecida. O que eu fiz? Eu tinha um amigo que trabalhava como guia de turismo. Eu colei na dele, porque todos os estrangeiros que vinham para o Rio de Janeiro entravam em contato com ele para arrumar um lugar para ficar, hotel barato. Eu ficava junto dele como uma forma de monitorar. O monitoramento é muito simples, é só observar. Até mesmo na linguagem corporal você consegue saber se é radical, se não é radical. [...] Eu monitorei muita gente, porque escrevia relatórios. Eu escrevia relatórios quinzenais e mandava para o serviço de inteligência. Eles faziam lá a avaliação deles, se havia periculosidade ou não.

Em outro trecho, com um toque cinematográfico, ele aponta uma situação concreta em que quase foi impelido a agir durante os Jogos Olímpicos do Rio de Janeiro. Ele conta que no encerramento das Olimpíadas, teve a Maratona. Naquele momento, eu estava em cima de um muro ali, monitorando as pessoas visualmente. Teve um momento até que eu tive uma sensação de perigo, porque vi um cara com a mochila muito cheia. Estar com a mochila muito cheia ali seria estranho. E ele tinha uma barba muito grande. Aí ele abaixou e tirou um equipamento de fotografia. Eu estava me preparando para pular em cima dele. Eu já estava passando para eles: 'tem um cara aqui que está muito estranho'.

Ao ser questionado sobre a acusação de ser considerado "líder" de um grupo, ele argumenta que "não há como ser líder 'online'. Você tem de se encontrar em algum lugar. Essa minha liderança poderia ter sido no sentido de estar atraindo as pessoas para dentro de uma 'arapuca'". A territorialidade, e não a desterritorialização, mostra-se fundamental como se supunha.

Em terceiro lugar, Wellington revela que hoje o EI está praticamente aniquilado, ao contrário do que era em 2014 quando estava no seu auge e inspirava maiores cuidados das autoridades. No entanto, ele alega que

o Brasil nunca vai ser alvo de terrorismo. Não mandou tropas para o Afeganistão, não mandou tropas para a Líbia, não mandou tropas para o Iraque. O Brasil é bem visto lá fora. Então a gente talvez só teria uma ameça na Copa e nas Olimpíadas por causa das delegações estrangeiras no Brasil. [...] Se eu fosse terrorista mesmo, eu teria feito alguma coisa. Tive oportunidade de fazer muita coisa. Como eu disse antes, a mussala estava fechada. Eu reabri ela para isso [monitorar radicais]. Ela nunca teve grupos ou pessoas radicais lá dentro.

De forma até certo ponto contraditória, ainda que descarte a possibilidade de terrorismo no Brasil pela falta de condições financeiras e "know how", ele revela com essa afirmação que 
isso não é algo impossível de acontecer diante das possibilidades que ele disse ter tido e que obviamente outros poderão ter.

Ainda sobre isso, Kruse questiona sobre a reprodução de conversas (presentes na acusação do MPF) a respeito de um ataque no carnaval em Salvador e a formação de um grupo paramilitar no Norte do país. Wellington responde da seguinte forma:

Eu acho que as pessoas discutem muita coisa, mas acabam não fazendo. Esse do carnaval eu só fiquei sabendo no próprio processo, porque era um fato isolado de um acusado. O outro fato, eu conheci, sim. Eles se conversavam muito, o Mohamed Abdul Hassam [Harrisson], né? Conversava-se muito sobre montar um grupo paramilitar. Mas eu sempre levava isso...não a sério. Quando eu o conheci pessoalmente, eu sabia que não tinha know how para isso [...] Eu acho que se tiver radical no Brasil, ele vai querer ir para fora. Não vai querer ficar no Brasil. O Brasil não tem o ambiente propício para viver o radicalismo. O radical vai querer ir para o Oriente Médio, viver lá com algum desses grupos e morrer por lá.

Tal como disseram muitos dos meus informantes, Wellington destaca novamente a improbabilidade de o radicalismo criar raízes em território nacional. No entanto, sua fala não descarta a hipótese de que eles possam eventualmente surgir no Brasil.

Por fim, é perguntado se entre os envolvidos no caso, há algum que Wellington considera radical ou perigoso. Sua resposta é muito interessante na medida em que faz eco àquilo que de certa forma eu escutei de meus informantes, especialmente de sheikhs como Jihad Hammadeh.

Ele afirma a Kruse:

Não. Tem gente que é radical. Existe uma frase que a gente fala muito: 'todo radical é wahabita, mas nem todo wahabita é um terrorista'. Ser radical não significa necessariamente que a pessoa é ou será terrorista. Vi muito maluco, fanfarrão, pessoas com distúrbios. Quando cheguei lá na prisão, vi que a maioria não fazia oração porque sigo a tradição mais esotérica. O próprio islã tradicional não considera o sufismo como islã, como parte dos muçulmanos.

$\mathrm{O}$ fato de ser chamado de radical ou de fundamentalista, como vimos anteriormente, não parece ser um problema para a maioria dos muçulmanos que alegam que ser radical é ir às "raízes" da religião ou aos seus "fundamentos", referindo-se aos escritos sagrados. Deste modo, todos seriam fundamentalistas os que recorrem aos seus livros, sejam cristãos, judeus ou muçulmanos.

A maioria dos acusados nas duas operações está em liberdade, muitos por falta de provas consistentes. Isso debilita o argumento da existência e articulação bem estruturada de células 
terroristas em território nacional, e de que são potencialmente perigosas no curto-médio prazo em termos de uma ação concreta.

Em relação aos investigados pela Operação Hashtag, os da Operação Átila parecem ter relações mais estreitas especialmente com pessoas de outros países e com projetos e ações mais delineados. Conclusão baseada no pouco material que tivemos acesso, especialmente nos trechos de diálogos publicados.

No entanto, há algumas importantes características em comum: a maioria dos envolvidos são convertidos ao islam e muitos vivem em estados com pouca presença e organização islâmica do ponto de vista institucional. Além disso, pelo menos dois dos indivíduos arrolados apresentam distúrbios mentais e fazem tratamento para esquizofrenia, algo que atesta ser possível que certas publicações, conversas ou apologias a determinados atos não se mostrem consistentes.

Os casos listados são recentes e aos poucos vão se tornando frequentes na mídia nacional que oferece um quadro descritivo das situações, mas ainda é pouco amparado por análises sérias e aprofundadas (usando o know-how de pesquisadores brasileiros sobre o assunto) sobre os motivos e repercussões que isso pode ocasionar no país, especialmente em relação ao conjunto das comunidades islâmicas brasileiras.

O então ministro-chefe do Gabinete de Segurança Institucional (GSI), Gal. Sérgio Etchegoyen, reconheceu que há brasileiros ligados a jihadistas, mas que "não dá pra falar em célula terrorista" no Brasi1 ${ }^{299}$. Ele também alega que o Brasil está preparado para enfrentar esse novo desafio e busca se antecipar aos possíveis atentados especialmente com o aporte da inteligência, do monitoramento virtual e da lei antiterrorismo recém sancionada.

Em algumas entrevistas que fiz com diversos membros de comunidades islâmicas de norte a sul do Brasil, as pessoas foram unânimes em dizer que é evidente que o Brasil tem que se prevenir contra qualquer ameaça terrorista. No entanto, essas mesmas pessoas e comunidades ponderam que a prevenção deve ser contra todo tipo de violência, não apenas o caso específico do terrorismo que frequentemente está ligado ao islam e, portanto, gera desconforto nessas comunidades que se tornam vulneráveis a atos preconceituosos por parte da população que sofre com a desinformação.

A conversa que tive com um refugiado sírio chamado Alaa ${ }^{300}$, em 2015, exemplifica em parte essa questão. Quando o questionei por que razões ele e sua família estavam saindo do Brasil em direção à Turquia, para então fazer a árdua e perigosa travessia para a Europa, ele

\footnotetext{
${ }^{299}$ Jornal O Estado de S. Paulo, 19 de maio de 2018.

${ }^{300}$ Entrevista realizada em 04.11.2015 na Mesquita de Campinas/SP (Sociedade Islâmica de Campinas/SP - SIC).
} 
elencou a falta de oportunidade de emprego, e a violência. Nas palavras dele: "eu gosto do Brasil, mas o que fazer? Aqui é muito perigoso".

Meu informante Ahmad Alkhatib, um dos investigados na Operação Hashtag, alegou que teve que explicar várias situações inerentes à religião islâmica às autoridades da Polícia Federal, que para ele, não conhecem quase nada sobre o islam ou sobre os muçulmanos.

Apesar de haver lacunas nos fatos noticiados, especialmente quando se remetem a possíveis redes terroristas que estariam usando o Brasil para desempenhar suas atividades, ao menos estes casos fomentam uma importante discussão que tira das sombras as comunidades muçulmanas que aqui habitam, mas que muitos desconhecem quem são, onde estão, o que fazem e quais suas respostas frente a esses novos desafios.

Neste caso, as consequências de se tratar do tema terrorismo como algo separado de outras formas de violência, mesmo porque está sempre associada à religião islâmica, engendram o perigo de estigmatizar tais comunidades especialmente em uma sociedade muito fiel à grande mídia e portadora, ainda, de muitos preconceitos justamente pela carência de maiores informações a respeito dos temas que envolvem o islam e os muçulmanos.

As comunidades islâmicas brasileiras não aceitam "colocar a população contra a comunidade muçulmana com falsos alarmes, por coisa que não existe", como afirmou meu informante Ahmad. O sheikh xiita Mohamed Khalil de Foz do Iguaçu/PR, também expôs sua preocupação quanto a notícias e eventos negativos envolvendo muçulmanos, pois diz que a cidade inteira sofre uma vez que o turismo decai em razão do medo e do preconceito que se cria na população.

A secretária-geral da Escola Árabe-Libanesa de Foz do Iguaçu/PR, Khouloud El-Birani, também mostrou preocupação quanto a isso, dizendo que as crianças e os jovens também se sentem por vezes constrangidos toda vez que se vincula muçulmanos com atentados ou quaisquer atividades ilegais e criminosas.

Todos são uníssonos em afirmar que não enxergam um preconceito flagrante, sistemático e estrutural no Brasil voltado aos muçulmanos. Entendem que o país acolhe muito bem a todos, que estão bem assimilados e que compartilham da boa convivência com os diversos segmentos da sociedade e correntes religiosas. Mas, lamentavelmente, justamente pela ignorância de parte da população e pelo viés midiático frequentemente portador de atribulações, membros dessas comunidades confessam que em casos isolados, seja nas ruas ou mais comumente pelas redes sociais, já constataram agressões islamofóbicas ${ }^{301}$, que segundo eles,

301 Virgínia, Anna. Islamofobia à brasileira. Jornal Folha de São Paulo, 15.01.2015. Disponível em https://bit.ly/1yHzOIb (acesso em 10.05.2019). 
fica ainda mais patente sempre que há um evento de comoção mundial envolvendo terrorismo, e agora, em situações envolvendo muçulmanos no próprio país. Grupos e minorias radicais praticam atos que respingam em todos da ummah.

O sheikh Ahmad Abdul conta o exemplo em que presenciou uma forma de preconceito, mais por ignorância do que uma agressão consciente e maldosa. Ele diz:

Uma vez teve passeata contra guerra no Iraque. Então, no Pelourinho, você conhece Pelourinho, né? [respondi que sim e ele continuou] De Pelourinho para cá, andamos. Eu andei com aquela roupa de sheikh. Quando cheguei num lugar que chama Saúde, uma senhora olhou assim [e fez um gesto facial] e disse:

- Puxa, meu Deus! Até aqui também tem guerra!

Falei:

- Senhora, não. Eu sou homem da paz.

- Então por que você está usando essa roupa? Não tem bomba aí dentro não? [exclamou].

Se eu for brigar com essa senhora, eu estou afirmando que eu sou o homem da bomba. Eu disse, não, senhora, na minha terra a gente usa essa roupa. Ela falou:

- Eu posso falar com o senhor?

- Claro!

Conversamos bastante, ela pediu desculpas e disse:

- Senhor, desculpas. Eu não sabia. Porque a mídia fala pra nós que as pessoas botam bomba dentro da roupa, desculpa.

Eu dei para ela panfleto e depois ela ligou para mim pedindo mais desculpas.

Ela não virou muçulmana, mas passou a ter respeito e admiração.

Em um encontro com Fatih Ozorpak ${ }^{302}$, ele sustenta essa situação ao revelar que Infelizmente, quando a mídia fala do Estado Islâmico, extremismo fundamentalista, então você acaba criando aquele conceito e todo mundo entende daquela maneira. Estamos no país Brasil: um país muito distante daqueles acontecimentos, muito assustado, muita gente tem muito preconceito.

O sheikh Jihad Hammadeh, corrobora esse raciocínio quando afirma que existe aqui uma discriminação e um preconceito, mas embasado em ignorância e falta de conhecimento. Inconsciente [pausa] Esse é fácil. É só dar

\footnotetext{
${ }^{302}$ Diretor do Centro Islâmico e de Diálogo Inter-religioso e Intercultural. Entrevista realizada em 13.06.2016 no Centro Cultural Brasil-Turquia (CCBT) em São Paulo.
} 
conhecimento e a pessoa pode mudar de opinião. O problema é o consciente, quando a pessoa não quer conhecer o outro lado, porque ela já tem uma posição. Aqui há falta de ferramentas para julgar e ela já julgou mesmo assim.

No contexto da modernidade, em que tudo se difunde velozmente e de forma cada vez mais líquida e capilar, a preocupação com o terrorismo sempre deve estar em pauta. A existência de poucos estudos e autores que se dedicam em investigar as ramificações e atividades jihadistas na América Latina e Brasil, aliado às frequentes notícias dos últimos anos sobre supostas atividades de suporte ao terrorismo no país, refletem essa sensação de preocupação por parte das autoridades e de um certo receio das comunidades islâmicas frente a novos estigmas.

Quando se trata de indivíduos e grupos isolados, de recém-convertidos, com pouca vivência religiosa, inclusive com problemas psiquiátricos (caso de alguns dos investigados na Operação Átila) ${ }^{303}$ a conformação, embrionária ou não, de células radicais que possam usar a religião como uma pretensa forma de justificar seus atos e intenções pelo caminho da violência, é uma possibilidade latente.

Não obstante, é reconfortante afirmar que não se encontram indícios de que haja radicalização de muçulmanos em solo brasileiro dentro das comunidades islâmicas institucionalizadas. Essa assertiva se baseia em minha participação de pregações em mesquitas, eventos sociais e religiosos bem como entrevistas realizadas com muçulmanos nascidos ou convertidos em algumas comunidades islâmicas no Sul, Sudeste e Nordeste do Brasil, onde se concentram as maiores e mais importantes delas.

A questão levantada por Roy (2017), se o que existe é uma radicalização do islam ou se há uma islamização do radicalismo, parece ser pertinente no caso brasileiro. A segunda opção parece ser mais adequada.

A seguir, são propostos alguns eixos que edificam a reflexão e a confiança nessa tese:

\section{a) $O$ perfil da população muçulmana no Brasil.}

O Brasil abriga grandes colônias de sírios e libaneses que imigraram ao país em importantes ondas no começo do século XX com a desintegração do Império Turco-Otomano e depois, a partir dos anos 60 e 70, com os conflitos no Oriente Médio envolvendo Israel, Síria e Líbano. Contudo, grande parte deles é de religião cristã e já foram bastante assimilados à cultura brasileira.

${ }^{303}$ https://bit.ly/2IM3nFe (acesso em 01.06.2018). 
A presença de muçulmanos no Brasil é mais antiga, data do século XIX com a vinda dos escravos Malês ${ }^{304}$ para o Nordeste. Já no século XX, muitos muçulmanos também vieram para o Brasil acompanhando os cristãos sírios e libaneses. Mais recentemente, embora a imigração tenha se reduzido, o número de brasileiros que se converteram ao islam tem crescido $^{305}$.

Do ponto de vista socioeconômico é possível afirmar que grande parte dos muçulmanos brasileiros pertencem a uma classe média-alta, embora existam registros de crescimento de convertidos em periferias mais pobres como em Embu das Artes/SP, que adquiriram notoriedade por meio da música ${ }^{306}$ (hip-hop e o rap) para divulgação do islam e sua reflexão enquanto fé, como é o caso do grupo Jihad Brasil. De qualquer forma, não é possível associar a condição social ao radicalismo.

Como vimos no início desta tese, se o número de muçulmanos tem aumentado especialmente com base em convertidos, isso implica diretamente na construção de novas mesquitas, mussalas e centros islâmicos ${ }^{307}$. Concomitantemente, o número de sheikhs (líderes religiosos das comunidades islâmicas) também aumenta, seja pela vinda deles de outras partes do mundo, seja por brasileiros convertidos que vão estudar em renomados centros de formação de religiosa como a famosa Al-Azhar do Egito ou em Qom no Irã (no caso dos líderes xiitas) e em seguida retornam para atuar frente às suas comunidades.

Em face disso, essas tendências poderiam representar uma ameaça iminente ao Brasil? A resposta é não. Primeiramente, do ponto de vista geográfico, as comunidades estão concentradas em apenas uma pequena fração do imenso território nacional. Elas se encontram de forma microscópica em termos quantitativos e já estão bastante assimiladas ao modo de vida brasileiro. O número de brasileiros convertidos, bem como seus líderes, tem assumido cada vez mais o protagonismo nessas comunidades, não tendo um vínculo marcante com a cultura árabe e com os problemas vigentes no Oriente Médio, o que ajuda a eliminar, em parte, motivos para radicalizações indesejáveis.

Importante lembrar que os mandados de busca de apreensão que foram cumpridos durante a Operação Hashtag foram em São Paulo, Rio Grande do Sul, Rio de Janeiro, Paraíba, Ceará, Goiás, Minas Gerais, Mato Grosso e Amazonas. No caso da Operação Átila, os investigados são de oito estados diferentes: Espírito Santo, Bahia, São Paulo, Minas Gerais, e Goiás, Paraná, Rio de Janeiro e Rio Grande do Sul.

\footnotetext{
${ }^{304}$ Cf. Reis, João José. A Revolta dos Malés. São Paulo: Brasiliense. 1987.

${ }^{305}$ Jornal O Estado de São Paulo. "Cresce o número de brasileiros que se convertem ao islã". 31.05.2015, p. A18.

Cf. https://bit.ly/2u0kQUT (acesso em 10.05.2019) e https://bit.ly/2Nm9zXP (acesso em 10.05.2019).

${ }^{306}$ https://abr.ai/2IPlnyi (acesso em 10.05.2019).

307 https://bbc.in/2MLmC3Y (acesso em 10.05.2019).
} 
Desses estados, em ambos os casos, apenas São Paulo e Paraná se destacam entre os mais proeminentes em termos da presença de muçulmanos como mostram os mapas da exibidos na Parte I. Nos demais, além de pouca presença numérica de muçulmanos, a sua organização é quase inexistente e sem elos com as principais instituições islâmicas do país. Essa “invisibilidade" também auxilia a entender a radicalização de certas pessoas nesses estados.

O provável autodidatismo em termos de estudos da religião islâmica especialmente entre os convertidos e os desprovidos de uma liderança erudita, no caso um sheikh, pode ajudar a entender o uso da religião em relação aos interesses político-ideológicos. Contrariamente, a impressão que se tem é que a religião se torna um engodo para ações que se baseiam em outros princípios e valores sem correlação alguma com a fé declarada. O sheikh Abdo Nasser sustenta essa reflexão ao insistir que "a religião muçulmana não tem nada com o terrorismo [...] Assim, a religião jamais pratica ou orienta para o terrorismo".

Essa resposta de certa forma já era esperada. Mas as relações entre a religião e a violência são bem mais complexas. A religião pode não orientar a violência, mas as pessoas podem se apropriar dela e justificar seus atos e interesses com base em interpretações tergiversadas. Ao mesmo tempo em que isso reforça a tese de que existe uma islamização do radicalismo, deixa de lado a questão dos "híbridos" de Bruno Latour. Não há apenas a religião ou apenas as pessoas, ou, a coisa-em-si e o humanos-entre-eles, mas o híbrido, religião-e-pessoas.

Ainda que muitos sheikhs e lideranças de associações islâmicas neguem, é importante ressaltar que autores como Ferreira (2007 e 2009), Chagas (2006), Oliveira (2006) e Paulo Pinto (2010) descrevem alguns desconfortos e desconfianças entre os brasileiros convertidos e os árabes dentro das comunidades.

Em algumas, como em Foz do Iguaçu/PR, o caráter étnico (árabes) é mais marcante. Já no Rio de Janeiro, a presença de brasileiros que visam se distanciar da identidade árabe criando um islam "nacional” é mais proeminente. Diferenças linguísticas e concepções religiosas seriam alguns desses possíveis pontos de divergência entre eles, mas que não resultam em conflitos e tensões mais graves. Apesar dessa distância étnica, cultural e até mesmo política, que aparentemente poderia afastar ainda mais os brasileiros da agenda jihadista, em alguns casos, essa distância é ignorada ao ponto de convertidos se apropriarem das lutas e da ideologia política de grupos com os quais não possuem nada em comum exceto por um perfil aparentemente niilista tal como propusemos no trabalho.

Um fato interessante é que um dos investigados da Operação Hashtag frequentava uma pequena mussala em João Pessoa/PB e teria sido expulso por defender o Estado Islâmico e se mostrar com ideias radicais e incompatíveis com a religião islâmica de acordo com membros 
da comunidade local. Muito antes, há cerca de 15 anos, igualmente o fez o presidente da Sociedade Beneficente Muçulmana do Rio de Janeiro, ao também expulsar de sua comunidade um dos acusados na Operação Átila por demonstrar atitudes e falas agressivas. Ambos eram convertidos.

Em Salvador/BA, há alguns anos o sheikh Ahmad Abdul disse ter ele próprio expulsado um jovem por ideias radicais. Ele assim contou em entrevista:

aqui também expulsamos. Expulsamos. Quando percebemos que um jovem está falando coisa que não tem nada a ver. Eu falei, olha bem, eu vou chamar sua mãe. Eu vou mandar nossa secretária fazer uma carta, uma para você e uma para sua mãe. Ele me perguntou por quê. Porque o que você está divulgando não tem nada a ver com a religião. Você está divulgando radicalismo na escola. "Você está reclamando que a escola não gosta de você. Como você quer que a escola goste de você?"

[Eu pergunto a idade do garoto que foi expulso] naquela época tinha 18 anos. Moleque. Eu falei: eu vou escrever a carta que você não é muçulmano mais. Você não pertence à gente. Ele me disse para não fazer isso. Eu disse: "você tem que parar. Você viu o que aconteceu no Rio [de Janeiro]? Eu vou fazer a mesma coisa". Chamei a mãe dele. A mãe dele não é muçulmana. A mãe dele pediu desculpas e disse que ele não estava agindo bem em casa. Eu falei para ela que radicalismo não tem aqui. Não é só aqui, é no Brasil inteiro. A gente não quer essas pessoas, porque não é do islam!

A maior parte dos investigados nas operações da Polícia Federal são de convertidos e muitos sem conexões com mesquitas e ou sociedades islâmicas ${ }^{308}$, o que sustenta o argumento de muitas comunidades com as quais tratei, de que justamente por desconhecer a religião e por sua pouca ou distorcida vivência, algumas pessoas fazem uso dela para fins próprios e contrários aos ensinamentos do islam, do ponto de vista da maioria muçulmanos. Do universo de 400 mil muçulmanos, vinte e cinco deles são investigados por organizar ações terroristas e por suscitar vínculos com grupos extremistas. Somente alguns deles estão presos. Nenhuma ação terrorista foi perpetrada.

Números que se mostram tímidos para colocar a sociedade em alerta iminente. No entanto, jamais devemos ignorar os riscos, que não têm respaldo no argumento meramente

\footnotetext{
308 Cf. Allan, S; Augusto, O; Thiago, A. O processo de radicalização e a ameaça terrorista no contexto brasileiro a partir da Operação Hashtag. Revista Brasileira de Inteligência. Brasília: Abin, n. 12, dezembro 2017, p.09.
} 
quantitativo. $\mathrm{O}$ atributo assimétrico ${ }^{309}$ do terrorismo é justamente o que faz com que poucos possam causar prejuízos a muitos. Por isso devemos ponderar mais elementos nessa discussão.

\section{b) Integração das comunidades islâmicas e suas redes de cooperação.}

As comunidades islâmicas brasileiras não possuem fortes vínculos entre si. Atuam como organismos isolados, cada uma cuidando e conduzindo suas atividades de forma independente. Há instituições como a CDIAL, WAMY e FAMBRAS que promovem a divulgação do islam, distribuem material publicitário, auxiliam financeiramente algumas comunidades, promovem acampamentos, palestras, aulas, dentre outras atividades. Contudo, não atuam como portavozes da comunidade em geral.

O sheikh Ahmad Abdul, quando interpelado a respeito dessa situação, ele alega que

Não tem [centralidade]. Tem centralidade com o sheikh Abdelhamid que é responsável da gente. O sheikh que elegemos. Então qualquer coisa ele tem que ouvir, tem diretoria la. Ele é presidente dos sheikhs [...] Mas pra dizer que é central, que manda, não existe isso. Cada centro islâmico é independente. Tem ligação com FAMBRAS, tem ligação o com Saifi [CDIAL] e Wamy.

Do ponto de vista institucional, todos os sheikhs e outras lideranças com os quais tive contato, assumem que não há uma união das comunidades islâmicas. Entretanto, o sheikh Jihad Hammedeh se lembra da União Nacional das Entidades Islâmicas (UNI) que é justamente aquela que, segundo ele,

é uma entidade mãe que congrega teoricamente as entidades islâmicas. É ela que vai reger administrativamente, cuidar, zelar administrativamente das instituições islâmicas. Então ela vai ser um representante político, administrativo da comunidade e que fala em nome das entidades.

Ele acrescenta que existe um trabalho que já dura mais de cinco anos que visa criar uma "instituição mãe" que possa fortalecer os laços entre as diversas comunidades e que a UNI deve ser a base para isso.

A razão encontrada para isso, também com base nas entrevistas, é a existência de uma pluralidade de ideias que muitas vezes não convergem para um senso comum. Conforme apontou Mustafa Göktepe ${ }^{310}$,

não há interação entre as comunidades. Isso é certeza. Há divergências [hesita um pouco e diz em tom sério] entre ideologias e diferenças culturais. Muitos fatores, inclusive religiosos, mas muito mais culturais, políticos e regionais do

\footnotetext{
${ }^{309}$ Cf. Stepanova (2008).

${ }^{310}$ Presidente do Centro Cultural Brasil-Turquia, com sede em São Paulo. Entrevista realizada em 13.06.2016 na sede do CCBT.
} 
que religiosos [...] E tem divisão, muito claramente entre xiita e sunita, isso também no mundo muçulmano existe, mas entre os muçulmanos a questão de região também - Egito, Líbano, Síria - áreas de influência que se refletem aqui.

Sob o viés religioso, o Conselho Superior dos Teólogos do Brasil, presidido pelo sheikh Abdulhamid Metwally ${ }^{311}$, seria o espaço de um maior estreitamento dessas relações e de discussões religiosas entre os sheikhs.

O grau de interação entre as comunidades islâmicas no Brasil reflete de certa forma a concha de retalhos políticos, ideológicos, culturais e religiosos que configura o Oriente Médio e o mundo muçulmano. O local é cada vez mais, à sua maneira, a síntese do mundo.

Diante desse quadro fragmentado tanto na organização como na composição dessas comunidades, não é possível pensar em uma rede articulada e com uma proposta que aponte direções e agendas comuns. Isso de certa forma pode inviabilizar conexões jihadistas, que sofreriam com descontinuidades em suas redes e impediriam que seus projetos escusos pudessem ganhar amplitude e número de militantes.

Paradoxalmente, esse isolamento celular ou a falta de um "controle central" pode, em tese, facilitar a cristalização de núcleos jihadistas de onde possam germinar os chamados "lobos solitários"? Indivíduos com propostas que poderiam destoar do restante da comunidade à qual pertence e ir em busca de projetos que possam compactuar com uma eventual visão religiosa distorcida, seria uma possibilidade?

Conforme foi possível observar até aqui, essa possibilidade existe. Basta observar que a maior parte dos lugares onde viviam os acusados pelas operações da Polícia Federal são de pouca ou nenhuma estrutura institucional e numericamente incipientes.

\section{c) Uso do espaço religioso para propagação de ideologias jihadistas.}

Esse item se relaciona com os dois anteriores em alguns aspectos. Primeiramente, como dito no item "a", o aumento no número de mesquitas e mussalas, na quantidade de convertidos, e a maior presença de sheikhs estrangeiros e de brasileiros que se dedicam ao estudo da religião no intuito de se tornarem líderes em suas comunidades, não supõe uma doutrinação religiosa de cunho radical.

As pregações em quase todas as situações são feitas em árabe e em português, de modo que a compreensão possa ser a melhor possível, e não possuem conteúdo beligerante e incitador de ideias jihadistas. Ao contrário, se dedicam em relembrar passagens do Alcorão e da vida de

\footnotetext{
${ }^{311}$ Entrevista realizada em 08.01.2017 na Mesquita Brasil em São Paulo.
} 
alguns profetas de forma a oferecer exemplos de boa conduta de sua fé. Em algumas situações relembram fatos que acontecem no mundo e condenam aqueles que usam o islam como pretexto para violência e intolerância. Como exemplo, se recusam a reconhecer o Estado Islâmico como grupo muçulmano. Ao menos foi isso que pude presenciar nas vezes em que participei de suas orações, festas religiosas e jantares de iftar no mês do Ramadan.

Nestes muitos contatos, também ficou claro que eles sustentam teorias conspiratórias de que as razões para tantos problemas no Oriente Médio e no mundo muçulmano são o sionismo, a presença "imperialista" Europeia e Norte-Americana em países islâmicos e a mídia como reprodutora de preconceitos. Com certo ressentimento, questionam por que um ataque terrorista na Europa ganha tanta atenção da mídia e comoção por parte da população, mas que não tem o mesmo tratamento quando ataques e violência de todos os tipos ocorrem em países muçulmanos.

Muitos dos sheikhs, ainda que tenham estudado em instituições conservadoras e tenham sido formados sob um discurso mais tradicional, não alimentam cismas geradores de conflitos que poderiam servir de base para uma radicalização de muçulmanos dentro das mesquitas. A moderação é a senda adotada de forma geral.

O sheikh Ahmad Abdul, que revelou ter estudado na Arábia Saudita, berço da corrente mais tradicional wahabita, reforça esta tese dizendo:

eu não posso negar isso. A gente fala que qualquer pessoa que frequenta qualquer centro islâmico aqui no Brasil é quase impossível. Porque, por enquanto, todo sheikh que está aqui no Brasil, estudaram mesmo! Mas tem aqueles que se dizem ser sheikh, mas não estudou. Mas eu brinco com os irmãos aqui, sheikh de Google [risos].

Neste caso, está implícito que o autodidadismo que muitos assumem ou a lealdade a sheikhs que possuam uma formação religiosa de origem duvidosa, correm o risco de ajudar a germinar posturas mais extremistas. $\mathrm{O}$ uso de redes sociais, cada vez mais comuns como fonte de pesquisa e conhecimento, são peças fundamentais na edificação de um proto-jihadismo que se encontra em forma de espasmos ainda tímidos no Brasil.

Em comunidades menores que não possuem um sheikh, como observado em Natal/RN, o presidente da associação ${ }^{312}$ e os membros mais antigos é que se encarregam de fazer os sermões. Como foi constatado durante minha visita, ainda que fosse uma sexta-feira de

\footnotetext{
${ }^{312}$ Muhamad Tawfiq explica que os recursos escassos da comunidade dificultam a participação de seus membros em palestras, encontros com demais associações islâmicas assim como para o convite de sheikhs que possam ministrar cursos e transmitir algum conhecimento para eles.
} 
Carnaval e dia da oração mais importante, não houve qualquer menção que eventualmente condenasse as práticas carnavalescas mundanas e muito menos algo que estimulasse qualquer visão mais radical sobre outros assuntos.

Portanto, se dentro das mesquitas e das próprias comunidades islâmicas não se observam indícios de radicalização ou da apropriação de um discurso que possa conduzir indivíduos para o caminho do jihadismo, haveria alguma outra possibilidade? Ao final do item "b" aventamos a possibilidade da existência de "lobos solitários" com ideais jihadistas atuando de forma autônoma.

Assim sendo, o autodidatismo e o uso indiscriminado das redes sociais e sites suspeitos pode ser um desses caminhos alternativos que podem contribuir com essa possibilidade.

Em se tratando de indivíduos que possuam tendências mais "político-ativistas" e que não se enquadram nos discursos pregados nas mesquitas ou não encontram uma liderança religiosa que possa responder aos seus anseios, muitos podem buscar respostas nas escrituras sagradas sem a devida orientação, correndo-se o risco de se apoiar em interpretações que divergem da maioria moderada. O sheikh Jihad Hammadeh afirma:

o que atrapalharia é que muitos que não têm conhecimento, interpretam à sua maneira, sem estudos corânicos. Quem poderia ajudar seriam apenas os sheikhs, os eruditos [...] e como é que o erudito se torna erudito? Com conhecimento. Só que aqui, o conhecimento não é restrito aos eruditos, está aberto para todos, por isso que você tem as universidades. Cada muçulmano tem que ter um sheikh como consultor.

O sheikh Mohammed Khalil corrobora e complementa a afirmação acima ao dizer que fraqueza do islam se deve a multiplicidade de interpretações do corão que além disso deixa a mensagem do islam fragmentada e atrasada. A pessoa passa a conhecer apenas pedaços. Mas isso acontece com outras religiões [e aponta o cristianismo e judaísmo]. Se eu vou obrigar que o texto, vamos dizer assim, deixar o texto como massa para servir aos meus interesses, isso não. É o contrário. Eu quero ser inclinado perante o texto, verdadeiro e claro. Não minha opinião, minhas ideias particulares.

Esses parecem ser os mesmos caminhos de radicalização descritos por Olivier Roy na França, porém em dimensões muito mais reduzidas.

Outro relato é de Fatih Ozorpak para quem o autodidatismo deve ser visto com cuidado, pois se "você vê uma pessoa que não lê, não estuda, só de falar o que ele está ouvindo, ele é a pessoa mais perigosa de todas. Então a religião não tem problema, os muçulmanos têm culpas". 
Por fim, o sheikh Abdelhamid Metwally é categórico em dizer que a ijtihad, a interpretação, não é para qualquer pessoa,

é para pessoa estudada, qualificada. Então tem um ponto aqui fundamental: onde é que essas pessoas rezam? Ou, aprendem com quem? Você já procurou? [...] o início do erro deles [dos extremistas] é de usar alguém que não tenha capacidade com alguém que possa ser fonte de busca dos pareceres religiosos. Então esse é o problema.

O sheikh inclusive levanta a discussão sobre as pessoas que foram presas e que teriam apontado Ahmad Alkhatib como seu "guia". Ele diz:

Primeiro, o sheikh Ahmad [Alkhatib] não tem qualificação, não nenhum certificado que prove que ele é um sheikh. Alguma coisa [ele] sabe, mas provavelmente se ele estudou, não tem. Como também não tem nenhuma sociedade que ele representa como sheikh, uma mesquita ou algo parecido.

Se de fato essa autonomia excessiva pode ser complicadora, ela poderia minimamente explicar alguns dos motivos que inspiraram ao menos algumas das pessoas investigadas na Operação Hashtag ou Operação Átila?

O suposto jihadismo que vemos de forma opaca no Brasil, com base nas operações policiais deflagradas e em outros depoimentos, se caracteriza por motivações e projetos aparentemente difusos e desarticulados, amador em termos de organização institucional e financeira, e cujos partícipes se mostram com questionável conhecimento da religião islâmica como suporte para seus projetos.

A aparente "revolta" que muitos alegam como sendo um combustível para o compartilhamento de ideias mais extremadas, se aproxima de uma forma pseudo-niilista em que o uso e propagação da violência falam mais alto do que a existência de um projeto religioso como resposta aos problemas existentes. O jihadismo "à brasileira" mostra-se incompleto e povoado por "homens-absurdos" como diria Camus. Quando Wellington é questionado se ele tem medo de ser preso novamente e se ele tem planos para o futuro, ele reponde

Não. Eu não tenho medo de ser preso de novo porque isso não vai acontecer. Eu nem esperava ser preso antes [...] Não estou fazendo planos agora porque estou mais em uma fase de "limpeza", digamos assim, na mente. 


\section{CONSIDERAÇÕES FINAIS}

O aporte metodológico oferecido pela história oral foi de extrema importância neste trabalho diante das características do objeto de nosso estudo, que foi conhecer algumas comunidades islâmicas no Brasil e tentar desvelar possíveis vertendes jihadistas no território nacional.

Trazer à luz essa discussão considerando o caráter microscópico dessas comunidades, apesar de seu crescimento recente e da pouca integração entre si, foi ao mesmo tempo desafiador e prazeroso. A exigência de uma prática historiográfica pautada em trabalhos de campo, imprescindíveis para a história oral, permitiu um mergulho mais profundo no interior dessas comunidades, que fez com que a pesquisa se tornasse menos solitária e mais solidária.

Como afirma Thompson (1998, p.28) "oral history is a history built around people"313, o que significa que as pessoas passam a ser protagonistas na construção de narrativas históricas. Ao mesmo tempo, ao historiador recai a grande responsabilidade de mediação dos relatos e de seleção daquilo que será produzido. Quase como um diretor de cinema, ele intervém ativamente, organizando os testemunhos sem deixar de ser um parceiro no diálogo que enseja todo esse processo, estreitanto ainda mais a relação entre o pesquisador e seu objeto de estudo.

Foi desta forma que percebi que poderia contribuir com algo novo, inédito e principalmente democrático, ao tentar colocar em relevo algumas dessas vozes ocultas pela história, com a clara consciência de que a seleção de um grupo de pessoas (informantes) jamais será plenamente representativo de uma comunidade inteira.

Há de fato muitas pesquisas relacionadas ao islam no Brasil ligadas aos campos da sociologia, antropologia e estudos etnográficos. Mas no tocante ao tema proposto por esta tese, com um olhar filosófico, histórico e geográfico, as narrativas baseadas na oralidade permitiram a descoberta de novos pontos de partida e a conformação de novas fontes de informação que possam ajudar a pavimentar outros estudos futuros dentro dessa perspectiva. Sabemos, entretanto, que as informações obtidas pelo aporte oral não podem prescindir de outras fontes documentais tradicionais, que em certos momentos puderam confirmá-las e em outros, confrontá-las.

Esta combinação que edificou o método do trabalho, nos revelou híbridos dos quais fala Latour (1994), compostos da mistura de política, sociedade, cultura, religião, normas, objetos e território, que ao invés de serem forçados a se encaixar em um hermetismo conceitual polarizado, buscamos compreender suas vicissitudes enquanto híbridos em sua realidade. A

\footnotetext{
313 “A história oral é a história contruída ao redor de pessoas” (tradução minha).
} 
grande diversidade de termos e expressões relacionadas ao islam e o pretenso fundamentalismo é um exemplo dessa profusão de híbridos que ao invés de serem dissecados enquanto tais, são comumente usados de forma indiscrimidada.

Jihadistas, por mais que tentem ser modernos na concepção latourniana, "purificando" sua visão de mundo sob os preceitos religiosos ainda que muitas vezes de modo seletivo e distorcido, não escapam à produção de híbridos na medida em que o mundo aparente e sua hibridez lhes condicionam. Os contextos em que estão inseridos oferecem diversos caminhos alternativos ao martírio que preconizam. Mas tal escolha é fruto da liberdade que têm enquanto seres humanos. Liberdade que eles mesmos não exergam ou que desejam suprimir.

A decisão de usar a escola filosófica existencialista para fomentar uma discussão sobre o jihadismo moderno, se apoiou nesta relação entre o mundo aparente e a forma como determinados indivíduos ou grupos reagem a ele de forma a condicionar a religião em função de seus interesses muito mais do que a religião os condiciona. A conformação de um "pseudoniilismo" tal como desenvolvido nesta tese pode oferecer um caminho para tentar entender esses fenômenos cada vez mais comuns ao redor do globo, e tão ruminados pelo Ocidente.

E no Brasil? A despeito de sua pequena comunidade islâmica, haveria condições financeiras, ideológicas e "filosóficas" para a fomentar atitudes extremistas? No início desta tese, a convicção da inexistência de movimentos jihadistas no Brasil era dada como certa. Incerto era o caminho que esta pesquisa percorreria na busca pelas respostas a essas perguntas.

Como um rio e seus meandros, a cada curva novas paisagens se desvelaram. O impossível cedeu lugar ao provável à medida que a lei antiterrorismo foi sancionada, e, de forma quase que imediata, as Operações Hashtag e Átila deflagraram um novo cenário nebuloso.

Diante das muitas violências que infelizmente fazem parte do cotidiano nacional, passamos a viver em um estado letárgico que banaliza e naturaliza a violência como inerente à cultura brasileira. Ao longo dos anos tentamos conviver com ela tal como Sísifo em sua terrível tarefa de escalar um monte com uma imensa pedra e ao final cair para logo se levantar e recomençar. Desta forma, as notícias que apontaram a presença de muçulmanos no Brasil com supostos vínculos com organizações terroristas e que estariam, ainda que de forma rudimentar, dispostos a provocar atentados no país, não gerou qualquer tipo de histeria na sociedade ou ações espetaculares por parte das autoridades, especialmente porque essas pessoas e grupos sequer executaram quaisquer atos.

O uso das redes sociais e aplicativos de comunicação surgem como ferramentas indispensáveis, tanto para a viabilização de contatos entre aqueles com ideais extremistas, como para buscar em uma religião algo que possa "justificar" suas ideologias ou "aliviar" a 
consciência por seus atos. Ao mesmo tempo, essa ferramenta não passa de modo incólume aos olhos das autoridades, que com o suporte da lei antiterrorismo, monitoram atitudes suspeitas e, ensaiando um manobra "pré-crime", se antecipam ao que poderia acontecer. Uma novidade normativa que até agora só muçulmanos foram protagonistas.

Como costuma acontecer, a comunidade islâmica é "apresentada" à sociedade brasileira sob a luz menos privilegiada. O todo mais uma vez é tomado pela parte, algo que produz incômodos nessas comunidades, cujo poder de se pronunciar e reagir ainda é bastante limitado.

A despeito disso, todas as informações que obtivemos a partir do contato com as lideranças e demais membros das comunidades islâmicas, revela que a moderação, o convívio pacífico, e o apelo ao discurso inter-religioso e tolerante são a regra. Assim, a chance de uma radicalização oriunda de dentro das mesquitas e demais sociedades islâmicas é extremamente baixa.

Mesmo assim, os recentes episódios envolvendo alguns muçulmanos com tendências mais extremistas, em sua totalidade de brasileiros convertidos, indicam que não se pode baixar a guarda diante dessas ameaças, ainda que pontuais. $\mathrm{O}$ autodidatismo associado às facilidades e perigos trazidos pelas redes virtuais, têm a capacidade de promover uma espécie de islamização do radicalismo que no caso brasileiro atestamos ser "incompleto".

Essa tese se assentou nos seguintes argumentos:

1) os centros islâmicos e suas lideranças, independente de sua formação teológica, não atuam como suporte físico ou religioso na formação de extremistas. Há relatos de que os fiéis que manifestaram um perfil de violência ou ideias mais beligerantes acabaram expulsos de suas comunidades. Seja dentro ou, principalmente, fora das comunidades islâmicas, não se reveleram traços de influência dos mentores modernos do radicalismo como Sayyid Qutb ou Hassan Al-Banna. Mesmo entre os investigados pela Polícia Federal, não se identificam vestígios de uma base teórica e conceitual fundamentada em Qutb ou qualquer outra influência; 2) praticamente todos aqueles que estiveram envolvidos ou foram investigados pelas autoridades brasileiras são convertidos. A "desetnização" da religião, na maioria das comunidades, tende a afastar o indivíduo dos problemas que envolvem o Oriente Médio e seus habitantes. O brasileiro muçulmano, especialmente aqueles que se converteram há pouco tempo, não são grandes conhecedores dos problemas que afligem aquela região e não teriam possíveis laços familiares e emocionais para se irmanarem aos jihadistas que lá atuam. Como atestam alguns trabalhos ${ }^{314}$, muitos querem desvincular sua imagem do árabe e seus estigmas,

${ }^{314}$ Cf. Ferreira (2009b); Montenegro (2002); e Chagas (2006). 
e vivenciar apenas a religião, numa manifestação neofundamentalista como observada por Olivier Roy. A postura de revolta que alguns apresentam, se amparam em leituras e informações enviesas ora trazidas pela mídia, não tão afável ao islam, ora pelas redes sociais, onde a doutrinação e aliciamento encontram ambiente mais fértil. Além disso, tal revolta está muito condicionada à situação do próprio país em que vivem (de crise política, social e econômica); 3) a condição mental de alguns indivíduos também suscita dúvidas a respeito de suas concretas motivações. Depressão e esquizofrenia são doenças que fizeram parte do perfil de alguns dos investigados, do mesmo modo que as tensões entre a modernidade e a pós-modernidade semeiam dilemas sociais e de ordem global.

4) a lei antiterrorismo, ainda que busque modernizar dentro de seu escopo, o arcabouço jurídico do Brasil face a outros países mais desenvolvidos e aos desafios dos novos tempos, não se mostra plenamente convincente em termos de definições empregadas e operacionalidade. Pesa que o aporte financeiro e o know-how necessários para o planejamento, preparação, aquisição de eventuais materiais e sua execução, são escassos e sem evidências concretas de apoio externo para um ato terrorista concreto. Além disso, a conformação das comunidades islâmicas no território bem como seus baixos níveis de integração e cooperação, não favorece a manutenção de uma rede jihadista contígua e com ancoragens seguras.

Diante deste quadro, esse radicalismo incompleto se justifica por um autodidatismo teológico, especialmente "online", pela fragilidade de argumentos motivadores, pela distância física e emocional dos acontecimentos envolvendo árabes e muçulmanos em regiões de conflito além da neutralidade política do Brasil nas relações internacionais, pela instabilidade emocional em alguns casos, pela carência financeira e amadorismo em termos organizacionais, e finalmente, pela articulação difusa no território.

A comunidade árabe-islâmica, presença de longa dada em solo nacional, já está bem aculturada e assimilada e não apresenta nenhum indício de hostilidade ou radicalismo que possam gerar especulações de envolvimento com organizações terroristas. Muitos, entretanto, ainda sustentam um discurso crítico e, por vezes, conspiratório, com relação aos Estados Unidos, à mídia, e ao sionismo, mas longe de se transformar em um engajamento políticoreligioso beligerante.

Interessante ressaltar que em nenhum momento desta pesquisa e daquilo que foi observado a partir das investigações das Operações Hashtag e Átila, notou-se qualquer indício da existência de homens-bomba ou que os supostos ataques poderiam assumir a forma suicida.

Comuns na Ásia, Oriente Médio e Europa Ocidental, esses ataques e a radicalização dentro desses contextos, permite inserí-los naquilo que chamamos de um niilismo 
fundamentalista. Um jihadismo que nega essa existência, o materialismo e os "consolos" mundanos, verdadeiros "homens-absurdos" que em muitas ocasiões sacrificam suas próprias vidas.

No caso brasileiro, a violência ou sua apologia atribuída a alguns indivíduos de fé islâmica se enquadram em um "pseudo-niilismo", dada a falta de um projeto de vida concreto, de retóricas difusas e aleatórias em que o islam é apenas um adjetivo. Essas manifestações acaloradas de suas "revoltas" se prestam mais em revolver aquilo que já se apresenta no mundo do que propriamente em se criar um fato novo, e estão muito menos dispostos em oferecer suas vidas como tributo a um "novo mundo". Por enquanto, ainda é algo que parece ser capaz de se diluir em meio às múltiplas facetas da violência que acomete o país em dados assustadores.

A jahiliyya e a soberania de Allah, conceitos consagrados por Sayyid Qutb parecem estar distantes do ideário extremista brasileiro, que necessitaria de um mergulho profundo nessas e outras referências para completar sua radicalização ou ao menos definir um projeto mais coeso. Ainda assim, encontrariam obstáculos para a criação e consolidação de redes jihadistas no Brasil, que não se constitui como um ambiente favorável para isso haja visto, dentre outros fatores, o perfil moderado das comunidades islâmicas que dificilmente compactuariam com esses projetos.

Se Qutb condenava aqueles que viviam na era da ignorância, sendo coniventes com ela, inclusive muçulmanos, os improváveis jihadistas brasileiros também não teriam sua "bênção", enquanto eles próprios seriam parte dessa ignorância.

\section{Bibliografia}

AFONSO, Julia; COUTINHO, Mateus; e MACEDO, Fausto. FBI alertou Brasil sobre terroristas. Jornal Estado de S. Paulo. São Paulo, 23 jul. 2016. p.A16.

ALLAN, S; AUGUSTO, O; THIAGO, A. O processo de radicalização e a ameaça terrorista no contexto brasileiro a partir da Operação Hashtag. Revista Brasileira de Inteligência. Brasília: Abin, n. 12, dezembro 2017. Disponível em https://bit.ly/31npv31 (acesso em 09 jun. 2019).

ALCORÃO Sagrado. São Paulo: Fambras, 2014.

ALI, Ayaan Hirsi. Herege. Por que o islã precisa de uma reforma imediata? São Paulo: Companhia das Letras. 2015.

ALIGHIERI, Dante. A divina comédia. São Paulo: Ed. Nova Cultural. 2002 [1321]. 
AHMED, Akbar. Journey into Islam: the crisis of globalization. Washington: Brookings Institution Press, 2007.

AMIR, Ahmad N.; SHURIYE, Abdi O; ISMAIL, Ahmad F. Muhammad Abduh's contributions to modernity. Asian Journal of Management Sciences and Education. Vol.1. No.1, April 2012. Disponível em https://bit.ly/2lP2pPt (acesso em 10 mai. 2019).

ARMSTRONG, Karen. Em nome de Deus: o fundamentalismo no judaísmo, no cristianismo e no islamismo. São Paulo: Companhia das Letras, 2009.

ATWAN, Abdel Bari. A história secreta da Al-Qaeda. São Paulo: Larousse, 2008.

ASSAYED, Ayatullah Al-Odhma e FADLULLAH, Mohammad Hussein. O aspecto moral da força do Islam. Volume VIII. São Paulo: Edições Arresala, 2005. Disponível em https://bit.ly/2NnXsJN (acesso em 05 mai.2019)

AYUBI, Nazih. Political Islam: religion and politics in the Arab World. London: Routledge, 1991.

BARROS, Liza Dumovich. O que importa é a intenção: a reconfiguração do "self religioso" na conversão de mulheres. O islã na mequita da luz. São Paulo: Revista Rever, ano 13, n.1, jan/jun. 2013. Pp.85-111.

BAUMAN, Zygmunt. Liquid modernity. Cambridge: Polity Press, 2000.

BEGERES BISNETO, Victor. Refugiados sírios em Campinas/SP e um Aladdin sem a lâmpada mágica. Revista Malala, São Paulo: v.04, n.06. Jul. 2016. Disponível em: https://bit.ly/2KIUFfQ (acesso em 10 mai. 2019).

BERMAN, Marshall. Tudo que é sólido desmancha no ar: a aventura da modernidade. São Paulo: Companhia das Letras, 2007.

BÍBLIA Sagrada. São Paulo: Editora Vida, 1984.

BRASIL. Lei 13.260 de 16 de março de 2016. Regulamenta o disposto no inciso XLIII do art. $5^{\circ}$ da Constituição Federal, disciplinando o terrorismo, tratando de disposições investigatórias e processuais e reformulando o conceito de organização terrorista; e altera as Leis n ${ }^{0} 7.960$, de 21 de dezembro de 1989, e 12.850, de 2 de agosto de 2013. Diário Oficial da União, Brasília, DF, 17 de março de 2016. Seção 1, p.1.

BROWN, Dan. Anjos e demônios. São Paulo: Arqueiro. 2004.

BRZEZINSKI, Zbigniew. The choice: global domination ou global leadership. New York: Basic Books, 2004.

BURUMA, Ian e MARGALIT, Avishai. Ocidentalismo: o Ocidente aos olhos de seus inimigos. Rio de Janeiro: Jorge Zahar Editora, 2006. 
BUZANELLI, Marcio Paulo. Porque é necessário tipificar o crime de terrorismo no Brasil. Revista Brasileira de Inteligência. Brasília: Abin, n. 8, set. 2013. Disponível em https://bit.ly/2wJRz2H (acesso em 09 jun. 2019).

CALVERT, John. Sayyid Qutb and the origins of radical Islamism. New York: Oxford Press, 2013.

CAMUS, Albert. L’ étranger. Paris: Folioplus, 2005 [1942].

Le mythe de Sisyphe. Paris: Galimard, 2013 [1942].

CASTRO, Isabelle Christine Somma de. Orientalismo na imprensa brasileira: a representação dos árabes e muçulmanos nos jornais Folha de S. Paulo e O Estado de S. Paulo antes e depois de 11 de setembro de 2001. Dissertação de Mestrado. Universidade de São Paulo, São Paulo, 2007.

CHAGAS, Gisele Fonseca. Conhecimento, identidade e poder na comunidade muçulmana sunita do Rio de Janeiro. Dissertação de Mestrado. Universidade Federal Fluminense, Niteroi, 2006.

COCKBURN, Patrick. A origem do estado islâmico: o fracasso da guerra ao terror e a ascensão jihadista. São Paulo: Autonomia Literária, 2015.

CUNNINGHAM, Conor. Genealogy of nihilism: philosophies of nothing and the difference of theology. New York: Routledge, 2002.

COUTINHO, Leonardo. A rede de terror finca raízes no Brasil. Revista Veja. São Paulo, 06 abr. 2011. Pp.88 a 96.

DELVAL, Raymond. Les musulmans en Amerique Latine et aux Caraïbes. Paris: Harmattan, 1992.

DEMANT, Peter Robert. Choque dos universalismos. Estudos sobre a interação Ocidente-Islã. Tese de livre docência. Universidade de São Paulo, São Paulo, 2007. . O mundo muçulmano. São Paulo: Contexto, 2008. . How to criticize Islam? "Innocence of muslims" and the war of representations in the mirror of the clash between radical islam and islamophobia. In: Revista Malala, São Paulo: v.3, n.5, 2015. Disponível em: https://bit.ly/2z8VERW (acesso em 10 mai. 2019). . Why be jihadist? Public intellectuals' blind spot for islamist terrorism. In: Revista Malala, São Paulo: v.4, n.06. Jul. 2016. Disponível em https://bit.ly/2WHa3jE (acesso em 15 jun. 2019).

DICKENS, Charles. Hard Times. London: Pinguin English Library. 2012 [1854].

DOSTOIEVSKI, Fiodor. Os demônios. São Paulo: Ed.34, 2013 [1872].

Crime e castigo. São Paulo: Ed. 34, 2001 [1866]. 
Notas do subsolo e o grande inquisidor. Rio de Janeiro: Ediouro, 2001.

EISENSTADT, Shmuel Noah. Fundamentalism, Sectarianism, and Revolution. The Jacobin dimension of modernity. Cambridge: University Press, 1999.

. Fundamentalismo e modernidade: heteroxias, utopismo e jacobinismo na constituição de movimentos fundamentalistas. Oeiras: Celta Editora, 1997.

EL DIN, Khaled Taky. Muçulmanos no Brasil: estudo sobre o manuscrito "a diversão do estrangeiro em tudo que é incrível”. S/d. Disponível em: https://bit.ly/2KH5nAd (acesso em 10 jan. 2016).

ESPOSITO, John L. Unholy war: terror in the name of islam. London: Oxford University Press, 2002.

ESPOSITO, John L. e MOGAHED, Dalia. Who Speaks For Islam?: What a Billion Muslims Really Think. Gallup Press, 2008.

FERREIRA, Francirosy Campos Barbosa. Redes islâmicas em São Paulo: "nascidos muçulmanos" e "revertidos". Revists Litteris: Dossiê Estudos Árabes \& Islâmicos, n.03, novembro de 2009a.

- Escuta sobre igualdade de gênero passa por entender a Xaria e por reflexão antropológia. In: Opera Mundi. Diálogos do Sul, 25.07.2018. Disponível em https://bit.ly/2mKNW7C (acesso em 10 mai. 2019).

. Jihadistas são todos muçulmanos. In: Revista Caros Amigos, 28 fev. 2016. Disponível em: https://bit.ly/2VjqwF8 (acesso em 10 mai. 2019).

- Teatralização do sagrado islâmico: a palavra, a voz e o gesto. Revista Religião e Sociedade, Rio de Janeiro, 29 (1) p.95-125, 2009 b.

. Entre arabescos, luas e tâmaras - performances islâmicas em São Paulo. Tese de doutorado. Universidade de São Paulo, São Paulo, 2007.

FUKUYAMA, Francis. Construção de Estados. Rio de Janeiro: Rocco, 2005.

FRIEDMAN, Thomas. O mundo é plano: uma breve história do século XXI. Rio de Janeiro: Objetiva, 2005.

GIDDENS, Anthony. As consequências da modernidade. São Paulo: Editora Unesp, 1991.

Runaway World: How Globalization Is Reshaping Our Lives. New York: Routledge, 2000.

GONÇALVES, Guilherme Leite e MACHADO, Marta Rodriguez de Assis. Por uma lei antiterrorismo de Estado. Ou não sobrará ninguém. In: Le Monde Diplomatique Brasil. 07 dez. 2015. Disponível em: https://bit.ly/2tOhUM4 (acesso em 10 mai. 2019). 
GRANTHAM, David. Terrorism in Latin America (Part One): The Infiltration of Islamic Extremists. In: National Center for Policy Analysis. No. 206 March, 2017. Disponível também em: https://bit.ly/2KCHsFz (acesso em 10 mai. 2019).

GÜLEN, Fethullah. Toward a global civilization of love and tolerance. New Jersey: The Light, 2004.

GRANGER, Gilles Gaston. A ciência e as ciências. São Paulo: Ed. Unesp, 2004.

HARVEY, David. A condição pós-moderna. São Paulo: Edições Loyola, 2007 [1989].

HICKS, Stephen R.C. Explaining postmodernism. Skepticism and socialism from Rousseau to Foucault. New Berlin/Milwaukee: Scholargy Publishing, 2004.

HUNTINGTON, Samuel. O choque de civilizações e a recomposição da ordem mundial. Rio de Janeiro: Biblioteca do Exército Editora, 1998.

IBN WARRAQ. Why I am not muslim. New York: Prometheus Books, 1995.

JACKSON, Roy. Fifty key figures in Islam. New York: Routledge, 2006.

JALAL, Ayesha. Combatentes de Alá: a jihad no sul da Ásia. São Paulo: Larousse do Brasil, 2009 .

JUNIOR, Mauro Pereira. Ciência Revelada: codificação religiosa e racionalização na comunidade muçulmana sunita do Rio de Janeiro. Niterói: 2011. UFF.

KARNAL, Leandro. Cordeiros de Deus. In: Jornal O Estado de S.Paulo. São Paulo, p.C7, 07 ago. 2016.

KEPEL, Gilles. Jihad. Paris: Gallimard, 2003.

KHATAB, Sayed. The political thought of Sayyid Qutb. The theory of Jahilyyiah. New York: Routledge, 2006.

KIERKEGAARD, Sören. O desespero humano. São Paulo: Ed. Martin Claret, 2004 [1849].

KIM, Douglas. O livro da filosofia. São Paulo: Globo livros, 2011.

KOSIK, Karel. Dialética do concreto. São Paulo: Paz e Terra. 2002 [1963].

KUNDERA, Milan. A insustentável leveza do ser. São Paulo: Companhia das Letras, 2008.

LAQUEUR, Walter. A history of terrorism. New York: Little, Brown, 1997.

LATOUR, Bruno. Jamais fomos modernos. Rio de Janeiro: Editora 34, 1994.

Reflexão sobre o culto moderno dos deuses fe(i)tiches. Bauru, SP: Edusc, 2002.

LEWIS, Bernard. O que deu de errado no Oriente Médio. Rio de Janeiro: Ed. Zahar, 2002. A crise do Islã: guerra santa e terror profano. Rio de Janeiro: Ed. Zahar, 2004a. . From babel to dragomans: interpreting the Middle East. New York: Oxford University Press, 2004b. 
MARQUES, Vera Lúcia Maia. Islã no Brasil: um estudo comparado. 26ª Reunião Brasileira de Antropologia, realizada entre os dias 01 a 04 de junho de 2008. Porto Seguro, Bahia, Brasil.

. Conversão ao islã no Brasil: diferenças étnicas e a construção de novas identidades. Lusotopie. XIV (1), 2007. Disponível em https://bit.ly/2KNLfg8 (acesso em 10 mai. 2019).

MATAIS, Andreza; SERAPIÃO, Fabio et. al. PF prende 10 suspeitos de terrorismo. Jornal Estado de S. Paulo. São Paulo, 22 jul. 2016. P.A16.

MARTON, Fabio. Muhammad Ahmed. In: Revista Aventuras na História, edição 153, Abril de 2016, pp. 29-39.

MAZZETTI, Mark; SCHMITT, Eric. In the age of ISIS, Who's a Terrorist, and who's simply deranged? In: The New York Times, July 2016. Disponível em: https://nyti.ms/2NJyrbj (acesso em 15 mai. 2019).

MONTENEGRO, Silvia M. Discursos e contradiscursos: o olhar da mídia sobre o islã no Brasil. Mana. 8(1), p.63-91, 2002.

Imigrantes árabes na fronteira sul-americana: narrativas de trabalho, religião e futuros imaginados. Revista de Estudos da Religião (Rever). V.13, n.01, jan/jun 2013. Disponível em https://bit.ly/341H8qb (acesso em 19 nov.2019)

Dilemas identitários do Islam no Brasil - a comunidade muçulmana sunita do Rio de Janeiro. Rio de Janeiro: Tese de Doutorado em Sociologia, IFCS/UFRJ, 2000.

MOREIRA, Leandro. O islã no Brasil: os muçulmanos imigrantes e o islamismo em São Paulo. São Paulo: Imprenta, 2004. Dissertação de Mestrado.

MORRISSEY, Charles T. On oral history interviewing. In: PERKS, Robert; THOMSON, Alistair. The oral history reader. London: Routledge, 1998.

NIETZSCHE, Friedrich. O anticristo. São Paulo: Rideel, 2005 [1895].

Ecce Homo. De como a gente se torna o que a gente é. São Paulo: L\&PM, 2013.

NORTON, Augustus Richard. Amal and the Shi'a. Struggle for the Soul of Lebanon. Austin: University of Texas, 1988.

OLIVEIRA, Vitória Peres de. O Islã no Brasil ou o Islã do Brasil? Revista Religião e Sociedade, Rio de Janeiro, v.26, n.1, p.83-114, 2006.

ORTEGA y GASSET, José. O homem e a gente: inter-comunicação humana. Rio de Janeiro: Livro Ibero-Americano. 1973 [1957].

OSMAN, Samira Abdel. Caminhos da imigração árabe em São Paulo: história oral de vida familiar. São Paulo: Imprenta, 1998. 
Mascates árabes em São Paulo: concentração urbana e inserção econômica. Revista Ipsis Libanis. Ano 1, Número 1, 2016. Disponível em https://bit.ly/2tSlowO (acesso em 10 mai.2019).

OTTOLENGHI, Emanuele. The Enemy in our Backyard: Examining Terror Funding Streams from South America. Washington DC: Foundation for Defense of Democracies (FDD). 08 jun. 2016.

OTTOLENGHI, Emanuele e HANNAH, John. In Venezuela's Toxic Brew, Failed Narco-State Meets Iran-Backed Terrorism. Foreign Policy, 23 mar. 2017. Disponível em: https://bit.ly/2mUIZH5 (acesso em 10 jul. 2017).

. To Combat Illegal Immigration, Trump Should Target Latin America's HezbollahNarco Nexus. Foreign Policy, 23 dec. 2016. Disponível em: https://bit.ly/2haoBPn (acesso em 10 jul. 2017).

PACKER, George. Exporting jihad. The Arab Spring has given Tunisians the freedom to act on their unhappiness. The New Yorker, March 28, 2016. Disponível em https://bit.ly/1ReqaHu (acesso em 14 abr. 2016).

PANIAGO, Paulo de Tarso Resende. Uma cartilha para melhor entender o terrorismo internacional. Conceitos e definições. In: REVISTA BRASILEIRA DE INTELIGÊNCIA/AGÊNCIA BRASILEIRA DE INTELIGÊNCIA Vol. 3, n. 4. Brasília: Abin, set/2007. Quadrimestral. ISSN 1809-2632. Disponível em https://bit.ly/2R1Lc3X (acesso em 09.06.2019).

PINTO, Paulo Gabriel Hilu da Rocha. Ritual, etnicidade e identidade religiosa nas comunidades muçulmanas do Brasil. São Paulo: Revista USP, n.67. Set/Nov 2005. Pp.228-250.

. Islã: religião e civilização. Uma abordagem antropológica. Aparecida, São Paulo: Ed. Santuário, 2010.

. Islã em números. Os muçulmanos no Censo Demográfico de 2010. In: TEIXEIRA, Faustino; MENEZES, Renata. Religiões em Movimento. O censo de 2010. Petrópolis, RJ: Vozes, 2013.

PINTO, Paulo Gabriel Hilu da Rocha; MONTENEGRO, Silvia. As Comunidades Muçulmanas na Tríplice Fronteira: Identidades Religiosas, Contextos Locais e Fluxos Transnacionais. Trabalho apresentado na 26a Reunião Brasileira de Antropologia. Porto Seguro/BA, 01 a 04 de junho de 2008.

PORTELLI, Alessandro. What makes oral history different. In: PERKS, Robert; THOMSON, Alistair. The oral history reader. London: Routledge, 1998. 
PORTO, Cesar Henrique de Queiroz. Uma reflexão do Islã na mídia brasileira: televisão e mundo muçulmano, 2001-2002. Tese de Doutorado. Universidade de São Paulo (FFCLH), São Paulo, 2012.

PRATT, Alan. Nihilism. In: The Internet Encyclopedia of Philosophy. Disponível em https://bit.ly/1dlY3YJ (acesso em 25 mar. 2016).

RAFFESTIN, Claude. Por uma geografia do poder. São Paulo: Ed. Ática, 1993.

RASHID, Ahmed. Jihad. São Paulo: Cosac\&Naify, 2003.

REIS, João José. Quilombos e revoltas escravas no Brasil. São Paulo: Revista USP, n.28. Dez/Fev. 1995/96. Pp.14-39. A Revolta dos Malés. São Paulo: Brasiliense. 1987.

REVISTA BRASILEIRA DE INTELIGÊNCIA/AGÊNCIA BRASILEIRA DE INTELIGÊNCIA Vol. 3, n. 4. Brasília: Abin, set/2007. Quadrimestral. ISSN 1809-2632. Disponível em https://bit.ly/2R1Lc3X (acesso em 09.06.2019).

ROSENDAHL, Zeny. Geografia da Religião: uma Proposição Temática. Revista Geousp: Espaço e Tempo. São Paulo, No 11, 2002.

ROTERDÃ. Erasmo de. Elogio da Loucura. São Paulo: Sapienza, 2005.

ROY, Olivier. The failure of political islam. Massachusetts: Harvad University Press, 1994. . L’islam mondialisé. Paris: Éditions du Seuil. 2004.

. La sainte ignorance: le temps de la religion sans culture. Paris: Éditions du Seuil, 2008. . Who are the new jihadis. The Guardian, 13 April 2017. Disponível em https://bit.ly/2p07rfA (acesso em 10 mai. 2019).

RUTHVEN, Malise. Fundamentalism: the search for meaning. New York: Oxford University Press, 2005.

SAID, Edward. L'Orientalisme: 1'Orient créé par l'Occident. Paris: Éditions du Seuil, 2005. Covering Islam. How the media and the experts determine how we see the rest of the world. London: Vintage Books, 1997.

SAMUEL, Raphael. Perils of transcript. In: PERKS, Robert; THOMSON, Alistair. The oral history reader. London: Routledge, 1998.

SANTOS, Alberto Pereira dos. Geopolítica das igrejas e anarquia religiosa no Brasil: por uma geoética do apoio mútuo. São Paulo: 2011. Tese de Doutorado, USP.

SANTOS, Milton. A natureza do espaço. Técnica e tempo. Razão e emoção. São Paulo: Edusp, 2002 [1996]. 
- Técnica, espaço, tempo: globalização e meio técnico-científico informacional. São Paulo: Hucitec, 1994.

SARTRE, Jean-Paul. L'être et le néant. Éssai d'ontologie phénoménologique. Paris: Gallimard, 1943.

SENA, Edmar Avelar. Islã e modernidade: um estudo sobre a comunidade muçulmana em Belo Horizonte. Juiz de Fora: 2007. Dissertação de mestrado, UFJF.

SILENTIO, Johannes de. [KIERKEGAARD, Soren]. Fear and Trembling. New York: Everymen's Library, 1994 [1843].

SILVEIRA, Maria Laura. Um país, uma região: fim de século e modernidades na Argentina. São Paulo: FAPESP; LABOPLAN - USP, 1999. 488p.

SIVAN, Emmanuel. Radical Islam, medieval theology and modern politics. New Haven: Yale University, 1985.

STEPANOVA, Ekaterina. Terrorism in asymmetrical conflict. Ideological and structural aspects. SIPRI Research Report n. 23. New York: Oxford press. 2008. Disponível em https://bit.ly/2wVF4RJ (acesso em 15 jun. 2019).

THOMPSON, Paul. História oral e contemporaneidade. Revista História Oral, v.5, 2002. Pp.09-

28. Disponível em https://bit.ly/2QQP23c (acesso em 27.12.2018).

. Oral History. In: PERKS, Robert; THOMSON, Alistair. The oral history reader. London: Routledge, 1998.

TIBI, Bassam. Islam between culture and politics. New York: Palgrave, 2001.

TEIXEIRA, Faustino; MENEZES, Renata. Religiões em movimento: o censo de 2010. Petrópolis: Vozes, 2013.

TURGUÊNIEV, Ivan. Pais e filhos. São Paulo: Cosac Naify, 2011 [1862].

VATTIMO, Gianni. Niilismo. In: BOBBIO, Norberto; MATTEUCCI, Nicola e PASQUINO,

Gianfranco. Dicionário de política I. Brasília: Ed. Universidade de Brasília, 1998.

VOLL, J. "Fundamentalism in the Sunni Arab World: Egypt and the Sudan," in Marty and Appleby, eds., Fundamentalisms Observed, pp. 345-403. In: EISENSTADT, Shmuel Noah. Fundamentalismo e modernidade: heteroxias, utopismo e jacobinismo na constituição de movimentos fundamentalistas. Oeiras: Celta Editora, 1997.

WALZER, Michael. Just and unjust wars. A moral argument with historical illustrations. New York: Basic Books, 2006.

ZIZEK, Slavoj. Bem-vindo ao deserto do real! São Paulo: Boitempo, 2002. Em defesa das causas perdidas. São Paulo: Boitempo, 2011. 


\section{ANEXOS}




\section{TRANSCRIÇÃO DAS ENTREVISTAS IDENTIFICACÃO}

Nome: Abdul Nasser

\section{Local de Nascimento: Jandaiá do Sul/PR Ano de Nascimento: 59 anos}

Ocupação: Sheikh Sunita da Mesquita Omar Ibn Al Khattab
Escolaridade: (a) Fundamental
(b) Médio
(c) Superior (Líbano)
(d) Pós-graduação

No dia 07/07/2015 entrevistei o sheikh Abdul Nasser da Mesquita Omar Ibn Khattab. Ele me convidou para o salat das $13 \mathrm{~h}$ e após isso tive meu encontro mais formal. Antes disso, cordialmente fui recebido em sua casa, ao lado da mesquita, por sua mulher e seu pequeno neto.

Sheikh Abdul é casado, tem filhos e é nascido no Brasil, na cidade de Jandaiá do Sul/PR. Filho de imigrantes libaneses, ainda quando pequeno voltou para a terra de seus pais no Líbano onde estudou do ensino básico ao superior e onde adquiriu sua formação religiosa. Antes de assumir a mesquita Omar Ibn Al Khattab onde já está há três anos, conduziu a mesquita de Brasília. Ele ainda possui um contrato de 2 anos a cumprir na mesquita de Foz. Ao ser questionado sobre se pretende ficar, assumiu que isso não depende dele e sim de conversas entre a administração da mesquita e órgãos religiosos do Líbano.

A comunidade islâmica de Foz, segundo ele, possui cerca de 10 mil muçulmanos, dos quais mil são assíduos frequentadores da mesquita.

Nossa conversa aconteceu após a oração na mesquita e se realizou dentro de seu átrio principal. Inicialmente, após apresentar meu tema de pesquisa e dar algumas informações sobre minha formação, deixei o sheikh expor seu pensamento sobre o islam. Ele diferenciou as grandes religiões monoteístas (cristianismo, judaísmo e islam) das religiões consideradas filosofias, como o budismo e o hinduísmo. O islam é a religião mais recente, pois foi fundada pelo último dos mensageiros de Deus, Maomé, sendo uma continuidade (usou essa palavra) das religiões monoteístas. Dissertou sobre a influência da cultura e conhecimento árabes para a civilização e citou filósofos, astrônomos e médicos.

Sugeriu ainda que eu usasse uma parte do meu trabalho para dizer que o islam é uma religião de paz e para isso fez uma digressão da palavra islam que deriva da palavra salam, paz.

Quando questionado sobre sua visão acerca de eventos recentes envolvendo muçulmanos, refletiu e abordou vários pontos.

Um primeiro ponto discutido e por ele próprio introduzido foi a questão da mídia. Para ele "a mídia não é aliada dos muçulmanos seja no Brasil como no Mundo. Os trata de forma preconceituosa e apenas destaca notícias ruins sobre a religião”. Mas indaga: quem controla os 
meios de comunicação? Nesse caso aponta os judeus como parte desse grupo e que pretendem, uma parte deles, dominar o mundo.

Em seguida, a conversa passou para a questão do terrorismo, tema que permeou quase toda a entrevista. Sobre isso o sheikh afirma: "me lembro do caso de um alemão (uma autoridade, porém não se lembrou do nome) que se converteu ao islam, e ao responder à mídia sobre o terrorismo, que por sua vez, nas entrelinhas, queria imputar uma culpa aos muçulmanos pelo terror, usou como argumentos: quem mais matou na bósnia? Quem praticou o imperialismo na África? E a I e II Guerras Mundiais, quem travou não foram os muçulmanos. Hoje, diz ele, "há nações muçulmanas invadidas por ocidentais". Ainda relembra da invasão dos Estados Unidos no Iraque e o colonialismo na América do Norte e do Sul que exterminou os índios e fez outros como escravos. Para o sheikh, o "terrorismo é conhecido apenas se um muçulmano o comete...Mas se um não muçulmano, por exemplo, aquele que derrubou um avião nos Alpes franceses, provoca um atentado, então ele tinha problema mental. Mas se fosse um muçulmano...olha que terror! Vai explodir o mundo inteiro!".

Nesse ponto, relembrei os episódios dos ataques ao periódico Charlie Hebdo assim como nos atentados do WTC e o sheikh atestou que há algumas provas que comprovam que não foram muçulmanos que os cometeram. Indaga: "quem controla o espaço aéreo dos Estados Unidos? Eles dominam os aviões do mundo inteiro... não dá pra acreditar que um avião atinja um centro comercial no centro de Nova Iorque como aquele e ninguém ficar sabendo de antemão... isso é um trabalho que foi feito para fins econômicos, para dominar as contas bancárias do mundo... a mídia está manchando muito a visão...(sobre o islam)... a religião muçulmana não tem nada com o terrorismo". Para isso se remete à saudação em árabe “assalamu alaikum", que a paz esteja convosco. Ele ensina que "um dos nomes, atributos de Allah é salam (paz). O lar em que entraremos nele no final de nossa vida é dar al salam (terra da paz). Assim, a religião jamais pratica ou orienta para o terrorismo".

Mas quando apontei o caso dos muçulmanos do Estado Islâmico, tendo em vista sua fala anterior, como eles seriam "enquadrados" pelo sheikh. Sobre isso ele afirma de forma bem curta e incisiva: "eles não apresentam o espírito da religião, não representam a nação islâmica, não representam os muçulmanos. São grupos estranhos, talvez criados por serviços de inteligência...pode ser americana ou outra qualquer".

O sheikh alega que não aceita interpretações que pregam a guerra ou o terror, uma vez que o corão não tem esse objetivo. E quem faz isso, faz uso de versículos isolados fora de contexto para que atendam interesses particulares. 
Sobre a insistência em que menciona o papel perverso dos Estados Unidos com relação se o Ocidente está em guerra contra o islam, diz que "os próprios lideres ocidentais assumem que o islam está em conflito com o Ocidente. O próprio G. W. Bush quando invadiu o Iraque, iniciou uma nova cruzada. Depois disse que foi um erro...a Condoleezza Rice, secretária de estado americano na época, disse que começou uma nova era, um novo nascimento no Oriente Médio".

Sobre praticar o islam no Brasil, elogia a diversidade do país e a tolerância. Para ele, "o Brasil abraçou todas as religiões e etnias. É um país aberto. Os muçulmanos são como qualquer outra 'etnia' que tem suas especificidades". Acrescenta o exemplo de que "na época da construção da Mesquita, o terreno foi doado pela prefeitura de Foz. Isso mostra que temos liberdade total para praticar a religião...o problema é que essas segundas e terceiras gerações vão perdendo certos laços e vão vivendo essa vida mais aberta". Alega também que nunca foi tratado de forma discriminada por brasileiros, mas sabe de alguns constrangimentos passados especialmente por mulheres por conta do uso do véu. Citou também o caso da mesquita de Ponta Grossa invadida por vândalos.

Em termos financeiros e mesmo de relações com outras mesquitas do país, a Omar ibn Al Khattab é independente. A comunicação entre outras mesquitas pelo país é mais frouxa. Citou o WAMY em São Bernardo do Campo como importante centro para o islam e fez uma indicação para que eu pudesse visitá-los.

Com relação à representação política, diz que se sentem representados. Aponta que há uma vereadora na cidade que é muçulmana, a Anice Ghazawi que, por exemplo, conseguiu aprovar uma lei que permite que a carteira de motorista, no caso de mulheres, a foto possa ser com o uso do véu, algo proibido em outras partes do Brasil.

Quando perguntado sobre quem seria seu modelo como muçulmano o sheikh elege Maomé, para ele o maior líder político, espiritual e militar.

No caso do fundamentalismo islâmico, entende que a palavra soa como pejorativa. Mas na verdade é a interpretação literal das escrituras. Se falar em fundamentalismo, há que se falar do fundamentalismo protestante, por exemplo, na Irlanda. Nessa explicação, o sheikh se mostrou um tanto lacônico.

Interessante notar que durante nossa conversa, por diversos momentos tivemos a companhia de grupos de turistas que visitavam a mesquita, tirando fotos, as mulheres usando véus cedidos pela própria mesquita, mas restritos à entrada da mesquita, sendo proibidos de andar sobre o tapete de orações. Quem os orientava era um senhor, colaborador da mesquita que apresentava dados e informações sobre o lugar. 
Ao final de nossa conversa, o sheikh pediu licença para sair, mas não sem antes me convidar para a oração noturna que começava às $20 \mathrm{~h}$, horário em que a mesquita ficaria mais cheia. Aceitei o convite e pontualmente estava lá no horário combinado. Entretanto, por uma falha na comunicação entre a administração da mesquita e a portaria, minha entrada não foi autorizada pelo segurança e não pude acompanhar de perto a oração. Fiquei apenas do lado de fora observando a intensa movimentação de carros que chegavam e de pessoas entrando.

Somente após o término das orações, o presidente da mesquita veio ao meu encontro com muitos pedidos de desculpa pelo descuido e esquecimento em avisar da minha presença. $\mathrm{O}$ motivo é que a mesquita recebe turistas em horários pré-definidos e à noite é proibida a entrada. De fato, enquanto estive junto à portaria, meia dúzia de pessoas apareceram querendo adentrar o espaço com câmeras fotográficas nas mãos, mas foram prontamente proibidos pelo segurança local, que permitiu fotos apenas da parte externa da mesquita. Interessante notar que conversando com o segurança, ele disse que não poderia me deixar entrar, pois os muçulmanos ficam "desconfiados" com pessoas estranhas ainda mais por eu estar usando uma mochila em que carregava minha câmera fotográfica e meu caderno de anotações.

Após o pedido de desculpas do presidente da mesquita e da autorização concedida para minha entrada, fui logo recebido pelo sheikh que estava sentado junto a outros em uma roda próxima à parte central da sala de orações. Tirei meus sapatos e me juntei a eles. Logo expliquei o ocorrido, seguido de uma lamentação pela parte do sheikh, mas que prontamente me apresentou aos demais, quando então pudemos tirar algumas fotos. 


\section{IDENTIFICACÃ̃}

Nome: Mohamed Khalil

Local de Nascimento: Líbano

Idade: 49 anos

Ocupação: Sheikh Xiita da Mesquita Imam Al Khomeini

Escolaridade: (a) Fundamental $\quad$ (b) Médio $\quad$ (c) Superior em Qom (Irã) (d) Pós-graduação

No dia 08/07/2015 entrevistei o sheikh xiita Mohamed Khalil da husseinya de Foz do Iguaçu que já tem 30 anos, é de 1983. Possui família no Líbano e mesmo aqui no Brasil, especialmente em Dourados/MT. Já viveu no Chile por três anos, está há dezessete no Brasil e há oito em Foz do Iguaçu. Informou ainda que há mais ou menos sete mil muçulmanos xiitas na cidade.

Para ele, o Brasil é como uma segunda pátria. Destacou o carinho e o calor do povo brasileiro. Ainda que haja exceções, o respeito em geral é grande. Nesse sentido, afirma que nunca foi discriminado, exceto em casos particulares após eventos graves (de terrorismo) no mundo. Ressalta também a "diversidade, a beleza da diversidade que Deus criou. Gosto de pessoas que fazem críticas construtivas e não destrutivas".

Sobre a questão da mídia, cerne de sua preocupação inicial, diz: "Vou contar uma coisa particular”. Relata que há 35 anos, quando ele tinha 13 anos, havia e ainda há uma revista muito importante no Líbano. Com seu português de sotaque bastante carregado, que mistura um pouco do francês e um pouco do espanhol, afirma: “au Beirute, capital da mídia, do jornalismo árabe. De todo o mundo árabe, o melhor lugar para liberdade de expressão é no Líbano".

Acusando a Reuters e a AP, ele assevera: "agora não me lembro...um deles...eles infelizmente, escreveram como ensinamentos, ou passos para os correspondentes deles no Oriente Médio. Por exemplo: quando eles querem mandar reportagens, fotos, textos, análises...um dos assuntos, e muito feio, que eles utilizaram, olha bem, as imagens que devem ser transmitidas na mídia, no jornal, no mundo árabe, sempre devem colocar algo de préhistórico, de retardado". Então ele cita Gaza e que interpela: "você sabe Gaza, como é?" ao que respondo: não conheço, apenas por leituras e imagens de fora. Imagino uma área superpovoada, muito precária e pobre. E ele continua: "Gaza é como qualquer cidade no Brasil. Tem centro, tem edifícios luxuosos, tem mercados, shoppings...de alta qualidade!...e tem periferia dos lugares pobres...vamos dizer assim...favelas. Um correspondente, infelizmente, desses agências, quando quer transmitir alguma notícia de Gaza, ele transmite a notícia, como um texto ou alguma coisa para ser ouvida, e a foto sempre tem que colocar um burro no meio. Tira fotos da periferia, não tira foto do centro, onde há vida digna. Então para ser justo, tem que transmitir 
as duas imagens. Mas infelizmente, eles insistem em dizer que palestinos ainda são retardados, mas os palestinos não são assim". Como quando um muçulmano, aqui, bate em sua mulher, faz um crime, vamos dizer, infelizmente a mídia, todavia, especialmente a Globo, ao invés de colocar o nome Mohammed, Khalid, um nome árabe...ah, um muçulmano! bateu em mulher! Mas quando quantos brasileiros, Carlos, João etc. batem, matam, infelizmente só colocam João, Carlos, o nome dele particular. A condenação é a ele, mas quando muçulmano, a condenação é à religião. Isso é uma política criminosa".

Nesse ponto, ao me referir sobre a Revista Veja, que publicou uma reportagem em 2011 sobre a existência de células terroristas que existiam na Tríplice Fronteira, o sheikh imediatamente me interrompeu, riu e disse: “a Veja é $o$ campeã do sensacionalismo”. Ele diz que gostou de quando um promotor federal condenou a notícia publicada pela Veja (2011), que dizia que "Bin Laden foi passado à nossa mesquita aqui", isto é, teria passado pela Tríplice Fronteira e frequentado a mesquita. Acrescentou que no ano de 2002, um promotor condenou a CNN depois dos atentados do WTC por ter insinuado a presença de terroristas no Brasil e que a Veja teria vinculado isso em uma de suas reportagens. Questionou: "sabe qual a percentagem de turistas que diminuiu? Bastante. Porque sofreu bastante a cidade, sofreu todos os hotéis. Infelizmente, o Brasil, eu tinha falado isso muitas vezes para jornalistas de alta qualidade aqui, dizendo que infelizmente, o jornalismo brasileiro é um jornalismo lactante, que ainda toma leite dos outros. Os jornalistas brasileiros devem ter uma independência de pesquisa, de notícia, de não traduzir...eles traduzem de outras mídias. Não é bom para um jornalista traduzir um texto inteiro e jogar no seu jornal. É um crime! Como assim? Eu traduzo uma coisa que eu não to observando, vivendo? A notícia tem que ser imparcial, para ganhar credibilidade junto à população".

Ao ser perguntado sobre o Estado Islâmico, o sheikh Mohammed Khalil faz uma interessante narrativa. Para ele, “devemos verificar a história desse grupo...a modificação, de onde nasceu, aonde chegou, quem acompanhou eles. No inicio não chamava Estado Islâmico, se chamava al mujahedin, foi criado pela CIA para combater os russos, soviéticos no Afeganistão e foi apoiada pela Arábia Saudita. Afeganistão, um país islâmico, pobre, sunita e foi naquela década, anos 70, final de 70, início dos 80 , onde o wahhabismo entrou de maneira muito forte no país porque o povo era pobre...e porque o povo pobre, quem dá comida para ele, já fica escravo. Depois levaram para a Arábia Saudita um monte de pessoas para estudar. A palavra Taleban...o que significa taliban? Estudantes. Taliban, palavra árabe e persa, vamos dizer urdu e também de pucth (pachtun). Em pachtun, palavra Talabê, estudante, taliban, plural de talabê, estudantes. Estudantes de quê? Estudantes da teologia. Teologia de quê? De 
wahhabismo. Foi criado centenas de escolas em nome de taleban. Depois quando terminou o papel em nome dos Mujahedin, foi Taleban. Depois foi Al-Qaeda. Depois de Al-Qaeda, no oriente médio, foi criado a Jabha Al Nusra na Síria, Nusra significa frente de apoio da AlQaeda. Depois foi como governante de Al-Qaeda no Iraque, que Abu Bakr, agora Abu Bakr Al Baghdadhi, agora assumiu o Estado Islâmico, que significa D (de Dawla - Estado), Alif (Islâmica), Sheem/Sham (Levante ou Síria), Aín (Iraque) - Daesh. O mapa que eles têm é ligado na ideologia deles, entendeu? Eles não dividem os países como agora existem. Eles não consideram essas fronteiras. Antes era: Daulat fi al islam bilad al rafdain. Iraque é chamado de Bilad Al Rafidain (bilad = país, rafidain= entre dois rios), nome antigo, pré-histórico. Depois quando Mohammed Al Jurani, aquele do Al Nusra, não fez o juramento de lealdade para Abu Bakr al Baghdadi, depois o Baghdadi já invadiu o norte da Síria (Raqqa). Então vamos analisar quem são os apoiadores. Inicialmente, ideologicamente, espiritualmente, historicamente, olha bem....Tudo isso foram os turcos, os otomanos. Para descobrir as origens do Daesh tem que verificar todas as pastas dos Otomanos, o que eles fizeram no mundo árabe, especialmente contra os xiitas. Eu odeio essa palavra xiita e sunita, eu não gosto. Mas uma realidade deve ser transmitida. Mas os otomanos, para o mundo árabe em geral, não só para os xiitas, foram uma desgraça, um problema...pois teve políticas que deixaram o mundo árabe retardado, por milhares de anos. Esses países que agora existem, esses líderes como Bashar al Assad, Mubarak - eu não to defendendo ninguém porque é uma realidade, eu não gosto de dizer - tanto que agora eu considero que Bashar e a Síria é vítimas. Mas quem deixou o sistema dos países, Saddam Hussein ficar 35 anos no poder, Mubarak no poder? (Nesse ponto eu interferi falando do pai de Bashar e o filho há muito tempo no poder e o sheik rebate)...a Arábia Saudita! (Exclama). A Arábia Saudita é uma contradição em seu relacionamento com os Estados Unidos. Como você considera a Arábia Saudita? Onde está a democracia? Nenhuma mulher pode dirigir o carro. Nenhuma mulher pode votar. Nenhuma mulher pode ser funcionária...num banco. Então, vamos dizer, o Estado Islâmico é um estado ligado 100\% às inteligências dos países que têm benefícios....para seus poderes no oriente médio, sejam econômicos, políticos e de segurança também. A Turquia tem um papel, Israel tem outro papel, Arábia Saudita e Qatar são os que detém poderes econômicos e esses dois últimos ideologicamente ligados ao wahhabismo. Esses grupos não representam a comunidade muçulmana”.

Ainda sobre a questão do Estado Islâmico e introduzindo a questão do terrorismo e do extremismo religioso, o sheikh dá o exemplo do sagrado Alcorão e afirma - "não recomendo dar o sagrado alcorão traduzido para qualquer pessoa. Porque o sagrado alcorão é um código! Como um código da justiça, vamos dizer assim, um código de direito. Se você não é especialista 
não vai compreender. Ao contrário, vai compreender ao contrário. Vai compreender coisas erradas do islam".

Ele cita a história do imam Ali, que para ele é um mestre, aluno do profeta. Conta que “certa vez teve um problema muito grande na história islâmica quanto a um grupo de rebeldes...Muawiya e seus simpatizantes. Imam Ali chegou para a nação islâmica inteira e entregou para ele o poder. Mas milhares foram à casa de Ali e se manifestaram democraticamente a favor dele, pedindo para ele assumir o poder, por isso ele ser o $4^{\circ}$ califa. Mas $1 / 4$ do mundo islâmico estava em Damasco e quem estava lá era Muawiya, e pediu para ele desistir. E fez uma guerra contra Ali. Ali mandou seu primo e ministro para conversar antes das batalhas para pelo menos explicar algumas coisas. Ali recomendou ao seu primo Abdullah: 'ô meu primo, não utilizo o sagrado alcorão nos teus argumentos, nas tuas provas contra eles, porque o sagrado alcorão tem a possibilidade de ser interpretado de maneiras diferentes"”.

Ele continua: "no sagrado alcorão é proibido usar um versículo, uma surata sem considerar o resto dos outros capítulos. O corão tem uma mensagem unida, um conteúdo conjunto. Eu não posso dizer somente que no Corão Deus diz 'combata com os idólatras'. Mas não pode ser assim. 'Combata com os idólatras quem combate com vocês', entendeu? Então, se eu vou me portar assim, eu sou criminoso. Mas se o outro lado continuar, você se torna um defensor de minha pátria. Se um inimigo quer invadir sua pátria, como aconteceu no Líbano com o a invasão do exército israelense...daí a resistência...tanto que a resistência sofreu, tanto que as vezes a resistência utilizou, entre parênteses, crimes, matou por exemplo uma criança...Mas está se defendendo! (bateu as mãos uma contra a outra). Aí, não to parabenizando, mas uma justificativa, pela lei internacional e pela lei teológica. Como por exemplo quando um ladrão entrou a tua casa acompanhado de seu filho e você quer se defender e o filho do bandido morre, é uma causa minha. O que eu tenho a ver com isso? Ele entrou, entendeu?"

O sheikh Mohammed, quando questionado a respeito de Sayyid Qutb e Mawdudi como mentores do extremismo religioso, ele diz: na realidade, durante a história islâmica, desde que surgiu o islam, foram criados e fundados, vamos dizer assim, grupos extremistas. Chamados de Al-Khawarij, rebeldes, contra os califas, especialmente contra o quarto califa. Na época do quarto califa, o imã Ali, quando ele conseguiu governar a nação islâmica naquela época, aproximadamente 35 anos após a migração profética, foram criados grupos rebeldes extremistas que utilizavam o ódio e a raiva e massacravam os muçulmanos mesmos. E mataram também os netos do profeta Mohammed. Fizeram o massacre em Karbala contra Hussein. Esses grupos, na classificação islâmica são chamados de rebeldes. Na realidade eles saíram contra a seguridade da nação islâmica, contra os muçulmanos modestos e honestos daquela época. Claro que em 
cada época, em cada ciclo, foram renovadas as mesmas ideias. As mesmas ideologias extremistas deles foram renovadas pelas pessoas. Inclusive por essas pessoas como Sayyid Qutb e, também Abu Ala Mawdudi...e agora como outros em nossa época atual: Al-Qaeda de Bin Laden, Al-Zawahiri, como mulá Omar no Iraque, com Daesh, etc. São pessoas que carregam a bandeira de matança, de desumanidade que eles querem realizar contra qualquer outro que não segue o pensamento deles. Claro que este não representa nada do islamismo. Allah, Deus altíssimo, quando mencionou a missão do profeta Mohammed, falou da misericórdia para toda a humanidade. Eles, essas pessoas, e esses seguidores desse pensamento rigoroso e desumano, eles alteraram a misericórdia do profeta Mohammed para dizer que o profeta Mohammed era um matador - Deus me livre! -. Então esses grupos são recusados, na realidade eles que criaram o ódio entre todas as pessoas especialmente na nossa região do Oriente Médio: no Iraque, Palestina, Síria, Líbano. Em todas essas regiões quando existiam outras pessoas que vivem de outras religiões e outras escolas de pensamento, eles não aceitaram nenhuma pessoa e não podem conviver com qualquer outra pessoa, infelizmente. Esses são Sayyid Qutb e Mawdudi...são fundadores do exstremismo e de ódio, fundadores de ideologias e de pensamento cheio de ódio e de veneno contra a humanidade. Por isso são recusados por nós nesse pensamento, nesta ideologia e neste paradigma da vida deles.

Em outro momento da conversa indago: o fundamentalismo seria uma a leitura literal das escrituras? O sheik concorda, mas vê um erro nisso. Pois quando Deus deixou o texto, deixou também ao ser humano fazer uma conclusão do islam. Para ele "desde a palavra Islam, desde o início, o profeta Maomé, tem um dito e isso está comprovado em todas as escolas xiitas e sunitas, que (cita em árabe): 'o muçulmano é aquele que deixa o mundo inteiro em paz por ele e não se deixa os muçulmanos em paz. Ou seja, quem quer viver comigo, em minha pátria, em minha escola, em minha, na minha casa tem que respeitar. $\mathrm{O} 8^{\circ}$ bisneto do profeta ele tem uma regra muito interessante: veio um homem casado com uma cristã se aconselhar e o bisneto do profeta disse que ele deveria obrigatoriamente construir uma capela para ela. Assim, se eu quero me casar com uma mulher, tenho que aceitar as condições dela”.

Nesse momento a entrevista é interrompida, assim como a gravação, pelo filho do sheik e entram um homem de meia idade e um garoto adolescente. A conversa entre o homem e o sheikh dura aproximadamente 15 minutos e é toda em árabe. Tive a impressão, através de palavras que consegui captar que o homem buscava conselhos do sheikh.

Quando retomamos a conversa, indaguei sobre os pontos fracos do islam e a questão das interpretações ijtihad. Nesse ponto o sheikh concorda que a "fraqueza do islam se deve a multiplicidade de interpretações do corão que além disso deixa a mensagem do islam 
fragmentada e atrasada. A pessoa passa a conhecer apenas pedaços. Mas isso acontece com outras religiões e aponta o cristianismo e judaísmo. Se eu vou obrigar que o texto, vamos dizer assim, deixar o texto como massa para servir aos meus interesses, isso não. É o contrário. Eu quero ser inclinado perante o texto, verdadeiro e claro. Não minha opinião, minhas ideias particulares. Jesus foi enviado aos judeus por Deus, e depois foi crucificado - ele diz, entre parênteses - foi perseguido, por pessoas com mentalidade egoísta. O problema maior do ser humano no mundo, desde que foi criado Adão, é o egoísmo. Desde que Abel foi morto por Caim, a inveja e o egoísmo passaram a ser o maior problema do ser humano. Também cita para isso, o exemplo de José, jogado em um poço por seus irmãos e depois virou escravo.

Acrescenta que "muitas pessoas recusam o satanás, recusam o diabo. Mas antes de recusar eles, temos que recusar nosso egoísmo. Eu não posso impor minha vontade. Há que se discutir. Meu filho quer pizza...ele não gosta de comida libanesa todos os dias, então vamos comer pizza. Temos que considerar a situação dos outros, considerar a capacidade dos outros, considerar nossa capacidade".

Sobre a questão envolvendo democracia e islam ser compatível, o sheikh dá vários exemplos: "se você vem à mesquita e coloca o seu celular sobre a mesa nesse lugar, ou colocou sua chave do carro nesse lugar. Eu não tenho direito de ocupar esse lugar. Tem que respeitar quem chegou antes. Significa quem ocupou esse lugar antes...Essa é a democracia”. Então, democracia para o sheik tem mais a ver com respeito do que com representação. Creio que aqui, o sheikh pode não ter compreendido bem a questão.

Ainda lembra de outro exemplo: "o profeta Mohammed, desde que ele entrou na cidade de Medina...Primeiro assunto: ele construiu uma mesquita, casa de lei, casa social, casa de assistência, casa da família...mesquita não é apenas um local de oração. Segunda coisa que ele fez, foi um pacto com os judeus. Para quê? Para que eles vivam tranquilamente, com todos os rituais deles. Então ele respeitou uma comunidade judaica. Depois os judeus começaram a fazer coisas ruins, eles desrespeitaram esse pacto. Aí os profeta tomou as medidas para contornar os problemas...o segundo califa, Omar, quando chegou a Jerusalém, fez uma carta muito famosa”. Sobre essa carta, o sheikh me recomendou que a procurasse e abaixo está descrita.

Em nome de Deus, o Clemente, o Misericordioso. Esta é a garantia de segurança que o servo de Deus, Umar, o Comandante dos Fiéis, tem dado ao povo de Jerusalém. Ele lhes deu uma garantia de segurança para si próprios, para as suas propriedades, suas igrejas, os seus cruzamentos, os doentes e saudáveis da cidade e para todos os rituais que pertencem à sua religião. Suas igrejas não serão habitadas por muçulmanos e não serão destruídas. Nem eles, nem a terra onde residem, nem as suas cruzes, nem as suas propriedades serão danificadas. 
Eles não serão convertidos à força. Nenhum judeu vai viver com eles em Jerusalém. [Quando Jerusalém se mantinha fechada aos judeus].

O povo de Jerusalém deve pagar os impostos como as pessoas de outras cidades e devem expulsar os bizantinos e os ladrões. Aqueles entre o povo de Jerusalém que queiram partir com os bizantinos, tomem as suas propriedades e abandonem suas igrejas e cruzes, assim estarão seguros até chegarem ao seu local de refúgio. Os moradores podem permanecer na cidade, se quiserem, mas devem pagar impostos como os cidadãos. Aqueles que desejarem podem ir com os bizantinos e aqueles que desejarem poderão voltar para suas famílias. Nada é para ser tomado deles antes que sua ceifa seja realizada.

Se eles pagam seus impostos de acordo com as suas obrigações, então as condições estabelecidas nesta carta estão sob o pacto de Deus, são da responsabilidade de Seu Profeta, dos califas e dos fiéis.

Citado em As Grandes Conquistas Árabes, de Tarikh Tabari (disponível em https://bit.ly/2NibjWb acesso em 10.07.15)

Para o sheikh, Omar não representa ele mesmo, mas o islam.

Como o assunto perpassou a questão judaica, perguntei como ele vê a questão entre os judeus e palestinos? O Islam e o Ocidente estariam em choque?

Ao que ele respondeu: “Os ocidentais têm uma filosofia muito profunda. Já sofreram muitas coisas - idade média, I e II G.M. Mas a filosofia do Ocidente é pautada por interesses político, econômicos e ideológicos. Para criar o Estado de Israel eles aproveitaram mais a ideologia do que a economia. Para os judeus deixarem seus locais de origem, Croácia, Rússia, Brasil, Argentina, Ucrânia, etc. e ocupar um território é necessária uma ideologia muito, muito forte. A terra prometida para nós, terra dos nossos antepassados, Moisés, Davi, Salomão. Uma fábrica de ideias ligadas à ideologia, ligada com uma interpretação do livro sagrado. Israel foi criado na palestina por vários motivos. Um dos motivos saciar os...vamos dizer assim...os judeus que mexem, não só na Palestina, em qualquer parte do mundo...a AIPAC (THE AMERICAN ISRAEL PUBLIC AFFAIRS COMMITTEE), lobby pró-Israel uma associação entre judeus e os Estados Unidos. A AIPAC, é ela quem domina nos Estados Unidos. Todos que servem para o sionismo, eles, os mais poderosos. Antigamente, antes da I GM, na época dos otomanos, um dos pontos positivos do governo otomano é que as comunidades judaica e cristã viviam em Jerusalém de modo pacífico. Por que justo agora há problemas? Os imigrantes palestinos no Chile são ortodoxos, $98 \%$. $10 \%$ da população chilena é de palestinos. Agora, terceira ou quarta geração. A maior comunidade rica no Chile é de palestinos ortodoxos. De 
onde saíram? Dos 98\% de palestinos, 95\% deles saíram de aldeias ligadas a Jerusalém, aldeias vizinhas. Elas foram esvaziadas pelos cristãos ortodoxos, e vieram a países com mais recursos, facilitando esquecer o território de origem. Eles venderam as terras, comércios, etc. por altos valores e depois chegaram os judeus e pegaram esses lugares. Por que na época de Saddam Hussein, e eu sou contra ele, havia mais de 200 mil cristãos? De que tipo? Dos cristãos que ainda preservam a língua do profeta Jesus, que ainda preservam o aramaico, os melhores preservadores do cristianismo. E agora quantos são? 15 mil. E agora, por que o EI foi ao norte do Iraque e ao norte da Síria? Pois são lugares onde há minorias religiosas, como cristãos, curdos, yazidis, xiitas. Eles massacraram os líderes sunitas, para criar um ambiente de pânico, de horror. Portanto, Israel e EI são todos, para mim, dominados pelos interesses do Ocidente. A cabeça são os Estados Unidos. O mundo árabe, como você indicou, os fragmentos islâmicos, todavia, até agora, ele não chegou, infelizmente, a um tempo de aplicar e praticar a democracia verdadeira. Ainda é uma criança. Não significa que não tem possibilidade. Mas quando? Quando o interesse dos estrangeiros, não mexam nos países...deixa quieto. Por exemplo: eu to com um problema com meu irmão. Eu posso resolver meu problema com meu irmão...Um terceiro tem interesse político e econômico. No Ocidente há duas linhas vermelhas: o petróleo e Israel. Essas duas coisas para o Ocidente são mais valiosas...o que eles fizeram no Iraque? Colin Powell, fez uma renovação de mentiras...armas nucleares, foguetes”.

O sheikh em seguida passou a discorrer sobre o conflito nos anos 90 entre Iraque e Kwait ainda sobre o possível conflito entre islam e o Ocidente. Para ele, quem inspirou Saddam a invadir o Kwait teria sido os Estados Unidos. "Durante dois meses, em 1990, antes da guerra entre Iraque e Kwait, mandaram uma embaixadora dos Estados Unidos à Bagdá. Ela mandou Saddam entrar no Kwait. Depois de dois meses, foi retirada essa embaixadora. Saddam Hussein verificou os argumentos que ela demonstrou e foi. Mandaram ele até o meio do poço e depois largaram ele...ele caiu no poço. Ele continuou. E quando continuou, houve uma justificativa internacional para combater com ele. Quanto eclodiu a guerra em 1991, houve uma revolução da população iraquiana, uma revolução verdadeira, do sul ao norte, por toda a parte contra Saddam. Só faltava Bagdá cair. As pessoas estavam com poucas armas. Mas quando Saddam foi autorizado pelos Estados Unidos a usar seus caças, aí a coisa mudou em um mês, por acordos políticos".

O sheikh ainda tenta amenizar as diferenças políticas, religiosas e étnicas entre os povos muçulmanos e mesmo não muçulmanos. Assim, ele conta que visita o Iraque todos os anos, desde Saddam uma vez que seu pai comprou uma casa lá. Disse que na época dele os sunitas e xiitas viviam em relativa harmonia. Para ele, “entre Iraque e Irã, especialmente na fronteira, 
como Paraguai e Brasil há muitas coisas que os unem. Há casamentos familiares, interesses políticos e religiosos. O boicote sofrido pelo Iraque só prejudicou a população. Mais de 1 milhão de crianças mortas...falta de remédios". Afirma ainda que "no Líbano, 37\% aproximadamente dos casamentos são entre xiitas e sunitas. Há aproximadamente 280 mil casais entre sunitas e xiitas. Aqui em Foz há ótimo relacionamento entre sunitas e xiitas, um frequenta mesquita do outro. O problema é o fanatismo, quando o ser humano perde seu equilíbrio".

Sobre a questão do fanatismo o sheikh cita uma história do Imam Ali quando três grupos inimigos, realizaram três batalhas contra ele. Disse que "nossos irmãos sunitas não falam sobre esse assunto. Que a maioria das pessoas que lideravam esses três grupos eram da 'escola sunita'. Mas os sunitas dobram essas páginas vermelhas da história e não querem falar sobre isso. História amarga, mas devemos tomar lições desse assunto. Quando Ali viu os três grupos contra ele, ele resistiu. Mas acabou assassinado em sua mesquita, durante sua oração. Quem eram os rebeldes? As pessoas de mentalidade fechada, chamados de Al Khawarij ${ }^{315}$. Um grupo de mentalidade fechada, de visão curta, de ideologia muito, muito sólida, que não é flexível. Ali, tem esse dito. Diz, com uma dor profunda no coração: essa religião (islâmica) foi utilizada como refém, foi sequestrada para alcançar os interesses particulares e os desejos limitados". Os rebeldes, usavam versículos do corão para atingir seus objetivos.

Nesse sentido o sheikh aconselha que "o Corão serve para quando uma pessoa está calma”, equilibrada. Diz: "Bismillah al-rahman al-rahim. Em nome de Deus, o poderoso, o juiz. Mas por que ele colocou em nome de Deus, o clemente e o misericordioso? Para que esse ser compassivo deve penetrar em todos os versículos. Mas tem versículos rígidos. Tem punições, tem castigos. Tem quem rouba, quem corrompe, que vandaliza. Mas essa punição é um tipo de misericórdia para a sociedade (sharia). A justiça é amarga para quem é amargo. Por exemplo, a propina, a corrupção social. Se alguém não tem uma justiça de ferro, como será a sociedade? Quando existe justiça, aplicada de maneira correta, a corrupção, a criminalidade, a desordem na sociedade diminuiria bastante".

Mudando um pouco de assunto, sobre a política brasileira, falei do fortalecimento de grupos evangélicos e que o dep. (PMDB) e presidente da câmara federal, Eduardo Cunha seria uma expressão dessa força. Perguntei como ele vê o crescimento das igrejas evangélicas, ao mesmo tempo em que há uma "tradição" católica no país e pertencendo a uma religião minoritária. Ele afirma: “os evangélicos foram criados há quantos anos? Como igreja criada

\footnotetext{
315 Significa rebeldes, insurreição, revolta - http://www.sunnah.org/aqida/ghunya/khawarij_fifteen_sects.htm
} 
separada da católica? Há 70 anos (?). As pregações deles, as cartas deles, os discursos deles...o R.R Soares....Por que ele só abre a bíblia e usa ideias somente do velho testamento? Sempre o povo judeu, a terra prometida...o povo escolhido, entendeu? Esqueceu o cristianismo verdadeiro".

Disse que já visitou dezenas de livrarias evangélicas. E notou muitas garrafinhas (5$10 \mathrm{ml}$ ) de azeite do monte de Sião de Israel e dentro dois pedaços de folha de azeitona vendidas por $\mathrm{R} \$ 10,00$. Exclama: “mas $100 \mathrm{ml}$ custa $\mathrm{R} \$ 13,00$ ! Olha o lucro! Uso da religião para se vender coisas e ganhar dinheiro. O Edir Macedo usa muitos símbolos judeus, os hinos e os rituais, por exemplo. Os evangélicos no Ocidente são diferente dos do Líbano. Lá eles não acreditam nos evangélicos ocidentais, pois dizem que foram criados aqui, suas igrejas, para diminuir o poder da igreja católica. Por quê? Porque a igreja católica, desde anos, vamos dizer, 150-200 anos, demonstrou verdadeiramente, como credos e mensagens, do lado verdadeiro da religião: o amor, o respeito.

Para o sheikh, "todas as guerras que acontecem no Oriente Médio, do fundo do coração, sem vaidade, estou lamentando pelos cristãos que vivem no Oriente Médio...os cristãos criaram uma milícia, e quem os está treinando? são os xiitas, em Bagdá. Por que eles vieram aos xiitas e não foram ao Ocidente? Por que o Ocidente é infiel. Eles desconfiaram totalmente. Por que no Líbano, o maior partido (Movimento Patriótico Livre, coalizão cristã e de visão secular), do líder Michel Aoun (ex-comandante do exército), fez uma aliança com o Hezbollah? Ideologicamente são distantes. Mas porque a convivência numa 'mesma casa' você tem que respeitar. Jamais permiti para mim mesmo, para minha família e meus amigos que devemos aniquilar os sunitas...também não é permitido dizer isso para judeus...originalmente eles são da minha pátria. Ele é um concidadão, tenho que respeitar ele. Os cristãos da fronteira síria-líbano estão aliados com o Hezbollah. Por isso o EI tem decapitado e perseguido também cristãos.

Os modelos de muçulmano para o sheikh Mohammed Khalil são o profeta Mohammed e o Imam Said Mussa Sadr. Aqui ele conta um pouco de sua história. Afirma que foi sequestrado pelo Gaddhafi há 37 anos na Líbia. Tinha origem libanesa, mas seu pai emigrou ao Irã e ele nasceu lá. Aos 38 anos de idade, se formou como líder religioso em Qom, ainda na época do xá. Em 1957, foi chamado por outro líder religioso supremo Abdul Hussein Sharif Al Din para substituí-lo. Depois, no ano de 1978, em 31/08 foi sequestrado por Gaddhafi, na verdade desapareceu na Líbia. Teria ido à Líbia a convite do Gaddafi para uma celebração. O sheikh diz: "Nós acusamos o regime da Líbia, claro!" Com um tom de nostalgia, continua: "Moussa Sadr, homem com mentalidade aberta, linda! Uma personalidade extraordinária! Esse um bom líder contemporâneo". O sheik disse que tinha entre 14 e 15 anos quando ele desapareceu. Mas 
a família sentiu muito a falta dele e para pedir justiça para encontrá-lo participou de manifestações. Termina se lembrando de que o Harakat Amal - nome de um partido político xiita no Líbano - foi criado por Mussa Sadr. 


\section{IDENTIFICACÃO}

Nome: Anice Ghazzawi

Local de Nascimento: Telêmaco Borba (PR) Idade: 48 anos

Ocupação: Advogada e vereadora (PT)
Escolaridade: (a) Fundamental
(b) Médio
(c) Superior
(d) Pós-graduação

No dia 08/07/2015, por volta das 9h de uma manhã muito chuvosa, me encontrei com a vereadora Anice Ghazaoui (PT). Nosso encontro se realizou no espaço da Escola Árabe Brasileira, junto à mesquita Omar ibn $\mathrm{Al}$ Khattab.

Inicialmente, após apresentar-me, de imediato introduziu "que o povo muçulmano é um povo pacífico...a religião não pode ser usada com uma base de sensacionalismo". Então o assunto mídia passou a dominar seu discurso, primeiro afirmando que "a mídia tem que vender. Matérias boas não dão repercussão. Vive-se de tragédias. No corão não diz que nós temos que pregar o ódio, a discórdia, o terrorismo. O Corão prega paz, o respeito. Só Deus tem o direito de tirar a vida."

Sobre a questão envolvendo o conflito Israel-Palestina, instiguei a vereadora sobre isso, uma vez que em parte de sua fala inicial citou brevemente a situação. Ela apontou a “desproporção nos ataques entre israelenses e palestinos. Israel com bombas e palestinos muitas vezes com pedras. A repercussão no mundo, quando um israelense é atingido é enorme. Enquanto que milhares e milhares de crianças, mulheres mortas e famílias são destruídas. A preocupação não é com essas pessoas que tiveram suas terras ocupadas (nesse ponto gaguejou, hesitou quanto ao uso do termo - “excluídas”). Não há uma política internacional que queira resolver isso. A alguém interessa esse conflito...falta vontade internacional para resolvê-lo". Mas ao ser questionada sobre quem poderia mediar, responde de forma um tanto vaga: "vários atores poderiam participar, por exemplo, a ONU. Mas ela deve exigir mais dos países".

Passando ao assunto da discriminação, Anice assume que muitos muçulmanos passam por preconceito. "Os muçulmanos têm uma religião maravilhosa que orienta a fazer o bem. Mas muitas vezes a religião é confundida com terrorismo, porque existem determinadas facções terroristas lá fora que por motivo A ou B se respaldam na religião". Então, confrontada com o caso do Estado Islâmico, sua voz se altera e de modo incisivo e acelerado diz: "de islâmico não tem nada". Ninguém os reconhece como muçulmanos...é uma facção que ninguém sabe de onde veio, quem os criou, de que forma apareceu". Anice alega que por diversas vezes fez esse debate na câmara dos vereadores com os seus pares e 
representantes de outras religiões para mostrar que as maiores vítimas desse grupo são os próprios muçulmanos. E disse isso ainda com voz altiva: "A forma como agem, de forma alguma é aceitável pelo verdadeiro islam".

Quanto à aceitação do islam no Brasil relata que "está começando a ter uma falta de respeito muito grande com as religiões. Não precisa ir pra França (isso após eu ter citado o Charlie Hebdo), é só ver São Paulo na parada gay". "Eu não sou católica, mas eu me senti ofendida, eu me senti ofendida com tudo o que eu vi nas imagens pela internet e televisão... Isso já passa a ser uma islamofobia, uma cristofobia, já passa ser uma falta de respeito com todas as religiões. Nós temos que ter uma base familiar e uma base religiosa...mexer com a fé dos outros é muito feio".

Abordando de forma mais precisa a questão dos ataques ao periódio Francês Charlie Hebdo ela resume que "foi um ato de extremismo por parte de quem cometeu o atentado ao Charlie Hebdo, mas ali também houve (e aqui nota-se um reforço na entonação de sua voz) um atentado à religião por parte da própria editora. Então tem que se ter o respeito...Por conta do sensacionalismo, tudo tem limite. Ainda acrescenta que todo tipo de discriminação, seja por raça, credo ou cor é um crime, até mesmo porque por ser advogada ela conhece de perto os casos e a legislação que pune esses casos.

Assim, relata que como advogada (somente como advogada?) é contra todo tipo de racismo. E então cita a rede Globo, afirmando ser sensacionalista. Por exemplo, relembra o caso da jornalista da emissora Maria Júlia Coutinho, que foi discriminada nas redes sociais por ser negra e sofreu injúrias raciais. Criou-se então uma campanha (entonação se altera), inclusive em termos nacionais contra o racismo, mas justamente por ser funcionária da emissora. Afirma que "a Globo tem sido uma das maiores incentivadoras à cristofobia, uma das maiores incentivadoras à islamofobia. Ela é a primeira a propagar o racismo e a discriminação entre religiões, entre raças. E quando ela é atingida, ela pega e toma-se como ofendida. Concordo com as manifestações de apoio à jornalista. Mas foi desproporcional...há pessoas que sofreram muito mais por uma discriminação do que a própria 'Maju', muito mais por conta da própria globo, muito mais! (fala em tom de indignação).

Sobre essa questão, usei o exemplo da novela "O Clone", veiculada pela Globo entre os anos de 2001 e 2002, se isso não foi uma forma positiva de levar à população brasileira um pouco de conhecimento sobre o islam e da cultura árabe, algo que fez sucesso entre a população na época. Anice rebateu dizendo "que muita coisa ali era fictícia...mas é o jornalismo que ajuda a propagar de forma equivocada informações sobre os muçulmanos. Mídias mal editadas e mal relatadas...a Globo não se importa que muitas vezes uma matéria sensacionalista que ela coloca, 
se reflete aqui, na nossa vida, no nosso cotidiano". Nesse ponto se lembra de um relato pessoal em que assim é descrito: "teve uma situação onde minha cunhada, que usa véu, estava no ponto de ônibus, com seus dois filhos, e foi agredida... a Globo não veio aqui relatar. Mas foi por conta de uma matéria que saiu na Globo...foi quando tinha ocorrido o episódio do ataque às torres gêmeas. Colocam todos os muçulmanos no mesmo nicho, e não é assim. Não diferenciam aqueles muçulmanos que fazem o bem, daqueles que propagam a sua fé, dos terroristas. A mídia hoje é a principal e é a responsável pelos atos de discriminação que acontecem”. Acrescenta "que muitas vezes a comunidade de Foz foi atacada pela mídia nacional e internacional por haver células terroristas aqui na fronteira". Nesse ponto citei o exemplo da edição da revista Veja de 06/04/2011 que inclusive sua capa trazia esse tema. Disse "que após anos, a CNN divulgou uma reportagem com três linhas, falando que não havia nada, que nunca teve nenhuma célula terrorista. Mas tudo isso depois de ter exposto uma comunidade inteira", lamenta.

Ainda se lembrou do caso de uma pessoa que invadiu a mesquita Omar ibn Al Khattab insultando as pessoas e querendo agredir fiéis e gritando o nome de sua religião. Comentou que "nem por isso se acusou a religião da pessoa em questão. Condenar toda uma sociedade, toda a comunidade islâmica, por causa de poucas pessoas é inaceitável”, ataca.

Tendo em vista esses grupos minoritários comentados anteriormente, coloquei em pauta se a possível fraqueza do islam se encontra na multiplicidade de interpretações. Mas de forma não coerente com a pergunta, citou o exemplo de que "na penitenciária da cidade, o número de muçulmanos presos é muito pequeno. Além disso, estão presos por crimes brandos. Questões envolvendo tráfico de drogas".

Nessa altura da entrevista, ela elogiou meu trabalho. O achou importante. Disse "que só de demonstrar interesse para fazer esse estudo para uma universidade já uma grande coisa...quando se vai in loco saber a verdade, é melhor ainda. Vocês têm a oportunidade, vocês dão voz a quem não tem a voz. Você acha que a Globo vem aqui pegar e conversar com a população? E quando vem, faz uma matéria distorcida".

Sobre seu trabalho na câmara dos vereadores de Foz do Iguaçu, questiono como representa os muçulmanos, se eles se sentem amparados em termos de algumas leis. Sobre isso, cite o exemplo dado pelo sheikh Abdul Nasser sobre a questão dos documentos poderem ter fotos de mulheres com o véu. Anice relata todo o trâmite realizado para essa conquista. Assim explicou: "existe uma normativa no CONTRAN...O Detran/PR tinha uma interpretação de que poderia usar o véu para tirar carteira de motorista assim como nos documentos do Estado, como o RG. Depois houve uma nova interpretação por parte do Detran do Paraná, proibindo o uso do véu nas carteiras de motorista e outros documentos. E passou a ter constrangimento, pois a 
partir do momento que se decide usar o véu, obrigar a tirá-lo passou a ser visto como uma forma de agressão". Aproveitou para dar o exemplo da aduana, "onde policiais constrangiam as mulheres, colocando o rosto dentro do carro, perto do rosto delas...busquei ajuda e informações em São Paulo, como era a interpretação da lei em São Paulo, pedi orientações dos sheikhs de São Paulo, consultei mulheres que usam o véu em São Paulo, fizemos audiências públicas...criou-se uma comissão para debater esse tema, fui à Curitiba e me reuni com o diretor geral do DETRAN do Paraná, dei um parecer como advogada e levei o parecer do procurador do Estado do Paraná a favor da resolução. Enfim, após vários debates consegui com que mudasse a interpretação da lei”. Ao ser questionada se essa lei só é aplicada em Foz do Iguaçu, ela disse em todo o Paraná e em São Paulo onde esse direito é reconhecido. Afirmou que o deputado estadual pelo partido Solidariedade do Rio de Janeiro Bebeto (ex-jogador de futebol) a procurou, pois pretendia levar essa discussão para seu estado.

Perguntei se há outros projetos de lei que pudesse beneficiar os muçulmanos e comentou que há estudos para um projeto que amplie o horário de almoço de trabalhadores para que possam comparecer em mais peso às orações das sextas-feiras. Se lembrou que conseguiu instituir o dia do povo muçulmano na cidade, que se celebra todo dia 12 de maio. Informou que esse ano é o segundo ano em que se celebra essa data. Acrescenta que nessa celebração houve a presença de muitos outros representantes religiosos. Argumentei que há debates sobre a instituição desse dia a nível federal, e Anice confirmou a informação, mas que ainda está em trâmite na esfera federal, projeto conduzido pelo deputado Protógenes Queiroz (PC do B de São Paulo).

Ao fim, como fiz com os outros entrevistados, perguntei qual seria seu modelo como muçulmano. Anice apontou Indira Gandhi (sem titubear), que traz uma inspiração de paz segundo ela. Mas ela aqui talvez não tenha se dado conta de que ela era hindu e não muçulmana. Não a corrigi. 


\section{IDENTIFICACÃO}

Nome: Khouloud El Birani

Local de Nascimento: Foz do Iguaçu

Idade: 25 anos

Ocupação: Farmacêutica e Secretária Geral da Escola Árabe-Brasileira.
Escolaridade: (a) Fundamental
(b) Médio
(c) Superior
(d) Pós-graduação

No dia 08/07/2015, por volta das 10h da manhã, me encontrei com Khouloud El Birani, uma jovem farmacêutica e secretária da escola árabe-brasileira, que não usa o véu, assim como a vereadora Anice. Primeiramente apresentou a Escola Árabe-Brasileira, que existe desde 1998 (já a escola Árabe-Libanesa, localizada em outro ponto da cidade é de 2001). A escola se situa no mesmo terreno da mesquita Omar ibn Al Khattab.

A escola tem aproximadamente 460 alunos do ensino infantil até o ensino médio. Aproximadamente 5\% deles não são muçulmanos e a maioria tem ascendência árabe distante. A escola é paga, mas há alunos bolsistas. As aulas tem 45 min, 6 aulas por dia. A escola é aberta a toda a comunidade de Foz do Iguaçu.

Quanto ao currículo da escola, além do obrigatório estipulado pelo MEC os alunos aprendem desde as séries iniciais o árabe e o ensino religioso. Há também o ensino de inglês e também de espanhol para alunos de fases finais. O currículo da disciplina árabe se assemelha ao que se faz com a língua portuguesa: gramática, produção e leitura de textos. Quanto aos professores, diz que são "normais" (palavra dela), a maioria não é muçulmana, exceto os de língua árabe e de inglês.

As meninas não são obrigadas a usar o véu, mas podem fazê-lo se o desejarem. Mas o uniforme é regra. Quanto ao material, a escola não possui um próprio, utilizando aqueles da Ática Scipione. No caso da disciplina de ensino religioso, o material é produzido pelo próprio professor abordando temas específicos em cada nível. Mas é comum a todos eles a conscientização social, regras de boa convivência, solidariedade e sobre a vida dos profetas. Não é ensinado apenas com o viés do Islam, mas sua influência é marcante uma vez que se trabalham e se estudam diversos versículos (suras) do Corão, sempre destacando seus aspectos positivos. "Não é um ensino religioso voltado para o islam". Algo muito presente no material. Destaca a importância em viver na diversidade, respeitando as diferenças.

Assume que a convivência em Foz é muito pacífica. Então o que vem de fora, trazido pela mídia em termos de conflitos ou estereótipos os alunos não reagem a isso. Não se nota uma reação das crianças quanto à preconceitos induzidos pela mídia. "Levam na esportiva", não 
refletem o que vem de fora. A escola também tenta filtrar muito do que vem de fora. A criança não se sente diferente.

Quanto às crianças, relata que são hiperativas, que falam mais alto que o normal em razão de uma característica dos árabes. Afirma: "os árabes por natureza falam mais alto".

Em determinado momento fomos interrompidos pelo proprietário da escola, quando fui apresentado a ele. Soube em seguida que ele também é professor de matemática.

Outro dado é que não há pausas para momentos de oração, mesmo durante o ramadã.

Khouloud não nota uma discriminação entre muçulmanos nativos e convertidos, pois confessa que por trabalhar o dia todo não tem muita convivência. Mas diz que a única diferença que nota é quanto à compreensão do idioma pelos convertidos, que é mais difícil e limitada. Mas isso não implica em um tratamento diferenciado.

Relata que o sheikh faz os sermões geralmente em árabe e em português, mas depende muito da situação em que é exigido e ao publico a que se destina. Quando há mais jovens, usa mais o português. As orações sempre em árabe. Mesmo os convertidos já entendem ao menos as orações. Mas em palestras usa outras línguas. Diz que não há um idioma que predomina sobre o outro. Mas o árabe nas reuniões é mais constante.

Charlie Hebdo: “A mídia não está a favor”. Em Foz não tem discriminação. Mas em outros lugares já presenciou discriminação, especialmente nos aeroportos. Disse que a mãe é libanesa, usando passaporte libanês (por causa do passaporte) apesar da mãe não usar o véu. Os fiscais federais olham de modo diferente. Perde-se mais tempo em aeroportos. Antes não se podia tirar documentos com véu para se fazer provas de concursos federais, por exemplo. Khouloud confessa que sabe de casos de pessoas que foram constrangidas por ter que tirar o véu para fazer provas. Contudo, entrou em contradição ao afirmar que em Foz já presenciou muçulmanas sendo chamadas de terroristas. Diz que "em Foz se leva na esportiva. Não leva em conta. Mas no fundo no fundo se sente". Como trabalha em farmácia, e por ser a única árabe muçulmana, já se viu observada de modo diferente. Para uns você é vista como "normal". Para outros não, ficam com o pé atrás especialmente pós EI. Afirma que há comentários de que estariam ocupando espaço de brasileiros, "roubando emprego de brasileiros".

Ao ser interpelada sobre o Estado Islâmico ela responde: “eu canso de dizer: eles não nos representam! Como alguém que decapita um ser humano vai ser muçulmano? E os árabes muçulmanos que estão decapitando? Quem formou esses grupos são países que têm interesses políticos. Esses grupos não são islâmicos, quem financiou são os Estados Unidos, 
Israel. Porque a religião não ensina isso! O PCC representa o Brasil? Então o EI não representa os muçulmanos".

Em seguida comenta sobre a criação do Estado de Israel em 1948. E lembra: "foi com o voto de minerva de um brasileiro na ONU que isso se deu. E até hoje não há um estado Palestino. Como? Se os palestinos estavam lá antes? O Estado de Israel ocupou o território. Se decretou para um, mas não para outro, por quê? Interesses políticos e econômicos”.

No Brasil, os árabes são muito bem-sucedidos, inclusive mais do que muitos brasileiros. Afirma que: "a inteligência dos árabes não se pode comparar (não quero discriminar ninguém). Nós temos facilidades que você não encontra facilmente. Por exemplo, em relação à matemática e às línguas. Isso é uma coisa genética. Um alemão que mora no Brasil não fala o alemão aqui. O Árabe, 90\% está falando o árabe. Mas não é um povo radical nem fanático".

Perguntei sobre a divisão no mundo muçulmano, entre xiitas e sunitas, sobre as influências da Arábia Saudita, Irã e Turquia, importantes atores no Oriente Médio e como isso é tratado com os alunos. Khouloud disse que "não entra em detalhes desnecessários sobre as divisões entre xiitas e sunitas. Nossa linhagem é uma só”. Justifica que as diferenças entre os sunitas sauditas e os turcos se baseiam em questões geográficas. "O entorno da Turquia é Europa. E o entorno da Arábia Saudita? A questão é geográfica, política e econômica, mais do que religiosa. O Líbano tem muitos cristãos. Aqui eu não saio de camiseta regata e shorts por opção familiar e minha, mas no Líbano isso pode ser visto. É uma questão que você tem que associar quem colonizou (França), que entorno está?” Afirma que há que "se entender que a religião é uma coisa, o povo é outra, a cultura é outra e o país (com ênfase) é outra. Na Arábia Saudita, se corta a mão de quem rouba. Aqui no Brasil, quantos inocentes morrem porque não existe a lei? Até que ponto você pode criticar algo que não se conhece? Há estrangeiros que não trocariam a Arábia Saudita".

Novamente a conversa recai sobre a mídia e afirma de modo incisivo: "quem são os proprietários da Globo? São judeus! Por isso há interesses políticos e econômicos”.

Sobre um modelo de muçulmano, ela cita Malala em primeiro lugar, Nelson Mandela e Mahatma Gandhi. Quando eu expus que em geral as pessoas apontariam Maomé como modelo e achei interessante a diversidade de respostas encontradas, Khouloud disse: "É que você perguntou sobre uma pessoa e não um profeta. Eu já entendo diferente: que o profeta é uma coisa, a pessoa é outra coisa". "Mas eu não trocaria...(pausa)..nem tudo tem que girar em torno da minha religião. Tem que ver que o que você acredita é pra você. Por que você 
vai querer saber da minha religião se você não crê?’. Aqui talvez possa haver implicitamente um sentimento de estar sendo constantemente criticada.

Afirma que conhece membros de uma igreja evangélica (na farmácia em que trabalha) a qual não quis dizer o nome, "que se auto intitulam os escolhidos por Deus e que só eles vão pro céu. E eu vou lá discutir isso? O que é meu é meu, o que é deles é deles”. E observa muito egoísmo nessa congregação. Ela conta "que eles vão à igreja deles só de terno e de gravata. E quem não tem?”. Disse que já perguntou aos evangélicos dessa congregação: "Vocês vão à igreja para se exibir, exibir coisas que eu considero materiais? E a resposta é que como eles não podem ir à baladas e festas, então onde eles podem mostrar o que têm é na igreja. Isso é pra você ver que as religiões têm suas particularidades. Mas o foco é sobre nós, pois somos os detentores do petróleo, somos detentores aí...de várias coisas”, conclui com uma certa excitação.

Com relação aos atentados do WTC ela comenta que "até hoje não comprovaram quem derrubou as torres gêmeas. Nos chamam de terroristas de graça! Nós somos chamados de terroristas de graça. Igual a um libanês que é chamado de turco, e não tem nada a ver”. Destaca que muitas ruas em Foz fazem menção aos muçulmanos e árabes, como a rua República do Líbano, Rua Palestina, Rua Meca...restaurantes, escolas, proprietários de grandes empresas, pessoas que colaboram para o desenvolvimento. "Se você fala em Foz, se fala em várias etnias". Lembra ainda que o vice-presidente da república, Michel Temer, tem origem libanesa.

Por fim questiono como é para um muçulmano viver em um país como o Brasil, predominantemente cristão, onde há muita liberdade, inclusive sexual, é exarcerbado. Ao que ela responde de forma sucinta: "é um povo (muçulmano) que mantém a cultura...dentro de casa. Tem vários jovens que não seguem a religião à risca, mas é a grande minoria”. 


\section{IDENTIFICACÃO}

Nome: Jihad Hassan Hammadeh

Local de Nascimento: Síria

Idade: 41 anos

Ocupação: Vice-presidente da WAMY e Vice-Representante da Comunidade Islâmica no Brasil. Consultor da novela "O Clone" exibida entre 2001 e 2002 pela Rede Globo e é presidente do Conselho de Ética da UNI (União Nacional Islâmica).

Desde 2017, o sheikh Jihad é Vice-Presidente da UNI (União Nacional das Entidades Islâmicas) e Presidente da CALCEE (Centro Árabe-Latino de Cultura de Estudos Estratégicos).

\section{Escolaridade: (a) Fundamental $\quad$ (b) Médio $\quad$ (c) Superior $\quad$ (d) Pós-graduação}

Na semana iniciada em 19/07/2015, iniciei meus contatos com a WAMY (World Association for the Islamic Youth), entidade indicada pelo sheikh Adbul Nasser de Foz do Iguaçu. Fui gentilmente atendido pelos funcionários Yuri e Elisângela (não muçulmana) que agendaram uma visita mediante uma carta formal.

Então, no dia 29/07/2015 tive meu encontro com o sheikh Jihad Hammadeh, vicepresidente da WAMY no Brasil. O sheikh é naturalizado brasileiro, mas nascido na síria e criado no Líbano. Veio para o Brasil aos 7 anos de idade. A partir dos 16 anos seus estudos foram feitos na Arábia Saudita. Após 10 anos, voltou e se estabeleceu no Brasil e aqui se formou em história na Uniban.

O sheikh Jihad, vestido de terno, falando um português muito claro e praticamente sem sotaque algum, me recebeu gentilmente em seu escritório e inicialmente tivemos uma conversa informal sobre comidas, já que ele me ofereceu um chá e também tâmaras. Também, por iniciativa do sheikh, tiramos uma foto juntos. Em seguida, me apresentei e procurei saber, incialmente, quais são os objetivos da WAMY e como se dá seu funcionamento.

O sheikh apresentou a WAMY afirmando que ela é "a maior entidade islâmica voltada aos jovens muçulmanos do mundo. Ela é uma ONG, não tem ligação com governo nenhum apesar da sede dela estar na Arábia Saudita. Não é sustentada pelo governo e sim por doações. E ela tem escritórios... por exemplo, nosso escritório aqui no Brasil...trabalhamos com os mesmos objetivos de lá (Arábia Saudita) porém nós temos a nossa manutenção daqui, interna. Então...a instituição é brasileira apesar do nome né, seguir o mesmo nome da WAMY, seguindo os mesmos objetivos porque nós temos essa mesma visão de zelar pelo jovem muçulmano, em particular, e o jovem em geral, sendo muçulmano ou não muçulmano. Por quê? Porque o jovem muçulmano está inserido em uma sociedade que tem todas as religiões. E ele não vive isolado...então a nossa visão é islâmica para a sociedade é a pluralista...não tem como fugir do pluralismo! Não tem como eu ser único! Sendo que eu não sou único, eu tenho que ter 
regras...essa religião ela tem que me orientar a viver em conjunto, em grupo em meio a multirreligiosidade".

Nesse momento, eu o interrompi para perguntar se ele seria contrário à ideia do assimilacionismo, algo que ele rejeita de início. Ele disse: "exatamente, não abandonar suas raízes". Mas logo ele hesita: "contra a questão da assimilação...não...eh...não sei...viver numa sociedade...eh... em harmonia com ela, sem abdicar dos seus princípios, de sua cultura, do seu credo e de sua ideologia. A religião islâmica é muito clara nisso...eh..eu tenho limites. Agora, não é necessário que aqui em tenha que comer kibe. Eu posso comer feijão e arroz. $\mathrm{Na}$ Alemanha eu posso comer salsicha, eu posso comer chucrute, contanto que eu respeite as regras...qual que é? É não ter carne de porco, nada de derivado de porco. O islam é tão pluralista...é que na realidade quando tem essas coisas na mídia e ataques, é porque a mídia que ataca ou a visão daqueles que criticam o islam é uma visão muito estreita, muito simplista. O islam é muito maior do que só isso...ele te dá uma visão de como lidar com situações. Ele não fala só...olha, a carne de porco é proibida! Tá...e depois? O que eu faço então? Me dê um substituto da carne de porco...tá. Você tem um mundo pra explorar, você pode usar o que você quiser. Mas isso, evite. O resto você pode usar. Então por exemplo: eu aqui no Brasil, nós sabemos que toda feijoada tem (ingredientes de porco). Os muçulmanos já adaptaram. Comem feijoada sem as partes de porco...colocam frango. Salsicha de frango".

Comentei sobre os alimentos Hallal e o sheikh citou abatedouros e lugares onde vendem. “Agora, se não vender? Eu continuo com a mesma regra. Eu substituo a carne de boi por frango ou peixe. E eu vou tendo que me adaptar. Ou eu começo a pensar na existência de um açougue hallal. A necessidade é a mãe das invenções, não é? Então a sua necessidade...as mesquitas nascem como? Da necessidade da comunidade. Começa com mussala, às vezes, e se transforma numa mesquita. Às vezes aparece a mesquita de uma vez...mas sempre vai aparecer por uma necessidade".

Em seguida, toco na questão da adaptação, se é mais fácil ou não, em um país sexista e de predomínio da religião cristã, especialmente com relação às gerações mais jovens. Nesse caso, o sheikh aponta que "esse é um dos trabalhos da WAMY. Qual é o objetivo da WAMY? É conscientizar os jovens, muçulmanos e não muçulmanos...valores que são comuns em todas as religiões. Por exemplo: ser honesto, não mentir, não trair, ser uma pessoa de confiança, ser uma pessoa correta, ser uma pessoa incorruptível e assim por diante...são valores éticos e morais que estão presentes em todos os credos e não credos também. Todos são unânimes quanto a isso. Então a WAMY trabalha nesse contexto de conscientizar os jovens da necessidade de resgatar esses valores e mantê-los. Sem se isolar da sociedade. Porque fazemos parte, não viver 
em guetos, nós somos parte da sociedade...então nós temos que fazer a nossa parte de divulgar esses valores, incentivar esses valores, pois fazem parte da sociedade. O mecanismo é a conscientização através do conhecimento, então nós temos várias publicações - em português e várias outras línguas também - falando dos princípios islâmicos, dos valores muçulmanos da convivência, sempre orientando e conscientizando. Fazemos palestras, congressos, encontros, cursos, acampamentos, cursos de extensão, parcerias com universidades, sempre prezando pela questão da conscientização e da educação. Pretendemos que os jovens sejam completos”.

Nesse momento, é feita a introdução, por parte do próprio sheikh, da questão do secularismo e da fé. Sobre o religioso e o secular ele afirma: "para nós não tem essa diferença (entre religioso e secular). O religioso já é secular. Não tem como dentro da concepção islâmica a pessoa ser religiosa sem ser secular. Não tem como. Não tem como a pessoa ser só de fé sem a razão. E não tem como a pessoa ser razoável sem a fé. Porque nós somos constituídos desses dois: a ciência e a fé, juntas, unidas em equilíbrio, em harmonia e assim por diante. Então a WAMY tenta levar esses valores aos jovens principalmente através desses meios". Com relação a esse importante assunto da conversa, ele será retomado em um momento mais adiante.

Ao citar a WAMY, aproveitei para tentar compreender um pouco sobre a hierarquia, se é que ela existe no Brasil, entre as comunidades e instituições islâmicas como CDIAL, WAMY e UNI. O sheikh afirma que estão trabalhando há mais ou menos 5 anos, para se criar uma "instituição mãe” (afirma com voz hesitante). Ele diz: "e já temos isso. Graças a Deus estamos em fase de fortalecimento delas e de conscientização. Então, por exemplo, a WAMY ela é uma das instituições existentes no Brasil. Porém nós temos a UNI - que é a União Nacional das Entidades Islâmicas - essa é uma entidade mãe que congrega teoricamente as entidades islâmicas. É ela que vai reger administrativamente, cuidar, zelar administrativamente das instituições eh...islâmicas. Então ela vai ser um representante político, administrativo da comunidade e que fala em nome das entidades. E tem uma instituição que reúne os sheikhs e divulgadores da religião no Brasil que é o Conselho Supremo dos Teólogos e Assuntos Islâmicos. Esse reúne a parte religiosa, os sheikhs, e as outras, as instituições. Então elas são as representações. Hoje nós queremos fortalecer isso, e por mais que exista...divergência de ideias, isso é natural. Agora, todos são unânimes de que nós precisamos de uma representação".

Argumentei sobre esse ponto, que as comunidades islâmicas parecem células isoladas, independentes sem algo que as una, e o sheikh disse que "isso é fato! Parecemos (isolados entre si) porque...eh...eu, to fazendo uma autocrítica aqui e uma autoanálise, nós...o que aparece nos sites é diferente da realidade. Por que eu digo isso? A comunicação nossa externa ela ainda não está adequada. Pois como estamos trabalhando internamente ainda falhamos nessa questão de 
nos expor, de nos externar, né, para a sociedade. Nós estamos num processo de reorganização interna".

Em seguida, abordei a questão do aumento do número de brasileiros convertidos ao islam. Qual seria a explicação para isso? Inclusive com convertidos que estudam para se tornar sheiks. O sheikh Jihad afirma "que é um movimento natural. Porque na realidade é um reflexo ainda pequeno do que acontece lá fora. É de se esperar, porque quando você se torna a pauta do jornalismo no mundo todo, você espera diversas reações, tanto uma reação contrária como a favor, porque desperta curiosidade. Ao mesmo tempo que desperta em alguns um ódio e discriminação, vai despertar em outros curiosidade".

Nesse momento, eu o interrompi para lembrar a novela "O Clone" da Rede Globo, da qual o sheikh foi consultor, e que foi um momento que despertou a curiosidade dos brasileiros de um "mundo" tão diferente e que culminou com o início de um processo de conversões ao islam, fato confirmado pelo sheikh. Ao mesmo tempo, pós-novela, a mídia tendeu para uma abordagem mais negativa da comunidade islâmica. Contudo, o movimento de conversão ao islam se intensifica. O sheikh confessa que sobre isso é preciso uma análise mais profunda. "Por quê?" Diz ele. "Porque no mesmo canal que no noticiário das 8 falava-se 'muçulmanos terroristas, muçulmanos tal, terrorismo islâmico', uma desconstrução do indivíduo muçulmano, logo depois vinha uma novela que falava sobre o profeta, sobre os muçulmanos, sobre os valores, sobre o 'tio Ali’ dando exemplo tal, então um desconstruía e o outro construía. Nítida uma...(aqui há uma pausa na fala) falta de comunicação interna do meio de comunicação mas também ao mesmo tempo, falta de uma ideia definida sobre o muçulmano. O que é o muçulmano? De repente eu to descendo o sarrafo e depois eu to elogiando! Mostrando ele bonzinho!".

Eu argumentei que hoje não há mais a contrapartida do bonzinho e ainda citei ainda o caso do rapaz que invadiu uma igreja batista nos Estados Unidos e assassinou 12 pessoas, mas não foi chamado de terrorista. Mas quando é um muçulmano, logo é rotulado de terrorista. Sobre isso o sheikh assevera: "porque aqui é o produto que está se vendendo. Antigamente, era o comunismo a bola da vez e agora são os muçulmanos a bola da vez e vende bem. Por quê? Porque hoje os muçulmanos...para justificar as invasões dos países islâmicos e...eh..tomar suas riquezas, eu primeiro preciso mostrar que eles são incapazes, são nocivos, que eles são maus, senão qual a justificativa de um invadir o país deles?” Nesse ponto ele compara o caso do Brasil, caso se queira tomar a Amazônia e a água potável que temos e os recursos naturais, o invasor não vai poder declarar guerra e simplesmente entrar à vontade. Ele acrescenta: "eles têm a opinião publica mundial, então para convencê-la que é legal entrar e ter a legalidade para invadir 
o Brasil e tomar seus recursos, tem que mostrar que o Brasil é incapaz. Então vai se desconstruindo o Brasil como indivíduos e como instituição. E aqui você ganha o apoio mundial para entrar no Brasil e tomar as riquezas, pois seremos incapazes de cuidar e de zelar por esse bem que é da humanidade. É o que acontece com os países islâmicos”, exclama.

Voltando ao secularismo e à fé, indaguei se o discurso daqueles que acusam os muçulmanos de fundamentalistas é justamente devido à separação entre fé e Estado, religião e ciência. Assim, haveriam duas leituras? Ou o fundamentalismo é a leitura literal das escrituras ou a pessoa é fundamentalista porque ele deixou de ser secular e se voltou exclusivamente à sua religião. Nesse caso, o sheikh explica que na primeira visão (leitura literal) "se você não for fundamentalista, automaticamente você é fanático. Significa o quê? Por que o fanático se torna fanático, extremista? Porque ele não segue os fundamentos da religião! (E a voz se altera)...que é a paz, o amor a Deus, seguir a Deus, então ele se torna, porque ele vai seguir a opinião dele, o entendimento dele e não mais o entendimento que Deus quer colocar. Então ele largou o fundamentalismo, o fundamental da religião e ele se tornou um pecador. Então se ele não segue os fundamentos da religião, ele não é religioso! Nem fundamentalismo e nem radical, são palavras ruins. O que é ruim? Extremismo e fanatismo. Isso que nós temos que usar. Agora, na outra visão da separação entre ser religioso e não ser é uma ideia errada da religião. Pelo contrário. Se eu sou fundamentalista, eu tenho que ter essa visão equilibrada entre razão e fé, entre o secular e o religioso, porque eu não vivo só no religioso e eu não vivo só no secular. Eu vivo nos dois. Quando eu tô na mesquita, eu tenho valores islâmicos. Quando eu saio da mesquita eu não tenho mais valores islâmicos? Quais são os valores islâmicos? Ser honesto, ser uma pessoa correta, solidário, ser respeitoso e tal, incorruptível, significa o quê? (pausa)...são valores religiosos. Quando eu sou presidente, quando eu sou ministro, deputado, político, comerciante, empresário, gari, eu deixei esses valores na mesquita? Por que eles só fazem parte da minha fé? Eu me isolei deles? Eu tirei a camisa da honestidade e agora eu sou secular? Ou secular também fala pra ser honesto? Esse indivíduo que é dentro da mesquita, se ele tá se lapidando como pessoa, esse benefício será visto, será distribuído e terá frutos na sociedade secular.

Argumentei que o secularismo é visto com base na separação igreja e Estado, ao que sheikh afirma: "de novo vamos voltar à análise simplista do Ocidente quando ele fala sobre isso. Então quando se diz sobre separar a religião do que é secular, do que é a ciência, aqui é a falta do entendimento da religião de novo. Porque está se julgando o islam a partir de uma ideia que se tem do cristianismo, da igreja. Por que...o que acontece hoje? (pausa)...eu sou acadêmico também (risos)...eu consigo transitar perfeitamente com toda a tranquilidade nesse meio e falar 
disso. O que eu percebo é que o Ocidente ele ainda...ele saiu de um extremo e caiu em outro extremo...ele tá precisando buscar o equilíbrio. Saiu da extremidade de uma fé, totalmente contrária à ciência, para ir para a ciência totalmente contrária à fé. E não estão conseguindo se entender e não vão se entender enquanto não juntar esses dois. O ser humano ele não é feito só de um nem só do outro. Nós somos feitos de fé e de ciência, de teoria e de prática, de oculto e de presente, de algo factível...por exemplo a alma e o corpo. Eu toco no corpo e não toco na alma! Você pode discutir 300 mil anos aqui e a gente não vai chegar numa solução sobre o que é a alma, mas sobre o corpo chega em 2 segundos. Corpo é isso. E a alma? Onde está? A alma é fé. Inteligência? Eu quero tocá-la, eu só acredito vendo...onde está minha inteligência? Coloque na palma da minha mão! Conhecimento? Eu vou ter que acreditar, vou ter que ter fé que existe...nem tudo que eu não vejo, quer dizer que não exista...então imagine: que fala-se de uma religião - eu tiro de você, de qualquer pessoa que esteja ouvindo essa conversa amanhã ah, os muçulmanos terroristas gostam de matar, degolar e tal, e não sei o que lá (exclama)...tudo bem...mas por que falam tanto desses muçulmanos e ao mesmo tempo é a religião que mais cresce no mundo? O que acontece? 'Sabe de uma coisa? Eu vou parar, vou dar uma lida...já to com ódio desses muçulmanos...eu vou ler para buscar mais informações a respeito desse bando de fanáticos'. Aí ele começa a ver essa conversa nossa, e fala: 'calma aí! O que é isso? Como assim? Não é lógico?...no mínimo vai provocar uma...uma reflexão. Você tem o muçulmano como bicho papão e de repente você conhece um muçulmano, ele sorri pra você e você fala: 'mas o bicho não é tão feio assim não"'.

Ao resumir essa parte, aponto que isso é resultado de uma minoria que fala por uma maioria, mas essa minoria que fala não é representativa. Ilustro com o caso do Estado Islâmico com o intuito de saber sua opinião sobre o assunto. Eles seriam representantes dos muçulmanos no mundo? O sheikh interrompe de forma direta e incisiva: "quem deu essa representação para eles? Não podemos ser simplistas e ver com o olhar do senso comum. Nem tudo o que a mídia passa pra mim eu tenho que aceitar. Eu tenho que analisar primeiro. Primeiro: quem deu notoriedade pra essa minoria? Quem deu voz a ela e quem deu essa representatividade? Foram os muçulmanos? (Pausa)...Quem os colocou como representantes? Quem divulgou o nome de Estado Islâmico?" Eu em silêncio, imaginando que ele responderia "mídia", o sheikh conclui: "você ficou sabendo através de quem? Através de mim? Através dos muçulmanos? A mídia é uma mídia islâmica ou ocidental?”.

Quando eu pergunto qual seria o objetivo desse grupo ou de quem "os teria forjado", o sheikh diz que há que se analisar outro ponto. "Quem é o maior beneficiado? É aquele que o criou. Então, se eles são um grupo muçulmano, os muçulmanos deveriam ser os primeiros 
beneficiados! E são?” E aos risos ele finaliza: “são os que mais estão morrendo!” O sheikh acrescenta: "nós estamos sendo difamados por conta deles, por causa dessa minoria. Então, imediatamente, eu...fica claro para mim, eu concluo que não foram os muçulmanos que criaram eles. E se fossem, teriam todo apoio imediatamente...e não estão tendo. Agora eu pergunto (pausa)...primeiro: quem escolheu o Estado Islâmico, esse nome? Porque ele é um nome estratégico. A segunda - porque tudo isso eu tenho que analisar como senso crítico, eu tenho que analisar de forma detalhada - essas armas vêm de onde? a roupa que eles usam, quem as costura? Quem faz as produções hollywoodianas deles? As facas são do mesmo fabricante (que eles degolam as pessoas)...quem me garante que não é um grupo, como era conhecido antigamente, a Legião Estrangeira, de contratar essas pessoas que estão vindo da Europa, dos outros lugares?” Eu sugiro: mercenários, por exemplo. E o sheikh concorda e continua: “onde eles estão embasados para matar tanta gente e matar principalmente muçulmanos (pausa)...da onde vem o dinheiro deles? Nós não podemos absorver o que a mídia diz e ficar por isso mesmo, como sendo uma verdade. Existem muitas verdades por trás disso. Por exemplo: a fonte de riqueza deles, da onde vem? Ok, da venda de petróleo...muito bom...e esse petróleo tá indo para os países através de quem, de qual meio? Petroleiros, oleodutos, galões, virtualmente? Ok...conseguiram levar esse petróleo. Mas como estão recebendo pagamento? Através de qual banco? São questões que eu gostaria de saber. Coisas simples! Bem arcaicas! Vamos pegar essas contas e bloquear!!! (Se exalta). Essas contas estão onde? Quando eles compram armas, eles compram de quem? Quem é o fabricante daquelas armas?"

Eu intervenho e digo que a resposta mais comum é que são armas abandonadas por tropas iraquianas ou armas enviadas aos rebeldes curdos e que eventualmente caem nas mãos do EI. O sheikh afirma que não são armas abandonadas. Diz que são armas recentes. Inclusive as roupas, que são novas e que vestem perfeitamente os homens do Estado Islâmico.

O sheikh insiste em questionar outros aspectos sobre o EI, por exemplo, o biotipo dos soldados do EI. Para ele: "todos os soldados tem a mesma altura...não tem gordo...só tem magro....aí você olha e se pergunta: esses são os árabes? (pausa)...que eu saiba os árabes tem de tudo, careca, baixinhos, gordinhos (risos)".

Com relação ao Charlie Hebdo e também relacionando com a questão da ijtihad, as interpretações múltiplas da religião que podem conduzir ao extremismo, pedi ao sheikh sua opinião sobre isso. Para tanto, ele conduziu a explicação pelo seguinte caminho: "primeiro, tudo de novo, cabe uma análise crítica. Fanático é fanático e tem tanto no cristianismo, como tem no judaísmo, como tem no budismo e como tem no ateísmo. Eles são uma exceção à regra. Eles vão ter um entendimento próprio. A questão aqui é que se forem (muçulmanos) eles não estão 
seguindo, saíram à regra. Pois se fosse uma regra geral, comum (praticar atos violentos), todos os muçulmanos que estão na França deveriam ser obrigados a ter feito isso já em 2006 quando foi a primeira vez que eles (Charlie Hebdo) fizeram isso. Principalmente em um mês que o jornal ia fechar. Mais do que isso. Aqui cabem outras análises (pausa)...as 9 horas da manhã não passava um carro lá na rua? (pausa)...e quem filmou, como é que filmou? (Pausa)...Não passou carro nem nas ruas adjacentes? Numa quarta-feira? A outra questão básica...os que morreram...nós vimos a ação, tem vídeos mostrando matando, teve tiroteio? Ou apareceram mortos? Uma outra pergunta: por que o carro que aparece na filmagem...o retrovisor era de uma cor e o carro que eles disseram que foi abandonado, que foi utilizado no atentado, o retrovisor externo tinha uma outra cor...um era cromado e o outro não...como? (pausa)...outra questão: um dos terroristas esqueceu a carteira de motorista dentro do porta-luvas! Imagine ele saindo e levou a carteira de motorista porque se a polícia parar, ele consegue provar...cheio de armas...mascarado...ele consegue comprovar que é ele! Esqueceu dentro do carro (trecho carregado de ironia). Outra questão: o policial que falaram que era muçulmano...o Ahmed...que é executado por um dos supostos terroristas - ele caiu no chão, tava fazendo a segurança, né ele cai no chão...ele é atingido por um tiro, ele cai, preste atenção, ele é atingido por um tiro de fuzil, ele cai, aí o terrorista vem e à queima roupa o executa, com um fuzil, com uma bala mais ou menos assim (e mostra com as mãos seu tamanho), e não existe um pingo de sangue! (pausa)...na realidade, a entrada de uma bala de fuzil, ela explode, ela na entrada ela explode...não é na saída (do corpo)". Nesse momento, eu reajo afirmando ser estranho, e o sheikh imediatamente me interrompe dizendo de forma imperativa: “é impossível! Estranho é alguma coisa que não é nítida. E aquilo é nítido! É impossível! E outra, ele dá um tiro e não dá tranco, um fuzil, daquele jeito? No mínimo estouraria a cabeça e ricochetearia, porque ele tá atirando pra baixo...muito forte...não se viu nada disso...nenhum pingo de sangue. O que eu espero de um tiro de fuzil é explodir a cabeça dele.

Eu complemento com a questão da sensibilização da sociedade, com a reunião de líderes que aconteceu em Paris pós-atentados. O sheikh diz: "e tudo isso, quem foi o maior beneficiado? Os muçulmanos? Nós temos que entender quem foi o maior beneficiado em toda essa história. Como na história da existência do califado islâmico. Num ciclo de dez anos, começando em 2001 a 2011, a mídia ocidental desconstruiu, vem desconstruindo o indivíduo islâmico...num ciclo de dez anos trabalhou-se na desconstrução do indivíduo muçulmano. Terrorista muçulmano, muçulmano terrorista, extremista muçulmano, nunca tem um nome, sempre o indivíduo muçulmano...o muçulmano virou um adjetivo, sempre ligado ao negativo. Depois do memorável discurso de Obama na Universidade de Al-Azhar no Egito, fecha-se um 
ciclo e abre-se outro, que é a desconstrução da entidade islâmica, e surge o Estado Islâmico...não mais o indivíduo islâmico, mas um grupo islâmico. Então, desconstruía-se o indivíduo, agora desconstrói-se o coletivo, em nome de um Estado Islâmico. Mostrando que o coletivo islâmico é prejudicial à saúde (risos)...é incompatível com a sociedade e os valores ocidentais. Aí vem a questão novamente da visão simplista...porque nós estamos vendo o agora. Um grupo pequeno fazendo um alarde danado através dos holofotes, do palanque ocidental, pela mídia ocidental e a mídia brasileira sendo coadjuvante nisso, né? Sendo papagaio de pirata, sendo reprodutora do que tá acontecendo lá fora e esquecemos de 14 séculos de governo islâmico nos quais os cientistas, eles tinham o amparo dos muçulmanos, dos governos islâmicos. $\mathrm{O}$ auge das descobertas cientificas...astronomia, antropologia, filosofia...vai....vai...vai..veja a península ibérica...veja a palestina..Então eu deleto isso e prevalece a visão simplista de hoje. É você não estudar a história, não conhecer a história e julgar só o momento, sem analisá-lo...é o que tão querendo passar...repetindo uma mentira até que se torne uma verdade".

Sobre isso, por conta dessa imagem negativa que se tem dos muçulmanos hoje, perguntei ao sheikh sobre a questão da discriminação aqui no Brasil com relação aos muçulmanos. O sheikh informou que de fato acontece, "porque você está toda hora na pauta do jornalismo e sempre de uma forma negativa e pejorativa. É nítido que você vai criar dentro da sociedade uma aversão, uma discriminação, um preconceito". Argumentei que após os ataques do Charlie Hebdo, noticiaram-se ataques contra muçulmanos no Brasil, como o caso de uma menina que sofreu agressões verbais, cusparadas e até pedras lançadas contra ela. O sheikh disse que essa menina é uma aluna dele.

Interpelei o sheikh querendo saber qual seria a explicação, fora as notícias negativas que afligem a comunidade, para a discriminação em se tratando de um país que foi forjado pelas mãos de imigrantes. Ele assim responde: "a discriminação que tem aqui Victor, o preconceito que existe no Brasil é diferente da discriminação que existe na Europa. Na Europa, o motivo dele é histórico, então ele é consciente. Por que a Turquia hoje não consegue, não permitem que ela entre na União Europeia, por que criam dificuldade? A Bósnia, da Europa, por que não entra comunidade europeia, não aceitam? Então existe algo premeditado e consciente...diferente da América Latina e do Brasil. Existe aqui uma discriminação e um preconceito, mas embasado em ignorância e falta de conhecimento. Inconsciente (pausa)...esse é fácil...é só dar conhecimento e a pessoa pode mudar de opinião. O problema é o consciente, quando a pessoa não quer conhecer o outro lado, porque ela já tem uma posição. Aqui há falta de ferramentas para julgar e ela já julgou mesmo assim. 
Dentro desse escopo, questionei se havia alguma solução para melhorar isso. Contei do meu encontro com a vereadora Anice Gazzauwi em Foz do Iguaçu, da conquista pelo direito de tirar fotos para documentos usando o véu (caso das mulheres) e também da proposta na câmara federal para instituir o ensino da cultura árabe-islâmica no currículo escolar. O sheikh afirma que "na realidade esse não é o nosso foco. Tanto que não tem tanta visibilidade. Eu acho que as entidades islâmicas - essa é uma responsabilidade muito grande - delas, as mesquitas, as entidades e associações de muçulmanos como a WAMY é o papel de conscientizar. Por isso que nós estamos focando na questão da conscientização. O que acontece: no final dessa nossa conversa agora, você fala eu tenho uma outra ideia do islam viu...se você parar para analisar, mesmo que você não concorde com a religião islâmica e tal, mas é um outro ponto de vista, um contraponto, e tem muita coisa lógica nisso. É o que aproxima as pessoas de serem muçulmanas (pausa). Eu quis mostrar pra você, o que traz uma pessoa para ser muçulmana. Por que está crescendo o número de muçulmanos? Porque ele tem resposta! Nessa mesma forma lógica, ele tem respostas objetivas: por que não podemos comer carne de porco, não podemos beber álcool, não pode usar entorpecentes, por que não pode ter adultério? Porque a religião segue essa razão, essa lógica e no final será para benefício da sociedade, para benefício da manutenção das entidades e das instituições sociais, como a família e outras."

Em seguida eu comento com sheikh, voltando na questão da interpretação, se ele concorda que só há um islam porque só há uma interpretação possível dos escritos sagrados. O que atrapalharia é que muitos que não têm conhecimento, interpretam à sua maneira, sem estudos corânicos. Quem poderia ajudar seriam apenas os sheikhs, os eruditos. O sheikh concorda e acrescenta: "como é que o erudito se torna erudito? Com conhecimento. Só que aqui, o conhecimento não é restrito aos eruditos, está aberto para todos, por isso que você tem as universidades. Cada muçulmano tem que ter um sheikh como consultor. Hoje, o Ocidente corre, corre, corre e depois volta pro islam. Pode analisar. Há 14 séculos o islam fala de bebida alcoólica que não pode. Hoje tem lei que proíbe venda de bebidas alcoólicas nas estradas porque faz mal e se beber não dirija. Eles fazem propaganda pro pessoal beber e daqui a pouco falam 'se beber não dirija.' Como? Se ele tá no bar ele vai embora como? Ah, vai de taxi! Muito bom, todos estão indo de taxi para casa. Muito Bom! (em tom irônico). Tem uma regra, um princípio da religião islâmica chamado princípio da jurisprudência, antes da jurisprudência tem os princípios, são regras gerais que diz (e cita em árabe): se você quiser ser obedecido ordene aquilo que é possível de ser cumprido (pausa). Beba, beba, beba...mas se beber não dirija! Como pode ser? Se o pessoal está fazendo o ‘esquentadinho’ dentro de casa já antes de sair...(pausa longa)...é ilógico. Então vamos lá: hoje nós temos um problema social muito grande...doenças 
venéreas, filhos abandonados, jogados no rio...frutos de adultério, gravidez indesejada. Ok, então vamos conscientizar...vamos distribuir camisinhas...resolveu o problema? (risos). Não resolveu o problema. Onde é que vai resolver o problema? Na regulamentação, na organização das relações sexuais. Vai ter que voltar no islam, na verdade nas regras religiosas, tanto judaica e cristã, porque é isso que elas ordenam. Hoje o maior...prejuízo do capitalismo é o materialismo. Transformou as pessoas em mercadorias, em produtos. Se é materialista, não tem mais humano, se não tem mais humano não tem sentimentos. Então, se não tem sentimentos, trair não tem problema. Se eu traio ou sou traído acabou a confiança. Faltou confiança, como é que você vai dar bom dia para seu vizinho?...Seus filhos gostam de você por causa do seu dinheiro (pausa)...está havendo uma desestruturação social. Qual é solução? Vai ter que correr para o islam. A religião tem a resposta disso. Eu falo islam porque sou muçulmano. Por isso não tem como dividir em laico e religioso, secular e fé...não tem como...são os dois juntos. Valores! Você vai controlar as pessoas por câmeras? Não tem como? Valores. Isso é que está atraindo as pessoas para o islam!".

O sheikh após uma pausa ele muda de assunto e afirma: "a Arábia Saudita, por exemplo. Por que falar 'islam da Arábia Saudita' ele é importante? Por que não podemos falar do islam da Indonésia, ou de Singapura, ou da Malásia? (pausa)...São países modernos, tem produção, por que não falar desse islam? Por que especificamente ali? Porque vem a bola da vez. Começa a desconstruir e a difamar para poder justificar um ataque ali...porque tem riquezas ali e querem ser tomadas. Iraque, Síria...Afeganistão...antes de entrar no Afeganistão, eu me lembro da Ana Paula Padrão (jornalista, na época do SBT), e fez uma divulgação negativa: 'as mulheres não tem isso, não tem aquilo, ópio, papoula e não sei o que mais'. Ela chegou lá...fez uma matéria horrível, horrível, horrível, horrível (falou em tom de desprezo). (pausa)...totalmente negativa. Que as mulheres não podiam estudar, não podiam ir ao cabeleireiro, como se os homens tivessem escola! (risos)...o país não tinha escolas! Por quê? Vinha um ataque ao Afeganistão. E também mostrou a plantação de papoula...sendo que nós sabemos que metade da plantação da produção de papoula do Afeganistão é comprada pelos Estados Unidos, para fins medicinais...fazer morfina e tal. Quem mostra está de que lado? Quem julga? fulano é terrorista, fulano é herói. Está do lado de quê? Qual é a sua ideologia? Eu preciso entender isso. Essas são as entrelinhas que não são faladas. A mesma notícia pode ser dada de várias formas". Após longa pausa ele diz: “o leão tá te atacando e eu mato o leão. Uma pessoa justa olha e que fala que uma pessoa defendeu a outra do leão. O meu amigo fala 'sheikh herói, defendeu um cristão da morte'. O meu inimigo falou o quê? 'Sheikh terrorista prejudica a fauna e a flora, agride o meio ambiente matando um felino inocente que só estava querendo se alimentar! (risos)". 
Seguindo a conversa, questionei sobre as fatwas. Quem teria a autoridade para emiti-las, uma vez que os jihadistas constantemente as emitem e justificam ataques ao redor do mundo. Para o sheikh, "são sentenças...que só os eruditos renomados e reconhecidos, com bagagem de conhecimento para dá-las. Fatwa de jihad só um grupo de eruditos podem fazer isso. Não é qualquer sheikh ou qualquer pessoa que pode fazer isso. Então tem um nível de fatwas que só um grupo de eruditos renomados é que podem emiti-las. Aí aparece um cara do Estado Islâmico que nunca escreveu...Bin Laden, que nunca li um texto dele sequer, não sei onde ele nasceu, onde ele se formou - lógico, sei onde ele foi treinado, com a CIA - mas não tem reputação dentro dos eruditos islâmicos, não é reconhecido como sheikh...a fatwa dele nem pode ser lida, nem pode ser considerada...e outra coisa...os talebans...chegou um momento em que fotografaram eles destruindo as estátuas de Buda... 'ó os muçulmanos como são ruins!' Calma. Quem está destruindo? Ah, os talebans! São muçulmanos! Ok. Dentro de um país islâmico, governado pelos muçulmanos há quanto tempo? 14 séculos? Como é que sobreviveram todo esse tempo se não fosse a tolerância dos muçulmanos? Ah, veio um grupo agora e fez isso? Ah, tudo bem! (em tom irônico). Ah, então não são os muçulmanos? Assim como o Estado Islâmico...que também fizeram isso (quebraram antiguidades). Como é que sobreviveram até hoje? Se são contra o islam, se são intolerantes, deviam já no primeiro século, no primeiro dia de governo deviam estourar isso ai. Agora, e as outras obras de arte? Destruídas ou foram vendidas? Ou foram roubadas? (fala em tom sarcástico). Como é que apareceu agora na Inglaterra o Corão dos mais antigos? Ah, o profeta estava lá, esteve na Inglaterra...é isso? (Em tom irônico). Logo depois que eles destruíram essas obras, como assim? Será que esse Corão não estava lá, onde está esse Estado Islâmico, por exemplo, hoje? Será que não pode ser uma das relíquias que foram usurpadas de lá? São questões que eu coloco...tão falando que eu sou terrorista...quem foi que jogou a bomba atômica mesmo (no Japão)? Tão me colocando como terrorista...Como é que um avião (caso do WTC) consegue derreter toda aquela estrutura e não queimou o passaporte de um dos suspeitos?"

Ao final da entrevista, perguntei ao sheikh jihad qual seria um modelo de muçulmano para ele. A resposta foi o profeta Mohammed, de imediato...mas ele parou, pensou e acrescentou os quatro califas e especialmente enfatizou Saladino. Para ele, Saladino era um líder, um estrategista, um comandante muçulmano, um devoto, uma pessoa justa e que tratou seu inimigo com justiça e compaixão. "O Ocidente tem que tirar o chapéu pra ele. O tratamento que ele deu, ficou na história".

Quando eu citei que em outras entrevistas os mais jovens geralmente citam Malala, o sheikh rebateu: "o que Malala fez? Sobreviveu. Só. Só ela que sobreviveu? Quem a 
transformou? A mesma mídia...por causa da mídia. Leram os livros? De onde que eles sabem disso?"

Ao término de nossa agradável conversa, o sheikh quis saber mais de mim e das minhas atividades e se comprometeu a ficar à minha disposição para eventuais dúvidas, informações e materiais que possam ser úteis à minha pesquisa. Por fim, me presenteou com algumas publicações da WAMY e um Corão português-árabe. 


\section{IDENTIFICACÃO}

Nome: Fatih Ozorpak, Mustafa Goktepe e Kamil Ergin.

Local de Nascimento: Istambul, Izmir, Istambul respectivamente.

Ocupação: Diretor do Centro Islâmico e de Diálogo Inter-religioso e Intercultural; Presidente do CCBT e Jornalista da Agência de Notícias CIHAN, respectivamente.
Escolaridade: (a) Fundamental
(b) Médio
(c) Superior
(d) Pós-graduação

No dia 13/06/2016 me reuni na sede do Centro Cultural Brasil-Turquia (CCBT) em São Paulo com Fatih Ozorpak, diretor do Centro Islâmico e de Diálogo Inter-religioso e Intercultural (CIDI), Mustafa Göktepe, presidente do CCBT, e com Kamil Ergin, jornalista da agência de notícias turca CIHAN.

O encontro se deu primeiramente com Fatih, que nos primeiros 30 minutos de conversa fez questão de falar um pouco da história da Turquia pós $1^{\mathrm{a}}$ Guerra Mundial, com a instauração da república na Turquia e todas as transformações políticas e culturais desde então, revelando a transição do idioma árabe pelo turco e dos diversos golpes militares que se sucederam desde os anos 60 até o período atual sob o comando do presidente Recep Tayyip Erdogan. Também dedica boa parte de sua fala para narrar a influência de Fethullah Gulen especialmente na educação desde seu surgimento nos anos 70 em meio a conflito entre universitários. Disse que Gulen identificava três grandes problemas no mundo islâmico: falta de ensino (educação); desunião (conflitos, separação dos povos); e pobreza. E para acabar com esses problemas, a educação era a arma. Para ele, "Gulen lutou contra a ignorância. Então várias escolas foram abertas, alojamentos para alunos ficarem, depois abriram as primeiras escolas com empresários. Nos anos 90 acabou a Guerra Fria e a separação dos países das URSS. E a maioria era habitada por descendentes turcos. Gulen começou a incentivar empresários...vocês vão lá, tentam fazer algumas coisas, investir nesses países, assim vocês podem ter escolas lá. Nos anos 90 escolas foram abertas no extremo oriente e nos anos 2000 na África. Hoje tem 160 países nesse movimento [Hizmet], que se destaca mais como ensino, escolas, ehh...universidades, hospitais...a parte educacional do movimento...Então o primeiro ponto importante no movimento é a educação. O segundo ponto importante é os empresários. Existe uma confederação empresarial da Turquia com 100 mil empresários associados e esses associados voluntariamente ajudam, fazem doações para abertura dos colégios...enfim. Só que Hizmet funciona localidade. Por exemplo: nós temos aqui um grupo de empresários turcos que estão mantendo as atividades educacionais daqui como o Centro Cultural. As atividades são mais locais. Há aqui uma escola internacional e secular...o ensino foi sempre secular e não religioso, 
enfatizando valores universais. Há somente uma escola no Brasil [de creche ao ensino médio]. A outra parte do movimento é a mídia. Tem os canais de televisão que hoje o governo fechou...infelizmente a Turquia não aguenta mais a oposição ou as ideias contrárias”. Interrompi a fala dele dizendo que o movimento Hizmet por meio da figura de Gulen apoiou o AKP, ao que Fatih respondeu: "quando eles começaram com novas aberturas democráticas o movimento apoiou, mas logo depois começou a virar corrupção e o suporte para algumas ações terroristas por parte do próprio governo...várias falhas, infelizmente...o governo foi avisado e a mídia começou a mostrar as coisas, então eles [o governo] não aguentaram e fecharam os canais de televisão, tiraram o satélite e com força policial eles invadiram o prédio do jornal que era 1 milhão de tiragens ao dia e hoje faliu...o governo tomou...só que o jornal tem em outros países...em outras línguas".

Fatih nesse momento pede um intervalo de 5 minutos, pois diz que precisa cuidar de outros assuntos uma vez que no dia da entrevista o CCBT iria receber convidados (padres e irmãs Paulinas) para romper o jejum do Ramadan como parte do programa do Diálogo InterReligioso e Intercultural. Nesse ínterim fui apresentado ao jornalista Kamil Ergin que trabalha na agência de notícias turca CIHAN. Depois de feitas as apresentações, ele me explicou um pouco sobre a questão da mídia na Turquia com comparações com a mídia daqui. Kamil explicou que "para entender a estrutura da mídia na Turquia e fazer uma comparação com a mídia no Brasil, a mídia na Turquia pertence a grupos econômicos...não existe grupo independente especialmente na área de comunicação. Geralmente são grandes empreiteiros, empresários da área de minas, são donos também da mídia...que não traz lucros pra eles, são somente um guarda-chuva para outras áreas. E classificando a característica de mídia, hoje temos três tipos de mídia: mídia pró-governo, outro podemos citar mídia central e mídia do Hizmet. Hoje grande parte da mídia pertence ao grupo pró-governo. Grande parte da mídia no passado era apoiada pelos militares...e durante esses últimos 13 anos de mandato do AKP de Erdogan [hoje no quarto mandato], um por um, esses grupos foram sendo convertidos. Como foi esse processo? Eh...Erdogan usou meios estatais para fiscalizar, castigar, ameaçar os empresários...eh...eles fizeram acordos. Por exemplo: o maior grupo de mídia, como se fosse a Globo daqui, ele teve que vender uma parte de sua mídia em troca de liberar 7 milhões de liras turcas como multas. $\mathrm{O}$ governo fez um acordo. Ele multou em 7 milhões e depois fez um acordo. Você pode vender a mídia e pagar a multa...depois ele foi revendido a um empresário prógoverno, aliado com Erdogan. Mais de três grupos foram convertidos dessa maneira...e durante esses 13 anos outros grupos foram criados. E hoje a gente chama esses grupos de 'mídia da piscina'...por que piscina? Porque ninguém sabe quem é dono desses grupos. Os empresários 
que apoiaram Erdogan fizeram doações para 'uma piscina de dinheiro'. Mas esses dinheiros não são só doações...são comissões. Uma troca...leilões do governo. Por exemplo: eles construíram muitas rodovias, construíram prédios públicos, estão construindo o maior aeroporto do mundo...com 23 bilhões de euros. Bom...mídia do Erdogan ficou crescendo cada ano mais forte....e.... mídia que era crítica logo, logo ficou em silêncio. E quando começou, por exemplo, as manifestações populares em Gezi Park, você deve lembrar, uma parte da mídia começou a criticar o governo do Erdogan...e depois começou uma perseguição desses grupos, os donos foram ameaçados...e por isso começou outra censura. Por exemplo...hoje acontece uma explosão, uma falha do governo e essa mídia não fala nada..não elogia mas também não fala mal...colocam um documentário de pinguim na hora de uma explosão...muitos jornalistas foram ameaçados, apanharam na rua, alguns foram baleados, presos...o nível de perseguição aumentou depois de investigação de corrupção no final de 2003...a mídia revelou grampos...e...colocaram em destaque...depois mudaram de atitude mudando a legislação. Você viu que eles bloquearam o youtube, para também controlar o acesso à internet....e depois começou a perseguição para o movimento [Hizmet], e a mídia do movimento tem característica bem diferente, pois não pertence a um grupo de empresário...foi criada totalmente pela sociedade civil nos anos 70...ela reúne uma plataforma que reúne muitas vozes diferentes. $\mathrm{Na}$ Turquia essa ideologia nos jornais é muito forte, ou seja, não existe aquele jornal imparcial...sempre foi a voz de um grupo...sempre defendendo interesses...ou militares, mais seculares, mais conservadores...sempre foi aliado para uma parte. Mídia do Hizmet além de também apresentar atividades do movimento ele foi uma plataforma que reunia todas as vozes, ou seja, nunca foi aliado com nenhum grupo político, para nenhum grupo de empresários e por isso entre as colunistas havia pessoas não muçulmanos, seculares, conservadores, armênios, alauítas...todos podiam falar, dar sua opinião. Cresceu muito rápido e se tornou o mais vendido da Turquia...bateu 1 milhão e 250 mil cópias por dia...e quando começou essas perseguições, o governo cortou os anúncios públicos e depois ameaçou os empresários que davam anúncios para o jornal, depois deportaram jornalistas estrangeiros que trabalhavam para o jornal, depois recolheram os jornais (das portas) com voluntários apoiadores do governo. Muitos ficaram assustados e deixaram de ler o jornal. Ou seja, as pessoas que gostavam do jornal somente para não aparecer como apoiador do movimento eles deixaram e também foi uma perda de leitores...caiu até 600 mil exemplares na última publicação. Mídia Hizmet tem investimentos em outros países como Estados Unidos, Europa, na África no mundo inteiro. Na Turquia era mais forte com rádio, canais, internet...Erdogan começou a cortar o sinal das televisões...eh...tirou das plataformas digitais também [a mídia Hizmet]. As vendas então 
caíram de 600 mil para 2.500”. Kamil fez questão de comentar sobre as manchetes alteradas de um dia para outro. Citou o caso de uma obra que estava sendo criticada mas no outro dia haviam elogios à Erdogan, afirmando que ele fazia pontes entre Europa e Ásia. Kamil complementa: “o maior grupo de mídia pró-governo é do cunhado de Erdogan. Então foi distribuído para sua família, empresários...95\% da mídia é controlada pelo governo". Interrompo e questiono o porquê disso. Kamil responde: "na história da Turquia, em 1923, quando foi fundada a nova república, Atatürk criou uma lei chamada 'silêncio total' e durante 4 anos a mídia foi proibida....e Atatürk fez reformas de 1923 até sua morte usando essa lei que totalmente proibia criticar, falar mal dessas reformas. $\mathrm{O}$ alfabeto foi mudado, vestimentas...aquelas reformas que teriam normalmente uma resistência muito forte...ele [Erdogan] tá fazendo a mesma coisa só que controlando a mídia. Ou seja, a mídia indiretamente tá proibida de falar mal dele, dos atos dele. Hoje em dia, o poder de Erdogan vem de duas coisas: uma é mídia, controlar a mídia...e a outra é controlar o sistema judiciário, porque foi montado novo molde com juízes escolhidos em uma corte que recebem ordens diretas do ministro da justiça. A mídia também apresenta ele como herói...pouca gente tem acesso à internet e às informações para questionar. Imagina, mais de 20 canais hoje estão transmitindo ao vivo todos os discursos dele!....3 ou 4 horas por dia, inclusive a TV estatal, que virou praticamente um secretariado, e a oposição não tem voz...por isso ele consegue facilmente manipular ou culpar qualquer pessoa que ele não goste".

A conversa termina, pois Kamil diz que tem um compromisso então retomo a entrevista com o prof. Fatih que inicia sua fala sobre as comunidades no Brasil e extremismo.

"Sr. Gulen, logo depois do 11 de setembro, ele deu uma entrevista condenando o terrorismo, eh...o que aconteceu nos Estados Unidos que ele diz, no Washington Post, dizendo que o muçulmano não pode ser terrorista e o terrorista não pode ser muçulmano e depois em cada atentado até os dias de hoje, que todos condenamos, que a religião não tem culpa mas os muçulmanos, os pessoas mal orientados, manipulados, ele acabaram sujando o nome da religião e eles também não são seguidores verdadeiros, não fazem todos os rituais e os atividades religiosos deles...hoje mesmo, o que se chama Estado Islâmico a gente tá muito eh...distorcido de ser chamado de Islam com nome de Estado que não é reconhecido por ninguém e são criminais [criminosos] que se uniram para fazer vários atentados e eles estão contra todos os ensinamentos do islam. Que se o islam diz no Alcorão 'se você mata uma pessoa inocente significa matar toda a humanidade...e se você salva uma pessoa isso significa que você salta toda a humanidade'...tá num versículo do Alcorão. Então você não pode declarar uma guerra próprio, você não pode sair na rua e matar alguém em nome da religião, você não pode nada de violência em nome da religião. E hoje nós falamos muito isso. O próprio Sr. Gulen deu numa 
entrevista e nesse entrevista ele destacou que não existe um país islâmico [infelizmente, diz em voz bem baixa]...existe os muçulmanos em vários países que eles estão vivendo, mas constitucionalmente, ou seja, o que que o próprio origem do islam tá mandando...não existe um país constitucionalizado dessa maneira”. Nesse momento questiono se Irã e Arábia Saudita ou mesmo Paquistão, não se enquadram em país islâmico. Fatih responde: "você pode chamar Irã ou Arábia Saudita...mas não são considerados...um tem rei, o outro tem outras coisas que são contra a base da religião. Assim, desse ponto uma pessoa sozinha não pode tentar uma guerra, quem declara guerra são os estados. Inclusive os estados reconhecidos. E o que está acontecendo? A Turquia está sofrendo, outros estão sofrendo e por conta desses problemas que estão acontecendo na região".

Questiono sobre a declaração das fatwas por alguns indivíduos que impelem grupos a praticar atentados e declarar guerras. Fatih esclarece que "hoje não existe um país que vai declarar guerra para outros muçulmanos entrarem...então isso praticamente não existe. Uma pessoa que sai e declara guerra em nome da religião, ou seja, guerra sagrada [jihad], ele não tem uma justificativa religiosamente. Todo mundo está sabendo disso. Então uma pessoa louca, maluco...é atividades terroristas. E a gente acredita que quando uma pessoa se envolve com esse tipo de atividade, religião manda que ele nunca vai sair da...do inferno. Então existe uma contrapartida desse ponto. Quando uma pessoa vai matar alguém em nome da religião, na verdade ele está enganado ou então voltamos no mesmo assunto de ignorância...falta de ensino, ignorância, e manipulação...que levam as pessoas a praticarem atividades violentas. Eu acredito que muitos que estão envolvidos ou são criminais, ou são mal orientados, ou drogados, então ninguém vai se matar na frente de todos...ou seja, a religião proíbe o suicídio...Então aceitar que uma pessoa vai matar alguém, então não tem justificativa”.

Levanto em seguida a questão da abertura ou não à interpretação livre do Alcorão, a ijtihad, o quanto isso pode contribuir para a fraqueza ou não da religião. Inicialmente Fatih fala sobre a jihad e sustenta: "vou te enviar um artigo que fala da jihad...jihad, a palavra se chama se esforçar...o próprio profeta...se todo mundo olhar a vida do profeta, chega a 100 horas ou menos o que ele passou nas guerras. Falamos que a religião islâmica foi revelada em 23 anos, nesse tempo, se você juntar nem chega a 100 horas! Todas as guerras e batalhas que ele participou. Existe alguns versículos no alcorão que existe aqueles de guerra...lá ele fala que foi...dado pra vocês...vocês podem guerrear, sair pra matar...esse foi muito específico...hoje você vê todos os traduções e interpretações que foi dado para aquele período. E mais uma coisa importante, quando o profeta vivia na cidade de Medina, tinha os judeus, que eles tinham um acordo lá. Então tudo que aconteceu...eles viviam sem guerra, sem nada, até aquele acordo 
continua até ninguém quebrar. E mais uma coisa que se destaca nos dizeres do profeta, nos livros de jihad, nos falares dele, separado do alcorão, onde é interpretado que ele avisa próprios seguidores dele, voltando da guerra pra cidade antiga deles, diz que nós estamos voltando do jihad menor para o jihad maior...o que é maior pra você, mais importante, que o jihad maior que a pessoa luta contra sua própria alma, com seu próprio espírito, com seus desejos carnais, seus desejos mundanos, aqueles que realmente muito mais difícil de vencer, de encarar do que você sair e matar alguém. E hoje nós estamos vendo que as pessoas que estão fazendo isso, como aqueles imagens, vídeos, horríveis, terroristas, que um muçulmano que se fala que um dia ele vai morrer, ele vai prestar conta de toda a vida dele para Deus...ele nem pode machucar ou magoar uma formiga, porque o próprio islam diz que vocês serão questionados de 4 coisas no outro mundo: $1^{\text {a }}$ coisa, seu corpo: onde você usou seu corpo, como você gastou a juventude dele, onde você esteve... $2^{\text {a }}$ coisa, seus bens, onde você gastou? Do lado bem, do lado ruim? $3^{\text {a }}$ coisa, sobre o tempo, onde você gastou seu tempo, que Deus deu uma previsão de tempo pra você e como você passou sua vida inteira? E a $4^{\mathrm{a}}$ coisa, a inteligência, porque Deus deu inteligência, ele pode e deve distinguir a verdade do falso. Então assim, todo mundo tem suficiente inteligência, para poder saber o que tá certo, e o que tá errado. Uma pessoa para se matar, completamente errado. Absolutamente errado...ele será questionado. Então quando olhamos para a religião islâmica, e seus ensinamentos, você vê que muitas pessoas lutam contra seu próprio ego, sua própria alma, nós chamamos isso pelo conceito de 'nefs'. E outro ponto muito importante também, que quando alguém que não fez estudo islâmico, que não conhece a vida do profeta, que não conhecem como vieram as revelações, o que aconteceu e como que veio aqui a revelação...então a pessoa deve conhecer toda aquela história. Além disso, a tradução do Alcorão não é Alcorão...então árabe é uma língua muito avançada, muito complicada, as vezes uma parte dele gramatical, cria outro sentido...então a pessoa que vai conhecer a religião dessa maneira, é impossível alguém vai falar que a religião islâmica é extremismo. Precisa de uma pessoa que entende Alcorão, precisa consultar para alguém. Alguém que tem uma habilitação. Da mesma forma: você vai pra um médico não habilitado? Ele vai matar você! Nós temos um ditado em turco que diz 'desabilitado um médico que tira sua vida, desabilitado um sheikh que tira sua outra vida'. Então, dessa maneira nós precisamos ter muito cuidado com..." e eu complemento usando a palavra autodidatismo, algo que é acordado pelo prof. Fatih, que continua: "você vê uma pessoa que não lê, não estuda, só de falar o que ele tá ouvindo, ele é a pessoa mais perigosa de todos. Então a religião não tem problema, os muçulmanos têm culpas...em outro artigo que foi dado pelo Sr. Gulen, diz que os muçulmanos precisam, necessitam, devem fazer autocrítica, por que nós estamos chegando 
nesse ponto? Como isso aconteceu? Porque um muçulmano que as pessoas estão vendo, estão colocando no lugar de um terrorista. Ou seja, se você falar pra qualquer pessoa, fecha seu olho, imagina um muçulmano e ele vai ver Osama Bin Laden ou Baghdadhi”.

Pergunto então se não há problemas com a palavra fundamentalismo. Fatih logo me interrompe dizendo que ela é "ler e entender a origem da religião. Infelizmente quando a mídia fala do Estado Islâmico, extremismo fundamentalista, então você acaba criando aquele conceito e todo mundo entende daquela maneira...estamos no país Brasil: um país muito distante daqueles acontecimentos, muito assustado, muita gente tem muito preconceito, e mais uma coisa também, que é um país que está vivendo em harmonia. No colégio, por exemplo, judeu, muçulmano e cristão estão estudando juntos. Inclusive muçulmanos são $1 \%$....maioria é cristão [evangélico, católico]. Nosso movimento sempre foi dos pioneiros de dar uma abertura para a fala, e fazer atividades inter-religiosos, diálogo, e enfim...primeira vez que Sr. Gulen foi visitar o papa, aquela ignorância fizeram ele infiel, agora ele encontrou com o papa, ele queria cristianizar o islam...aí você nem imagina quantos palavrões as pessoas que ficaram xingando porque foram manipulados. Hoje a mesma coisa tá acontecendo contra o movimento, através da mídia da Turquia, e quando você sai e fala e você vê o que você ta fazendo, quando alguém pesquisa com certeza vai achar o que tá certo e o que tá errado. E nós, nessa época, nesse período precisamos conhecer mais a religião, inclusive a mídia tem uma responsabilidade muito grande, mas não tem como comparar, uma pessoa que matou outra, a mídia já tá mostrando...já tá julgado, já tá feito, já tá condenado...então, temos de condenar as pessoas,...mas você não condena a lei você condena as pessoas. Então a religião, ou de outra maneira, que manda as pessoas ficarem mais honestos, manda as pessoas ficarem mais sensíveis com tudo, quando você estuda você vê que a religião não tem culpa por isso...então as pessoas...a maioria tem problemas psicológicos, maioria tem problemas psiquiátricos, então nesse ponto acho que cada vez mais precisamos de mais ensino, lutar contra a ignorância, e conseguir realizar atividades boas".

Nesse momento o prof. Fatih interrompe a conversa dizendo que vai ter que buscar um grupo de católicos para trazer ao CCBT para o evento intercultural e inter-religioso que aconteceria mais tarde juntamente com o iftar de Ramadan. Antes disso, ele fala um pouco sobre Centro Islâmico que dirige.

"Nós temos uma pequena mesquita, as vezes nós fazemos atividades aqui [no CCBT] pois estamos usando juntos os espaços sociais...o diálogo inter-religioso faz parte...nos encontramos com padres, judeus, eh...com ortodoxos, evangélicos...e diálogo pra nós é no sentido de que cada vez mais necessitamos. Como dialogar com outras religiões e outras culturas, 
rigorosamente pensamos que não vamos deixar nossa religião, também o outro não vai deixar sua religião. Segundo ponto, não vamos deixar nossos deveres religiosos para encontrar outra pessoa de outra religião e ele não deve deixar seus deveres. E dessa maneira podemos sentar ao redor de uma mesa, conversar, compartilhar, com uma sociedade que tem todas as cores, mesmo com suas diferenças mas que essas diferenças são as riquezas da própria sociedade. Existe uma metáfora que a gente conta muito: existe uma figura extraordinária, que não é regular. Ela tem vários pontinhos ou espinhos e o professor pergunta para seus alunos: 'como é que vocês conseguiram fazer isso com uma esfera plena, perfeita? Todo mundo começou a falar que a gente tira aquelas partes de espinhos e deixa ele menor, uma esfera inteira, perfeita. Foi um aluno que falou que encheria todos aqueles buracos e conseguiria uma esfera maior'. Existe duas maneiras: em geral nós pensamos em cortar. Ele diferente, o outro também...esse usa véu, o outro kippa, outro usa chapéu, então dessas coisas faz cada vez a outra pessoa ficar mais distante de você. E antes de acontecer os conflitos, ninguém perguntava ao outro sobre a religião, cultura...hoje chegamos num ponto que se ele é de outra cidade não quer se casar ou fazer amizade. Se for de outra igreja não quer se encontrar e esse realmente é o problema e cada vez os religiosos precisam sentar juntos e mostrar que não existe conflito entre as religiões. Hoje estamos num momento mais moderno e todo mundo tem que ser respeitado onde ele está".

Ao ser perguntado sobre as comunidades islâmicas, prof. Fatih responde: "tem várias comunidades islâmicas, eu conheço algumas...a nossa que estou comentando...." Nesse ponto eu acrescento se há diferenças, na visão dele, entre convertidos e nativos. E ele diz: “existe convertidos brasileiros que eu conheci que são pessoas maravilhosas...que interagem bem...mas existe cultura claro, que não vão ter a mesma tonalidade de pensamento e interpretação, mas islam é uma coisa que abrange todos, e quando se fala de comunidade islâmica no Brasil ele é uma grande variedade que tem (libaneses, sírios, palestinos, africanos), então cada um tem a sua própria cultura. Só que quando você pensa que quando faz aquela ordem na hora da oração, um fica do lado do outro. Não existe uma diferença entre os outros. Uma pessoa que chegue na frente só quando é o orientador. Ele também não está num nível superior aos outros, então no Islam não existe superioridade, não existe raça nem cor, não existe língua. E assim os outros religiões também. Ninguém alimenta violência...acho que o que tá acontecendo ao redor, é que as outras pessoas ficam cruzando as pernas e ficam assistindo o que tá acontecendo. A mídia quer mostrar quem tá batendo no outro, quem tá tirando cabeça do outro, isso que ela quer mostrar...não quer mostrar uma coisa boa". 
Ao ser questionado sobre as entidades islâmicas, se há uma relação entre elas, citei a WAMY, o próprio CCBT, CDIAL, entre outras, e prof. Fatih afirma: "nós não temos uma ligação direta. Nós temos ligação à religião, não temos direta, institucional”.

Antes de encerrar e sair para seu compromisso, o prof. Fatih me apresenta ao sheikh Assam, teólogo turco e diretor do centro islâmico com quem tive apenas uma breve conversa informal.

Passados breves instantes, tive meu contato com o prof. Mustafa Goktepe, presidente do CCBT que já está há 12 anos no Brasil. No começo da conversa ele quis saber um pouco da minha pesquisa e da minha vida pessoal, e conversamos um pouco sobre a Turquia, quando o prof. Mustafa demonstrou bastante tristeza e desânimo com a situação atual de seu país nos planos político, econômico e social. Com relação à mídia, retomou alguns aspectos do fechamento de jornais na Turquia como o Zaman e o cerceamento dos meios de comunicações pelo governo. Mas comentou que há um portal de notícias chamado Voz da Turquia que visa preencher uma lacuna aqui no Brasil que para ele é carente de notícias sobre a Turquia e Oriente Médio.

Insisti com ele sobre as razões da pouca integração entre as comunidades islâmicas no Brasil. Para o Prof. Mustafá, "não há interação entre as comunidades...isso é certeza. Há divergências....[hesita um pouco e diz em tom sério]...entre ideologias e diferenças culturais...muitos fatores...inclusive religiosos...mas muito mais culturais, política e regionais do que religiosas. O mesmo com o cristianismo aqui...veja..quantos protestantes, católicos e outros credos".

Argumentei se caso houvesse uma maior união entre as comunidades elas poderia ter mais voz e se expressar em relação a assuntos diversos perante a sociedade. Então o prof. Mustafa me interrompe e diz: "mas isso quando tinha califado [risos]...o que Erdogan quer declarar de novo [risos]. Mas não há isso. Nem Arábia Saudita, nem Egito, nem Turquia...não existe. Não pode existir, porque não há uma união, não tem uma interpretação muito similar. Sobre uma ação terrorista, nós chamamos terrorista, outros chamam de 'graças a Deus matamos'. Não dá pra unir essas pessoas, sabe?" E pergunto: mas há pessoas que falam assim aqui? Prof. Mustafá diz: "claro que tem! [com tom de obviedade]. No mundo inteiro tem. Aqui eu não conheço todos eles, mas há uma divisão muito clara aqui ainda. Em São Paulo e um pouco em Foz do Iguaçu. Mas aqui é uma imagem do Brasil eu posso dizer. E tem divisão, muito claramente entre xiita e sunita, isso também no mundo muçulmano existe, mas entre os muçulmanos a questão de região também - Egito, Líbano, Síria,...áreas de influência que se refletem aqui. O que eu não consigo entender é como as mesquitas têm sheikhs vindos do Egito. Quase todos 
eles. Ou vieram e ficaram aqui, ou ainda vem...o governo egípcio paga e eles passam um tempo aqui e alguns voltam e outros ficam".

Disse ao prof. Mustafa que o discurso das comunidades que visitei é sempre o mesmo sobre os diversos assuntos. Prof. Mustafa me que "você pergunta as coisas básicas, essenciais, e por isso todos nós somos muçulmanos. Nos assuntos fundamentais...é tudo igual...todos vão dizer que 'acreditamos em Deus único, queremos paz, tal'...aí começa a perguntar coisas delicadas e nem todos os muçulmanos vão poder denunciar, condenar claramente como nós fazemos...ataque em Orlando, porque um bar gay. Mas não importa, pois quem morreu lá é ser humano. Esse primeiro lugar. Tem pessoas que não conseguem dizer isso. Sempre 'mas, mas, mas'...esse 'mas' nós teremos que tirar. Tem coisas nos assuntos delicados que fazem acontecer separação, divisão".

Cito o caso do EI, onde muitos muçulmanos alegam ser uma criação sionista, ocidental que visa desestabilizar o Oriente Médio, como se o discurso fosse único. Então o prof. Mustafa alega que "você poderá encontrar muitas justificativas para esse exemplo. Mas você vai ouvir isso. Os sheikhs mudam de opinião...regionalmente eles têm uma posição. Nem todos os sheikhs gostam da gente...posição política...e nós somos apolíticos. Nós não gostamos de política. Nós não temos posição política. E como nesse momento Erdogan é contra a gente....ele usa a religião para fazer política, por isso uso a palavra islamista. Isso é comum em países árabes, e vários sheikhs adoram Erdogan, amam ele [aumenta a entonação]. Esses sheikhs que têm admiração por ele não aceitam ou não conseguem mudar de posição, porque ele é autoritário hoje, nem é religioso mais, mas usa o discurso religioso. Essa é a política islamista. E não participam dos jantares simplesmente, que tinham uma relação boa com a gente e tal...o próprio sheikh Jihad [em voz baixa me diz: 'isso não passa pra ele por favor'] ele vinha, a gente ia...mas não participa mais...por quê? Porque ele sabe que não apoiamos mais Erdogan. Ele deve gostar de Erdogan. Ele convidou para a Turquia alguns sheikhs, viajou para vários lugares, inclusive na América Latina, levou vários sheikhs para formar uma opinião. Justamente para ele ser visto como um líder. Esse califado não é minha palavra...ele citou isso. 'Deveríamos usar essa força do califado de novo'...chegou a dizer isso.

Sobre a questão da interpretação do Corão o prof. Mustafa assevera: "Tem a realidade de 1400 anos e tem a realidade de hoje. Como na nossa crença o islam é a última religião...não tem uma adaptação, uma interpretação para hoje, para amanhã, para sempre, vamos dizer. Então essas pessoas na realidade...e o problema é isso...você colocou bem o dedo. Muitos interpretam. Mas não é só imames...pessoas também. Até imames interpretam...não deveriam, não podem”. E indago: então o fundamentalismo não tem problema, de ler o fundamento da religião? 
Mustafá responde: “isso é errado! Pode ler, mas não pode agir com o que leu lá. Até árabe...mesmo a língua do Alcorão seja árabe. Porque não é só a língua o negócio...o negócio é o conhecimento total. Inclusive a fé. Tem também uma expressão interna. Você ser muçulmano não é só, materialmente, nasceu dos pais, ler o corão, falar árabe...não é isso. E esse série de fatores que falta em muitas pessoas que orientam muçulmanos, que fazem com que as pessoas interpretem dessa forma, os sheikhs também. E todos eles acham justificativas pelo que fazem. Todas acham, justamente por falta de conhecimento, por falta dessa atualização, na própria vida, na própria consciência, formação, conhecimento, inspiração, podemos dizer tudo isso. $\mathrm{O}$ fundamentalismo é para se fundamentar no Alcorão. Justamente é o que eles fazem. Mas eles entendem...de como chama?...de pé a letra...ah, literalmente! Mas não é isso, porque aquilo não é simplesmente palavras, como alguém qualquer escreveu. Você tem uma realidade de 1500 anos, tem a realidade de lá...porque se eu não precisasse de interpretação, não precisaríamos de profeta! [se exalta]. Deus simplesmente deixaria o Alcorão e todo mundo leria e interpretaria. Aí sairia uma religião por cabeça. O profeta viveu 23 anos durante a revelação para interpretar da forma que Deus mandou aquele. A vida do profeta, as palavras do profeta, justamente são interpretação completa do Alcorão sagrado. O que ele fez justamente mais ou menos é o que era a palavra naqueles tempos, para aquela realidade. Isso acontece...muitos tempos...no [Império] Otomano teve um bom tempo, que tinha pessoas que poderiam interpretar...tivemos quase três séculos completos com total tranquilidade na representação do islam muito bem feito e com admiração total do mundo muçulmano e inclusive um envolvimento muito grande com Europa, com os ocidentais. Isso era Otomano. Até meados de 1800, talvez século XVII...e...isso não existe hoje. Tem pessoas, logicamente que possam interpretar, ler, atualizar, só que o efeito deles é limitado, porque uma ação dessa...um muçulmano mal interpretando mata 50 pessoas num bar tem mil efeitos mais que o Fethullah Gulen tenta fazer em 40 anos um islam moderado como a gente vive aqui e apresenta um islam...não vou dizer pacífico pois o islam já é uma religião pacífica como qualquer outra religião na realidade. O islam moderado, o islam atualizado ou interpretado para esse tempo vivido por milhares de pessoas, talvez milhões de pessoas, como meus amigos aqui e em muitos lugares do mundo, mas o efeito disso é demorado.

Questiono novamente a falta de união entre as comunidades islâmicas no Brasil e a falta de uma voz uníssona sobre alguns aspectos que incidem sobre os muçulmanos. Mas o prof. Mustafá explica que "essas diferenças culturais, regionais, podemos dizer linguísticas talvez, mas muito mais políticas, fazem com que esse encontro não aconteça. Tenha várias vozes”. E eu acrescento me referindo aos convertidos, que sem a interferência política e regional entre eles, poderiam tecer mais laços. Nesse caso o prof. Mustafá diz: "pior ainda! [se exalta] porque 
eles são convertidos através de orientadores, eles procuram alguém para saber tal, e geralmente eles têm uma formação de quem orientou ele, acaba sendo mais um. Até pior. Eles são muito mais isolados. Eu tenho vários amigos, alguns inclusive se converteram com minha ajuda, isso pessoal... a gente não faz trabalho no centro dessa forma...minha esposa por exemplo...ela se converteu e depois de ter convivência comigo...e eu nunca pedi pra se converter. E eles têm esse isolamento muito mais forte do que própria comunidade muçulmana. Eu sou muçulmano desde nascido e até eu estou um pouco isolado nas mesquitas porque tem...árabe...um pouco mais cultural do que religiosa. Imagina eles [convertidos] ainda". Nesse momento citei um trabalho da prof. Francirosy sobre as diferenças sentidas entre os muçulmanos nativos e os convertidos que se sentiam isolados na comunidade, talvez significando um processo de desetnização da religião, quando o convertido não deseja se associar à cultura árabe no caso. Nesse caso o prof. Mustafa complementa: “a desetnização da religião existe no Ocidente...mas isso não é a realidade. Isso apenas se deu na verdade...Alcorão na verdade ser em árabe...a revelação é em árabe. Maioria dos muçulmanos não é árabe. $80 \%$ dos muçulmanos não é árabe. Maior país muçulmano fica na Ásia...Indonésia...Paquistão, Malásia...eh...aquela região....grande maioria. Árabe 19\%-20\% dos muçulmanos. Só que na realidade o Alcorão foi revelado em árabe, surgiu de lá...como todas as religiões surgiram de lá [Oriente Médio]...Mesopotâmia antiga...mas esse raciocínio acontece...e nem todos os árabes são muçulmanos, aqui principalmente não é...é cristão, ortodoxo. No Brasil, as comunidades islâmicas são o espelho do mundo muçulmano...daqui a 2 meses e meio, 3 meses, começa o Hajj [peregrinação à Meca] e vem muçulmano de to-dos os lu-ga-res do mundo [frase pausada e enfática]. Aí você vê a diferença entre muçulmanos...você vê pessoas muito gentis...depois vê pessoas muito feias, sujas [com voz em baixo tom]...olha...até dentro do judaísmo tem várias linhas né...um fala mal do outro...no cristianismo muito dividido, muito mais do que islam talvez...só que a divisão do islam por causa dessas maldades, dessas coisas que são relacionados ao islam e não digo por causa dos muçulmanos...eu não considero eles muçulmanos [os que promovem o terror] e por isso parece muito dividido e muito mais complexo".

Ao final da conversa pergunto a ele qual seria seu modelo de muçulmanos, que o inspira. Antes mesmo que eu terminasse de formular a questão ele imediatamente ele responde. "Meu inspirador é ele. Eu leio, sigo e vejo e justamente toda minha posição...ele é o único líder religioso muçulmano que se posiciona diante das coisas atuais, escrevendo para jornais internacionais de grande impacto e sem receio nenhum de se posicionar. Isso não é qualquer um que faz. Eu igualmente como ele pensa. Logicamente ele forma minha opinião, minha fé...ajuda nisso. Os pontos comuns...o que é mais importante. O primeiro dele é ser 
humano...valores humanos...que vale para todos. Ser humano e valores humanos, que são as bases do nosso movimento [Hizmet] que ele inspirou. Quanto tem essas duas, como a gente diz...eh...como chama? Para desenhar o círculo?..Compasso! Esses duas coisas sendo fixos, primeiro a parte de ser humano o outro você pode ir abrindo conforme sua interpretação de valores...esse eixo tá muito bem fixado nesses valores comuns. E aí religião entra como uma das coisas. Mas não é base principal. Por isso a gente não interpreta o islam no movimento como um movimento religioso. Nós somos religiosos. Mas nós não divulgamos a religião. Nós não trabalhamos para a religião. Ela faz parte de nossas vidas e nossa inspiração vem da religião. Mas justamente um [exclama] dos fatores, a religião. Um dos fatores que a gente encontra pontos comuns na religião. Mas ele não é a motivação, ele não é causa principal do Hizmet”.

Após a conversa participei do iftar juntamente com membros do CCBT e de comunidades católicas (padres e irmãs Paulinas). 


\section{IDENTIFICACÃO}

Nome: Ahmad Mohamad AlKhatib

Local de Nascimento: Líbano

Idade: $\mathrm{n} / \mathrm{d}$

Ocupação: Preside a ONG Livro Aberto - Guarulhos

Escolaridade: (a) Fundamental (b) Médio (c) Superior (Líbano) (d) Pós-graduação

No dia 23/09/2016 entrevistei o Ahmad via skype.

Ahmad disse ter ficado 7 anos em Guarulhos e depois mais 2 anos em Campinas/SP.

"Tenho prazer de servir e de participar e de estar aqui colocando nem que seja uma letra, uma palavra para gente transmitir a verdade para as pessoas e não ocultar a verdade e nem desviar a atenção delas por atos que podem trazer injustiça para as pessoas, né? Eu posso, com prazer, responder as perguntas e antes gostaria de apresentar a situação que aconteceu [sobre a prisão de pessoas no Brasil suspeitas de planejar atentados terroristas]...que aconteceu com a polícia federal.

Acredito eu, existia moleques, rapazes que são brasileiros que são revertidos ao islamismo né, e eles não tinham a intenção nenhuma de fazer terrorismo acredito eu...eles poderiam ser pessoas assim, revolucionárias. São jovens né, muito jovens...então são pessoas revolucionárias, revoltadas com a situação que acontece nos países muçulmanos porque é...como eles são novos muçulmanos e eles captam as mensagens e informações deles dos livros. Não tem essa experiência de um muçulmano que nasceu muçulmano. Então eles já se revoltam pela injustiça que acontece no mundo inclusive terrorismo...no terrorismo, os mais injustiçados são os muçulmanos.

Quem analisa bem, vê que são os muçulmanos os mais injustiçados com isso né. Então, vê o que tá acontecendo no Iraque, na Síria, no Iêmen, na Palestina. Então as vezes eles [os rapazes presos] mencionam na internet algo errado. Eu tenho uma ONG e nessa ONG tinham duas pessoas que trabalhavam comigo e que foram presos. E nessas conversas entre eles, criaram um grupo, grupo que vão lutar contra a injustiça do mundo, contra os incrédulos...coisa assim...e nesses grupos ele sempre tentam escolher um sheikh, eles tentam escolher um líder...líder executivo, um líder que...vamos dizer assim, que direciona a vida deles conforme a jurisprudência islâmica.

Na conversa entre eles, que foi pega pela polícia federal fui eu mencionado o sheikh deles. Mas eu não fiquei sabendo né? Eu não sabia que era assim. Por quê? Porque eu tenho uma ONG e você precisa saber disso...isso não é errado e nem certo...isso é a realidade...os revertidos brasileiros aqui eles não têm a mesma...como vou dizer isso...os muçulmanos árabes, 
que vieram que vieram dos países árabes não têm a mesma fé que tem os brasileiros. Então eles [muçulmanos árabes] não enxergam eles [revertidos brasileiros] com bons olhos. Então eles são assim....meio...os brasileiros são meio discriminados no meio da comunidade muçulmana árabe. Então os sheikhs e os sábios muçulmanos, os que são acadêmicos islâmicos, eles não tratam os brasileiros bem. Eu trato muito bem os brasileiros então eles têm comigo uma aliança muito forte. Então é por isso que eles me escolheram como sheikh.

Existe já uma comunidade muito grande de muçulmanos brasileiros. Já tá crescendo muito né? O islamismo tá crescendo muito até aqui no Brasil né? Então eles procuram líderes...líderes que estejam com eles né? Então através da minha ONG, a maioria dos brasileiros muçulmanos, eles vão lá, tem os projetos deles, os sonhos deles do islamismo, a gente tenta colocar em prática. Então por isso que foi mencionado numa das conversas entre eles e a polícia federal me chamou... '- é verdade que você é o orientador, não sei o quê sobre os meninos? - Falei não. Nem estou sabendo dessa conversa e ninguém incentiva eles a fazer isso'. Mas graças a Deus, os dois que trabalhavam lá comigo na ONG saíram, não estão mais presos. E os outros que tentaram comprar arma estão presos”.

Questionei sobre o motivo de se radicalizarem, especialmente aqui no Brasil, se existe um ambiente propício para isso. O motivo seria a discriminação nas mesquitas como afirmado? O sheikh logo afirma: “não, não...isso não faz eles se radicalizarem, de jeito nenhum. O que faz eles se radicalizar é a situação dos muçulmanos no mundo, né? A situação que está na Síria...nesses lugares, como os muçulmanos são tratados...e só isso não faz eles serem radicais, mas ser simpatizante, entendeu? É eles tentar gostar mais de um lado do que de outro. E tem outra coisa. Eu queria te contar, mas já que você antecipou: as mesquitas aqui não são motivos nenhum para eles ter nada [radicalismo]. Os muçulmanos brasileiros não gostam, na verdade não têm uma boa relação com os muçulmanos árabes...e poucos sheikhs que falam o português, então eles são amigos daqueles que falam o português, que estão com eles né.

O sheikh Abdu Nasser que nasceu aqui, o sheikh Jihad que nasceu aqui, eles são brasileiros, mas eles não têm esse tempo, a realidade deles não permite de eles estarem com os jovens né. Eles não têm tempo para acolher essas pessoas, que têm desejos, sonhos, projetos, são pessoas superinteligentes para falar a verdade viu. Um deles, o que foi preso, o Antonio Andrade que trabalhava comigo na ONG é super inteligente, é universitário, formado na universidade, não é uma pessoa leiga...outro fala três línguas...mas o Brasil não dá oportunidade para esses jovens - não to falando dos muçulmanos só, mas de qualquer jovem né - Não dá oportunidade de se expandir, de conseguir executar um projeto, seja qual for: econômico, social, qualquer coisa. Então eles ficam presos. Quando eles encontram uma porta, uma saída, eles vão 
para aquela saída. E às vezes uma saída errada. Então um desses - você fez a pergunta da arma - onde esses rapazes pelo que eu fiquei sabendo das conversas que a polícia federal teve, que eu tive acesso pelo meu advogado. Então um deles parece que tentou comprar arma...um deles já tinha problemas com a justiça, que se tornou muçulmano, ele estava preso e tudo mais...então esse ElKadre que chamou eles pra criar esse grupo parece que tentou comprar arma. Mas o resto não. Nunca revelou essa ideia. Os dois eu conheço muito bem, nunca tiveram essa ideia. E outra coisa eu pesquiso muito, bastante sobre grupos radicais...porque eu aprendi muito na minha vida que para se afastar do mal tem que saber como é o mal. Sobre radicalismo eu pesquiso bastante e converso com as pessoas. Você dá aula então você sabe, qualquer jovem, qualquer pessoa que você vai dar aula pra ele, se você não tiver a prova, se você não tiver alguma informação, informação exata, ele te escuta por respeito".

$\mathrm{Eu}$ interrompo e pergunto sobre as escrituras e suas traduções. A questão da interpretação, da ijtihad, se isso não pode distorcer a visão deles, por exemplo, incorrendo no perigo de fazer uma leitura conveniente aos seus propósitos.

O sheikh diz que "não. Você vai escrever para o mundo, se Deus quiser, uma informação, para o povo brasileiro, em português, uma informação que tem que ser com fidelidade, e nem eu posso te passar informação errada, seja o que for, nem que eu seja prejudicado por isso, mas tem que ser a informação verdadeira e correta. Nada de interpretações erradas. Isso que a mídia fala não é verdade. O que acontece é que existe uma revolta. O Antonio Andrade é uma pessoa informada! Ele lê e pesquisa. Hoje você pode abrir o jornal, eu estava agora a pouco assistindo a RedeTV, e 81 crianças foram massacradas por um avião russo (se exalta), entendeu? Aí, o mundo, quando explode um carro na França o mundo faz passeatas, faz tudo! Até o facebook pinta com a bandeira da França...agora aquelas crianças não têm nome? (se exalta novamente).

Então ele fica revoltado. Um muçulmano novo...eu estudei na Síria 7 anos...eu sei o que é viver em ditadura. Você não sabe. Você não chegou a viver a ditadura no Brasil? (Eu respondi que não). Graças a Deus ele continua. Mas eu vivi. Eu tenho certeza que a ditadura no Brasil não era $1 \%$ do que é a ditadura na Síria. Eu não podia ter barba, não podia ter três pessoas paradas na rua - mais que duas não pode - tudo não é você viver como um robô, mas como um escravo na realidade. Isso que você tá vendo é as pessoas que chegaram a um limite na Síria. Vamos morrer e não vamos ficar com essa humilhação. Chegaram ao limite. Acabou. Já morreu mais de 1 milhão na síria [número superestimado] e não querem parar. Síria tem 27 milhões [de pessoas] e já saiu 15 milhões. Mesmo assim eles não querem parar. Então eu quero dizer assim: esses jovens não é nada de interpretação [do corão] viu, é revolta, é revolta. Revolta do mundo por ter dois pesos e duas medidas. Isso é informação correta que eu to lhe passando. Isso pra 
gente ser fiel com as pessoas. Eu não falaria isso pra polícia federal! Eu passei coisas pra polícia federal mas eu não aceito que você [Polícia Federal] escreve isso! Eu acho que vocês devem se informar, eu falei isso pra polícia federal, vocês devem se informar. Por que você quer o quê? Proteger seu povo? Não dá pra proteger com injustiça. Tem que ser com justiça. Tem uma coisa que você não conhece que eu vou te aproximar mais: sabe o PKK? Já ouviu falar do PKK? [Digo que sim]. Dos curdos né? Tem 16 grupos curdos. Tem 12 que os Estados Unidos apoiam. Eles fazem carro bomba. Eu tenho vídeo. Eles fazem um monte de explosões, mas nunca é considerado terrorista lá. E aí? O exército do Iraque mata com faca as pessoas. Eu tenho vídeos também, mas não é terrorista. Por que é os Estados Unidos que estão apoiando o exército do Iraque, entendeu? Então as pessoas têm essas informações e ficam revoltados. Então são dois pesos e duas medidas? Então não é interpretação".

Questiono se os muçulmanos sofrem um tipo de preconceito aqui no Brasil.

O sheikh diz que "preconceito aqui no Brasil não tem. O povo brasileiro é hospitaleiro, um povo que recebe bem as pessoas, não só árabes e muçulmanos. Eu to há 27 anos aqui, não to há pouco tempo. E tem outra coisa: eu falei isso na polícia federal e falo ainda...não há motivos de terrorismo aqui a não ser que eles, esses meninos querem criar algo pra chamar a atenção, causar [usa a gíria], dizer que eu existo, falar que a gente quer fazer alguma coisa pelo mundo islâmico, pelos muçulmanos, pelas pessoas injustiçadas, pode ser que eles querem fazer isso".

Complemento dizendo que isso poderia até prejudicar a comunidade muçulmana que repudia essas ações que passa a ser vista de maneira negativa. Os rapazes que pensam nisso não pensam no restante da comunidade? O sheikh responde: "eu to sofrendo com isso. To sofrendo muito porque eles mencionaram meu nome, também pediram informações pra mim e eu passei informações para eles da religião islâmica. É que eu volto a falar assim...Estado Islâmico não tem intenção nenhuma, nem com a Bolívia, Argentina, Brasil, nem com a América Latina toda, nada. Eles não participam da guerra lá. Não há terrorismo do Estado Islâmico no Brasil. Primeira coisa. Agora, se alguns rapazes querem causar, querem fazer...aí já é outro tipo. Acho que o Brasil tem que buscar o que que falta que nós devemos oferecer para nossos jovens para eles não participarem disso. Não deveria pensar o Brasil se o Estado Islâmico está acolhendo esses rapazes ou não. Quando a gente vê que nosso filho tá saindo fora de casa, tem que pensar não porque o vizinho acolheu ele, mas porque ele fugiu de casa. O Brasil tem todas as condições de ser o melhor país do mundo".

Pergunto se não falta informação ao brasileiro sobre o islam e os muçulmanos. O sheikh diz: "falta muita informação, muita mesmo. Pelo que eu estudei, pelo que eu sei, o Estado 
Islâmico não tem nenhuma intenção aqui”. Nesse caso, citei a ameaça feita anteriormente aos jogos olímpicos do Rio de Janeiro, por um suposto integrante do Estado Islâmico. Sobre isso, o sheikh afirma que "essa informação não é verdadeira. Essa ameaça, primeiramente, eu afirmo pra você, ele usou a palavra merda, eu não uso, mas to falando pra você que nunca [se exalta] o Estado Islâmico...se alguém no Estado Islâmico menciona isso ele é castigado, você entendeu? Com poucas palavras, eu digo que isso é falso. O Brasil não tem nada a ver com isso. É claro que o Brasil tem que se prevenir, tomar cuidado, não to dizendo que não, mas não é pra colocar o povo contra a comunidade muçulmana com falsos alarmes, por coisa que não existe. Só porque quero vender mídia? Não se preocupa se essa família será exposta, se aquele será prejudicado. A respeito do Estado Islâmico, é que o Brasil só fala do Estado Islâmico. Mas tem muitos. Hoje tem o Jabhat Al-Nusra, ele também, os Estados Unidos usou ele...é que o líder dele era também do Estado Islâmico...a Arábia Saudita comprou ele...a Arábia Saudita é filial dos Estados Unidos. Então comprou ele e aí colocou o grupo dele mais quatro grupos como terroristas. Então não é só eles [EI] que fazem terrorismo. Essas pessoas têm outro objetivo lá, não querem vir pra cá".

Indago, ao se falar da Arábia Saudita, se as mesquitas e obras que recebem dinheiro da Arábia Saudita também não estariam sendo usadas para espalhar a doutrina Wahabita.

(31min) O sheikh então responde após breve silêncio: "Isso não faz sentido. Nem um pouco. Veja: evangélico você sabe. É aquele que volta pro texto da bíblia. O wahhabita é isso. Só! Só isso. Não é nada de terrorismo, radicalismo...Wahab, foi quem criou...e colocaram os seguidores dele como wahabitas. Arábia Saudita, é 99,99\% salafista wahabita. E são liberais, e são seculares [?]. É uma mistura muito complexa. É igual católico que vai pro templo budistas. Tem muito amigo meu que faz isso. Lá é assim, pela ideologia e pela prática islâmica e não pelo radicalismo. Não tem nada a ver com o radicalismo".

Argumento com o sheikh se então não seriam fundamentalistas, que retornam ao fundamental da religião. Quis saber se era essa a leitura fundamentalista que ele possui. Finalizo, questionando: o que é fundamentalismo?

"Essa informação não é correta. Se eu falar para você a palavra crente, quem você imagina? Evangélico! Apesar de que a palavra crente não tem nada a ver com os evangélicos somente. É uma palavra geral: eu sou crente, você é crente, todo mundo é crente. Então esse desvio mental pela mídia que foi feito, é o que acontece com o wahhabista, o fundamentalista ou...isso que acontece. A mídia que é contra...porque hoje o que se tenta criar no mundo ocidental há muito tempo...dividiram a sociedade e o governo num grupo e a religião se tornou um hobby no Ocidente. Não é um hobby que se tornou? Ela não comanda nem rege nossa vida 
mais no Ocidente, não é verdade? Então no mundo oriental falo assim, no oriente islâmico, não só oriental...no mundo islâmico o que rege a vida deles é a religião. O que o mundo tenta fazer hoje? Isso até tem um pensador brasileiro que tava falando disso, na Tv Cultura, no [programa] Roda Viva...ele tem uma barbicha branca..." e eu cito Luis Felipe Pondé e o sheikh concorda: “isso! Ele então falou mais ou menos isso. O que acontece hoje em dia é que eles querem que os muçulmanos, para fazer uma globalização melhor no mundo, que os muçulmanos sejam muçulmanos! Não querem que eles se tornam nem judeus, nem budista nem nada. Os muçulmanos estão lutando contra isso. E quem que luta mais contra isso? Quem que não aceita isso? Os salafistas. Não que os salafistas sejam radicais ou terroristas, não! Não aceitam isso porque tem os argumentos, entendeu? Eles lutam pela mídia, pela informação através das escolas, faculdades e através da distribuição de livros e de tudo que é meio contra essa ideia ocidental, tá. Então o que o Ocidente junto com o Irã classificaram - depois você pergunta do Irã o que você quiser pois eu sei que na sua mente 'tan' acendeu uma luzinha (risos) - que eles fazem contra os salafistas? Uma má propaganda que eles são terroristas, eles que é a fonte de terrorismo...mas não é nada disso. Pelo contrário! Hoje, quem mais luta contra o terrorismo são os salafistas! E são os wahhabistas. 80\% do dinheiro que tá sendo gasto com o Estado Islâmico é da Arábia Saudita, e são wahhabistas, salafistas! Então eu acho que a informação não está sendo bem passada".

Eu indago com base na fala do sheikh que então a mídia é responsável por fazer distorções dos conceitos. O Sheikh diz: "muito!"

Voltei à questão dos rapazes que foram presos pela polícia federal perguntando sobre como está a atual situação deles e do próprio sheikh.

Ele então assim responde: "a Veja falou e a Band falou semana passada. Eram 14. Soltaram 4, tem outro preso. Mas tem um menor que não foi pra lá. Mas a investigação continua. Até eu estou sendo investigado ainda, entendeu?" Aproveito para saber se eles estão sendo enquadrados pela atual lei antiterrorismo aprovada no país. E ele diz que "tudo pela lei nova...você não pode...tipo...compartilhar um vídeo do Estado Islâmico...uma vez eu compartilhei um vídeo, acho que em 2014 de um artista russo que se tornou...que foi lá...famoso na Rússia...fugiu para lá pro Estado Islâmico. E tem uma doutora, reitora de uma universidade da Arábia Saudita - o pai dela era muito sábio, tinha vários livros - e ela fugiu para lá. A gente tenta entender por que essas pessoas largam essa vida tão confortável...um advogado bem sucedido na Califórnia...então eles [polícia federal] me perguntaram porque você...eu falei porque no Líbano discutiu comigo...que quem vai pra lá sempre as pessoas que são loucas né? Mas eu mandei para ele um vídeo que não é...esse cara é um artista, na Rússia é bem de vida, 
falei do advogado da Califórnia, a reitora da universidade da Arábia Saudita...eu falei: 'me explica, o que é isso'? Então eles entenderam....ah, mas 'por que você compartilhou isso daí? Compartilhei para mostrar lá...foi em 2014, não tinha lei nenhuma...foi pra mostrar, eu não tenho participação. Eu nunca compartilhei e nunca incentivei e nunca elogiei, nunca falei nada! Foi um modo de mostrar para ele um vídeo no meu facebook”.

Disse então que isso poderia ser fruto de um estereótipo do tipo: se a pessoa fala árabe ou é árabe, viajou para o Oriente Médio e publica algumas informações sobre os conflitos, já se acende um alerta nas autoridades e pessoas. Ele disse que "é por aí. Se eu for pra qualquer país desse, se eu fizer qualquer coisa eu sou terrorista? Eu tenho um amigo, sheikh Ali Achkar. Fala com ele, é importante. Ele foi procurado pela polícia federal também...ele é brasileiro, terceira geração - o avô era libanês - mas tá morando na Espanha. Ele se chama Antonio Junior, mas mudou o nome para Ali.

Entro no assunto sobre a fragmentação das comunidades islâmicas no Brasil, porque não há uma voz única, um porta-voz que emita um parecer único. Questiono se não existe interesse de ninguém para fazer essa união ou se o problema é ideológico e religioso.

O sheikh afirma: "não tem união. Comigo você não vai ouvir nada que elogie ou esconde né. Não tem essa união e não existe isso por vários motivos. Primeiramente há um grande motivo - na verdade vários e não um motivo só que ajudaram nessa separação - mas o grande motivo é o dinheiro. Por quê? Porque quando se iniciou essas organizações [sociedades beneficentes, por exemplo,], iniciou-se com comerciantes...e esses comerciantes se tornaram religiosos e eles têm pouco conhecimento do islamismo $\mathrm{O}$ islamismo é diferente das outras organizações e só funciona através da sabedoria e do conhecimento. Não funciona de outro jeito. Por isso a primeira palavra revelada pelo Alcorão é 'leia'. Então se você não tem conhecimento, você é um causador de problemas. Você é um prejudicador e não benéfico se não tem conhecimento do islam. Qualquer muçulmano é uma obrigação. Você sabe que nós temos cinco orações, jejum...são obrigações...o conhecimento também é obrigação, é um pilar do islamismo. Se você não é um conhecedor do islamismo, você é um grande causador de prejuízo aos muçulmanos e sociedade islâmica”.

Nesse ponto, interrompo e questiono se os radicais islâmicos se incluem nessa situação. O sheikh Ahmad responde: "Sim, sim, eles não têm o conhecimento. Como eles buscam conhecimento? Eles buscam conhecimento que interessa para eles chegarem no objetivo deles. Igual aos comerciantes que estão hoje: a maioria da carne do Brasil exportada para o Golfo e para os países muçulmanos precisa de um certificado, esse certificado tem que ser de uma associação islâmica. Então a disputa pelo dinheiro é muito grande. Grande demais até. Alguns 
muçulmanos têm esse certificado, porque a exportação de carne representa uma grande fatia da economia do Brasil. Isso tá gerando grupos de empresários de origem muçulmana. E pra isso, cada um deles tem que ter 3 ou 4 sheikhs do lado dele e esses sheikhs recebem [dinheiro]...essa corrupção na sociedade islâmica. É uma corrupção...não vou chamar de um nome mais bonito.

Agora, quem traz um grande prejuízo para nossa comunidade, aonde tem a disputa pela liderança que cada um quer falar em nome...mas ninguém fala no nome do islam, estão falando em nome do comércio usando a fachada do islam, entendeu? Por isso não tem a liderança. Olha Victor, ninguém é diferente de ninguém tá? Deus revelou guia, guia para os seres humanos largar o ego, a inveja e largar esses mau caráter. Deus não se beneficia de nada disso, ele deu esse guia para os seres humanos para eles conseguir se tratar, conseguir comunicar, saber como lidar um com o outro. Esse ego, esse ponto preto que nós temos no coração dos seres humanos funciona com a ignorância e se apaga com a sabedoria. Vou te contar a história de um...um..um...senhor católico, Michel Khilo que é da Síria, ele é católico, era da oposição contra o Hafez Assad, pai do Bashar, ele falou que um dia ele, foi preso né?, qual que era a acusação? Que ele era da irmandade muçulmana....e ele é católico.

Eu mando o vídeo dele para você. Ele entrou na cadeia, aí ele era famoso um pouco, era conhecido, era professor, saía na mídia, nas revistas, aí o carcereiro era cristão também, e falou: 'eu te conheço! De onde eu te conheço? - ah eu sou um pouco conhecido. - Mas quem é você? - Eu sou Michel Khilo. - Ah, o senhor é Michel Khilo? - Olha, já que o senhor é inteligente, eu quero que o senhor - ele tava numa solitária escura - mande calar a boca de uma mulher e a criança ali do lado senão eu vou fazer algo'. O carcereiro já tava muito tempo lá, com problema psicológico. Aí ele foi lá na criança, de cinco anos, seis anos. O carcereiro disse que se ele conseguisse fazer a criança parar de gritar ele ia levar Michel Khilo para o sol, passar um dia no sol. Aí ele falou, o Michel para a criança, começou a contar uma história para ela. Falou pra ele assim: 'vc já viu um passarinho que tem asas? O garoto respondeu: - o que é passarinho? Aí ele falou: é aquele que fica na árvore! - Que árvore tio?' A criança tinha nascido na cadeia... A criança nunca saiu na rua, não sabe de nada. Por quê? Porque o irmão dessa mulher fugiu pra Jordânia - essa é uma história verídica viu? - aí pegaram a irmã dele. E lá eles estupraram ela e a criança nasceu lá. Então eu acho que é...não está se concertando o mundo pela maneira certa. A nossa comunidade aqui, como qualquer outra, quando o dinheiro está presente, a irmandade, a harmonia...tudo vai estar funcionando.

Os pensadores muçulmanos árabes eles falaram que o mundo, desde do Adão para cá, passou por várias etapas. Na época de Moisés e Abraão a liderança que era importante. Hoje é o dinheiro. De Jesus a Mohammed, era a humanidade. Agora essa nossa época, o que mais 
prevalece é o dinheiro, aquilo que o ser humano possui. Hoje em dia adaptamos a religião pelo dinheiro. Antes era o dinheiro adaptado pela religião. O segundo motivo maior [da falta de união entre as comunidades] é que a maioria dos presidentes das nossas sociedades são comerciantes que vieram de lá que não tem nada a ver com a sabedoria e conhecimento. Até quando um tenta subir um pouco, quebram as pernas dele...não deixam ele liderar”.

A conversa se torna mais informal quando falo do presidente da Mesquita de Campinas, prof. Mohammed Habib e do seu filho Nader, o qual o sheikh tem grande amizade. Nesse momento o sheikh confessa que: "o que acontece em Campinas, um dos motivos que me fez sair de lá, eu pedi demissão, era também o sistema arcaico que eles têm. O Dr. Mohammed e o Nader, são gente finíssima, não to falando da pessoa deles...eu fui lá quando eles me convidaram porque faltou um sheikh lá, me convidaram para faze um discurso lá, eles gostaram, porque eu falo português e tudo mais, fiz vários projetos, vários congressos lá na mesquita e a gente conseguiu fazer vários eventos. Aí eu falei pro Nader: 'olha, eu preciso ter projeto...ser sheikh de mesquita...eu não sou disso viu? Aí ele falou, então vamo! O que você precisa? Disse que primeiro precisava fazer escola nesse espaço, vamos fazer outros projetos de visitar favelas, as comunidades, fazer um plano de saúde para essas pessoas, temos muita gente na nossa comunidade que são dentistas, médicos, árabes-muçulmanos que podem doar uma hora por semana cada um para a gente estar presente nesse mundo também. Mas sempre falava vamo, vamo, vamo, mas nunca saía nada. Eu falei, olha, da licença...tchau! Eu montei minha ONG aqui, recebi 470 famílias sírias que vieram refugiados e até hoje eu dou auxílio para eles. Fazer oração e jejum é entre você e Deus. O que Deus quer exatamente não é isso! Isso é o remédio que ele dá pra gente para ficar vivo, mas para ajudar o próximo. A oração e o jejum é o remédio que a gente toma! Pra quê? Pra se fortalecer. O trabalho nosso, da nossa alma, a alimentação da nossa alma é ajudar o próximo".

Retomo a questão do fundamentalismo pedindo ao sheikh Ahmad que me dê uma definição para o conceito. Ele responde: “eu acho que o fundamentalismo não existe...é...um ser humano que não tem oportunidade que procurou...a força interna que está nele, procurou um espaço para ela e achou o fundamentalismo nisso. Na realidade não existe fundamentalismo mesmo, né, pra mim...existe pessoas que têm uma energia muito forte de servir, de fazer algo e achou espaço para se expressar...independente da religião. Há um pensador muçulmano...eu sou fã dele, que é superinteligente, que estudou geopolítica na Oxford...que ele fala que os britânicos não são políticos, são artistas em política. Vejo que a Grã-Bretanha, esses países, eles dão oportunidade...você vê o Japão, eles dão oportunidade e não tem fundamentalismo. Eu vejo assim: o mundo, os países, devem entender que essas energias que têm essas pessoas, que tem 
esse poder de querer fazer alguma coisa, de querer se expressar...é...não adianta oprimir eles...opressão social cria loucos, opressão ideológica cria fundamentalista, opressão...é...financeira cria ladrão...não adianta oprimir. Se oprimir as pessoas, você vai ter terrorista e fundamentalista. Porque o fundamentalista, ele é fundamentalista porque também não conseguiu colocar o que ele pensa, o que ele tem de projeto, a oportunidade dele...não veio oportunidade para ele, entendeu?"

Finalmente, faço a pergunta que fiz em todas as entrevistas sobre qual o modelo de muçulmano para o entrevistado, uma pessoa que o inspira. O sheikh Ahmad diz: "você não quer que eu fale Mohammed né? Imagino que estava esperando por isso. Mas eu vou explicar por quê. No Alcorão, está dizendo Deus para os muçulmanos não terem exemplos entre os seres humanos, exceto em Mohammed. Para nós, os profetas, os mensageiros de Deus até Jesus, Salomão, até Davi, até Ló...eu mencionei eles de propósito esses 4. Para os muçulmanos e para os cristãos originais, esses homens são escolhidos de Deus e são protegidos, não praticam erros...erros graves eu falo. Todos são seres humanos, mas não praticam erros como fornicação, como roubar...entendeu? Então nós temos eles como exemplos, os mensageiros de Deus, não podemos ter outros como exemplos. Mas quem eu me inspiro atualmente?...Eu me inspiro em dois sábios muçulmanos: um egípcio e um saudita. Um deles, esse saudita, estudou na Índia...você não conhece...ele até tem uns 40 anos só. Decorou seis livros, decorou o Alcorão...os entrevistadores quando falam com ele ficam com os olhos arregalados...porque ele fala a verdade. Ele foi preso pelo governo saudita e mas já foi solto...ele se chama Tarif...ele fala com propriedade, não faz interpretação...ele sabe o que tá falando...ele não fala só sobre o islamismo...ele falou um tempo atrás de como a sociedade regrediu...a matança entre as pessoas, a injustiça entre as pessoas".

Eu finalizo agradecendo as informações e a gentileza em me atender e de forma simpática ele conclui: "quando precisar estou à disposição. Eu não to cedendo uma entrevista, uma informação para o Victor...eu considero assim: é uma obrigação minha mostrar a verdade para as pessoas, então aquele que aliado a nós como o Victor, que quer mostrar de uma maneira diferente, eu considero você como aliado que quer orientar as pessoas e não desviar as pessoas né. Nosso profeta fala assim que aquele que guarda uma informação, oculta uma informação Deus colocará uma focinheira de fogo na boca dele no juízo final, então a informação é muito mais valiosa do que qualquer riqueza financeira. Através da informação é que vamos ter tudo".

Comento sobre o niilismo, a parte da pesquisa em que tento relacionar esse conceito com o de fundamentalismo. O sheikh comenta: "isso faz parte da família...o mundo material. As pessoas me procuram quando tem um problema entre marido e mulher. Eu conversei com um 
homem, faz seis anos - ele é parente meu - ele brigou com a mulher dele e fui falar com ele. Eu disse: ‘tio, por que você fez isso? -Ah, ela me dá muito prejuízo'. Eu fiquei chocado! 'Vocês estão fazendo negócio? Um dando prejuízo pro outro?' Você ouve isso muito entre os casais. 'Eu vou casar com ele porque ele tem grana'...não existe mais família [se exalta]. Existe dinheiro. Então se o núcleo da sociedade está nisso, então imagina o resto. Eu acho que é difícil...a mídia fez o ser humano virar isso, dominou a mente do ser humano. Hoje, o materialismo se tornou mais importante que qualquer outra coisa.

Meu filho está aqui, está me ouvindo...é....a polícia federal levou tudo...o iPad dele, meu, da minha mulher...eu tenho a empresa e eles levaram tudo da empresa né...aí meu filho a cada duas semanas ou a cada semana pergunta: ‘quando eles vão devolver meu iPad?' ele não me pergunta o que vai acontecer comigo, o que aconteceu com o Antonio que também era tipo...ele educava ele, dava aula para ele...to falando do meu filho, só se importa com o material. Hoje é difícil...e pra gente devolver o mundo para o eixo, precisa de muita gente junto. Nós estamos fazendo um grupo...voltado para a humanidade...é preciso...a gente precisa disso. O rei Salomão vê uma formiga caída no chão com as pernas para cima - o rei Salomão falava com os animais - e ele falou assim para a formiga: 'posso te ajudar? - Não, me deixa assim que to fazendo meu serviço. - Mas que serviço? [retrucou o rei Salomão]. - É que eu vou defender a Terra, o céu vai cair hoje. - Mas você vai defender? - Eu faço a minha parte [finalizou a formiga]'. Eu sou a formiga. 


\section{IDENTIFICACÃO}

Nome: Sheikh Abdel Hamed Mohammed Ali Metwally

Local de Nascimento: Egito

Idade: 44 anos

Ocupação: sheikh Mesquita Brasil; primeiro vice-presidente do Conselho Superior dos Teólogos e Assuntos Islâmicos no Brasil.
Escolaridade: (a) Fundamental
(b) Médio
(c) Superior
(d) Pós-graduação

No dia 08/01/2017 entrevistei o sheikh da Mesquita Brasil, Abdel Hamed. O encontro aconteceu na própria mesquita. Ao chegar, acontecia uma aula de religião para mulheres islâmicas e alguns recém-revertidos. Aproximadamente 20 pessoas estavam presentes. Pretendia esperar o fim dessa aula para que então pudesse ser atendido pelo sheikh. Mas a convite dele, me juntei aos presentes e assim como os demais, ouvi a aula ministrada pelo sheikh que falava sempre em árabe, mas contava com a tradução de Yusuf.

Pensei que tivesse havido um mal-entendido, pois quando fiz o agendamento dessa visita junto à secretaria, fui claro em dizer que gostaria de entrevistar o sheikh. Informaram-me que eu deveria chegar "às $12 \mathrm{~h}$, pois haveria aula de religião para mulheres". Entendi que meu encontro se daria após esse compromisso. Não foi bem o que ocorreu. Quando entrei na sala principal da mesquita acreditava que a aula estava próxima do fim. No entanto, como ela durou até as 13h10 aproximadamente, devo ter chegado logo no seu início.

Ao final da aula, houve uma rodada de perguntas feitas pelos presentes. Após algumas delas, o sheikh me convidou para fazer perguntas, mas respondi que o assunto que gostaria de tratar não tinha relação com o tema da aula e preferi fazê-las em particular, caso não houvesse objeção da parte dele. Foi nesse instante que suspeitei que a informação passada ao sheikh era a de que eu faria apenas uma visita.

De qualquer forma, ele acenou positivamente e quando a aula chegou ao fim, uma pequena oração foi feita e então ele me chamou para sentar-me próximo dele e do tradutor. Apresentei-me, expliquei a intenção da entrevista, agradeci a oportunidade e iniciei os questionamentos.

Minha conversa começou com temas amenos, perguntando sobre o sheikh que é formado pela faculdade Da'wa Islâmica do Cairo, tem mestrado e doutorado no departamento de religiões e doutrinas e foi enviado ao Brasil pelo Ministério de Aucaf do Egito ao Brasil. Também é vice-presidente do Conselho Superior dos Teólogos e Assuntos Islâmicos no Brasil.

Em seguida eu disse que já conhecia diversas comunidades islâmicas e algumas de suas lideranças - e citei exemplos - e queria a posição do sheikh sobre o tema do trabalho, sobre o 
fundamentalismo, a possibilidade de radicalização de muçulmanos no Brasil e citei o exemplo daqueles que foram presos por supostamente estarem planejando ataques terroristas no país e de que forma a globalização e a modernidade podem contribuir para isso.

Segundo o sheikh: "a primeira coisa que precisa saber é que a moderação é fundamental para todas as coisas. De onde é quem vem, por exemplo, o extremismo? Isso pode resultar de duas coisas: pode ser por ignorância ou má compreensão. Tudo isso é detestável. A gente aconselha a todos integrantes da sociedade como também os novos...aqueles que se revertem ao islam para que eles procurem seu conhecimento por pessoas qualificadas, que estudaram. Não vão procurar conhecimento através da internet ou através de redes de publicação social seja qualquer que for, facebook, instagram ou outros - não é aí que tem que ir buscar. Tem de procurar alguém que tenha conhecimento para que ele possa receber um conhecimento correto. Por quê? Não é todo aquele que escreve e coloca na internet sabe o que está escrevendo ou tem conhecimento daquilo que está escrevendo. E outros têm intenções de o quê? Adulterar a mensagem ou de corromper outras pessoas que querem a verdade. Por isso vemos essas pessoas que passaram por essa situação [caso das prisões de 14 muçulmanos no Brasil em julho de 2016] até indo parar na cadeia...você vai ver que muitos deles eram o quê? Eram seguidores de pessoas desconhecidas, enquanto não se sabe o que tem por trás daquelas pessoas. Então o correto é a pessoa procurar um teólogo que tenha estudado e que tenha fidelidade no que ele passa às pessoas para que ele se assimile desse teólogo. Por isso...tem o dito de um grande sábio dizendo que 'para esse conhecimento, essa religião. Vejam com quem vocês buscam a vossa religião'. Então tem que ser uma pessoa que tenha a capacidade intelectual, que tenha estudado. Não é qualquer um que se fantasia que se diz sheikh só para alguém se basear em seu conhecimento".

Pergunto então sobre a ijthad, a livre interpretação, se o autodidatismo é perigoso.

O sheikh diz: "quando você fala ijtihad é para teólogo. Não é para qualquer um. O que é ijtihad? É você...é diligência. Quando o teólogo não tem uma fonte, uma prova do Alcorão, uma sunna do profeta (que a paz desça sobre ele), ele pode fazer uma diligência para chegar a um certo resultado. Não é pra qualquer um. É para pessoa estudada, qualificada. Então tem um ponto aqui fundamental: onde é que essas pessoas rezam? Ou, aprendem com quem? Você já procurou?" Nesse momento ambos me olham com um tom inquisitivo e até certo ponto irônico. Respondi que havia conversado com o sheikh Ahmad AlKhatib que trabalhou com uma das pessoas que havia sido presa pela polícia federal e que o teria colocado como "mentor", como seu guia sem que o próprio sheikh Ahmad tivesse conhecimento. 
Ele responde: “então...primeiro o sheikh Ahmad não tem qualificação, não nenhum certificado que prove que ele é um sheikh...alguma coisa sabe, mas provavelmente se ele estudou, não tem. Como também não tem nenhuma sociedade que ele representa como sheikh...uma mesquita ou algo parecido". Sobre isso, apontei que durante um período ele teria passado por Campinas/SP. Sou interrompido. "Ele ia só fazer sermão e voltava". Isso de fato é verdade, pois o próprio sheikh Ahmad em sua entrevista me disse que quando faltou o sheikh na Mesquita de Campinas, ele foi chamado e para fazer sermões até pelo fato de falar português, mas que ele não tinha interesse em ser sheikh de mesquita, uma vez que seu interesse maior era em projetos (aulas, cursos, trabalhos em comunidades etc). Ainda argumentei que independente de quem seja, isso pode ser um perigo: de alguém que não tenha conhecimento influenciar outras pessoas.

O sheikh afirma que "o início do erro deles é de usar alguém que não tenha capacidade com alguém que possa ser fonte de busca dos pareceres religiosos. Então esse é o problema. Eu não digo que o sheikh Ahmad não tenha essa capacidade. Até pode ter...mas muito dessas pessoas que chegam a cair no extremismo é por falta de conhecimento, ou seja, o conhecimento dele é baseado nas pessoas que não têm nem prudência nem sabedoria adequada que possa levar a um caminho reto".

Indago se outra causa de extremismo possa estar ligada aos aspectos da globalização e da modernidade: desigualdade, injustiças, busca por homogeneizar culturas e valores etc em que muitos não aceitam isso e sequestram a religião para atitudes extremistas. Ele diz: "não há nenhuma pessoa que tenha direito de querer colocar outras pessoas no que ele pensa ou na ideologia dele. Os profetas vieram para trazer as mensagens de Deus exatamente para ensinar o Alcorão. Não tinha a obrigação de colocar ninguém...é...à força na ideologia deles. Então o que nós temos a dizer é propagar o que é a verdade e impedir o que é falsidade. Agora, você colocar as pessoas...e...e... ideologizar as pessoas isso aí não pode! Não pode! [se exalta]. Você propaga o bem. Quem quer que siga. Agora, você matar as pessoas...os profetas...tinham pessoas que não acreditavam neles e até os combatiam. Mas não vimos nenhuma situação em que eles faziam o que hoje as pessoas fazem em nome da religião. Então se eles fazem isso, entre aspas, em nome da religião é porque não entenderam a religião. Tem muitos versículos que falam que não é imposição da religião. Então você nunca pode obrigar as pessoas a seguir o que você quer. Agora, dizer por exemplo que fazem o que fazem pela injustiça, pelo o que ocorre no mundo.... por que não começam pelo seu país? Por exemplo, acabar com a injustiça com aquilo que acontece dentro do país. Não olha pra Síria, não olha pro Iraque, não olha pra aqueles países do mundo que tão no conflito. Aqui tem por exemplo, crimes organizados. Tudo 
isso faz parte da injustiça. Então por que não acreditar em resolver o que está dentro do seu país? Isso por falta de conhecimento."

Após essa fala, introduzo a questão sobre a fragmentação entre as comunidades islâmicas no Brasil e porque não há uma resposta clara e uníssona dessas comunidades aos eventos negativos que envolvem a religião e alguns de seus supostos seguidores e mesmo de tentar coibir. A reflexão proposta pelo sheikh é a seguinte: "não existe nenhuma separação entre o que é as sociedades. Muito pelo contrário. Elas estão juntas, elas têm uma voz única. O que você vê talvez é a verdade das organizações islâmicas. Por quê? A cidade de São Paulo, por exemplo. Não seria possível, as pessoas todas rezar aqui. Por isso tem a mesquita aqui, de São Bernardo, tem Brás, tem não sei o que...mas todos esses têm o quê? Tem suas lideranças. Sheikhs que estão lá. E esses sheikhs, eles fazem parte do que? Conselho superior de teólogos. Então você pensa que estão divididos...não se trata de nenhuma divisão. O que existe, ao contrário disso, é a aquelas pessoas que tentam buscar seu conhecimento através de internet. Porque acabam já caindo nessa armadilha satânica até acontecer o que aconteceu com eles [os presos pela polícia federal]. Então...mas pra quem é sensato, ele tem liderança sim e tem sheikh. Onde se encontra o primeiro centro islâmico na América Latina? Aqui, a Mesquita Brasil! A instituição tem aproximadamente 80 anos. E desde sua fundação até hoje sempre recebeu um grupo de teólogos que vem do Egito...vem ensinar aqui. E nunca aconteceu absolutamente nada. Você veio aqui hoje e viu um grupo de brasileiros aprendendo aqui. O que que você ouviu falar?” Eu respondi: aspectos da religião; regras religiosas, algo inofensivo, coisas boas. O sheikh continua: "coisas boas! É isso que sempre se ensina!".

Questiono sobre o papel que a mídia tem para desconstruir a imagem do islam que por sua vez provoca reações na sociedade, de preconceito e desconfiança. E nota-se uma falta de que instituições como o conselho superior dos teólogos terem uma voz mais ativa e mostrar o "verdadeiro islam". O sheikh afirma: "mas infelizmente as pessoas não querem ler, não querem estudar. Querem ouvir só o que a mídia fala. A Globo News não sei o que disse e acabou! Mas nós estamos vendo que a própria mídia está a frente de tudo para conseguir manipular a favor deles [se exalta]. Como a política brasileira, que também mudou. Graças a eles! [exclama]...tem muitos que vem aqui pesquisar e tentar conhecer a face verdadeira do islam e quando conhecem acabam abraçando o islam".

O sheikh interrompe querendo saber se há mais perguntas e aponta discretamente para o relógio. Ao mesmo tempo percebo que há uma maior movimentação na mesquita e me dou conta de que o sheikh teria outro compromisso. Aproveito para então fazer uma última questão acerca do fundamentalismo islâmico, sua opinião sobre o assunto. Ele diz: "a etimologia da 
palavra é essa: se voltar para as escrituras sagradas sob orientação de um sheikh. Agora...usar com outros fundamentos é o que se está fazendo hoje em dia. Por exemplo: você ouviu ontem, sobre....aquilo...como chama? No presídio [briga entre facções em Roraima e Manaus] no norte do Brasil? Aquilo ali não é terrorismo! Aquilo é crime organizado. Agora, se um muçulmano mata alguém, aí é terrorismo! [se exalta em tom irônico]. Isso tudo é o quê? Alienação! Ontem, nos Estados Unidos [atentado em Fort Lauderdale]! É isso que acontece. Lá é atirador. Mas se for muçulmano é terrorista! Por quê? Esses coisas sobre política...política geral...querem manchar a imagem dos muçulmanos e do islam”. Eu pergunto por quê?

“É isso que eles fazem...querem manchar! [se exalta]. Mesmo assim, qual é a maior religião do mundo hoje em dia? O islam é a que mais cresce! Parece uma omelete: mais bate, mais cresce [risos]. Então, cada vez que eles falam assim, as pessoas acabam buscando a verdade. Eles buscam a verdade e acabam abraçando o islam. E você vê hoje em dia...tão falando tudo que tão falando...mas alguém está falando o que está acontecendo em Burma, com os muçulmanos? República Centro Africana? Pessoas a ser queimadas vivas! Na Síria! Em Burma, os monges o que que fazem com muçulmanos? [Nesse momento, começa a chamada à oração na mesquita feita por um jovem] ninguém fala absolutamente nada. O segredo é conhecer melhor o islam [finaliza].

Agradeço a oportunidade do encontro e peço autorização para que eu possa enviar demais dúvidas por e-mail e o sheikh disse que estará disponível para respondê-las. 


\section{IDENTIFICACÃO}

Nome: Alaa El Din Moussally/Nader

Local de Nascimento: Damasco/Brasil (não informou a cidade), respectivamente.

Idade: 27 anos/nd.

Ocupação: desempregado/secretário da SIC (Sociedade Islâmica de Campinas).
Escolaridade: (a) Fundamental
(b) Médio
(c) Superior
(d) Pós-graduação

Na quarta-feira dia 04/11/2015 pude me encontrar com três refugiados sírios no Centro Islâmico de Campinas. Eles eram Mouhamad Brnbou, Alaa El-Deen Moussally e Hoda Dado e estão no Brasil há aproximadamente um ano. Para dar maior fluidez à conversa em razão do idioma, uma vez que falam o português de forma muito básica, houve a intermediação de Nader, secretário do Centro Islâmico de Campinas, que por vezes também fez interferências pessoais à conversa. Entretanto, entre os três refugiados, foi Alaa El-Deen quem mais forneceu informações e toda a conversa ficou em torno dele. Enquanto isso, seu primo Mouhamad e sua tia Hoda basicamente observaram e apenas confirmaram algumas informações.

A primeira pergunta foi sobre o que faziam lá antes de vir ao Brasil e por que escolheram esse país como refúgio. Alaa disse que "em Síria, trabalho com mármore. Minha família é de Damasco...lá menos complicado porque é perto da casa do presidente. Veio para Brasil, porque Brasil ser mais fácil...não precisa visto...eu gosta do Brasil, mas o que faz? Aqui muito perigoso". Nesse instante houve alguns risos, especialmente dele e de Nader, uma vez que é uma situação um tanto ambígua já que saíram de um país em guerra civil mas têm medo da violência do Brasil.

Ao ser perguntado sobre por onde passou desde que chegou ao Brasil, ele disse: "Eu morar em São Paulo três semanas...mas não gostei...muita gente, muito carro...aqui mais tranquilo".

Revelaram, entretanto, que no domingo seguinte, portanto dia 08/11/2015 estariam de partida para Turquia. Estão deixando o Brasil. Afirmaram isso com olhar cabisbaixo e com voz em tom de desolação.

Nader então resume a fala de Alaa: "Então, a ideia deles é ir para a Turquia agora, e aí pegar o barco para atravessar o mar. Eles vão arriscar". Alaa complementa demonstrando uma grande preocupação com a travessia: "você viu criança morta na praia em Grécia?...mas o que faz?" Ao que Nader diz que "eles querem arriscar e fazer a mesma travessia semana que vem”.

Alaa ainda afirma que "quero voltar para o Brasil um dia...mas depois...agora muito difícil". Ao perguntado se tem parentes na Síria ainda Alaa responde: “pai, mãe e tem 
irmão...mas não vão para outro país...tá difícil...não querem sair, tem casa, empresa, deixa tudo vai pra outro país, não querer...mas tão bem, graças a Deus”.

Perguntei qual foi o marco, ou o momento em que decidiram fugir da Síria e vir para o Brasil, se teria sido perda de casas em bombardeios, medo, perda de parentes etc. Alaa diz que “eu tenho casa e fábrica também...destruiu com guerra. Todo dia tem ataque". Mouhamad acrescenta que "dois irmão da minha mãe faz quatro anos não saber onde está".

Questionei sobre a política síria, com relação à presença de Assad e de outras pessoas que querem sua saída. Alaa confessa: "nós não gostar de Assad...muito dictador, sabe dictador?". E eu acrescentei: e se não existisse o Estado Islâmico, mesmo assim teriam deixado a Síria? E ele diz simplesmente: "é complicado". Em seguida quis saber qual a opinião deles sobre a possível saída de Assad e Alaa me interrompe dizendo: “Assad não sai. Difícil. Muito difícil. Mas se sai, fica pior. Sabe, agora tem islâmico do Daesh, Al-Qaeda. Mas a Rússia ajuda presidente. Irã também. Hezbollah libanês também".

Nader então exprime sua opinião sobre o conflito com base na fala de Ala: "para gente entender, que o conflito que tem lá, tanto na Síria como em outras localidades do Oriente Médio, não caiam na armadilha de achar que aquilo é religioso, nem que fala na tv que são conflitos religiosos. Não tem absolutamente nada de religioso [e aumenta a entonação]. São conflitos políticos. Tudo isso que tá acontecendo lá é em função da geopolítica mundial. Só que a gente analisar o que o Alaa tá falando, a gente um presidente e tem grupos contra...rebeldes, por exemplo o Estado Islâmico, a Al-Qaeda, o Hezbollah...se a gente analisar essa conjuntura a gente vai ver que esses grupos também são grupos políticos. Os partidos políticos que surgiram no mundo árabe, surgiram nas décadas de 50 e 60, após a Segunda Guerra Mundial. Então esses países se aliaram ao comunismo e à URSS. Se pegamos o Iraque, o Saddam Hussein e outros, o próprio Bin Laden no Afeganistão, lembra do filme Rambo III? Em que os americanos defendiam os afegãos contra o domínio soviético. Depois o que aconteceu? Quando houve o desmantelamento da URSS e a Rússia ficou isolada pois as demais repúblicas lutaram pela independência...com desmembramento daquela estrutura, algumas repúblicas do Oriente Médio também ó [e bate com as mãos] largaram mão dos soviéticos. Só que o Bashar Al-Assad...o pai dele... [e Alaa intervém lembrando o nome de Hafez Al-Assad]...o pai dele Hafez por exemplo, e o próprio Bashar, eles mantiveram aliados aos russos. Então o que aconteceu? Os Estados Unidos foram lá e arrebentou....eles compraram Saddam Hussein, depois transformaram ele num vilão, arrebentaram com ele. Depois o Ghadafi, arrebentaram com ele. E olha como esses caras morreram! [exclamou]. Então os americanos vão ocupando aquela região dessa maneira. Então, como Bashar manteve-se aliado aos russos, então os russos não deixam ninguém entrar 
lá. Eles têm o poder de veto dentro do conselho de segurança da ONU. Então ninguém pega, ninguém tira o Bashar de lá! [exclama mais uma vez]. Os americanos patrocinaram esse grupo de jovens rebeldes que pegaram no Oriente Médio, Europa e Ásia - tem indiano, paquistanês, tem europeu - a maioria é de vagabundo". Nesse ponto Alaa interrompe, concorda e complementa que esses jovens aliciados "estão felizes, pois não tem o que fazer no país deles...desempregados".

Nader continua: "os americanos patrocinam, deram treinamento para eles na Inglaterra, providenciaram armas e os britânicos treinaram. Isso quem falou foi a Cristina Kirchner [presidente da Argentina], na última reunião da ONU. A Dilma foi contra apoiar...tanto os rebeldes como o Bashar. Brasil não apoia. E a Argentina a mesma coisa. A Cristina Kirchner falou assim: 'vocês há dois anos falaram pra gente que tinha que derrubar o Bashar, que ele era um ditador, e apoiar os rebeldes. Agora vocês falam que são os rebeldes que formaram esse dito Estado Islâmico? É um grupo terrorista, e Bashar tem que ser protegido”. Essa inversão de valores, a gente tem que prestar atenção. Lê nas entrelinhas o quanto de sujeira tem por trás disso. E quem paga o pato? O povo [apontando para os refugiados ali presentes]. Esses grupos que tão lá, todos eles hoje representam uma ameaça. Você [Victor] perguntou se o Bashar sair....Vai ficar muito pior! [exclama]. Porque é um bando de maluco, tudo interesseiro, estão lá pelo dinheiro e pelo poder, ninguém quer saber de religião".

Sobre isso insisti em saber se o Estado Islâmico representa os muçulmanos e a religião. Nader, assim como Ala, Hoda e Mouhamad em tom uníssono e sacudindo a cabeça negativamente respondem: “de jeito nenhum!”. Nader acrescenta: "a gente vê daqui do Ocidente esses vagabundos lá matando pessoas de forma bárbara, de forma horrosa...aquilo é assassinato! Dizem Allahu Akbar! E corta a cabeça do cara! Taca fogo em outro! O que é isso? [se exalta]. No Islam tem um versículo no Corão que se você mata um inocente equivale a ter matado a humanidade toda. Quantas pessoas existem hoje na humanidade? Ah, 6 ou 7 bilhões? Não! Na humanidade toda quer dizer desde o primeiro ser humano, desde Adão até o último que ainda vai nascer...é um pecado gravíssimo! Você não pode tirar a vida de ninguém. Então o que esses vagabundos estão fazendo não é o Islam, isso é política, isso são grupos, guerrilhas armadas que não tem vínculo nenhum com a religião. E eles ficam lá com turbante, ficam gritando palavras de ordem...são um bando de vagabundos, eles não são muçulmanos”. Logo em seguida Alaa lembra da questão sectária em seu país: "ainda tem problema entre alauíta, xiita e suni". Nader completa que "quando Saddam Hussein foi derrubado do poder, teve seu grupo de fiéis, que eram da cúpula do exército...esse grupo é sunita e se manteve fiel a Saddam Hussein. Então eles [Estado Islâmico] têm treinamento, são militares, são profissionais e tem 
armas. Há outra coisa, que pouco se fala mesmo em mesquitas que é: qual o mapa do Islam? Porque dentro do Islam, você tem facções, você tem grupos. Então chamam de sunita aquele que segue a tradição do profeta, chama de xiita aquele que é considerado mais radical, mas de onde veio isso? Shi’a veio de partidário de Ali que era primo do profeta, foi o quarto califa depois da morte do profeta alguns disseram pra ele quando o profeta morreu que ele deveria ter assumido pois ele era parente de sangue dele. E ele próprio, Ali, falou não. Mas esse movimento foi crescendo...para nós muçulmanos em geral era algo fraco, a gente não ouvia falar disso até 15, 20 anos atrás com a intensidade que tem hoje. Por exemplo, os opositores de Saddam Hussein eram de maioria xiita e na Síria você tem sunita, xiita e alauíta como o presidente. Então são facções que já se distanciaram e muito, se afastaram do que é o Islam”. Interrompo para perguntar se ele e sua família são sunitas ou xiitas. Ala responde: "sou muçulmano". Nader acrescenta: "a gente não vê diferença. Tem até uma piada que a gente conta, mas não vai falar la fora [risos], teve um debate entre um sheikh sunita e outro xiita. Só que eles combinaram de fazer esse debate na mesquita xiita. Aí quando o sheikh sunita entrou lá, ele tirou o chinelo e colocou debaixo do braço e pisou no carpete. Aí o sheikh xiita falou: 'espera aí, para com isso! Por que você está entrando com um chinelo? Coloca na estante lá'. Aí o sheikh sunita disse: 'não, é ensinamento do profeta que quando se entra numa mesquita xiita deve-se colocar o chinelo debaixo do braço'. E o xiita responde: 'mas na época do profeta nem existia xiita!' E o sheikh sunita então diz: 'então acabou o debate' [risos]. Só que pra discutir essas questões no Ocidente é muito difícil. Por quê? Porque a população ocidental mal sabe o que é o Islam. O que acham que é o Islam? Terrorista! Homem-bomba! Barbudos!” Alaa aproveita, e rindo brinca: "eu uso barba só porque gosto viu!".

Após esse bloco de reflexão, perguntei qual foi o "choque" ao chegar ao Brasil, quais foram as principais diferenças em se tratando de culturas bem distintas. Além disso, se sofreram algum tipo de preconceito aqui. Alaa diz que "adoro Síria. Nasci lá. Quero voltar para lá”. Aqui é muito diferente de lá. Por exemplo, olha mulher aqui: aqui não fecha cabelo [não se usa o véu]...por exemplo...a gente...comida...não pode comida de porco...cerveja...mas eu bebo e fumo [risos]. O que faz falta quando ir embora é a simpatia de brasileiros. Sempre trata bem, com sorriso. Na Síria, um pouco mais fechado. Mas agora no Brasil tem crise...esse difícil....pouco salário, pouco trabalho...acho que Brasil pobre também. A gente precisa, mas o brasileiro precisa mais. Agora por exemplo: quanto tá o dólar? Quase quatro! Sabe, quando eu cheguei no Brasil, sabe quando [custava] o dólar? R \$2,30 [o dólar] Agora olha só, uma ano [depois], muito diferente". 
Questionei em seguida, se não seria mais fácil eles irem para outro país árabemuçulmano mais próximo, como Egito e Jordânia, por exemplo, até por afinidades culturais e linguísticas. Alaa explica “que lá não pode, não tem visto. Brasil, olha só...muito longe, mas visto fácil. Eles abre porta e depois fecha rápido". Nader complementa: “a política nesses países árabes, se partir da lógica da língua e da cultura como você [Victor] disse ser um facilitador, mas é a política que manda. Então esses governos não abrem espaço para os sírios, não abrem espaço para entrar...é como o Alaa falou: abre um período pequeno, dá uma janela e depois fecha rápido. Porque são países em crise, estão em uma situação ruim também, a vida lá é dura, também tão desempregados, passam fome. Para o Líbano foram vários sírios, cerca de 1 milhão, mas o país é pequeno, você praticamente dobra a população. Quando se abre a oportunidade como o Brasil, de receber sírios, desde que os custos sejam deles, há maior fluxo para cá. Só que quem atravessa o oceano, são pessoas que têm condições [financeiras]. Então a gente fala, até para prefeitura de Campinas: olha, o governo brasileiro recebeu de graça mão-de-obra qualificada. A especialidade desse aqui é mármore [apontando para Ala], outro vizinho deles trabalha com pintura, decoração mais alto nível, eles têm conhecimento lá que aqui você não vê. Tem médicos, engenheiros...tem pessoas que vem de um bom nível profissional...seria inteligência nossa, e dos governos ocidentais, absorver essa mão-de-obra qualificada que aqui a gente carece um pouquinho.

No momento final da conversa, quando perguntei quais a perspectivas de futuro, um futuro próximo, uma vez que estão de partida para a Turquia tentar a travessia para a Europa, Alaa diz que "espera que lá, temos que aprender a língua, mas acho que vai ter mais oportunidade que aqui. Lá tem apoio de governo". Perguntei para qual país tem preferência e Alaa disse ser “Alemanha, Suíça ou Suécia...eu vai ver quando chegar lá...está na mão de Deus”. Descobri posteriormente que a maior intenção era a Suécia pelo fato de lá já ter um parente, um tio.

Nader disse, com relação à pretensa travessia, que "se colocar na ponta do lápis, as chances são pequenas...mas não adianta falar que não mudam de ideia. A família deles quer arriscar. O primo de Alaa, Mouhamad, disse que não vai a lugar algum sem Alaa. Cria-se um vinculo muito forte nessas situações....eles estão indo embora sabendo que ou todo mundo ou alguém vai morrer [na travessia].

Sobre o fundamentalismo Alaa, através de Nader, afirma que "não pode generalizar. Nem todo muçulmano é radical. Não gosta e não aceita, eles são minoria. Tem muitas informações que a mídia [sionista] traz que são falsas. Não posso dizer que há problema com judeu...ele é um crente como outro qualquer, judeu é meu irmão. Tanto é que a gente usa a 
palavra sionista, o sionismo que já é uma estrutura política, paramilitar, que foi quem elaborou a criação do Estado de Israel, desde Theodor Herzl, que elaborou um plano para em 50 anos se criar o Estado Judeu. Aí eles tinham opções: Argentina, Sibéria e Palestina. Eles optaram pela palestina pois era o único país no mundo que não tinha milícia, não tinha exército, não tinha quem protegesse sua fronteira. E em 1948, se criou o Estado de Israel. Não tenho nada contra o judeu. O problema é o sionismo. O judeu não é o problema, é o sionismo [repete]. A criação de Israel naquela região desequilibrou o Oriente Médio e aí você começa ter aquele choque de forças, com o imperialismo norte-americano, com uma célula, com um núcleo, com a presença do Estado Israelense".

A conversa terminou após cerca de uma hora pois teriam que voltar para Hortolândia, cidade em que moram, para continuar a se desfazer de alguns móveis da casa e também teriam que ir trocar dinheiro para a viagem. Agradeci a oportunidade, desejei sucesso nessa perigosa empreitada e tiramos fotos. Aliás, apenas com os celulares deles, pois não queriam que fotos deles pudessem eventualmente correr por redes sociais, pois estão preocupados com sua segurança e de sua família, que parte dela ainda mora na Síria. 


\section{IDENTIFICACÃO}

Nome: Issa Alturk

Local de Nascimento: Homs

Idade: 35

Ocupação: Auxiliar de cozinha no Brasil/ Comerciante na Síria no ramo de tecidos.
Escolaridade: (a) Fundamental
(b) Médio
(c) Superior
(d) Pós-graduação

No dia 25/09/2015, eu e um amigo egípcio chamado Hossan nos encontramos na mesquita de Campinas e em seguida fomos a um restaurante no centro da cidade chamado Restaurante Castelo, há 6 meses aberto, dirigido pela família Zeina, refugiada da Síria e que chegou à cidade há 2 anos aproximadamente. A família é composta por quatro pessoas, o pai Abu Kamel, sua esposa e duas filhas. Abu Kamel era engenheiro na Síria e uma de suas filhas, médica, estava ao caixa quando lá estive. Hossan, me ajudou com a tradução e a fluidez na conversa, pois entre os presentes, todos ainda tinham dificuldades com o idioma local. Logo de início, ao ser apresentado, perguntaram-me se eu era jornalista (por eu estar com uma bolsa que lembra aquelas de carregar câmeras). Mas logo os saudei e respondi em meu árabe básico: Assalamu aleikum! Aná Ostádon. Aná àmalo fi madrassa Liceu. (Sou professor. Trabalho na escola Liceu) E todos se supreenderam, e riram quebrando um pouco o gelo. Avisei que sabia um pouco da língua, mas que a achava muito difícil.

Enquanto almoçávamos, cerca de 6 sírios, todos recém-chegados ao Brasil, estavam na mesa ao lado conversando, entre eles Issa e seus primos Fadi, Jouny e Elias. Aos poucos fui me inserindo à conversa mediada por meu amigo Hossan que já conhecia o dono do restaurante Abu Kamel, que por sua vez nos apresentou aos demais e se juntou a nós para falar sobre sua vinda ao Brasil. Muito se falou sobre isso e pouco sobre a situação do país de onde vieram, apesar de minha insistência em algumas perguntas e curiosidades. Sobre isso, todas elas eram respondidas de forma superficial e genérica. Imagino que ainda fruto do trauma vivido, dos entes perdidos e talvez por certa desconfiança com relação à minha pessoa, ainda estranha para todos.

Todos demonstraram gratidão e alegria com a recepção e hospitalidade dos brasileiros, mas que não sabiam que o país estava passando por uma grave crise econômica e com preços elevados, encarecendo seus custos de vida. Todos foram unânimes em dizer que escolheram o Brasil por causa da facilidade em se obterem vistos.

Quando perguntei a Abu Kamel quais os motivos que os levaram a sair de seu país, se eram devido ao governo de Bashar Al Assad ou à presença de grupos extremistas como o Estado Islâmico, Abu Kamel então pegou um porta-guardanapos que estava sobre a mesa e disse: "esse 
minha casa. Aqui, governo. Aqui, Daesh. Eu sair por causa da guerra”. Deixou claro que sua casa ficava exatamente na linha de fogo entre o governo e os jihadistas. Ainda afirmou que perdeu vários amigos e vizinhos e que já não reconhecia o bairro em que viva. Foi então que resolveu vir para o Brasil com sua família.

Posteriormente, ele se retirou e a conversa se concentrou entre mim, Hossan e Issa, que era quem estava há mais tempo no Brasil e fala um português mais compreensível. Contudo, a conversa se deu quase toda em árabe. Os outros apenas acenavam com a cabeça concordando com o que era dito à medida que havia tradução de Hossan.

Como dito antes, nessa primeira conversa, pouco foi revelado sobre o conflito e muito sobre a vida que têm levado aqui no Brasil. Os relatos a seguir são feitos pela tradução do árabe para o português com ajuda de Hossan.

Issa reclamou que moram "todos juntos (quatro adultos e duas crianças) no mesmo quarto...eu estou casado e tenho um filho de 11 meses. Para escolher uma casa fui até Sumaré para conseguir uma casa mais barata, mas não estava achando...o custo de vida no Brasil é muito caro para a família".

Perguntei sobre como foi chegar a um país com costumes tão diferentes da Síria, especialmente em termos religiosos. Além disso, quis saber se sofreram algum tipo de preconceito no tempo em que aqui estão. Como resposta, Issa disse que "não tiveram problemas quanto ao preconceito e que em termos culturais, o maior choque foi a presença mais flagrante de homossexuais em diversos lugares, como praças públicas e a quantidade de mendigos na rua, algo raro na Síria."

Um ponto bastante sensível na conversa, até certo ponto emocionante, foi quando Issa disse que "se demorar mais um pouco [para as coisas melhorarem] eu vou tentar outro caminho, vou pegar um barco e tentar a Europa. Prefiro morrer no mar a ver minha família morrer aqui aos poucos. Citou a Alemanha como exemplo e disse que quando se chega lá, um casal ganha do governo mil euros, com seguro, com tudo, até com escola. Aqui não há nenhuma ajuda do governo, apenas de pessoas”. Nem escola para aprender português encontram. O pouco de dinheiro que consegue, a maior parte vai para o aluguel e outra parte para escola do filho.

Entre os pontos positivos, destaca que o povo brasileiro "abraça eles... são receptivos. Quando sabem que venho da Síria, ficam com pena, me chamam de 'tadinho' mas me ajudam. Já nos países árabes como Egito, sentem preconceito”. Meu tradutor Hossan, disse que não concorda com esse último ponto, mas apenas traduz literalmente o que é dito. Nesse momento, Abu Kamel interfere dizendo que "para brasileiros, sírios não são estrangeiros, eles nos abraçam". 
Issa também afirma que "antes da crise, da guerra, eu trabalhava, tinha algum dinheiro. Mas quando aconteceu a guerra perdi tudo. Vendi tudo o que tinha, especialmente joias de casamento para vir para cá. Fogão, geladeira e a própria casa não foram vendidos pois quase ninguém queria comprar pois estavam também em fuga. Apesar disso, achava que teria algum apoio, algo que não aconteceu. Então o peso de ter que cuidar da família é muito grande em um lugar sem ajuda".

Com relação às doações, perguntei como eu poderia ser útil, e Hossan assim traduziu: “depende da ajuda e de quem ajuda. Se alguém doa de maneira que nós sentimos ser um tipo de obrigação ou por querer alguma vantagem em troca, não aceitamos. Aceitamos quando notamos algum carinho, quando percebem que a pessoa de fato quer ajudar, sem arrogância, sem demonstrar pena só por serem sírios". O constrangimento quanto a receber doações se deve ao fato de que na Síria eles não precisavam da ajuda de ninguém, tinham emprego e recursos. Mas nessa fase eles precisam, pois estão no 'zero', começando do nada.

No dia 01/11/2015 tive meu segundo encontro, agora sozinho, com Issa. Ele se deu no Shopping D. Pedro em frente ao restaurante Outback, onde trabalha como ajudante de cozinha.

Issa tinha uma fábrica de roupas que vendia para lojas. Segundo ele, "eu vende roupa para loja que vende pessoas [para pessoas]". Seu trabalho no Outback na opinião dele é "mais ou menos...muito difícil ônibus para Matão [onde mora]. Eu falou [para meu] chefe: tempo do trabalho não muito bem [bom]...eu falou precisa fazer trabalho 8 horas até 4 ou 5 horas". Nos dias em que horários de trabalho vão até mais tarde, ele vai até o centro de Campinas e dorme na casa do seu irmão. Sobre sua família no Brasil, ele diz que seu "irmão trabalhando como pedreiro e pintor. Irmão, primos, todos trabalham com pintura, colocam telhados, pisos”.

Sobre o valor que ganha no restaurante ele diz: "Eu trabalho 1 h e ganho $\mathrm{R} \$ 4,90$ [R $\$ 4,90$ por hora de trabalho]. Trabalho 6 hora, 7 hora em um dia...um semana eu preciso trabalho [trabalhar] 35hora. 35hora, mais ou menos...R $\$ 75$. Quatro semana...até $\mathrm{R} \$ 800,00$ por mês. Mas eu tenho 'tip' [gorjeta]. O tip ajuda pouco...uma semana $\mathrm{R} \$ 100,00$ reais, outra $\mathrm{R} \$ 125,00$ ”.

Pergunto se tem mantido contato com a Síria. Então ele diminui o tom de voz, faz um silêncio e responde: "mas aqui tenho trabalho graças a Deus". E eu insisto sobre as informações que tem da Síria, sobre parte da família que ficou lá. Ele disse: "quase toda família lá, entende? Pai e mãe não. Mora em Jordânia. Um irmão, tio e tia em Síria. Eles não deixa Síria”. Perguntei os locais em que vivem e ele citou três lugares: "Hama, Damasco, Homs. Mas família ali é muito difícil."

Sobre as ações internacionais, especificamente com a recente entrada da Rússia nos enfrentamentos, ele reage: "Eu acho Rússia fazer bem. Porque América [Estados Unidos]...ela 
fazer guerra Estado Islâmico. Mas um ano não fazer nada. Rússia um mês! [e exalta e gesticula com a mão indicando que já está resolvido]. Agora América paga 1 milhão de dolars para terroristas...1 milhão! vai parar na mão de terroristas. Mas quase todas pessoas em Brasil falou [falam que] Bashar Al-Assad não bem [não é bom]. Mas ele fazer Síria muito forte, ele fazer Síria muito bonita, ele fazer Síria muito, muito forte. Mas Arábia Saudita, Qatar, Turquia quer tirar Assad. Por quê? Antes América fazer guerra Iraque. Todos presidentes árabes fala assim: não...não precisa fazer guerra Iraque. Iraque muito perto, irmãos. Não precisa fazer guerra. Assad falou: por que precisa Saddam tirar? [Tirar Saddam do poder]. América fazer guerra Iraque, Iraque acabou. Terrorista depois [terroristas chegam em seguida].

América fala precisa fazer pez [paz] com Israel. Ele [Bashar] fala não. Israel tem guerra com Síria em Golan. Ele fala não: Israel voltar Golan eu fazer pez [Israel devolve Golan então eu faço a paz].

Mas América, Europa, fazer média internacional...Bashar Al Assad não bem [não é bom]. Não precisa. Pessoas olha a verdade [as pessoas enxergar a verdade].

Ao falar das diferenças sectárias que tem seus simpatizantes e que polarizam os apoios, como Síria, Irã e Hezbollah de um lado e Turquia, Qatar e Arábia Saudita de outro ele diz. "Você sabe: muslimano tem suni e shi'i [entre muçulmanos há sunitas e xiitas]. Quase todo árabe suni. Mas Bashar shi’i, Irã, shi’i. 1400 anos suni e shi’i em guerra. Até agora não tem pez [e bate as mãos em sinal de inexistência]. Bashar shi'i, precisa shi'i [justificando a ajuda do Irã e outros grupos xiitas]. Na Síria não tem problema, suni, shi`i, cristianos [cristãos]...não tem problema. Se presidente fazer bem, não tem problema. Normal. Ele [Assad] shi'i mas fazer Síria muito bem, tem dinheiro bom, muito forte. Salário pessoas antes, muito bom...5mil...agora 20 mil lira [se exalta, demonstra alegria]". Pergunto quanto isso seria em dólares e ele responde: “ehhh...antes guerra mais ou menos...ehhhh...600 a 700 dolars. Mas agora, 20 mil...3 mil, 4 mil alugar casa....muito barato. Síria, muito barato. Aqui...Coca-cola...ehhh...um garrafa 2 litro R\$ $5,00 \ldots$..em Síria...quanto em reais? $\mathrm{R} \$ 1,50$ reais!"’.

Ao final da conversa, uma vez que demonstrava ansiedade para terminar até porque precisava pegar um ônibus para retornar para casa, finaliza: “Quero trabalho, trabalho, trabalho...melhor trabalho. Eu falo amigos: preciso olhar outro trabalho. Salário é pouco...Aqui quase $\mathrm{R} \$ 1.000$, e só aluguel casa, 800 reais".

Por fim perguntei sobre seu pequeno filho Diego (com perto de 1 ano de idade). Disse que está em uma creche. Mas que o diretor não cobra a mensalidade.

Entreguei um jogo de cobertores e roupas de cama como doação. Ele agradeceu, me abraçou, virou as costas e seguiu para o ponto de ônibus. Um fato que chamou a atenção é que 
ao pegar a sacola com as doações, senti um pouco de constrangimento da parte dele, pois estávamos conversando em público e ainda persiste aquele dúbio sentimento de orgulho e de grande necessidade. 


\section{IDENTIFICACÃO}

Nome: Muhamad Tawfiq/ Abdoul Savadogo/Thiago

Idade: 54 anos/n.d/n.d.

Local de Nascimento: Ouagadougou/Burkina Faso/Israel/Brasil, respectivamente.

Ocupação: Antropólogo/Presidente da AMBN e Comerciante/Cientista Social

Em 24/02/2017 realizem minha mais recente entrevista na comunidade islâmica de Natal/RN, considerada a terceira maior do Nordeste. Primeiramente acompanhei o sermão que foi realizado pelo presidente da Associação Muçulmana Beneficente de Natal/RN, Muhamad Tawfiq, uma vez que não há sheikh. Todo o sermão foi feito em português, mas com algumas frases em árabe que logo eram traduzidas para os presentes. Era o dia de inauguração do espaço que abriga a sede, o que foi positivo do ponto de vista do registro desse evento pois havia muitos presentes.

A entrevista aconteceu em grupo, com a presença de Muhamad Tawfiq, Abdoul Hadi Savadogo e Thiago.

Inicialmente, ainda no salão de orações, assim que o sermão teve fim iniciei de modo informal um bate papo com Abdoul que logo se apresentou em um bom português [está no país há 4 anos] mas com um acentuado sotaque francês e quis saber o motivo de minha visita e sobre o que eu estava pesquisando. Expliquei o que desejava saber e também perguntei sobre sua origem, seus estudos e o modo como enxerga o islam no Brasil, especialmente ele que é cidadão de Burkina Faso.

Abdoul diz: "você vê, por exemplo, não só na questão do islam mas a questão social de forma geral. Os estrangeiros, algo que a sociedade não conheça, a população tem uma reação mais ou menos mais tranquila aqui. Aí você vai...como se diz...tirando a poeira...e você vê claramente que tem aqueles que não sabem...e acham que são [muçulmanos] perigosos. O que tá claro é o assédio, por exemplo, das comunidades muçulmanas, o assédio principalmente quando se fala de comunidade muçulmana no Brasil, são as pessoas árabes, do oriente...o que as pessoas chamam de as comunidas brancas africanas como Líbia, Egito. Então as comunidades brancas muçulmanas são elas geralmente que são vistas como as comunidades muçulmanas e que pela imigração são as mais velhas também. A questão que eu queria trazer é o fato que eles são de um certo jeito as comunidades que movem, como se diz, a economia. E o assédio são nessas pessoas. Os muçulmanos principalmente, os muçulmanos que são ricos. Depois, os que não são ricos eles sofrem o assédio simplesmente porque como a lei 
antiterrorismo foi adotado tem que ter pessoas que pagam pra justificar. Então eles, não tem o dinheiro que as autoridades querem, mas eles vão ser aqueles que vão pagar, que vão pra cadeia. Nesse instante somos interrompidos pelo Sr. Muhamad Tawfiq que nos convidou gentilmente para lanchar junto aos outros.

\section{MOHAMAD TAWFIQ/ABDOUL/THIAGO}

Após o lanche, Mohamad Tawfiq me convidou para sentarmos em uma sala logo na entrada da sede. A conversa inicialmente se deu apenas entre nós dois e algum tempo depois, Abdoul e Thiago se juntaram a nós a convite do próprio Muhamad e meu também.

Sendo assim, Mohamad Tawfiq, presidente da associação islâmica me apresentou a comunidade. À medida que as pessoas iam deixando a sede, ele me introduzia a elas e contava sobre a origem de cada um: "Veja, esses aqui são de Senegal, trabalham num bairro comercial aqui que chama Alecrim, são muitos senegaleses aqui...são uns 10, 15. Desses, aqui tem quatro só hoje. Aí, cada vez eu trago três comigo...fico revezando. E tem outros que chegam de ônibus. Para ele sair de lá e chegar meio-dia, eu tenho que largar 10h o trabalho, e chegar aqui, voltar e se tem sorte vai voltar 14 horas. Sexta-feira dia sagrado [foi o dia em que me reuni com ele], mas não é folga. Deus não falou, "fiquem meio quietos". Ele disse: "na hora da oração da sextafeira deixa seu comércio, seu trabalho e vai fazer oração e depois volta". Agora, nos países muçulmanos é folga.

Se um dia, se Deus quiser, você chegasse num país muçulmano....eu estive na Arábia Saudita dois anos atrás com minha esposa fazendo o Hajj [peregrinação à Meca] - minha esposa é brasileira - [ eu aproveito e pergunto a origem de Muhamad, que diz: 'eu sou de origem palestina. Nasci em Nazaré, vivi em uma cidade dentro de Israel...sou palestino-israelense...sou cidadão israelense mas origem palestina, dos meus pais. Não detesto nem Israel nem Palestina nem Brasil, todos somos humanos. Até o criminoso e terrorista eu não detesto....Deus que vai castigá-lo, não eu']. Então na Arábia Saudita dois anos atrás, quando chegava na hora da oração, eu tava fora digamos da mesquita, chegando do lado da mesquita, durante o chamado da oração...assim que chama a oração, 10-15 minutos começa a oração. Por quê? Para dar tempo para povo chegar. Então quando a gente andava do hotel para ir pra mesquita, todo comércio aberto mas não tinha ninguém. Então é isso...quando você num país muçulmano mesmo você tá vendo as notícias...ahh, terrorismo, bombas...não sei o quê...o cara fecha o comércio, loja de ouro, loja comida...deixa aberto e vai orar. Como pode chamar seu povo de terrorista e violento? Agora, temos sim violentos....ah, paciência! [exclama]. Quem fez a Primeira e a Segunda Guerra Mundial? Era muçulmano ou era não muçulmanos? A bomba atômica? Era muçulmanos que lançaram? Aqui, coitados dos índios! Quem matou eles? Fomos nós? Não! [exclama 
novamente]. Então vamos chamar os muçulmanos de terroristas? Pare! [exclama]. Pense direito, veja a história. Consulte o senhor Gulgle [Google]. Não é minhas palavras. A Primeira Guerra Mundial...os africanos que eles trouxeram...à força. Mas a história é grande...e vou deixar para você, veja o que você quer saber".

Comecei dizendo que primeiramente gostaria de conhecer a comunidade, um pouco de sua história, quando fui interrompido já com a resposta: "foi fundada em 2008. Por quatro pessoas: três brasileiros e um africano. Eu sempre repito sempre essa história. Olha que interessante: a comunidade muçulmana de Natal não tinha nenhum árabe no fundação. Então, o islam não é para os árabes. O islam é para toda a humanidade. Agora, que o profeta era árabe, que o islam nasceu na península árabe é outra história. Você sabe que os árabes são de 18 a $20 \%$ dos muçulmanos do mundo! [acrescentei concordando com sua opinião de que só na Índia há mais muçulmanos que muitos países do Oriente Médio]. Ele adiciona ainda: "Indonésia quase todinha ela muçulmana....bom, então eu cheguei ela [comunidade de Natal] já tava fundada. Até vi nos jornais da época a abertura da comunidade. Minha esposa falou 'hoje! Hoje'!. E eu não acredito!...nem sabia que tinha muçulmanos em Natal”.

Perguntei quem apoiava a comunidade em termos financeiros. Muhamad explica: "para ser sincero, para entender...entre eu e você só, são 800 reais mensais só da Fambras (Federação das Associações Muçulmanas do Brasil)...800 reais mensais. Agradecidos...é...dá pra pagar o lanche, o almoço do mês. Qualquer centavo que entra não vamos dizer pouco ou muito, nós vamos dizer agradecidos, hamidulillah, como a gente fala, graças a Deus. Se esse rapaz deu um centavo...se ele deu 10 reais para a mesquita e eu dou 100, talvez Allah aceita mais o 10 reais dele, porque tá desempregado ou trabalha no camelô. Aí...800 reais e mais nosso esforço aqui. Isso que você tá vendo aqui [a sede da comunidade] um de nós doou e dois reformaram. Não chegou nenhum centavo de fora. Se ninguém aparecer para doar, paciência. Quer ou não quer ajudar, como disse pra você, é no juízo final não eu que vou julgar. Nossa religião diz 'não deixa sua mão esquerda saber o que sua mão direita dá'. Se eu ajudo você em 10 reais, esconda de sua mão esquerda, ou seja, faça em segredo. A nossa caridade feita em público não é aceita. Porque vc tá humilhando o outro, o necessitado. Eu não falo mal.

Eu vou nas igrejas, certo? Vou e escuto as vezes pastores, padres...quero saber. Porque amanhã se tiver um debate, eu sei o que eles falam. Mas eles não sabem nossa religião". Eu interrompo questionando se isso é um problema. Ele responde: “prablema não. Pra eles, não pra nós. O prablema deles que não debate num mesa redonda, eles saem perdendo. Eles já várias vezes perderam numa mesa redonda. Não perderam porque é competição, mas por não responder direito". 
Sobre a quantidade de membros na comunidade Muhamad argumenta: "as 65 pessoas que temos aqui [em mensagens posteriores, Muhamad disse na semana seguinte ao nosso encontro eles fizeram um levantamento que apontou que há 76 muçulmanos sendo 55 brasileiros, 13 africanos e 08 árabes] é difícil de juntar. Por causa do trabalho...como vai pedir pro patrão que ‘vou sair $11 \mathrm{~h} 30$ e voltar $13 \mathrm{~h} 30$ pra oração. Mas que oração!?’ A população não sabe...afinal não estamos de fórias [férias], não estamos em São Paulo onde há comunidades maiores. Tinha um irmão nosso que trabalhou para um patrão espanhol aqui que ele deixava ele sair. Porque o espanhol como viveu na Espanha já sabia como funcionava. Vai dizer para um potiguar, coitado, que nem sabe que tem mesquita. Também a gente não fala mal dos caras, é o dono da empresa. Não deixa e ponto final. A gente ora para Deus. Se ele vê que você quer mesmo fazer a oração e seu patrão não deixou, é como você tivesse cumprido a oração. Nosso trabalo [trabalho] aqui é não sair nas ruas e ficar na praça gritando, divulgando o islam. Porque como muçulmanos, Deus não pediu isso. Ele só diz fale de mim uma palavra, quem sou eu, um versículo. As vezes a gente pega livros que chega pra nós, da Fambras, Wamy do Sheikh Jihad e a gente distribui aqui na cidade...é...quase todo mês temos um evento fora...convidados. Dia 02/03 estou convidado numa igreja é...formatura de uma turma. Eu participei duas vezes. Porque uma vez tinha uma muçulmana...então ela pediu que como tem padre e pastor, um muçulmano. Então eu fui lá. Depois do evento deram os parabéns. Disseram que sabia pouco de vocês [muçulmanos]. Agora dia 02/03 numa igreja que não tem nenhum muçulmano nessa turma. Porque eles me chamaram uma vez para dar palestras sobre refugiados e islam e fui nessa turma. Isso foi dois anos atrás. Agora essa turma tá se formando e me chamaram. E eu vou. Eu agradeço. Então se eles não tivessem gostado da nossa fala, não iam chamar a gente. Se eles ficaram só ouvindo TV, terroristas, oprimindo as mulheres, ninguém vai chamar você. Mas quando você prova pra ele que essas mulheres têm direito, mais do que a mulher cristã, prova, que tá nos livros sagrados...a mulher muçulmana teve direito no voto 1400 anos atrás. A mulher brasileira agora, só em 1932. Na Inglaterra em mil oitocentos e quebrados. A mulher brasileira obteve direito da herança do marido em 1969. Se o marido morreu, se lasca. Nossas mulheres asseguraram o direito da herança do marido mais de 1400 anos atrás! [exclama]”.

Questiono se isso além de outros problemas que envolvem preconceito contra o islam deriva do quanto a mídia expõe casos envolvendo muçulmanos, minorias que fazem seus atos refletir em toda a comunidade. Muhamad diz: "na verdade, a mídia hoje nos Estados Unidos está desmascarando o Trump...a mídia! Ela está do lado dos muçulmanos. Não está contra os muçulmanos. Agora...o que eles viram é que chegou alguém que é louco, doido querendo mandar os muçulmanos...o povo levantou...não é bem assim. Se tem grupo ruim deles 
[muçulmanos] você vai banir 2 biliones de pessoas? Não é possível. A mídia brasileira infelizmente fizeram várias reportagens conosco aqui. Só que quando eles lançaram na TV, no programa, na grade deles...assistimos...meu Deus! [diz com voz de desânimo] Não fala nada do islam....fala dos costumes. Por que o repórter, coitado, não conhece o islam. O repórter, coitado, está sendo pressionado para fazer a reportagem.

Ele tem que fazer uma coisa bonita para agradar o patrão dele. Então ele não vai escolher as palavras...sei lá...o ângulo...talvez o fundo...talvez o sorriso...talvez a mão assim ou assim...e não sai nada do islam, só costumes. Então o que sai na mídia, não sai do islam verdadeiro. Sai uma mulher usando o hijad, alguém orando. Ah, a gente vê dia e noite na TV e depois dizem terroristas [exclama]. Aqui não falou terroristas mas a gente já ouviu terroristas de outra pessoa. Porque a mídia não tem o tempo aqui e não tem obrigação de explicar o que é o islam. Tem um canal aqui da assembleia legislativa. Fizeram reportagem conosco. Como esse canal tem grade pequena, fica repetindo, passou mais de dezenas de vezes. Tem algumas coisas boas, não tem nada ruim, mas ele não fala muito sobre o islam, mas fala alguns pontos positivos. Só que o bom pra nós é que tá dizendo 'tem muçulmanos aqui na cidade. Ei acorda! Tem muçulmanos aqui na cidade'. Temos página no Facebook, tem gente entra lá querendo conhecer”.

Pergunto então se toda vez que ocorre um atentado terrorista no mundo, a comunidade sofre algum tipo de agressão, preconceito ou algo do gênero. O entrevistado afirma que "na cara ninguém fala pra você. Agora, se tem pensamento em casa, alguém xingando...paciência. O palmeirense xinga corintiano, corintiano xinga saopaulino...todo mundo xinga o outro. Porque quando alguém fala na sua cara, você pode responder. Talvez você pudesse esclarecer para ele que ele tá errado. Agora, quando alguém fala na TV, é pior. Porque não chegou até ele para explicar. Uma vez alguém enviou e-mail, até eu fui na Polícia Federal. Levei o e-mail que recebemos.... 'vou passar aí, jogar água...queimar as caras de vocês...não sei o quê...' mas eu achei que fosse um aventureiro, um menino, um adolescente que viu na TV sobre terroristas...o cara fica louco! [se exalta]. Eu mesmo. Eu mesmo se ouvir alguém falando que do bairro tal são terroristas, são ruim...vou xingá-los...lógico... 'meu filho, não vai naquele bairro. São gente sem vergonha, ladrões, safados'. Então esse coitado que nunca ouviu falar do islam, quando ele xinga nóis, eu não fico com raiva. Fico com pena porque não chegou pra ele a informação correta. Incrível que tem muitos professores que chamam nóis para explicar para os alunos deles: 'não, eles não são terroristas'. Se fossem terroristas os dois bilhões de muçulmanos no mundo já teriam acabado com toda a raça humana". 
Questiono se no caso de indivíduos ou grupos que promovem atentados terroristas interpretam as escrituras de acordo com suas conveniências e interesses, resultado de uma crise de autoridade, a falta de alguém com conhecimento para guiá-lo a senda correta.

"Se você pegar o mapa do mundo árabe, maioria muçulmana, mais de $80 \%$ muçulmana. Veja o mapa político. Todos os países tem ditador. Todos eles. A única democracia que tinha na Palestina, quando o Hamas ganhou as eleições - e eu não sou a favor do Hamas...também não sou contra, prablema deles - se eles vão cometer crimes em nome do islam, eu fico contra. Aonde diz no Alcorão para jogar bomba nesses caras? Agora, quando há conflito político, se resolvam os dois juntos, longe do islam. Então todos os governantes são ditadores. Até agora tem alguns deles. A maioria do povo árabe sofreu e está sofrendo até agora, que eles não podem abrir a boca. Não pode abrir a boca para dizer o que você pensa. Você tem que abrir a boca para dizer 'sim senhor!' O cara chega o tempo que cansa. Quando ele vai se revoltar, você precisa de um líder para te ajudar.

O prablema no mundo árabe é que não tem líderes. Qualquer líder político que aparecia, chegou o governador e 'trilique!' Matava ele, matava a família, colocava sei la investigação que não existia contra ele...ah ‘traiu a pátria, tem que morrer’! Então não há líderes no mundo árabe para liderar a oposição. Para liderar a outra parte, que não deixaram crescer. Que deixaram crescer no Egito a irmandade muçulmana. Quando a irmandade muçulmana conseguiu ganhar a eleição de forma democrática. Sinceramente, eu não apoiei Mursi para se candidatar, porque o islam é para adorar a Deus e não para entrar na política. Fique quieto, rezando, adorando seu criador. Para quê estar se metendo no jogo sujo? Eu fiquei contra. Mesmo assim ganharam, não ganharam? Aí o mundo acharam um jeito para tirar o cara. Ta certo? Tiraram ele. A falta de liderança no mundo árabe fazia de que o povo simples que está sofrendo, sendo esmagado, qualquer um que grita 'eu vou levar vocês pra salvação! Eu vou derrubar o tiranos!'. Quem fez isso? Al-Qaeda usando o islam. Eles fizeram isso. Os mais fracos acreditaram neles, juntaram a eles. Só que com o tempo começaram a descobrir: 'ah, não é bem assim, a gente queria alguém que tirasse a gente do sofrimento e estamos sofrendo com vocês a mais. Vocês estão matando nossos filhos, estuprando nossas mulheres'! O Estado Islâmico quantas vezes não mataram familiares em nome de Deus. Que Deus é esse que mandava matar seus familiares?”.

Toco no assunto sobre as prisões de alguns muçulmanos aqui no Brasil pela Polícia Federal (Operação Hashtag) e da minha conversa com o sheikh Ahmad Alkhatib e questiono se de fato há ambiente e uma predisposição de algumas comunidades por meio de alguns de seus indivíduos de radicalização. 
Imediatamente, Muhamad Tawfiq diz que "não, absolutamente...no Brasil não tem. Mas Victor, essas pessoas que são indignados, revoltam contra injustiça, injustiça social. Mas o prablema é que aqui no Brasil não vai resolver o prablema no Oriente Médio com simples anúncio no Facebook. Você acaba com a comunidade islâmica pacífica aqui no Brasil. Porque você não tá sozinho!" Insisto em saber se a falta de uma liderança em uma comunidade islâmica pode levar um indivíduo a interpretar equivocadamente o Corão e a agir de forma radical. Ele responde: "aqui no Brasil temos liderança ainda bem". Nesse momento, Abdoul Hadi interrompe e diz: "a violência...o islam não encaminha para a violência...vamos concordar que somos seres humanos e diante de certas coisas você fica totalmente frágil emocionalmente. Olha os bombardeamentos! Eu imagino o sentimento...muitas vezes...as pessoas...os fundamentalistas eles convivem com a população. A população não está de acordo com eles mas a população também não tem como fugir deles. Porque a comunidade internacional...como você acessa a comunidade internacional e como ela pode ajudar? Individualmente até pode, mas coletivamente como a comunidade internacional ajuda? E acontece que quando tem bombardeamento geral, eu imagino um pai e uma mãe diante dos filhos deles mortos em certas condições. O que eles se tornam? Voh...você perde a noção! [exclama]”. Muhamad Tawfiq acrescenta: "não precisa ser na Síria. Aqui no Brasil quando você vê uma família morta, você não fica indignado? Você pode ir no facebook falar mal de assassino, falar que tem que matar o assassino...agora se eu sou muçulmano e aconteceu lá, tem que matar o americano...ah, é terrorista! [em tom irônico]". Abdoul ri e exclama: "exatamente".

Thiago, frequentador da comunidade, continua: "E tem uma coisa também: o entre aspas, Estado Islâmico, não existe...Para a comunidade muçulmana internacional, Meca, Arábia Saudita, não existe. Não existe. Esses são criminosos...". Abdoul completa: "não chamamos de Estado Islâmico para não alimentar essa ideia". Thiago prossegue: "houve uma sucessão de eventos desde a primavera árabe...Líbia, Tunísia, Egito...o que isso tem a ver com particularidades desses lugares...se você vê o professor Mustafá Abdullah que esteve aqui, um antropólogo, professor na Free University na Alemanha, ele é egípcio, ele num seminário que teve organizado pelo professor Williton, veio fazer uma fala sobre o movimento das mulheres no Egito, não é? Que na década de 80 devido aos conflitos com Israel houve muitas baixas de homens e as mulheres do Egito começaram a ocupar posições de liderança, né? Que há também uma ala no Egito muito liberal, né? O Egito é muito heterogêneo, não é só aquela comunidade tradicional. Existem mulheres que não usam hijab no Egito. É muito laico o Egito né? Então o movimento feminista teve uma importância muito grande na destituição de Hosni Mubarak. Isso apareceu na mídia...internacional? Então veja: é muito particular o que acontece em cada 
uma dessas localidades, o que aconteceu na Líbia, o que aconteceu no Egito, e os interesses que estão relacionados à Síria. O maior, o maior porto militar da Rússia fora da Rússia é na Síria. Então quando os Estados Unidos dizem vamos invadir aí a Rússia, não, peraí! Mercenários, empobrecidos, em alta vulnerabilidade social de países do leste da África - Somália, Etiópia esses países extremamente pobres...eles [membros do Estado Islâmico] são recrutados como mercenários para atuar dentro da Síria por exemplo. Agora teve o evento do Iêmen né? Que o Iêmen fica naquele subcontinente lá embaixo né? O que foi que o rei da Arábia Saudita fez? Doou 280 milhões de dólares para a OTAN invadir o Iêmen e morreu em um só dia 17 mil pessoas. Então assim: a própria comunidade muçulmana do mundo, não sei se tem um conselho, deve ter um conselho religioso de Imãs...já houve...um conselho internacional de imãs islâmicos né, afirmando e reafirmando que não existe nenhum Estado Islâmico. Isso não é iniciativa da comunidade islâmica, né? Não sai na mídia...como eu digo? Na mídia...dos analfabetos né? Na televisão não sai”.

Muhamad Tawfiq retoma: "meu Deus...o que ele tá dizendo que não sai na mídia...desculpa...eu tenho um cliente que foi entregar um material, deu para alguém, até falou algumas palavras em árabe 'shariah!', 'ummah'...que escuta num canto, não sei aonde, por que publicamente não sai para dizer que o Estado Islâmico não tem nada a ver com o islam? Falam! Ah, mas a gente não vê! Por isso os caras acreditam!"

Eu pergunto se a própria palavra "fundamentalismo" não contribui para confundir as coisas, já que é sempre vista como forma negativa, uma vez que se tomar a etimologia da palavra, ela se remete à raiz, o fundamental da religião...Tawfiq interrompe e diz: "é essa que eu sempre defendo!”. Continuo: se o fundamental é a Bíblia ou o Corão, então todos são fundamentalistas e o conceito perde agudez. Tawfiq novamente interrompe e exclama: "eu sou fundamentalista!". Abdoul também afirma: “aí você vê a sutilidade do veneno. Que do jeito que a mensagem de nabi Issa (profeta Jesus) se tornou cristianismo [enfatiza o 'ismo'], islam se tornou islamismo [enfatiza novamente o 'ismo']. Quem redefiniu a palavra? Não são os próprios que estão lutando contra o islam, que deram esse nome, islamismo. Mas já islamismo não é islam. Porque islamismo é bem específico. É o islam político. Como as teorias da liberdade aqui na América. É se encostar sobre os valores islâmicos pra lutar. É o que os irmãos não Egito, o que a Irmandade Muçulmana no Egito fez. Só que depois eles se tornaram corruptos. Sempre usando o nome de islamismo, mas pela história eles realmente lutavam pelo islam. O islam político para mudar a sociedade. Só que depois eles não acompanharam. Porque depois eles ser pervertiram [perverteram]. É isso! [exclama]. Então eles se pervertiram mas sempre usaram a legitimidade histórica". 
Thiago toma a palavra e diz de forma enfática e em ritmo de voz acelerado: “enfim, o que eu tava querendo dizer é que não tem como objetivamente tratar o sintagma, vamos dizer assim, Estado Islâmico como um dado adquirido. Não é. Por exemplo, quando caiu o xá no Irã na década de 70...né? Quando teve aquela grande revolução e ele botou toda a riqueza num avião, família e foi pra França...e nunca mais voltou. Ali se constituiu um estado realmente religioso. Agora, dizer que hoje está constituído no Iêmen, está constituído na Síria, está constituído no Iraque um estado islâmico e que isso tem todo e total apoio de um bilhão e quinhentos milhões de muçulmanos no mundo isso não tem. Ao contrário. As comunidades muçulmanas têm até que lidar com esse problema...dizer 'não somos terroristas, não apoiamos esses criminosos",

Nesse instante, Abdoul complementa a fala anterior ao afirmar: "mas, mas como você mesmo disse, temos que se críticos também...diante de umas autoridades muçulmanas...que usam a religion para assegurar a autoridade deles. E aí se torna o quê? Eles não fazem mais...humm...não lidam mais com a religion para a população, mas usam a religion para se manter. Aí já é outra coisa. Arabia Saudita, ela é exactamente nessa posição. Você vê a Arabia Saudita, a política da Arabia Saudita no mundo inteiro, é isso, é pra se manter. Aí, o que eles fazem? As coisas que são assim...as regras básicas do Islam, só você olhar isso e ver a atuação de uma pessoa, de uma autoridade, você já sabe que ela tá encaminhando algo que não é o islam..." Thiago completa: "que é o impostor". Abdoul retoma sorrindo e diz: "exatamente! [exclama]. É o orgulho dele...é a questão do prestígio social, é a questão de riqueza, é a questão do poder...de alianças...então, não é o islam. O islam fundamentalmente está sempre com a população, sempre com os direitos humanos. Fundamentalmente. E mesmo ao nome de salvar vidas, você não pode...hummm...como se diz...hummm...ferir os princípios islâmicos. Tá...vou salvar alguém...por conta disso você mata? O islam nunca pediu isso [sorri]”"

Thiago novamente se posiciona: "Tawfiq falou certa vez num sermão, sobre a Turquia, que o Mohamed II...não...uuu...na Segunda Guerra, mandou os...que os alemães estavam procurando os muçulmanos e judeus..." Muhamed Tawfiq interrompe e corrige Thiago: "era Mohammed V de Marrocos, o rei de Marrocos. Quando na Segunda Guerra Mundial o Hitler estava caçando os judeus...para acabar com os que fugiram da Europa para a África, e o Hitler mandou uma carta pedindo que entregasse os judeus imediatamente para o Alemanha. O rei respondeu a carta dizendo que os judeus que moravam aqui são cidadãos marroquinos...qualquer um que vai ferir ou vai se meter com cidadão marroquino vai se meter comigo. Eu defendo meus cidadãos, em outras palavras, tá certo?" 
Thiago continua: "ou seja, antes de ter mesmo a carta internacional dos direitos humanos, as próprias lideranças islâmicas já tinham esse princípio”. Muhamed Tawfiq prossegue: "Thiago, 1400 anos atrás estabeleceram...quando o profeta Muhammed, migrou de Meca para Medina...quando estabeleceu governo muçulmano, quando começou o islam crescer por dentro...porque para o islam, crescer...tem que crescer por dentro para crescer para fora...como assim por dentro? Tem que entender o islam. Aprender, buscar o conhecimento. A Medina tornou-se mais de $90 \%$ muçulmana...porque tem judeus moram lá. O profeta deu pra eles, deu pra eles os direitos, faça suas orações da maneira que vocês faziam, façam seus comércio da maneira que faziam...faça o que quiser. Eu não lembro qual...acho que Abdoul Aziz, que Deus me perdoe, não lembro quem era o líder, talvez Omar Ibn AlKhatab...quando mandou exército para Síria, uma das cidades da Síria, eles entraram lá...a comunidade local da Síria mandou uma carta para um líder muçulmano dizendo: 'olha, nós aprendemos...chegou pra nós a notícia que a religião de vocês através do profeta Muhammed diz que jamais vocês muçulmanos entrassem numa cidade a força até pedir permissão dos moradores, vocês entraram a força e não pediram permissão. Vocês não pediram permissão'...mandaram carta. Voltou a carta para o exército sair da cidade. Ficaram lá fora até aceitar a entrada deles...depois até essa cidade virou muçulmana com o tempo. Então não é assim que falam para nós entra, mata...é...degola".

Interrompo e questiono por que as comunidades no Brasil não são unidas, se parecem como células isoladas, sem ligação entre si e sem uma voz única...Muhamed Tawfiq me interrompe e diz: "deixa eu dizer...você me perguntou quem ajuda você. E eu disse para você, 800 reais. Ou seja, a Fambras deposita esse dinheiro e manda livros e panfletos. A Wamy nos manda livretos. Não temos contato com outras comunidades. Eu tenho contato com as comunidades do nordeste. Eu conheço os líderes locais...até temos grupo para saber como chegar livros, para poder correr atrás de ajuda...pode ser de fora, pode ser de São Paulo, de Rio, de qualquer lugar para a gente manter. Pelo menos pagar aluguel das nossas comunidades. A gente pagava aluguel antes e agora não tá pagando. Nós temos contas para pagar. Só que alguns dos líderes locais eles não querem muita conversa porque eles são filial de uma instituição muçulmana no sul do Brasil [diz pausadamente, quase que soletrando as sílabas]. E aquela instituição não quer que a instituição dele se meta com outras comunidades, só obedecer a eles. As ordens deles, então para você entender...que ser um grupo pequeno no nordeste...a gente não consegue se entender porque alguém tá se metendo de fora, do sul e sudeste entre nós para deixar claro que nossa instituição de... 'Londrina, somos fortes' e não precisamos entrar como membro de uma comunidade do nordeste...ou com congresso....associação das comunidades 
islâmicas do nordeste. Não temos essa ligação entre nós...forte. Temos ligação, entre um sheikh que posta no facebook, ou outro sheikh que posta também no facebook contra um ato terrorista ou contra...ato contra muçulmanos no Brasil. A gente as vezes copia e coloca no facebook. Agora, juntar nóis...não tem como [exclama]. Com 800 reais você não pode juntar...levar alguém de nós para um congresso ou conferência dos muçulmanos no Brasil, em São Paulo. Ninguém infelizmente quer fazer esse congresso...por quê? Porque são três comunidades grandes aqui no Brasil: Fambras, Cdial e Wamy. E infelizmente começaram, as duas, Cdial e Fambras como instituições comerciais...com abate Hallal. Como têm contratos com países muçulmanos sobre o hallal, esses países muçulmanos como Arábia Saudita e Qatar diz: 'olha, eu compro de você hallal, agora uma parte de seu lucro você tem que ajudar as comunidades muçulmanas'...por isso eles ajudam nóis. Agora, será só isso? Essa percentagem de lucro que eles têm, que ele tem para ajudar as comunidades?".

Aproveito a para saber se também não há aspectos culturais, políticos e ideológicos que podem afetar a maior integração. Muhamad diz: “tem. Tem...famílias...é famílias”. Nesse ponto, Thiago interrompe e diz: "a história e o desenvolvimento dessa espiritualidade que é muito singular em relação a outras religiões monoteístas. Tanto o catolicismo apostólico romano que você tem uma hierarquia muito definida desde o coroinha, o padre, o...o bispo, o cardeal, o papa, então existe toda hierarquia que quando o papa fala lá no Vaticano, ele fala com todo o mundo. Mesmo a igreja católica anglicana também manteve a hierarquia. Depois da reforma protestante com a definição da primeira igreja protestante, que é a presbiteriana, não é? Você também tem o supremo conselho do Brasil, por exemplo, das igrejas presbiterianas, então quando o supremo conselho fala, quando a confederação dos bispos fala, quando o papa fala, há uma hierarquia bem definida. E no islam não há hierarquia. O Tawfiq hoje fez o sermão, se amanhã ele tá viajando, outra pessoa pode ir lá e fazer o sermão. Mas a hierarquia não está dada. A submissão é voluntária”. Abdoul também emite sua opinião sobre o assunto e reflete: “essa hierarquia, não tá no princípio do islam, mas as comunidades não querem...seguir isso". Interrompo brevemente para acrescentar que isso faz com que cada comunidade pense de forma diferente, ao que Abdoul exclama: “exactamente! É isso, é isso! Isso é a realidade do islam. Nunca tem a mesma voz. Todo mundo é livre de pensar. O islam é o convite mesmo do islam o...que cada um seja crítico até com os dirigentes".

Muhamad Tawfiq interrompe a fala de Abdoul para me apresentar a um amigo e a outra pessoa que está interessada em conhecer a comunidade, quando Thiago novamente toma a palavra e conclui: "mas enfim...em termos, digamos assim, de uma constelação que reúna as vozes não de todas, mas de algumas comunidades muçulmanas, nós temos essas instituições - 
a Fambras, tem a Cdial que é latino americana não é? - inclusive no mês passado eu comentei até com o Tawfiq da mensagem da Fambras para o Congresso Nacional em relação a esses criminosos, a esses atos terroristas que aconteceram na Europa que as associações beneficentes muçulmanas do Brasil, que no nosso caso e outros que são federadas à Fambras, repudiam esse tipo de prática”. Pergunto se são essas entidades que possuem uma voz oficial das comunidades como um todo. Porém Thiago afirma: "não oficial, mas que se aproxima do que a gente tem historicamente em outras religiões. Por quê? Se a Fambras levanta e diz 'os muçulmanos do Brasil...' aí alguém pode dizer 'não! Peraí, a nossa comunidade nem é associada à essa federação'. Aí se o papa diz que é melhor ser ateu do que ser um cristão hipócrita, aquilo ali é a voz de Deus na Terra".

Tawfiq então reage e afirma: “existe o conselho de teólogos no Brasil...muçulmanos...existe aqui...que eles podem dar opinião sobre o parecer religioso, não político, entendeu...religioso! Como não temos prablemas com a religião aqui...todo mundo tem o Alcorão, tem a sunna, entendemos direto, se às vezes tenho uma dúvida eu ligo para um sheikh, ou outro sheikh, dois ou três para ter resposta entendeu? Mas prablemas maiores não temos. Se não temos aproximação 100\% com eles, não temos prablemas com eles também. Falta união como existe na igreja católica ou evangélica que tem um líder, o dono da igreja e os caras lá embaixo têm que obedecer. Nós obedecemos Deus e o seu profeta. Agora, lá pra baixo, tem alguns com pensamento diferente de outro...um mais esforçado que outro...outro mais ou menos inteligente que outro...existe. Por isso você vai pro conselho de teólogos...mas no final das contas obedecemos Deus e o profeta. Essa que não há dúvida. Pode odiar você, odiar a ele, mas Deus e seu profeta e os ensinamentos deles sagrados. Então Deus e o profeta falaram do Estado Islâmico? Não, não falaram...no alcorão Deus fala 'odeia aquele que tira a vida do outro'....Deus não gosta de alguém que mate outro. Então como vou matar? Como você no Estado Islâmico você vai matar em nome de Deus [exclama] se Deus fala no alcorão não matem! Deus deu a vida e é ele que tira. Deus fala no alcorão...para Deus... 'se matasse ser humano na Terra, como fosse ter matado a humanidade inteira. Se salvasse ser humano, para Deus, foi como ter salvado a humanidade inteira [fala em tom sereno, como se fosse a prece mesma]. Puxa...você acha que eu vou matar um homem para Deus colocar na minha costas crime contra toda a humanidade para no dia do juízo final vou me ferrar no inferno? Eu não vou fazer isso".

Abdoul completa: "nem ao profeta Deus deu esse direito. Sempre Deus disse: 'o seu papel...a sua missão é só transmitir a mensagem. Nem é de converter uma pessoa. Converter isso é Deus. Mas dar a mensagem, transmitir a mensagem. Era só isso a missão do profeta. 
Então, a primeira condição, a primeira condição do islam é a liberdade. Ele é ateu, meu filho é ateu...ele faz todo que ele quiser. Eu posso não concordar, mas isso ele pode". Muhamad acrescenta: "que vai questionar ele não sou eu, é Deus. Sua obrigação é mostrar pra ele o caminho certo. Até seria ignorância de você ficar calado. Mas você não pode obrigá-lo a seguir o islam, não é seu papel converter. Então vai lá pro Estado Islâmico e diga pra eles, por que estão matando? Convertendo quem para o islam? [Abdoul ri] Deus não quer isso.

Quanto perguntei a Mohamad Tawfiq sobre qual seu modelo/exemplo de muçulmano, que o inspira, ele foi categórico: "meu modelo, é seguir o Alcorão e a sunna do profeta. Fomos criados somente para adorar a Allah, não atribuir parceiros a Ele, cumprir as orações, pagar o zakat, jejuar o Ramdan, realizar o hajj, ser benevolente com meus pais, fazer o bem, ser justo, e respeitar os vizinhos, mesmo não muçulmanos. Afastar de tudo que Allah proibiu para mim: associar a alguém a Ele, matar, roubar, mentir, trair..."

Nesse momento começam trabalhar pedreiros que estavam realizando a reforma da sede e o barulho de furadeiras e ferramentas torna a continuidade da conversa impossível. Além disso, Muhamad Tawfiq olha para o relógio e entendo que é hora de encerrar a entrevista. Já passava das 14 horas da tarde. Agradeço a conversa e registramos fotos, que inclusive uma delas foi publicada no Facebook da comunidade. 


\section{IDENTIFICACÃO}

Nome: Sheikh Ahmad Abdul

Local de Nascimento: Nigéria

Idade: 68 anos

Ocupação: sheikh do Centro Cultural Islâmico da Bahia (CCIB).
Escolaridade: (a) Fundamental
(b) Médio
(c) Superior
(d) Pós-graduação

No dia 09/01/2019 entrevistei o sheikh da CCIB, Ahmad Abdul. O encontro aconteceu na casa do centro islâmico. Ao chegar, o sheikh me acolheu gentilmente e se mostrou extremamente simpático e falando um português bastante claro, mas preservando seu sotaque nativo.

Inicialmente expliquei o propósito da visita e a importância em conhecer a comunidade islâmica sediada em Salvador ao sheikh que atentamente me escutou e elogiou o trabalho e o interesse.

A primeira pergunta que fiz foi sobre o tamanho da comunidade islâmica, pois com base nas informações passadas por Mohammed Tawfiq da comunidade de Natal/RN, esta seria a maior do nordeste. Isso foi confirmado pelo sheikh que disse:

“Aqui maior do que Pernambuco. A comunidade aqui...Bahia, estado grande. Então, no Bahia inteiro a gente tem mais ou menos 700 muçulmanos. A maior, aqui, Salvador. Por enquanto só tem aqui, centro islâmico. A gente tem que ir pra outras cidades...porque não tem outras mesquitas lá no interior. Então quando tem alguma palestra, alguma coisa, eu com alguns irmão vamos para lá (interior). Mas se tem festa a gente convida eles. Quem pode, vem. E Bahia é grande! Grande mesmo.

Em seguida, quis saber um pouco de sua história. Ele então responde:

“Eu sou da Nigéria. Cheguei em 1992. Eu estudei na Arábia (Saudita) e servi na minha terra e depois vim pra cá pelas mãos do nosso irmão Saifi (Ahmad Ali Saifi). Você conhece Jihad?" Respondi que sim e ainda citei outros com quem já tive contato. Ele me pergunta: "Saifi você não conhece?” Eu disse que não tive contato com ele. Então o sheikh Ahmad continua. "Saifi é o pai de todos [exclama sorrindo]. (Sheikh) Metwally é o presidente dos sheikhs no Brasil. Mas Saifi é o pai de todos...deixa eu mostrar uma foto pra você. Então...é...a primeira vez aqui na Bahia? Bahia é bom. Olha, esse é Abdelhamid...esse nosso presidente...[enquanto procura a foto]". Aproveito para perguntar mais sobre sua chegada no Brasil e se ele veio direto para a Bahia. Ele diz:

“Cheguei em 1992 e fiquei um tempo em São Paulo com Saifi, porque não falava português [...] eu vou achar a foto...olha ele aqui [me mostra a foto]. Ele é comerciante, muita 
gente conhece ele. Ele é de São Bernardo do Campo. Ele que comprou essa casa [sede do centro islâmico]. Na verdade, ele me procurou pra vir pra cá. Ele que comprou aqui...mas não era aqui, era outro lugar alugado. Quando eu cheguei ele me perguntou: você vai ficar com a comunidade? Naquela época a comunidade é de três, quatro, cinco [pessoas]. Então eu falei vou pensar. Então ele falou, pensa. A gente compra. E comprou. Claro, as pessoas pagaram ele, lá da Arábia. Comprou em 94, entendeu?"

Aproveitei a deixa para saber quem é que mantinha o custeio do centro islâmico. Ele responde: “Aqui a Fambras ajuda, principalmente com os livros. Saifi também ajuda...é...ele que carregou tudo, até que chegou um ponto que disse pra ele que não é vergonha pra nós ter que pagar luz e ele disse que não tinha problema e continuou pagando. Algumas outras pessoas ajuda, quem tem ajuda".

Em seguida, abordo a questão da fragmentação das comunidades islâmicas que constatei até aqui. Ele então afirma:

"Não tem...tem centralidade com o sheikh Abdelhamid que é responsável da gente. O sheikh que elegemos. Então qualquer coisa ele tem que ouvir, tem diretoria la. Ele é presidente dos sheikhs. Mas dos centros islâmicos, teve agora em novembro um congresso de Saifi que é fantástico. Muita gente da Arábia Saudita, muita gente de fora...então quando a gente precisa alguma coisa a gente fala para Saifi. Mesma coisa a FAMBRAS. Mas pra dizer que é central, que manda, não existe isso. Cada centro islâmico é independente. Tem ligação com FAMBRAS, tem ligação o com Saifi [CDIAL]...Wamy tá la também. Wamy tá ajudando aqui também. Tem muita coisa que Wamy oferece. Se eu precisa ir pra fora, eu liga FAMBRAS. Eles já me ligou: 'sheikh, você tá precisando de livro? Não, agora não. É a mesma coisa Saifi. Teve agora congresso e mandaram passagem pra mim. Entendeu? Precisa de alguma coisa, a gente liga para eles. Todas as comunidades sabem o que Wamy, Saifi e FAMBRAS pode oferecer".

Ainda sobre o assunto, questiono se há algum tipo de ajuda externa, de outros países/governos.

Sheikh Ahmad respondeu: "como eu falou pra você, quem pagou essa casa foi a Arábia Saudita. Saifi comprou, por meio dele”. Indago se ele tem ligação com a Arábia Saudita.

"Saifi? Sim! [exclama]. Ele tem com a Arabia Saudita, com o Kwait...ele grande homem [exclama]. No congresso que ele fez agora, tinha ministro da Arábia Saudita lá. Saifi famoso".

Neste ponto, pergunto se o fato de ter ajuda desses países, não haveria a possibilidade de haver uma certa influência teológica nas comunidades que são ajudadas por eles, nas pregações. Ele então de modo enfático diz: "Não! Não tem nada a ver. Não tem nada a ver se a 
gente tem alguma coisa que não pertence ao islam. De estar divulgando uma coisa que não tem nada a ver com o islam...ai não vai ter apoio dessas pessoas. Nem apoio da Arabia Saudita, nem apoio do Kwait, nem apoio de Saif, nem apoio de Wamy, porque islam é regra, tem regra principal, entendeu? Quando você desviar dessa regra principal, não tem apoio. Eu estudei na Arábia. As pessoas que fala que é wahhabista. A gente que sabe quem são eles. Não existe isso não. O que o wahhabista quer é padrão, não tira nada e não bota nada. Se você conseguir praticar as regras. As regras principal tem que praticar. Mas tem regras voluntário. Se você não tá conseguindo praticar as regras voluntário, não bota nada. Entende o que to falando? Isso é que wahhabistas estão dizendo. Mas quando as pessoas acham que são radical, é que não conhece. wahhabista diz que se você está fazendo alguma coisa que não é do profeta Mohamed, que não é do Islam, onde você viu isso? As pessoas acham que qualquer wahhabista tem barba. Não. É verdade que o profeta diz que é bom ter barba. Tá no islam. Mas se você não tem barba, não tem problema. Mas as principais você tem que observar, senão islam vai chegar num ponto de bagunça, bagunça. Olha esses jovens hoje que são radicais. Porque eles aplicam coisas que não tem nada a ver com o islam".

Eu interrompo para saber se eles usam partes do corão para justificar seus atos. O sheikh continua e exclama: "Isso! Entendeu? Tira do contexto. Eles não quer viver com os sheikhs. Entendeu? Wamy tá lá. FAMBRAS tá lá. Saifi tá lá. Porque todos esses instituição têm pessoas responsáveis que são sheikhs. Sheikh Jihad, Sheikh Masloum, Sheikh Abduni. Mas se você acha que eles não presta, eu quero outro sheikh e coloca as coisas como obrigatória fora da realidade do islam, entendeu?"

Pergunto se ele acha que o extremismo atual é mais por conta do autodidatismo dos indivíduos, que buscam conhecer a religião por conta própria fora das mesquitas.

O sheikh concorda com essa afirmação dizendo: "Isso. Duas coisas aqui: esses grupo pode ser o que você tá falando. Ou pode ser que eles não sabem nada sobre o islam, só política que eles mesmo sabem o que estão fazendo. Na minha terra tem Boko Haram. O que é boko? Livro! Palavra em inglês. Haram, proibido. O que significa isso: qualquer universidade, colégio que tem ligação com o Ocidente não aceitamos [ele grita]. Amigo, onde eles aprender isso? Se profeta disse pra buscar conhecimento tanto pra homem quanto pra mulher. É obrigatório. Onde que seja [exclama]. O interesse é político. Esse grupo Boko Haram, você sabe, são pobres. Mas agora são poderoso, tem dinheiro, tem armas, de onde vem esse dinheiro, quem oferece pra eles. Estado Islâmico, quem fornece pra eles? Entendeu? Eu não sei se você entrou no Google...Tony Blair. Tony Blair disse que uma coisa que eu fiz na minha vida que eu me arrepender é minha participação com aquele presidente Bush. Porque intenção da gente, isso 
que ele falou, para libertar o povo. Entregamos armamentos na mão deles. E deixamos armas nas mãos deles. Hoje eles estão usando essas armas contra o povo deles, contra a gente. Ele falou...entre no Google...é pior meu povo ocidental continuar fazendo a mesma coisa até hoje. Política, amigo. Política. Esses grupos não sabe nada sobre o islam. E tá usando califa porque eles sabem a importância de califa no islam, entendeu? Imagina...eles mata e mostra pra todo mundo [ri]. Mata homem, mulher, criança, destrói igreja, mesquita...política. Eles mesmo sabe disso. Na minha terra, Boko Haram, no início as pessoas tavam pensando que eles estavam tentando pro governo que naquela época era cristão. Nigéria não é um estado islâmico. Nigéria é igual aqui. Laico. O que eu quero dizer pra você, meu amigo, esses grupo radical que estão no mundo islâmico hoje, por ignorância não quer ficar com os sheikhs. Eles querer sheikhs deles. Não estudam nada! [se exalta]. Bota barba, pega pouquinho do Alcorão, e procura alguns lugares lá...olha! aqui diz que pode fazer jihad! [exclama]. Quem não é muçulmano não pode viver com a gente no mesmo lugar. Eu sempre falo: gente, onde estamos? No Brasil. Se Brasil não abrir porta pra nós, se Estados Unidos não abrir porta pra nós, onde você estuda que é proibido viver com muçulmano. Não existe. Não existe isso. A gente tem a reunião com outros líderes religiosos aqui, até com as religiões africanas. A gente tem muita coisa em comum. A paz!"

Neste momento, entro no assunto envolvendo a lei antiterrorismo e as operações da polícia federal que prenderam muçulmanos por supostos envolvimentos com grupos extremistas e por apologia à violência. Pergunto qual a visão do sheikh a respeito disso.

Ele assim coloca: “olha bem meu amigo. A gente tem pessoas responsável. Nosso irmão, nosso presidente sheikh Abdulhamid Metwally, e sheikh Abduni também, ele está na frente...e o grupo da gente não está contra a lei. A lei serve pra todos nós. O problema é quem está aplicando essa lei. Pega as pessoas erradas, entendeu, eh...com motivo ou sem motivo. Eu falo do Ahmad (Alkhattib), porque as vezes ele estava com algumas dessas pessoas. Eu liguei pra São Paulo. E me disseram que ele estava tentando resolver isso. Então quando acontece isso, ali mesmo não tem problema. O problema são as pessoas que aplicam a lei no lugar errado. Eh...eu quero dar um exemplo: eu tava viajando da Nigéria. Cheguei num aeroporto aqui. Todo mundo passou. Polícia Federal me conhece aqui. Mas essa pessoa não me conhece. Pegou minha mala toda. Eu sentei...ele pegou todas as coisas da mala...um por um, um por um, um por um. Estava com fome...depois um chefe de polícia chegou e perguntou de quem era a mala. O homem disse:

- Desse senhor. Você não tem medo não? ele perguntou assim.

- Medo de que? Eu não tenho nada pra esconder. 
Então quando o rapaz terminou ele pediu desculpas. Você sabe, tem problemas de drogas transportadas pra Nigéria, Europa...Então deve ter chegado pra ele alguma informação...tem um nigeriano chegando ai. Quando ele fez tudo, não tinha nada e pediu desculpa. Eu disse pra ele que ele estava fazendo seu trabalho, mas disse a ele pra não pensar que todos nigerianos são de drogas. Também não pensa que todos muçulmanos são terroristas. Então a lei mesmo não tem problema. Problema as pessoas que tão aplicando a lei”.

Então, vou direto ao ponto e pergunto se ele acha que não existe a menor possibilidade de radicalização no Brasil. O sheikh Ahmad responde: "não, eu não posso negar isso. A gente fala que qualquer pessoa que frequenta qualquer centro islâmico aqui no Brasil é quase impossível. Porque por enquanto, todo sheikh que está aqui no Brasil, estudaram mesmo! Mas tem aqueles que se dizem ser sheikh, mas não estudou. Mas eu brinco com os irmãos aqui, sheikh de Google [risos]. Ontem à noite uma moça passou aqui. Ela quer converter ao islam. Eu perguntei pra ela o que ela sabe do islam. Onde você estuda? Ela disse: 'na internet'. Eu disse: com que sheikh? Ela disse o nome de um sheikh. Tudo bem. Quero dizer que é impossível [ressalta], é impossível qualquer brasileiro que está com esses sheikhs conhecidos, impossível aprender coisa errada. Agora esses jovens [investigados nas operações da Polícia Federal] não tem nada a ver com esses sheikhs. Falam mal deles, negam eles. Eles não sabem nada! [exclama]".

Complemento dizendo que encontrei relatos de que algumas comunidades no Brasil chegaram a expulsar alguns de seus membros por conta de ideias mais extremistas. O sheikh então me interrompe e afirma: "isso que eu quero falar agora. Aqui também expulsamos. Expulsamos. Quando percebemos que um jovem está falando coisa que não tem nada a ver...eu falei, olha bem, eu vou chamar sua mãe. Eu vou mandar nossa secretária fazer uma carta, uma pra você e uma pra sua mãe. Ele me perguntou por quê. Porque o que você está divulgando não tem nada a ver com a religião. Você tá divulgando radicalismo na escola. Você tá reclamando que escola não gosta de você...como você quer que a escola gosta de você?"

Eu pergunto a idade do garoto que foi expulso. O sheikh diz: "naquela época tinha 18 anos. Moleque. Eu falei: não é obrigado você vim pra cá, mas eu vou escrever a carta que você não é muçulmano mais. Você não pertence a gente. Ele me disse pra não fazer isso. Eu disse: 'você tem que parar. Você viu o que aconteceu no Rio [de Janeiro]? Eu vou fazer a mesma coisa'. Chamei a mãe dele. A mãe dele não é muçulmana. A mãe dele pediu desculpa e disse que ele não tava agindo bem em casa. Eu falei pra ela que radicalismo não tem aqui. Não é só aqui...é no Brasil inteiro. A gente não quer essas pessoas, porque não é do islam! Uma senhora chegou aqui, alguns anos atrás. É da Bahia, mas não é de Salvador. Ela disse querer converter 
para o islam. Eu quis saber como ela soube daqui. 'Ah, através da internet. Bom, ficou aqui comigo um tempão. Numa sexta-feira, dirigi meu sermão e falei sobre radicalismo. Eu falei que islam não tem nada a ver com radicalismo. A palavra islam significa paz, muçulmano, homem da paz. Eu deu três exemplos que o profeta Mohammed deu pra nós. Um homem chegou no profeta e disse que ele quer continuar rezando sempre. Oração da gente cinco vezes por dia. Ele disse que ia rezar a noite também. O profeta disse: 'eu não trouxe essa religião assim'. Isso é radicalismo. Seu corpo precisa descansar. Radicalismo. Segundo: outro disse, profeta, a gente jejum trinta dias, mas eu posso mais que isso, eu vou fazer pra sempre e vou comer só a noite. Eu quero dedicar minha vida a Deus. Profeta disse, 'isso é radicalismo! Você é mais do que eu? Radicalismo eu não trouxe pra você. Terceiro: Mohammed, eu sou homem de Deus. O profeta disse: 'que bom'. E o homem disse: 'Mas minha mulher me atrapalha muito em casa e eu vou mandar ela embora'

- Por quê?

- Porque eu quero Deus!

Profeta disse:

- Eu sou o profeta de Deus, tenho meus filhos, minha esposa. Não é a religião que eu trouxe pra você. Isso é radicalismo. Islam tem regras, tem que seguir.

O segundo califa chegou na mesquita e uma pessoa estava lá. Omar saiu e depois voltou e o homem estava lá. Ele então disse:

- Amigo, você não sair daqui não?

- Não, eu sempre aqui.

- Quem está te ajudando para sustentar sua família?

- Meu irmão.

- Olha, seu irmão melhor do que você.

- Por quê?

- Você acha que Deus vai mandar ouro do céu pra você? Tem que dividir seu tempo. Tempo pra sua família, tempo pra trabalho, tempo pra comunidade. Mas se você quer viver na mesquita isso é pobreza. Isso é radicalismo.

Ser muçulmano está na maneira de agir, de falar, de respeitar os outros que faz declarar quem é você. Teve seminário aqui. No final da minha fala uma mulher veio pra mim e disse:

- Sheikh, a palestra que você fez agora não tem nada a ver com o que meu filho divulga pra nós em casa.

- Mas quem é seu filho?

- Fulano. Muçulmano! 
- Ele disse o que?

- Me disse que a partir de que ele virou muçulmano, a minha comida não presta mais. Não fala com o pai, não fala comigo, ele tranca o quarto dele. Não fala com mais ninguém porque não somos muçulmanos.

- Mas não tem nada a ver isso o que você tá falando.

- Deus, no Alcorão, diz: 'após Deus, os profetas e seus pais. Deus diz, não adora nada senão eu. E seus pais, tem que respeitar, tratar eles muitíssimo bem.

- Mas meu filho disse que não.

- Mas ele disse que é muçulmano? Então ele não tá com a gente aqui. Se ele diz que é muçulmano, ele aprendeu isso em outro lugar, no Google! [exclama].

A mãe me visitou aqui, pediu desculpas e disse que ele não é daqui mesmo [da comunidade]".

Neste instante, abordo a questão da mídia na divulgação de certas informações a respeito da religião e se ele acha que ela poder estar ajudando a prejudicar a imagem do islam. Sem que eu completasse a questão ele afirma: "claro! Olha, meu amigo. Eles perguntam pra mim sempre. O que você acha do que está acontecendo hoje? Em 2001...a gente tem um professor que se chama Ubiratan. Ele não é muçulmano. Mas como ele é historiador, a gente convida ele sempre pra participar e falar da história do islam aqui. Um dia ligou pra mim assim. Ele falou em 2001:

- Sheikh, você não acha que o mundo, a mídia tá querendo acabar com o islam?

- Impossível. Não tem isso. Eles podem fazer tudo, mas islam continua andando, crescendo.

Passou 10 anos, ele me ligou e me disse:

- Sheikh, você falou a verdade.

Algumas pessoas da mídia por interesse ou ignorância, entendeu? Tem gente que não sabe nada do islam. É verdade. Qualquer coisa que do Estado Islâmico, é coisa de muçulmano. Muçulmano é assim. Qualquer coisa em países árabes é islam que ensina isso. Eu não estou generalizando, mas parece que o objetivo principal da mídia é o que? Chamar atenção. Pelo aspecto negativo.

Aqui nesta casa, teve entrevista comigo. Duas horas. Da TV Bahia. Uma coisa que ia passar domingo a noite. E começou a divulgar a chamada. Aí um irmão me ligou e me disse:

- Sheikh, você não tá vendo tv?

- Mas o que está acontecendo?

- Disse que você falou alguma coisa que... 
Falaram: olha, domingo vai passar a religião que diz isso e aquilo, que a mulher isso e aquilo...

O que eu fiz? Vamo processar TV Bahia. Primeiro vou ligar.

- Posso falar com Paulo?

- Paulo não tá aqui, por quê?

- Ele me entrevistou. Pode passar o celular dele?

- Não posso.

- Se ele não está quero falar com o chefe dele.

- Não, a gente não pode fazer isso. Sobre o quê?

- Senhora, eu não falei tudo isso na tv não.

A moça disse:

- Tá bom. Por favor, não fala com diretor. Porque isso vai prejudicar Paulo.

Mas eu falei:

- Mas Paulo pode prejudicar a gente? Eu vou falar com o diretor.

- Deixa, eu vou verificar primeiro. Aí eu ligo pra você.

Dez minutos depois ela me ligou e disse:

- Sheikh, por favor, desculpa. Não tem nada a ver o que chamada tá dizendo.

Depois, Paulo mesmo vem pra cá pedir desculpa. Uma moça tava com ele e disse:

- Sabe o que é isso? A chamada é pra público.

- Então não pode fazer chamada da maneira que fizeram.

- Mas tem que ter uma coisa que tem novidade, impacto.

Mas essa moça não sabia que isso pode prejudicar a gente. Por ignorância. Não sabia quando vai pra tv, pode prejudicar as pessoas. O interesse é só pra chamar a atenção de muitos.

Tem revista aqui...como que chama...revista Veja ou...como chama? Teve aqui um ano, de São Paulo e me entrevistou. A gente chega aqui e não vê revista...não saiu aqui. Mas a moça disse pra não me preocupar. São Paulo ligou pra mim, Wamy ligou pra mim, é...todos... 'Sheikh, o que tá acontecendo aí? você falou tudo isso?'

Distorceram tudo. Eles sabem que tudo que tá falando nenhum sheikh vai falar isso. Então peguei revista, liguei pra lá. Diretor de setor disse:

- Por favor, não fala mais. A gente quer pedir perdão. Porque o centro islâmico aqui tá dizendo que vai processar a gente. A gente vai fazer outra coisa.

- Me conta o que aconteceu? 
- A moça saiu da Bahia, entrevistou você, entrevistou alguém de outra religião e a parte do islam ela perdeu, sumiu. Então pra não deixar espaço livre assim, então o que ela sabia do islam, o que estava na cabeça dela, ela colocou.

- Ela colocou uma coisa que tá prejudicando o islam não só aqui, mas no mundo inteiro.

Essa pessoa ligou e se desculpou. Então, centro islâmico me ligou e disse que não precisa mais processar.

Imagine, o que está acontecendo não é só comigo só. Eu falei pra você. Algumas mídias estão fazendo a cabeça desses jovens que por ignorância não sabem o que é islam. Ou por interesse.

Pergunto ao sheikh que ele ou os membros da comunidade sentem algum tipo de preconceito.

Ele diz: "nesta casa eu falo sempre que...eu não chama isso...a curiosidade que leva as pessoas para falar das nossas irmãs mulheres que usa hijab na rua. Uma vez eu...teve...passeata contra guerra no Iraque. Então, no Pelourinho, você conhece Pelourinho né? [respondi que sim e ele continuou] De Pelourinho pra cá, andamos. Eu andei com aquela roupa de sheikh. Quando cheguei num lugar que chama Saúde, e uma senhora olhou assim [e fez um gesto facial] e disse

- Puxa meu Deus! Até aqui também tem guerra!

Falei:

- Senhora, não. Eu sou homem da paz.

- Então por que você tá usando essa roupa? Não tem bomba ai dentro não? [exclamou]

Se eu for brigar com essa senhora, eu estou afirmando que eu sou o homem da bomba. Eu disse, não, senhora, na minha terra a gente usa essa roupa. Ela falou:

- Eu posso falar com o senhor?

- Claro!

Conversamos bastante e ela pediu desculpas e disse:

- Senhor, desculpas. Eu não sabia. Porque a mídia fala pra nós que as pessoas bota bomba dentro da roupa, desculpa.

Eu dei pra ela panfleto e depois ela ligou pra mim, pedindo mais desculpas. Ela não virou muçulmana, mas passou a ter respeito e admiração. Disse que agora sabe que é tudo mentira. Eu falei pra ela, que no dia que ela falou isso pra mim começou brigar...se eu começo a brigar você ia achar o que? Religião islâmica é a religião da paz, do respeito. Por isso a gente ta fazendo passeata pra paz. Então, o que eu falo pras pessoas é que não precisa brigar na rua. Tem algumas pessoas que a curiosidade leva elas a falar bobagem porque a mídia fala sempre, sempre, sempre. Uma senhora de 42 anos chegou aqui ontem. Ela disse que estava estudando 
pra ser muçulmana. Eu disse que bom! E seu marido? Ela disse que ele não liga pra nada. Ela disse que a mãe dela era cristã. Ela me disse assim:

- Deixa eu contar uma história pra você. No dia que eu passei aqui com o carro, Centro Islâmico! Meu Deus! Esse povo já invadiu o Brasil! Deus me livre! Eu nunca mais vou passar aqui! [gritou como que imitando a fala da senhora].

- Por quê?

- Sheikh, porque a mídia passa pra nós que vocês são terroristas. Agora eu descobri que não tem nada a ver o que a mídia fala. Por isso eu estou aqui

[risos]

Um dia fui ao dentista. Ele me conhece muito bem. Ele me abraçou e eu abracei ele. Ele tava com amigos lá. Ele me apresentou dizendo que eu era sheikh de muçulmanos. Quando ele falou isso, um dos amigos se afastou pra lá. Entendeu? O que eu fiz? Eu fui lá, perguntei:

- meu amigo, por que você se afastou?

- muçulmano! Deus me livre!

- Por quê?

- Vocês mata! [exclama]. Vocês são terrorista!

Sem esconder nada. Então meu amigo dentista disse:

- Por que você está generalizando?

- Amigo, estou mentindo?

Eu falei:

- Sim, não tem nada a ver com o islam.

- Então por que a mídia fala tudo isso?

- Você está confiando em tudo que a mídia fala.

Neste ponto, questiono se o sheikh considera que o atual presidente Jair Bolsonaro e as recentes notícias de que ele vai transferir a embaixada brasileira de Tel-Aviv para Jerusalém poderia gerar algum desconforto na comunidade, entre os árabes de modo geral. Ele responde: “eu não posso falar, não sou brasileiro. Não tenho passaporte daqui. Mas islam respeita muito, muçulmano respeita muito o apoio que Brasil está dando para os muçulmanos. Mas se fechar as portas dos muçulmanos...ele pode dificultar pra nós...a maneira que ele tá falando...ele vai levar a embaixada...imagine os árabes que estão aqui no Brasil. Quantos são os muçulmanos aqui no Brasil? Hoje, o que precisamos aqui, nos Estados Unidos, é facilitar, unir. Muçulmanos não estão aqui pra dizer 'não, o Brasil vai virar país islâmico', não existe isso. Pra isso, a gente tá estudando o que ele quer fazer pra nós e pro Brasil inteiro. Falei no sermão outro dia que 
Brasil está abrindo 'a pasta nova', vamos pedir a Alá pra ajudar todos nós. Se der certo, ótimo pra todos. Mas se der errado, será ruim pra todos".

Disse então que o Brasil tem tradição em acolher imigrantes e é formado por eles. Lembrei dos Malês, escravos muçulmanos que vieram para o Brasil e protagonizaram uma revolta no século XIX. Quis saber dele se ainda havia algum remanescente desse povo na comunidade. Ele afirmou da seguinte forma: "Já não tem mais. Tem uma mulher que a gente pode dizer...dona Ivone, já faleceu. Mas tem a história...todo ano tem seminário sobre os Malês, convidamos professores...professor João dos Reis que escreveu aquele livro 'A revolta dos Malês', entendeu? Nada melhor, meu amigo, que as pessoas pesquisem sobre o islam.

A gente não vai negar que existem alguns muçulmanos radicais, por ignorância ou política. Político porque essas pessoas estão conseguindo alguma coisa. Mas não querem saber o que é o islam, que tem regras...universal. No islam tem xiita e sunita. Você não vai ver um sheikh que fala que xiita são radicais. Tem regras que não concordamos. Mas pra dizer que eles são radicais, não é isso. Existe grupos nos sunitas, jovens, que são radicais. Islam diz: 'fala a verdade'. Sê sincero. Isso está dentro de você pra falar a verdade. Pra mentir você tem que fazer esforço pra procurar o que não tem. Por isso criança que não mente. Por isso pra ensiná-la é difícil. O islam é pra preservar aquilo que já está dentro de você, por isso o islam diz que todas as crianças nascem na pureza natural. Os pais e a sociedade é que tentam pra muda-la. Pra respeitar é natural. Islam é paz!

Neste instante ele avisa que precisa rezar e começa a se despedir de mim que prontamente agradeço a atenção e informações. Ele ainda de modo muito gentil me dá abertura para perguntar outras dúvidas futuras via whatsapp. Em seguida tiro algumas fotos do espaço e vou embora. 


\section{Fotografias adicionais}
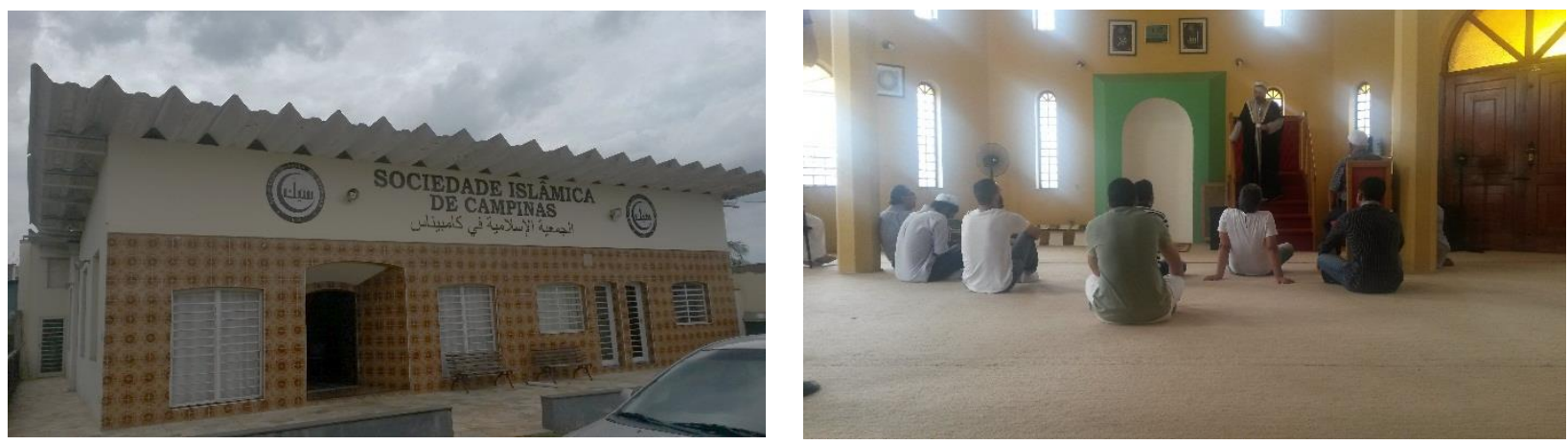

SIC - respectivamente: fachada do salão de eventos e sermão em uma sexta-feira (Campinas/SP, 25.09.2015).
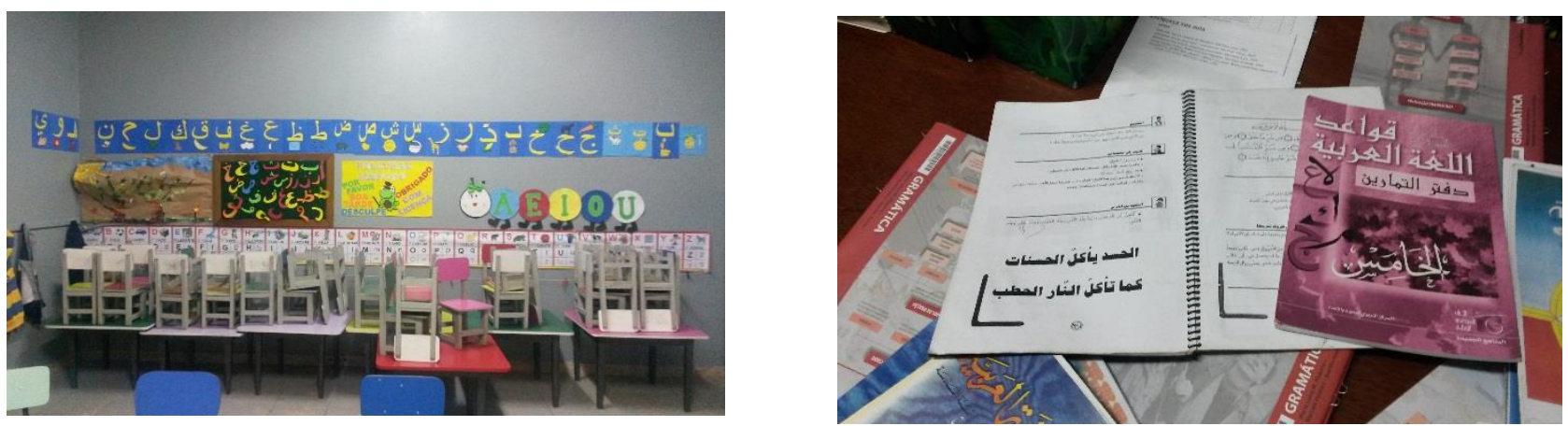

Escola Árabe-Brasileira - respectivamente: sala de aula e material didático (Foz do Iguaçu/PR, 08.07.2015).
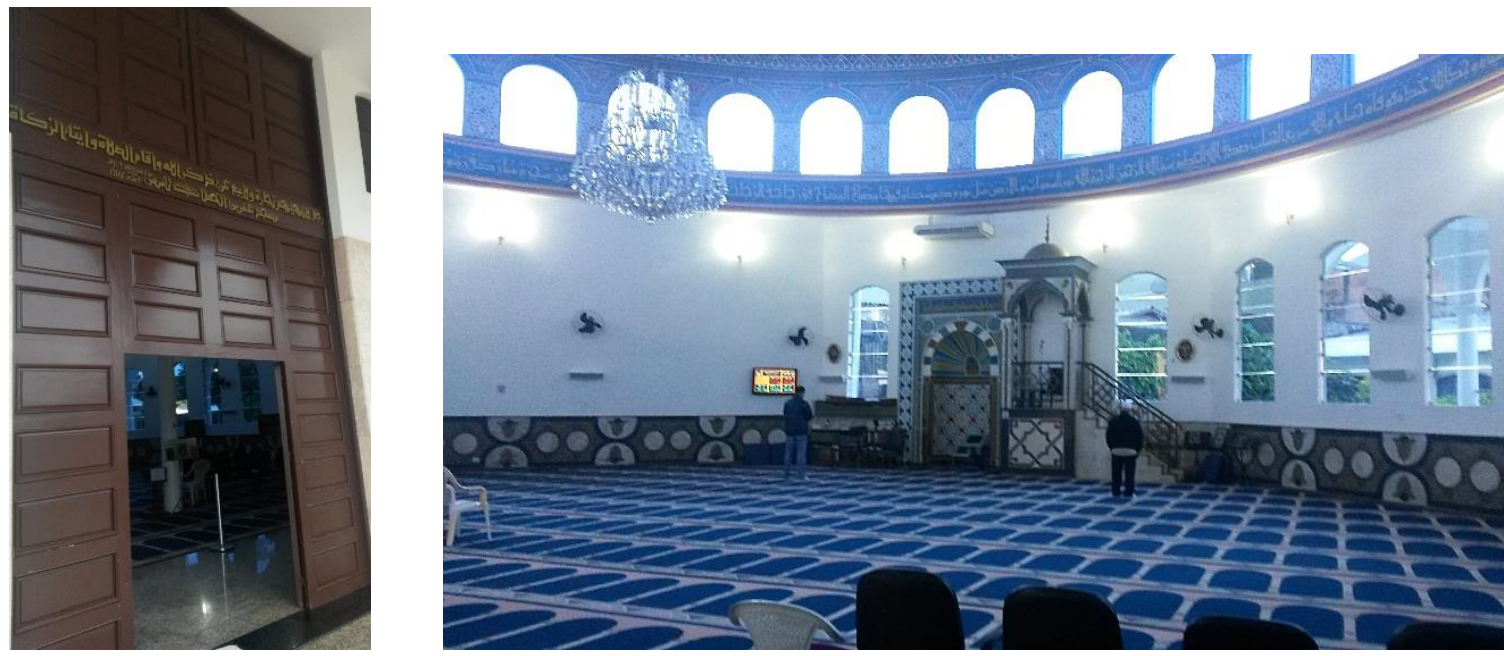

Mesquita Omar Ibn-AlKhatab - respectivamente:Pórtico e salão principal (Foz do Iguaçu/PR, 07.07.2015). 

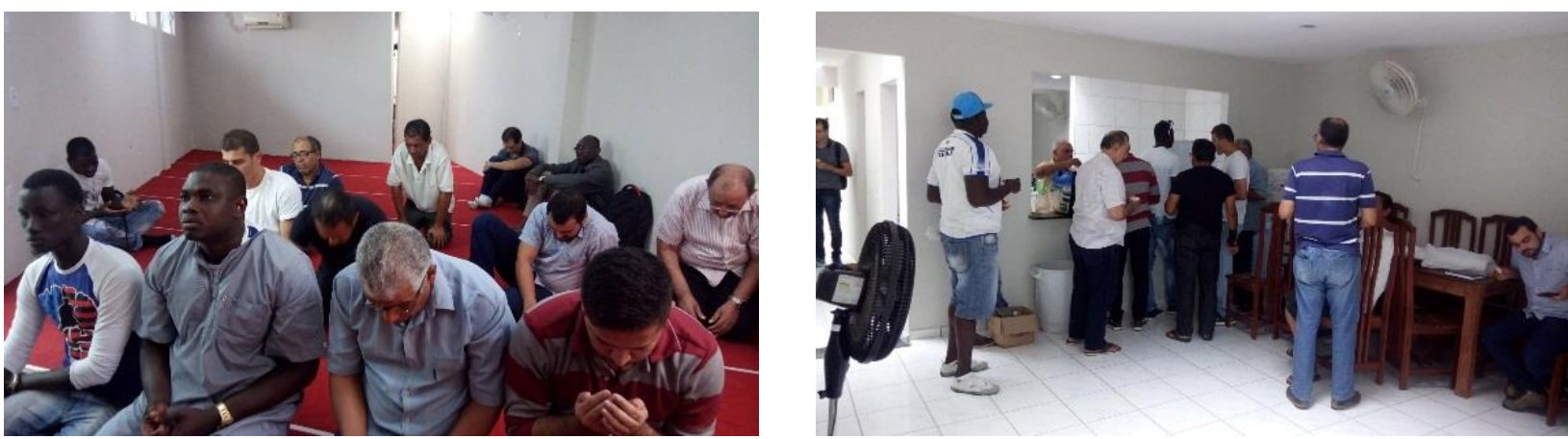

SBMRN - respectivamente: salat e almoço (Natal/RN, 24.02.2017).
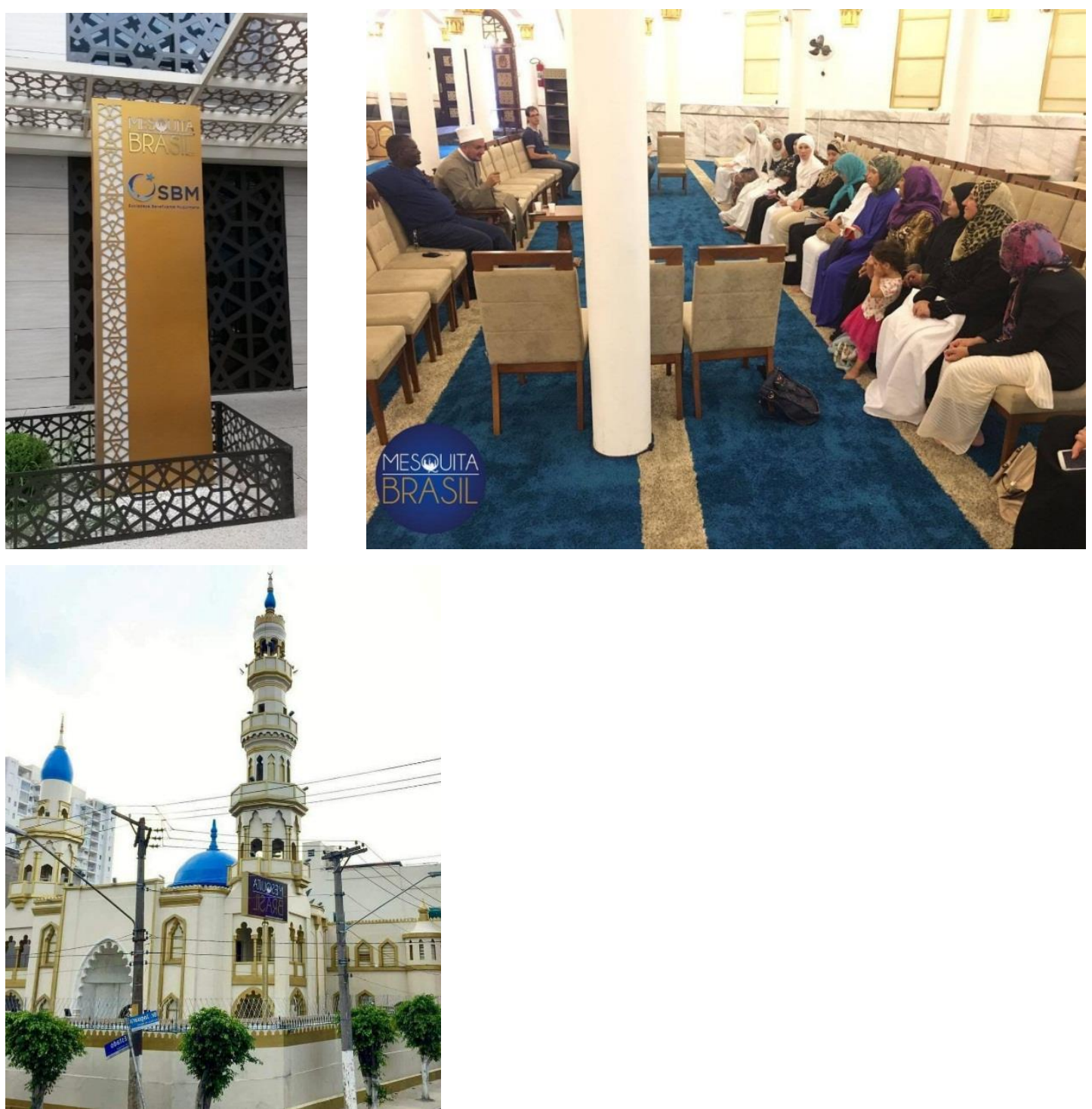

Mesquita Brasil - Respectivamente: entrada principal, aula de religião para mulheres com o sheikh Abdelhamid e vista da fachada. (São Paulo/SP, 07.01.2017). 


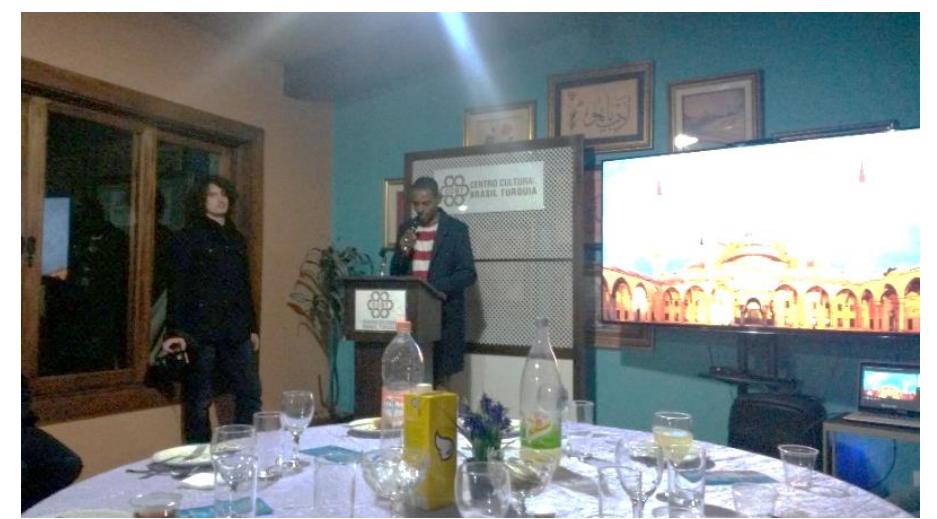

CCBT - Iftar, encontro inter-religioso (São Paulo/SP, 13.06.2016). 